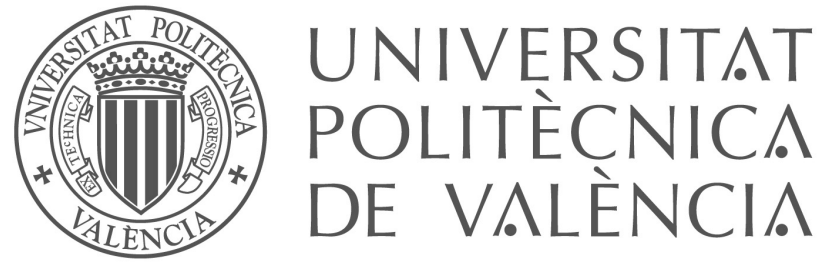

\title{
Effect of limonene on anaerobic digestion of citrus waste and pretreatments for its improvement
}

PhD Thesis

Supervised by:

Xavier Flotats (GIRO/UPC) and Eduardo Palomares (UPV)

Begoña Ruiz Fuertes

Valencia, October 2015 

A mis padres,

Conceso y Antonia

A José Manuel 



\section{Agradecimientos}

Llega el final de este camino, que a veces parecía no tener fin, y siento que estoy en deuda con muchas personas que me han ayudado de una u otra manera a sacar adelante esta tesis. Voy a nombrar a algunas de ellas, sabiendo que me dejo muchas más que espero que me perdonen el olvido.

En primer lugar, quiero agradecer a mis directores, el Dr. Xavier Flotats y el Dr. Eduardo Palomares, no sólo sus acertados consejos y revisiones en el plano científico, sino también su apoyo, paciencia y comprensión.

El trabajo experimental de esta tesis ha sido realizado en las instalaciones de dos instituciones: Bayerische Landesanstalt für Landwirtschaft, Institut für Landtechnik (LfL-ILT) en Freising, Alemania, y en el centro tecnológico AINIA en Valencia, España.

Muchas personas del LfL-ILT han colaborado en este trabajo. Doy las gracias en especial al Dr. Felipe Kaiser y al Dr. Andreas Gronauer por su supervisión y apoyo, y a Diana Andrade por toda su ayuda dentro y fuera del laboratorio y por hacerme sentir como en casa aunque estaba a miles de kilómetros. Gracias también a todas las personas que colaboraron, directa o indirectamente: Uli, Luise, Raphaela, Anke, Volker, Markus, Manfred, Hans, Gabi... Gracias también a Karl-Heinz por toda su ayuda con la planta piloto y por tantas historias divertidas.

También quiero agradecer a las personas de AINIA que hicieron posible esta tesis. A Roberto, que me arreglaba la planta piloto, a Carme y Begoña que me dieron las claves para descifrar los cromatogramas, a Vicente y muchos otros por su colaboración con los análisis químicos y a Mireia por sus revisiones críticas y sobre todo por el apoyo moral en los momentos de bajón, que fueron unos cuantos.

Gracias también al personal de la UPV por guiarme en los entresijos administrativos de la gestión de la tesis, en especial a Marga Vila que me lo explicó todo tan bien.

Finalmente, gracias a todas esas personas fuera del ámbito académico que han "sufrido" esta tesis, de muchas maneras, pero en especial en forma de horas robadas. Gracias a mi marido y a mi familia por su apoyo y comprensión durante todo este tiempo. 



\section{Table of contents}

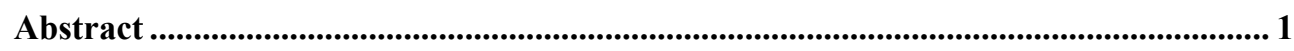

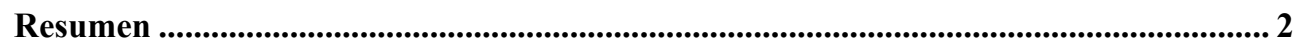

Resum ..........................................................................................................................

\section{Chapter 1. CONTEXT, OBJECTIVES AND THESIS OUTLINE}

$1.1 \quad$ Introduction ................................................................................................................ 6

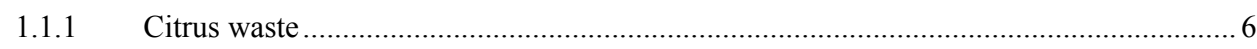

1.1.2 Inhibition of anaerobic digestion of citrus waste by CEO ........................................... 7

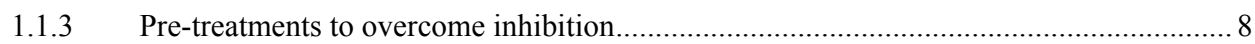

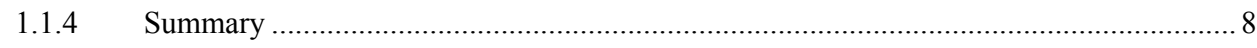

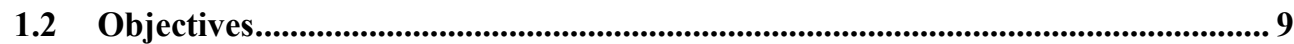

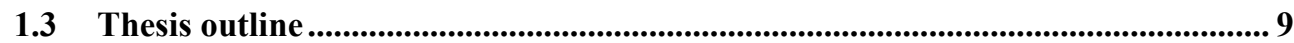

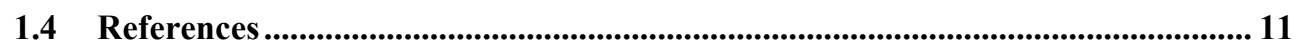

Chapter 2. Citrus ESSENTIAL OILS AND THEIR INFLUENCE ON THE ANAEROBIC DIGESTION PROCESS. AN OVERVIEW

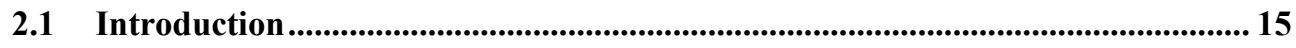

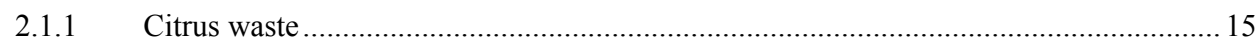

2.1.2 Citrus waste management and valorisation............................................................. 15

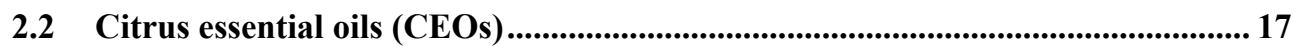

2.2.1 General characteristics of citrus essential oils ............................................................ 17

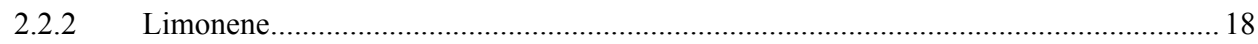

2.3 Antimicrobial effect of citrus essential oils .................................................... 23

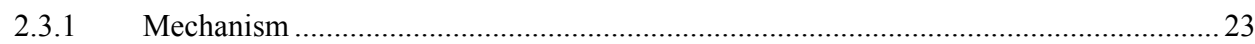

2.3.2 Factors affecting the antimicrobial effect of essential oils......................................... 25

2.3.3 Adaptation of microorganisms to essential oils ........................................................ 26 
2.3.4 Quantification of antimicrobial effect on microorganisms .......................................... 28

2.3.5 Microorganisms resistant to citrus essential oils: biotransformation of limonene ........... 34

2.4 Effect of citrus essential oils on the anaerobic digestion process ........................ 36

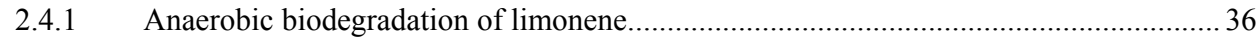

2.4.2 Effect of citrus essential oils on the anaerobic digestion .................................................. 36

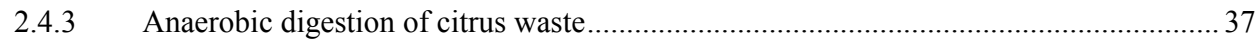

2.4.4 Summary of the effect of citrus essential oils on the anaerobic digestion process........... 40

2.5 Pre-treatments for recovery or removal of citrus essential oils ............................. 42

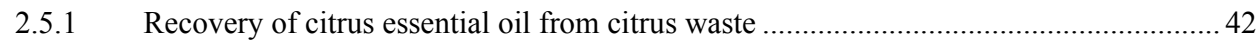

2.5.2 Removal of citrus essential oil from citrus waste ......................................................... 42

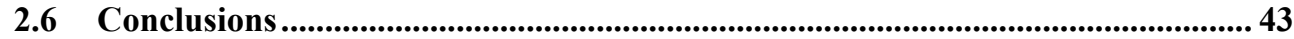

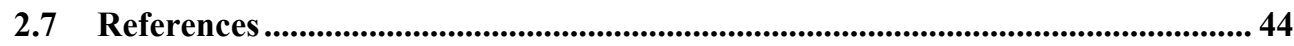

CHAPTER 3. EFFECT OF LIMONENE ON BATCH ANAEROBIC DIGESTION OF CITRUS PEEL WASTE

3.1 Introduction .53

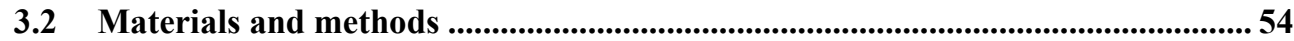

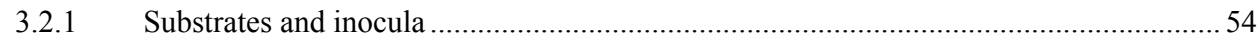

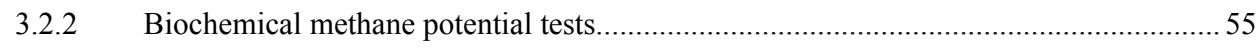

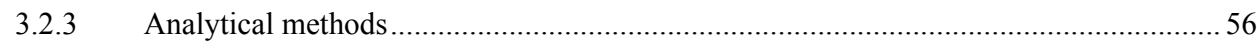

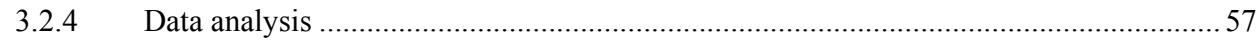

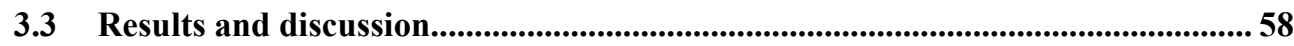

3.3.1 Biochemical methane potential of citrus waste …..................................................... 59

3.3.2 Effect of citrus essential oil on the batch anaerobic digestion of orange peel.................59

3.3.3 Effect of low limonene concentrations $\left(50-200 \mathrm{mg} \cdot \mathrm{kg}^{-1}\right)$ on the anaerobic digestion..... 63

3.3.4 Effect of high limonene concentrations $\left(200-3000 \mathrm{mg} \cdot \mathrm{kg}^{-1}\right)$ on the anaerobic digestion 65

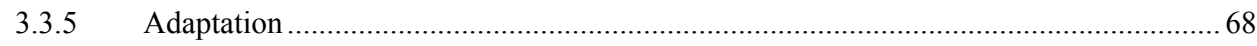

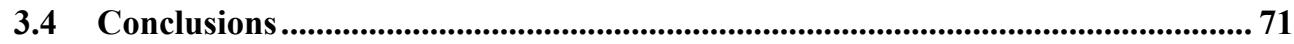

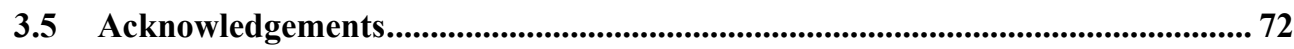

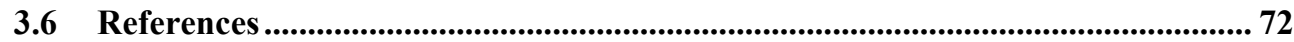




\section{Chapter 4. StRATEgIES TO AVOID INHIBITION OF ANAEROBIC DIGESTION OF CITRUS WASTE: EFFECT ON LIMONENE CONCENTRATION, METHANE POTENTIAL AND PRODUCTION RATE}

4.1 Introduction ............................................................................................................. 77

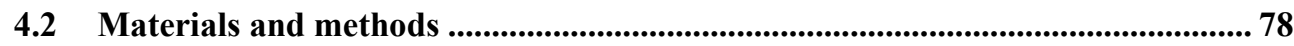

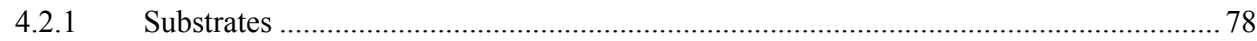

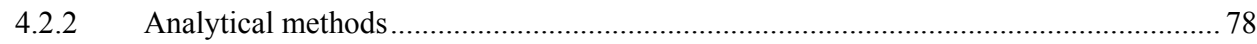

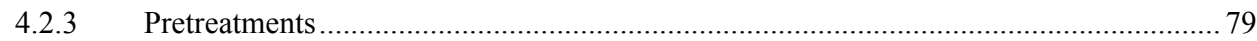

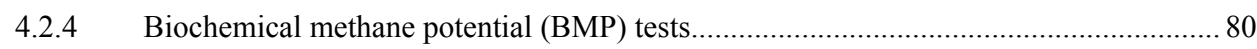

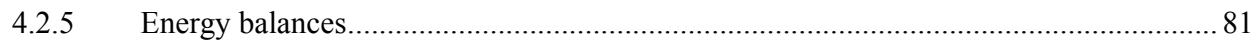

$4.3 \quad$ Results and discussion................................................................................................. 82

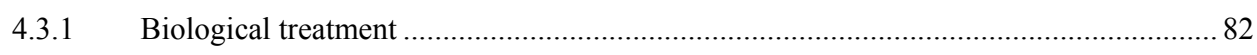

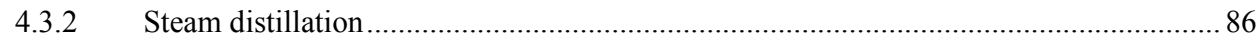

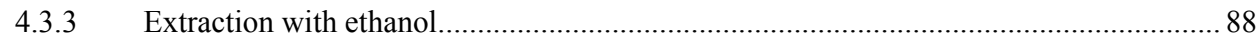

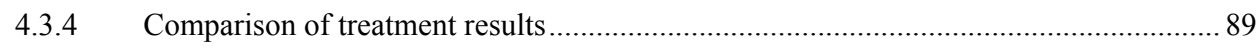

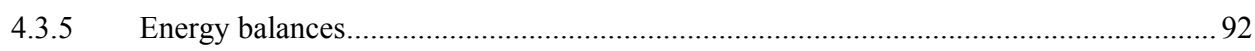

4.4 Conclusions .................................................................................................................. 93

4.5 Acknowledgements..........................................................................................................93

4.6 References .......................................................................................................................... 93

CHAPTER 5. CODIGESTION OF CITRUS WASTE WITH CHICKEN AND PIG MANURE AS A STRATEGY TO OVERCOME INHIBITION OF ANAEROBIC DIGESTION BY CITRUS ESSENTIAL OIL

5.1 Introduction 99

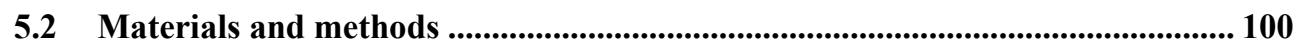

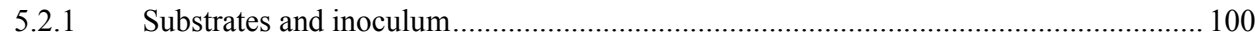

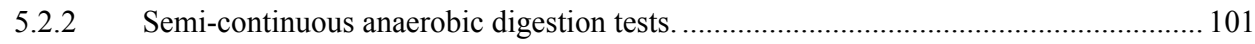

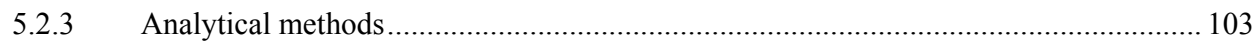


5.3 Results and discussion............................................................................................. 103

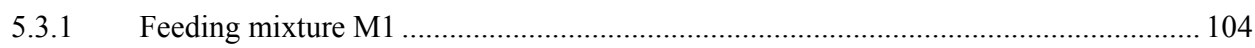

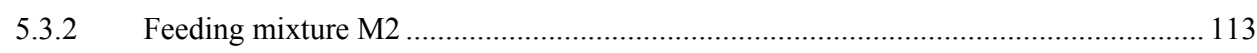

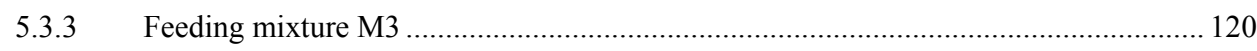

5.3.4 Comparison of results of M1, M2 and M3 ............................................................. 126

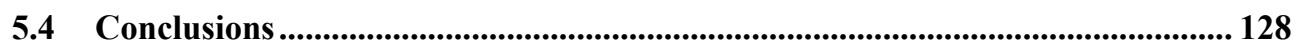

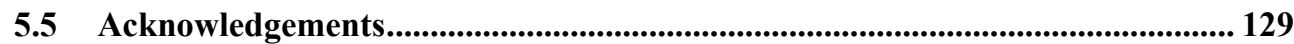

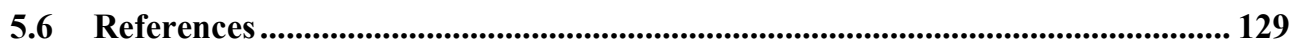

CHAPTER 6. THERMAL AND MECHANICAL PRETREATMENTS OF CITRUS FRUIT AND CODIGESTION WITH COW MANURE AS STRATEGIES TO OVERCOME INHIBITION OF ANAEROBIC DIGESTION BY CITRUS ESSENTIAL OIL

6.1 Introduction ............................................................................................................... 133

6.2 Materials and methods ........................................................................................ 134

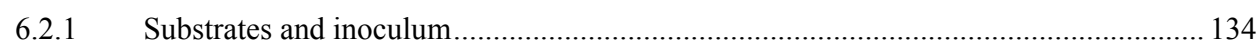

6.2.2 Semi-continuous anaerobic digestion tests.......................................................... 134

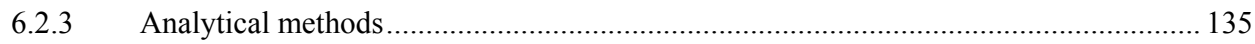

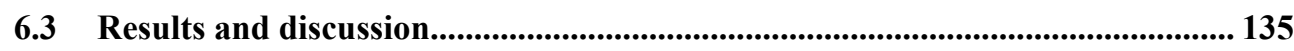

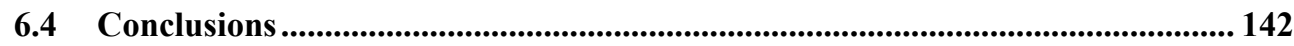

6.5 Acknowledgements.......................................................................................... 142

6.6 References ......................................................................................................................... 147

CHAPTER 7. BiOlOGICAL AND EXTRACTIVE PRETREATMENTS OF ORANGE PEEL AND CODIGESTION WITH COW MANURE AS STRATEGIES TO OVERCOME INHIBITION OF ANAEROBIC DIGESTION BY CITRUS ESSENTIAL OIL 


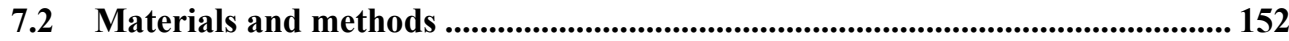

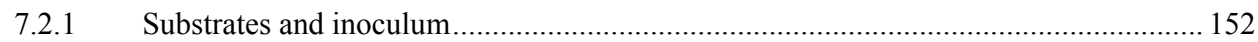

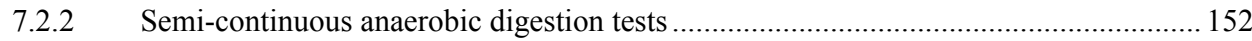

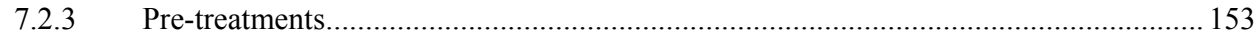

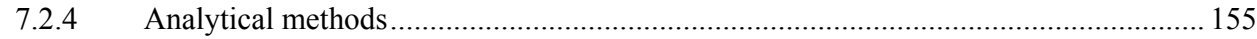

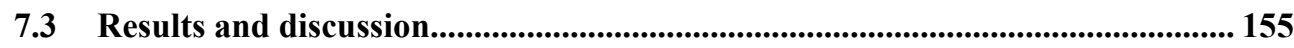

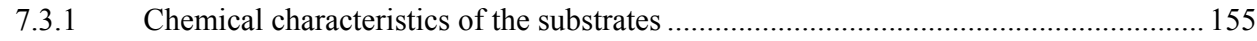

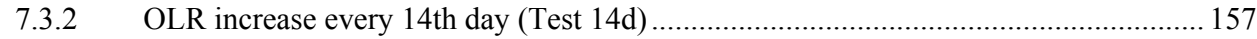

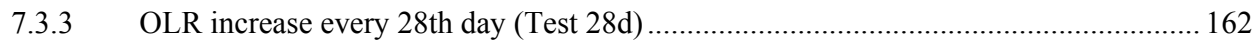

7.3.4 Biological treatment and OLR increase every 14th day (Test 14dBT) ........................ 168

7.3.5 Biological treatment and OLR increase every 28th day (Test 28dBT) ........................ 176

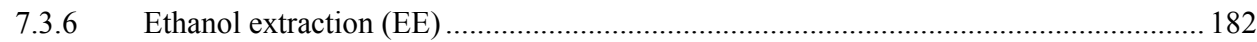

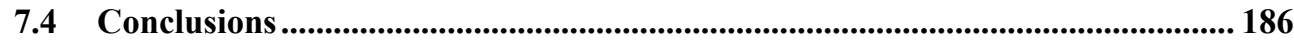

7.5 Acknowledgements.......................................................................................................... 188

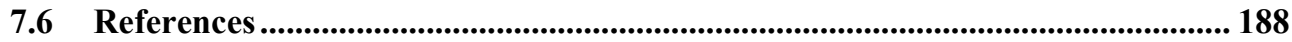

CHAPTER 8. CONCLUSIONS AND SUGGESTIONS FOR FUTURE RESEARCH

8.1 Conclusions

8.1.1 Review on anaerobic digestion of citrus peel and inhibition by citrus essential oil...... 192

8.1.2 Inhibitory concentration of limonene in batch anaerobic digestion ............................. 192

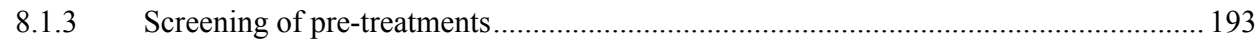

8.1.4 Anaerobic co-digestion of citrus waste and manure ................................................... 193

8.1.5 Combination of co-digestion and pre-treatments to overcome inhibition..................... 194

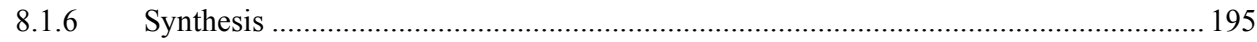

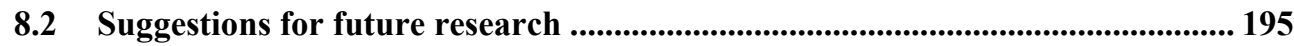




\section{List of tables}

\section{CHAPTER 2. Citrus ESSENTIAL OILS AND THEIR INFLUENCE ON THE ANAEROBIC DIGESTION PROCESS. AN OVERVIEW}

Table 2.1. Chemical composition of citrus pulp. 17

Table 2.2. Chemical composition of citrus essential oils (\%). 20

Table 2.3. Chemical composition of citrus essential oils (\%) (continued). 21

Table 2.4. Chemical composition of citrus essential oils (\%) (continued). 22

Table 2.5. Physical and chemical properties of limonene (WHO, 1998; Sikkema et al., 1995; Hazra et al., 2002).

Table 2.6. Inhibitory effect of citrus essential oils or its components on microorganisms (in vitro tests).

Table 2.7. Inhibitory effect of citrus essential oils or its components on microorganisms (in vitro tests) (continued).

Table 2.8. Inhibitory effect of citrus essential oils or its components on microorganisms (in vitro tests) (continued).

Table 2.9. Inhibitory effect of citrus essential oils or its components on microorganisms (in vitro tests) (continued).

Table 2.10. Inhibitory effect of citrus essential oils or its components on microorganisms (in vitro tests) (continued).

Table 2.11. Biotransformation of limonene. 36

Table 2.12. Effect of citrus essential oils or their components in anaerobic digestion.

\section{CHAPTER 3. EFFECT OF LIMONENE ON BATCH ANAEROBIC DIGESTION OF CITRUS PEEL WASTE}

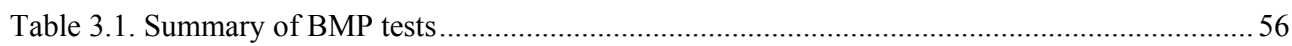

Table 3.2. Chemical characteristics of citrus waste tested. All units are expressed in wet basis..........58

Table 3.3. Main results of BMP tests on citrus waste (average values \pm standard deviation).............. 59

Table 3.4. Main results of BMP tests of ground and unground orange peel (average values \pm standard deviation).

Table 3.5. Main results of batch anaerobic digestion tests of microcrystalline cellulose with different doses of commercial limonene and different inocula (average values \pm standard deviation). 


\section{Chapter 4. StRATEgIES TO AVOID INHIBITION OF ANAEROBIC DIGESTION OF CITRUS WASTE: EFFECT ON LIMONENE CONCENTRATION, METHANE POTENTIAL AND PRODUCTION RATE}

Table 4.1. Pretreatments applied to the orange peel 79

Table 4.2. Summary of BMP tests 81

Table 4.3. Chemical characteristics of untreated and biologically treated orange peel and cow manure.

Table 4.4. Results of biological treatment of orange peel and co-digestion experiments of orange peel and cow manure. 85

Table 4.5. Results of steam distillation experiments (see Table 4.1 for treatment conditions). 87

Table 4.6. Results of solid-liquid extraction with ethanol experiments (see Table 4.1 for treatment conditions).

CHAPTER 5. CODIGESTION OF CITRUS WASTE WITH CHICKEN AND PIG MANURE AS A STRATEGY TO OVERCOME INHIBITION OF ANAEROBIC DIGESTION BY CITRUS ESSENTIAL OIL

Table 5.1. Summary of semi-continuous anaerobic digestion tests. 102

Table 5.2. Chemical characteristics of animal manures and citrus waste used for the experiments. . 103

Table 5.3. Summary of semi-continuous anaerobic digestion tests. 104

Table 5.4. Main observations in semi-continuous anaerobic digestion of M1. 109

Table 5.5. Results of semi-continuous anaerobic co-digestion test M1: average values and standard deviation in each period.

Table 5.6. Main observations in semi-continuous anaerobic digestion of M2

Table 5.7. Results of semi-continuous anaerobic co-digestion test M2: average values and standard deviations in each period.

Table 5.8. Main observations in semi-continuous anaerobic digestion of mixture M3.

Table 5.9. Results of semi-continuous anaerobic co-digestion test M3. Each period corresponds to constant OLR and HRT. Average values and standard deviations are shown......

Table 5.10. Summary of main results of tests M1, M2 and M3. 126 


\section{CHAPTER 6. THERMAL AND MECHANICAL PRETREATMENTS OF CITRUS FRUIT AND CODIGESTION WITH COW MANURE AS STRATEGIES TO OVERCOME INHIBITION OF ANAEROBIC DIGESTION BY CITRUS ESSENTIAL OIL}

Table 6.1. Summary of semi-continuous anaerobic digestion tests. 135

Table 6.2. Chemical characteristics of cow manure and orange fruit. 136

Table 6.3. Feeding mixture properties for each anaerobic digestion test performed.......................... 136

Table 6.4. Average values and standard deviation in each period of experiment A. .......................... 143

Table 6.5. Average values and standard deviation in each period of experiment B.......................... 144

Table 6.6. Average values and standard deviation in each period of experiment C........................... 145

Table 6.7. Average values and standard deviation in each period of experiment D. ........................ 146

\section{CHAPTER 7. BIOLOGICAL AND EXTRACTIVE PRETREATMENTS OF ORANGE PEEL AND CODIGESTION WITH COW MANURE AS STRATEGIES TO OVERCOME INHIBITION OF ANAEROBIC DIGESTION BY CITRUS ESSENTIAL OIL}

Table 7.1. Summary of semi-continuous anaerobic digestion tests. 152

Table 7.2. Chemical characteristics of animal manures and citrus waste used for the experiments $14 \mathrm{~d}, 14 \mathrm{dBT}, 28 \mathrm{~d}$ and $28 \mathrm{dBT}$.

Table 7.3. Chemical characteristics of cow manure and orange peel after ethanol extraction, used for experiment EE.

Table 7.4. Feeding mixture properties in the anaerobic digestion tests.

Table 7.5. Main observations in semi-continuous anaerobic digestion of experiment $14 \mathrm{~d}$. 161

Table 7.6. Results of semi-continuous anaerobic co-digestion experiment $14 \mathrm{~d}$ : average values and standard deviation in each period.

Table 7.7. Main observations in semi-continuous anaerobic digestion of experiment $28 \mathrm{~d}$. 167

Table 7.8. Results of semi-continuous anaerobic co-digestion experiment $28 \mathrm{~d}$ : average values and standard deviations in each period.

Table 7.9. Main observations in semi-continuous anaerobic digestion of $14 \mathrm{dBT}$.

Table 7.10. Results of semi-continuous anaerobic co-digestion 14dBT: average values and standard deviation in each period.

Table 7.11. Main observations in semi-continuous anaerobic digestion of $28 \mathrm{dBT}$. 180 
Table 7.12. Results of semi-continuous anaerobic co-digestion 28dBT: average values and standard deviation in each period. 181

Table 7.13. Main observations in semi-continuous anaerobic digestion of EE. 186

Table 7.14. Results of semi-continuous anaerobic co-digestion EE: average values and standard deviation in each period. 187 


\section{List of figures}

\section{CHAPTER 2. CitRUS ESSENTIAL OILS AND THEIR INFLUENCE ON THE ANAEROBIC DIGESTION PROCESS. AN OVERVIEW}

Figure 2.1. Structure of citrus (Iglesias et al., 2007). 18

Figure 2.2. Seasonal variation of limonene concentration in the essential oil of clementine (Citrus reticulata), orange (Citrus sinensis) and red grapefruit (Citrus paradise) (based on data from Droby et al., 2008). Vertical bars indicate standard error.

Figure 2.3. Molecular formula of limonene.

Figure 2.4. Cell wall of Gram-positive bacteria (cronodon.com). 25

Figure 2.5. Cell wall of and Gram-negative bacteria (cronodon.com). 25

Figure 2.6. Decrease of rumen gas production from acetic acid, cellulose and starch in mesophilic batch anaerobic conditions. Data from Crane et al. (1957).

\section{CHAPTER 3. EFFECT OF LIMONENE ON BATCH ANAEROBIC DIGESTION OF CITRUS PEEL WASTE}

Figure 3.1. Laboratory set-up where biochemical methane potential tests were carried out. 56

Figure 3.2. Maximum slope calculation from the curves of cumulative biogas production. The value for $\mathrm{A}$ in the linear regression equation $\mathrm{y}=\mathrm{Ax}-\mathrm{B}$ is the maximum slope.......58

Figure 3.3. Evolution of several parameters in BMP test of OP2/OPG2. From left to right and from up to down: VS, COD, acetic (HAc) and propionic (HPr) acid, total COD from the VFA, partial pressure of hydrogen in the biogas, and cumulative methane production.

Figure 3.4. Evolution of the limonene concentration in the digesters in BMP test of OP2/OPG2 and its transformation into $\mathrm{p}$-cresol and $\alpha$-terpineol.

Figure 3.5. Cumulative methane production and partial pressure of hydrogen in the biogas from microcrystalline cellulose with 0 and $50 \mathrm{mg} \cdot \mathrm{kg}^{-1}$ of (S)-limonene.

Figure 3.6. Cumulative methane production and partial pressure of hydrogen in the biogas from microcrystalline cellulose with 0,100 and $200 \mathrm{mg} \cdot \mathrm{kg}^{-1}$ of (S)-limonene.

Figure 3.7. Net results of the BMP tests of microcrystalline cellulose with the indicated high limonene concentrations, after substracting the methane production of the inoculum. Standard deviations are not shown, for clarity.

Figure 3.8. Cumulative methane production and partial pressure of hydrogen in the biogas for the indicated limonene concentration compared with the vials with no limonene.

Figure 3.9. Cymene GC peak area in the vials of the experiment with high limonene concentrations, in day 113 (black squares) and in day 217 (grey diamonds). Note the different scales 
of the two curves. 70

Figure 3.10. Methane production and partial pressure of hydrogen in the biogas for the first and second run of the BMP experiments, for 600 and $1000 \mathrm{mg} \cdot \mathrm{kg}^{-1}$ of limonene. 71

Figure 3.11. Percentages of the maximum MPR from cellulose with different concentrations of limonene in the digester. Vertical lines indicate IC50 values $\left(423 \mathrm{mg} \cdot \mathrm{kg}^{-1}\right.$ and $669 \mathrm{mg} \cdot \mathrm{kg}^{-1}$ of limonene for first and second run, respectively).......

Chapter 4. StRATEgIES TO AVOID INHIBITION OF ANAEROBIC DIGESTION OF CITRUS WASTE: EFFECT ON LIMONENE CONCENTRATION, METHANE POTENTIAL AND PRODUCTION RATE

Figure 4.1. BMP test of untreated and biologically treated OP1: cumulative methane production and partial pressure of hydrogen in the biogas. 85

Figure 4.2. BMP test of untreated and biologically treated OP2 in co-digestion with cow manure: cumulative methane production and partial pressure of hydrogen in the biogas..

Figure 4.3. BMP test of OP3 untreated and after steam distillation: cumulative methane production and partial pressure of hydrogen in the biogas.Standard deviations are not represented for clarity.

Figure 4.4. BMP test of OP3 untreated and after solid-liquid extraction with ethanol: cumulative methane production and partial pressure of hydrogen in the biogas. Standard deviations are not represented for clarity.

Figure 4.5. BMP and MPR increase in the batch anaerobic digestion of orange peel depending on the temperature of the pretreatment.

Figure 4.6. GC peak area of limonene and $\alpha$-terpineol at the end of the batch anaerobic digestion of untreated and biologically treated OP2 in co-digestion with cow manure, mixtures M1 to M4 (see mixture compositions in Table 4.2).

Figure 4.7. Thermal energy required for the pretreatments and potentially recovered from the methane generated with the pretreated orange peel.

CHAPTER 5. CODIGESTION OF CITRUS WASTE WITH CHICKEN AND PIG MANURE AS A STRATEGY TO OVERCOME INHIBITION OF ANAEROBIC DIGESTION BY CITRUS ESSENTIAL OIL

Figure 5.1. Laboratory set-up for the semi-continuous anaerobic digestion tests. 101

Figure 5.2. Specific biogas and methane production, and methane content in the biogas (\%-vol) of the mixture M1 for the five periods studied. Averages and standard deviations of the different periods are represented.

Figure 5.3. Methane production and concentration in the biogas from M1. 105 
Figure 5.4. Hydrogen and hydrogen sulphide in the biogas from M1. ......................................... 105

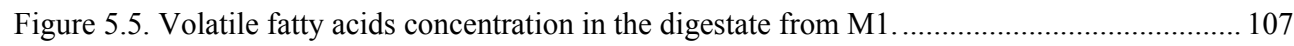

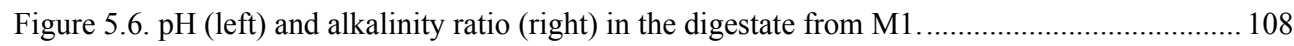

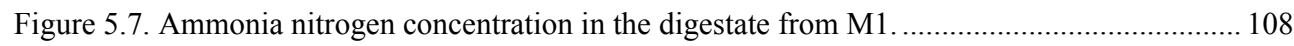

Figure 5.8. Evolution of the GC peaks during the semi-continuous anaerobic digestion of M1....... 110

Figure 5.9. Specific biogas and methane production, and methane content in the biogas (\%-vol) of the mixture M2 for the eitght periods studied. Averages and standard deviations of the different periods are represented.

Figure 5.10. Methane production and concentration in the biogas from M2. ................................. 114

Figure 5.11. Hydrogen and hydrogen sulphide in the biogas from M2 ......................................... 114

Figure 5.12. Volatile fatty acids concentration in the digestate from M2 .................................... 115

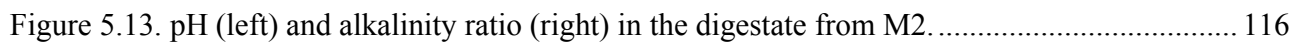

Figure 5.14. Ammonia nitrogen concentration in the digestate from M2 ...................................... 117

Figure 5.15. Evolution of the GC peaks during the semi-continuous anaerobic digestion of M2 ..... 118

Figure 5.16. Specific biogas and methane production, and methane content in the biogas (\%-vol) of mixture M3 for the seven periods studied. Averages and standard deviations of the different periods are presented....................................................................... 120

Figure 5.17. Methane production and concentration in the biogas from M3 ................................. 121

Figure 5.18. Hydrogen and hydrogen sulphide in the biogas from M3 ........................................ 121

Figure 5.19. Volatile fatty acids concentration in the digestate from M3 ...................................... 122

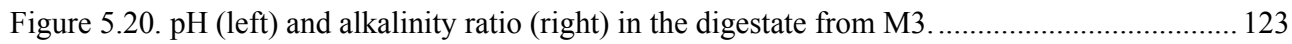

Figure 5.21. Ammonia nitrogen concentration in the digestate from M3 ...................................... 124

Figure 5.22. Evolution of the GC peaks during the semi-continuous anaerobic digestion of M3...... 124

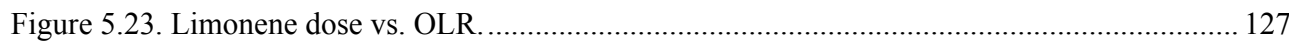

Figure 5.24. VS removal in semi-continuous anaerobic digestion of the three mixtures................... 128

CHAPTER 6. THERMAL AND MECHANICAL PRETREATMENTS OF CITRUS FRUIT AND CODIGESTION WITH COW MANURE AS

STRATEGIES TO OVERCOME INHIBITION OF ANAEROBIC DIGESTION BY CITRUS ESSENTIAL OIL

Figure 6.1. Laboratory set-up for the semi-continuous anaerobic digestion tests (LfL-ILT in Freising, Germany).

Figure 6.2. Specific methane production, and methane concentration in the biogas. Averages and standard deviations of the different periods are represented. 
Figure 6.3. Methane concentration in the biogas. Averages of three runs are presented.

Figure 6.4. Volumetric methane production. Averages of three runs are presented.

Figure 6.5. Partial pressure of hydrogen (left) and hydrogen sulphide (right) in the biogas. Averages of three runs are presented.

Figure 6.6. Total volatile fatty acids concentration (left) and $\mathrm{pH}$ (right). Averages of three runs are presented.

Figure 6.7. Alkalinity ratio (left) and concentration of ammonia nitrogen (right). Averages of three runs are presented.

Figure 6.8. Volatile fatty acids concentration. Averages of three runs are presented.

CHAPTER 7. BIOLOGICAL AND EXTRACTIVE PRETREATMENTS OF ORANGE PEEL AND CODIGESTION WITH COW MANURE AS

STRATEGIES TO OVERCOME INHIBITION OF ANAEROBIC DIGESTION BY CITRUS ESSENTIAL OIL

Figure 7.1.Laboratory set-up for the semi-continuous anaerobic digestion tests. 153

Figure 7.2. Equipment used for the ethanol extraction of the citrus essential oil from the orange peel.

Figure 7.3. Experimental horizontal dryer used for the drying step after ethanol extraction of the orange peel.

Figure 7.4. Specific biogas and methane production and methane content in the biogas (\%-vol) of the test $14 \mathrm{~d}$ for the six periods studied. Averages and standard deviations of the different periods are presented.

Figure 7.5. Methane production and concentration in the biogas in test $14 \mathrm{~d}$.

Figure 7.6. Hydrogen and hydrogen sulphide in the biogas from test $14 \mathrm{~d}$.

Figure 7.7. Volatile fatty acids concentration in the digestate from test $14 \mathrm{~d}$.

Figure 7.8. $\mathrm{pH}$ (left) and alkalinity ratio (right) in the digestate from experiment $14 \mathrm{~d}$. 160

Figure 7.9. Ammonia nitrogen concentration in the digestate from experiment $14 \mathrm{~d}$. 160

Figure 7.10. Specific biogas and methane production and methane content in the biogas (\%-vol) of the experiment $28 \mathrm{~d}$ for the six periods studied. Averages and standard deviations of the different periods are presented.

Figure 7.11. Methane production and concentration in the biogas in test $28 \mathrm{~d}$. 164

Figure 7.12. Hydrogen and hydrogen sulphide in the biogas from experiment $28 \mathrm{~d}$. 164

Figure 7.13. Volatile fatty acids concentration in the digestate from experiment $28 \mathrm{~d}$. 165

Figure 7.14. $\mathrm{pH}$ (left) and alkalinity ratio (right) in the digestate from experiment $28 \mathrm{~d}$. 166

Figure 7.15. Ammonia nitrogen concentration in the digestate from experiment $28 \mathrm{~d}$. 166 
Figure 7.16. Main GC peaks area in the CEO analysis of $28 \mathrm{~d}$ digestate. 167

Figure 7.17.Specific biogas and methane production and methane content in the biogas (\%-vol) of the experiment $14 \mathrm{dBT}$ for the five periods studied. Averages and standard deviations of the different periods are presented

Figure 7.18. Methane production and concentration in the biogas, test $14 \mathrm{dBT} \ldots \ldots \ldots \ldots \ldots \ldots \ldots \ldots \ldots \ldots \ldots . . . . . . . . . . . . . .170$

Figure 7.19. Hydrogen and hydrogen sulphide in the biogas from 14dBT.................................... 170

Figure 7.20. Volatile fatty acids concentration in the digestate from 14dBT. ................................. 171

Figure 7.21. pH (left) and alkalinity ratio (right) in the digestate from $14 \mathrm{dBT}$. ............................... 172

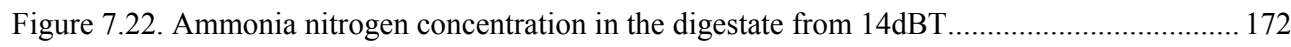

Figure 7.23. GC peak area of the CEO analysis in tests $14 \mathrm{~d}$ and $14 \mathrm{dBT}$ (data from the digestate collected on day 64 of experiment).

Figure 7.24. Specific biogas and methane production and methane content in the biogas (\%-vol) of the experiment $28 \mathrm{dBT}$ for the five periods studied. Averages and standard deviations of the different periods are presented.

Figure 7.25. Methane production and concentration in the biogas, test 28dBT

Figure 7.26. Hydrogen and hydrogen sulphide in the biogas from $28 \mathrm{dBT}$. 177

Figure 7.27. Volatile fatty acids concentration in the digestate from $28 \mathrm{dBT}$. 178

Figure 7.28. $\mathrm{pH}$ (left) and alkalinity ratio (right) in the digestate from $28 \mathrm{dBT}$. 179

Figure 7.29. Ammonia nitrogen concentration in the digestate from $28 \mathrm{dBT}$. 179

Figure 7.30. Main GC peaks area in the CEO analysis of 28dBT digestate. 180

Figure 7.31. Specific biogas and methane production and methane content in the biogas (\%-vol) of the experiment EE for the seven periods studied. Averages and standard deviations of the different periods are presented.

Figure 7.32. Methane production and concentration in the biogas in test EE. 183

Figure 7.33. Hydrogen and hydrogen sulphide in the biogas from EE. 183

Figure 7.34. Volatile fatty acids concentration in the digestate from EE. 184

Figure 7.35. $\mathrm{pH}$ (left) and alkalinity ratio (right) in the digestate from EE 184

Figure 7.36. Ammonia nitrogen concentration in the digestate from EE 185

Figure 7.37. Main GC peaks area in the CEO analysis of EE digestate. 185 


\begin{abstract}
Anaerobic digestion is a sustainable and technically sound way to valorise citrus waste if the inhibitory effect of the citrus essential oil (CEO) is controlled. Several strategies have been proposed to overcome these difficulties: keeping the organic loading rate (OLR) in low values to avoid excess dosage of inhibitor, supplementing the citrus waste with nutrient and buffering solutions or pre-treating the citrus waste in order to reduce the CEO concentration, either by recovery or by degradation of the CEO. Nevertheless, although some of them have been proven successful in recovering/degrading the CEO, none of them has been applied at full scale operation.
\end{abstract}

The main objective of this thesis is to study the effect of the limonene (the main component of CEO) on the anaerobic digestion of citrus waste and to evaluate different strategies to improve this process.

In a first approach to the problem, the effect and dynamics of the limonene in the anaerobic digestion process is studied in batch mode. The biochemical methane potential of several citrus waste types was assessed. The inhibitory concentration of limonene for the anaerobic digestion process was estimated also, observing a certain adaptation degree.

Different strategies to avoid inhibition of the anaerobic digestion by limonene were studied in batch mode, namely biological treatment by fungi of the Penicillium genus, steam distillation and ethanol extraction. All treatments decreased the limonene concentration in the orange peel, with different efficiencies. Methane potential and production rate in the batch anaerobic digestion of the pretreated orange peel were not affected by the biological treatment, but an increase was observed after steam distillation and also after ethanol extraction. This effect was attributed to the removal of minority compounds of the CEO. Energy balance was negative for steam distillation and positive for the other two tested strategies.

Continuous anaerobic co-digestion experiments of orange and mandarin peel with chicken and pig manure allowed observing the importance of the limonene dosage on the inhibitory effect. Systemic inhibition was observed in the mixture with higher limonene concentration, with symptoms of inhibition on methanogenesis, protein hydrolysis pathway, sulphate reduction and acetogenesis. The degradation of the limonene produced inhibitory compounds as well, causing persistent inhibition effects even after almost complete limonene degradation.

Continuous anaerobic co-digestion of pretreated citrus waste with cow manure allowed for stable processes when the pretreatment was able to remove the limonene with high efficiency and without producing other inhibitory compounds (such as $\alpha$-terpineol in the biological treatment). Thus, the pretreatments allowing for better results in terms of process stability were mechanical removal of the flavedo and ethanol extraction of the limonene. The anaerobic digestion is able to degrade the limonene, but its by-products can be even more inhibitory than the limonene itself. Therefore, it is concluded that to apply CEO recovery strategies before anaerobic digestion is recommended, since these could possibly the valorization of CEO as added value product and to increase biogas production. 


\section{Resumen}

La digestión anaerobia es una vía sostenible y técnicamente viable para valorizar los residuos cítricos si se controla el efecto inhibidor del aceite esencial cítrico (AEC). Se han propuesto varias estrategias para superar esta dificultad: mantener la velocidad de carga orgánica (VCO) en valores bajos para evitar dosis excesivas del inhibidor, suplementar el residuo cítrico con soluciones de nutrientes y tampón o pretratar el residuo cítrico para reducir la concentración de AEC, ya sea por recuperación o degradación del mismo. Sin embargo, aunque algunas de ellas han sido exitosas para recuperar o degradar el AEC, ninguna ha sido llevada a escala industrial.

El objetivo principal de esta tesis ha sido estudiar el efecto del limoneno (el componente principal del AEC) en la digestión anaerobia de los residuos cítricos y evaluar diferentes estrategias para mejorar este proceso.

En una primera aproximación al problema, se estudió el efecto y la dinámica del limoneno en la digestión anaerobia en discontinuo. Se evaluó el potencial bioquímico de metano de varios tipos de residuo cítrico y se estimó la concentración inhibitoria del limoneno para el proceso de digestión anaerobia, observando un cierto grado de adpatación.

Se estudiaron diferentes estrategias para evitar la inhibición de la digestión anaerobia por limoneno en modo discontinuo: tratamiento biológico mediante hongos del género Penicillium, arrastre de vapor y extracción con etanol. Todos los tratamientos disminuyeron la concentración de limoneno en la piel de naranja, con diferentes eficiencias. El potencial de metano y la velocidad de producción en la digestión anaerobia discontinua de la piel de naranja pretratada no se vieron afectados por el tratamiento biológico, pero se observó un incremento tras el arrastre de vapor y la extracción con etanol. Este efecto se atribuyó a la extracción de compuestos minoritarios del AEC. El balance energético fue negativo para el arrastre de vapor y positivo para las otras dos estrategias.

Los experimentos de co-digestión anaerobia en continuo de piel de naranja y mandarina con gallinaza y purín porcino permitieron observar la importancia de la dosis de limoneno sobre el efecto inhibitorio. Se observó inhibición sistémica en la mezcla con mayor concentración de limoneno. La degradación del limoneno produjo a su vez compuestos inhibitorios, con lo que el efecto inhibitorio persistió incluso tras la completa degradación del limoneno.

La co-digestión anaerobia en continuo de residuo cítrico pretratado y estiércol de vacuno permitió tener procesos estables cuando el pretratamiento era capaz de eliminar el limoneno con alta eficiencia y sin producir otros compuestos inhibitorios (como $\alpha$-terpineol en el caso del tratamiento biológico). Así, la eliminación mecánica del flavedo y la extracción del limoneno con etanol fueron los pretratamientos que dieron mejor resultado en términos de estabilidad del proceso. La digestión anaerobia es capaz de degradar el limoneno, pero sus subproductos pueden ser aún más inhibitorios que el propio limoneno. Por ello, se concluye que son recomendables los pretratamientos de recuperación de AEC, ya que permiten su valorización como producto de valor añadido y, a la vez, incrementar la producción de biogás mediante digestión anaerobia. 


\section{Resum}

La digestió anaeròbia és una via sostenible i tècnicament viable per valoritzar els residus cítrics si es controla l'efecte inhibitori de l'oli essencial cítric (OEC). S'han proposat diverses estratègies per tal de superar aquesta dificultat: mantenir la velocitat de càrrega orgànica (VCO) en valors baixos per a evitar dosis excessives de l'inhibidor, suplementar el residu cítric amb solucions de nutrients i tamponants o pretratar el residu cítric per a reduir la concentració d'OEC, ja siga per recuperació o per degradació del mateix. Tanmateix, encara que algunes d'elles han estat exitoses per recuperar o degradar l'OEC, cap ha estat escalada a nivel industrial.

L'objectiu principal d'aquesta tesi ha estat estudiar l'efecte del limonè (el component principal de l'OEC) en la digestió anaeròbia dels residus cítrics i avaluar diferents estratègies per a millorar aquest procés.

En una primera aproximació al problema, es va estudiar l'efecte i la dinàmica del limonè a la digestió anaeròbia en discontinu. Es va avaluar el potencial bioquímic de metà de diferents tipus de residu cítric i es va estimar la concentració inhibitòria del limonè per al procés de digestió anaeròbia, observant-se un cert grau d'adaptació.

S'estudiaren diferents estratègies per a evitar la inhibició de la digestió anaeròbia per limonè en modus discontinu: tractament biològic amb fongs del gènere Penicillium, destillació amb vapor i extracció amb etanol. Tots els tractaments reduiren la concentració de limonè a la pell de taronja, però amb eficiències diferents. El pre-tractament biològic no va influir en el potencial de metà ni en la velocitat de producció de la digestió anaeròbia discontínua de la pell de taronja. En canvi, s'observà un increment d'ambdós paràmetres amb la destillació amb vapor i l'extracció amb etanol. Aquest efecte es va atribuir a l'extracció de components minoritaris de l'OEC. El balanç energètic va ser negatiu per a la destil·lació amb vapor i positiu per a les altres dues estratègies.

Els experiments de co-digestió anaeròbia en continu de pell de taronja i mandarina, amb gallinassa i purins de porc varen permetre observar la importància de la dosi de limonè sobre l'efecte inhibitori. Es va observar inhibició sistèmica a la mescla amb major concentració de limonè. La degradació del limonè va produir inhibidors, de manera que l'efecte inhibitori va persistir fins i tot després de la completa degradació del limonè.

La co-digestió anaeròbia en continu de residu cítric pretractat i fem de boví va permetre tenir processos estables quan el pretractament era capaç d'eliminar el limonè amb alta eficiència $\mathrm{i}$ sense produir altres molècules inhibitòries (com $\alpha$-terpineol en el cas del tractament biològic). Així, l'eliminació mecànica de l'epicarpi i l'extracció del limonè amb etanol foren els pretractaments que donaren millor resultat en termes d'estabilitat del procés. La digestió anaeròbia és capaç de degradar el limonè, però els seus subproductes poden ser encara més inhibitoris que el propi limonè. Per això, es conclou que son recomanables els pretractaments de recuperació de OEC, ja que permenten la seva valorització com productes de valor afegit i, a la vegada, incrementar la producció de biogàs mitjançant digestió anaeròbia. 


\section{Chapter 1}

\section{Context, objectives and thesis outline}

\section{Table of contents}

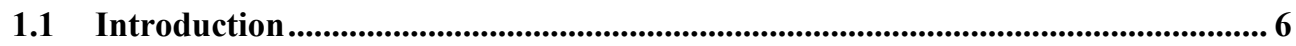

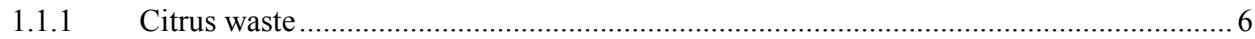

1.1.2 Inhibition of anaerobic digestion of citrus waste by CEO ............................................

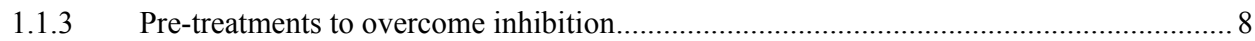

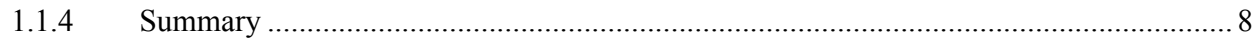

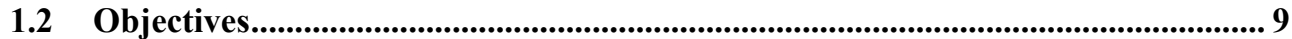

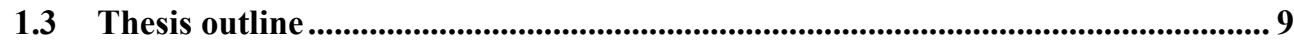

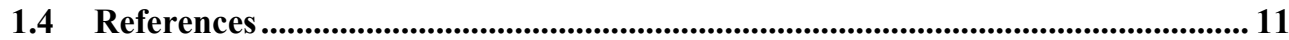




\subsection{Introduction}

\subsubsection{Citrus waste}

Citrus waste mainly consists of: (a) waste generated by the juice manufacturing industry, consisting in peel and pressed pulp; (b) fruits discarded for commercial reasons (damaged fruit, as example); and (c) fruits discarded due to regulations that limit production. This material is not allowed to enter the food chain and therefore is considered to be waste.

Citrus processing for juice extraction produces around 500 tonnes of waste per 1000 tonnes of fruit processed (Lane, 1983a; Lohrasbi et al., 2010). The percentage of fruit discarded due to commercial or regulatory issues is more difficult to calculate, but it ranges from $2 \%$ to $10 \%$ depending on the type of citrus considered and environmental aspects, such as weather conditions. This leads to millions of tons of waste every year in the citrus producing regions (CAPA, 2011).

Citrus waste typically has a low $\mathrm{pH}(3-4)$, high water content (around $80-90 \%$ ) and high organic matter content (around $95 \%$ of total solids). These characteristics mean that citrus waste should not be disposed of in landfills according to the European regulations (Council Directive 2008/98/EC of 10 November 2008 on waste). Traditionally, citrus waste from the juice manufacturing industry has been used as livestock feed, thanks to its nutritive value, which is similar to that of barley grains or sugar beet pulp. However, the juice manufacturing companies are currently facing waste management difficulties due to the market saturation.

Non-hazardous waste management schemes do not usually accept citrus waste for composting, due to its low $\mathrm{pH}$, the presence of essential oils that inhibit the composting process and the fast biodegradation of this waste, which can cause anaerobiosis problems in compost piles.

Thermal treatment alternatives (incineration, gasification or pyrolysis) cannot be applied to citrus waste due to its high water content. Although they would be technically feasible, they would not be efficient from an energy or an economic point of view, since a previous dehydration step would be necessary.

The manufacture of bioethanol from citrus waste has recently been evaluated as a valorisation alternative. A bioethanol yield of 50-60 L-tonne ${ }^{-1}$ of waste (Boluda-Aguilar and López-Gómez, 2013) was obtained, equivalent to 294-352 kWh·tonne ${ }^{-1}$ of waste. However, the investment necessary to set up a bioethanol plant is estimated to be around 3-8 times higher than the necessary investment for a biogas plant (Cavinato et al., 2010; Karellas et al., 2010; Sánchez-Segado et al., 2012; Sorda et al., 2013). From the perspective of energy, this valorisation option is not as efficient as methane (biogas) production through the anaerobic digestion of citrus waste. In addition, by using co-digestion strategies, other by-products could be co-treated with the orange waste, thereby contributing to integral waste management within the producing area. 
For all these reasons, anaerobic digestion is a sound alternative for valorisation of citrus waste. However, its citrus essential oil (CEO) content inhibits the bioprocess. The major component of CEO in citrus waste is limonene, which accounts for $68-98 \%$ in sweet orange essential oil (Moufida and Marzouk, 2003).

\subsubsection{Inhibition of anaerobic digestion of citrus waste by $C E O$}

Several in vitro studies have been found in the literature regarding the effect of limonene on the different groups of bacteria that take part in the anaerobic digestion. Thus, limonene is proven inhibitory for both methanogenic and hydrolytic - acidogenic bacteria (Srilatha et al., 1995; Castillejos et al., 2006). Acetoclastic methanogens and the lactate degradation are also inhibited, while hydrogenotrophic methanogenesis is more resistant to inhibition by limonene (Crane et al., 1957).

The described antimicrobial mechanism is non-reversible (Bakkali et al., 2008). Nevertheless, some changes in the membrane structure have been described for Escherichia coli and Brochotrix thermospacta when exposed to sublethal concentrations of CEO (Di Pasqua et al., 2006 and 2007). This suggests a possible adaptation of the microorganisms to the CEO.

On the other hand, limonene can also be degraded, as observed by Harder and Probian (1995), who studied the biodegradation of limonene and other monoterpenes in the absence of oxygen, with the monoterpene as the sole carbon and energy source, and nitrate present in the medium as electron acceptor. The degradation product was $\alpha$-terpinene.

Very broad differences have been found in the yields and performance of the anaerobic digestion in semi-continuous operation mode. The majority of the studies have been done using citrus waste as the only substrate for the anaerobic digestion, using nutrients and buffering solutions to compensate the lack of nutrients and the low $\mathrm{pH}$ of the citrus waste. In semi-continuous anaerobic digestion, it is important not only the inhibitor's concentration in the feed, but also the loading rate of the digester, since these two parameters determine the daily dosage of inhibitor to the digester. Only three studies have aimed to find the maximum CEO dosage in terms of CEO amount per volume unit of the digester and day. Mizuki et al. (1990) found that the limit dosage was 26 $\mathrm{mg}_{\text {limonene }} \cdot \mathrm{L}_{\text {digester }}{ }^{-1} \cdot$ day $^{-1}$. Srilatha et al. (1995) carried out successful anaerobic digestion of citrus waste at $14.4 \mathrm{mg}_{\text {limonene }} \cdot \mathrm{L}_{\text {digester }}{ }^{-1} \cdot \mathrm{day}^{-1}$. And Lane (1984) fixed this value at 75 $\mathrm{mg}_{\text {limonene }} \cdot \mathrm{L}_{\text {digester }}{ }^{-1} \cdot$ day $^{-1}$. The three studies used citrus waste in their experimental works. Nevertheless, the origin of the waste was different: Mizuki et al. (1990) used mandarin, while Srilatha et al. (1995) digested fungal pretreated oranges and Lane (1984) industrial orange waste. This can have led to different CEO compositions and therefore to different inhibition effects.

None of the studies found in the literature aimed to evaluate the inhibitory concentration of limonene, its degree of biodegradation and dynamics in the anaerobic digestion process. 


\subsubsection{Pre-treatments to overcome inhibition}

One option to improve anaerobic digestion of citrus waste is the prior removal of CEO from the waste. Two strategies can be applied: (a) recovery of the CEO in order to obtain valuable components, in accordance with the concept of biorefinery, or (b) removal of CEO solely to enhance biogas production. The choice between recovery and removal depends on the economic feasibility of the whole process; the former implies a higher cost but yields a valuable product, while the latter involves a cost with the only advantage of a higher biogas production, which must therefore be high enough to compensate for the cost.

The most effective strategies for the removal or recovery of limonene are steam distillation, extraction with solvents and solid state fermentation.

Steam distillation to recover limonene from citrus peel has been previously analyzed by Mizuki et al. (1990) and Martín et al. (2010) with efficiencies between 70 and 99\%, demonstrating the technical feasibility of this operation.

Extraction of limonene by solvents has been assessed by Arce et al. (2004) using a mixture ethanol and water. In quaternary mixtures, limonene is better separated when the ethanol proportion in the solvent is higher (Arce et al., 2005). Other solvents have been studied such the n-hexane (Wikandari et al., 2013) but the remaining solvent in the peel inhibited the anaerobic digestion.

Biological pre-treatment of the citrus peel can be carried out either by fungi enzymes (Akao et al., 1992) or by solid-state fermentation (Srilatha et al., 1995). In order to reduce the operating costs of the treatment, the latter seems preferable.

\subsubsection{Summary}

Anaerobic digestion is a sustainable and technically sound way to valorise citrus waste if the inhibitory effect of the citrus essential oil is controlled. The main technical difficulties are related to the presence of essential oils in the peel that can inhibit anaerobic digestion since they cause cell toxicity. Although adaptation seems possible according to in vitro tests applied to some particular microorganisms, pilot scale trials of anaerobic digestion of citrus waste have failed when a particular OLR is reached or a daily inhibitor dosage is surpassed. However, this dosage varies depending on the particular characteristics of the citrus waste, which is dependent on the variety, geographic origin, the climate of the last campaign and other environmental aspects. This is due to the fact that, depending on these aspects the composition of the $\mathrm{CEO}$ is different, thus modulating the inhibitory effect.

Several strategies have been adopted to overcome these difficulties: keeping the OLR in low values to avoid excess dosage of inhibitor, supplementing the citrus waste with nutrient and buffering solutions or pre-treating the citrus waste in order to reduce the CEO concentration, either by recovery or by degradation of the CEO. Nevertheless, although some of them have been proven successful in recovering/degrading the CEO, none of them has been taken to full scale operation. 


\subsection{Objectives}

In this thesis, the effect of the limonene on the anaerobic digestion has been experimentally evaluated with the aim to achieve a stable process in which the citrus waste can be efficiently degraded.

The main objective is to study the effect of the limonene on the anaerobic digestion of citrus waste and to evaluate different strategies to improve this process.

Particular objectives have been:

- To review the available literature about citrus essential oils and their influence on the anaerobic digestion process.

- To study the effect and dynamics of the limonene in the anaerobic digestion in batch mode.

- To estimate the inhibitory concentration of limonene for the anaerobic digestion process.

- To identify and to study strategies allowing economically feasible anaerobic digestion of citrus waste:

○ co-digestion with cow, pig and chicken manure with the aim to avoid supplementation with micronutrients or buffering solutions;

○ biological treatment by fungi to remove the limonene and co-digestion of the pretreated waste;

- steam distillation to recover the limonene and co-digestion of the pretreated waste;

- ethanol extraction to recover the limonene and co-digestion of the pretreated waste.

The particular objectives are addressed in the different chapters as described in section 1.3.

\subsection{Thesis outline}

The influence of the citrus essential oils on the anaerobic digestion has been studied. Citrus waste represents more than the half of the whole fruit when processed for juice extraction, representing a high amount of waste stream that should not be disposed in landfills owing to the current environmental regulations. Among all valorisation possibilities (livestock feed, energy valorisation, composting, bioethanol production), anaerobic digestion for methane generation appears as the most technically and environmentally sound. However, the citrus essential oils can inhibit the biological process of anaerobic digestion. In chapter 2, the characteristics of citrus essential oils, as well as the mechanisms of their antimicrobial effects and the potential adaptation mechanisms are reviewed. Previous studies of anaerobic digestion of citrus waste in different conditions are presented, but some controversy exists on the limiting dosage of limonene to achieve a stable process. Finally, 
several available strategies to avoid process inhibition by citrus essential oil are summarized.

In chapter 3, the anaerobic digestion process inhibition by limonene, the main component of citrus essential oils (CEO) present in citrus peel, is studied.

The biochemical methane potential (BMP) of different types of citrus waste (orange peel, mandarin peel, mandarin pulp and rotten fruit) was tested, being the results in the range 354-398 $\mathrm{L}^{-\mathrm{kg}_{\mathrm{Vs}}}{ }^{-1}$. Grinding the orange peel $\left(2.5 \mathrm{~g}_{\text {limonene }} \cdot \mathrm{kg}^{-1}\right)$ did not influence the BMP values, but slowed the kinetics, due to the increased availability of CEO caused by the grinding.

The effect of limonene $\left(0-3000 \mathrm{mg} \cdot \mathrm{L}^{-1}\right)$ on the batch anaerobic digestion of microcrystalline cellulose was also assessed. The minimum inhibitory concentration was $200 \mathrm{mg} \cdot \mathrm{kg}^{-1}$. The half maximal inhibitory concentration, $\mathrm{IC}_{50}$, was $423 \mathrm{mg} \cdot \mathrm{kg}^{-1}$ in an initial run and $669 \mathrm{mg} \cdot \mathrm{kg}^{-1}$ in a second run of batch experiments. The methane course and $\mathrm{IC}_{50}$ values indicate that there is a reversible inhibition and certain biomass adaptation during the anaerobic digestion process, despite the non-reversible antimicrobial mechanism described in the literature for limonene to date.

In chapter 4, three different strategies to avoid inhibition of the anaerobic digestion of orange peel by limonene were assessed in terms of reduction of limonene concentration and effect on the methane potential and production rate. The strategies tested were based on removal (biological treatment) or recovery (steam distillation and ethanol extraction) of the essential oil of the peel. All treatments decreased the limonene concentration in the orange peel with efficiencies of $22 \%, 44 \%$ and $100 \%$ for the biological pretreatment, steam distillation and ethanol extraction, respectively. Methane potential and production rate in the batch anaerobic digestion of the treated orange peel were not affected by the biological treatment, but an increase was observed after steam distillation under certain conditions and also after ethanol extraction. Since the initial limonene concentration in the batch anaerobic digesters was always under the minimum inhibitory concentration, this effect was attributed to the removal of minority compounds of the citrus essential oil. Energy balance was negative for steam distillation and positive for the other two tested strategies.

In chapter 5, anaerobic co-digestion of citrus waste (orange and mandarin peel) was carried out with chicken and pig manure, in order to improve the nutrients balance and to reduce the concentration of the essential oil in the mixture.

Different proportions of the four substrates were used, leading to different concentrations of limonene and also of the minority compounds of citrus essential oil, which are known to modulate the inhibitory effect of limonene. Two levels of limonene concentrations were tested: $3.1 \pm 0.9 \mathrm{~g} \cdot \mathrm{kg}^{-1}$ and $1.4 \pm 0.4 \mathrm{~g} \cdot \mathrm{kg}^{-1}$. At the lower limonene concentration, two different compositions of citrus waste were tested: $1: 1$ and 1:1.5 of orange peel and mandarin peel (volatile solids basis). The maximum stable organic loading rate (OLR) reached for the mixture with higher limonene concentration was $1.01 \mathrm{~kg}_{\mathrm{VS}} \cdot \mathrm{m}^{-3} \cdot \mathrm{d}^{-1}$. The lower limonene concentration mixture allowed reaching higher OLR of $2.2 \mathrm{~kg}_{\mathrm{vs}} \cdot \mathrm{m}^{-3} \cdot \mathrm{d}^{-1}$ corresponding to a limonene dose of $27 \mathrm{mg} \cdot \mathrm{L}_{\text {digester }}{ }^{-1} \cdot \mathrm{d}^{-1}$. The methane yield at these 
conditions was $0.23 \mathrm{~m}^{3} \cdot \mathrm{kg}_{\mathrm{Vs}}{ }^{-1}$. At the lower limonene concentration, the citrus waste composition had an effect on the maximum OLR, being lower for the mixture with higher content of orange peel vs. mandarin peel.

Systemic inhibition was observed in the mixture with higher limonene concentration, with symptoms of inhibition on methanogenesis, protein hydrolysis pathway, sulphate reduction, and acetogenesis. Acetogenesis was inhibited in all mixtures but at different limonene doses.

The rate of increase of the limonene dose was related to the maximum reachable OLR. The degradation of the limonene produced inhibitory compounds as well, causing the inhibitory effect to persist even after almost complete limonene degradation.

In chapter 6, anaerobic co-digestion of citrus fruit, with and without pretreatment, was carried out with cow manure, which brought alkalinity and nutrients to the mixture. The pretreatment consisting in mechanical removal of the flavedo allowed reaching a higher organic loading rate and methane production in a stable manner $\left(4.12 \mathrm{~kg}_{\mathrm{vs}} \cdot \mathrm{m}^{-3} \cdot \mathrm{d}^{-1}, 120\right.$ $\left.\mathrm{L}_{\mathrm{CH} 4} \cdot \mathrm{kg}_{\mathrm{VS}}{ }^{-1}, \quad 0.49 \mathrm{~m}_{\mathrm{CH} 4}{ }^{3} \cdot \mathrm{m}_{\text {digester }}{ }^{-3} \cdot \mathrm{d}^{-1}\right)$ than the experiments without treatment $(2.72$ $\left.\mathrm{kg}_{\mathrm{Vs}} \cdot \mathrm{m}^{-3} \cdot \mathrm{d}^{-1}, 111 \mathrm{~L}_{\mathrm{CH} 4} \cdot \mathrm{kg}_{\mathrm{Vs}}{ }^{-1}, 0.33 \mathrm{~m}_{\mathrm{CH} 4}{ }^{3} \cdot \mathrm{m}_{\text {digester }}{ }^{-3} \cdot \mathrm{d}^{-1}\right)$ or with thermal treatment $(2.96$ $\left.\mathrm{kg}_{\mathrm{VS}} \cdot \mathrm{m}^{-3} \cdot \mathrm{d}^{-1}, 123 \mathrm{~L}_{\mathrm{CH} 4} \cdot \mathrm{kg}_{\mathrm{VS}}{ }^{-1}, 0.36 \mathrm{~m}_{\mathrm{CH} 4}{ }^{3} \cdot \mathrm{m}_{\text {digester }}{ }^{-3} \cdot \mathrm{d}^{-1}\right)$.

In chapter 7, anaerobic co-digestion of orange peel was carried out with cow manure, in order to provide enough nutrients and buffer capacity to the digester. Three different strategies were tested to avoid the expected inhibition by citrus essential oil: long adaptation times, biological treatment by fungi of the orange peel and ethanol extraction of the limonene from the orange peel.

Neither the long adaptation times, nor the biological treatment, allowed for a stable process with a mixture composition of $80 \%$ orange peel and $20 \%$ cow manure (volatile solids basis). On the contrary, the ethanol extraction of the limonene previously to the anaerobic co-digestion of $95 \%$ orange peel and $5 \%$ cow manure (volatile solids basis) allowed to reach a stable process until an organic loading rate of $3.5 \mathrm{~kg} \mathrm{vs}^{-3} \mathrm{~m}^{-3} \cdot \mathrm{d}^{-1}$, with a methane yield of $286 \mathrm{~L} \cdot \mathrm{kg}_{\mathrm{VS}}{ }^{-1}$ and $0.99 \mathrm{~m}^{3} \cdot \mathrm{m}_{\text {digester }}{ }^{-3} \cdot \mathrm{d}^{-1}$. At higher organic loading rates, accumulation of volatile fatty acids was observed due to organic overloading, but not due to inhibition by citrus essential oil.

\subsection{References}

Akao, T., Mizuki, E., Saito, H., Okumura, S., 1992. The methane fermentation of Citrus unshu peel pretreated with fungus enzymes. Biores. Technol. 41, 35-39.

Arce, A., Marchiaro, A., Soto, A., 2004. Liquid-liquid equilibria of linalool + ethanol + water, water + ethanol + limonene, and limonene + linalool + water systems. J. Solut. Chem. 33, 561-569.

Arce, A., Marchiaro, A., Martínez-Ageitos, J.M., Soto, A., 2005. Citrus essential oil deterpenation by liquid-liquid extraction. Can. J. Chem. Eng. 83, 366-370.

Bakkali, F., Averbeck, S., Averbeck, D., Idaomar, M., 2008. Biological effects of essential oils - a review. Food Chem. Toxicol. 46, 446-475. 
Boluda-Aguilar, M., López-Gómez, A., 2013. Production of bioethanol by fermentation of lemon (Citrus limon L.) peel wastes pretreated with steam explosion. Ind. Crop. Prod. 41, 188-197.

CAPA (2011). Informe del sector agrario valenciano 2011. Capítulo IV: estadísticas agrícolas. Cuadro 4.12: superficies, producciones y destino de la producción de cítricos. Comunitat Valenciana. Campaña 2010/2011. Conselleria de Agricultura, Pesca y Alimentación.

Castillejos, L., Calsamiglia, S., Ferret, A., 2006. Effect of essentials oil active compounds on rumen microbial fermentation and nutrient flow in in vitro systems. J. Dairy Sci. 89, 2649-2658.

Cavinato, C., Fatone, F., Bolzonella, D., Pavan, P., 2010. Thermophilic anaerobic codigestion of cattle manure with agro-wastes and energy crops: comparison of pilot and full scale experiences. Bioresour. Technol. $101,545-550$.

Crane, A., Nelson, W.O., Brown, R.E., 1957. Effects of D-limonene and a-D-pinene on in vitro carbohydrate dissimilation and methane formation by rumen bacteria. J. Dairy Sci. 40, 1317-1323.

Di Pasqua, R., Hoskins, N., Betts, G., Mauriello, G., 2006. Changes in membrane fatty acids composition of microbial cells induced by addition of thymol, carvacrol, limonene, cinnamaldehyde, and eugenol in the growing media. J. Agric. Food Chem. 54, 2745-2749.

Di Pasqua, R., Betts, G., Hoskins, N., Edwards, M., Ercolini, D., Mauriello, G., 2007. Membrane toxicity of antimicrobial compounds from essential oils. J. Agric. Food Chem. 55, 4863-4870.

Harder, J., Probian, C., 1995. Microbial degradation of monoterpenes in the absence of molecular oxygen. Appl. Environ. Microbiol. 61, 3804-3808.

Karellas, S., Boukis, I., Kontopoulos, G., 2010. Development of an investment decision tool for biogas production from agricultural waste. Renew. Sustain. Energy Rev. 14, 1273-1282.

Lane, A.G., 1983. Removal of peel oil from citrus peel press liquors before anaerobic digestion. Environ. Technol. Lett. 4, 65-72.

Lane, A.G., 1984. Anaerobic digestion of orange peel. Food Technol. Aust. 36, 125-127.

Lohrasbi, M., Pourbafrani, M., Niklasson, C., Taherzadeh, M.J., 2010. Process design and economic analysis of a citrus waste biorefinery with biofuels and limonene as products. Biores. Technol. 101, 7382-7388.

Martín, M.A., Siles, J.A., Chica, A.F., Martín, A., 2010. Biomethanization of orange peel waste. Biores. Technol. 101, 8993-8999.

Mizuki, E., Akao, T., Saruwatari, T., 1990. Inhibitory effect of Citrus unshu peel on anaerobic digestion. Biol. Wastes 33, 161-168.

Moufida, S., Marzouk, B., 2003. Biochemical characterization of blood orange, sweet orange, lemon, bergamot and bitter orange. Phytochem. 62, 1283-1289.

Sánchez-Segado, S., Lozano, L.J., de los Ríos, A.P., Hernández-Fernández, F.J., Godínez, C., Juan, D., 2012. Process design and economic analysis of a hypothetical bioethanol production plant using carob pod as feedstock. Biores. Technol. 104, 324-328.

Sorda, G., Sunak, Y., Madlener, R., 2013. An agent-based spatial simulation to evaluate the promotion of electricity from agricultural biogas plants in Germany. Ecol. Econ. 89, 43-60.

Srilatha, H.R., Nand, K., Sudhakar Babu, K., Madhukara, K., 1995. Fungal pretreatment of orange processing waste by solid-state fermentation for improved production of methane. Proc. Biochem. 30, 327-331.

Wikandari, R., Nguyen, H., Millati, R., Niklasson, C., Taherzadeh, M.J., 2013. A novel method of orange wastes pretreatment for biogas production. WASTES: Solutions, Treatments and Opportunities. In: 2nd International Conference. Braga (Portugal), September 11th-13th 2013. 


\title{
Chapter 2
}

\section{Citrus essential oils and their influence on the anaerobic digestion process. An overview}

\begin{abstract}
Citrus waste accounts for more than half of the whole fruit when processed for juice extraction. Among valorisation possibilities, anaerobic digestion for methane generation appears to be the most technically feasible and environmentally friendly alternative. However, citrus essential oils can inhibit this biological process. In this paper, the characteristics of citrus essential oils, as well as the mechanisms of their antimicrobial effects and potential adaptation mechanisms are reviewed. Previous studies of anaerobic digestion of citrus waste under different conditions are presented; however, some controversy exists regarding the limiting dosage of limonene for a stable process (24-192 mg of citrus essential oil per liter of digester and day). Successful strategies to avoid process inhibition by citrus essential oils are based either on recovery or removal of the limonene, by extraction or fungal pre-treatment respectively.
\end{abstract}

This chapter has been published as:

Ruiz B., Flotats X., 2014. Citrus essential oils and their influence on the anaerobic digestion process: An overview. Waste Management 34, 2063-2079.

http://dx.doi.org/10.1016/j.wasman.2014.06.026 


\section{Table of contents}

2.1 Introduction ............................................................................................................. 15

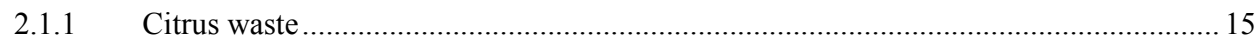

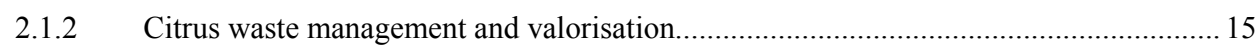

2.2 Citrus essential oils (CEOs) ....................................................................................... 17

2.2.1 General characteristics of citrus essential oils .............................................................. 17

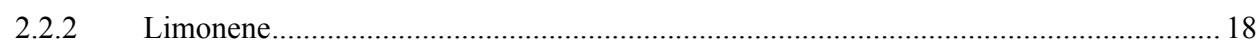

2.3 Antimicrobial effect of citrus essential oils ............................................................... 23

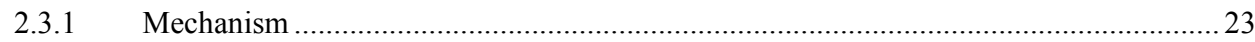

2.3.2 Factors affecting the antimicrobial effect of essential oils...........................................25

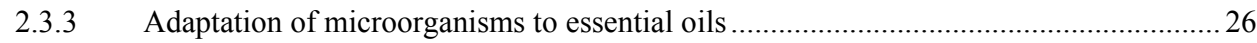

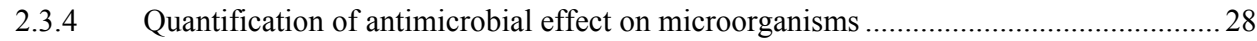

2.3.5 Microorganisms resistant to citrus essential oils: biotransformation of limonene .......... 34

2.4 Effect of citrus essential oils on the anaerobic digestion process ........................... 36

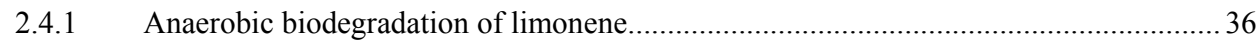

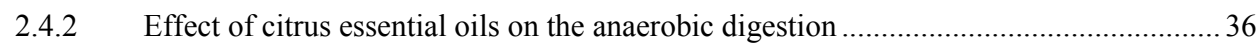

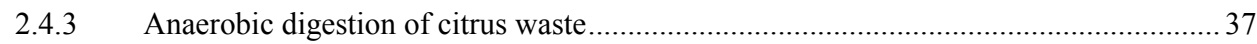

2.4.4 Summary of the effect of citrus essential oils on the anaerobic digestion process.......... 40

2.5 Pre-treatments for recovery or removal of citrus essential oils .............................. 42

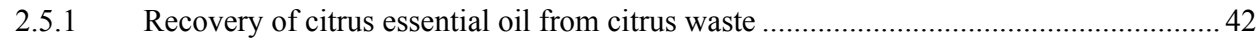

2.5.2 Removal of citrus essential oil from citrus waste ......................................................... 42

2.6 Conclusions ............................................................................................................................ 43

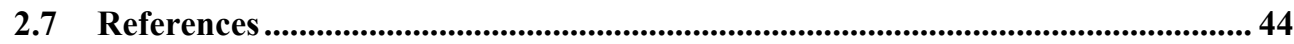




\subsection{Introduction}

\subsubsection{Citrus waste}

Citrus waste mainly consists of: (a) waste generated by the juice manufacturing industry, consisting in peel and pressed pulp; (b) fruits discarded for commercial reasons (damaged fruit, as example); and (c) fruits discarded due to regulations that limit production. This material is not allowed to enter the food chain and therefore is considered to be waste.

The amount of waste generated depends on the harvest, since it is a fraction of the total amount of fruit produced. Citrus processing for juice extraction produces around 500 tonnes of waste per 1000 tonnes of fruit processed (Lane, 1983a; Lohrasbi et al., 2010). The percentage of fruit discarded due to commercial or regulatory issues is more difficult to calculate, but it ranges from $2 \%$ to $10 \%$ depending on the type of citrus considered and environmental aspects, such as weather conditions. The most recent data correspond to the $2010 / 2011$ season, when the total citrus production in the region of Valencia (eastern Spain) was 3.5 million of tons. Of this, around 0.4 million of tonnes $(11 \%$ of the total production) was reported as losses. Another 0.4 million of tonnes was used in the industry, which could be expected to produce around 0.2 million of tonnes of waste (CAPA, 2011).

\subsubsection{Citrus waste management and valorisation}

Citrus waste typically has a low pH (3-4), high water content (around 80-90\%) and high organic matter content (around 95\% of total solids). These characteristics mean that citrus waste should not be disposed of in landfills according to the European regulations (Council Directive 2008/98/EC of 10 November 2008 on waste). Traditionally, citrus waste from the juice manufacturing industry has been used as livestock feed, thanks to its nutritive value, which is similar to that of barley grains or sugar beet pulp. This is due to its high carbohydrate content, the significant proportion of cell wall components and its low degree of lignification (see Table 2.1). However, the juice manufacturing companies are currently facing waste management difficulties due to the market saturation.

Non-hazardous waste management schemes do not usually accept citrus waste for composting, due to its low $\mathrm{pH}$, the presence of essential oils that inhibit the composting process and the fast biodegradation of this waste, which can cause anaerobiosis problems in compost piles.

Thermal treatment alternatives (incineration, gasification or pyrolysis) cannot be applied to citrus waste due to its high water content. Although they would be technically feasible, they would not be efficient from an energy or an economic point of view, since a previous dehydration step would be necessary.

The manufacture of bioethanol from citrus waste has recently been evaluated as a valorisation alternative. A bioethanol yield of 50-60 L-tonne ${ }^{-1}$ of waste (Boluda-Aguilar and López-Gómez, 2013) was obtained, equivalent to 294-352 $\mathrm{kWh} \cdot$ tonne $^{-1}$ of waste. 
However, the investment necessary to set up a bioethanol plant is great: around 600 $€ \cdot$ tonne $^{-1}$ of waste treated per year (Sánchez-Segado et al., 2012), compared with the 75-200 € tonne $^{-1} \cdot$ year $^{-1}$ necessary for a biogas plant (Cavinato et al., 2010; Karellas et al., 2010; Sorda et al., 2013). From the perspective of energy, this valorisation option is not as efficient as methane (biogas) production through the anaerobic digestion of citrus waste. The biochemical methane potential (BMP) of citrus peel is between 0.46 and 0.64 $\mathrm{m}_{\mathrm{CH} 4}^{3} \cdot \mathrm{kg}_{\mathrm{vs}}{ }^{-1}$ (Gunaseelan, 2004; Kaparaju and Rintala, 2006; Koppar and Pullammanappallil, 2013). That is equivalent to $78-110 \mathrm{~m}_{\mathrm{CH} 4}^{3}$ tonne $^{-1}$ of waste with $18 \%$ total solids (TS) and 95\% volatile solids (VS, dry matter basis) and to 737-1040 $\mathrm{kWh} \cdot$ tonne $^{-1}$ of waste: 1.5-2 times higher than the values obtained with bioethanol. In addition, by using co-digestion strategies, other by-products could be co-treated with the orange waste, thereby contributing to integral waste management within the producing area. The methane production in the mesophilic semi-continuous anaerobic digestion of citrus waste ranges between 0.21 and $0.29 \mathrm{~m}_{\mathrm{CH} 4}^{3} \mathrm{~kg}_{\mathrm{Vs}}{ }^{-1}$ (Lane, 1984; Srilatha et al., 1995). Higher values of $0.3-0.6 \mathrm{~m}_{\mathrm{CH} 4}^{3} \cdot \mathrm{kg}_{\mathrm{vs}}{ }^{-1}$ have been reported at thermophilic conditions (Kaparaju and Rintala, 2006; Martín et al., 2010).

For all these reasons, anaerobic digestion is a sound alternative for valorisation of citrus waste. However, its citrus essential oil (CEO) content inhibits the bioprocess. The objective of the present work is to review the effect of CEO on the anaerobic digestion and to analyse the pre-treatments that make it feasible.

Table 2.1. Chemical composition of citrus pulp.

\begin{tabular}{|c|c|c|c|c|c|c|c|}
\hline Parameter (units) & $\begin{array}{c}\text { Citrus } \\
\text { pulp }\end{array}$ & $\begin{array}{c}\text { Dried } \\
\text { citrus pulp }\end{array}$ & $\begin{array}{c}\text { Citrus } \\
\text { pulp }\end{array}$ & $\begin{array}{l}\text { Citrus pulp } \\
\text { silage }\end{array}$ & $\begin{array}{c}\text { Orange } \\
\text { waste }\end{array}$ & $\begin{array}{c}\text { Orange } \\
\text { peel }\end{array}$ & $\begin{array}{c}\text { Orange } \\
\text { peel }\end{array}$ \\
\hline References & $\begin{array}{c}\text { De Blas } \\
\text { et al., } \\
2010\end{array}$ & $\begin{array}{c}\text { Bampidis \& } \\
\text { Robinson, } \\
2006\end{array}$ & $\begin{array}{l}\text { Calsamiglia } \\
\text { et al., } 2004\end{array}$ & $\begin{array}{c}\text { Bampidis\& } \\
\text { Robinson, } \\
2006\end{array}$ & $\begin{array}{c}\text { Mahmood } \\
\text { et al., } \\
1998\end{array}$ & $\begin{array}{c}\text { Kammoun } \\
\text { Bejar et } \\
\text { al., } 2012\end{array}$ & $\begin{array}{c}\text { Morton, } \\
1987\end{array}$ \\
\hline Water content $(\%)$ & 10.8 & 11.7 & 82.5 & 79.0 & 79.02 & 74.8 & 72.5 \\
\hline Ashes (\% d.m.) & 7.1 & 5.87 & 6.25 & 5.5 & 3.78 & 3.313 & $2.9 \cdot 10^{-3}$ \\
\hline Protein (\% d.m.) & 6.4 & 7.37 & 8.29 & 7.3 & 6.53 & 8.015 & 5.45 \\
\hline Fat (\% d.m.) & 1.6 & 3.43 & 3.32 & 9.7 & - & 0.955 & 0.73 \\
\hline Fibre (\% d.m.) & 13.3 & - & 14.1 & - & 10.59 & 42.129 & - \\
\hline Starch (\% d.m.) & 0.5 & - & 2.90 & - & $<1.00$ & - & - \\
\hline Sugar (\% d.m.) & 22.8 & - & 20.3 & - & 15.00 & 46.649 & - \\
\hline $\mathrm{pH}$ & - & - & 3.93 & - & 4.30 & - & - \\
\hline $\mathrm{Ca}(\%$ d.m.) & 1.50 & 1.49 & 0.93 & 2.04 & - & 1.201 & 0.58 \\
\hline $\mathrm{P}(\%$ d.m.) & 0.12 & 0.35 & 0.15 & 0.15 & - & - & 0.07 \\
\hline $\mathrm{Na}(\%$ d.m. $)$ & 0.08 & 0.08 & 0.08 & 0.09 & - & 0.312 & 0.01 \\
\hline $\mathrm{Cl}$ (\% d.m.) & 0.05 & 0.08 & 0.05 & & - & - & - \\
\hline $\operatorname{Mg}(\%$ d.m. $)$ & 0.14 & 0.15 & 0.14 & 0.16 & - & 0.156 & - \\
\hline $\mathrm{K}(\%$ d.m.) & 0.85 & 2.51 & 0.68 & 0.62 & - & 0.222 & 0.77 \\
\hline S (\% d.m.) & 0.11 & 0.07 & 0.13 & 0.02 & - & - & - \\
\hline $\mathrm{Cu}$ (mg/kg d.m.) & 6.0 & 6.7 & - & 6 & - & 11.28 & - \\
\hline $\mathrm{Fe}$ (mg/kg d.m.) & 220 & 230 & - & 160 & - & 15.85 & 8 \\
\hline Mn (mg/kg d.m.) & 12 & 7.7 & - & 7 & - & - & - \\
\hline $\mathrm{Zn}$ (mg/kg d.m.) & 9 & 14 & - & 16 & - & 18.67 & - \\
\hline Co (mg/kg d.m.) & - & 0.16 & - & 0.16 & - & - & - \\
\hline
\end{tabular}

"_": no data available at the referred paper. 


\subsection{Citrus essential oils (CEOs)}

\subsubsection{General characteristics of citrus essential oils}

CEO are liquids that contain, among other components, the volatile aroma compounds of citrus plants. They are found in small vesicles located in the flavedo or exocarp of citrus fruit (see Figure 2.1). Their antimicrobial properties are well known and have been reported and used for medicinal purposes since at least the $4^{\text {th }}$ century (Fisher and Phillips, 2008).

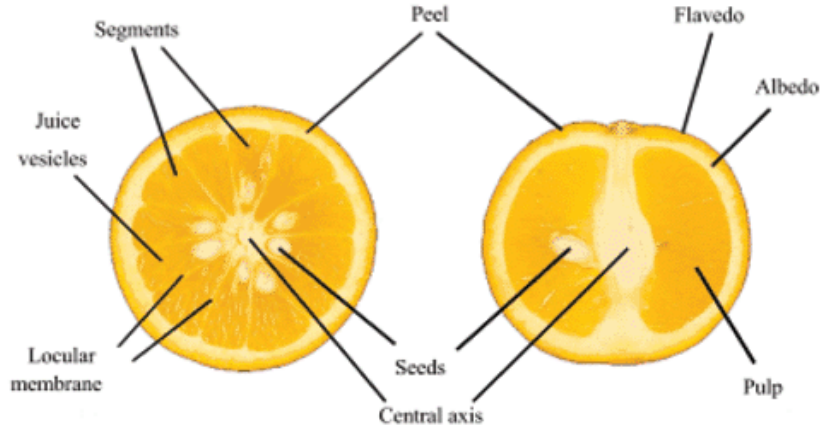

Figure 2.1. $\quad$ Structure of citrus (Iglesias et al., 2007).

The composition of CEO varies markedly according to variety, the seasonality (see Figure 2.2), geographical origin and the ripeness of the fruit (Burt, 2004; Fisher and Phillips, 2008; Droby et al., 2008). Nevertheless, several common characteristics can be outlined.

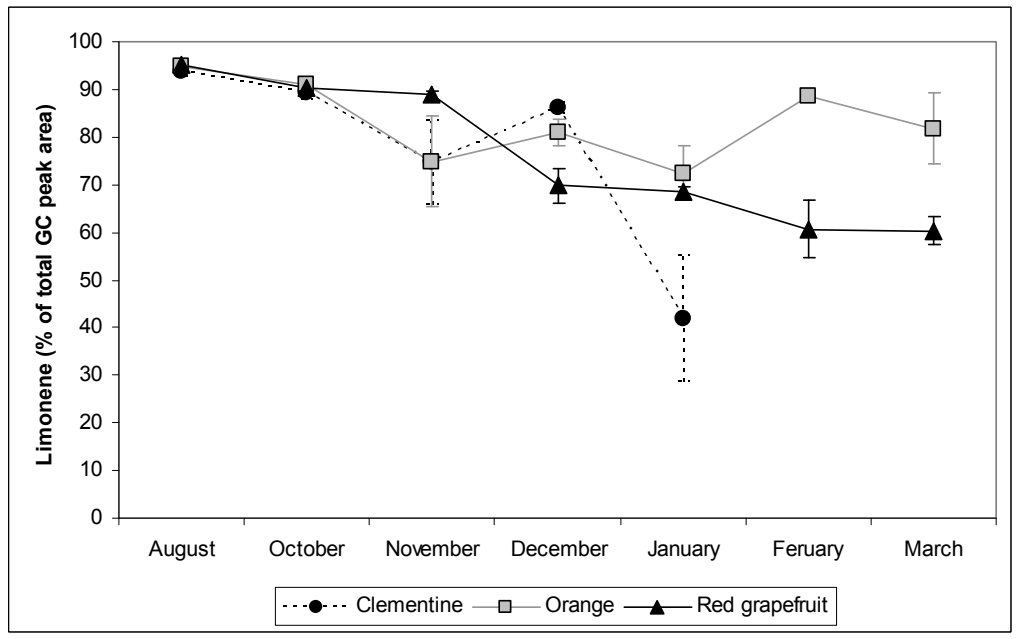

Figure 2.2. Seasonal variation of limonene concentration in the essential oil of clementine (Citrus reticulata), orange (Citrus sinensis) and red grapefruit (Citrus paradise) (based on data from Droby et al., 2008). Vertical bars indicate standard error. 
CEO contain an extremely wide variety of compounds. Usually, the number of components varies between 20 and 60 (Bakkali et al., 2008). Of these, $85-99 \%$ are volatile compounds: the remaining $1-15 \%$ are non volatile compounds. The volatile compounds are a mixture of monoterpenes (limonene, among others), sesquiterpenes and sesquiterpenoids such as aldehydes (citral), ketones, acids, alcohols (linalool) and esters (Smith et al., 2001). The major components are monoterpenes, combinations of two isoprene $\left(\mathrm{C}_{5} \mathrm{H}_{8}\right)$ molecules, which account for around $97 \%$ of the CEO; alcohols, aldehydes and esters, represent a further 1.8-2.2\% of the CEO (Fisher and Phillips, 2008; Moufida and Marzouk, 2003).

Several references of the chemical composition of different CEO are summarised in Table 2.2. The main component is limonene. Its concentration in the essential oil may vary between 32 and $98 \%$, depending on the variety: $32-45 \%$ in bergamot, $45-76 \%$ in lemon and 68-98\% in sweet orange (Moufida and Marzouk, 2003).

Since the main component of CEO is limonene, the chemical, physical and biological properties of this compound greatly affect the properties of the CEO (Bakkali et al., 2008). For this reason, the documented antimicrobial effect of CEO can be found attributed to the essential oil or to limonene as well, as its main component.

\subsubsection{Limonene}

Limonene is a monoterpene whose empirical formula is $\mathrm{C}_{10} \mathrm{H}_{16}$. It is a colourless liquid at room temperature. It exists as two optical isomers D- and L-limonene, and the racemic mixture called dipentene (WHO, 1998). Other synonyms for D-limonene are R-(+)-limonene, (+)-carvene, (R)-4-isopropenyl-1-methyl-1-cyclohexene and $(+)$-p-mentha-1,8-diene, and for L-limonene the synonyms are S-(-)-limonene, (-)-carvene, (S)-4-isopropenyl-1-methyl-1-cyclohexene and (-)-p-mentha-1,8-diene (Duetz et al., 2003).

The fragrance of limonene differs depending on the isomer. D-limonene has an orange fragrance, while the fragrance of L-limonene is that of turpentine (de Carvalho and da Fonseca, 2006). The physical and chemical properties of limonene are outlined in Table 2.5. The structural formula of limonene is shown in Figure 2.3.

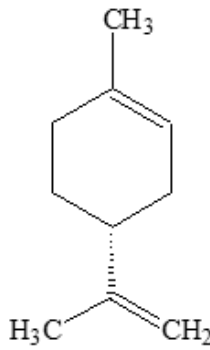

(R)

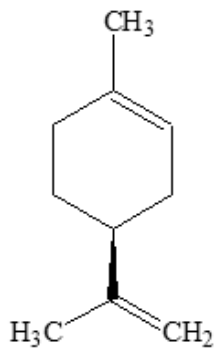

(S)

Figure 2.3. Molecular formula of limonene. 
Table 2.2. Chemical composition of citrus essential oils (\%).

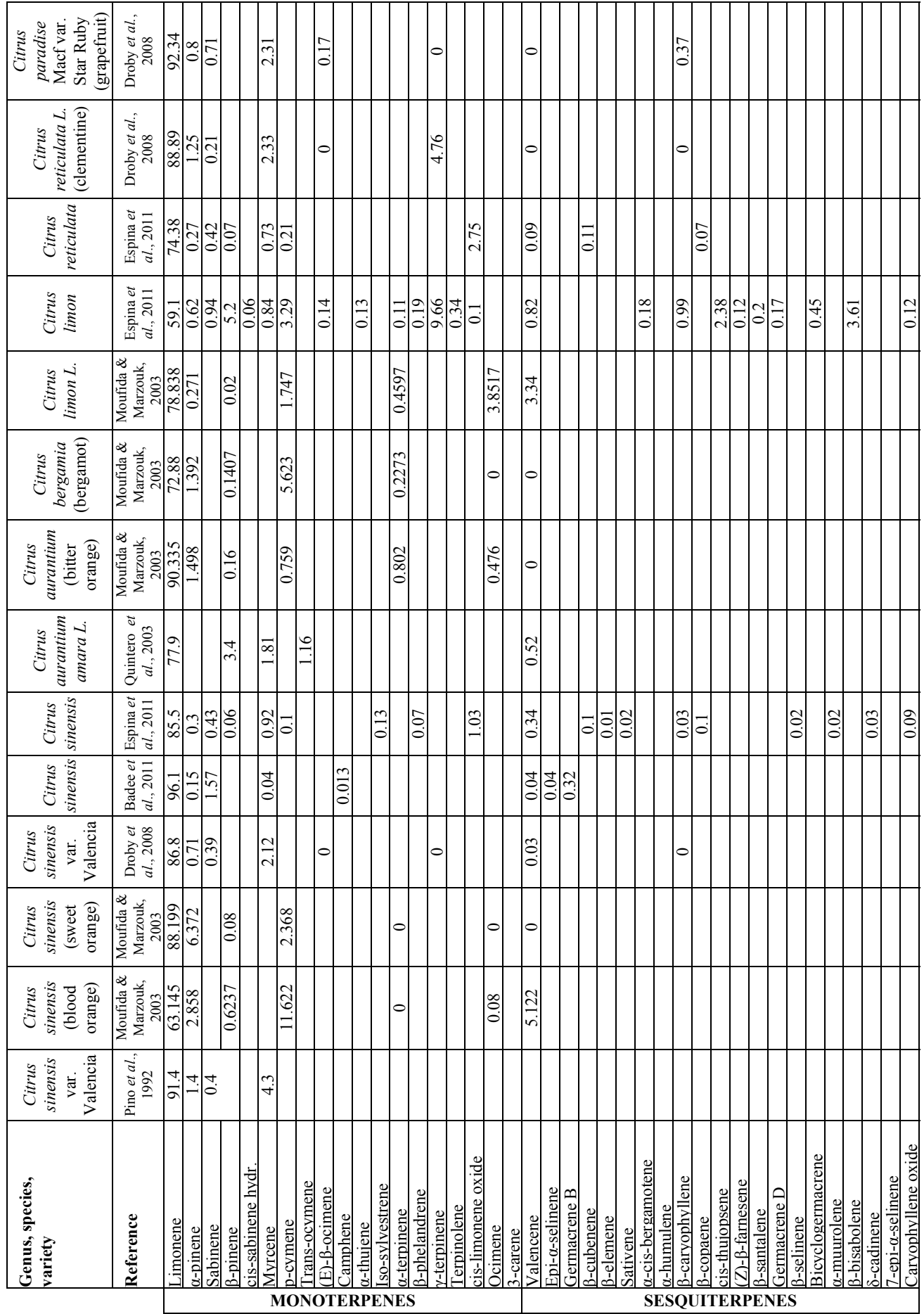


Table 2.3. Chemical composition of citrus essential oils (\%) (continued).

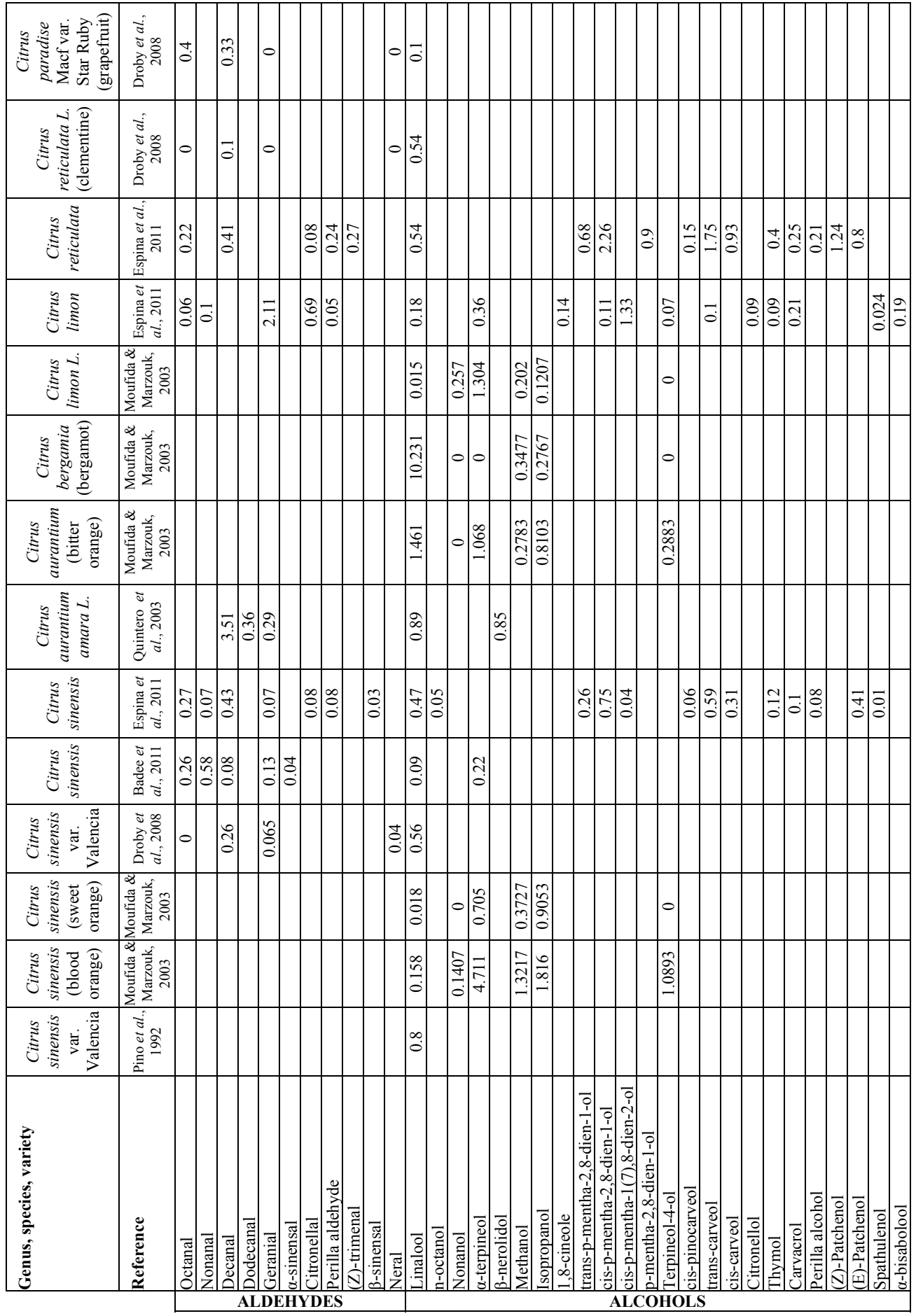


Table 2.4. Chemical composition of citrus essential oils (\%) (continued).

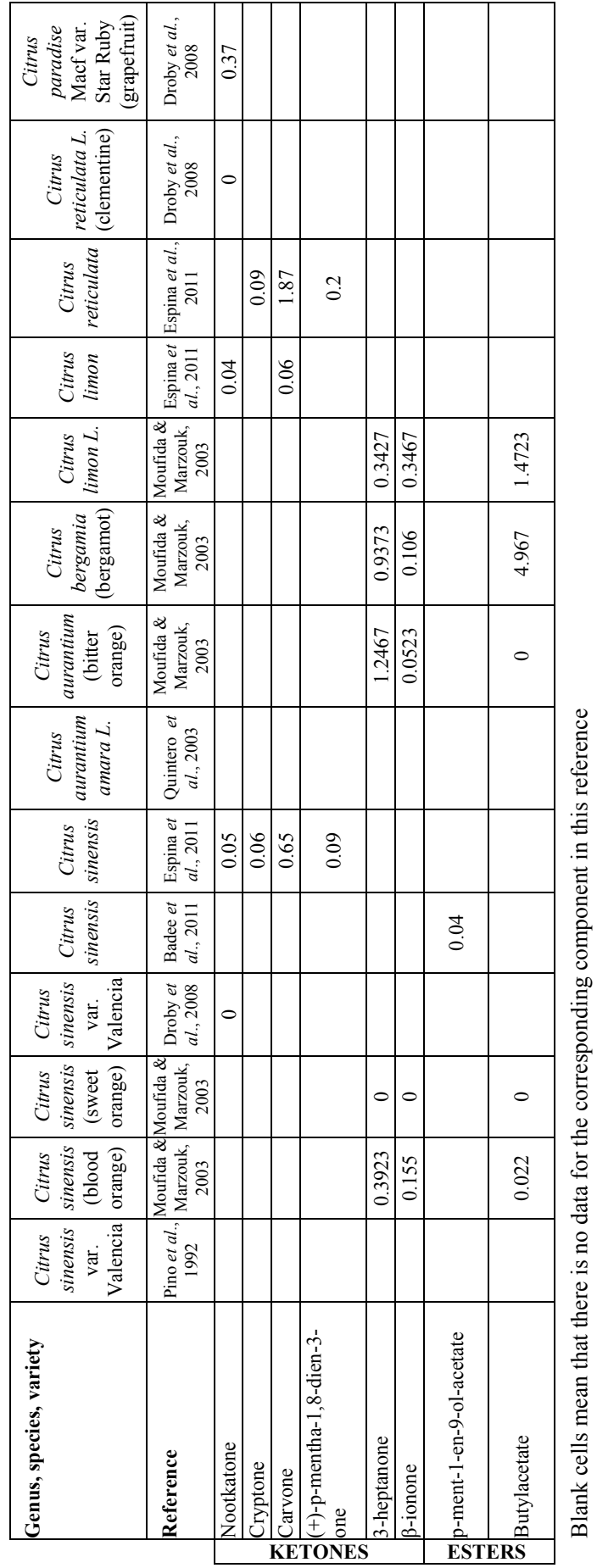


Table 2.5. Physical and chemical properties of limonene (WHO, 1998; Sikkema et al., 1995; Hazra et al., 2002).

\begin{tabular}{|l|l|}
\hline Molecular weight & 136.23 \\
\hline Melting point $\left({ }^{\circ} \mathrm{C}\right)$ & -74.35 \\
\hline Boiling point $\left({ }^{\circ} \mathrm{C}\right)$ & $175.5-176.0$ \\
\hline Density $\left(\mathrm{g} \cdot \mathrm{cm}^{-3}\right.$ at $\left.20^{\circ} \mathrm{C}\right)$ & 0.84 \\
\hline Vapour pressure $\left(\mathrm{Pa}\right.$ at $\left.20^{\circ} \mathrm{C}\right)$ & 190 \\
\hline Water solubility $\left(\mathrm{mg} \cdot \mathrm{L}^{-1}\right.$ at $\left.25^{\circ} \mathrm{C}\right)$ & 13.8 \\
\hline Henry's law constant $\left(\mathrm{kPa} \mathrm{m}^{3} \cdot \mathrm{mol}^{-1}\right.$ at $\left.25^{\circ} \mathrm{C}\right)$ & 34.8 \\
\hline Log $\mathrm{K}_{\text {Ow }}$ & 4.23 \\
\hline Log P & 4.46 \\
\hline Activation energy $\left(\mathrm{kJ} \cdot \mathrm{mol}^{-1}\right)$ & 37.87 \\
\hline
\end{tabular}

Limonene does not have any functional groups available for hydrolysis; its cyclohexene ring and ethylene group are chemically resistant to hydrolysis. Biological degradation has been observed in some species of microorganisms, such as Penicillium digitatum, Corynespora cassiicola, Diplodia gossypina and a soil strain of Pseudomonas sp. (Dhavalikar and Bhattacharyya, 1966; Shulka and Bhattacharayya, 1968). Standard aerobic degradation tests show that limonene is aerobically up to $94 \%$ biodegradable in 14 days (Schwartz et al., 1990). Nevertheless, part of the disappearance of limonene may be due to evaporation, as it is difficult to assess the relative importance of this way of removal during the tests. Anaerobic biodegradation of low concentrations of limonene $\left(35-200 \mathrm{mg} \cdot \mathrm{L}^{-1}\right)$ has been also tested at $30^{\circ} \mathrm{C}$ with granular sludge, but no evidence of any metabolism of limonene was observed, which was attributed to toxicity of the limonene to the microorganisms (Sierra-Álvarez et al., 1990). Further discussion on the biodegradation of limonene is provided in Sections 2.3 and 2.4.

The water solubility of limonene is very low $\left(0.101 \mathrm{mmol} \cdot \mathrm{L}^{-1}\right.$ at $\left.25^{\circ} \mathrm{C}\right)$, since it is a hydrophobic molecule. It is less soluble than other hydrocarbons, such as benzene (22.9 $\left.\mathrm{mmol} \cdot \mathrm{L}^{-1}\right)$, toluene $\left(6.28 \mathrm{mmol} \cdot \mathrm{L}^{-1}\right)$ or cyclohexane $\left(0.683 \mathrm{mmol} \cdot \mathrm{L}^{-1}\right)$. Similarly, the partition coefficient $(\log \mathrm{P}, 4.46)$ of limonene is much higher than $\log \mathrm{P}$ of the above mentioned hydrocarbons: 2.13, 2.69 and 3.44 for benzene, toluene and cyclohexane, respectively (Sikkema et al., 1995). Since the partition coefficient is the ratio of concentrations of a compound in the two phases of a mixture of two immiscible solvents at equilibrium (in this case, octanol and water), this indicates that the hydrophobic (lipophilic) nature of limonene is even stronger than that of conventional hydrophobic solvents. Another important characteristic of limonene is its high volatility $\left(37.87 \mathrm{~kJ} \cdot \mathrm{mol}^{-1}\right.$ activation energy). This is a common feature of CEO; for example, the activation energy of lemon essential oil is $33.2 \mathrm{~kJ} \cdot \mathrm{mol}^{-1}$, which means that this substance is highly volatile (Hazra et al., 2002).

The main industrial use of limonene is as precursor to carvone or $\alpha$-terpineol (Badee et al., 2011). Other uses of limonene are as a fragrance in cosmetics and food products, as a 
component in industrial solvents and aromatherapy (Bakkali et al., 2008). The extraction method differs depending on the final application. Thus, for pharmaceutical and food uses, the preferred extraction methods are steam distillation and cold expression. For perfume uses, other methods such as extraction with lipophilic solvents or supercritical fluids are used (Bakkali et al., 2008).

\subsection{Antimicrobial effect of citrus essential oils}

\subsubsection{Mechanism}

To explain the mechanism of the antimicrobial effect of essential oils, it is first important to understand how the compounds in them interact with microorganisms. All the components of CEO are hydrocarbons, and most of them have one or more carbon cycles in their structure. Most cyclic hydrocarbons are hydrophobic; which is of great importance for the mode of action of these compounds on microorganisms.

The antimicrobial activity of terpenes and terpenoids (cyclic hydrocarbons) is due mainly to their interaction with the cell membrane (Bakkali et al., 2008; Dorman and Deans, 2000; Griffin et al., 1999).

To reach a microorganism, a compound must undergo several phases. First, it has to be dissolved in the aqueous medium surrounding the microorganism. Hydrophobic compounds such as essential oils have low water solubility, so their bioavailability is low. Nevertheless, it has been demonstrated that the dissolution rates of some hydrocarbons were higher in the presence of bacteria than in sterile controls (Thomas et al., 1986), due to surface-active compounds produced by microorganisms which cause emulsification in the cell environment, increasing dissolution rates and removing limitations on mass transfer (Sikkema et al., 1995). It has further been demonstrated (Hili et al., 1997) that the inhibitory effect of essential oils is higher in the presence of solubilisers such as dimethylsulphoxide (DMSO).

Second, the hydrocarbon has to enter the cell envelope. This step differs depending on the type of the microorganism, since the cell envelope is different for each type. The cell envelope of microorganisms consists of a cell wall and one or two lipid membranes (Beveridge and Graham, 1991). Additionally, some eubacteria and archea have a crystalline surface layer (S-layer) surrounding the membrane(s) as shown in Figure 2.4 (Sleytr and Messner, 1988). Due to the membrane structure, Gram-negative bacteria can tolerate higher concentrations of lipophilic compounds than Gram-positive bacteria can (Burt, 2004; Dorman and Deans, 2000; Fisher and Phillips, 2008; Sikkema et al., 1995; Smith-Palmer et al., 1998). This is due to the external cell wall around the cell membrane of Gram-negative bacteria (see Figure 2.5) being hydrophilic and repelling lipophilic compounds. However, the cell wall of Gram-negative bacteria is not completely impermeable to lipophilic compounds, and small molecules can interact with water through the formation of hydrogen bridges, then pass through the cell wall by diffusion through the lipopolysaccharydes (LPS) layer or through the proteins and finally interact with the lipid bilayer of the cytoplasmic 
membrane (Dorman and Deans, 2000; Griffin et al., 1999). In vitro studies have also demonstrated that essential oils have a very similar effect on both Gram-negative and Gram-positive bacteria, with the only important difference being the exposure time necessary for the effect to occur (Fisher and Phillips, 2008). In contrast, Mizuki et al. (1990) observed that during anaerobic digestion of Citrus unshu peel, the concentration of Gram-positive bacteria increased and that of Gram-negative bacteria decreased; wich suggests that Gram-positive bacteria are more resistant to essential oils.

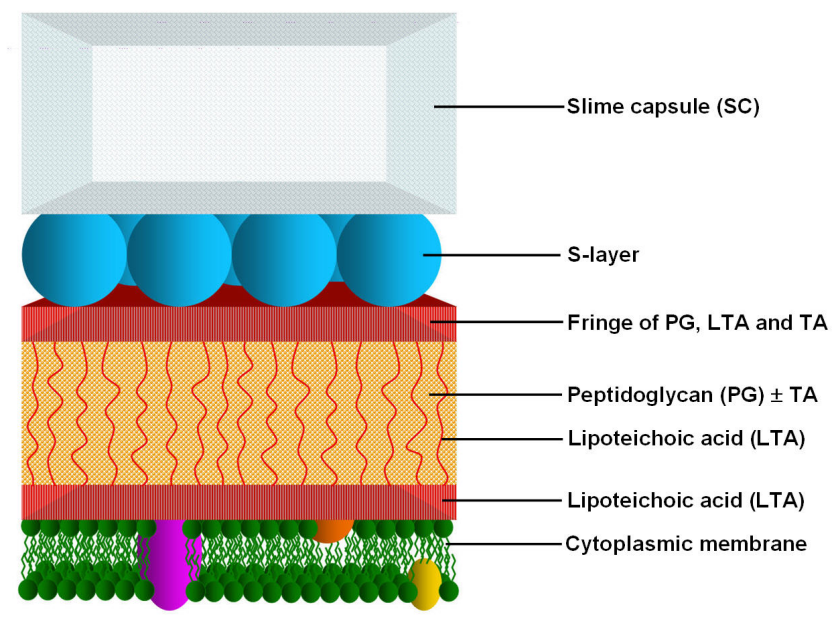

Figure 2.4. Cell wall of Gram-positive bacteria (cronodon.com).

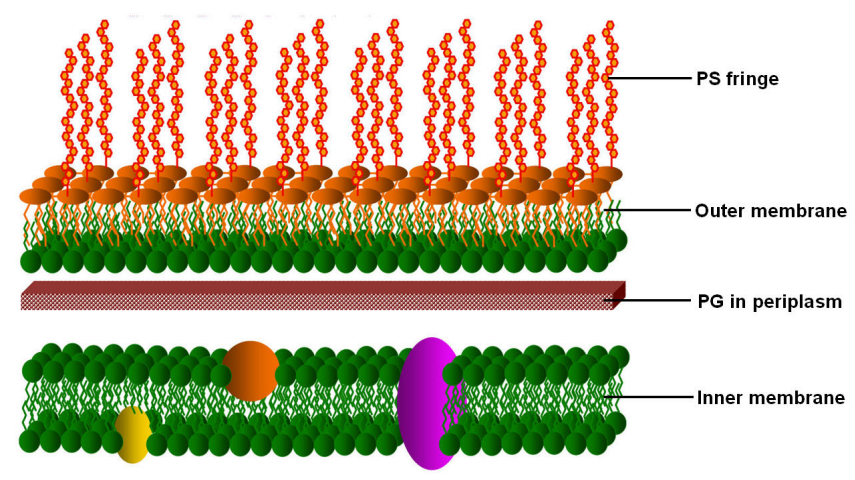

Figure 2.5. Cell wall of and Gram-negative bacteria (cronodon.com).

Third, once the hydrocarbon has reached the cytoplasmic membrane, the partitioning determines to what extent the molecule accumulates in the membrane. This is why octanol/water partition coefficients have been used to predict the toxicity of hydrocarbons (Bakkali et al., 2008; Sikkema et al., 1995). 
Fourth, accumulated lipophilic hydrocarbons change the membrane structure. They accumulate in the central part of the lipid bilayer, either in the area between the opposing monolayers or aligned with the acyl chains of the phospholipids. The site of accumulation depends of the structure of the hydrocarbon. Cyclic hydrocarbons tend to accumulate in the inner part of the bilayer, causing an increase of its surface area. The membrane fluidity then changes, and this may cause swelling of the bilayer, altering the conformation of the embedded proteins (Fisher and Phillips, 2008; Griffin et al., 1999; Sikkema et al., 1995). The structure of the layers of polysaccharids, fatty acids and phospholipids is also changed, and the membrane becomes more permeable (Bakkali et al., 2008). Eventually, leakage of the cell contents occurs. Although a certain amount of leakage can be tolerated without loss of viability, a massive loss of cytoplasm or of certain molecules or ions can lead to cell death, even before lysis (Burt, 2004).

Fifth, besides the change in the membrane structure, there is also a change in the function of the membrane as a selective barrier, an energy transducer and a matrix for enzymes (Di Pasqua et al., 2006; Fisher and Phillips, 2008; Sikkema et al., 1995). Leakage of the cell contents leads to a loss of ions and reduction of the membrane potential, the collapse of the proton pump and depletion of the ATP pool. The cytoplasm then coagulates and lipids and proteins are damaged. The loss of macromolecules and lysis are the final stages of the mechanism (Bakkali et al., 2008). Besides these effects on the membrane, the components of essential oils also act on the membrane proteins; either altering the lipid-protein interaction, or interacting directly with the hydrophobic parts of the membrane proteins (Burt, 2004).

\subsubsection{Factors affecting the antimicrobial effect of essential oils}

The antimicrobial action of hydrophobic molecules depends on their chemical nature. A distinction can be made between phenolic and non-phenolic compounds (Burt, 2004). Phenolic compounds (such as carvacrol, eugenol and thymol) have a strong antimicrobial effect, due mainly to their hydroxyl group, although the phenolic ring also plays a significant role in this effect. This has been demonstrated by comparing the antimicrobial effect of menthol, which has a non-phenolic ring and is inactive, with carvacrol, which has a phenolic ring and exhibits antimicrobial activity (Ultee et al., 2002). In non-phenolic compounds, the antimicrobial activity is influenced by the type of alkyl group; alkenyl being more active than alkyl. Thus, limonene (with an alkenyl group) is more active than pcymene (with an alkyl group) against microorganisms (Dorman and Deans, 2000). Other compounds such as aldehydes and alcohols are also of major importance in the cytotoxic activity of essential oils (Bakkali et al., 2008).

Many authors have concluded that essential oils exhibit greater antimicrobial activity than that of their major components taken together. This leads one to suppose that either the minor components are critical to the antimicrobial activity or that synergistic effects may occur (Burt, 2004; Droby et al., 2008; Hili et al., 1997). The major components reflect the biological properties of essential oils, but their activity, for example the cell penetration, hydrophobicity and fixation on membranes, can be modulated by the minor components 
(Bakkali et al., 2008; Mizuki et al., 1990). The composition of CEO results in interactions between the components that both qualitatively and quantitatively change their evaporation rates (Saiyasombati and Kasting, 2003).

The antimicrobial action of essential oils is also affected by environmental factors. Thus, low $\mathrm{pH}$, mild heat, chelators, low water activity, high pressure and a low oxygen environment can enhance the antimicrobial action of essential oils (Burt, 2004).

Temperature seems to be a highly significant parameter. On the one hand, cells growing at low temperature $\left(8^{\circ} \mathrm{C}\right)$ have a high degree of un-saturation in their membrane phospholipids, which maintains membrane fluidity. In contrast, cells that grow at $45^{\circ} \mathrm{C}$ show less membrane fluidity, since the fatty acids of their phospholipids tend to be more saturated (Karatzas et al., 2000). This would mean that cells growing at $45^{\circ} \mathrm{C}$ are more resistant to essential oils than cells growing at $8^{\circ} \mathrm{C}$. On the other hand, the evaporation of essential oils depends on their concentration and on the temperature, water content and pressure. Diffusion of essential oil components across cell membranes is greater at high temperature (Fisher and Phillips, 2008). It has also been demonstrated that a concentration below the minimum inhibitory concentration (MIC) combined with a temperature of $54^{\circ} \mathrm{C}$ causes greater inactivation than either condition separately (Espina et al., 2011). Thus, it is not clear whether a higher temperature is beneficial or not from the point of view of the anaerobic digestion process, since thermophilic microorganisms exhibit reduced membrane fluidity but the diffusion of essential oils is higher. A parallel effect is the evaporation of the components of essential oils, which occurs more rapidly at higher temperatures. It is known that the antimicrobial effects of essential oils decrease over time-in a matter of hours - due to evaporation (Droby et al., 2008; Inouye et al., 2003; Saiyasombati and Kasting, 2003).

Another environmental factor that enhances essential oil toxicity is a low oxygen partial pressure. This can be due either to the lower oxygen concentration resulting in less oxidation of the essential oils, or to the fact that anaerobic bacteria are more sensitive to essential oil toxicity than aerobic bacteria are (Paster et al., 1990).

Water activity and $\mathrm{pH}$ also seem to influence the antimicrobial activity of some components of essential oils. Citral was more effective against Aspergillus flavus at a water activity of 0.95 (MIC $1400-1600 \mathrm{mg} \cdot \mathrm{L}^{-1}$ ) than at a water activity of $0.99\left(\mathrm{MIC} 1800 \mathrm{mg} \cdot \mathrm{L}^{-1}\right.$ ). Lower $\mathrm{pH}$ values were found to minimise the antimicrobial effects. However, the reasons for these effects were not fully elucidated (López-Malo et al., 2005).

\subsubsection{Adaptation of microorganisms to essential oils}

The most common adaptive response of cells to stress is to maintain membrane fluidity constant, regardless of the environmental conditions. This is known as homeoviscous adaptation (Di Pasqua et al., 2006) and can be achieved in several ways: (a) by changing the proportion of fatty acids with iso and anteiso ramifications; (b) by isomerizing fatty acids from cis to trans; (c) by altering the average length of the fatty acid chains; (d) by changing the protein content; or (e) by modifying fatty acid composition. For example, 
bacteria growing at a low temperature show higher unsaturation; while in acid media, microorganisms contain longer fatty acids (Fozo et al., 2004; Keweloh and Heipieper, 1996; Suutari et al., 1990; Suutari and Laakso, 1994). Unsaturated fatty acids (UFAs) increase membrane fluidity, while saturated fatty acids (SFAs) make membranes more rigid (Di Pasqua et al., 2006).

It has been demonstrated that in the presence of limonene, some bacteria change their lipid profile. The strains studied were exposed to their maximum sublethal concentration (MSC), and their lipid profiles were analysed after incubation. Escherichia coli (Gram-negative) decreases its content of palmitic acid (C16) and increases the proportions of linoleaidic (C18:2 trans), docosanoic (C22) and eicosapentaenoic (C20:5 cis) acid. Brochothrix thermospacta (Gram-positive) also decreases its palmitic acid concentration, while increasing unsaturated cis-10-pentadecanoic (C15:1 cis) and linolenic (C18:3 cis) acids. In contrast, the lipid profile of Salmonella enterica, Salmonella typhimurium and Pseudomonas fluorescens (all Gram-negative) did not change in the presence of the limonene solution (Di Pasqua et al., 2006). There are two pathways for the synthesis of UFAs: anaerobic (fatty acids are newly synthesised) and aerobic (existing fatty acids are modified). If the increase in UFAs does not correspond with the decrease of SFAs of the same length, then the anaerobic pathway is responsible for the synthesis of UFAs. This is the case of the lipid profile change in E. coli for which it has been demonstrated that adaptation occurs, but not if this adaptation increases resistance of microorganisms to limonene or other compounds (Di Pasqua et al., 2006). In a later study (Di Pasqua et al., $2007)$ the same microorganisms were exposed to a higher concentration of limonene $(0.2$ $\mathrm{M}$, which is above the MSC for the strains studied). After incubation, lipid profiles were analysed and membrane structure were observed by scanning electron microscopy (SEM). $S$. typhimurium and E. coli changed their lipid profile to one composed mainly of caproic acid (C6:0). The lipid profile of B. thermospacta showed increased butyric acid (C4:0) and oleic acid, while linoleaidic acid decreased remarkably. In the case of P. fluorescens, an increase in myristic and stearic acids occurred when it was treated with limonene. Finally, in the $S$. aureus lipid profile, myristoleic and palmitic acids increased with the corresponding decrease in the UFAs of the same chain length. Apart from these changes, morphological differences were detected in the structure of E. coli, S. enterica, $P$. fluorescens and B. thermospacta. In the first study, it was observed that when applying a limonene concentration lower than the MIC, an increase in UFAs was detected. This phenomenon is related with an increase in membrane fluidity. In the second study, in which the limonene concentration was higher than the MIC, the concentrations of UFAs were lower than those of SFAs, which would have as a consequence an increase in the membrane rigidity. Structural changes were also observed via SEM, which appear to be related with the decrease in UFAs. The adaptation mechanism consisting of cis-to-trans isomerisation was not observed in these studies.

Other bacterial adaptation mechanisms against lipophilic compounds are changes in the membrane composition, changes in the cell wall (from hydrophobic to hydrophilic), the development of an S-layer that acts as molecular sieve, active excretion and immobilisation of the cells in polymeric structures (Sikkema et al., 1995). 
Changes in the membrane composition can affect fatty acids, phospholipids or LPS. Changes in fatty acid composition can lead to reductions in the partition coefficient, and thus the concentration of hydrocarbons inside the membrane would decrease. The type of phospholipid head group could influence susceptibility to lipophilic compounds. The conversion cis-to-trans of the acyl chains of phospholipids may cause higher ordering and thus less membrane fluidity. A change in the outer membrane LPS (hydrophilic LPS) would have a repellent effect on hydrophobic compounds (Sikkema et al., 1995). It has been demonstrated that Bacillus cereus adapts to carvacrol after being grown in non-lethal concentrations (Ultee et al., 2000). The adaptation mechanism in this case is to change the fatty acid and phospholipid head group composition in the membrane; thus reducing membrane fluidity and passive permeability (Ultee et al., 2000). Pseudomonas aeruginosa develops resistance to Melaleuca alternifolia essential oil by changing the barrier and energy functions of its outer membrane (Longbottom et al., 2004).

To sum up, the mode of action of essential oils against microorganisms affects several parts or functions of the cell at the same time. This is why it is difficult for bacteria to show resistance or adaptation. However, a certain resistance to sublethal concentrations of some essential oils has been observed in some bacteria (Bakkali et al., 2008).

\subsubsection{Quantification of antimicrobial effect on microorganisms}

Many authors have studied the antimicrobial effect of CEO or of their components through in vitro tests. A summary of these studies is shown in Table 2.6.

Many different ways of quantifying inhibition or toxicity effects appear in the literature: MIC, MSC, minimal bactericide concentration (MBC) or the length (mm) of the inhibition zone. The MIC is the lowest concentration of a substance that inhibits growth of the organism tested. The MSC is the highest concentration of a substance that allows growth. The MBC appears only to have been used by Espina et al. (2011) and is defined as the lowest concentration at which bacteria failed to grow in trypticase soy broth yeast extract (TSBYE) with the subsequent transfer to trypticase soy agar containing yeast extract (TSAYE) plates. Other authors use qualitative expressions such as "effective concentration" "moderate effect".

As a general rule, fungi show more resistance to CEO than bacteria. A special case is Penicillium, which is stimulated by the presence of CEO.

No great differences can be observed between the effects of CEO or their components on different groups (Gram-positive or Gram-negative) of bacteria. The fact that the bacteria are aerobic or anaerobic does not seem to matter, either.

Considering the results in Table 2.6 for the same species, neither is it clear that essential oils are more inhibitory than their individual components. However, the comparisons are between different studies, and the initial bacteria counts could influence the results. 
Table 2.6. Inhibitory effect of citrus essential oils or its components on microorganisms (in vitro tests).

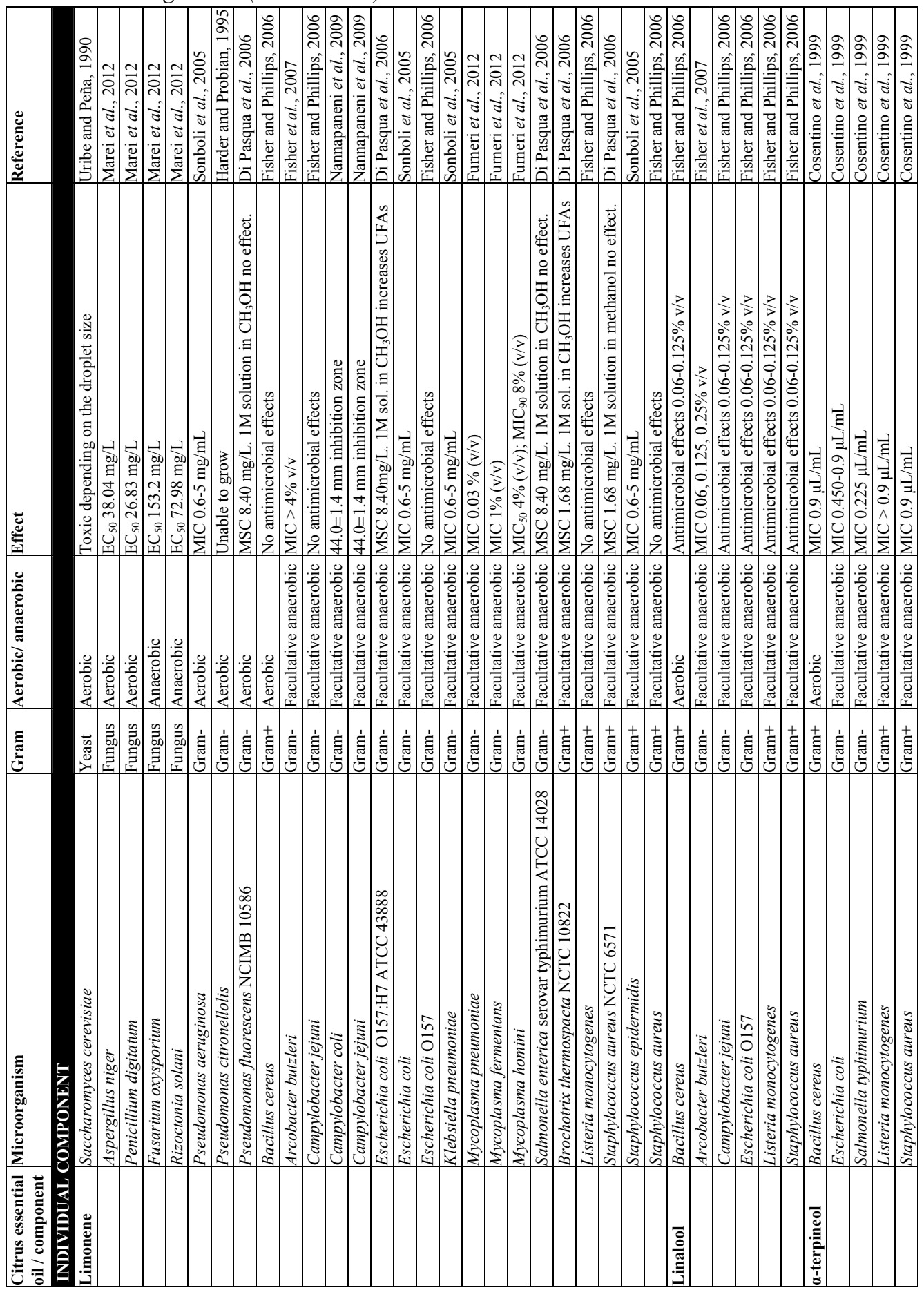


Table 2.7. Inhibitory effect of citrus essential oils or its components on microorganisms (in vitro tests) (continued).

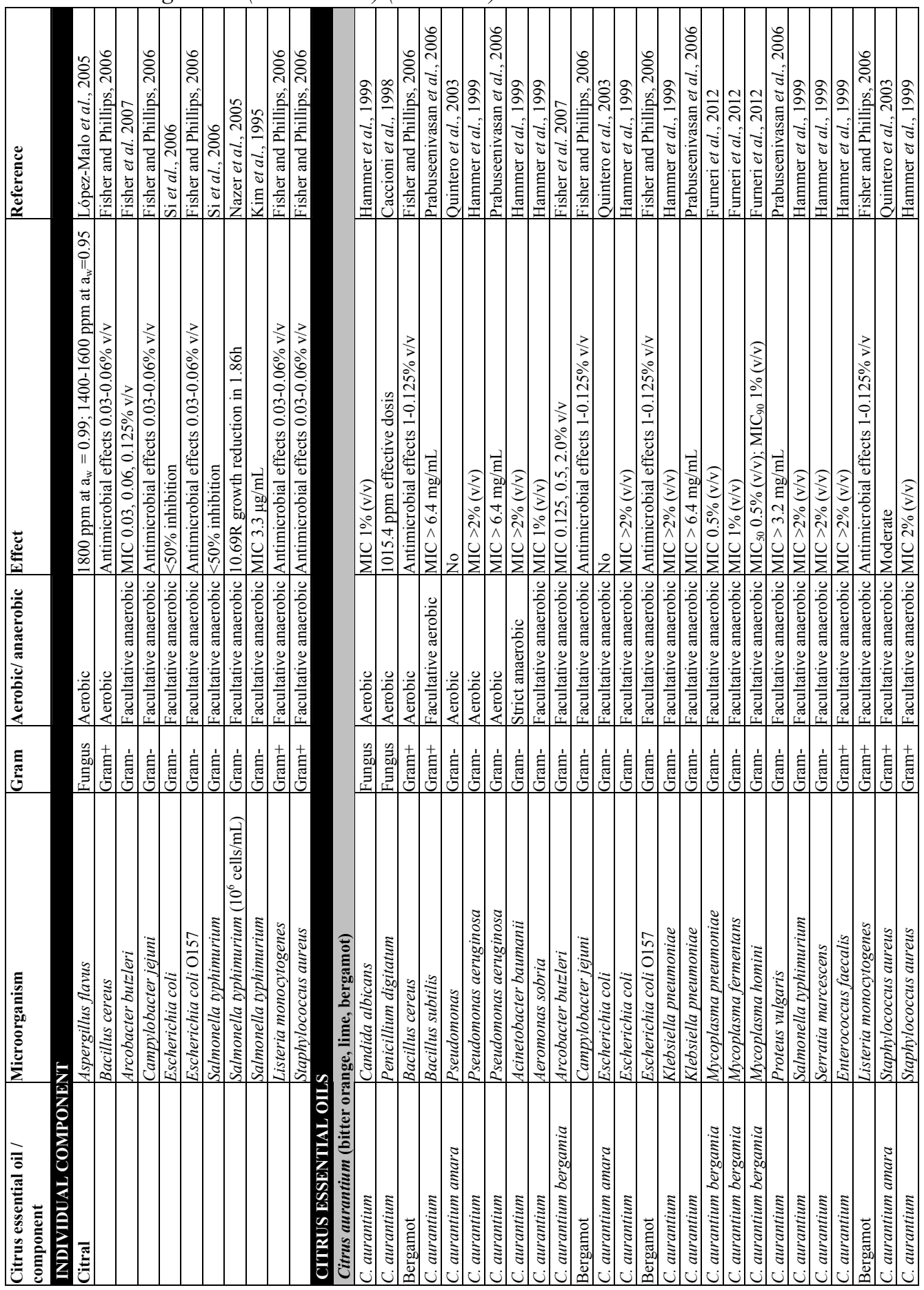


Table 2.8. Inhibitory effect of citrus essential oils or its components on microorganisms (in vitro tests) (continued).

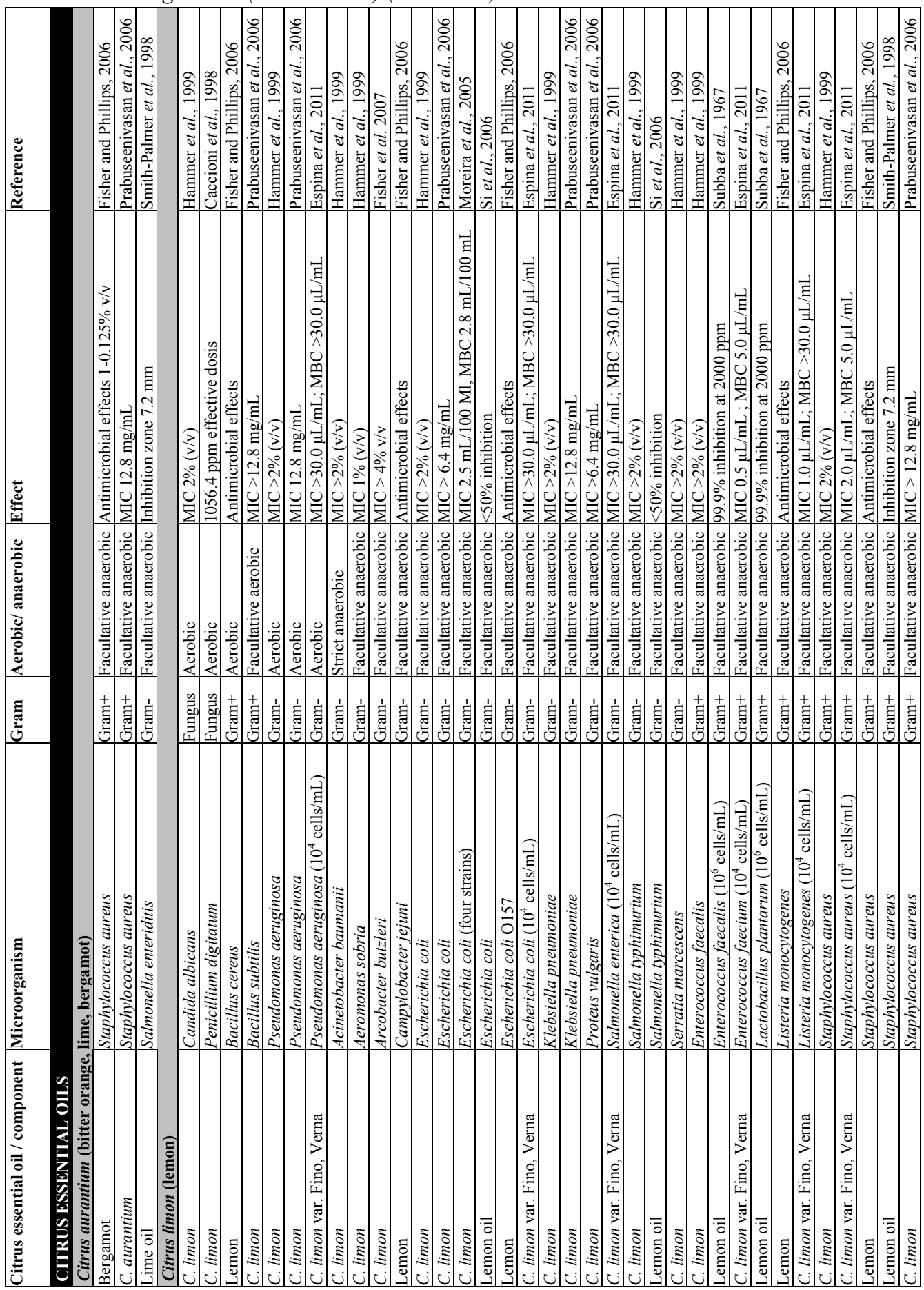


Table 2.9. Inhibitory effect of citrus essential oils or its components on microorganisms (in vitro tests) (continued).

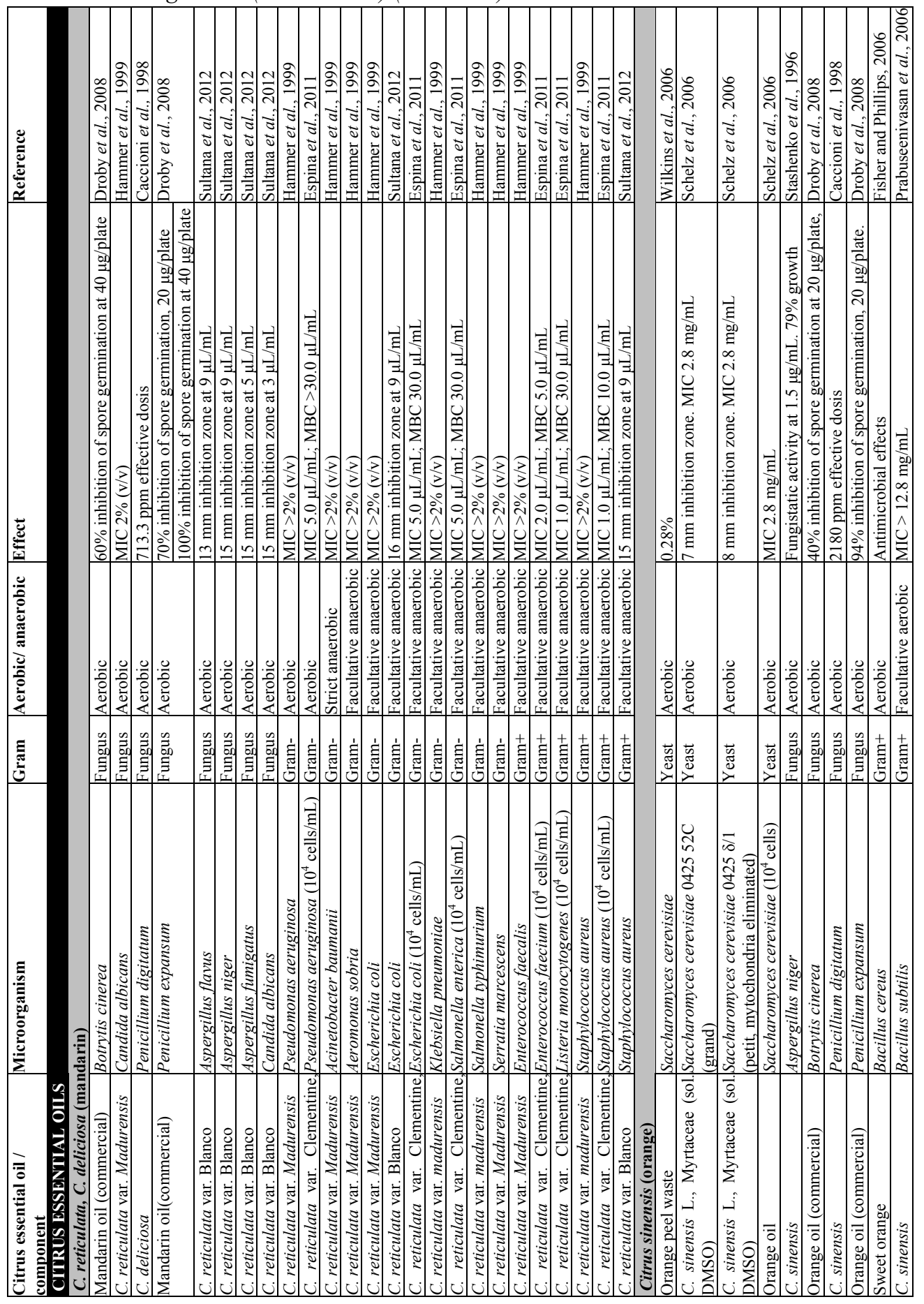


Table 2.10. Inhibitory effect of citrus essential oils or its components on microorganisms (in vitro tests) (continued).

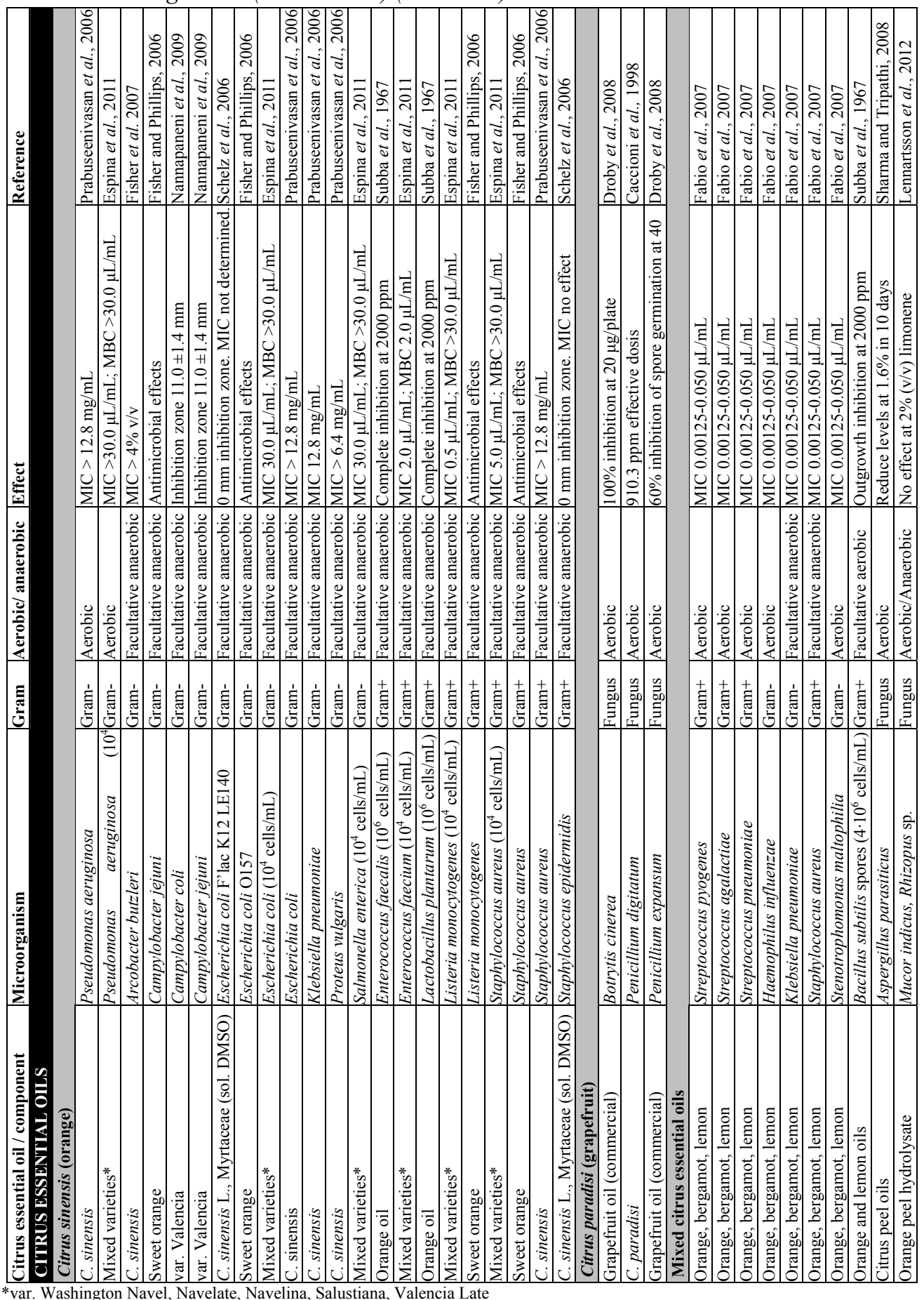

var. Washington Navel, Navelate, Navelina, Salustiana, Valencia Late 


\subsubsection{Microorganisms resistant to citrus essential oils: biotransformation of limonene}

While studies detailed in Section 2.3.4 deal with the antimicrobial effect of CEO on microorganisms, other studies have focused on the isolation of microorganisms able to grow in and degrade limonene, using it for the synthesis of other compounds. Annually, the citrus industry recovers 36,000 tonnes of D-limonene, with a relatively low price (Badee $e t$ al., 2011), while some limonene degradation products can have a higher market value. For example, while the value of limonene is $1-2 \$ \mathrm{~kg}^{-1}$ (Duetz et al., 2003; Zhou et al., 2007), menthol or carvone can reach $30-60 \$ \cdot \mathrm{kg}^{-1}$ on the market, and other products such as perillyl alcohol cost as much as $600 \$ \cdot \mathrm{kg}^{-1}$ (Duetz et al., 2003). Another valuable component is $\alpha$-terpineol (an aromatic compound). In what follows, we present some examples of the biotransformation of limonene to yield other valuable products.

Facultative anaerobic bacteria such as Geobacillus stearothermophilus and Escherichia coli have been reported to produce carveol, a-terpineol, perillyl alcohol and perillyl aldehyde from limonene (Chang et al., 1995; Chang and Oriel, 1994). Rhodococcus erythropolis DCL14 (aerobic, Gram-positive) can grow on limonene and on its 2-oxyfunctionalised stereoisomers, degrading it through the action of the enzyme carveol dehydrogenase (van der Werf and Boot, 2000). Pseudomonas putida MTCC 1072 (aerobic, Gram-negative) oxidises limonene to produce perillyl alcohol and p-menth-1-ene-6,8-diol with yields of $36 \%$ and $44 \%$ respectively, with the maximum theoretical yields being $44 \%$ and $56 \%$ (Chatterjee and Bhattacharyya, 2001).

Other products obtained biologically from limonene are carveol, carvone, perillaaldehyde, perillic acid, iso pipiritenol, a-terpineol, limonene-1,2-epoxide, limonene-1,2-diol and limonene-8,9-epoxide. Several references to the microbial degradation of limonene to obtain other added value products are summarised in Table 2.11.

The limonene degradation mechanism involves the use of enzymes which are not always regiospecific (Duetz et al., 2003). The bioconversion of limonene to $\alpha$-terpineol can be inhibited either by the product or by the substrate (Badee et al., 2011).

Special cases are the fungi $P$. digitatum and Penicillium italicum, which are naturally present in the peel of citrus fruit, but they become active only after the release of essential oil, which occurs if the peel is damaged. Spores of fungi adjacent to damaged vesicles grow in $4 \mathrm{~h}$ and colonisation is observed in $140 \mathrm{~h}$, even if they are not in direct contact with the oil, indicating that $\mathrm{CEO}$ are not toxic and stimulate the growth of Penicillium (Droby et al., 2008). $P$. digitatum exhibited a 6.5 -fold increase in germination and the increase in $P$. italicum was 2.5-3-fold. B. cinerea and $P$. expansum were not affected (stimulated or inhibited) by CEO (Droby et al., 2008). 
Table 2.11. Biotransformation of limonene.

\begin{tabular}{|c|c|c|c|c|}
\hline Microorganism & Gram & $\begin{array}{l}\text { Aerobic/ } \\
\text { anaerobic }\end{array}$ & Products & Reference \\
\hline Armillareira mellae & Fungus & Aerobic & $\alpha$-terpineol, limonene-1,2-diol & Draczynska, 1987 \\
\hline Aspergillus cellulosae M-77 & Fungus & Aerobic & $\begin{array}{l}\text { Carveol, perillyl alcohol, } \alpha- \\
\text { terpineol, limonene-1,2-diol }\end{array}$ & Noma et al., 1992 \\
\hline Cladosporium sp. T12 & Fungus & Aerobic & $\alpha$-terpineol & Kraidman et al., 1969 \\
\hline Cladosporium sp. $\mathrm{T} 7$ & Fungus & Aerobic & Limonene-1,2-diol & Mukherjee et al., 1973 \\
\hline Corynespora cassiicola DSM62474/5 & Fungus & Aerobic & Limonene-1,2-diol & Abraham et al., 1986b \\
\hline Diplodia gossypina ATCC 10936 & Fungus & Aerobic & Limonene-1,2-diol & Abraham et al., 1986b \\
\hline Hormonema sp. UOFS Y-0067 & Fungus & Aerobic & Iso pipiritenol & Van Dyk et al., 1998 \\
\hline Penicillium digitatum NRRL1202 & Fungus & Aerobic & $\alpha$-terpineol & Tan et al., 1998 \\
\hline Penicillium digitatum DSM62840 & Fungus & Aerobic & $\alpha$-terpineol & Abraham et al., 1986a \\
\hline Penicillium digitatum & Fungus & Aerobic & Carveol, carvone & Bowen, 1975 \\
\hline Pleurotus sapidus & Fungus & Aerobic & Carveol, carvone & Onken \& Berger, 1999 \\
\hline Bacillus stearothermophilus BR388 & Gram+ & Aerobic & $\begin{array}{l}\text { Perillyl alcohol, } \\
\text { perillaaldehyde, } \alpha \text {-terpineol }\end{array}$ & Chang \& Oriel, 1994 \\
\hline Rhodococcus erythropolis DCL 14 & Gram+ & Aerobic & Carveol & $\begin{array}{l}\text { van der Werf \& Boot, } \\
2000\end{array}$ \\
\hline Rhodococcus opacus PWD4 & Gram+ & Aerobic & Carveol, carvone & Duetz et al., 2001 \\
\hline Rhodococcus opacus & Gram+ & Aerobic & Trans-carveol, carvone & $\begin{array}{l}\text { de Carvalho \& da } \\
\text { Fonseca, } 2003\end{array}$ \\
\hline Pseudomonas sp. PL & Gram- & Aerobic & $\begin{array}{l}\text { Carveol, carvone, perillic acid, } \\
\text { limonene-1,2-diol }\end{array}$ & $\begin{array}{l}\text { Dhavalikar \& } \\
\text { Bhattacharyya, } 1966\end{array}$ \\
\hline Pseudomonas incognita & Gram- & Aerobic & Perillic acid & $\begin{array}{l}\text { Rama Devi \& } \\
\text { Bhatacharyya, } 1977\end{array}$ \\
\hline Pseudomonas gladioli & Gram- & Aerobic & Perillic acid, $\alpha$-terpineol & $\begin{array}{l}\text { Cadwallader } \text { et al., } \\
1989\end{array}$ \\
\hline Pseudomonas putida MTCC 1072 & Gram- & Aerobic & $\begin{array}{l}\text { Perillyl alcohol, p-menth-1- } \\
\text { ene-6,8-diol }\end{array}$ & $\begin{array}{l}\text { Chatterjee \& } \\
\text { Bhattacharyya, } 2001\end{array}$ \\
\hline Pseudomonas putida GS1 & Gram- & Aerobic & Perillic acid & Speelmans et al., 1998 \\
\hline Xanthobacter sp. C20 & Gram- & Aerobic & Limonene-8,9-epoxide & $\begin{array}{l}\text { Van der Werf et al., } \\
2000\end{array}$ \\
\hline Alcaligenes defragans & Gram- & $\begin{array}{l}\text { Facultative } \\
\text { anaerobic }\end{array}$ & Isoterpinolene & Heyen \& Harder, 1998 \\
\hline Escherichia coli (3.6 kb from BR388) & Gram- & $\begin{array}{l}\text { Facultative } \\
\text { anaerobic }\end{array}$ & $\begin{array}{l}\text { Carveol, carvone, perillyl } \\
\text { alcohol, perillaaldehyde }\end{array}$ & Cheong \& Oriel, 2000 \\
\hline Escherichia coli (9.6 kb from BR388) & Gram- & $\begin{array}{l}\text { Facultative } \\
\text { anaerobic }\end{array}$ & $\begin{array}{l}\text { Perillyl alcohol, } \\
\text { perillaaldehyde, } \alpha \text {-terpineol }\end{array}$ & Chang et al., 1995 \\
\hline $\begin{array}{l}\text { Escherichia coli (cym genes from } \\
\text { Pseudomonas putida } \mathrm{F} 1)\end{array}$ & Gram- & $\begin{array}{l}\text { Facultative } \\
\text { anaerobic }\end{array}$ & Perillic acid & Mars et al., 2001 \\
\hline
\end{tabular}




\subsection{Effect of citrus essential oils on the anaerobic digestion process}

\subsubsection{Anaerobic biodegradation of limonene}

Limonene has been shown to inhibit both methanogenic and hydrolytic-acidogenic bacteria (Castillejos et al., 2006; Srilatha et al., 1995). While terminal double bonds can be sufficient to allow methanogenic degradation of hydrocarbons, branching and terminal ring closures, as limonene has (Figure 2.3), may contribute to the molecule stability in anoxic environments (Schink, 1985).

Microbial oxidation of carbon double bonds $(\mathrm{C}=\mathrm{C})$ usually requires the presence of molecular oxygen as a cosubstrate. This is why monoterpenes are considered to be recalcitrant in anoxic media (Harder and Probian, 1995). However, the hydrogenation of double bonds in anaerobic media is thermodynamically favourable (Lalman and Bagley, 2001; Thauer et al., 1977).

Other authors have reported that denitrifying bacteria produce $\alpha$-terpinene or 2 -carene from limonene in anaerobic environments, depending on the presence or absence of nitrate, respectively (Harder and Probian, 1995). Specifically, several strains of the denitrifying bacteria Alcaligenes defragrans have been reported to anaerobically transform alkenoic monoterpenes in the presence of nitrate (Foss et al., 1998). These bacteria are able to transform isolimonene into isoterpinolene (Heyen and Harder, 1998), which seems to be achieved by bacterial enzymes that rearrange unsaturated monoterpenes. Further metabolism of monoterpenes is determined by the C-1 sp2 hybridisation of menthadienes (Hylemon and Harder, 1999). The same authors suggest that transformation products might be ionic compounds that would remain as intracellular substrates; this would seem to rule out any inhibitory effect of the degradation products of limonene.

A recent study identified the most abundant microorganisms present in limonene-degrading methanogenic cultures (Rotaru et al., 2012). That study revealed that methane production is possible with limonene as the only carbon source. Chemical analysis identified acetate as an intermediate, and microbial observations suggest that formate and hydrogen were also intermediates for methane production. The most abundant bacteria were Deltaproteobacteria (specifically Syntrophobacter fumaroxidans) and the candidate bacterial group OP3, while the archaea identified were Methanosaeta, Methanospirillum and Methanoculleus (acetate, hydrogen and formate-transforming, respectively). OP3 is a proposed group of bacteria found in anoxic environments which belongs to the Planctomycetes/Verrucomicrobia/Chlamydiae superphylum (Glöckner et al., 2010). However, although advances have been made in the identification of the microorganisms that take part in limonene degradation in methanogenic cultures, the exact degradation pathway remains unknown.

\subsubsection{Effect of citrus essential oils on the anaerobic digestion}

Crane et al. (1957) studied the effects of two CEO components (limonene and pinene) on methane formation from several substrates by rumen bacteria. The substrates were acetic 
acid, formic acid, cellulose, starch and cellobiose. Acetic acid consumption was inhibited by a limonene concentration of $9 \cdot 10^{-4} \mathrm{M}$, but that of formic acid was not, indicating that the methanogenesis pathway via $\mathrm{CO}_{2}$ reduction (hydrogenotrophic methanogenesis) was not affected by limonene. Another conclusion of the study was that the metabolism of lactate was partially affected by limonene. This has to be taken into account in the anaerobic digestion of ensiled materials, where high concentrations of lactate are expected. The rumen gas production decrease caused by different concentrations of limonene is shown in Figure 2.6.

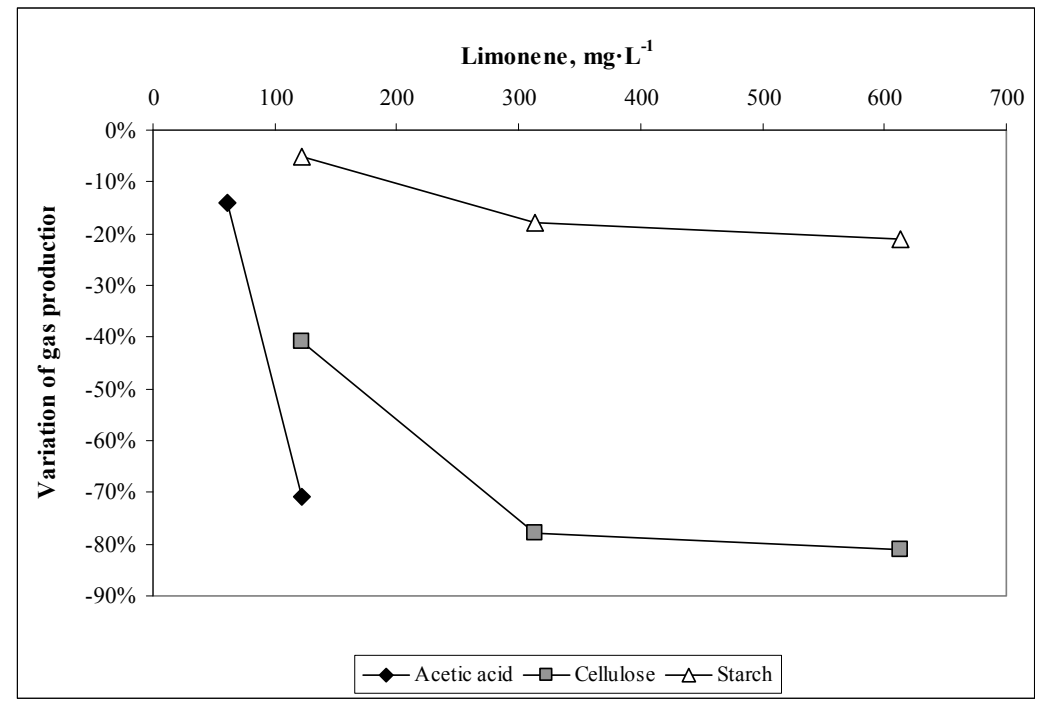

Figure 2.6. Decrease of rumen gas production from acetic acid, cellulose and starch in mesophilic batch anaerobic conditions. Data from Crane et al. (1957).

Oh et al. (1967) analysed the effects of a CEO and its individual components on the anaerobic digestion of alfalfa hay using rumen from different origins as the inoculum. They found that the biogas production could be either inhibited or stimulated by the addition of the CEO or its components, depending on the oil concentration and the type of rumen.

Varel and Miller (2001) studied the inhibitory effect of several essential oil components on the anaerobic digestion of cattle waste with the objective of reducing odours during storage. They concluded that limonene did not effectively control the VFA formation, but carvacrol and thymol did.

\subsubsection{Anaerobic digestion of citrus waste}

Lane (1980) studied the anaerobic digestion of several types of citrus waste: (a) waste whole peel from a commercial orange juice plant, comminuted and enriched with nitrogen and phosphorus; (b) orange albedo from another plant operating an oil recovery process in which the oil-containing flavedo was removed prior to juice extraction; (c) hand-peeled 
albedo; and (d) pelletised orange peel for animal feed (commercial product). In all cases the digestion was carried out with nutrient solutions, at a temperature of $37^{\circ} \mathrm{C}$ and an organic loading rate (OLR) of $2 \mathrm{~kg}_{\mathrm{TS}} \cdot \mathrm{m}^{-3} \cdot \mathrm{d}^{-1}$. All the digestion processes halted after 2-3 weeks and, as a result, aromatic acids appeared such as benzoic, phenylacetic and phenylpropionic acid. The acids were not themselves toxic, but were considered a symptom of toxicity caused by other compounds. In the same study, anaerobic digestion of a standard substrate (whey-peptonecellulose medium, WPC) with $0.1 \%(\mathrm{v} / \mathrm{v})$ of different additives was studied. The additives were: cold-pressed orange oil, cold-pressed lemon oil, distilled orange oil, limonene and lemon oil distillation residue (non-volatile fraction). The temperature and OLRs were the same as in the previous studies and digestion again halted after 2-3 weeks in all cases. This study demonstrated that not only is limonene toxic for the anaerobic digestion process, but also other components of CEO are too.

In a later study, Lane (1983b) found differences in the anaerobic digestion of citrus peel press liquors $\left(5.7 \mathrm{~g} \cdot \mathrm{L}^{-1}\right.$ suspended solids, $70 \mathrm{~g} \cdot \mathrm{L}^{-1}$ chemical oxygen demand (COD), peel oil concentration less than $0.2 \mathrm{~g} \cdot \mathrm{L}^{-1}$ after aeration) depending on the reactor configuration. An upflow anaerobic sludge blanket (UASB) reactor was more effective and showed higher resistance to toxicity than a continuously-stirred tank reactor (CSTR) configuration. The UASB reactor reached an OLR of $11.15 \mathrm{~g}_{\mathrm{COD}} \cdot \mathrm{L}^{-1} \cdot \mathrm{d}^{-1}$, with a hydraulic retention time (HRT) of 7 days and 95\% COD removal; while the CSTR became overloaded at an OLR of 7.41 $\mathrm{g}_{\mathrm{COD}} \cdot \mathrm{L}^{-1} \cdot \mathrm{d}^{-1}$ with an HRT of 10.7 days. In mixed digestion, COD removal was $80 \%$ and the gas yield was $0.832 \mathrm{~L} \cdot \mathrm{g}_{\text {CoDdestroyed }}{ }^{-1}$.

Later, Lane (1984) studied the anaerobic digestion of orange peel. The substrate was waste orange peel from commercial juicing plants equipped with oil recovery equipment. The peel was comminuted $(8 \mathrm{~mm})$, diluted with water to $10 \% \mathrm{TS}(\mathrm{w} / \mathrm{v})$ and supplemented with macro- and micronutrients. The peel oil content was reduced in two ways: in the juicing factory and by distillation in the laboratory. Anaerobic digestion was found to be stable up to an OLR of $3.5 \mathrm{~kg}_{\mathrm{TS}} \cdot \mathrm{m}^{-3} \cdot \mathrm{d}^{-1}$ corresponding to a CEO dosage of $95 \mathrm{mg} \cdot \mathrm{L}_{\text {digester }}{ }^{-1} \cdot \mathrm{d}^{-1}$ when laboratory treatment was used. The industrial treatment resulted in stable anaerobic digestion up to an OLR of $3 \mathrm{~kg}_{\mathrm{Ts}} \cdot \mathrm{m}^{-3} \cdot \mathrm{d}^{-1}$ corresponding to a CEO dosage of 75 $\mathrm{mg} \cdot \mathrm{L}_{\text {digester }}{ }^{-1} \cdot \mathrm{d}^{-1}$. In this study macro- and micronutrient solution were used in the anaerobic digestion of orange peel and the author suggested that livestock waste, such as pig or chicken manure, could be used as the nitrogen source, in order to avoid the cost of supplementing a full-scale reactor with nutrients. The effect of the addition of pig or chicken manure was not evaluated in this work.

Mizuki et al. (1990) studied the anaerobic digestion of mandarin peel (C. unshu) obtained from a canning plant. It was comminuted, homogenised and supplemented with nitrogen and phosphorus. Digestion was carried out at $37^{\circ} \mathrm{C}$ with an HRT of 10 days. The OLR varied between 0.5 and $4.0 \mathrm{~g}_{\mathrm{TS}} \cdot \mathrm{L}^{-1} \cdot \mathrm{d}^{-1}$. The anaerobic digestion of the peel halted at an OLR of $2.0 \mathrm{~g}_{\mathrm{TS}} \cdot \mathrm{L}^{-1} \cdot \mathrm{d}^{-1}$ when the peel oil dosage was near $70 \mu \mathrm{L} \cdot \mathrm{L}_{\text {digester }}{ }^{-1} \cdot \mathrm{d}^{-1}$. The digestion of pectin with natural essential oil gave a more precise result of $65 \mu \mathrm{L} \cdot \mathrm{L}_{\text {digester }}{ }^{-1} \cdot \mathrm{d}^{-1}$ as the maximum value of peel oil dosage for stable anaerobic digestion to proceed. 


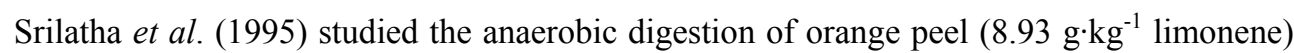
at $30^{\circ} \mathrm{C}$ in $1500 \mathrm{~L}$ digesters. They found that the limit OLR for this substrate was 2.5 $\mathrm{kg}_{\mathrm{Vs}} \cdot \mathrm{m}^{-3} \cdot \mathrm{d}^{-1}$ corresponding to a limonene dosage of $24 \mathrm{mg} \cdot \mathrm{L}_{\text {digester }}{ }^{-1} \cdot \mathrm{d}^{-1}$.

Kaparaju and Rintala (2006) studied the thermophilic anaerobic digestion of orange waste from a juice extraction plant. The waste was comminuted to less than $7 \mathrm{~mm}$, the $\mathrm{pH}$ was adjusted to 8 and the TS adjusted to $8 \%$ with distilled water. Batch anaerobic digestion at $55^{\circ} \mathrm{C}$ yielded $0.49 \mathrm{~m}_{\mathrm{CH} 4}{ }^{3} \cdot \mathrm{kg}_{\mathrm{Vs}}{ }^{-1}$, showed no lag phase and reached a plateau after 40 days. The semi-continuous process showed severe instability at an OLR of $5.6 \mathrm{~kg} \mathrm{vs}_{\mathrm{vs}} \cdot \mathrm{m}^{-3} \cdot \mathrm{d}^{-1}$ and reinoculation was necessary. Operation at $4.2 \mathrm{~kg}_{\mathrm{vs}} \cdot \mathrm{m}^{-3} \cdot \mathrm{d}^{-1}$, although not acidified, resulted in a marked increase of propionate (up to $2502 \mathrm{mg} \cdot \mathrm{L}^{-1}$ ) compared with a normal acetate concentration of $239 \mathrm{mg} \cdot \mathrm{L}^{-1}$. Operation at lower OLRs $\left(2.8-4.2 \mathrm{~kg}_{\mathrm{vs}} \cdot \mathrm{m}^{-3} \cdot \mathrm{d}^{-1}\right.$, HRT $40-26$ days, test period $15-20$ days) produced $0.6-0.5 \mathrm{~m}_{\mathrm{CH} 4}{ }^{3} \cdot \mathrm{kg}_{\mathrm{Vs}}{ }^{-1}$.

Chanakya et al. (2009) examined the fermentation characteristics of orange peel as one of the main components of the organic fraction of municipal solid waste (OFMSW) in India. The orange peel was cut into $10-25 \mathrm{~mm}$ pieces, placed inside a nylon mesh bag and subjected to different solid retention times (SRT; 0-30 d) in a plug-flow anaerobic digester. The nylon mesh bag was removed at periodic intervals and different parameters were measured to characterise the anaerobic degradation of the citrus waste. The small amounts placed in the bag and the conditions of the experiment were intended to guarantee no inhibition due to essential oils. Around $90 \%$ of the initial total solids, mainly composed of pectin and cellulose, were decomposed within the first 4 days. The BMP test of orange peel with a $1 \%(\mathrm{w} / \mathrm{w})$ concentration of dried substrate at $30^{\circ} \mathrm{C}$ yielded poor results (around 110 $\left.\mathrm{ml}_{\mathrm{CH} 4} \cdot \mathrm{g}_{\mathrm{TS}}{ }^{-1}\right)$. This was attributed to the rapid disintegration of the substrate that it was postulated would lead to a build-up of volatile fatty acids (VFA) to levels above inhibitory thresholds. Other causes of toxicity were not included in the study; but a lack of adaptation or an insufficient amount of the inoculum could have been the causes of the toxicity.

Martín et al. (2010) also studied the thermophilic anaerobic digestion of orange waste from the juice manufacturing industry. The waste was comminuted to less than $2 \mathrm{~mm}$ and $70 \%$ limonene was extracted by laboratory steam distillation prior to anaerobic digestion. Then, the waste was diluted to $60-140 \mathrm{~g}_{\mathrm{COD}} \cdot \mathrm{L}^{-1}$. The limonene concentration of the resulting product was $2 \mathrm{mg} \cdot \mathrm{L}^{-1}$. Batch tests were carried out at mesophilic and thermophilic temperatures. In continuous operation, the process was stable until an OLR of $3 \mathrm{~kg}_{\mathrm{vs}} \cdot \mathrm{m}^{-3} \cdot \mathrm{d}^{-1}$ and produced $0.27-0.29 \mathrm{~m}_{\mathrm{CH} 4}{ }^{3} \cdot \mathrm{kg}_{\mathrm{vs}}{ }^{-1}$. These results are lower than those obtained by Kaparaju and Rintala (2006), who obtained 0.6 and $0.5 \mathrm{~m}_{\mathrm{CH} 4}{ }^{3} \cdot \mathrm{kg}_{\mathrm{Vs}}{ }^{-1}$ at an OLR of 2.8 and $4.2 \mathrm{~kg}_{\mathrm{VS}} \cdot \mathrm{m}^{-3} \cdot \mathrm{d}^{-1}$, respectively, in thermophilic anaerobic digestion of citrus waste.

Other studies focus on the effect of limonene or CEO on the fermentation with a view to producing ethanol from organic waste. Wilkins et al. (2006) found that D-limonene inhibited ethanolic batch fermentation when the limonene concentration was greater than $2.8 \mathrm{~mL} \cdot \mathrm{L}^{-1}$, though limonene was removed (38-60\%) during the fermentation. Oberoi et al. (2011) demonstrated that a limonene concentration of $0.9 \mathrm{~mL} \cdot \mathrm{kg}^{-1}$ did not affect the batch ethanolic fermentation of Citrus reticulata waste. 
Few studies have focused on the co-digestion of citrus waste with other co-substrates. Mandal and Mandal (1997) evaluated the batch anaerobic co-digestion of orange peel and cow dung $(1: 1 \mathrm{w} / \mathrm{w})$, and observed that biogas production was much lower than expected. Martín et al. (2013) tested the anaerobic co-digestion of glycerol and orange peel $(1: 1$, COD basis) after dilution to reduce the concentration of limonene. They achieved stable operation in a sequential batch mode up to an OLR of $1.91 \mathrm{~kg}_{\mathrm{vs}} \cdot \mathrm{m}^{-3} \cdot \mathrm{d}^{-1}$. Beyond this, over-acidification occurred.

A summary of the previously mentioned studies is presented in Table 2.12.

\subsubsection{Summary of the effect of citrus essential oils on the anaerobic digestion process}

In batch tests developed at mesophilic temperature $\left(35-39^{\circ} \mathrm{C}\right), \mathrm{CEO}$ starts to inhibit anaerobic digestion at a concentration of $10 \mathrm{mg} \cdot \mathrm{L}^{-1}$ (Oh et al., 1967). Beyond this, the extent of the inhibition differs depending on various factors; the type of substrate and the type of inoculum having the most influence (see Table 2.12). There are not enough data at the thermophilic temperature $\left(55^{\circ} \mathrm{C}\right)$ to draw any conclusions regarding inhibiting concentrations at this temperature.

Very broad differences have been found in anaerobic digestion in a semi-continuous operating mode. The majority of studies used citrus waste as the only substrate for the anaerobic digestion; using nutrients and buffering solutions to compensate the lack of nutrients and the low $\mathrm{pH}$ of the citrus waste. In semi-continuous anaerobic digestion, not only is the concentration of the inhibitor in the feed important, but so is the loading rate of the digester, since these two parameters determine the dosage rate of inhibitor into the digester. In some cases only the concentration of the inhibitor in the feed is given and it is not possible to calculate the dosage rate. Only few studies have determined the maximum CEO dosage in terms of CEO per unit volume of the digester and day. Srilatha et al. (1995) carried out successful anaerobic digestion of citrus waste at $24 \mathrm{mg}_{\text {limonene }} \cdot \mathrm{L}_{\text {digester }}{ }^{-1} \cdot \mathrm{d}^{-1}$. In the study of Forgács et al. (2011), the anaerobic co-digestion of citrus waste and OFMSW was inhibited at $34 \mathrm{mg}_{\text {limonene }} \cdot \mathrm{L}_{\text {digester }}{ }^{-1} \cdot \mathrm{d}^{-1}$. Mizuki et al. (1990) found that the dosage limit was $50 \mathrm{mg}_{\mathrm{CEO}} \cdot \mathrm{L}_{\text {digester }}^{-1} \cdot \mathrm{d}^{-1}$. Lane (1984) fixed this value at $75 \mathrm{mg}_{\mathrm{CEO}} \cdot \mathrm{L}_{\text {digester }}{ }^{-1} \cdot \mathrm{d}^{-1}$ for industrial orange peel and $95 \mathrm{mg}_{\mathrm{CEO}} \cdot \mathrm{L}_{\text {digester }}{ }^{-1} \cdot \mathrm{d}^{-1}$ for lab-distilled orange peel. Akao et al. (1992) carried out successful anaerobic digestion of citrus waste up to $192 \mathrm{mg}_{\mathrm{CEO}} \cdot \mathrm{L}_{\text {digester }}{ }^{-1} \cdot \mathrm{d}^{-1}$. These studies used citrus waste in their experiments, but the origin of the waste was different: Mizuki et al. (1990) and Akao et al. (1992) used mandarin waste, while Srilatha et al. (1995) and Lane (1984) used industrial orange waste. This could have led to different CEO compositions and therefore to different inhibition effects. 
Table 2.12. Effect of citrus essential oils or their components in anaerobic digestion.

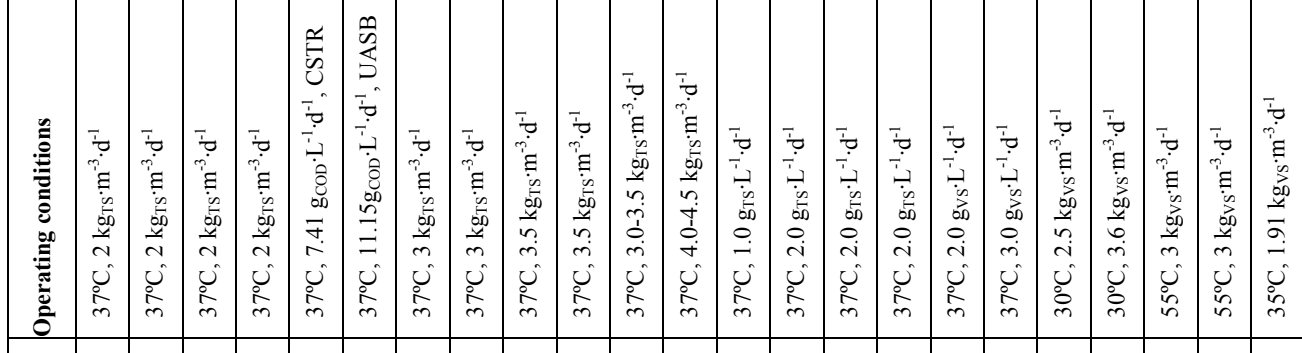

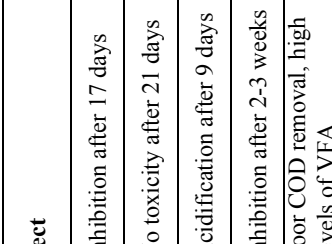

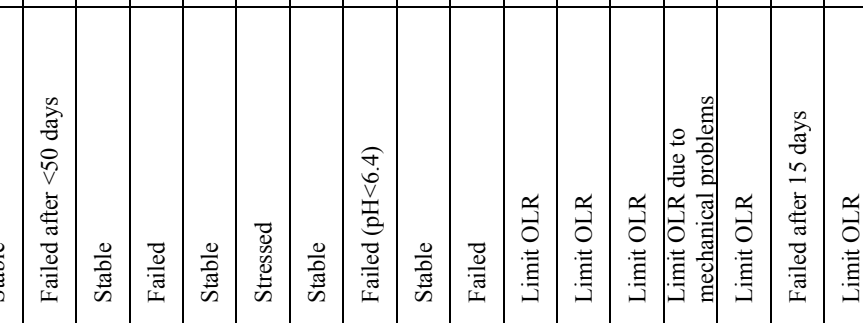

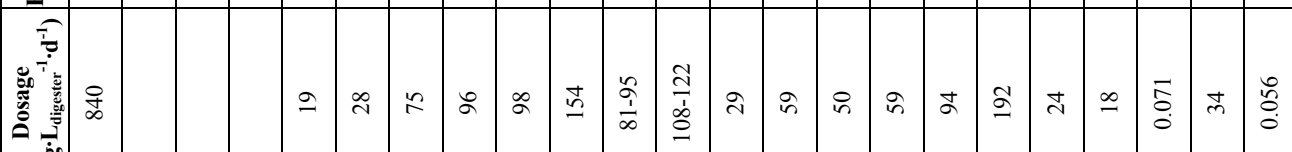
$\stackrel{\dot{b}^{\prime}}{\mathrm{g}}$

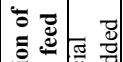

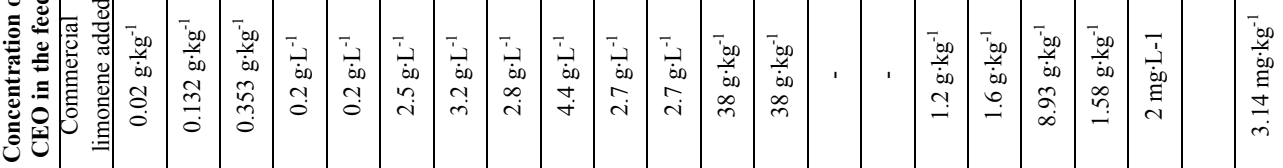

\begin{tabular}{|c|c|c|c|c|c|c|c|c|c|c|c|c|c|c|c|c|}
\hline 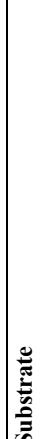 & 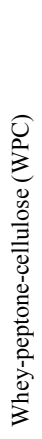 & 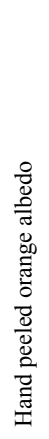 & 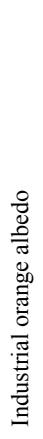 & 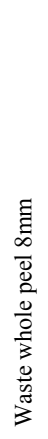 & 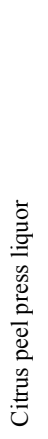 & 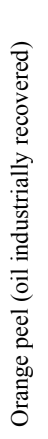 & 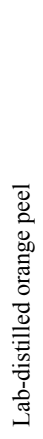 & 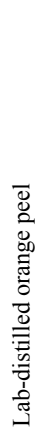 & 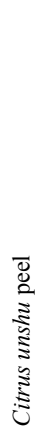 & $\begin{array}{l}\text { 丞 } \\
\text { م. }\end{array}$ & 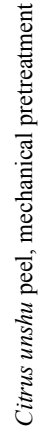 & 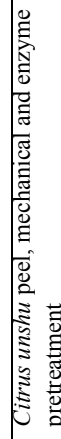 & 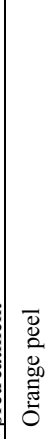 & 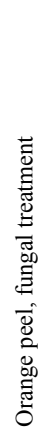 & 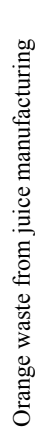 & 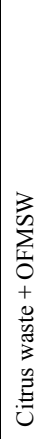 \\
\hline
\end{tabular}




\subsection{Pre-treatments for recovery or removal of citrus essential oils}

One option to improve anaerobic digestion of citrus waste is the prior removal of CEO from the waste. Two strategies can be applied: (a) recovery of the CEO in order to obtain valuable components, in accordance with the concept of biorefinery, or (b) removal of CEO solely to enhance biogas production. The choice between recovery and removal depends on the economic feasibility of the whole process; the former implies a higher cost but yields a valuable product, while the latter involves a cost with the only advantage of a higher biogas production, which must therefore be high enough to compensate for the cost.

\subsubsection{Recovery of citrus essential oil from citrus waste}

Recovery strategies include cold pressing, steam distillation and liquid extraction with solvents. Extraction with supercritical fluids is also possible and it is used in the industry for the production of high purity compounds; but, despite its proven effectiveness for the extraction of limonene from orange peel (Mira et al., 1999), it will not be analysed here since the high investment required and operating costs mean that it is not often used (Wang and Weller, 2006).

Centrifugation of citrus peel press liquors can reduce the oil level from 9.4 to $2.0 \mathrm{~g} \cdot \mathrm{L}^{-1}$. However, the final concentrations are still toxic for anaerobic digestion, making centrifugation an unattractive pre-treatment (Lane, 1983a).

Liquid-liquid extraction of limonene has been tested by Arce et al. (2004) to obtain limonene from ternary systems with aqueous solutions of ethanol. Limonene is completely soluble in ethanol but not in water. In quaternary mixtures, limonene is better separated when the proportion of ethanol in the solvent is higher (Arce et al., 2005). Wikandari et al. (2013) studied the anaerobic digestion of orange peel after solid-liquid extraction with nhexane. Although the limonene extraction yield was more than $80 \%$, depending on the operating conditions, the methane production was lower than expected due to the inhibitory effect of the solvent that remained with the peel.

Steam explosion has been proposed as pre-treatment to recover the limonene previous to the anaerobic digestion of citrus waste. This treatment was able to remove $94.3 \%$ of the limonene and allowed stable thermophilic anaerobic co-digestion of treated citrus waste with organic fraction of municipal solid waste (OFMSW). The same mixture was strongly inhibited when the citrus waste was untreated (Forgács et al., 2011).

\subsubsection{Removal of citrus essential oil from citrus waste}

Pre-treatments to remove CEO include aeration and biological treatments.

Aeration has been successfully used as removal treatment prior to the anaerobic digestion of citrus peel press liquors. Aeration $\left(2 \mathrm{~L}_{\mathrm{air}} \cdot \mathrm{min}^{-1}, 30^{\circ} \mathrm{C}\right)$ of $3 \mathrm{~L}$ of press liquor can cause a reduction in oil levels from 9.4 to $0.1 \mathrm{~g} \cdot \mathrm{L}^{-1}$ within $6-8 \mathrm{~h}$. This reduction is mainly due to evaporation or stripping of the oil, rather than to microbial degradation, although limonenedegrading organisms are present. The COD of the liquid treated has been reduced by $27.5 \%$ 
(Lane, 1983a). This treatment, although effective, is more appropriate for liquids than for solid waste. Moreover, the COD removal caused by the pre-treatment would result in reduced methane yield.

Biological pre-treatment with fungus enzymes has also been reported (Akao et al., 1992). In this case, Aspergillus and Penicillium enzymes were used to pre-treat peel waste, comminuted for $10 \mathrm{~min}$, homogenised for $20 \mathrm{~min}$, supplemented with nitrogen and phosphorus, and diluted to $20-30 \mathrm{~g}_{\mathrm{Vs}} \cdot \mathrm{L}^{-1}$. The pre-treated peel was anaerobically digested at $37^{\circ} \mathrm{C}$ with an HRT of 10 days. The anaerobic digestion of the pre-treated peel was stable at an OLR of 2.0 and $3.0 \mathrm{~g}_{\mathrm{Vs}} \cdot \mathrm{L}^{-1} \cdot \mathrm{d}^{-1}$. In contrast, anaerobic digestion of untreated peel was found to be unstable at an OLR of $3.0 \mathrm{~g}_{\mathrm{VS}} \cdot \mathrm{L}^{-1} \cdot \mathrm{d}^{-1}$. Further experiments demonstrated that the removal of the essential oil was mainly due to the mixing during the pre-treatment, not to enzyme activity.

Another biological pre-treatment that has been tested is solid-state fermentation with selected strains of Sporotrichum, Aspergillus, Fusarium and Penicillium (Srilatha et al., 1995). In that study, anaerobic digestion of citrus waste was carried out in a semicontinuous mode in $1 \mathrm{~m}^{3}$ digesters with an HRT of 25 days, operating for 6 months. The pre-treatment reduced the limonene concentration from $1.00 \%$ in the untreated waste to $0.45 \%$ in the treated waste (both percentages on a dry weight basis), which represented an $82.4 \%$ removal on a wet basis. The maximum OLR that was achieved with anaerobic digestion of untreated citrus waste $\left(1 \%\right.$ limonene) was $2.5 \mathrm{~kg}_{\mathrm{VS}} \cdot \mathrm{m}^{-3} \cdot \mathrm{d}^{-1}$. This corresponded to a limonene dosage of $24 \mathrm{~g} \cdot \mathrm{m}^{-3} \cdot \mathrm{d}^{-1}$ and a biogas production of $0.42-0.50 \mathrm{~m}^{3} \cdot \mathrm{kg}_{\mathrm{vs}}{ }^{-1}$ containing $50 \%$ methane. In contrast, the maximum OLR tested with treated waste $(0.45 \%$ limonene) was $3.6 \mathrm{~kg}_{\mathrm{vs}} \cdot \mathrm{m}^{-3} \cdot \mathrm{d}^{-1}$, corresponding to a limonene dosage of $18 \mathrm{~g} \cdot \mathrm{m}^{-3} \cdot \mathrm{d}^{-1}$ and a biogas production of $0.5-0.6 \mathrm{~m}^{3} \cdot \mathrm{kg}_{\mathrm{vs}}{ }^{-1}$ containing $55 \%$ methane. Higher OLRs for treated waste were not tested due to mechanical problems.

\subsection{Conclusions}

Anaerobic digestion is a sustainable and technically feasible way to valorise citrus waste. The main technical difficulties are related to the presence of essential oils in the peel that can inhibit anaerobic digestion, as they are cytotoxic. Although adaptation has been shown to be possible through in vitro tests, pilot scale trials of anaerobic digestion of citrus waste have failed when a particular OLR is reached or a daily inhibitory dosage is surpassed. However, this dosage varies depending on the particular characteristics of the citrus waste.

Successful strategies to overcome these difficulties are the recovery of limonene through extraction techniques or to remove it by fungal pre-treatment. The choice will depend on the economic and energy balance of the whole process. No experiences at full scale operation have been found.

Several issues remain for future research:

- The biodegradation of CEO, and specifically limonene; the mechanism by which the CEO inhibit the anaerobic digestion has still not been elucidated. 
- The inhibitory concentration of CEO, and specifically limonene, for the anaerobic digestion processes.

- The identification and study of strategies that would allow economically feasible anaerobic digestion of citrus waste; these include avoiding supplementation, the use of low-cost pretreatments and biorefinery concepts.

\subsection{References}

Abraham, W.R., Hoffmann, H.M.R., Kieslich, K., Reng, G., Stumpf, B., 1986a. Microbial transformations of some monoterpenoids and sesquiterpenoids. Enzymes in organic chemistry. Ciba Foundation Symposium III. Pitman, London. 146-160.

Abraham, W.R., Stumpf, B., Kieslich, K., 1986b. Microbial transformations of terpenoids with 1-p-menthene skeleton. Appl. Microbiol. Biotechnol. 24, 24-30.

Akao, T., Mizuki, E., Saito, H., Okumura, S., 1992. The methane fermentation of Citrus unshu peel pretreated with fungus enzymes. Biores. Technol. 41, 35-39.

Arce, A., Marchiaro, A., Martínez-Ageitos, J.M., Soto, A., 2005. Citrus essential oil deterpenation by liquid-liquid extraction. Can. J. Chem. Eng. 83, 366-370.

Arce, A., Marchiaro, A., Soto, A., 2004. Liquid-liquid equilibria of linalool + ethanol + water, water + ethanol + limonene, and limonene + linalool + water systems. J. Solut. Chem. 33, 561-569.

Badee, A.Z.M., Helmy, S.A., Morsy, N.F.S., 2011. Utilisation of orange peel in the production of -terpineol by Penicillium digitatum (NRRL 1202). Food Chem. 126, 849-854.

Bakkali, F., Averbeck, S., Averbeck, D., Idaomar, M., 2008. Biological effects of essential oils - a review. Food Chem. Toxicol. 46, 446-475.

Bampidis, V.A., Robinson, P.H., 2006. Citrus by-products as ruminant feeds: a review. Animal Feed Sci. Technol. $128,175-217$.

Beveridge, T.J., Graham, L.I., 1991. Surface layers of bacteria. Microbiol. Rev. 55, 684-705.

Boluda-Aguilar, M., López-Gómez, A., 2013. Production of bioethanol by fermentation of lemon (Citrus limon L.) peel wastes pretreated with steam explosion. Ind. Crop. Prod. 41, 188-197.

Bowen, E.R., 1975. Potential By-products From Microbial Transformation of Dlimonene. Florida State Horticultural Society, Florida, p. 304.

Burt, S., 2004. Essential oils: their antibacterial properties and potential applications in foods - a review. Int. J. Food Microbiol. 94, 223-253.

Caccioni, D.R.L., Guizzardi, M., Biondi, D.M., Agatino, R., Ruberto, G., 1998. Relationship between volatile components of citrus fruit essential oils and antimicrobial action on Penicillium digitatum and Penicillium italicum. Int. J. Food Microbiol. 43, 73-79.

Cadwallader, K.R., Braddock, R.J., Parish, M.E., Higgins, D.P., 1989. Bioconversion of D-limonene by Pseudomonas gladioli. J. Food Sci. 54, 1241-1245.

Calsamiglia, S., Ferret, A., Bach, A., 2004. Tablas FEDNA de valor nutritivo de Forrajes y Subproductos fibrosos húmedos. Fundación para el Desarrollo de la Nutrición Animal, Madrid, 70 pp.

CAPA (2011). Informe del sector agrario valenciano 2011. Capítulo IV: estadísticas agrícolas. Cuadro 4.12: superficies, producciones y destino de la producción de cítricos. Comunitat Valenciana. Campaña 2010/2011. Conselleria de Agricultura, Pesca y Alimentación. 
Castillejos, L., Calsamiglia, S., Ferret, A., 2006. Effect of essentials oil active compounds on rumen microbial fermentation and nutrient flow in in vitro systems. J. Dairy Sci. 89, 2649-2658.

Cavinato, C., Fatone, F., Bolzonella, D., Pavan, P., 2010. Thermophilic anaerobic codigestion of cattle manure with agro-wastes and energy crops: comparison of pilot and full scale experiences. Bioresour. Technol. $101,545-550$.

Chanakya, H.N., Sharma, I., Ramachandra, T.V., 2009. Micro-scale anaerobic digestion of point source components of organic fraction of municipal solid waste. Waste Manage. 29, 1306-1312.

Chang, H.C., Oriel, P., 1994. Bioproduction of perillyl alcohol and related monoterpenes by isolates of Bacillus stearothermophilus. J. Food Sci. 59, 660-662.

Chang, H.C., Gage, D.A., Oriel, P.J., 1995. Cloning and expression of a limonene degradation pathway from Bacillus stearothermophilus in Escherichia coli. J. Food Sci. 60, 551-553.

Chatterjee, T., Bhattacharyya, D.K., 2001. Biotransformation of limonene by Pseudomonas putida. Appl. Microbiol. Biotechnol. 55, 541-546.

Cheong, T.K., Oriel, P.J., 2000. Cloning and expression of the limonene hydroxylase of Bacillus stearothermophilus BR388 and utilization in two-phase limonene conversions. Appl. Biochem. Biotechnol. 84, 903-915.

Cosentino, S., Tuberoso, C.I.G., Pisano, B., Satta, M., Mascia, V., Arzedi, E., Palmas, F., 1999. In vitro antimicrobial activity and chemical composition of Sardinian Thymus essential oils. Lett. Appl. Microbiol. 29, 130-135.

Crane, A., Nelson, W.O., Brown, R.E., 1957. Effects of D-limonene and a-D-pinene on in vitro carbohydrate dissimilation and methane formation by rumen bacteria. J. Dairy Sci. 40, 1317-1323.

De Blas, C., Mateos, G.G., García-Rebollar, P., 2010. Tablas FEDNA de composición y valor nutritivo de alimentos para la fabricación de piensos compuestos ( $3^{\mathrm{a}}$ edición). (FEDNA tables of composition and nutritive value of foods for the manufacturing of compound feeds (3rd Edition). Fundación Española para el Desarrollo de la Nutrición Animal. Madrid. 502 pp.

De Carvalho, C.C.C.R., da Fonseca, M.M.R., 2006. Bioransformation of terpenes. Biotechnol. Adv. 24, 134-142.

De Carvalho, C.C.C.R., da Fonseca, M.M.R., 2003. Towards the bio-production of trans-carveol and carvone from limonene: induction alter cell growth on limonene and toluene. Tetrahedron Asymmetry 14, 3925-3931.

Dhavalikar, R.S., Bhattacharyya, P.K., 1966. Microbiological transformation of terpenes. VII. Fermentation of limonene in a soil pseudomonad. Indian J. Biochem. 3, 144-157.

Di Pasqua, R., Hoskins, N., Betts, G., Mauriello, G., 2006. Changes in membrane fatty acids composition of microbial cells induced by addition of thymol, carvacrol, limonene, cinnamaldehyde, and eugenol in the growing media. J. Agric. Food Chem. 54, 2745-2749.

Di Pasqua, R., Betts, G., Hoskins, N., Edwards, M., Ercolini, D., Mauriello, G., 2007. Membrane toxicity of antimicrobial compounds from essential oils. J. Agric. Food Chem. 55, 4863-4870.

Dorman, H.J.D., Deans, S.G., 2000. Antimicrobial agents from plants: antibacterial activity of plant volatile oils. J. Appl. Microbiol. 88, 308-316.

Draczynska, L.B., 1987. Oxidation of selected p-menthane derivatives by means of Armilariella mellea (honey fungus), a parasite of woodlands. J. Basic Microbiol. 27, 191-196.

Droby, S., Eick, A., Macarisin, D., Cohen, L., Rafael, G., Stange, R., McColum, G., Dudai, N., Nasser, A., Wisniewski, M., Shapira, R., 2008. Role of citrus volatiles in host recognition, germination and growth of Penicillium digitatum and Penicillium italicum. Postharvest Biol. Technol. 49, 386-396. 
Duetz, W.A., Fjallman, A.H.M., Ren, S.Y., Jourdat, C., Witholt, B., 2001. Biotransformation of D-limonene to (+) trans-carveol by toluene-grown Rhodococcus opacus PWD4 cells. Appl. Environ. Microbiol. 67, 28292832 .

Duetz, W.A., Bouwmeester, H., van Beilen, J.B., Witholt, B., 2003. Biotransformation of limonene by bacteria, fungi, yeasts, and plants. Appl. Microbiol. Biotechnol. 61, 269-277.

Espina, L., Somolinos, M., Lorán, S., Conchello, P., García, D., Pagán, R., 2011. Chemical composition of commercial citrus fruit essential oils and evaluation of their antimicrobial activity acting alone or in combined processes. Food Control 22, 896-902.

Fabio, A., Cermelli, C., Fabio, G., Nicoletti, P., Quaglio, P., 2007. Screening of the antibacterial effects of a variety of essential oils on microorganisms responsible for respiratory infections. Phytother. Res. 21, 374-377.

Fisher, K., Phillips, C., 2006. The effect of lemon, orange and bergamot essential oils and their components on the survival of Campylobacter jejuni, Escherichia coli O157, Listeria monocytogenes, Bacillus cereus and Staphylococcus aureus in vitro and in food systems. J. Appl. Microbiol. 101, 1232-1240.

Fisher, K., Rowe, C., Philips, C.A., 2007. The survival of three strains of Arcobacter butzleri in the presence of lemon, orange and bergamot essential oils and their components in vitro and on food. Lett. Appl. Microbiol. 44, 495-499.

Fisher, K., Phillips, C., 2008. Potential antimicrobial uses of essential oils in food: is citrus the answer? Trends Food Sci. Technol. 19, 156-164.

Forgács, G., Pourbafrani, M., Niklasson, C., Taherzadeh, M.T., Hováth, I.S., 2011. Methane production from citrus wastes: process development and cost estimation. J. Chem. Technol. Biotechnol. 87, 250-255.

Foss, S., Heyen, U., Harder, J., 1998. Alcaligenes defragrans sp. nov., description of four strains isolated on alkenoic monoterpenes $((+)$-menthene, a-pinene, 2-carene and a-phellandrene) and nitrate. Syst. Appl. Microbiol. 21, 237-244.

Fozo, E.M., Kajafasz, J.K., Quivey Jr., R.G., 2004. Low pH-induced membrane fatty acids alterations in oral bacteria. FEMS Microbiol. Lett. 238, 291-295.

Furneri, P.M., Mondello, L., Mandalari, G., Paolino, D., Dugo, P., Garozzo, A., Bisignano, G., 2012. In vitro antimycoplasmal activity of Citrus bergamia essential oil and its major components. Eur. J. Med. Chem. $52,66-69$.

Glöckner, J., Kube, M., Shrestha, P.M., Weber, M., Glöckner, F.O., Reinhardt, R., Liesack, W., 2010. Phylogenetic diversity and metagenomics of candidate division OP3. Environ. Microbiol. 12, 1218-1229.

Griffin, S.G., Wyllie, S.G., Markham, J.L., Leach, D.N., 1999. The role of structure and molecular properties of terpenoids in determining their antimicrobial activity. Flavour Frag. J. 14, 322-332.

Gunaseelan, V.N., 2004. Biochemical methane potential of fruits and vegetable solid waste feedstocks. Biomass Bioenergy 26, 389-399.

Hammer, K.A., Carson, C.F., Riley, T.V., 1999. Antimicrobial activity of essential oils and other plant extracts. J. Appl. Microbiol. 86, 985-990.

Harder, J., Probian, C., 1995. Microbial degradation of monoterpenes in the absence of molecular oxygen. Appl. Environ. Microbiol. 61, 3804-3808.

Hazra, A., Dollimore, D., Alexander, K., 2002. Thermal analysis of evaporation of compounds used in aromatherapy using thermogravimetry. Thermochim. Acta 392-393, 221-229.

Heyen, U., Harder, J., 1998. Cometabolic isoterpinolene formation from isolimonene by denitrifying Alcaligenes defragrans. FEMS Microbiol. Lett. 169, 67-71. 
Hili, P., Evans, C.S., Veness, R.G., 1997. Antimicrobial action of essential oils: the effect of dimethylsulphoxide on the activity of cinnamon oil. Lett. Appl. Microbiol. 24, 269-275.

Hylemon, P.B., Harder, J., 1999. Biotransformation of monoterpenes, bile acids, and other isoprenoids in anaerobic ecosystems. FEMS Microbiol. Rev. 22, 475-488.

Iglesias D.J., Cercós M., Colmenero-Flores J.M., Naranjo M.A., Ríos G., Carrera E., Ruiz-Rivero O., Lliso I., Morillon R., Tadeo F.R., Talon M., 2007. Phisiology of citrus fruiting. Brazilian J. Plant Physiol. 19 333362.

Inouye, S., Abe, S., Yamaguchi, H., Asakura, M., 2003. Comparative study of antimicrobial and cytotoxic effects of selected essential oils by gaseous and solution contacts. Int. J. Aromather. 13, 33-41.

Kammoun Bejar, A., Boudhrioua Mihoubi, N., Kechaou, N., 2012. Moisture sorption isotherms - experimental and mathematical investigations of orange (Citrus sinensis) peel and leaves. Food Chem. 132, 1728-1735.

Kaparaju, P.L.N., Rintala, J.A., 2006. Thermophilic anaerobic digestion of industrial orange waste. Environ. Technol. 27, 623-633.

Karatzas, A.K., Bennik, M.H.J., Smid, E.J., Kets, E.P.W., 2000. Combined action of Scarvone and mild heat treatment on Listeria monocytogenes Scott A. J. Appl. Microbiol. 90, 463-469.

Karellas, S., Boukis, I., Kontopoulos, G., 2010. Development of an investment decision tool for biogas production from agricultural waste. Renew. Sustain. Energy Rev. 14, 1273-1282.

Keweloh, H., Heipieper, H.J., 1996. Trans unsaturated fatty acids in bacteria. Lipids 31, 129-136.

Kim, J., Marshall, M.R., Wei, C., 1995. Antibacterial activity of some essential oil components against five foodborne pathogens. J. Agric. Food Chem. 43, 2839-2845.

Koppar, A., Pullammanappallil, P., 2013. Anaerobic digestion of peel waste and wastewater for on site energy generation in a citrus processing facility. Energy $60,62-68$.

Kraidman, G., Mukherjee, B.B., Hill, I.D., 1969. Conversion of D-limonene into an optically active isomer of aterpineol by a Cladosporium species. Bacteriol. Proc. p. 63.

Lalman, J.A., Bagley, D.M., 2001. Anaerobic degradation and methanogenic inhibitory effect of oleic and stearic acids. Water Res. 35, 2975-2983.

Lane, A.G., 1980. Production of aromatic acids during anaerobic digestion of citrus peel. J. Chem. Tech. Biotechnol. 30, 345-350.

Lane, A.G., 1983a. Removal of peel oil from citrus peel press liquors before anaerobic digestion. Environ. Technol. Lett. 4, 65-72.

Lane, A.G., 1983b. Anaerobic digestion of citrus peel press liquors. Environ. Technol. Lett. 4, 349-352.

Lane, A.G., 1984. Anaerobic digestion of orange peel. Food Technol. Aust. 36, 125-127.

Lennartsson, P.R., Ylitervo, P., Larsson, C., Edebo, L., Taherzadeh, M.J., 2012. Growth tolerance of Zygomicetes Mucor indicus in orange peel hydrolysate without detoxification. Process Biochem. 47, 836-842.

Lohrasbi, M., Pourbafrani, M., Niklasson, C., Taherzadeh, M.J., 2010. Process design and economic analysis of a citrus waste biorefinery with biofuels and limonene as products. Biores. Technol. 101, 7382-7388.

Longbottom, C.J., Carson, C.F., Hammer, K.A., Mee, B.J., Riley, T.V., 2004. Tolerance of Pseudomonas aeruginosa to Melaleuca alternifolia (tea tree) oil is associated with the outer membrane and energydependent cellular processes. J. Antimicrob. Chemother. 54, 386-392.

López-Malo, A., Alzamora, S.M., Palou, E., 2005. Aspergillus flavus growth in the presence of chemical preservatives and naturally occurring antimicrobial compounds. Int. J. Food Microbiol. 99, 119-128. 
Mahmood, A.U., Greenman, J., Scragg, A.H., 1998. Orange and potato peel extracts: analysis and use as Bacillus substrates for the production of extracellular enzymes in continuous culture. Enzyme Microbial Technol. $22,130-137$.

Mandal, T., Mandal, N.K., 1997. Comparative study of biogas production from different waste materials. Energy Convers. Manage. 38, 679-683.

Marei, G.I.K., Rasoul, M.A.A., Abdelgaleil, S.A.M., 2012. Comparative antifungal activities and biochemical effects of monoterpenes on plant pathogenic fungi. Pest. Biochem. Phisiol. 103, 56-61.

Mars, A.E., Gorissen, J.P.L., van den Beld, I., Eggink, G., 2001. Bioconversion of limonene to increased concentrations of perillic cid by Pseudomonas putida GS1 in a fed-batch reactor. Appl. Microbiol. Biotechnol. 56, 101-107.

Martín, M.A., Siles, J.A., Chica, A.F., Martín, A., 2010. Biomethanization of orange peel waste. Biores. Technol. 101, 8993-8999.

Martín, M.A., Fernández, R., Serrano, A., Siles, J.A., 2013. Semi-continuous anaerobic co-digestion of orange peel waste and residual glycerol derived from biodiesel manufacturing. Waste Manage. 33, 1633-1639.

Mira, B., Blasco, M., Berna, A., Subirats, S., 1999. Supercritical CO2 extraction of essential oil from orange peel. Effect of operation conditions on the extract composition. J. Supercrit. Fluids 14, 95-104.

Mizuki, E., Akao, T., Saruwatari, T., 1990. Inhibitory effect of Citrus unshu peel on anaerobic digestion. Biol. Wastes 33, 161-168.

Moreira, M.R., Ponce, A.G., del Valle, C.E., Roura, S.I., 2005. Inhibitory parameters of essential oils to reduce a foodborne pathogen. LWT - Food Sci. Technol. 38, 565-570.

Morton, J., 1987. Orange. In: Fruits of Warm Climates. Julia F. Morton, Miami, FL, pp. 134-142.

Moufida, S., Marzouk, B., 2003. Biochemical characterization of blood orange, sweet orange, lemon, bergamot and bitter orange. Phytochem. 62, 1283-1289.

Mukherjee, B.B., Kraidman, G., Hill, I.D., 1973. Synthesis of glycols by microbial transformations of some monocyclic terpenes. Appl. Microbiol. 25, 447-453.

Noma, Y., Yamasaki, S., Asakawa, Y., 1992. Bioransformation of limonene and related compounds by Aspergillus cellulosae. Phytochem. 31, 2725-2727.

Oberoi, H.S., Vadlani, P.V., Nanjundaswamy, A., Bansal, S., Singh, S., Kaur, S., Babbar, N., 2011. Enhanced ethanol production from Kinnow mandarin (Citrus reticulata) waste via a statistically optimized simultaneous saccharification and fermentation process. Biores. Technol. 102, 1593-1601.

Oh, H.K., Sakai, T., Jones, M.B., Longhurst, W.M., 1967. Effect of various essential oils isolated from Douglas fir needles upon sheep and deer rumen microbial activity. Appl. Microbiol. 15, 777-784.

Onken, J., Berger, R.G., 1999. Effects of R-(+)-limonene on submerged cultures of the terpene transforming basidiomycete Pleutorus sapidus. J. Biotechnol. 69, 163-168.

Paster, N., Juven, B.J., Shaaya, E., Menasherov, M., Nitzan, R., Weisslowicz, H., Ravid, U., 1990. Inhibitory effect of oregano and thyme essential oils on moulds and foodborne bacteria. Lett. Appl. Microbiol. 11, $57-63$.

Pino, J., Sánchez, M., Sánchez, R., Roncal, E., 1992. Chemical composition of orange oil concentrates. Food/Nahrung 36, 539-542.

Prabuseenivasan, S., Jayakumar, M., Ignaciumuth, S., 2006. In vitro antibacterial activity of some plant essential oils. BMC Complement. Altern. Med. 6, 39.

Quintero, A., González, C.N., Sánchez, F., Usubillaga, A., Rojas, L., 2003. Constituents and biological activity of Citrus aurantium amara L. essential oil. Acta Horticult. (ISHS) 597, 115-117. 
Rama Devi, J., Bhattacharyya, P.K., 1977. Microbiological transformations of terpenes. XXIII. Fermentation of geraniol, nerol and limonene by a soil pseudomonad, Pseudomonas incognita (linalool strain). Indian J. Biochem. Biophys. 14, 288-291.

Rotaru, A.E., Schauer, R., Probian, C., Mussmann, M., Harder, J., 2012. Visualization of candidate division OP3 cocci in limonene-degrading methanogenic cultures. J. Microbiol. Biotechnol. 22 (4), 457-461.

Saiyasombati, P., Kasting, G.B., 2003. Two-stage kinetic analysis of fragrance evaporation and absorption from the skin. Int. J. Cosmet. Sci. 25, 235-243.

Sánchez-Segado, S., Lozano, L.J., de los Ríos, A.P., Hernández-Fernández, F.J., Godínez, C., Juan, D., 2012. Process design and economic analysis of a hypothetical bioethanol production plant using carob pod as feedstock. Biores. Technol. 104, 324-328.

Schink, B., 1985. Degradation of unsaturated hydrocarbons by methanogenic enrichment cultures. FEMS Microbiol. Ecol. 31, 69-77.

Schwartz, S.M., Boethling, R.S., Leighton, T., 1990. Fate of the terpenes anethole and dipentene in a bench-scale activated sludge system. Chemosphere 21, 1153-1160.

Shulka, O.P., Bhattacharyya, P.K., 1968. Microbial transformation of terpenes: Part XI - pathways of degradation of alpha \& beta pinenes in a soil pseudomonad (PL-strain), Indian. J. Biochem. 5, 92-101.

Sierra-Álvarez, R., Kato, M., Lettinga, G., 1990. The anaerobic biodegradability of paper mill wastewater constituents. Environ. Technol. 11, 891-898.

Sikkema, J., de Bont, J.A.M., Poolman, B., 1995. Mechanisms of membrane toxicity of hydrocarbons. Microbiol. Rev. 59, 201-222.

Sleytr, U.B., Messner, P., 1988. Crystalline surface layers in prokaryotes. J. Bacteriol. 170, 2891-2897.

Smith, D.C., Forland, S., Bachanos, E., Matejka, M., Barrett, V., 2001. Qualitative analysis of citrus fruits extracts by GC/MS: an undergraduate experiment. Chem. Educ. 6, 28-31.

Smith-Palmer, A., Stewart, J., Fyfe, L., 1998. Antimicrobial properties of plant essential oils and essences against fie important food-borne pathogens. Lett. Appl. Microbiol. 26, 118-122.

Sonboli, A., Eftekhar, F., Yousefzadi, M., Kanani, M.R., 2005. Antibacterial activity and chemical composition of the essential oil of Grammosciadium platycarpum Boiss. From Iran. Z. Naturforsch 60c, 30-34.

Sorda, G., Sunak, Y., Madlener, R., 2013. An agent-based spatial simulation to evaluate the promotion of electricity from agricultural biogas plants in Germany. Ecol. Econ. 89, 43-60.

Speelmans, G., Bijlsma, A., Eggink, G., 1998. Limonene bioconversion to high concentrations of a single and stable product, perillic acid, by a solventresistant Pseudomonas putida strain. Appl. Microbiol. Biotechnol. 50, 538-544.

Srilatha, H.R., Nand, K., Sudhakar Babu, K., Madhukara, K., 1995. Fungal pretreatment of orange processing waste by solid-state fermentation for improved production of methane. Proc. Biochem. 30, 327-331.

Stashenko, E.E., Martínez, R., Pinzón, M.H., Ramírez, J., 1996. Changes in chemical composition of catalytically hydrogenated orange oil (Citrus sinensis). J. Chromatogr. A 752, 217-222.

Subba, M.S., Southmithri, T.C., Suryanarayana, R., 1967. Antimicrobial action of citrus oils. J. Food Sci. 32, 225227.

Sultana, H.S., Ali, M., Panda, B.P., 2012. Influence of volatile constituents of fruit peels of Citrus reticulata Blanco on clinically isolated pathogenic microorganisms under in-vitro. Asian Pac. J. Trop. Biomed., S1299-S1302.

Suutari, M., Linkkonen, K., Laakso, S., 1990. Temperature adaptation in yeast: the role of fatty acids. J. Gen. Microbiol. 136, 1469-1474. 
Suutari, M., Laakso, S., 1994. Microbial fatty acid and thermal adaptation. Crit. Rev. Microbiol. 20, $285-328$.

Tan, Q., Day, D.F., Cadwallader, K.R., 1998. Bioconversion of (R)-(+)-limonene by P. digitatum (NRRL 1202). Proc. Biochem. 33, 29-37.

Thauer, R.K., Jungermann, K., Decker, K., 1977. Energy conservation in chemotrophic anaerobic bacteria. Bacteriol. Rev. 41, 100-180.

Thomas, J.M., Yordy, J.R., Amador, J.A., Alexander, M., 1986. Rates of dissolution and biodegradation of waterinsoluble organic compounds. Appl. Environ. Microbiol. 52, 290-296.

Ultee, A., Kets, E.P.W., Alberda, M., Hoekstra, F.A., Smid, E.J., 2000. Adaptation of the food-borne pathogen Bacillus cereus to carvacrol. Arch. Microbiol. 174, 233-238.

Ultee, A., Bennink, M.H.J., Moezelaar, R., 2002. The phenolic hydroxyl group of carvacrol is essential for action against the food-borne pathogen Bacillus cereus. Appl. Environ. Microbiol. 68, 1561-1568.

Van der Werf, M., Boot, A.M., 2000. Metabolism of carveol and dihydrocarveol in Rhodococcus erythropolis DCL14. Microbiol. 146, 1129-1141.

Van der Werf, M.J., Keijzer, P.M., Van der Schaft, P.H., 2000. Xanthobacter sp C20 contains a novel bioconversion pathway for limonene. J. Biotechnol. 84, 133-143.

Van Dyk, M.S., Van Rensburg, E., Moleki, N., 1998. Hydroxylation of (+) limonene, (-) a-pinene and (-) b-pinene by a Hormonema sp. Biotechnol. Lett. 20, 431-436.

Varel, V.H., Miller, D.N., 2001. Plant-derived oils reduce pathogens and gaseous emissions from stored cattle waste. Appl. Environ. Technol. 67, 1366-1370.

Wang, L., Weller, C.L., 2006. Recent advances in extraction of nutraceuticals from plants. Food Sci. Technol. 17, $300-312$.

Wikandari, R., Nguyen, H., Millati, R., Niklasson, C., Taherzadeh, M.J., 2013. A novel method of orange wastes pretreatment for biogas production. WASTES: Solutions, Treatments and Opportunities. In: 2nd International Conference. Braga (Portugal), September 11th-13th 2013.

Wilkins, M.R., Grohmann, K., Widmer, W.W., 2006. Effect of D-limonene on the fermentation of citrus peel waste. ASABE meeting presentation. Paper number: 067007.

WHO, 1998. Concise International Chemical Assessment Document 5. World Health Organization, LIMONENE, ISBN 924153005 7. ISSN 1020-6167.

Zhou, W., Widmer, W., Grohmann, K., 2007. Economic analysis of ethanol production from citrus peel waste. Proc. Fla. State Hort. Soc. 120, 310-315. 


\title{
Chapter 3
}

\section{Effect of limonene on batch anaerobic digestion of citrus peel waste}

\begin{abstract}
The objective of this study was to analyse the anaerobic digestion process inhibition by limonene, the main component of citrus essential oils (CEO) present in citrus peel.

The biochemical methane potential (BMP) values of the citrus waste tested (orange peel, mandarin peel, mandarin pulp and rotten fruit) were $354-398 \mathrm{~L} \mathrm{~kg}_{\mathrm{Vs}}{ }^{-1}$. Grinding the orange peel $\left(2.5 \mathrm{~g}_{\text {limonene }} \cdot \mathrm{kg}^{-1}\right)$ did not influence the BMP values, but slowed the kinetics, due to the increased availability of CEO caused by the grinding.

The effect of $(\mathrm{R})$-limonene $\left(0-3000 \mathrm{mg} \cdot \mathrm{L}^{-1}\right)$ on the batch anaerobic digestion of microcrystalline cellulose was also assessed. The half maximal inhibitory concentration, $\mathrm{IC}_{50}$, was $423 \mathrm{mg} \cdot \mathrm{kg}^{-1}$ in an initial run and $669 \mathrm{mg} \cdot \mathrm{kg}^{-1}$ in a second run of batch experiments. The methane course and $\mathrm{IC}_{50}$ values indicate that there is a reversible inhibition and certain biomass adaptation during the anaerobic digestion process, despite the non-reversible antimicrobial mechanism described in the literature for limonene to date.
\end{abstract}

This chapter has been submitted to a peer reviewed journal as:

Ruiz B., Flotats X., 2015. Effect of limonene on batch anaerobic digestion of citrus peel waste. Biochemical Engineering Journal (under review). 


\section{Table of contents}

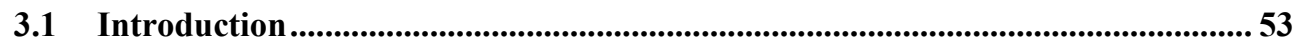

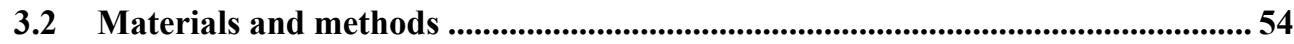

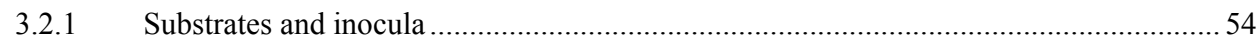

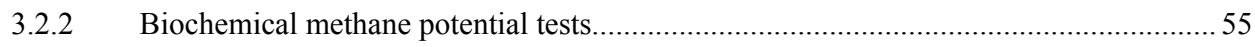

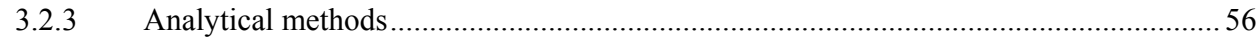

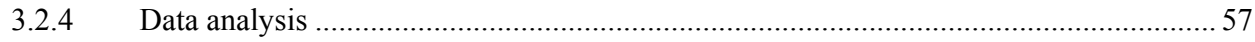

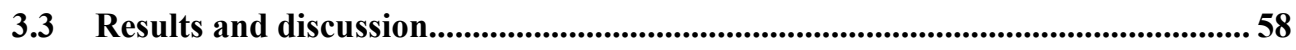

3.3.1 Biochemical methane potential of citrus waste …......................................................... 59

3.3.2 Effect of citrus essential oil on the batch anaerobic digestion of orange peel.................59

3.3.3 Effect of low limonene concentrations $\left(50-200 \mathrm{mg} \cdot \mathrm{kg}^{-1}\right)$ on the anaerobic digestion..... 63

3.3.4 Effect of high limonene concentrations $\left(200-3000 \mathrm{mg} \cdot \mathrm{kg}^{-1}\right)$ on the anaerobic digestion 65

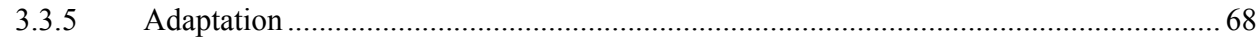

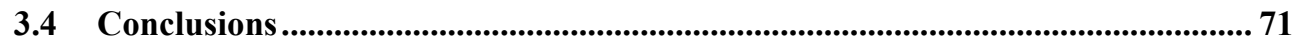

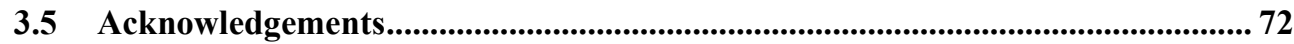

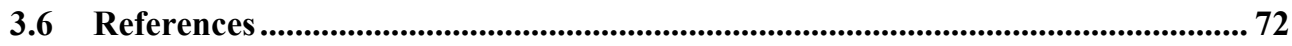




\subsection{Introduction}

Citrus waste, peel and pressed pulp, is generated during the juice manufacturing process. Another source of waste is the fruit discarded for commercial reasons or due to production limiting regulations. The amount of waste generated varies, since it is a fraction of the total amount of fruit produced and processed. The processing of citrus fruit for juice extraction produces around 500 tons of waste per 1000 tons of fruit processed (Lane, 1983; Lohrasbi et al., 2010). The percentage of fruit discarded as a result of commercial or regulatory issues ranges from $2 \%$ to $10 \%$. In the region of Valencia (eastern Spain), 3.5 million tons of citrus fruit was produced in the production year 2010-2011. Of this, around 0.4 million tons ( $11 \%$ of the total production) was reported as losses. Another 0.4 million tons was industrially processed to make juice, which would produce around 0.2 million tons of waste (CAPA, 2011).

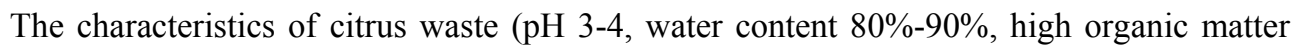
content) constrain the alternatives for its management or valorization. The use of citrus waste as livestock feed is possible due to its nutritive value (similar to that of sugar beet pulp), which is the result of its high carbohydrate content, its significant proportion of cell wall components and its low level of lignification (De Blas et al., 2010). However, the market for this material is becoming saturated. Composting citrus waste is a complex process due to its low $\mathrm{pH}$, the presence of essential oils that inhibit the composting process and the fast rate of biodegradation of the waste, which can cause anaerobiosis problems. Thermal treatment alternatives (incineration, gasification or pyrolysis) are not feasible for citrus waste due to its high humidity; neither is disposal in landfill sites. The manufacture of bioethanol from citrus waste, although technically possible, requires a very large investment (Sánchez-Segado et al., 2012) and is not as energy efficient as methane (biogas) production through anaerobic digestion: while methane production can yield more than 700 $\mathrm{kWh}$ per tonne of waste, the energy yield of the bioethanol production process is only around $300 \mathrm{kWh}$ per tonne (Ruiz and Flotats, 2014).

Given this situation, anaerobic digestion is a technically feasible, environmentally friendly and energy efficient process for the valorization of citrus waste. However, citrus essential oil (CEO) can inhibit this bioprocess; as observed in several studies of the inhibitory effect of limonene (the major component of CEO) on anaerobic digestion of citrus waste (Lane, 1984; Mizuki et al., 1990; Srilatha et al., 1995, Kaparaju and Rintala, 2006; Martín et al., 2010, Martín et al., 2013, Koppar and Pullammanappallil, 2013). Nevertheless, there is no consensus regarding the inhibitory concentration of this compound. While we have found no references to the determination of the $\mathrm{IC}_{50}$ inhibitory concentration of citrus waste, inhibitory doses of limonene in semi-continuous anaerobic digestion are reported to vary from $24 \mathrm{mg} \cdot \mathrm{L}^{-1} \cdot \mathrm{d}^{-1}$ to $75 \mathrm{mg} \cdot \mathrm{L}^{-1} \cdot \mathrm{d}^{-1}$ (Lane, 1984; Mizuki et al., 1990; Srilatha et al., 1995). This range of values could be due to the different conditions applied in the experiments (the operating conditions of the digester, use of additives, different varieties of fruit, etc.). In addition, the studies observed that minority components of essential oils also seem to have an inhibitory effect, since CEO inhibition is stronger than inhibition by commercial 
limonene. More recent work on the anaerobic digestion of citrus waste did not aim to find the inhibitory concentration of limonene and therefore no information on this is provided (Kaparaju and Rintala, 2006; Martín et al., 2010, Martín et al., 2013, Koppar and Pullammanappallil, 2013).

The CEO antimicrobial mechanism is based on cell malfunction and lysis. Once dissolved in the aqueous medium, the CEO accumulates in the membrane of the microorganisms and changes its structure. The membrane fluidity changes, becomes more permeable and finally leakage of the cell contents occurs (Bakkali et al., 2008). We found no studies on the possible adaptation of the microorganisms responsible for the anaerobic digestion to CEO.

The objectives of this study were: (i) to determine the biodegradability of citrus waste, (ii) to study the inhibitory effect of limonene on the anaerobic digestion of citrus waste and (iii) to characterize this inhibition and the possible adaptation of the biomass.

\subsection{Materials and methods}

The anaerobic digestion of citrus waste was assessed using different approaches.

The biochemical methane potential (BMP) of the most common citrus waste was determined by testing the following materials: orange peel (OP1, OP2), mandarin peel (MP), mandarin pulp (MPU) and rotten mandarin (MR).

The effect of the limonene naturally present in the orange peel, as the main component of $\mathrm{CEO}$, on the batch anaerobic digestion was assessed by digesting orange peel (OP2) that contained a known concentration of limonene $\left(2.5 \pm 0.5 \mathrm{~g} \cdot \mathrm{L}^{-1}\right)$. This material was digested with and without grinding it until a paste-like material (OPG2) was obtained.

The effect of commercial limonene on batch anaerobic digestion was further characterized by digesting microcrystalline cellulose in the presence of different concentrations of limonene (from 50 to $3000 \mathrm{mg} \cdot \mathrm{kg}^{-1}$ ). Two sets of experiments were carried out: low concentrations $\left(50-200 \mathrm{mg} \cdot \mathrm{kg}^{-1}\right)$ and high concentrations $\left(200-3000 \mathrm{mg} \cdot \mathrm{kg}^{-1}\right)$ of limonene. The overall objective of the experiments was to quantify the inhibitory effect of the limonene by calculating the inhibition constant $\mathrm{K}_{\mathrm{I}}$ ( or $\left.\mathrm{IC}_{50}\right)$.

The adaptation of the biomass to the inhibitor was evaluated by adding a new load of cellulose and limonene to some of the batch anaerobic digesters used in the experiment with high limonene concentrations, once biogas production had stopped.

\subsubsection{Substrates and inocula}

Inocula. Inocula of different origins were used, depending on their availability at the time of performing the experimental work. Digestate from a full scale (FS) agricultural biogas plant fed with cow manure and vegetable substrates at mesophilic temperatures and 3 $\mathrm{kg}_{\mathrm{vs}} \cdot \mathrm{m}^{-3} \cdot \mathrm{d}^{-1}$ was used on most occasions. When this was not available, digestate from cow manure digesters, of $1 \mathrm{~m}^{3}$ (pilot scale, PS) or $36 \mathrm{~L}$ (lab scale, LS), operating at mesophilic temperatures was used. 
Commercial reagents. Commercial reagents used for the BMP tests of cellulose with different concentrations of limonene were (S)-(-)-limonene, 97\% purity (Alfa Aesar, US), (R)-(+)-limonene, 97\% purity (Sigma, US) and microcrystalline cellulose, powder (Sigma Aldrich, US).

Substrates. Citrus waste of different origins was used. Orange (Citrus sinensis) peel (OP1) was prepared from oranges bought at a local market. Orange peel (Navelina variety) samples were collected from a Spanish juice manufacturing facility where no limonene extraction was performed (OP2). The OP2 samples for the BMP tests were used with and without grinding until a paste-like material (OPG2) was obtained. Mandarin (Citrus reticulata) waste samples-mandarin peel (MP), mandarin pulp (MPU) and rotten mandarin (MR) — were collected from a juice manufacturing facility and from a citrus fruit cooperative, both in Spain, and used without further pretreatment.

\subsubsection{Biochemical methane potential tests}

BMP tests were conducted according to the VDI Standard 4630 "Fermentation of organic materials" (VDI, 2006). Two-litre glass bottles, placed in incubation chambers (Binder, Germany) with forced air circulation set at $38^{\circ} \mathrm{C}$ were used as anaerobic digesters. The gas volume was measured using Ritter Milligascounters MGC-1 (Ritter, Germany). The laboratory set-up where the BMP tests were carried out is shown in Figure 3.1. Tests were run in triplicate with an inoculum to substrate ratio (ISR) of $2.6 \pm 0.8$ and an initial inoculum concentration in terms of volatile solids of $26.9 \pm 8.8 \mathrm{~g}_{\mathrm{VSinoculum}} \cdot \mathrm{L}^{-1}$. Ambient temperature and pressure were continuously recorded for normalization of the gas volume to standard temperature and pressure (STP) conditions: $0^{\circ} \mathrm{C}$ and $1 \mathrm{~atm}$.

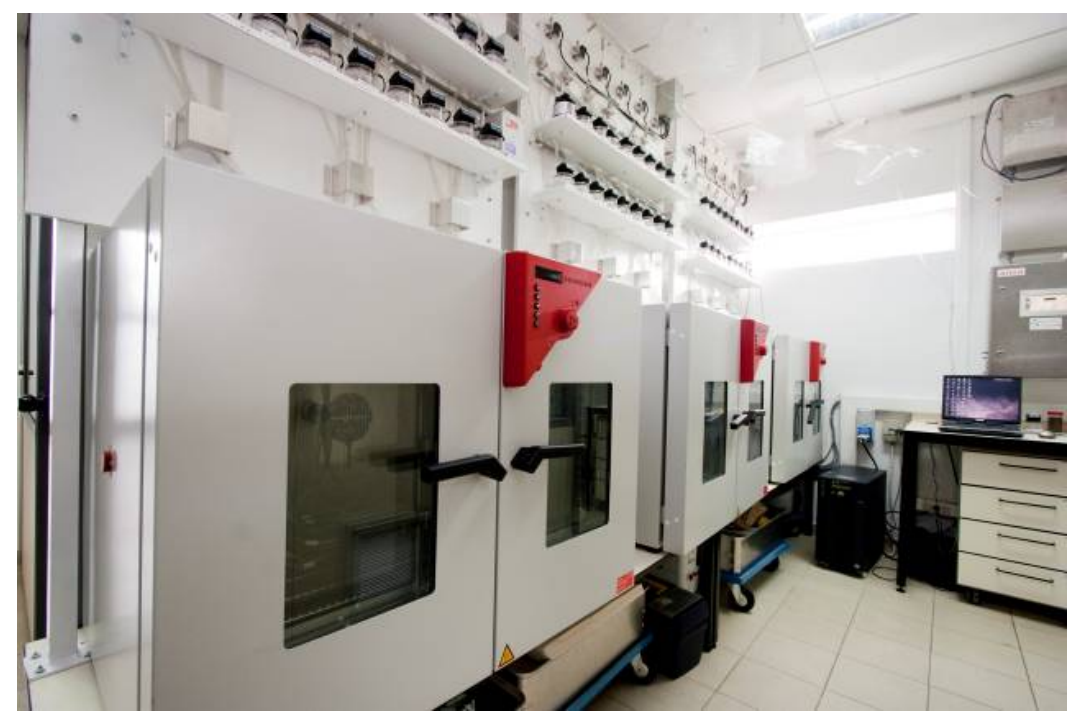

Figure 3.1. Laboratory set-up where biochemical methane potential tests were carried out. 
Table 3.1 summarizes all the BMP tests, indicating the code, substrates, and inoculum type, as well as the characteristics and initial concentration used in the test. No buffering solution or nutrients were added to the batch digesters.

Table 3.1. Summary of BMP tests

\begin{tabular}{|c|c|c|c|c|c|c|}
\hline \multirow[b]{2}{*}{ Code } & \multirow[b]{2}{*}{ Substrate(s) } & \multicolumn{5}{|c|}{ Inoculum } \\
\hline & & Type & $\begin{array}{l}T S \\
(\%)\end{array}$ & $\begin{array}{c}V S \\
(\% T S)\end{array}$ & $\begin{array}{c}\text { ISR (VS } \\
\text { basis) }\end{array}$ & $g_{\text {VSinoculum }} \cdot L^{-1}$ \\
\hline OP1 & Orange peel 1 & PS & 6.6 & 77.8 & 3.9 & 24.7 \\
\hline OP2 & Orange peel 2 & FS & 5.2 & 78.9 & 2.4 & 19.4 \\
\hline MP & Mandarin peel & LS & 4.5 & 74.0 & 2.3 & 16.1 \\
\hline MPU & Mandarin pulp & LS & 4.5 & 74.0 & 2.3 & 15.8 \\
\hline MR & Rotten mandarin & LS & 4.5 & 74.0 & 2.7 & 15.9 \\
\hline OPG2 & Orange peel 2 , ground & FS & 5.2 & 78.9 & 2.5 & 19.4 \\
\hline LL0a & Cellulose & FS & 8.3 & 77.3 & 2.0 & 31.7 \\
\hline LL50 & Cellulose + S-limonene $50 \mathrm{mg} \cdot \mathrm{kg}^{-1}$ & FS & 8.3 & 77.3 & 2.0 & 31.7 \\
\hline LLOb & Cellulose & FS & 9.0 & 80.4 & 2.2 & 35.4 \\
\hline LL100 & Cellulose + S-limonene $100 \mathrm{mg} \cdot \mathrm{kg}^{-1}$ & FS & 9.0 & 80.4 & 2.2 & 35.4 \\
\hline LL200 & Cellulose + S-limonene $200 \mathrm{mg} \cdot \mathrm{kg}^{-1}$ & FS & 9.0 & 80.4 & 2.2 & 35.7 \\
\hline HL0 & Cellulose & FS & 9.1 & 77.7 & 2.0 & 34.4 \\
\hline HL200 & Cellulose + R-limonene $200 \mathrm{mg} \cdot \mathrm{kg}^{-1}$ & FS & 9.1 & 77.7 & 2.0 & 34.5 \\
\hline HL600 & Cellulose + R-limonene $600 \mathrm{mg} \cdot \mathrm{kg}^{-1}$ & FS & 9.1 & 77.7 & 2.0 & 34.6 \\
\hline HL1000 & Cellulose + R-limonene $1000 \mathrm{mg} \cdot \mathrm{kg}^{-1}$ & FS & 9.1 & 77.7 & 2.0 & 34.6 \\
\hline HL2000 & Cellulose + R-limonene $2000 \mathrm{mg} \cdot \mathrm{kg}^{-1}$ & FS & 9.1 & 77.7 & 2.0 & 34.5 \\
\hline HL2000S & Cellulose + S-limonene $2000 \mathrm{mg} \cdot \mathrm{kg}^{-1}$ & FS & 9.1 & 77.7 & 2.0 & 34.4 \\
\hline HL3000 & Cellulose + R-limonene $3000 \mathrm{mg} \cdot \mathrm{kg}^{-1}$ & FS & 9.1 & 77.7 & 2.0 & 34.4 \\
\hline
\end{tabular}

Type: origin of the inoculum. LS: lab scale, PS: pilot scale, FS: full scale.

\subsubsection{Analytical methods}

Analysis of total solids (TS), volatile solids (VS), phosphorus, potassium, total Kjeldahl nitrogen (TKN), ammonia nitrogen $\left(\mathrm{NH}_{4}{ }^{+}-\mathrm{N}\right)$, total and soluble chemical oxygen demand (COD, sCOD) and $\mathrm{pH}$ were carried out according the Standard Methods of Analysis (APHA-AWWA-WEF, 2006). Due to the high degree of heterogeneity of the samples, the COD and sCOD results had very large standard deviations and were not considered realistic. Therefore, COD values were estimated based on VS content. 
The individual volatile fatty acids (VFA) acetate, propionate, iso-butyrate, n-butyrate, isovalerate, n-valerate, iso-caproate, caproate and heptanoate were analysed using a $\mathrm{CE}$ instruments 8000 TOP gas chromatograph with an HP-FFAP capillary column (Agilent, US) and a flame ionization detector (FID). CEO composition and limonene were analysed by GC-MS with a Thermo Finnigan (Trace DSQ) gas chromatograph equipped with a VF5MS capillary column (Agilent, US). Helium was used as the carrier gas in both VFA and CEO composition analysis.

The concentrations of methane, carbon dioxide, oxygen, hydrogen sulphide and hydrogen in the gas were determined with a gas analyser (Awite, Germany), by means of infrared (concentration of $\mathrm{CH}_{4}, \mathrm{CO}_{2}$ and $\mathrm{O}_{2}$ ) and electrochemical (concentration of $\mathrm{H}_{2} \mathrm{~S}$ and $\mathrm{H}_{2}$ ) sensors.

\subsubsection{Data analysis}

The biogas and methane yield of the BMP tests were calculated according the VDI 4630 Standard (VDI, 2006). Methane production rate (MPR) was calculated as the maximum slope of the cumulative methane production curves. The maximum slope is usually found after the lag phase (if any). For example, in Figure 3.2, the maximum slope is found between days 3 and 6 of experiment.

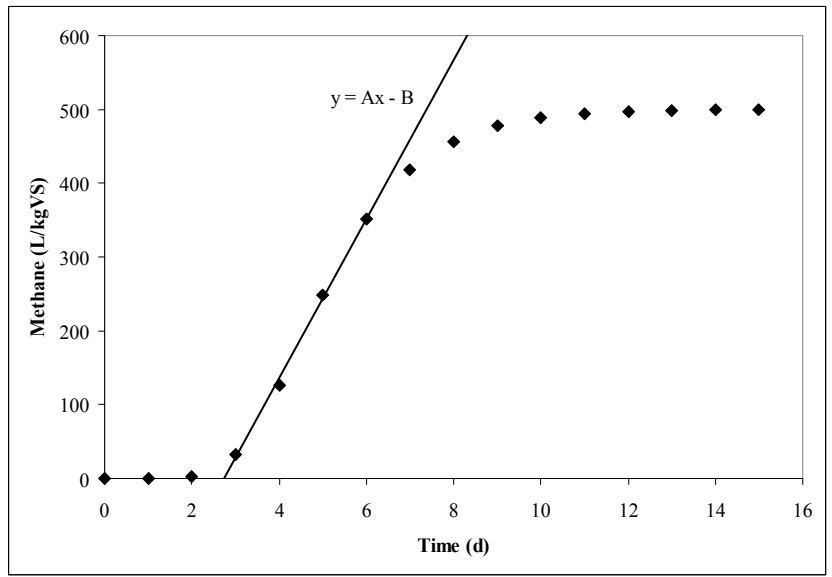

Figure 3.2. Maximum slope calculation from the curves of cumulative biogas production. The value for $A$ in the linear regression equation $y=A x-B$ is the maximum slope.

The methanization index $(\% \mathrm{M})$, acidification index $(\% \mathrm{~A})$ and biodegradability $(\% \mathrm{BD})$ were calculated according to Field et al. (1998) when enough data were available. The values taken for $\mathrm{Y}_{\mathrm{A}}$ (the coefficient of cellular yield of acidogenic bacteria) and $\mathrm{Y}_{\mathrm{M}}$ (coefficient of cellular yield of methanogenic bacteria) were $0.1 \mathrm{gCOD}_{\text {cel }} \cdot \mathrm{gCOD}_{\text {removed }}{ }^{-1}$ and 0.055 $\mathrm{gCOD}_{\text {cel }} \cdot \mathrm{gCOD}_{\text {removed }^{-1}}$ respectively (Batstone et al., 2000). As mentioned above, the initial COD concentrations for the calculation of these indexes were estimated from the VS value, 
assuming a COD:VS ratio of 1.4 (Kaparaju and Rintala, 2006). Although some of the final biodegradability values were not realistic, they could serve for comparison purposes.

In the experiments to evaluate the effect of commercial limonene on the batch anaerobic digestion of microcrystalline cellulose, the inhibition constant $\left(\mathrm{K}_{\mathrm{I}}\right.$ or $\left.\mathrm{IC}_{50}\right)$ was calculated as the limonene concentration that lowers the initial MPR by $50 \%$.

Statistical analysis was carried out to detect significant differences between the results of the experimental tests. To evaluate whether the average values of two of the tests run in triplicate were different, the t-test $(\alpha=0.05)$ for two samples considering different variances was applied.

\subsection{Results and discussion}

The origin and chemical characteristics of the citrus waste used in the BMP tests are summarized in Table 3.2.

Table 3.2. Chemical characteristics of citrus waste tested. All units are expressed in wet basis.

\begin{tabular}{|c|c|c|c|c|c|}
\hline Parameter (units) & $\begin{array}{c}\text { C. } \\
\text { peel }\end{array}$ & C. sinensis peel & $\begin{array}{c}\text { C. reticulata } \\
\text { peel }\end{array}$ & $\begin{array}{c}\text { C. reticulata } \\
\text { pulp }\end{array}$ & $\begin{array}{c}\text { C. } \\
\text { reticulata } \\
\text { rotten }\end{array}$ \\
\hline Origin & Market & Juice manuf. & Juice manuf. & Juice manuf. & Cooperative \\
\hline Code & $O P 1$ & $O P 2 / O P G 2$ & $M P$ & $M P U$ & $M R$ \\
\hline TS $(\%)$ & $18.3 \pm 0.2$ & $15.4 \pm 0.8$ & $24.5 \pm 0.3$ & $14.7 \pm 0.2$ & $13.7 \pm 0.2$ \\
\hline VS (\%TS) & $96.7 \pm 0.6$ & $96.0 \pm 0.0$ & $96.4 \pm 0.6$ & $96.8 \pm 0.6$ & $96.6 \pm 0.6$ \\
\hline $\mathrm{EC}\left(\mu \mathrm{S} \cdot \mathrm{cm}^{-1}, 20^{\circ} \mathrm{C}\right)$ & $570 \pm 39$ & $589 \pm 9.9$ & $893 \pm 61$ & $530 \pm 36$ & $719 \pm 49$ \\
\hline $\mathrm{pH}\left(20^{\circ} \mathrm{C}\right)$ & $4.24 \pm 0.28$ & $4.0 \pm 0.0$ & $3.1 \pm 0.2$ & $3.6 \pm 0.2$ & $3.3 \pm 0.2$ \\
\hline TOC $\left(\mathrm{g} \cdot \mathrm{kg}^{-1}\right)$ & 2.9 & $4.7 \pm 0.2$ & 5.2 & 3.9 & 5.0 \\
\hline $\mathrm{N}-\mathrm{NH}_{4}^{+}\left(\mathrm{mg} \cdot \mathrm{kg}^{-1}\right)$ & n.a. & $218.5 \pm 70.0$ & $246 \pm 31$ & $735 \pm 93$ & $163 \pm 21$ \\
\hline $\mathrm{TKN}\left(\mathrm{mg} \cdot \mathrm{kg}^{-1}\right)$ & $1830 \pm 216$ & $1183 \pm 503$ & $2877 \pm 340$ & $2333 \pm 275$ & $1555 \pm 184$ \\
\hline Phosphorus (mg $\left.\cdot \mathrm{kg}^{-1}\right)$ & $194 \pm 14$ & $206 \pm 11$ & $270 \pm 17$ & $226 \pm 16$ & $178 \pm 13$ \\
\hline Potassium $\left(\mathrm{mg} \cdot \mathrm{kg}^{-1}\right)$ & $1171 \pm 176$ & $1242 \pm 53$ & $1868 \pm 280$ & $1358 \pm 204$ & $1189 \pm 178$ \\
\hline Limonene $\left(g \cdot \mathrm{kg}^{-1}\right)$ & n.a. & $2.5 \pm 0.5$ & n.a. & n.a. & n.a. \\
\hline Acetic acid $\left(\mathrm{mg} \cdot \mathrm{kg}^{-1}\right)$ & n.a. & $0 \pm 0(*)$ & $902 \pm 90(*)$ & $96 \pm 10(*)$ & $120 \pm 12(*)$ \\
\hline
\end{tabular}

n.a.: not analysed. $\left(^{*}\right)$ the rest of VFA (propionic, iso-butyric, butyric, iso-valeric, valeric, caproic and heptanoic) were also analysed but not detected in the samples. 


\subsubsection{Biochemical methane potential of citrus waste}

The results of the BMP tests in terms of BMP, MPR and biodegradability index are summarized in Table 3.3.

Table 3.3. Main results of BMP tests on citrus waste (average values \pm standard

\begin{tabular}{|c|c|c|c|}
\hline & $\begin{array}{c}\text { Biochemical methane } \\
\text { potential }\left(\mathrm{L} \cdot \mathrm{kg}_{\mathrm{vs}}{ }^{-1}\right)\end{array}$ & $\begin{array}{l}\text { Methane production rate } \\
\left(\mathrm{L} \cdot \mathrm{kg}_{\mathrm{SV}}{ }^{-1} \cdot \mathrm{d}^{-1}\right)\end{array}$ & $\begin{array}{l}\text { Biodegradability index, } \\
\text { estimated }(\% \mathrm{BD})\end{array}$ \\
\hline MR & $398.2 \pm 19.5$ & $82.7 \pm 5.2$ & $95.0 \pm 4.6$ \\
\hline MPU & $365.0 \pm 9.5$ & $78.6 \pm 4.1$ & $87.1 \pm 2.3$ \\
\hline MP & $370.6 \pm 20.0$ & $56.8 \pm 5.8$ & $88.4 \pm 4.8$ \\
\hline OP2 & $353.9 \pm 38.2$ & $42.8 \pm 3.3$ & $84.5 \pm 9.1$ \\
\hline OP1 & $357.3 \pm 31.1$ & $39.9 \pm 3.2$ & $85.2 \pm 7.3$ \\
\hline
\end{tabular}

The average BMP obtained for orange peel was $356 \mathrm{~L}_{\mathrm{CH} 4} \cdot \mathrm{kg}_{\mathrm{Vs}}{ }^{-1}$. The results obtained by Martín et al. (2010) were lower, $230 \mathrm{~L}_{\mathrm{CH} 4} \cdot \mathrm{kg}_{\mathrm{Vs}}{ }^{-1}$, probably due to the loss of organic matter during the prior extraction of limonene performed in that study. Gunaseelan (2004) obtained $455 \mathrm{~L}_{\mathrm{CH} 4} \cdot \mathrm{kg}_{\mathrm{VS}}{ }^{-1}$, and other authors (Kaparaju and Rintala, 2006; Koppar and Pullammanappallil, 2013) reported higher methane yields for orange peel at thermophilic temperatures (490 and $640 \mathrm{~L}_{\mathrm{CH} 4} \cdot \mathrm{kg}_{\mathrm{VS}}{ }^{-1}$ respectively). The BMP obtained for the mandarin waste (peel: $371 \mathrm{~L}_{\mathrm{CH} 4} \cdot \mathrm{kg}_{\mathrm{Vs}}{ }^{-1}$; pulp: $365 \mathrm{~L}_{\mathrm{CH} 4} \cdot \mathrm{kg}_{\mathrm{Vs}}{ }^{-1}$; rotten whole fruit: $398 \mathrm{~L}_{\mathrm{CH} 4} \cdot \mathrm{kg}_{\mathrm{Vs}}{ }^{-1}$ ) are similar to the results of Gunaseelan (2004), who reported 486, 433 and $494 \mathrm{~L}_{\mathrm{CH} 4} \cdot \mathrm{kg}_{\mathrm{Vs}}{ }^{-1}$ for peel, pulp and rotten fruit, respectively.

Unfortunately, limonene concentration was not measured for all samples before these BMP tests, making not possible to relate univocally the initial CEO content with the production indexes obtained. Nevertheless, listing the different materials in Table 3.3 sorted by the expected essential oil (limonene) concentration, from lowest to highest (MR, whole fruits with expected degradation by fungi, to OP1, orange peel where the CEO is located, respectively), the MPR presents decreasing values.

The values shown in Table 3.3 thus seem to confirm the hypothesis that CEO, with limonene as its major constituent, inhibits anaerobic digestion, but the different origins and compositions of the waste, or different CEO compositions (Mizuki et al., 1990), could explain the different results obtained also. This hypothesis will be contrasted with known limonene concentrations in the following sections.

\subsubsection{Effect of citrus essential oil on the batch anaerobic digestion of orange peel}

The effect of limonene (naturally present in orange peel as the main component of the $\mathrm{CEO}$ ) on the batch anaerobic digestion was assessed by digesting orange peel with a known 
limonene concentration $\left(2.5 \pm 0.5 \mathrm{~g} \cdot \mathrm{kg}^{-1}\right)$ and different initial availabilities of the CEO, achieved by grinding the peel or not as a pretreatment.

The results in terms of BMP and MPR are given in Table 3.4. Grinding the peel prior to the batch anaerobic digestion tests had no statistically significant influence in the BMP, but the MPR was 28\% lower for the ground peel (a statistically significant difference with a confidence level higher than 95\%).

Table 3.4. Main results of BMP tests of ground and unground orange peel (average values \pm standard deviation).

\begin{tabular}{|c|c|c|c|c|}
\hline Substrate & $\begin{array}{c}\text { Limonene } \\
\text { concentration in the } \\
\text { peel }\left(\mathrm{g} \cdot \mathrm{kg}^{-1}\right)\end{array}$ & $\begin{array}{l}\text { Initial limonene } \\
\text { concentration in the } \\
\text { digester }\left(\mathrm{mg} \cdot \mathrm{kg}^{-1}\right)\end{array}$ & $\begin{array}{c}\text { Biochemical } \\
\text { methane potential } \\
\left(\mathrm{L} \cdot \mathrm{kg}_{\mathrm{vs}}{ }^{-1}\right)\end{array}$ & $\begin{array}{l}\text { Methane production } \\
\text { rate }\left(\mathbf{L}^{\prime} \cdot \mathbf{k g}_{\mathrm{vs}}{ }^{-1} \cdot \mathbf{d}^{-1}\right)\end{array}$ \\
\hline OP2 & $2.5 \pm 0.5$ & $121.5 \pm 1.2$ & $353.9 \pm 38.2$ & $42.8 \pm 3.3$ \\
\hline OPG2 & $2.5 \pm 0.5$ & $122.6 \pm 0.9$ & $296.2 \pm 71.4$ & $31.0 \pm 4.8$ \\
\hline
\end{tabular}

Additional parameters were monitored at $0,3,6,8,10,13$ and 28 days, specifically: VS, COD, sCOD, $\mathrm{pH}$, ammonia nitrogen, VFA, limonene and hydrogen partial pressure in the biogas. The evolution of some of these parameters is shown in Figure 3.3.

Although only small differences were observed in COD, VS evolved differently depending on whether the orange peel was ground or not, with lower VS degradation for ground orange peel. The $\mathrm{pH}$ values remained adequate for anaerobic digestion in all cases (Kim et al., 2003; Yu and Fang, 2002). Ammonia nitrogen also remained in the non-inhibitory range (Chen et al., 2008) and no differences were observed between OP2 and OPG2.

The maximum VFA concentration in the digesters with OPG2 was higher and remained higher for longer than the VFA concentration in the digesters with OP2. The hydrogen partial pressure in the biogas showed a similar evolution in both cases, except for the first two values (days 1 and 3) when the hydrogen concentration in the biogas produced by OP2 was lower than that from OPG2. The higher VFA and hydrogen accumulation in the initial days of the experiment with OPG2 compared to OP2 indicates a probable partial inhibition in the case of OPG2, which could be explained by the increased availability of the inhibitor than in OP2.

The limonene concentration in the digesters (see Figure 3.4) decreased rapidly with a very similar trend in both OP2 and OPG2, and was almost negligible after day 5 of the experiment. However, the inhibitory effect was observed until day $10\left(\mathrm{H}_{2}\right.$ and VFA accumulation). There are two possible explanations: a) cell death caused by limonene and b) the degradation products of the limonene or other CEO components are inhibitors as well. 

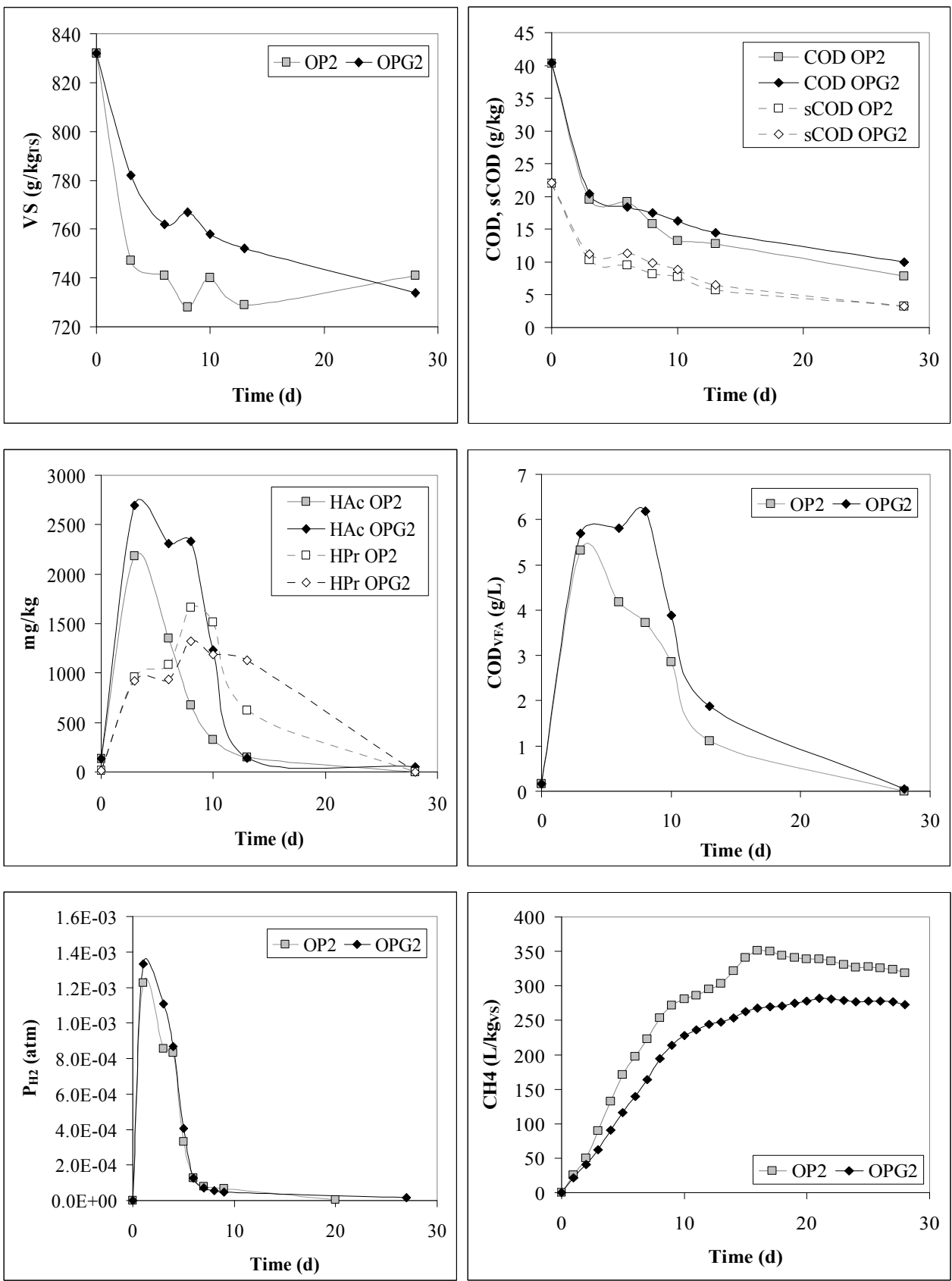

Figure 3.3. Evolution of several parameters in BMP test of OP2/OPG2. From left to right and from up to down: VS, COD, acetic (HAc) and propionic (HPr) acid, total COD from the VFA, partial pressure of hydrogen in the biogas, and cumulative methane production. 

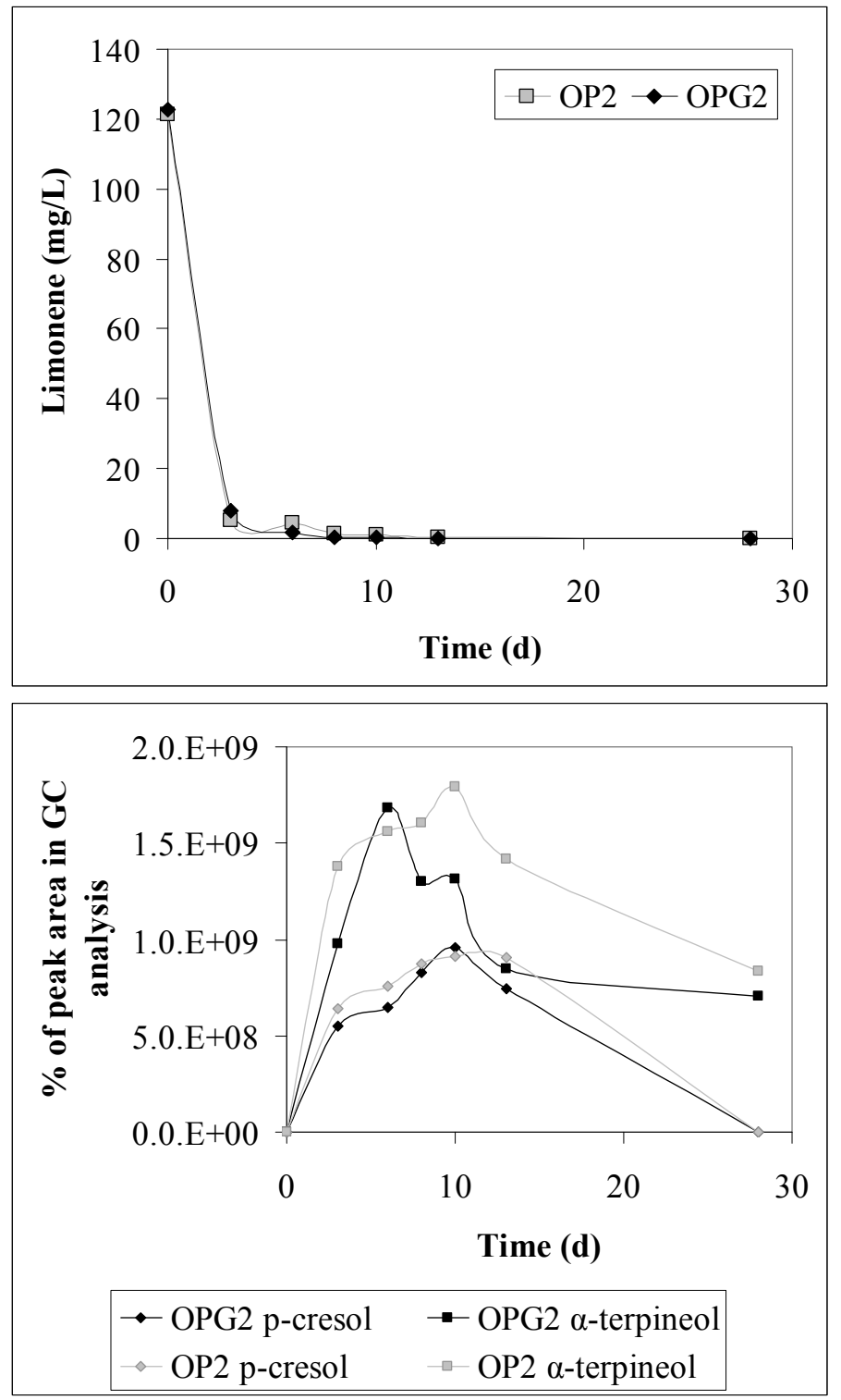

Figure 3.4. Evolution of the limonene concentration in the digesters in BMP test of OP2/OPG2 and its transformation into p-cresol and $\alpha$-terpineol.

Facultative anaerobic bacteria such as Geobacillus stearothermophilus and Escherichia coli have been reported to produce carveol, $\alpha$-terpineol, perillyl alcohol and perillyl aldehyde from limonene (Chang et al., 1995; Chang and Oriel, 1994). Other authors have reported that denitrifying bacteria produce $\alpha$-terpinene or 2-carene from limonene in anaerobic environments, depending on the presence or absence of nitrate, respectively (Harder and 
Probian, 1995). Specifically, several strains of the denitrifying bacteria Alcaligenes defragrans have been reported to anaerobically transform alkenoic monoterpenes in the presence of nitrate (Foss et al., 1998). This bacterium is capable of transforming isolimonene into isoterpinolene (Heyen and Harder, 1998). All these compounds are potential inhibitors of anaerobic digestion. With this in mind, the chromatograms for the limonene analysis were reviewed, which allowed us to confirm that the limonene was transformed to $\mathrm{p}$-cresol and to $\alpha$-terpineol. By the end of the experiments, the p-cresol had been removed and only $\alpha$-terpineol was detected (see Figure 3.4).

This experiment confirms that limonene does have a negative effect on the anaerobic digestion. The anaerobic digestion of OPG2 yielded lower MPR and biodegradability, lower VS degradation and higher VFA and hydrogen accumulation than OP2 in the first days of the experiment. This is explained by the fact that, after grinding, all the limonene contained in the oil vesicles of the flavedo of the orange would have been released into the medium, and therefore its inhibitory effect started immediately. In contrast, the limonene in untreated orange peel was gradually released into the medium. As a consequence, its inhibitory effect would have been distributed over a longer time.

\subsubsection{Effect of low limonene concentrations $\left(50-200 \mathrm{mg} \mathrm{kg}^{-1}\right)$ on the anaerobic digestion}

In order to better evaluate the toxic effect of limonene on the anaerobic digestion process, batch anaerobic digestion of microcrystalline cellulose, a substrate with a theoretical BMP of $415 \mathrm{~L}^{\mathrm{kg}} \mathrm{Vs}^{-1}$, was carried out in the presence of three doses of commercial (S)-limonene $\left(50,100\right.$ and $\left.200 \mathrm{mg} \cdot \mathrm{kg}^{-1}\right)$. The cumulative biogas production curves are shown in Figure 3.6 and Figure 3.6. The results in terms of BMP, MPR and methanization index are given in Table 3.5. Only the results of the BMP tests performed at the same time with the same inoculum and collected at the same day, are compared in Table 3.5.

Table 3.5. Main results of batch anaerobic digestion tests of microcrystalline cellulose with different doses of commercial limonene and different inocula (average values \pm standard deviation).

\begin{tabular}{|c|c|c|c|c|}
\hline Test & $\begin{array}{l}\text { Initial limonene } \\
\text { concentration in the } \\
\text { digester }\left(\mathrm{mg} \cdot \mathrm{kg}^{-1}\right)\end{array}$ & $\begin{array}{c}\text { Biochemical } \\
\text { methane potential } \\
\left(\mathbf{L} \cdot \mathrm{kg}_{\mathrm{vs}}{ }^{-1}\right)\end{array}$ & $\begin{array}{c}\text { Methane } \\
\text { production rate } \\
\left(\mathrm{L} \cdot \mathrm{kg}_{\mathrm{Sv}}{ }^{-1} \cdot \mathrm{d}^{-1}\right)\end{array}$ & $\begin{array}{c}\text { Methanization index } \\
(\%)\end{array}$ \\
\hline LL0a & 0 (control) & $441.6 \pm 6.9$ & $204.9 \pm 20.4$ & $99.7 \pm 1.6$ \\
\hline LL50 & $50.5 \pm 0.8$ & $437.0 \pm 10.6$ & $204.0 \pm 8.2$ & $98.2 \pm 2.4$ \\
\hline LL0b & 0 (control) & $440.8 \pm 17.6$ & $83.7 \pm 3.7$ & $99.5 \pm 4.0$ \\
\hline LL100 & $100.7 \pm 2.2$ & $425.6 \pm 10.8$ & $80.3 \pm 2.2$ & $95.1 \pm 2.4$ \\
\hline LL200 & $196.7 \pm 0.8$ & $405.3 \pm 6.9^{(*)}$ & $77.6 \pm 1.4^{(*)}$ & $89.8 \pm 1.5^{(*)}$ \\
\hline
\end{tabular}

Note: Asterisks indicate statistically significant differences with the corresponding BMP test with $0 \mathrm{mg} \cdot \mathrm{kg}^{-1}$ limonene and the same inoculum. n.a.: not analysed. 


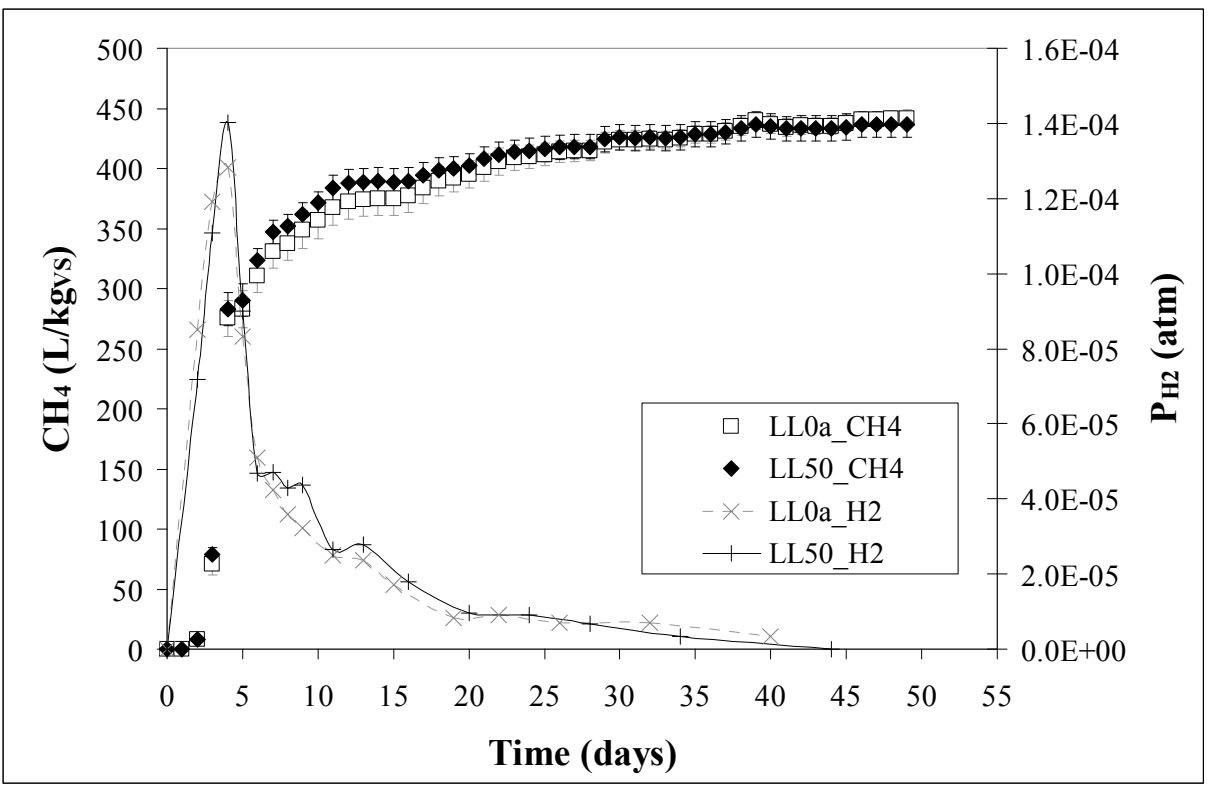

Figure 3.5. Cumulative methane production and partial pressure of hydrogen in the biogas from microcrystalline cellulose with 0 and $50 \mathrm{mg} \cdot \mathrm{kg}^{-1}$ of (S)-limonene.

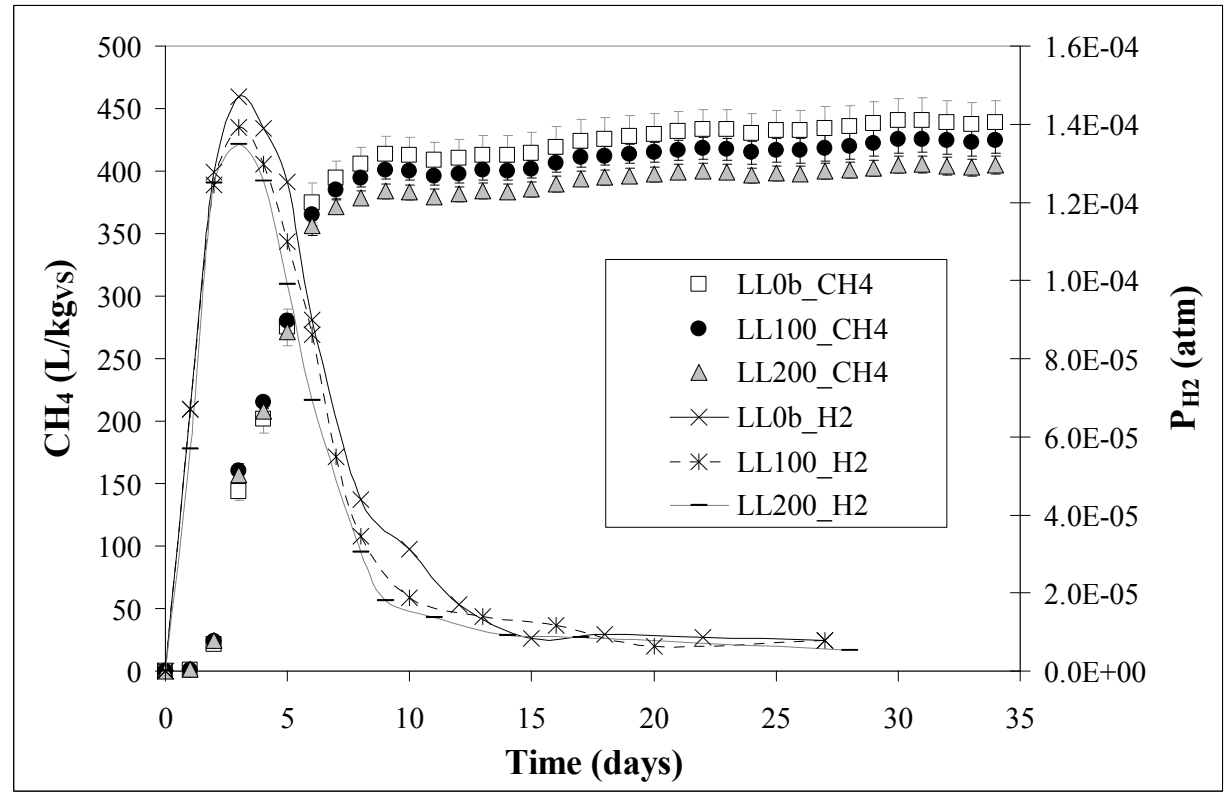

Figure 3.6. Cumulative methane production and partial pressure of hydrogen in the biogas from microcrystalline cellulose with 0,100 and $200 \mathrm{mg}^{\mathrm{kg}} \mathrm{kg}^{-1}$ of (S)limonene. 
The addition of $50 \mathrm{mg} \cdot \mathrm{kg}^{-1}$ of limonene to the digesters did not have a significant effect on the BMP or on the methanization index, which remained around $100 \%$. All the curves show a lag; since this is observed for both digesters (with and without limonene) it cannot be attributed to the presence of limonene but to the activity of the inoculum.

The addition of $100 \mathrm{mg} \cdot \mathrm{kg}^{-1}$ of limonene to the digesters did not have any effect on BMP, MPR or methanization index. In contrast, the experiments conducted with $200 \mathrm{mg} \cdot \mathrm{kg}^{-1}$ of limonene yielded lower BMP, MPR and methanization index than the experiments without limonene (decreases of between $6 \%$ and 12\%). These differences were statistically significant with a confidence level higher than 95\% (see Table 3.5).

In conclusion, the highest limonene concentration tested in these experiments $\left(200 \mathrm{mg} \cdot \mathrm{kg}^{-1}\right)$ caused a decrease in the BMP, the MPR and the methanization index; while 50 and 100 $\mathrm{mg} \cdot \mathrm{kg}^{-1}$ of limonene had no significant effect on the batch anaerobic digestion of microcrystalline cellulose.

\subsubsection{Effect of high limonene concentrations $\left(200-3000 \mathrm{mg}^{-\mathrm{kg}^{-1}}\right)$ on the anaerobic digestion}

In order to better characterize the effect of limonene on the anaerobic digestion of microcrystalline cellulose, an additional experiment with a broader range of concentrations of limonene was carried out.

The concentrations of (R)-limonene tested were $0,200,600,1000,2000$ and $3000 \mathrm{mg} \cdot \mathrm{kg}^{-1}$. An additional batch with $2000 \mathrm{mg} \cdot \mathrm{kg}^{-1}$ of (S)-limonene was tested in order to detect whether (R)- and (S)-limonene have different inhibitory effects. The specific cumulative methane production curves, after subtracting the methane production of the inoculum, are presented in Figure 3.7. Figure 3.8 shows both the methane production and the partial pressure of hydrogen in the biogas.

The methane production of the digesters with $200 \mathrm{mg} \cdot \mathrm{kg}^{-1}$ of limonene was $7.6 \%$ lower than with no limonene. However, this difference was not statistically significant. The methane concentration in the biogas of the digester with $200 \mathrm{mg} \cdot \mathrm{kg}^{-1}$ of limonene showed a decreasing trend after day 28 , as opposed to the digester without limonene, where the methane concentration remained constant. The process was stable and no acidification occurred, as indicated by the low final concentrations of VFA: the acetic acid concentration in the digesters with 0 and $200 \mathrm{mg} \cdot \mathrm{kg}^{-1}$ of limonene was 19 and $11 \mathrm{mg} \cdot \mathrm{kg}^{-1}$ respectively.

The digesters with $600 \mathrm{mg} \cdot \mathrm{kg}^{-1}$ of limonene reached almost the same maximum biogas production as the digesters with 0 and $200 \mathrm{mg} \cdot \mathrm{kg}^{-1}(15 \%$ and $7 \%$ lower respectively, with statistically significant differences with respect to the vials with no limonene), but in this case the kinetics was severely affected. A much slower process was observed, reaching a plateau of biogas production after 120 days of the experiment. In addition, a two-stage curve is observed, indicating the presence of two main organic fractions with different biodegradabilities. The first stage covers the period between day 0 and day 50; the second from day 50 onwards. The first stage is characterized by a higher partial pressure of hydrogen and a lower methane concentration than the experiments with 0 and $200 \mathrm{mg} \cdot \mathrm{kg}^{-1}$ 
of limonene; while the second stage shows similar values of hydrogen and methane. In the first period, the higher hydrogen concentration indicates inhibition of the hydrogenotrophic methanogenesis, which is more severe than in the digesters with $200 \mathrm{mg} \cdot \mathrm{kg}^{-1}$ of limonene. In the second period, the process has recovered from the inhibition, as indicated by the low concentration of VFA detected $\left(14 \mathrm{mg} \cdot \mathrm{kg}^{-1}\right.$ of acetic acid) and the low partial pressure of hydrogen.

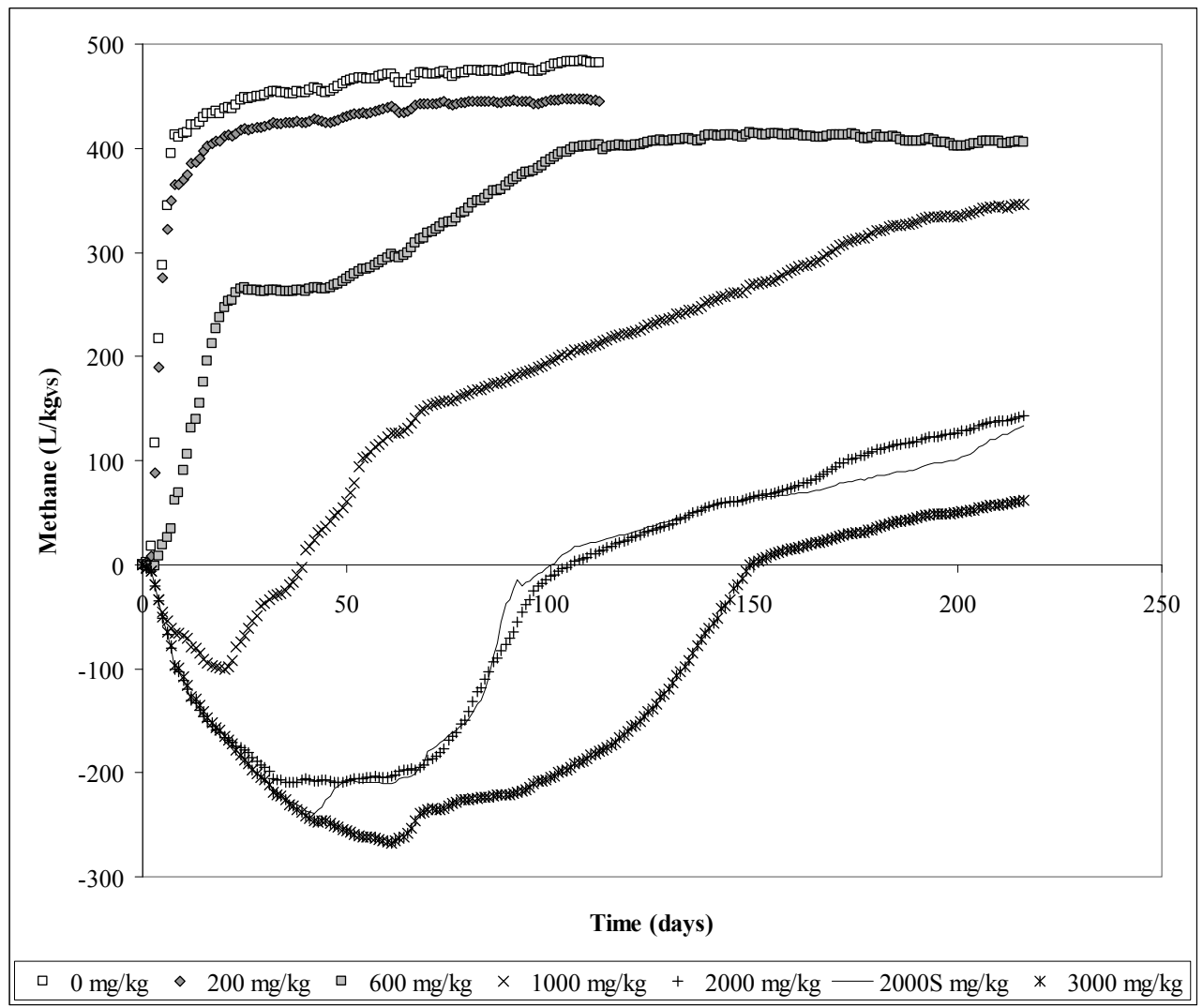

Figure 3.7. Net results of the BMP tests of microcrystalline cellulose with the indicated high limonene concentrations, after substracting the methane production of the inoculum. Standard deviations are not shown, for clarity.

In the case of limonene concentrations of $1000 \mathrm{mg} \cdot \mathrm{kg}^{-1}$ and higher, there is a strong initial inhibition of the process, characterized by biogas production lower than that of the inoculum only (negative values of the curves). However, after a certain time (20,35 and 60 days for 1000,2000 and $3000 \mathrm{mg} \cdot \mathrm{kg}^{-1}$ respectively), the biogas production starts to increase. 

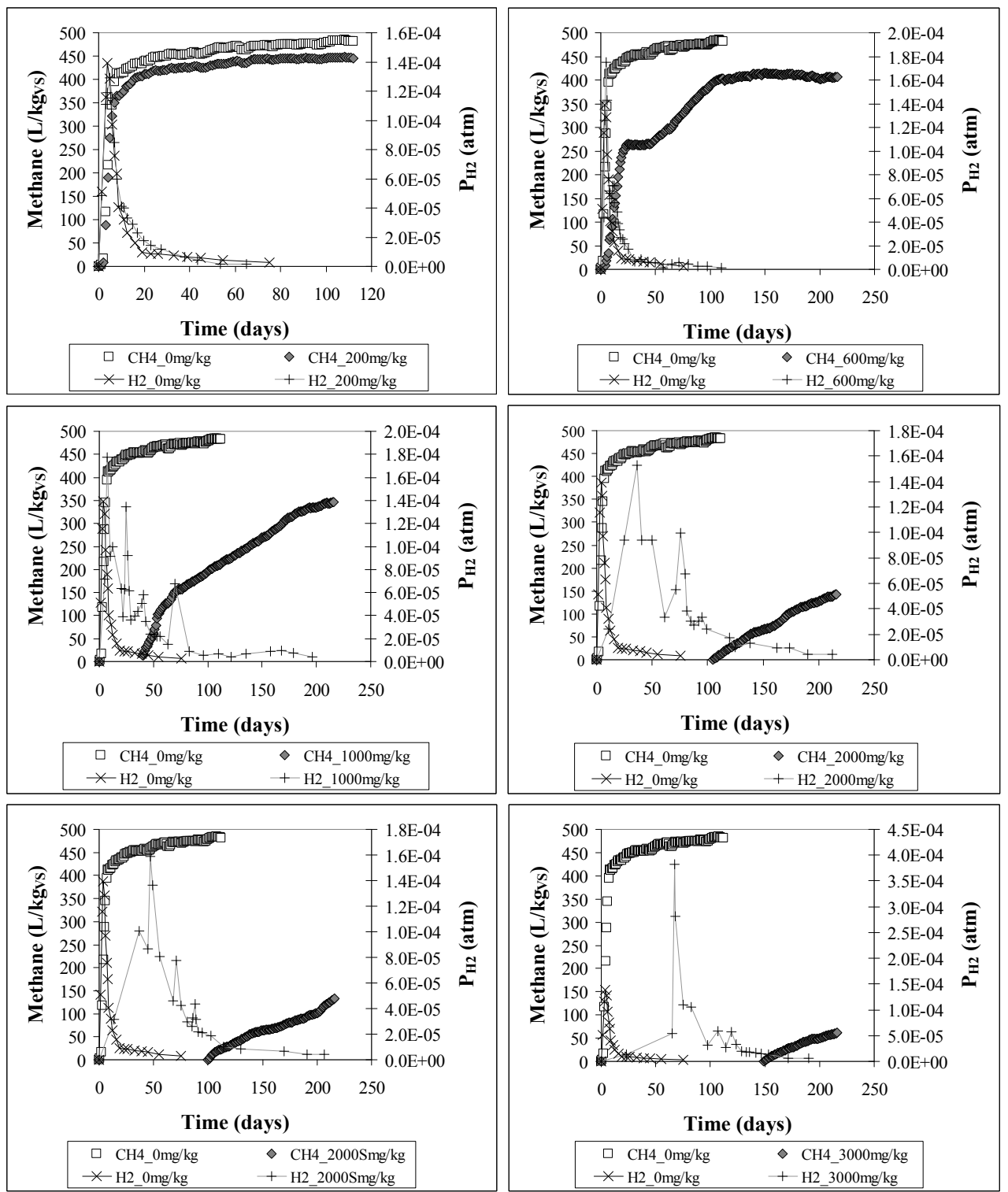

Figure 3.8. Cumulative methane production and partial pressure of hydrogen in the biogas for the indicated limonene concentration compared with the vials with no limonene. 
In the experiments with $1000 \mathrm{mg} \cdot \mathrm{kg}^{-1}$ of limonene, the two steps are not as clearly marked as in the digesters with $600 \mathrm{mg} \cdot \mathrm{kg}^{-1}$ of limonene. The partial pressure of hydrogen remained high for around 100 days, a longer period than in the vials with lower limonene concentrations. The methane concentration in the biogas after this point stabilized at around $55 \%$. The low VFA concentration detected at this point $\left(38 \mathrm{mg} \cdot \mathrm{kg}^{-1}\right.$ of acetic acid) confirms the recovery in the process.

Similar results were obtained for vials with 2000 and $3000 \mathrm{mg} \cdot \mathrm{kg}^{-1}$ of limonene; in these cases the time to reduce the partial pressure of hydrogen in the biogas to negligible levels was even higher (150 and 175 days respectively). Moreover, hydrogen did not start to accumulate from the beginning of the experiment. This suggests an inhibition of all processes of the anaerobic digestion and not only of the hydrogenotrophic methanogenesis which was the case with the experiments with $1000 \mathrm{mg} \cdot \mathrm{kg}^{-1}$ of limonene and less. As for the two isomers of limonene, no significant differences were observed at $2000 \mathrm{mg} \cdot \mathrm{kg}^{-1}$ (values not shown), although higher VFA accumulations were detected in the experiments with R-limonene. At day 113, the vials fed with $2000 \mathrm{mg} \cdot \mathrm{kg}^{-1}$ of R-limonene had 127 $\mathrm{mg} \cdot \mathrm{kg}^{-1}$ of acetic acid and $647 \mathrm{mg} \cdot \mathrm{kg}^{-1}$ of propionic acid, while the concentrations of the same acids in the vials fed with $2000 \mathrm{mg} \cdot \mathrm{kg}^{-1}$ of S-limonene were 67 and $359 \mathrm{mg} \cdot \mathrm{kg}^{-1}$ respectively.

The highest VFA concentrations were found in the vials fed with the highest concentration of limonene $\left(3000 \mathrm{mg} \cdot \mathrm{kg}^{-1}\right): 5118 \mathrm{mg} \cdot \mathrm{kg}^{-1}$ of acetic acid, $681 \mathrm{mg} \cdot \mathrm{kg}^{-1}$ of propionic acid, $925 \mathrm{mg} \cdot \mathrm{kg}^{-1}$ of butyric acid and $120 \mathrm{mg} \cdot \mathrm{kg}^{-1}$ of valeric acid. Despite these high values, the VFA analysis performed at day 217 gave much lower VFA concentrations in the digesters with 2000 and $3000 \mathrm{mg} \cdot \mathrm{kg}^{-1}$ of limonene: 24 and $49 \mathrm{mg} \cdot \mathrm{kg}^{-1}$ of acetic acid respectively. The vials fed with $3000 \mathrm{mg} \cdot \mathrm{kg}^{-1}$ of limonene had $10 \mathrm{mg} \cdot \mathrm{kg}^{-1}$ of propionic acid and no other acids were detectable.

Limonene concentration was analyzed in days 113 and 217 of experiment, and it was not detected in any of the vials, despite the strong inhibition observed in the vials with higher limonene concentrations. Further analysis of the chromatogram revealed that cymene was produced from limonene, as shown in Figure 3.9. Unlike to the results obtained in the BMP test of orange peel, $\alpha$-terpineol was not detected in the BMP tests with cellulose and (R)limonene. The different composition of the CEO in contrast to the commercial (R)limonene might be the cause for this observation.

\subsubsection{Adaptation}

The results of the experiment with high concentrations of limonene described in section 3.3.4 suggest that there is an adaptation of the microorganisms, since a recovery in biogas production was observed after the initial inhibition. To confirm this, an additional experiment was carried out that consisted of new BMP tests using as the inoculum the digested material from the BMP tests at the corresponding limonene concentration and adding the same amounts of cellulose and limonene as in the first run. This was carried out with the vials with 600 and $1000 \mathrm{mg} \cdot \mathrm{kg}^{-1}$ of limonene. 


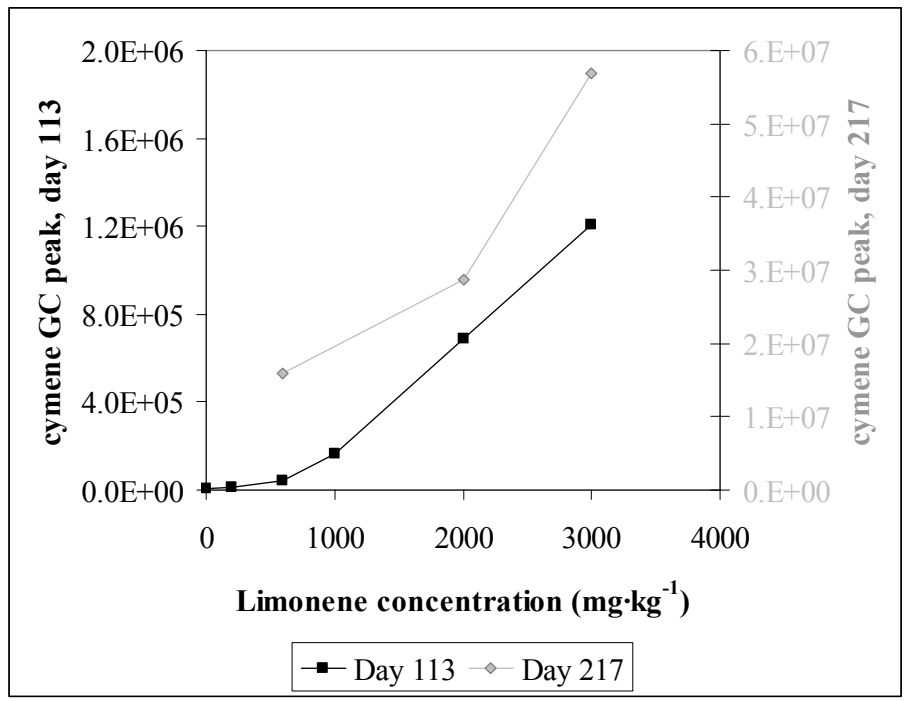

Figure 3.9. Cymene GC peak area in the vials of the experiment with high limonene concentrations, in day 113 (black squares) and in day 217 (grey diamonds). Note the different scales of the two curves.

The results in terms of BMP and partial pressure of hydrogen in the biogas are presented in Figure 3.10. The kinetics of the biogas production in this test with 600 and $1000 \mathrm{mg} \cdot \mathrm{kg}^{-1}$ of limonene were much faster in this second run, reaching the plateau in biogas production after just 12 days in the case of $600 \mathrm{mg} \cdot \mathrm{kg}^{-1}$ of limonene. The partial pressure of the hydrogen in the biogas was also lower, indicating a more stable process.

The antimicrobial mechanism of limonene described by Bakkali et al. (2008) suggests non-reversible inhibition. However, the results of our experiments lead us to conclude that recovery and adaptation is possible. Di Pasqua et al. (2006 and 2007) observed changes in the lipidic profile of several microorganisms when exposed to limonene. These changes led to different degrees of rigidity of the membrane depending on the limonene concentration, with changes in morphology also observed. Those studies observed that some type of adaptation occurs, but did not quantify it. In order to provide an initial quantification, $\mathrm{IC}_{50}$ values were calculated using the results of methane production during the first and second runs of experiments for the different limonene concentrations tested.

Figure 3.11 shows the values of the percentages of the maximum MPR from microcrystalline cellulose at the different concentrations of limonene used in the experiments with low and high concentration of limonene. From the extrapolation of these data, the concentration of limonene at which the maximum slope decreases to $50 \%\left(\mathrm{IC}_{50}\right)$ is estimated to be $423 \mathrm{mg} \cdot \mathrm{kg}^{-1}$. The $\mathrm{IC}_{50}$ was calculated again with the new values of the slopes of the experiments with 600 and $1000 \mathrm{mg} \cdot \mathrm{kg}^{-1}$ (second run), giving a value of 669 $\mathrm{mg} \cdot \mathrm{kg}^{-1}$ of limonene: $58 \%$ higher than in the first run. 
The two values of $\mathrm{IC}_{50}$ obtained are lower than the usual concentration of limonene in the citrus waste (Ruiz and Flotats, 2014) and therefore inhibition of anaerobic digestion of citrus waste by limonene is always to be expected.
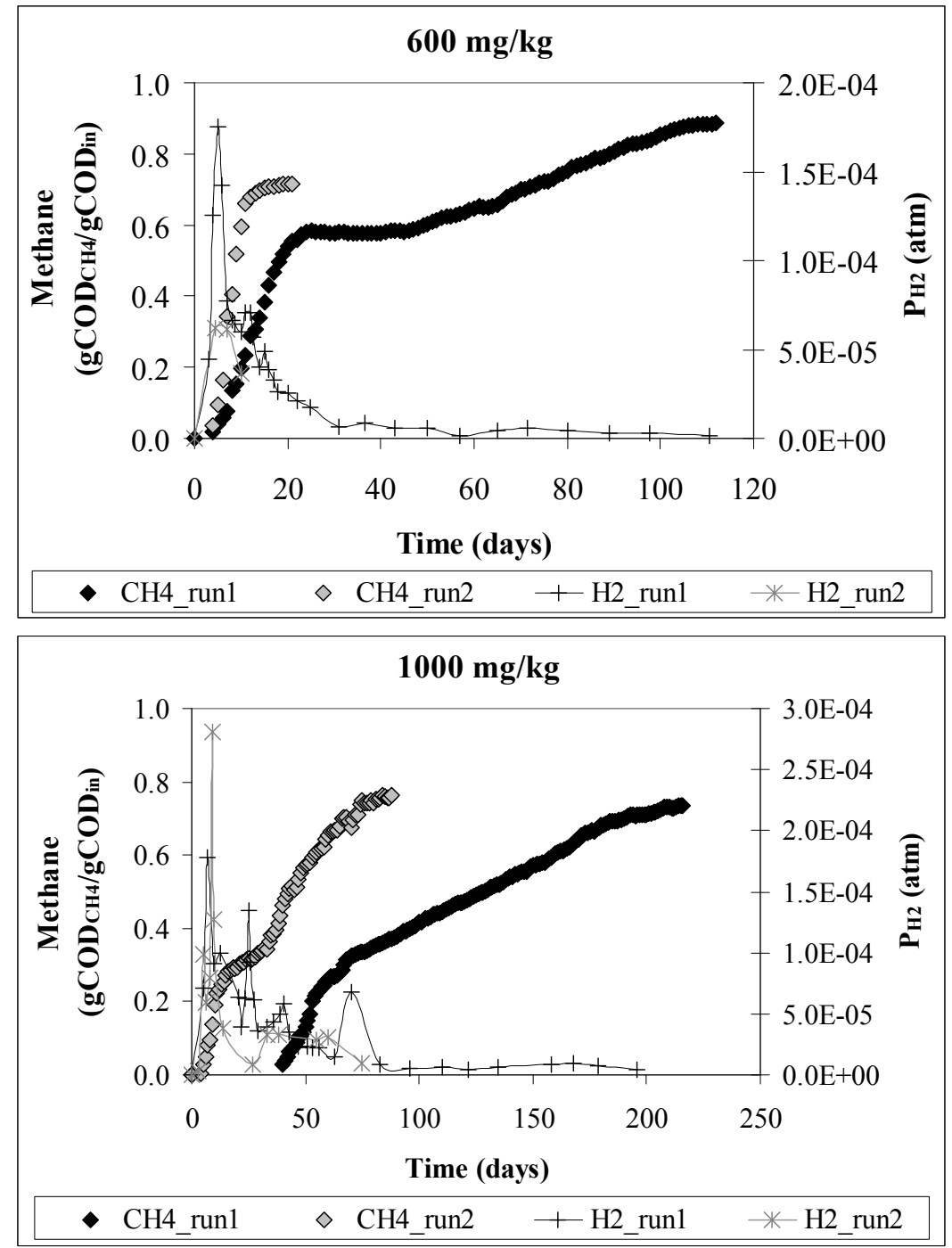

Figure 3.10. Methane production and partial pressure of hydrogen in the biogas for the first and second run of the BMP experiments, for 600 and $1000 \mathrm{mg} \cdot \mathrm{kg}^{-1}$ of limonene. 


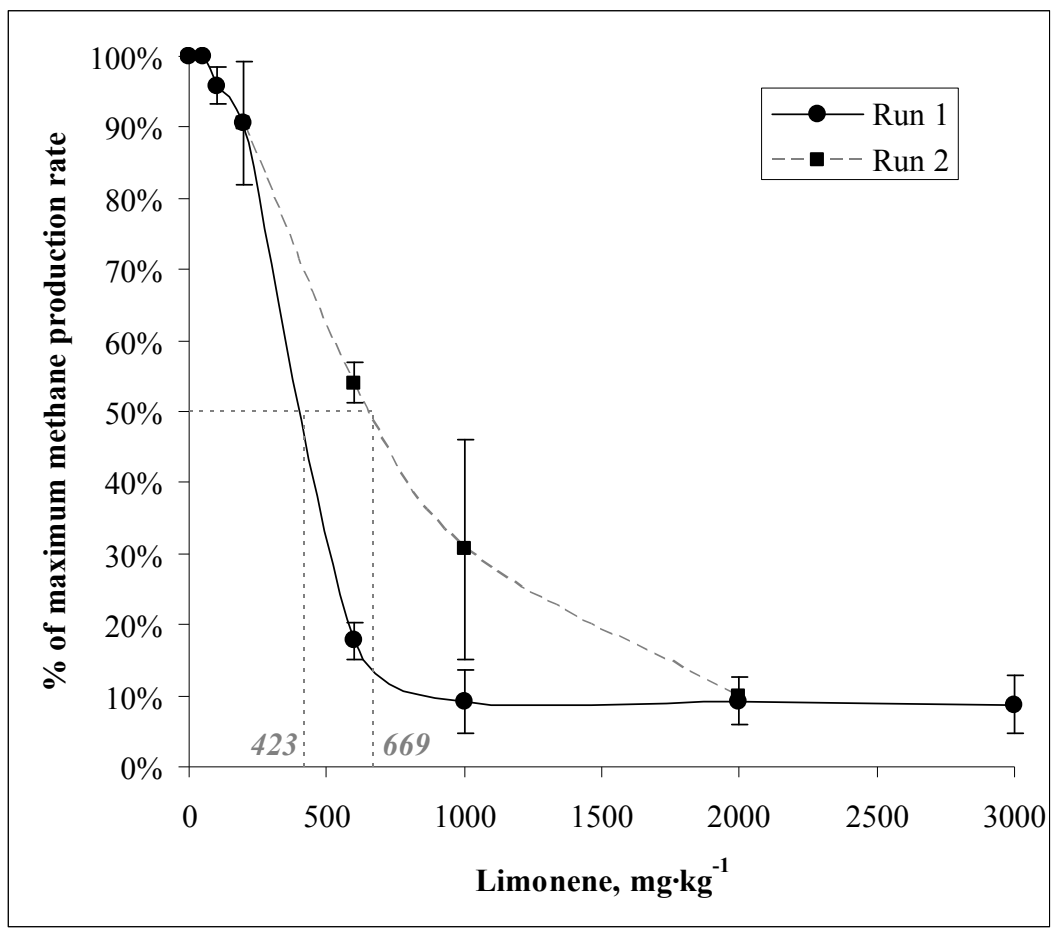

Figure 3.11. Percentages of the maximum MPR from cellulose with different concentrations of limonene in the digester. Vertical lines indicate $I C_{50}$ values $(423$ $\mathrm{mg} \cdot \mathrm{kg}^{-1}$ and $669 \mathrm{mg} \cdot \mathrm{kg}^{-1}$ of limonene for first and second run, respectively).

\subsection{Conclusions}

The limonene in citrus peel has an inhibitory effect on anaerobic digestion for concentrations higher than $200 \mathrm{mg} \cdot \mathrm{kg}^{-1}$ of limonene in the digester. This inhibitory effect seems to be due to cymene, which is produced from limonene during the anaerobic digestion.

Grinding the citrus peel releases the limonene into the medium and increases its inhibitory effect. Toxicity is observed after biodegradation of the limonene, which is attributed to its biotransformation into other inhibitory compounds.

The $\mathrm{IC}_{50}$ of limonene is lower than its usual concentration in citrus waste, which suggests that inhibition of the anaerobic digestion of citrus waste is always to be expected.

Recovery and adaptation of the anaerobic biomass was observed despite the non-reversible inhibition mechanism reported in the literature. 


\subsection{Acknowledgements}

Some of the results of this study were obtained within research on the project PS-120000-2007-6, cofinanced by the Spanish Ministry of Economy and Competitiveness.

\subsection{References}

APHA-AWWA-WEF. 2006. Standard Methods for the examination of water and wastewater. American Public Health Association / American Water Works Association / Water Environment Federation. 19 ${ }^{\text {th }}$ ed., Washington DC, USA.

Bakkali, F., Averbeck, S., Averbeck, D., Idaomar, M. 2008. Biological effects of essential oils - A review. Food and Chemical Toxicology 46, 446-475.

Batstone D.J., Keller J., Angelidaki I., Kalyuzhny S.V., Pavlostathis S.G., Rozzi A., Sanders W.T.M., Siegrist H., Vavilin V.A. 2002. Anaerobic Digestion Model No. 1. ISBN 1-900222-24-8.

CAPA. 2011. Informe del sector agrario valenciano 2011. Capítulo IV: estadísticas agrícolas. Cuadro 4.12: superficies, producciones y destino de la producción de cítricos. Comunitat Valenciana. Campaña 2010/2011. Conselleria de Agricultura, Pesca y Alimentación.

Chang H.C., Gage D.A., Oriel P.J. 1995. Cloning and expression of a limonene degradation pathway from Bacillus stearothermophilus in Escherichia coli. Journal of Food Science 60(3) 551-553.

Chang H.C., Oriel P.J. 1994. Bioproduction of perillyl alcohol and related monoterpenes by isolates of Bacillus stearothermophilus. Journal of Food Science 59, 660-662.

Chen Y., Cheng J.J., Creamer K.S. 2008. Inhibition of anaerobic digestion process: A review. Bioresource Technology 99, 4044-4064.

De Blas C., Mateos G.G., García-Rebollar P. 2010. Tablas FEDNA de composición y valor nutritivo de alimentos para la fabricación de piensos compuestos ( $3^{\mathrm{a}}$ edición). (FEDNA tables of composition and nutritive value of foods for the manufacturing of compound feeds ( $3^{\text {rd }}$ Edition). Fundación Española para el Desarrollo de la Nutrición Animal. Madrid. 502 pp.

Di Pasqua, R., Hoskins, N., Betts, G., Mauriello, G. 2006. Changes in membrane fatty acids composition of microbial cells induced by addiction of thymol, carvacrol, limonene, cinnamaldehyde, and eugenol in the growing media. Journal of Agricultural and Food Chemistry 54, 2745-2749.

Di Pasqua, R., Betts, G., Hoskins, N., Edwards, M., Ercolini, D., Mauriello, G. 2007. Membrane toxicity of antimicrobial compounds from essential oils. Journal of Agricultural and Food Chemistry 55, 4863-4870.

Field J., Sierra-Álvarez R., Lettinga G. 1988. Ensayos anaerobios. Depuración anaerobia de aguas residuales. Actas del $4^{\circ}$ seminario D.A.A.R. Pp. 52-81. Valladolid (Spain). ISBN 84-7762-054-7.

Foss S., Heyen U., Harder J. 1998. Alcaligenes defragrans sp. nov., description of four strains isolated on alkenoic monoterpenes $((+)$-menthene, $\alpha$-pinene, 2-carene and $\alpha$-phellandrene) and nitrate. Syst. Appl. Microbiol. $21,237-244$.

Gunaseelan V.N. 2004. Biochemical methane potential of fruits and vegetable solid waste feedstocks. Biomass and Bioenergy 26, 389-399.

Harder J., Probian C. (1995). Microbial degradation of monoterpenes in the absence of molecular oxygen. Applied and Environmental Microbiology 61, 3804-3808.

Heyen U., Harder J. (1998). Cometabolic isoterpinolene formation from isolimonene by denitrifying Alcaligenes defragrans. FEMS Microbiology Letters 169, 67-71.

Kaparaju P.L.N., Rintala J.A. (2006). Thermophilic anaerobic digestion of industrial orange waste. Environmental Technology 27, 623-633. 
Koppar A., Pullammanappallil P. (2013). Anaerobic digestion of peel waste and wastewater for on site energy generation in a citrus processing facility. Energy 60, 62-68.

Kim, M., Gomec, C.Y., Ahn, Y., Speece, R.E. (2003). Hydrolysis and acidogenesis of particulate organic material in mesophilic and thermophilic anaerobic digestion. Environment Technology 24, 1183-1190.

Lane, A.G. (1983). Removal of peel oil from citrus peel press liquors before anaerobic digestion. Environmental Technology Letters 4, 65-72.

Lane, A.G. (1984). Anaerobic digestion of orange peel. Food Technology in Australia 36, 125-127.

Lohrasbi, M., Pourbafrani, M., Niklasson, C., Taherzadeh, M.J. (2010). Process design and economic analysis of a citrus waste biorefinery with biofuels and limonene as products. Bioresource Technology 101, 7382-7388.

Martín M.A., Siles J.A., Chica A.F., Martín A. (2010). Biomethanization of orange peel waste. Bioresource Technology 101, 8993-8999.

Martín M.A., Fernández R., Serrano A., Siles J.A. (2013). Semi-continuous anaerobic co-digestion of orange Peel waste and residual glycerol derived from biodiesel manufacturing. Waste Management 33, 1633-1639.

Mizuki, E., Akao, T., Saruwatari, T. (1990). Inhibitory effect of Citrus unshu peel on anaerobic digestion. Biological Wastes 33, 161-168.

Sánchez-Segado S., Lozano L.J., de los Ríos A.P., Hernández-Fernández F.J., Godínez C., Juan D. (2012). Process design and economic analysis of a hypothetical bioethanol production plant using carob pod as feedstock. Bioresource Technology 104, 324-328.

Srilatha, H.R., Nand, K., Babu K.S., Madhukara, K. (1995). Fungal pretreatment of orange processing waste by solid-state fermentation for improved production of methane. Proc. Biochem. 30, 327-331.

VDI - Verein Deutscher Ingenieure (2006). Fermentation of organic materials. Characterisation of the substrate, sampling, collection of material data, fermentation tests. ICS 13.030.30; 27.190.

Yu, H.Q., Fang, H.H.P. (2002). Acidogenesis of dairy wastewater at various pH levels. Water Science and Technology 45, 201-206. 


\title{
Chapter 4
}

\section{Strategies to avoid inhibition of anaerobic digestion of citrus waste: effect on limonene concentration, methane potential and production rate}

\begin{abstract}
Three strategies to avoid the inhibition of the batch anaerobic digestion of orange peel by limonene were assessed in terms of reduction in the limonene concentration and their effects on methane potential and production rate. The strategies tested were based on removal (biological treatment) or recovery (steam distillation and ethanol extraction) of limonene. All the treatments decreased the concentration of limonene in the orange peel with efficiencies of $22 \%, 44 \%$ and $100 \%$ for the biological treatment, steam distillation and ethanol extraction, respectively. The methane potential and production rate of the treated orange peel were not affected by the biological treatment; but increases were observed after applying the other two strategies. Since the initial limonene concentration in the digesters was always below its minimum inhibitory concentration, these observed effects were attributed to the removal of minor components of the citrus essential oil. The energy balance was negative for steam distillation and positive for the other two tested strategies.
\end{abstract}

This chapter has been submitted to a peer reviewed journal as:

Ruiz B., de Benito A., Rivera J.D., Flotats X., 2015. Strategies to avoid inhibition of anaerobic digestion of citrus waste: effect on limonene concentration, methane potential and production rate. Waste Management and Research (submitted). 


\section{Table of contents}

4.1 Introduction ................................................................................................................... 77

4.2 Materials and methods ................................................................................................ 78

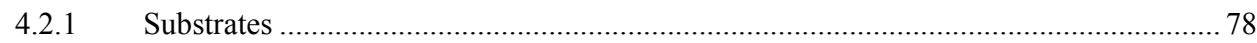

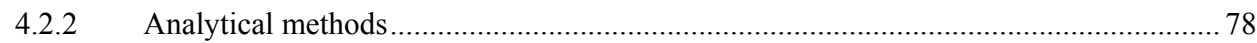

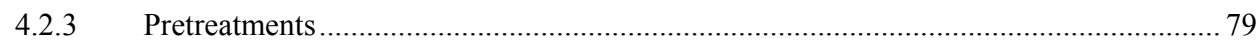

4.2.4 Biochemical methane potential (BMP) tests.............................................................. 80

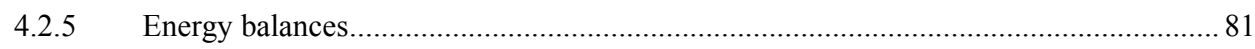

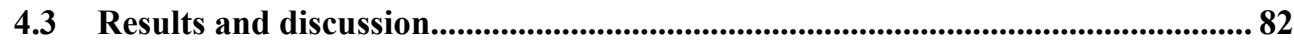

4.3.1 Biological treatment ....................................................................................... 82

4.3.2 Steam distillation ...................................................................................... 86

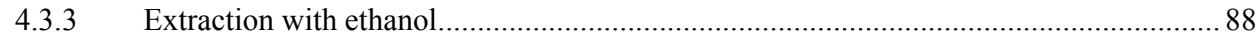

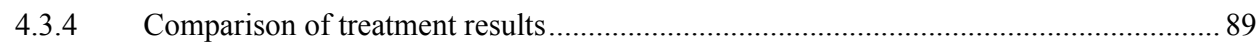

4.3.5 Energy balances.................................................................................................. 92

4.4 Conclusions .................................................................................................................. 93

4.5 Acknowledgements....................................................................................................... 93

4.6 References ........................................................................................................................ 93 


\subsection{Introduction}

The dynamics of limonene, the major component of citrus essential oil (CEO), in the anaerobic digestion of citrus waste was characterized by Ruiz and Flotats (2015) and it was shown that limonene clearly has an inhibitory effect on the process. The $\mathrm{IC}_{50}$ value was found to be $423 \mathrm{mg} \cdot \mathrm{kg}^{-1}$, and the minimum inhibitory concentration of limonene was around $200 \mathrm{mg} \cdot \mathrm{kg}^{-1}$. Since the usual concentrations of limonene in the citrus waste greatly exceed this amount (Ruiz and Flotats, 2014), an inhibitory effect is always expected in the anaerobic digestion of citrus waste. In order to avoid this effect, pretreatments can be applied to remove the limonene from citrus waste. Pretreatment methods reported in the literature adopt two different approaches: removal or recovery (extraction). Pretreatments to remove CEO include aeration and biological treatment (BT). Recovery strategies include centrifugation, steam distillation (SD), steam explosion and liquid extraction with organic solvents.

Aeration and centrifugation have been used for the removal and recovery, respectively, of CEO from citrus peel press liquors (Lane, 1983). Aeration with $0.67 \mathrm{~L}_{\text {air }} \cdot \mathrm{L}_{\text {digester }} \cdot \mathrm{min}^{-1}$ at $30^{\circ} \mathrm{C}$ for $6-8 \mathrm{~h}$ led to reductions in the CEO content and chemical oxygen demand (COD) of such liquors of $98.9 \%$ and $27.5 \%$ respectively, due to the evaporation or the stripping of the essential oil. The CEO removal achieved with centrifugation was 78.7\%. However, these treatments are more appropriate for liquids than for solid waste. Moreover, the reduction of the COD would result in decreased methane potential.

BT is based mainly on the activity of fungi. Treatment with fungi enzymes obtained from Aspergillus and Penicillium was studied by Akao et al. (1992). Such treatment favoured the anaerobic digestion, but the authors concluded that the main cause for the CEO removal was not the enzyme pretreatment, but the mixing applied during the process, which lasted for 10 days. Srilatha et al. (1995) assessed solid-state fermentation of citrus waste with selected strains of Sporotrichum, Aspergillus, Fusarium and Penicillium. This pretreatment reduced the limonene concentration by $55 \%$ (on a dry matter basis), which allowed reaching a higher organic loading rate (OLR) to be effective in the subsequent anaerobic digestion process and also produced a higher methane yield than the untreated substrate.

$\mathrm{SD}$ is another alternative that has been proven to be effective, reaching a limonene removal yield of $70 \%$ in a laboratory set-up, with 1 hour contact time, a water/peel ratio of $6 / 1$ $(\mathrm{w} / \mathrm{w})$ and a particle size of $<2 \mathrm{~mm}$ (Martín et al., 2010). This process is commonly used at industrial scale for limonene recovery, where yields are usually around $50 \%$.

Steam explosion has also been proposed as pretreatment to recover the limonene prior to the anaerobic digestion of citrus waste. This treatment removed up to $94.3 \%$ of the limonene and allowed stable thermophilic anaerobic co-digestion of the treated citrus waste with the organic fraction of municipal solid waste. Digestion of the same mixture was strongly inhibited when the citrus waste was untreated. The investment necessary for steam explosion means that this solution is only affordable for large-scale facilities (Forgács et al., 2011). 
Studies on liquid-liquid extraction of limonene from ternary and quaternary mixtures have revealed that ethanol is effective for limonene extraction from an aqueous mixture (Arce $e t$ al., 2004; Arce et al., 2005). Solid-liquid extraction using n-hexane has been assessed and shown a good limonene extraction efficiency $(80 \%)$, but poor methane production in the subsequent anaerobic digestion, due to solvent remaining in the peel (Wikandari et al., 2013).

In addition to the limonene inhibition, the $\mathrm{C} / \mathrm{N}$ ratio of the citrus waste is often higher than optimum (Ruiz and Flotats, 2014). Lane (1984) pointed out that co-digestion of citrus waste with animal manures could provide the necessary nutrient balance, thus avoiding the need for supplementation with nutrients.

The most appropriate techniques for pretreating the citrus waste in order to avoid the subsequent inhibition of anaerobic digestion by limonene, taking into account the waste characteristics and the limonene removal efficiency reported in the literature, are: solidstate fermentation with fungi, extraction with organic solvents (incorporating solvent removal after the treatment) and SD. However, these methods could have other effects on the anaerobic digestion process due to factors such as organic matter removal or temperature effects. The objective of this study was to assess the limonene removal efficiency of these pretreatments applied to citrus waste and to evaluate their effects on the biochemical methane potential (BMP). The effect of co-digestion with cow manure (CM) to improve the nutrient balance was also assessed.

\subsection{Materials and methods}

\subsubsection{Substrates}

Three samples of orange (Citrus sinensis) peel (OP) were used. Sample OP1 was prepared from oranges bought in a local market, by peeling the oranges and cutting the peel into pieces of 2-3 cm. Samples OP2 and OP3 were taken from a Spanish juice manufacturing facility where no limonene had been extracted. These latter samples were pieces approximately 3-4 cm long and $1 \mathrm{~cm}$ wide. No further preparation was undertaken before the pretreatments. CM for the co-digestion experiments was collected from a Spanish dairy farm.

\subsubsection{Analytical methods}

Analysis of total solids (TS), volatile solids (VS), conductivity, alkalinity, phosphorus, potassium, total Kjeldahl nitrogen (TKN), ammonia nitrogen $\left(\mathrm{NH}_{4}{ }^{+}-\mathrm{N}\right)$, total and soluble chemical oxygen demand (COD, sCOD) and $\mathrm{pH}$ were carried out according the Standard Methods of Analysis (APHA-AWWA-WEF, 2006). Due to the high degree of heterogeneity of the samples, the COD and SCOD results had very large standard deviations in all cases and were therefore not considered realistic and useful. Therefore, COD values for the calculation of biodegradability were estimated based on VS content, using the values of Kaparaju and Rintala (2006). 
The individual volatile fatty acids (VFA), acetate, propionate, iso-butyrate, n-butyrate, isovalerate, n-valerate, iso-caproate, caproate and heptanoate, as well as limonene and $\alpha$ terpineol, were analysed by gas chromatography as described in Ruiz and Flotats (2015).

\subsubsection{Pretreatments}

Three different pretreatments were applied to the OP: BT, SD and solid-liquid extraction using ethanol (EE). The samples used for the pretreatments were: OP1 and OP2 for BT; and OP3 for SD and EE. All the pretreatment conditions are summarized in Table 4.1.

Table 4.1. Pretreatments applied to the orange peel

\begin{tabular}{|c|c|c|c|c|c|}
\hline Code & $\begin{array}{c}\text { Orange peel } \\
\text { sample }\end{array}$ & Fungi inoculation & $\begin{array}{c}\text { Temperature } \\
\left({ }^{\circ} \mathbf{C}\right)\end{array}$ & Time & Air and humidity \\
\hline BT1 & OP1 & Natural & Ambient & $\begin{array}{c}\text { Until } \\
\text { complete } \\
\text { invasion }\end{array}$ & $\begin{array}{c}\text { Aerobic, no humidity } \\
\text { loss prevention }\end{array}$ \\
\hline BT2 & OP2 & $\begin{array}{c}\text { Controlled inoculation } \\
\text { with P. digitatum and } P . \\
\text { italicum }\end{array}$ & $25^{\circ} \mathrm{C}$ & 1 week & $\begin{array}{c}\text { Aerobic, with } \\
\text { humidity loss } \\
\text { prevention }\end{array}$ \\
\hline
\end{tabular}

\begin{tabular}{|c|c|c|c|c|c|}
\hline Code & $\begin{array}{c}\text { Orange peel } \\
\text { sample }\end{array}$ & $\begin{array}{c}\text { Steam flow rate } \\
\left(\mathbf{m L} \cdot \mathbf{m i n}^{-1}\right)\end{array}$ & $\begin{array}{c}\text { Temperature } \\
\left({ }^{\circ} \mathbf{C}\right)\end{array}$ & $\begin{array}{c}\text { Contact time } \\
(\mathbf{m i n})\end{array}$ & Pressure (atm) \\
\hline SD1 & OP3 & 8 & 100 & 60 & 1 \\
\hline SD2 & OP3 & 8 & 100 & 180 & 1 \\
\hline SD3 & OP3 & 16 & 100 & 60 & 1 \\
\hline SD4 & OP3 & 16 & 100 & 180 & 0.38 \\
\hline SD5 & OP3 & 8 & 75.1 & 120 & 0.38 \\
\hline SD6 & OP3 & 16 & 75.1 & 120 & 1 \\
\hline
\end{tabular}

\begin{tabular}{|c|c|c|c|c|c|}
\hline Code & $\begin{array}{c}\text { Orange peel } \\
\text { sample }\end{array}$ & Solvent & $\begin{array}{c}\text { Temperature } \\
\left({ }^{\circ} \mathbf{C}\right)\end{array}$ & $\begin{array}{c}\text { Contact time } \\
(\mathbf{m i n})\end{array}$ & Peel/solvent ratio \\
\hline EE1 & OP3 & $70 \%$ ethanol, $30 \%$ water & Ambient & 60 & $1: 10$ \\
\hline EE2 & OP3 & $70 \%$ ethanol, $30 \%$ water & 40 & 60 & $1: 10$ \\
\hline
\end{tabular}

BT: biological treatment; SD: steam distillation; EE: ethanol extraction. 
Two variations of BT were applied. For one, OP1 was cut and placed in contact with OP naturally infected with fungi of the Penicillium genus at room temperature and in contact with air. The treatment was considered to have finished when the whole sample has been invaded by Penicillium (visual control). The other BT applied to OP2 consisted of controlled inoculation of the sample with a mixture of Penicillium digitatum and Penicillium italicum. This inoculum was prepared by growth in PDA (potato dextrose agar) at $25^{\circ} \mathrm{C}$ for 5-7 dys. Once the degree of sporulation of the microorganisms was adequate, the spores were purified following ASTM Standard G-21:1996. An Aztek Contempo Airbrush air atomizer (Testors, USA) was used to inoculate OP2, in order to guarantee homogeneous inoculation throughout the whole sample. The PDA was composed by potato infusion $\left(4 \mathrm{~g} \cdot \mathrm{L}^{-1}\right)$, dextrose $\left(20 \mathrm{~g} \cdot \mathrm{L}^{-1}\right)$ and bacteriological agar $\left(15 \mathrm{~g} \cdot \mathrm{L}^{-1}\right)$ and had a $\mathrm{pH}$ of 5.6 \pm 0.2 . The sample was then incubated for one week at $25^{\circ} \mathrm{C}$ in partially closed recipients that allowed contact with the air but preventing massive loss of humidity.

SD was applied to OP3 in a laboratory set-up composed of a round bottomed flask where the steam was generated, an intermediate vessel where the steam was bubbled through the sample, and a glass refrigerator to condensate the extract. Different contact time, steam flow rate and pressure conditions were applied (see Table 4.1).

EE was carried out with a mixture of $70 \%$ ethanol and $30 \%$ water (on a volume basis), with a peel/solvent ratio of $1: 10$, for 60 minutes. The extraction was performed in a water bath at ambient temperature (EE1) and at $40^{\circ} \mathrm{C}$ (EE2). Continuous mixing was applied during the extraction. After the extraction step, the samples were dried in an experimental horizontal dryer with air at $25^{\circ} \mathrm{C}$ and a superficial speed of $1 \mathrm{~m} \cdot \mathrm{s}^{-1}$ for over $14-15$ hours. These conditions were selected to ensure complete removal of residual ethanol and avoid loss of organic matter.

\subsubsection{Biochemical methane potential (BMP) tests}

BMP tests were conducted according to the VDI Standard 4630: Fermentation of organic materials (VDI, 2006). The experimental set-up and methodology for the data analysis of the results are described in Ruiz and Flotats (2015). The tests were run in triplicate with an inoculum-to-substrate ratio (ISR) of $2.6 \pm 2.1$ and an initial inoculum concentration of 16.2 $\pm 10.7 \mathrm{gVS}_{\text {inoculum }} \cdot \mathrm{L}^{-1}$. Methane production data are expressed at standard pressure and temperature conditions $\left(0^{\circ} \mathrm{C}\right.$ and $\left.1 \mathrm{~atm}\right)$.

Digested material from a full-scale agricultural biogas plant fed with CM and vegetable substrates at mesophilic temperature and an organic loading rate of $3 \mathrm{~kg} \mathrm{vS}_{\mathrm{vS}} \cdot \mathrm{m}^{-3} \cdot \mathrm{d}^{-1}$ was used as the inoculum for the BMP tests. When this material was not available, digested material from a pilot-scale digester of $1 \mathrm{~m}^{3}$ fed with $\mathrm{CM}$ at the mesophilic temperature range was used.

In all cases, the initial limonene concentration in the batch anaerobic digesters was below the minimum inhibitory concentration $\left(200 \mathrm{mg} \cdot \mathrm{kg}^{-1}\right)$ for batch anaerobic digestion observed by Ruiz and Flotats (2015). Therefore, no inhibition was expected due to the limonene concentration. 
Table 4.2 summarizes all BMP tests, indicating the substrates and the inoculum type, as well as the characteristics and initial concentration used in the test. Due to the inoculum composition, we added neither buffering solution nor nutrients to the digesters.

Table 4.2. $\quad$ Summary of BMP tests

\begin{tabular}{|c|c|c|c|c|c|c|}
\hline \multirow{2}{*}{ Substrate } & \multirow{2}{*}{ Treatment } & \multicolumn{5}{|c|}{ Inoculum } \\
\hline & & Source* & $\begin{array}{c}\text { TS } \\
(\%)\end{array}$ & $\begin{array}{c}\text { VS } \\
(\% \mathrm{TS})\end{array}$ & ISR** & $\mathbf{g V S}_{\text {inoculum }} \cdot \mathbf{L}^{-1}$ \\
\hline OP1 & None & PS & 6.6 & 77.8 & 3.9 & 24.7 \\
\hline OP1 & BT1 & PS & 6.6 & 77.8 & 4.0 & 25.0 \\
\hline M1: OP2 and CM, 1:1 (d.m.) & None & FS & 4.4 & 73.1 & 1.5 & 14.6 \\
\hline M2: OP2 and CM, 3:1 (d.m.) & None & FS & 4.4 & 73.1 & 1.4 & 14.3 \\
\hline M3: OP2 and CM, 1:1 (d.m.) & BT2 applied to OP2 & FS & 4.4 & 73.1 & 1.6 & 14.8 \\
\hline M4: OP2 and CM, 3:1 (d.m.) & BT2 applied to OP2 & FS & 4.4 & 73.1 & 1.4 & 14.3 \\
\hline OP3 & None & FS & 6.9 & 76.8 & 4.4 & 26.8 \\
\hline OP3 & SD1 & FS & 6.9 & 76.8 & 4.7 & 26.2 \\
\hline OP3 & SD2 & FS & 6.9 & 76.8 & 5.4 & 26.2 \\
\hline OP3 & SD3 & FS & 6.9 & 76.8 & 4.5 & 26.2 \\
\hline OP3 & SD4 & FS & 6.9 & 76.8 & 5.6 & 26.2 \\
\hline OP3 & SD5 & FS & 1.6 & 12.5 & 0.2 & 0.9 \\
\hline OP3 & SD6 & FS & 1.6 & 12.5 & 0.2 & 1.0 \\
\hline OP3 & EE1 & FS & 1.6 & 12.5 & 0.2 & 1.0 \\
\hline OP3 & EE2 & FS & 1.6 & 12.5 & 0.2 & 1.0 \\
\hline
\end{tabular}

*Inoculum source: PS: pilot-scale digester; FS: full-scale biogas plant. ISR**: inoculum to substrate ratio, VS basis.

\subsubsection{Energy balances}

Simplified energy balances were estimated in order to compare the thermal energy required for the pretreatments and the thermal energy obtained from the methane produced by the anaerobic digestion of the treated OP. 
For BT, no comparison was made since it is an ambient temperature treatment and additional thermal energy is not required.

For SD, we considered the consumed energy to be that thermal energy required to increase the water temperature to the boiling point and to evaporate the water,

$$
\mathrm{E}_{\mathrm{SD}}=\mathrm{m}_{\mathrm{w}} \cdot\left(\mathrm{C}_{\mathrm{p}, \mathrm{w}} \cdot \Delta \mathrm{T}_{\mathrm{w}}+\mathrm{L}_{\mathrm{v}, \mathrm{w}}\right),
$$

where $E_{S D}$ is the total thermal energy consumed by SD $(J) ; m_{w}$ is the mass of water $(g) ; C_{p, w}$ is the specific heat of water $\left(4.18 \mathrm{~J} \cdot \mathrm{g}^{-1} \cdot{ }^{\circ} \mathrm{C}^{-1}\right) ; \Delta \mathrm{T}_{\mathrm{w}}$ is the difference between the ambient temperature and the boiling temperature $\left({ }^{\circ} \mathrm{C}\right)$; and $\mathrm{L}_{\mathrm{v}, \mathrm{w}}$ is the latent vaporization heat of water $\left(2260 \mathrm{~J}^{-1} \mathrm{~g}^{-1}\right)$.

For EE1, the energy is mostly required to evaporate the ethanol at the end of the treatment. So only $10 \%$ of the ethanol used for the experiment was considered in the estimations of the energy required, since $90 \%$ of the ethanol could be removed by simply letting the sample drain on a filter. For treatment EE2, additional energy consumption is required to heat the ethanol-water mixture to $40^{\circ} \mathrm{C}$. The thermal energy necessary for the $\mathrm{EE}$ treatments was calculated using the following equation:

$$
\mathrm{E}_{\mathrm{EE}}=\mathrm{m}_{\mathrm{e}} \cdot \mathrm{C}_{\mathrm{p}, \mathrm{e}} \cdot \Delta \mathrm{T}_{\text {treat }}+0.1 \cdot \mathrm{m}_{\mathrm{e}} \cdot\left(\mathrm{C}_{\mathrm{p}, \mathrm{e}} \cdot \Delta \mathrm{T}_{\mathrm{vap}}+\mathrm{L}_{\mathrm{v}, \mathrm{e}}\right),
$$

where $E_{E E}$ is the thermal energy required to remove the residual ethanol after $E E(J) ; m_{e}$ is the mass of ethanol $(\mathrm{g}) ; \mathrm{C}_{\mathrm{p}, \mathrm{e}}$ is the specific heat of the ethanol-water mixture used $(2.96$ $\left.\mathrm{J} \cdot \mathrm{g}^{-1} \cdot{ }^{\circ} \mathrm{C}^{-1}\right) ; \Delta \mathrm{T}_{\text {treat }}$ is the difference between the treatment and the ambient temperatures $\left({ }^{\circ} \mathrm{C}\right)$, which is 0 for EE1; $\Delta \mathrm{T}_{\text {vap }}$ is the difference between the ambient temperature and the boiling point of the ethanol-water mixture; and $\mathrm{L}_{\mathrm{v}, \mathrm{e}}$ is the latent vaporization heat of the ethanolwater mixture $\left(1267 \mathrm{~J} \cdot \mathrm{g}^{-1}\right)$.

The thermal energy recovered from the methane produced was calculated for $80 \%$ of the maximum methane production obtained in the BMP test, as an estimated achievable value in a continuous process, taking into account a calorific value of methane of $802.6 \mathrm{~kJ} \cdot \mathrm{mol}^{-1}$ (Perry and Green, 1999) and a thermal efficiency of the boiler of $85 \%$, which is an average of values found in the literature (Jaffrin et al., 2003; Pinto Mariano et al., 2013).

\subsection{Results and discussion}

\subsubsection{Biological treatment}

The chemical characteristics of OP1, OP2 before and after BT are shown in Table 4.3.

OP1 underwent treatment BT1, at ambient temperature and with no control of the humidity. Consequently, a loss of water was observed. In case of OP2 (treatment BT2), temperature and humidity control were applied during the treatment, and no loss of humidity was observed. 
Although a loss of organic matter was expected due to the consumption of carbohydrates by the fungi used in the pretreatment (Zheng et al., 2014), no significant variation in the VS concentration was observed after BT.

The increase in the TKN (due to organic nitrogen only), phosphorus and potassium concentrations could be related to the inoculation of the OP samples with Penicillium (including the culture medium), or to the humidity or volume variations during treatment.

Table 4.3. Chemical characteristics of untreated and biologically treated orange peel and cow manure.

\begin{tabular}{|c|c|c|c|c|c|}
\hline Parameter, units & $\begin{array}{c}\text { OP1, } \\
\text { untreated }\end{array}$ & $\begin{array}{c}\text { OP1 after } \\
\text { BTI }\end{array}$ & $\begin{array}{c}O P 2, \\
\text { untreated }\end{array}$ & $\begin{array}{c}\text { OP2 after } \\
\text { BT2 }\end{array}$ & CM \\
\hline $\mathrm{TS}\left(\mathrm{g} \cdot \mathrm{kg}^{-1}\right)$ & $183 \pm 2$ & $270 \pm 4$ & $160 \pm 2$ & $110 \pm 1$ & $92 \pm 1$ \\
\hline VS (g.kg ${ }^{-1}$ d.m. $)$ & $967 \pm 6$ & $951 \pm 9$ & $960 \pm 7$ & $953 \pm 8$ & $827 \pm 30$ \\
\hline $\mathrm{EC}\left(\mu \mathrm{S} \cdot \mathrm{cm}^{-1}, 20^{\circ} \mathrm{C}\right)$ & $570 \pm 39$ & n.a. & $582 \pm 40$ & $588 \pm 40$ & $>11700$ \\
\hline $\mathrm{pH}\left(20^{\circ} \mathrm{C}\right)$ & $4.24 \pm 0.28$ & n.a. & $4.0 \pm 0.3$ & $3.9 \pm 0.3$ & $7.6 \pm 0.5$ \\
\hline $\mathrm{N}-\mathrm{NH}_{4}^{+}\left(\mathrm{g} \cdot \mathrm{kg}^{-1}\right)$ & n.a. & n.a. & $269 \pm 34$ & $175 \pm 22$ & $19.61 \pm 2.47$ \\
\hline TKN $\left(g \cdot \mathrm{kg}^{-1}\right)$ & $1830 \pm 183$ & $3780 \pm 540$ & $832 \pm 96$ & $1947 \pm 231$ & $38.6 \pm 4.6$ \\
\hline Phosphorus $\left(\mathrm{g} \cdot \mathrm{kg}^{-1}\right)$ & $194 \pm 13$ & $424 \pm 28$ & $198 \pm 139$ & $143 \pm 100$ & $6.50 \pm 0.45$ \\
\hline Potassium $\left(\mathrm{g} \cdot \mathrm{kg}^{-1}\right)$ & $1171 \pm 176$ & $2408 \pm 35$ & $1205 \pm 18$ & $890 \pm 133$ & $21.32 \pm 3.20$ \\
\hline Alkalinity $\left(\mathrm{gCaCO}_{3} \cdot \mathrm{kg}^{-1}\right)$ & n.a. & n.a. & n.a. & n.a. & 842 \\
\hline Acetic acid $\left(\mathrm{g} \cdot \mathrm{kg}^{-1}\right)$ & n.a. & n.a. & 0 & $1254 \pm 121$ & $22.9 \pm 2.3$ \\
\hline Propionic acid $\left(\mathrm{g} \cdot \mathrm{kg}^{-1}\right)$ & n.a. & n.a. & 0 & 0 & $6.7 \pm 0.6$ \\
\hline Iso-butyric acid $\left(\mathrm{g} \cdot \mathrm{kg}^{-1}\right)$ & n.a. & n.a. & 0 & $18 \pm 1$ & $0.86 \pm 0.06$ \\
\hline Butyric acid $\left(\mathrm{g} \cdot \mathrm{kg}^{-1}\right)$ & n.a. & n.a. & 0 & 0 & $3.15 \pm 0.30$ \\
\hline Iso-valeric acid $\left(\mathrm{g} \cdot \mathrm{kg}^{-1}\right)$ & n.a. & n.a. & 0 & $14.3 \pm 1.1$ & $1.34 \pm 0.14$ \\
\hline Valeric acid $\left(\mathrm{g} \cdot \mathrm{kg}^{-1}\right)$ & n.a. & n.a. & 0 & 0 & $0.73 \pm 0.08$ \\
\hline Limonene $\left(\mathrm{g} \cdot \mathrm{kg}^{-1}\right)$ & n.a. & n.a. & $2192 \pm 672$ & $1177 \pm 363$ & n.a. \\
\hline Limonene removal $(\%) *$ & - & n.a. & - & 22 & - \\
\hline
\end{tabular}

EC: electric conductivity; *dry matter basis; n.a.: not analyzed. 
The limonene removal efficiency was $22 \%$ (on a dry matter basis), which is lower than the $55 \%$ obtained by Srilatha et al. (1995).

The results of the BMP test of OP1 before and after applying BT1 are shown in Figure 4.1 and Table 4.4. The BMP, methane production rate (MPR) and anaerobic biodegradability index (BD) were not statistically different for treated and untreated OP1. The only difference observed was a greater accumulation of hydrogen during the first days of the experiment in the case of untreated OP1, indicating partial inhibition of the hydrogenotrophic methanogenesis which is not observed in the biologically treated sample.

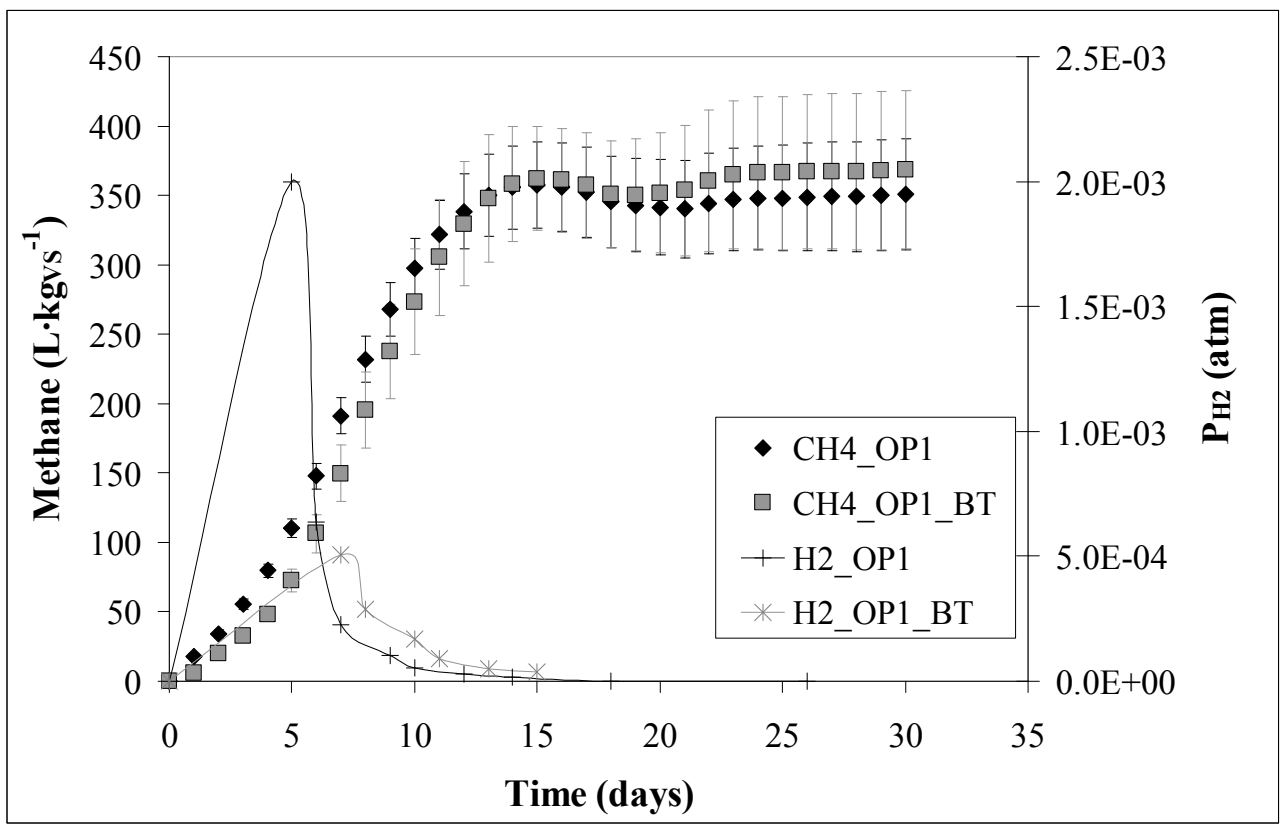

Figure 4.1. BMP test of untreated and biologically treated OP1: cumulative methane production and partial pressure of hydrogen in the biogas.

BMP tests of untreated and treated OP2 in co-digestion with CM were carried out at different proportions as indicated in Table 4.2; the results are presented in Figure 4.2 and Table 4.4. Four OP and CM mixtures were tested: two in a proportion of $1: 1$ and two in a proportion of 3:1. One of the mixtures from each pair contained OP that had received treatment BT2. The initial limonene concentration in the batch anaerobic digesters was lower in the mixtures with treated OP, but in all cases it was below the minimum inhibitory concentration (200 $\mathrm{mg} \cdot \mathrm{kg}^{-1}$ ) observed in batch anaerobic digestion of cellulose with limonene by Ruiz and Flotats (2015), and no effect was expected due to the limonene concentration. The four mixtures were compared in pairs, in order to evaluate the effect of the mixture composition and the effect of the BT applied to the OP. No statistically significant diference was found in any of the parameters assessed (BMP, MPR, BD); thus 
we concluding that BT does not have any beneficial effect on the batch anaerobic digestion of citrus peel under the conditions tested.

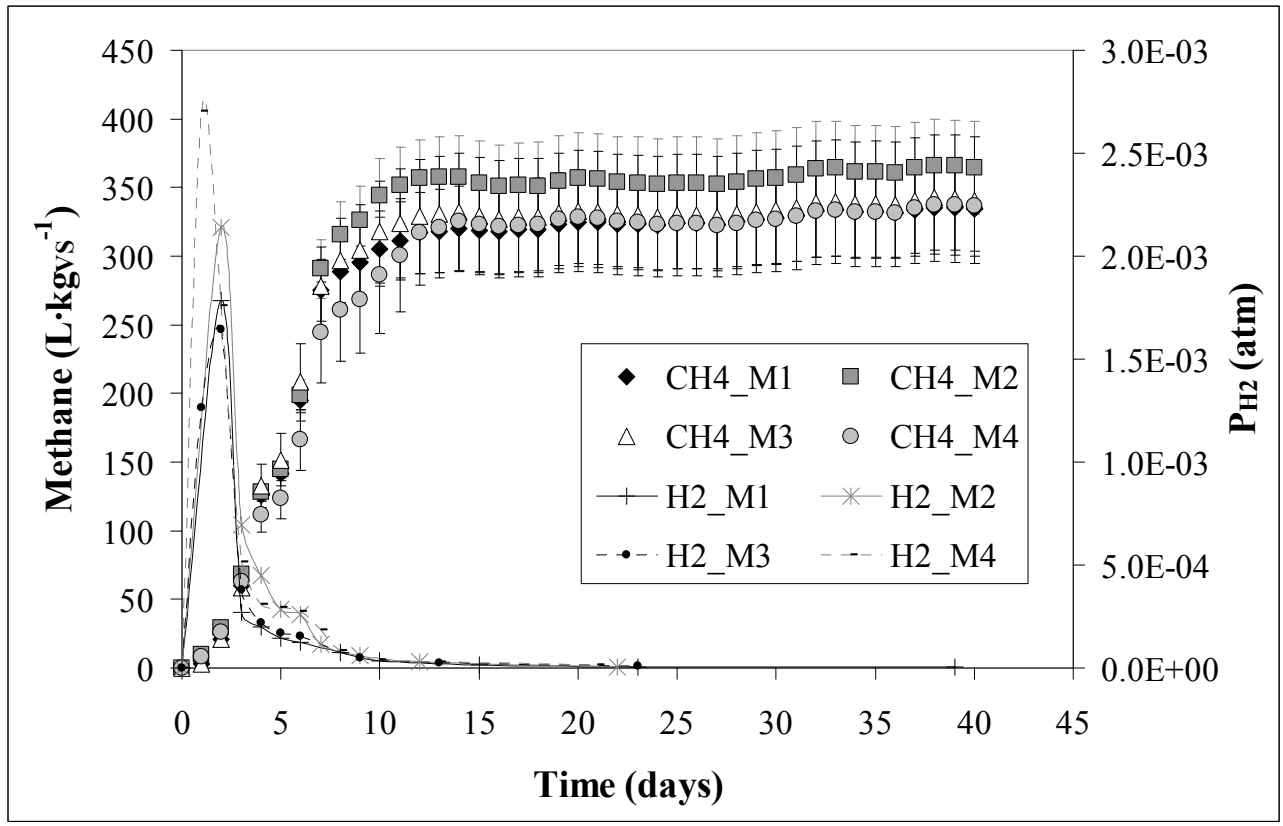

Figure 4.2. BMP test of untreated and biologically treated OP2 in co-digestion with cow manure: cumulative methane production and partial pressure of hydrogen in the biogas.

Table 4.4. Results of biological treatment of orange peel and co-digestion experiments of orange peel and cow manure.

\begin{tabular}{|c|c|c|c|c|c|}
\hline $\begin{array}{l}\text { Mixture composition } \\
\text { (dry matter basis) }\end{array}$ & $\begin{array}{c}\text { Treatment } \\
\text { of OP }\end{array}$ & $\begin{array}{c}\text { Initial limonene } \\
\text { concentration in } \\
\text { the digester } \\
\left(\mathrm{mg} \cdot \mathrm{kg}^{-1}\right)^{*}\end{array}$ & $\begin{array}{c}\text { BMP } \\
\left(\mathrm{L}_{\mathrm{CH} 4} \cdot \mathrm{kg}_{\mathrm{vs}}{ }^{-1}\right)\end{array}$ & $\begin{array}{c}\text { MPR } \\
\left(\mathrm{L}_{\mathrm{CH} 4} \cdot \mathrm{kg}_{\mathrm{Sv}}{ }^{-1} \cdot \mathrm{d}^{-1}\right)\end{array}$ & $\begin{array}{c}\text { Estimated } \\
\text { BD }(\%)\end{array}$ \\
\hline OP1 & None & n.a. & $359.3 \pm 31.0$ & $39.9 \pm 3.2$ & $85.7 \pm 7.4$ \\
\hline OP1 & BT1 & n.a. & $373.5 \pm 49.2$ & $41.3 \pm 6.3$ & $87.7 \pm 11.6$ \\
\hline M1: OP2 and CM, 1:1 & None & $84.6 \pm 0.0$ & $335.2 \pm 34.0$ & $49.7 \pm 4.9$ & $87.6 \pm 8.9$ \\
\hline M2: OP2 and CM, 3:1 & None & $122.4 \pm 0.0$ & $366.3 \pm 33.6$ & $51.6 \pm 4.5$ & $91.2 \pm 8.4$ \\
\hline M3: OP2 and CM, 1:1 & BT2 & $60.7 \pm 0.0$ & $342.5 \pm 46.3$ & $51.4 \pm 5.9$ & $89.5 \pm 12.1$ \\
\hline M4: OP2 and CM, 3:1 & BT2 & $90.6 \pm 0.0$ & $337.7 \pm 33.2$ & $41.1 \pm 7.4$ & $84.0 \pm 8.3$ \\
\hline
\end{tabular}

*The final limonene concentrations in the digesters was negligible $\left(<0.05 \mathrm{mg} \cdot \mathrm{kg}^{-1}\right)$ in all cases. 


\subsubsection{Steam distillation}

The results of BMP tests with untreated OP and after the six SD treatments are summarized in Figure 4.3 and Table 4.5.
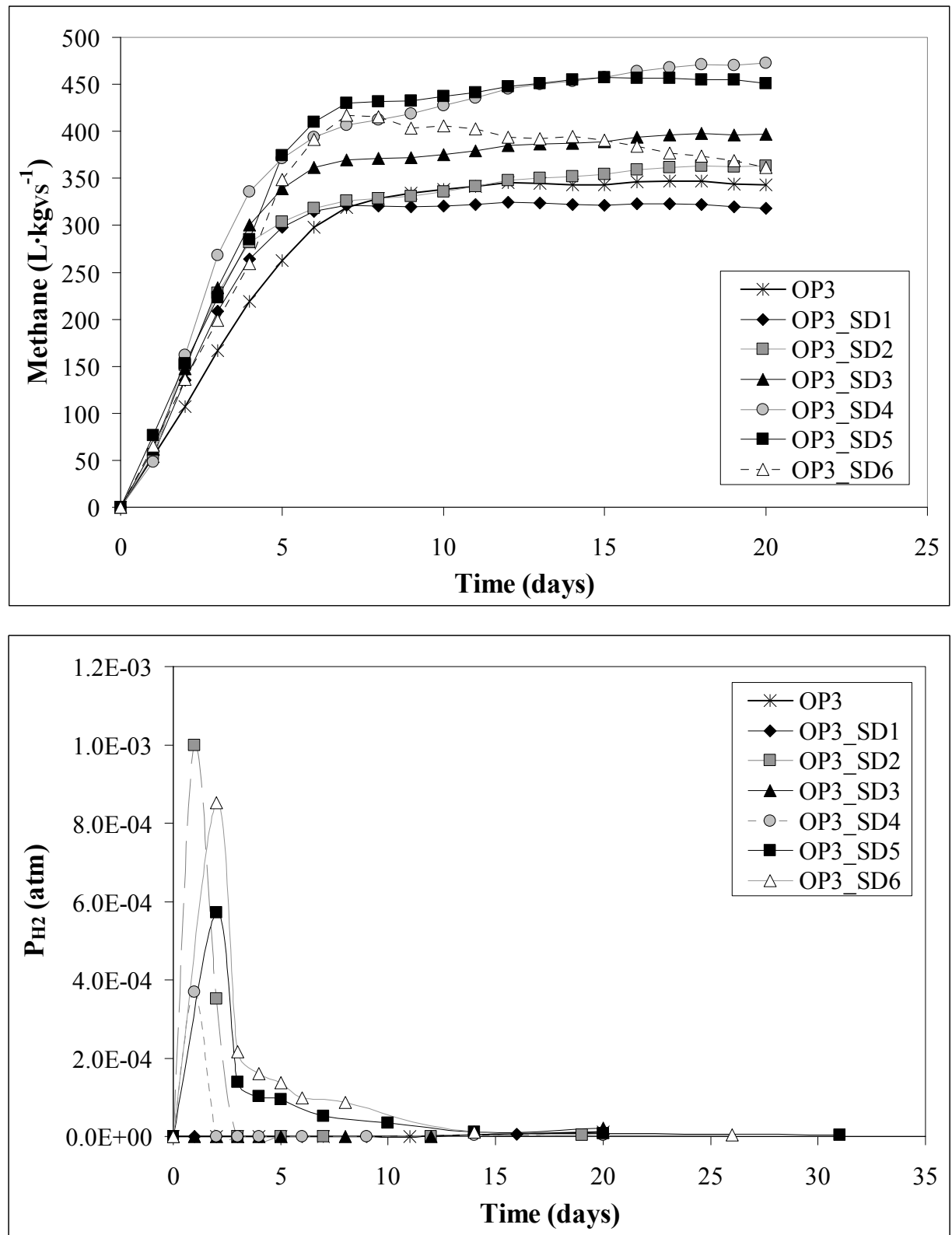

Figure 4.3. BMP test of OP3 untreated and after steam distillation: cumulative methane production and partial pressure of hydrogen in the biogas.Standard deviations are not represented for clarity. 
Table 4.5. Results of steam distillation experiments (see Table 4.1 for treatment conditions).

\begin{tabular}{|c|c|c|c|c|c|c|c|}
\hline \multirow{2}{*}{ 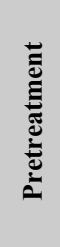 } & \multicolumn{3}{|c|}{$\begin{array}{l}\text { VS and limonene concentration in } \\
\text { the substrate }\end{array}$} & \multicolumn{4}{|c|}{ Results of the BMP test } \\
\hline & $\begin{array}{c}V S \\
\left(g \cdot g^{-1} \text { d.m. }\right)\end{array}$ & $\begin{array}{l}\text { Limonene } \\
\left(g \cdot \mathrm{kg}^{-1}\right)\end{array}$ & $\begin{array}{l}\text { Limonene } \\
\text { removal } \\
\text { efficiency } \\
(\%)+\end{array}$ & $\begin{array}{c}\text { Initial limonene } \\
\text { concentration in } \\
\text { the digester } \\
\left(m g \cdot \mathrm{kg}^{-1}\right)^{* *}\end{array}$ & $\begin{array}{c}B M P \\
\left(L_{C H 4} \cdot k_{V S}{ }^{-1}\right)\end{array}$ & $\begin{array}{c}M P R \\
\left(L_{C H 4} \cdot \mathrm{kg}_{S V^{-1}} \cdot d^{-1}\right)\end{array}$ & $\begin{array}{l}\text { Estimated } \\
B D(\%)\end{array}$ \\
\hline No & 960 & 2.9 & - & $112.7 \pm 0.0$ & $348 \pm 1$ & $55 \pm 5$ & $83.0 \pm 0.2$ \\
\hline SD1 & 962 & 2.8 & 0 & $163.0 \pm 0.0$ & $\begin{array}{c}325 \pm 11 \\
(-7 \% *)\end{array}$ & $\begin{array}{l}70 \pm 2 \\
(+27 \%)\end{array}$ & $\begin{array}{l}77.5 \pm 2.7 \\
(-7 \% *)\end{array}$ \\
\hline SD2 & 966 & 1.6 & 7 & $90.3 \pm 0.0$ & $\begin{array}{c}364 \pm 73 \\
(+5 \%)\end{array}$ & $\begin{array}{c}75 \pm 13 \\
(+37 \% *)\end{array}$ & $\begin{array}{l}86.8 \pm 17.5 \\
\quad(+5 \%)\end{array}$ \\
\hline SD3 & 969 & 1.9 & 0 & $110.6 \pm 0.0$ & $\begin{array}{c}398 \pm 59 \\
(+14 \%)\end{array}$ & $\begin{array}{c}80 \pm 10 \\
(+46 \% *)\end{array}$ & $\begin{array}{l}94.9 \pm 14.0 \\
(+14 \%)\end{array}$ \\
\hline SD4 & 963 & 0.9 & 44 & $52.2 \pm 0.0$ & $\begin{array}{l}473 \pm 24 \\
(+36 \% *)\end{array}$ & $\begin{array}{c}97 \pm 6 \\
(+76 \% *)\end{array}$ & $\begin{array}{c}112.8 \pm 5.8 \\
(+36 \% *) \dagger\end{array}$ \\
\hline SD5 & 960 & 1.7 & 17 & $95.7 \pm 0.0$ & $\begin{array}{c}465 \pm 83 \\
(+34 \%)\end{array}$ & $\begin{array}{c}74 \pm 8 \\
(+34 \% *)\end{array}$ & $\begin{array}{c}111.0 \pm 19.7 \\
(+34 \%) \dagger\end{array}$ \\
\hline SD6 & 962 & 1.9 & 18 & $90.5 \pm 0.0$ & $\begin{array}{l}417 \pm 20 \\
(+20 \% *)\end{array}$ & $\begin{array}{c}69 \pm 3 \\
(+25 \% *)\end{array}$ & $\begin{array}{l}99.6 \pm 4.8 \\
(+20 \% *)\end{array}$ \\
\hline
\end{tabular}

Values in brackets are the increments with respect to the blank. *Increments with respect to the blank (no pretreatment) are statistically significant $(\alpha=0.05) .{ }^{* *}$ The final limonene concentrations in the digesters was negligible $\left(<0.05 \mathrm{mg} \cdot \mathrm{kg}^{-1}\right)$ in all cases. $\dagger$ Biodegradability values higher than $100 \%$ are attributed to several sources of error such as COD estimation for solid samples, and are explained as complete biodegradation of the substrate. $\$$ dry matter basis.

All the treated samples except the one with milder conditions (SD1) yielded higher BMP, MPR and BD than the control. At ambient pressure, the best results $(36 \%$ more BMP and a $76 \%$ increase in MPR) were observed for the treatment with the higher steam flow rate and the longest contact time (SD4, see conditions in Table 4.1). This treatment also removed the most limonene (44\%). Partial vacuum conditions, SD5 and SD6, corresponding to low and high steam flow rate respectively, resulted in a 34 and 20\% increment in BMP respectively, and a 34 and 25\% increase in MPR also respectively. The partial vacuum applied in SD5 increased the extraction efficiency compared with the treatment at the same flow rate and higher contact time (SD2). Under these pressure conditions, the higher flow rate applied in SD6 did not significantly increase limonene removal further.

The fact that the maximum efficiency of limonene extraction was achieved for the treatment at the higher steam flow rate and longest contact time (SD4, see Table 4.1) is in line with the results of Cannon et al. (2013), who observed that longer contact times allow higher efficiencies in essential oil recovery by SD. The limonene extraction efficiency 
obtained by Martín et al. (2010) was higher (70\%); although the results cannot be directly compared due to the different operating conditions of the experiments.

\subsubsection{Extraction with ethanol}

The results of BMP tests are summarized in Figure 4.4 and Table 4.6.

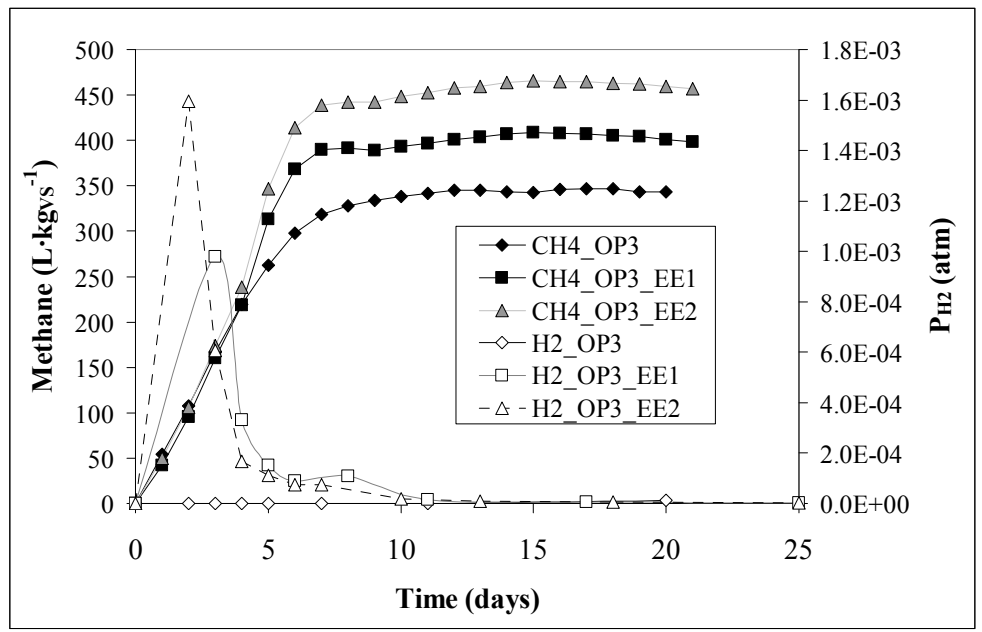

Figure 4.4. BMP test of OP3 untreated and after solid-liquid extraction with ethanol: cumulative methane production and partial pressure of hydrogen in the biogas.

Standard deviations are not represented for clarity.

Table 4.6. Results of solid-liquid extraction with ethanol experiments (see Table 4.1 for treatment conditions).

\begin{tabular}{|c|c|c|c|c|c|c|c|}
\hline \multirow{2}{*}{ 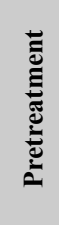 } & \multicolumn{3}{|c|}{$\begin{array}{l}\text { VS and limonene concentration in } \\
\text { the substrate }\end{array}$} & \multicolumn{4}{|c|}{ Results of the BMP test } \\
\hline & $\begin{array}{c}V S \\
\left(g \cdot k g^{-1} \text { d.m. }\right)\end{array}$ & $\begin{array}{l}\text { Limonene } \\
\left(g \cdot \mathrm{kg}^{-1}\right)\end{array}$ & $\begin{array}{l}\text { Limonene } \\
\text { removal } \\
\text { efficiency } \\
(\%)+\end{array}$ & $\begin{array}{c}\text { Initial limonene } \\
\text { concentration in } \\
\text { the digester } \\
\left(m g \cdot \mathrm{kg}^{-1}\right) * * *\end{array}$ & $\begin{array}{c}B M P \\
\left(L_{C H 4} \cdot k g_{V S}^{-1}\right)\end{array}$ & $\begin{array}{c}M P R \\
\left(L_{C H 4} \cdot k_{S V}^{-1} \cdot d^{-1}\right)\end{array}$ & $\begin{array}{c}\text { Estimated } \\
B D(\%)\end{array}$ \\
\hline No & 960 & 2.9 & - & $112.7 \pm 0.0$ & $348 \pm 1$ & $55 \pm 5$ & $83.0 \pm 0.2$ \\
\hline EE1 & 954 & 0.01 & 99.96 & $0.0 \pm 0.0$ & $\begin{array}{l}413 \pm 37 \\
(+19 \% *)\end{array}$ & $\begin{array}{c}67 \pm 3 \\
(+22 \% *)\end{array}$ & $\begin{array}{c}98.4 \pm 8.9 \\
(+19 \% *)\end{array}$ \\
\hline EE2 & 985 & 0.01 & 99.82 & $0.1 \pm 0.0$ & $\begin{array}{l}465 \pm 22 \\
(+34 \% *)\end{array}$ & $\begin{array}{c}74 \pm 3 \\
(+35 \% * *)\end{array}$ & $\begin{array}{c}107.9 \pm 5.0 \\
(+30 \% *) \dagger\end{array}$ \\
\hline
\end{tabular}

Values in brackets are the increments with respect to the blank. *Increments with respect to the blank (no pretreatment) are statistically significant $(\alpha=0.05) .{ }^{* *}$ The final limonene concentrations in the digesters was negligible $\left(<0.05 \mathrm{mg} \cdot \mathrm{kg}^{-1}\right)$ in all cases. $\dagger$ Biodegradability values higher than $100 \%$ are attributed to several sources of error such as COD estimation for solid samples, and are explained as complete biodegradation of the substrate. $\$$ dry matter basis. 
EE led to limonene removal efficiencies of close to $100 \%$. The organic matter concentration (measured as VS) remained constant. After the treatment, the samples were dried at low temperature to evaporate the residual ethanol and then BMP tests were carried out.

Both treatments caused higher hydrogen to accumulate than in the untreated sample. The treatment at $40^{\circ} \mathrm{C}$ showed greater hydrogen accumulation in the biogas at the beginning of the experiment.

Both treatments resulted in increments of BMP, MPR and BD. The treatment at $40^{\circ} \mathrm{C}$ yielded higher values of MPR and BMP than the extraction at ambient temperature (see Table 4.6).

\subsubsection{Comparison of treatment results}

Given that the effect of the limonene inhibition starts at around $200 \mathrm{mg} \cdot \mathrm{kg}^{-1}$ (Ruiz and Flotats, 2015), and that the initial limonene concentration in the digesters was below this value, the improvement of the anaerobic digestion yield observed with some of the pretreatments tested should be attributed to other causes.

BT removed up to $22 \%$ of the limonene from the OP. No effect was observed in BMP, MPR or BD.

The best SD treatment in terms of limonene removal removed as much as $44 \%$ of the initial limonene present in the OP, and the associated increments of BMP, MPR and BD were $36 \%, 76 \%$ and $36 \%$, respectively. Other SD treatments, resulting in limonene removal efficiencies similar to those achieved by BT (SD6, with limonene removal of 18\%), showed increases of BMP, MPR and BD (20\%-25\%), which were not observed for BT.

EE was the best treatment in terms of limonene removal, with efficiencies of nearly $100 \%$ in the extractions at both ambient temperature and $40^{\circ} \mathrm{C}$. The improvements in BMP, MPR and BD after EE1 and EE2 were similar to those obtained after SD6 and SD4, respectively.

The increments in BMP and MPR achieved by the most effective treatments in each category (BT, SD, EE) are shown in Figure 4.5. The maximum BMP increment observed was around 35\%. Similar results were obtained for MPR except in the SD4 treatment, where the MPR increment was higher. This treatment was the most intensive in terms of temperature, contact time and steam flow rate, which could have had an effect on the kinetics of the process, increasing the MPR.

The total organic matter in the OP, measured as VS, remained constant after all the pretreatments. Thus, the improvements in the anaerobic digestion process have to be related either to an increase of the biodegradability of the organic matter of the OP or to the removal of other inhibitory compounds.

The organic matter in OP is highly biodegradable, due to its high sugars content. The fibre content varies between $11 \%$ and $42 \%$ d.m. (Ruiz and Flotats, 2014). This fraction is less biodegradable, and thermal pretreatments can increase the solubilisation of the fibre and 
increase its biodegradability. However, the temperatures required to achieve this effect are higher than those used in our study (Sambusiti et al., 2013).

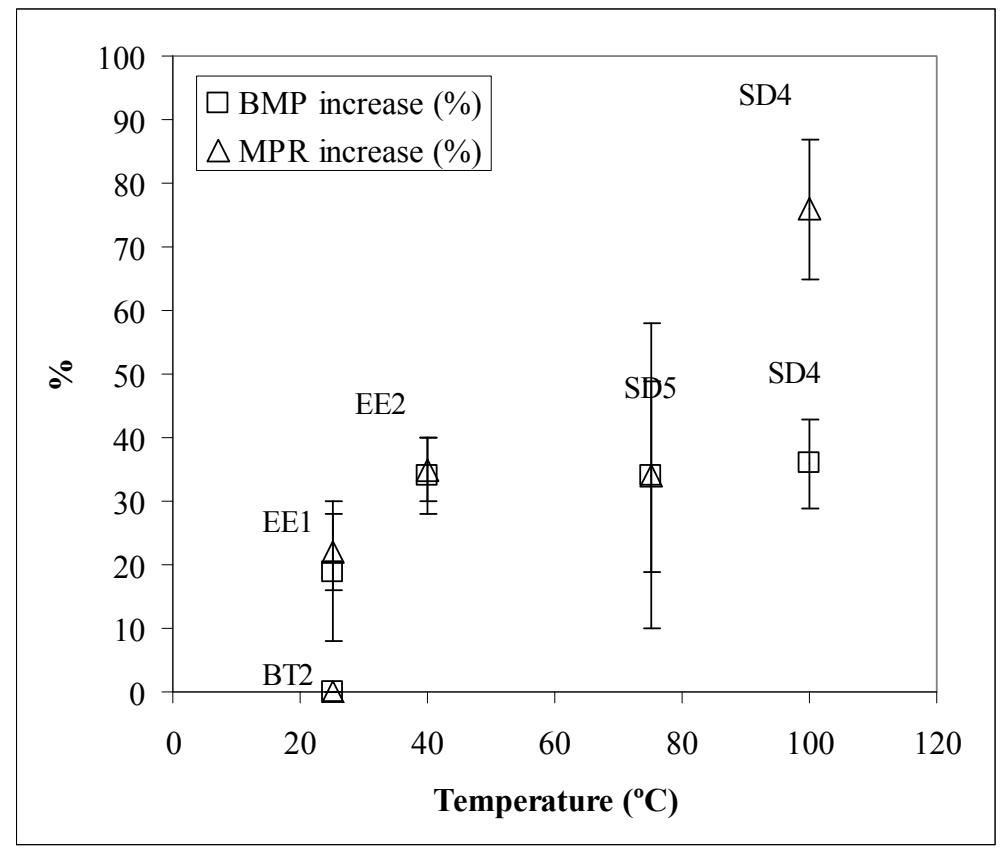

Figure 4.5. BMP and MPR increase in the batch anaerobic digestion of orange peel depending on the temperature of the pretreatment.

Therefore, the remaining possibility is the removal of an inhibitory compound other than limonene. Mizuki et al. (1990) observed that the minor compounds present in CEO can have a strong inhibitory effect.

The possible causes could be related to the pretreatment conditions, i.e. the biological process in the case of BT, thermal effects in the case of SD and chemical or thermal effects for EE.

The biodegradation of the limonene by Penicillium digitatum produces $\alpha$-terpineol, with bioconversion efficiencies higher than $90 \%$ in conditions similar to the pretreatment applied in this work (Badee et al., 2011). Other reported products of the biodegradation of limonene by Penicillium digitatum are carveol and carvone (Bowen, 1975). These have been reported to have antimicrobial effects (Ait-Ouazzou et al., 2012; Burt, 2004; Riahi et al., 2013; Viljoen et al., 2005) and therefore could inhibit anaerobic digestion. In particular, the antimicrobial effect of $\alpha$-terpineol is between 1000 and 5000 times greater than that of limonene, in accordance with their minimum inhibitory concentrations for microorganisms such as E. coli and S. aureus (Cosentino et al., 1999; Sonboli et al., 2005; Di Pasqua et al., 2006). This biotransformation was observed in our experiments: during BT, the limonene present in the OP was transformed to $\alpha$-terpineol with $67 \%$ efficiency (see Figure 4.6). However, although no increase of the BMP, MPR or BD was observed, no decrease was 90 
detected either. A possible increase of the BMP of the co-digestion mixtures with pretreated OP could have been masked by an inhibitory effect of the $\alpha$-terpineol, which was not completely degraded by the end of the batch anaerobic digestion in the case of mixture M4 (see Figure 4.6).

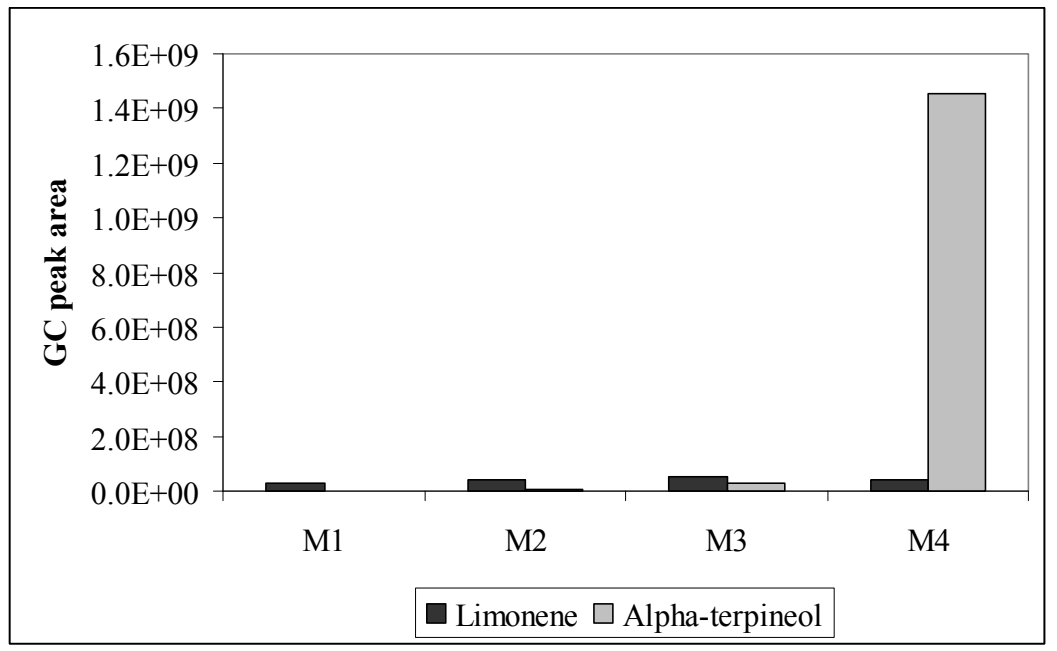

Figure 4.6. GC peak area of limonene and $\alpha$-terpineol at the end of the batch anaerobic digestion of untreated and biologically treated OP2 in co-digestion with cow manure, mixtures M1 to M4 (see mixture compositions in Table 4.2).

SD could have removed other minor compounds of the essential oil that have been proven to strongly influence the inhibitory effect (Lane, 1980; Mizuki et al., 1990). This would explain the fact that the BMP, MPR and BD increased as long as the treatment time and steam flow rate increased. Rezzoug and Louka (2009) observed that the CEO obtained by steam distillation $(2 \mathrm{~h}$ contact time, water/peel ratio $7 / 1 \mathrm{w} / \mathrm{w})$ contained $94.4 \%$ limonene, $1.3 \%$ myrcene, $0.5 \% \alpha$-pinene, $0.39 \%$ linalool and $0.38 \% \quad \beta$-pinene (all w/w). Blanco Tirado et al. (1995) performed steam distillation with 1-1.5 kg orange fruit peel, with 1 $\mathrm{kg} \cdot \mathrm{h}^{-1}$ steam at $1.1 \mathrm{~atm}$ and obtained $0.17 \% \mathrm{CEO}$. Limonene was the main component (91.03-92.57\%). Other compounds were terpinolene (1.83-2.61\%), n-octanal $(1.50-1.64 \%)$, $\beta$-pinene $(0.63-1.05 \%), \gamma$-terpinene $(0.41-1.09 \%), \alpha$-pinene $(0.28-0.32 \%)$, comphene $(0.27$ $0.35 \%)$ and decanal (0.11-0.35\%). Under $0.25 \%$ of the contents were geraniol, geranial, neral, terpinen-4-ol, nerol, $\delta$-elemene, 3-carene, isopulegol, $\delta$-cadinene, sabinene, $\alpha$ phellandrene, 1,4-cineole, trans- $\beta$-ocimene, n-octanol, cis-epoxylimonene, perillaldeyde, $\beta$ caryophyllene, germacrene $\mathrm{D}$ and $\beta$-myrcene (all percentages are GC peak areas). To the best of our knowledge, the quantification of the inhibitory effect of these minor components, compared to that of limonene on the same microorganisms, has not been reported; but the studies by Lane (1980) and Mizuki et al. (1990) demonstrate that the inhibitory effect of CEO (containing the minor components) is higher than the inhibitory effect of limonene alone. 
The EE was equally as efficient at removing limonene at both ambient temperature and $40^{\circ} \mathrm{C}$. This is in line with the fact that the liquid-liquid equilibrium of the ternary mixture water-limonene-ethanol is independent of the temperature in the range of temperatures used in this work (Cháfer et al., 2004). However, temperature could have an effect on the extraction efficiency of the minor components. This would also explain the similar methane yield increments observed with SD, despite the lower efficiency at limonene removal; since $\mathrm{SD}$ is carried out at temperatures higher than those used in the EE, the removal of minor components could have been improved. This could be explained by the similarity of the boiling points of limonene and some of the most abundant minor components of the CEO. The boiling point of limonene is $175.5-176^{\circ} \mathrm{C}$, and the boiling points of the most abundant of the compounds mentioned above are similar: $167^{\circ} \mathrm{C}$ for myrcene, $156^{\circ} \mathrm{C}$ for $\alpha$-pinene, $166^{\circ} \mathrm{C}$ for $\beta$-pinene, $158.5^{\circ} \mathrm{C}$ for comphene, $171^{\circ} \mathrm{C}$ for $\mathrm{n}$-octanal (data from PubChem Compound Database, NCBI).

\subsubsection{Energy balances}

The thermal energy required for the pretreatments was estimated and compared with the thermal energy that could potentially be recovered from the methane generated from the treated OP. The results are displayed in the Figure 4.7. The energy required for the pretreatment was higher than that potentially produced by the methane for all SD treatments. The opposite was the case for EE. The reason for this is the large amounts of energy necessary to generate the steam for SD, compared with the energy necessary to evaporate the residual alcohol in the case of EE.

From the point of view of OP valorization, in terms of energy production, the most interesting treatments are BT (no thermal energy required) and the EE.

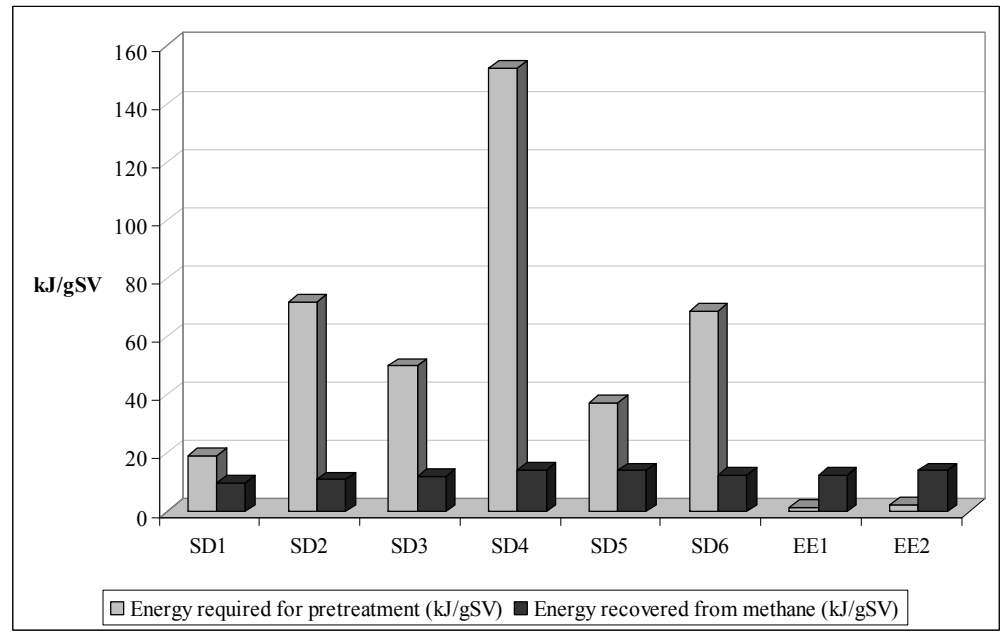

Figure 4.7. Thermal energy required for the pretreatments and potentially recovered from the methane generated with the pretreated orange peel. 


\subsection{Conclusions}

The three pretreatments applied to OP reduced the limonene concentration. The most efficient were EE, followed SD and BT.

BT did not improve the methane yield. Penicillium is able to degrade limonene, but during the treatment $\alpha$-terpineol is produced, which exhibits strong inhibition.

$\mathrm{SD}$ and EE resulted in improved methane potential and production rate. These improvements are attributed to the extraction of minor components that are known to strongly influence the toxic effect of CEO.

For industrial application focused on recovering energy from OP, the most interesting treatments would be BT and EE, due to their favourable energy balances. The limonene recovery achieved with the ethanol extraction could improve the profitability of the whole process.

\subsection{Acknowledgements}

Some of the results of this research correspond to the projects PS-120000-2007-6 and IAP560630-2008-14, cofinanced by the Spanish Ministry of Economy and Competitivity.

\subsection{References}

Ait-Ouazzou A., Cherrat L., Espina L., Lorán S., Rota C., Pagán R. 2011. The antimicrobial activity of hydrophobic essential oil constituents acting alone or in combined processes of food preservation. Innovative Food \& Science Emerging Technologies 12, 320-329.

Akao, T., Mizuki, E., Saito, H., Okumura, S. 1992. The methane fermentation of Citrus unshu peel pretreated with fungus enzymes. Bioresource Technology 41, 35-39.

APHA-AWWA-WEF (2006). Standard Methods for the examination of water and wastewater. American Public Health Association / American Water Works Association / Water Environment Federation. 19 ${ }^{\text {th }}$ ed., Washington DC, USA.

Arce, A., Marchiaro, A., Martínez-Ageitos, J.M., Soto, A. 2005. Citrus essential oil deterpenation by liquid-liquid extraction. The Canadian Journal of Chemical Engineering 83, 366-370.

Arce, A., Marchiaro, A., Soto, A. 2004. Liquid-liquid equilibria of linalool + ethanol + water, water + ethanol + limonene, and limonene + linalool + water systems. Journal of Solution Chemistry 33, 561-569.

Badee A.Z.M., Helmy S.A., Morsy N.F.S. 2011. Utilisation of orange peel in the production of $\alpha$-terpineol by Penicillium digitatum (NRRL 1202). Food Chemistry 126, 849-854.

Batstone D.J., Keller J., Angelidaki I., Kalyuzhny S.V., Pavlostathis S.G., Rozzi A., Sanders W.T.M., Siegrist H., Vavilin V.A. 2000. Anaerobic Digestion Model No. 1. ISBN 1-900222-24-8.

Blanco Tirado C., Stashenko E.E., Combariza M.Y., Martinez J.R. 1995. Comparative study of Colombian citrus oils by high-resolution gas chromatography and gas chromatography-mass spectrometry. Journal of Chromatography A 697, 501-513.

Bowen E.R. 1975. Potential by-products from microbial transformation of D-limonene. Florida State Horticultural Society, Florida, p. 304. 
Burt S. 2004. Essential oils: their antimicrobial properties and potential applications in foods - a review. International Journal of Food Microbiology 94, 223-253.

CAPA 2011. Informe del sector agrario valenciano 2011. Capítulo IV: estadísticas agrícolas. Cuadro 4.12: superficies, producciones y destino de la producción de cítricos. Comunitat Valenciana. Campaña 2010/2011. Conselleria de Agricultura, Pesca y Alimentación.

Cannon J.B., Cantrell C.L., Astatkie T., Zheljazkov V.D. 2013. Modification of yield and composition of essential oils by distillation time. Industrial Crops and Products 41, 214-220.

Cháfer A., Muñoz R., Burguet M.C., Berna A. 2004. The influence of the temperature on the liquid-liquid equilibria of the mixture limonene + ethanol + H2O. Fluid Phase Equilibria 224, 251-256.

Cosentino, S., Tuberoso, C.I.G., Pisano, B., Satta, M., Mascia, V., Arzedi, E., Palmas, F. 1999. In vitro antimicrobial activity and chemical composition of Sardinian Thymus essential oils. Letters of Applied Microbiology 29, 130-135.

De Blas C., Mateos G.G., García-Rebollar P. 2010. Tablas FEDNA de composición y valor nutritivo de alimentos para la fabricación de piensos compuestos ( $3^{\mathrm{a}}$ edición). (FEDNA tables of composition and nutritive value of foods for the manufacturing of compound feeds (3rd Edition). Fundación Española para el Desarrollo de la Nutrición Animal. Madrid. 502 pp.

Di Pasqua, R., Hoskins, N., Betts, G., Mauriello, G. 2006. Changes in membrane fatty acids composition of microbial cells induced by addition of thymol, carvacrol, limonene, cinnamaldehyde, and eugenol in the growing media. Journal of Agricultural and Food Chemistry 54, 2745-2749.

Field J., Sierra-Álvarez R., Lettinga G. 1988. Ensayos anaerobios. Depuración anaerobia de aguas residuales. Actas del $4^{\circ}$ seminario D.A.A.R. Pp. 52-81. Valladolid (Spain). ISBN 84-7762-054-7.

Forgács, G., Pourbafrani, M., Niklasson, C., Taherzadeh, M.T., Hováth, I.S. 2011. Methane production from citrus wastes: process development and cost estimation. J. Chem. Technol. Biotechnol. 87, 250-255.

Jaffrin A., Bentounes N., Joan A.M., Makhlouf S. 2003. Landfill biogas for heating greenhouses and providing carbon dioxide supplement for plant growth. Biosystems Engineering 86, 113-123.

Kaparaju, P.L.N., Rintala, J.A., 2006. Thermophilic anaerobic digestion of industrial orange waste. Environ. Technol. 27, 623-633.

Lane, A.G. 1980. Production of aromatic acids during anaerobic digestion of citrus peel. Journal of Chemical Technology and Biotechnology 30, 345-350.

Lane A.G. 1983. Pretreatment of citrus peel press liquor before anaerobic digestion. Environmental Technology Letters 4, 73-78.

Lane, A.G. 1984. Anaerobic digestion of orange peel. Food Technology in Australia 36, 125-127.

Lohrasbi, M., Pourbafrani, M., Niklasson, C., Taherzadeh, M.J. 2010. Process design and economic analysis of a citrus waste biorefinery with biofuels and limonene as products. Bioresource Technology 101: 73827388 .

Martín M.A., Siles J.A., Chica A.F., Martín A. 2010. Biomethanization of orange peel waste. Bioresource Technology 101, 8993-8999.

Mizuki, E., Akao, T., Saruwatari, T. 1990. Inhibitory effect of Citrus unshu peel on anaerobic digestion. Biological Wastes 33, 161-168.

NCBI - National Center for Biotechnology Information. PubChem Compound Database. http://pubchem.ncbi.nlm.nih.gov/ [accessed: Apr. 3, 2015].

Rezzoug S.A., Louka N. 2009. Thermomechanical process intensification for oil extraction from orange peels. Innovative Food Science and Emerging Technologies 10, 530-536. 
Perry R.H., Green D.W., Maloney J.O., eds. 1999. Perry's Chemical Engineers' Handbook, 7th edition. McGrawHill. ISBN 0-07-115448-5.

Pinto Mariano A., Dias M.O.S., Junqueira T.L., Cunha M.P., Bonomi A., Maciel Filho R. 2013. Utilization of pentoses from sugarcane biomass: Techno-economics of biogas vs. butanol production. Bioresource Technology 142, 390-399.

Riahi L., Elferchichi M., Ghazghazi H., Jebali J., Ziadi S., Aouadhi C., Chograni H., Zaouali Y., Zoghlami N., Mliki A. 2013. Phytochemistry, antioxidant and antimicrobial activities of the essential oils of Mentha rotundifolia L. in Tunisia. Industrial Crops and Products 49, 883-889.

Ruiz B., Flotats X. 2014. Citrus essential oils and their influence on the anaerobic digestion process: An overview. Waste Management 34, 2063-2079.

Ruiz B., Flotats X. 2015. Effect of limonene on batch anaerobic digestion of citrus peel. Submitted.

Sambusiti C., Monlau F., Ficara E., Carrère H., Malpei F. 2013. A comparison of different pre-treatments to increase methane production from two agricultural substrates. Applied Energy 104, 62-70.

Sánchez-Segado S., Lozano L.J., de los Ríos A.P., Hernández-Fernández F.J., Godínez C., Juan D. 2012. Process design and economic analysis of a hypothetical bioethanol production plant using carob pod as feedstock. Bioresource Technology 104, 324-328.

Sonboli, A., Eftekhar, F., Yousefzadi, M., Kanani, M.R. 2005. Antibacterial activity and chemical composition of the essential oil of Grammosciadium platycarpum Boiss. From Iran. Z. Naturforsch 60c, 30-34.

Srilatha, H.R., Nand, K., Sudhakar Babu, K., Madhukara, K. 1995. Fungal pretreatment of orange processing waste by solid-state fermentation for improved production of methane. Process Biochemistry 30, 327331.

VDI - Verein Deutscher Ingenieure 2006. Fermentation of organic materials. Characterisation of the substrate, sampling, collection of material data, fermentation tests. ICS 13.030.30; 27.190.

Viljoen A.M., Subramoney S., van Vuuren S.F., Baser K.H.C., Demirci B. 2005. The composition, geographical variation and antimicrobial activity of Lippia javanica (Verbenaceae) leaf essential oils. Journal of Ethnopharmacology 96, 271-277.

Wikandari R., Nguyen H., Millati R., Niklasson C., Taherzadeh M.J. 2013. A novel method of orange wastes pretreatment for biogas production. Wastes: solutions, treatments and opportunities. 2nd international conference. September, 11th -13 th 2013.

Zheng, Y., Zhao, J., Xu, F., Li, Y. 2014. Pretreatment of lignocellulosic biomass for enhanced biogas production. Progress in Energy and Combustion Science 42, 35-53. 


\title{
Chapter 5
}

\section{Co-digestion of citrus waste with chicken and pig manure as a strategy to overcome inhibition of anaerobic digestion by citrus essential oil}

\begin{abstract}
Anaerobic co-digestion of citrus waste (orange and mandarin peel) was carried out with chicken and pig manure, in order to improve the nutrients balance and to reduce the concentration of the essential oils in the mixture.

Different proportions of the four substrates were used, leading to different concentrations of limonene and also of the minority compounds of citrus essential oil, which are known to modulate the inhibitory effect of limonene. Two levels of limonene concentrations were tested: $3.1 \pm 0.9 \mathrm{~g} \cdot \mathrm{kg}^{-1}$ and $1.4 \pm 0.4 \mathrm{~g} \cdot \mathrm{kg}^{-1}$. At the lower limonene concentration, two different compositions of citrus waste were tested: $1: 1$ and 1:1.5 of orange peel and mandarin peel (volatile solids basis). The maximum stable organic loading rate (OLR) reached for the mixture with higher limonene concentration was $1.01 \mathrm{~kg}_{\mathrm{VS}} \cdot \mathrm{m}^{-3} \cdot \mathrm{d}^{-1}$. The lower limonene concentration mixture allowed reaching higher OLR of $2.2 \mathrm{~kg} \mathrm{vs}^{-3} \mathrm{~m}^{-3} \cdot \mathrm{d}^{-1}$ corresponding to a limonene dose of $27 \mathrm{mg} \cdot \mathrm{L}_{\text {digester }}{ }^{-1} \cdot \mathrm{d}^{-1}$. The methane yield at these conditions was $0.23 \mathrm{~m}^{3} \cdot \mathrm{kg}_{\mathrm{vs}}{ }^{-1}$. At the lower limonene concentration, the citrus waste composition had an effect on the maximum OLR, being lower for the mixture with higher content of orange peel vs. mandarin peel.

Systemic inhibition was observed in the mixture with higher limonene concentration, with symptoms of inhibition on methanogenesis, protein hydrolysis pathway, sulphate reduction, and acetogenesis. Acetogenesis was inhibited in all mixtures but at different limonene doses.

The rate of increase of the limonene dose was related to the maximum reachable OLR. The degradation of the limonene produced inhibitory compounds as well, causing the inhibitory effect to persist even after almost complete limonene degradation.
\end{abstract}




\section{Table of contents}

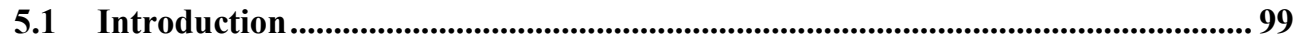

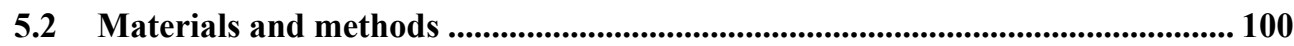

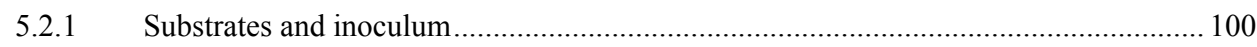

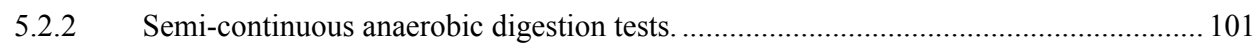

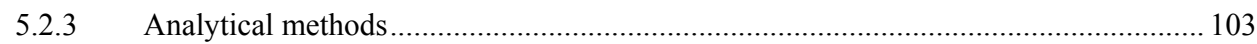

$5.3 \quad$ Results and discussion.............................................................................................. 103

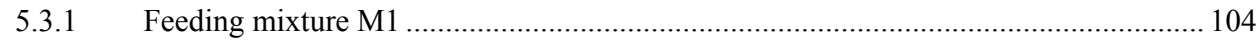

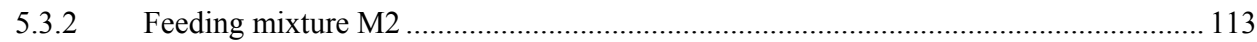

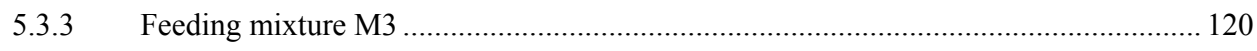

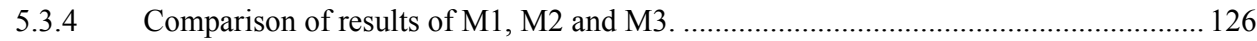

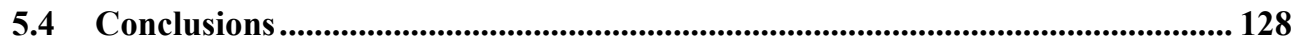

5.5 Acknowledgements...................................................................................................... 129

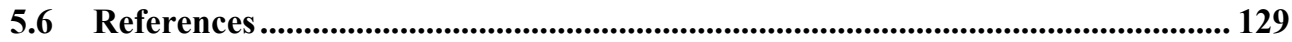




\subsection{Introduction}

Citrus waste is generated in the process of juice manufacturing with a ratio of 500 tons of waste per 1000 tons of fruit processed (Lane, 1983; Lohrasbi et al., 2010). Other sources of waste are the fruits discarded for commercial reasons or due to production limiting regulations, which ranges $2-10 \%$ (CAPA, 2011).

Anaerobic digestion is a technically feasible, environmentally friendly and energy efficient process for the valorisation of citrus waste. However, the citrus essential oil (CEO), inhibitor of the anaerobic digestion, and the lack of nutrients, hampers the valorisation of citrus waste through this technology.

Lane (1980) studied the anaerobic digestion of orange peel from a commercial orange juice plant, comminuted and enriched with nitrogen and phosphorus, at a temperature of $37^{\circ} \mathrm{C}$ and an organic loading rate (OLR) of $2 \mathrm{~kg}_{\mathrm{TS}} \cdot \mathrm{m}^{-3} \cdot \mathrm{d}^{-1}$. The process failed after 2-3 weeks. Later on, Lane (1984) studied the anaerobic digestion of orange peel from the same origin but after a limonene extraction treatment. The peel was comminuted $(8 \mathrm{~mm})$, diluted with water to $10 \%$ solids (w/v) and supplemented with macro- and micronutrients. Anaerobic digestion was found to be stable up to an OLR of $3.5 \mathrm{~kg}_{\mathrm{TS}} \cdot \mathrm{m}^{-3} \cdot \mathrm{d}^{-1}$ corresponding to a peel oil dose of $75 \mathrm{mg} \cdot \mathrm{L}_{\text {digester }}{ }^{-1} \cdot \mathrm{d}^{-1}$. The author used a macro- and micronutrients solution but suggested that livestock wastes such as pig or chicken manure could be used as nitrogen source.

Mizuki et al. (1990) studied the anaerobic digestion of mandarin peel from a canning industry. It was comminuted, homogenized and supplemented with nitrogen and phosphorus. Digestions were carried out at $37^{\circ} \mathrm{C}$ and failed at an OLR of $2.0 \mathrm{~kg}_{\mathrm{TS}} \cdot \mathrm{m}^{-3} \cdot \mathrm{d}^{-1}$ corresponding to a peel oil dosage of $26 \mathrm{mg} \cdot \mathrm{L}_{\text {digester }}{ }^{-1} \cdot \mathrm{d}^{-1}$.

Srilatha et al. (1995) assessed the anaerobic digestion of orange peel, reaching a maximum OLR of $2.3 \mathrm{~kg}_{\mathrm{vs}} \cdot \mathrm{m}^{-3} \cdot \mathrm{d}^{-1}$ corresponding to a limonene dosage of $24 \mathrm{mg} \cdot \mathrm{L}_{\text {digester }}{ }^{-1} \cdot \mathrm{d}^{-1}$. The methane production was around $0.23 \mathrm{~m}^{3} \cdot \mathrm{kg}_{\mathrm{vs}}{ }^{-1}$.

Kaparaju and Rintala (2006) studied the thermophilic anaerobic digestion of orange waste from a juice extraction industry. The waste was comminuted to less than $7 \mathrm{~mm}$, the $\mathrm{pH}$ was adjusted to 8 and total solids (TS) adjusted to $8 \%$ with distilled water. The semi-continuous process showed severe instability at an OLR of $5.6 \mathrm{~kg}_{\mathrm{vs}} \cdot \mathrm{m}^{-3} \cdot \mathrm{d}^{-1}$ and reinoculation was necessary, although an increase in the propionic acid was detected already at 4.2 $\mathrm{kg}_{\mathrm{vS}} \cdot \mathrm{m}^{-3} \cdot \mathrm{d}^{-1}$. The operation at lower OLR $\left(2.8-4.2 \mathrm{~kg}_{\mathrm{vs}} \cdot \mathrm{m}^{-3} \cdot \mathrm{d}^{-1}\right.$, HRT 40-26 days, test period 15-20 days) yielded a methane production of $0.6-0.5 \mathrm{~m}^{3} \cdot \mathrm{kg}_{\mathrm{vs}}{ }^{-1}$.

Martín et al. (2010) also studied the thermophilic anaerobic digestion of orange waste from juice manufacturing industry. The waste was comminuted to less than $2 \mathrm{~mm}$ and $70 \%$ limonene was extracted by laboratory steam distillation prior to anaerobic digestion. The waste was then diluted to $60-140 \mathrm{~g} \mathrm{COD} \cdot \mathrm{L}^{-1}$. The limonene concentration of the resulting product was $2 \mathrm{mg} \cdot \mathrm{L}^{-1}$. In continuous operation, the process was stable until an OLR of 3 $\mathrm{kg}_{\mathrm{vs}} \cdot \mathrm{m}^{-3} \cdot \mathrm{d}^{-1}$ and produced $0.27-0.29 \mathrm{~m}^{3} \mathrm{CH}_{4} \cdot \mathrm{kg}_{\mathrm{vs}}{ }^{-1}$. Martín et al. (2013) studied also the anaerobic co-digestion of orange peel with glycerol, and found that it was more stable at 
mesophilic than at thermophilic temperature in semi-batch operation. The process was stable up to an OLR of $1.91 \mathrm{~kg}_{\mathrm{vs}} \cdot \mathrm{m}^{-3} \cdot \mathrm{d}^{-1}$ with a methane production of $0.33 \mathrm{~m}^{3} \cdot \mathrm{kg}_{\mathrm{Vs}}{ }^{-1}$. Beyond this point, the process was acidified. Macro/micronutrients and buffering solutions were added to improve the microbial activity.

Forgács et al. (2011) assessed the anaerobic co-digestion of citrus waste and organic fraction of municipal solid waste (OFMSW). The citrus waste was previously pre-treated to remove the citrus essential oil. The amount of citrus waste in the mixture was $30 \%$ of the volatile solids (VS). The specific methane production was $0.555 \pm 0.0159 \mathrm{~m}^{3} \cdot \mathrm{kg}_{\mathrm{vs}}{ }^{-1} \cdot \mathrm{d}^{-1}$ at an OLR of $3 \mathrm{~kg} \mathrm{VS} \cdot \mathrm{m}^{-3} \cdot \mathrm{d}^{-1}$ corresponding to a limonene dose of $34 \mathrm{mg} \cdot \mathrm{L}_{\mathrm{digester}}{ }^{-1} \cdot \mathrm{d}^{-1}$.

All experiments found in the literature (except the one of Srilatha et al., 1995) with orange peel as the only substrate needed supplementation with buffering solutions, macro and micronutrients, due to the low $\mathrm{pH}$ and the lack of nutrients of the citrus waste. At industrial scale, this would reduce the economic feasibility of the plants. Lane (1984) suggested that the co-digestion of citrus waste with nitrogen-rich manure from pigs or chicken could be an economic alternative. This author estimated that a weekly charge of $4 \mathrm{~kg}_{\mathrm{TS}} \cdot \mathrm{m}^{-3}$ would be enough to maintain the nitrogen levels about $200 \mathrm{mg} \cdot \mathrm{L}^{-1}$. However, previous investigations have demonstrated that $200 \mathrm{mg} \cdot \mathrm{L}^{-1}$ of nitrogen might not be sufficient for a stable process (Ruiz et al., 2013).

The objective of this work was to study the anaerobic co-digestion of citrus waste with pig and chicken manure. The aim of the co-digestion is to reduce the limonene dose by the dilution effect and to supply the buffering capacity and nutrients, thus avoiding the industrial process of limonene extraction and the additive (nutrients and buffering solutions) costs. The effect of different limonene dosages to the digester depending on the citrus fraction in the mixture and the OLR has been assessed.

\subsection{Materials and methods}

\subsubsection{Substrates and inoculum}

Substrates for experimental tests included animal manures and citrus waste.

Chicken manure (CM) was obtained from a laying-hens farm near Valencia (Spain), directly from the belts under the cages where the manure is collected. Pig manure (PM) was collected from the reception lagoon (prior to solid-liquid separation) of a closed cycle pig farm near Valencia (Spain). Two samples (PM1 and PM2) were collected at the same farm but at different dates.

Citrus waste was taken from a juice manufacturing facility located near Valencia (Spain) when no limonene extraction was done. Two different materials were used: orange (Citrus sinensis) peel (OP) and mandarin (Citrus reticulata) peel (MP).

To start the anaerobic digestion process, the digesters were filled with $80 \%$ cow manure, $10 \%$ pig slurry and $10 \%$ chicken manure $(\mathrm{w} / \mathrm{w})$, and were left without feeding until the 
biogas production reached a plateau. The total solids (TS) and volatile solids (VS) of the described mix were 75.0 and $60.7 \mathrm{~g} \cdot \mathrm{kg}^{-1}$ respectively.

\subsubsection{Semi-continuous anaerobic digestion tests.}

Semi-continuous anaerobic digestion tests were carried out according the Verein Deutscher Ingenieure (VDI) Standard 4630 Fermentation of organic materials (VDI, 2006). This standard recommends to increase OLR in steps of $0.5 \mathrm{~kg} \mathrm{vs}^{\cdot} \cdot \mathrm{m}^{-3} \cdot \mathrm{d}^{-1}$ each 14 days until reaching the maximum stable conditions, and keep then the OLR for enough time to reach steady state. Since the objective was to find the maximum OLR possible, the steady state was not reached.

Jacketed continuously stirred tank reactors (CSTR) of $36 \mathrm{~L}$ total volume (30 L working volume) were used as anaerobic digesters (Figure 5.1). The operating temperature was $38^{\circ} \mathrm{C}$ in all digesters. Feeding of substrates and removal of same amount of digestate was done once a day. Gas volume was measured by Ritter Milligascounters ${ }^{\circledR}$ MGC-10. Methane production data were expressed at standard pressure and temperature conditions $\left(0^{\circ} \mathrm{C}\right.$ and 1 atm).

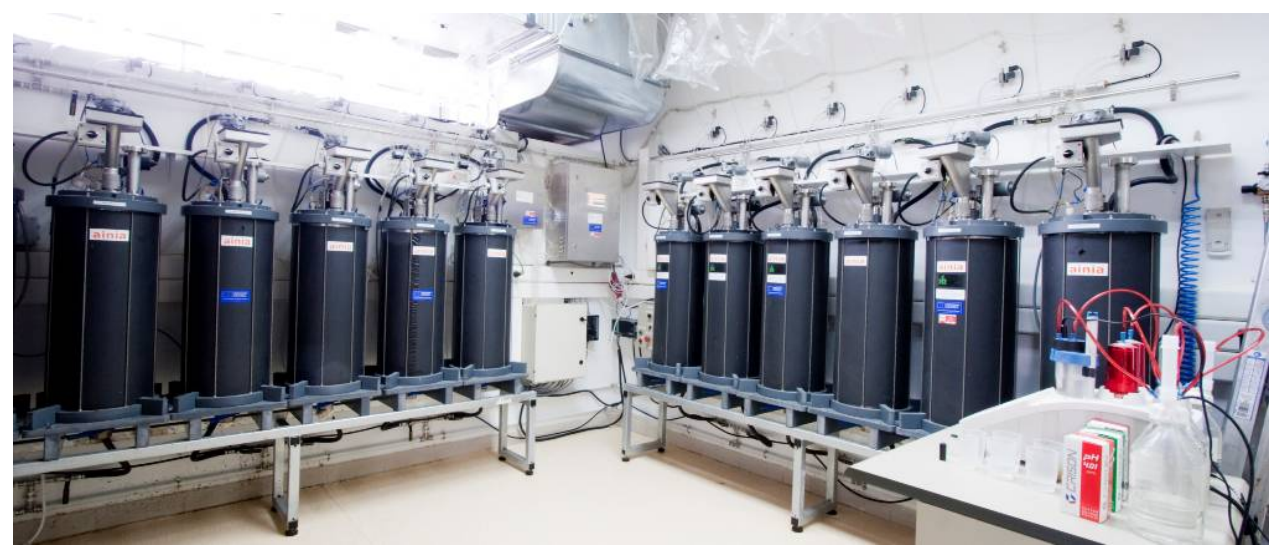

Figure 5.1. Laboratory set-up for the semi-continuous anaerobic digestion tests.

The inoculum described in 2.1 was used for the start-up of the digesters. Feeding started with an organic loading rate (OLR) of $0.5 \mathrm{~kg}_{\mathrm{vs}} \cdot \mathrm{m}^{-3} \cdot \mathrm{d}^{-1}$, and was progressively increased until its maximum. OLR was considered to reach its maximum when the alkalinity ratio and volatile fatty acids (VFA) concentration exceeded the limits reported for stable operation (Effenberger et al., 2007): total VFA $>2000 \mathrm{mg} \cdot \mathrm{L}^{-1}$; acetic acid $>1000 \mathrm{mg} \cdot \mathrm{L}^{-1}$; propionic acid $>500 \mathrm{mg} \cdot \mathrm{L}^{-1}$; butyric acid $>500 \mathrm{mg} \cdot \mathrm{L}^{-1}$, alkalinity ratio $>0.3$; methane concentration $<48 \%$.

Citrus waste was digested with two types of animal manures: pig and chicken manure. Different proportions citrus waste/manure were used, that resulted in different limonene doses to the digester. Three different mixtures of orange waste, mandarin waste, chicken manure and pig manure were tested in semi-continuous anaerobic digestion (M1, M2 and 
M3). Table 5.1 summarizes the data of the semi-continuous tests carried out, indicating for each mixture, the substrates and their proportions and the average characteristics of the mixture. Neither buffering solution nor nutrients were added to the digesters. The nitrogen

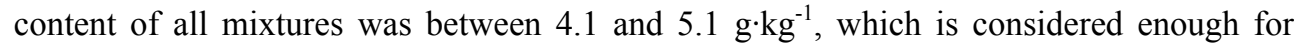
anaerobic digestion (Rittmann and McCarty, 2001).

The ratio citrus waste:manure (VS basis) in M1 was 4:1. M2 had lower limonene concentration, by modifying this ratio to $1.5: 1$. M3 had a ratio of $1: 1$ but with the same limonene concentration (achieved by modifying the relative proportion between OP and MP). The ratio OP:MP was approximately 1:1 in M1 and M2, and 1:1.7 in M3. Therefore, the composition of minority compounds in M3 was different than in M1-M2.

Table 5.1. Summary of semi-continuous anaerobic digestion tests.

\begin{tabular}{|c|c|c|c|}
\hline Test & Substrates & $\%$ & $\%(V S)$ \\
\hline \multirow{6}{*}{ M1 } & Orange peel (OP) & 34.5 & 42.3 \\
\hline & Mandarin peel (MP) & 35.1 & 36.3 \\
\hline & Chicken manure (CM) & 14.9 & 18.9 \\
\hline & Pig manure (PM1) & 15.5 & 2.5 \\
\hline & Total manure & 30.4 & 21.4 \\
\hline & Total citrus waste & 69.6 & 78.6 \\
\hline \multirow{6}{*}{ M2 } & Orange peel (OP) & 15.0 & 32.2 \\
\hline & Mandarin peel (MP) & 15.1 & 27.1 \\
\hline & Chicken manure (CM) & 13.0 & 28.9 \\
\hline & Pig manure (PM2) & 56.9 & 11.8 \\
\hline & Total manure & 69.9 & 40.7 \\
\hline & Total citrus waste & 30.1 & 59.3 \\
\hline \multirow{6}{*}{ M3 } & Orange peel (OP) & 10.2 & 18.8 \\
\hline & Mandarin peel (MP) & 20.0 & 31.1 \\
\hline & Chicken manure (CM) & 20.0 & 38.1 \\
\hline & Pig manure (PM1) & 49.8 & 12.0 \\
\hline & Total manure & 69.8 & 50.1 \\
\hline & Total citrus waste & 30.2 & 49.9 \\
\hline
\end{tabular}

Each experiment was divided in periods characterized by constant OLR and hydraulic retention time (HRT). Analytical control of the digesters was done once a week. 


\subsubsection{Analytical methods}

Analysis of total solids (TS), volatile solids (VS), phosphorus, potassium, total Kjeldahl nitrogen (TKN), ammonia nitrogen (NH4+-N), total and soluble chemical oxygen demand (COD, sCOD) and total carbon were carried out according the Standard Methods of Analysis (APHA-AWWA-WEF, 2006). Due to the high degree of heterogeneity of the samples, the COD and SCOD results had very large standard deviations and were not considered realistic. Therefore, COD values for the calculation of biodegradability and the theoretical methane production were estimated based on VS content.

Individual volatile fatty acids (VFA) acetic, propionic, iso-butyric, butyric, iso-valeric valeric, iso-caproic, caproic and heptanoic, as well as limonene and other CEO components, were analysed by gas chromatography as described by Ruiz and Flotats (2015).

Total mesophilic anaerobes were analyzed according the method described in PascualAnderson (1982).

The biogas composition was analysed each 6 litres of biogas produced by means of an Awite Serie-6 gas analyzer (Awite GmbH, Germany). This device is equipped with infrared sensors for methane, carbon dioxide and oxygen, and electrochemical sensors for hydrogen sulphide and hydrogen.

\subsection{Results and discussion}

Chemical characteristics of manures and citrus waste samples are summarized in Table 5.2.

Table 5.2. Chemical characteristics of animal manures and citrus waste used for the experiments.

\begin{tabular}{|c|c|c|c|c|c|}
\hline Parameter, units & $\begin{array}{c}\text { Chicken } \\
\text { manure } \\
(\mathrm{CM})\end{array}$ & $\begin{array}{c}\text { Pig } \\
\text { manure } \\
\text { (PM1) }\end{array}$ & $\begin{array}{c}\text { Pig } \\
\text { manure } \\
\text { (PM2) }\end{array}$ & $\begin{array}{c}\text { Orange } \\
\text { peel } \\
(\mathrm{OP})\end{array}$ & $\begin{array}{c}\text { Mandarin } \\
\text { peel } \\
\text { (MP) }\end{array}$ \\
\hline Total solids (TS), $\%$ & $26.8 \pm 0.35$ & $3.6 \pm 0.05$ & $2.8 \pm 0.04$ & $20.1 \pm 0.3$ & $16.9 \pm 0.2$ \\
\hline Volatile solids (VS), \%TS & $74.8 \pm 12.9$ & $70.2 \pm 12.1$ & $67.0 \pm 11.6$ & $96.6 \pm 16.7$ & $96.6 \pm 16.7$ \\
\hline Total carbon, $\mathrm{g} \cdot \mathrm{kg}^{-1}$ & 98 & 13 & 10.6 & 93 & 78 \\
\hline Total Kjeldahl Nitrogen (TKN), $\mathrm{g} \cdot \mathrm{kg}^{-1}$ & $14.4 \pm 1.7$ & $3.3 \pm 0.4$ & $2.8 \pm 0.3$ & $2.3 \pm 0.3$ & $2.0 \pm 0.2$ \\
\hline Phosphorus, $\mathrm{mg} \cdot \mathrm{kg}^{-1}$ & $3821 \pm 267$ & $694 \pm 49$ & $630 \pm 44$ & $203 \pm 14$ & $220 \pm 15$ \\
\hline Potassium, $\mathrm{mg} \cdot \mathrm{kg}^{-1}$ & $2886 \pm 433$ & $1519 \pm 228$ & $1056 \pm 158$ & $707 \pm 106$ & $797 \pm 120$ \\
\hline $\mathrm{C} / \mathrm{N}$ ratio & 7 & 4 & 3.8 & 41 & 40 \\
\hline Limonene, $\mathrm{g} \cdot \mathrm{kg}^{-1}$ & n.a. & n.a. & n.a. & 5.4 & 3.6 \\
\hline
\end{tabular}

n.a.: not analyzed.

The resulting properties of the feeding mixtures used in the experiments are summarized in Table 5.3. 
Table 5.3. Summary of semi-continuous anaerobic digestion tests.

\begin{tabular}{|c|c|c|c|}
\hline Test & TS $\mathbf{( g \cdot \mathbf { k g } ^ { - 1 } )}$ & $\mathbf{V S} \mathbf{( g \cdot \mathbf { k g } ^ { - 1 } )}$ & Limonene $\mathbf{( g \cdot \mathbf { k g } ^ { - 1 } )}$ \\
\hline M1 & $174 \pm 2$ & $155 \pm 3$ & $3.1 \pm 0.9$ \\
\hline M2 & $107 \pm 1$ & $82 \pm 4$ & $1.4 \pm 0.4$ \\
\hline M3 & $126 \pm 2$ & $100 \pm 5$ & $1.3 \pm 0.4$ \\
\hline
\end{tabular}

\subsubsection{Feeding mixture M1}

The specific biogas and methane production, the methane concentration in the biogas and the average daily dosage of limonene in each period are presented in Figure 5.2. Biogas and methane production decrease as the OLR (and consequently, the limonene dose) increases. At OLR $1.5 \mathrm{~kg}_{\mathrm{Vs}} \cdot \mathrm{m}^{-3} \cdot \mathrm{d}^{-1}$ (period III) a rise in the VFA concentration was detected and it was necessary to stop the process to avoid acidification (period IV). After partial recovery the feeding was restarted at OLR $1.5 \mathrm{~kg}_{\mathrm{vs}} \cdot \mathrm{m}^{-3} \cdot \mathrm{d}^{-1}$ (period V) but it was not possible to achieve a stable process and the test was stopped.

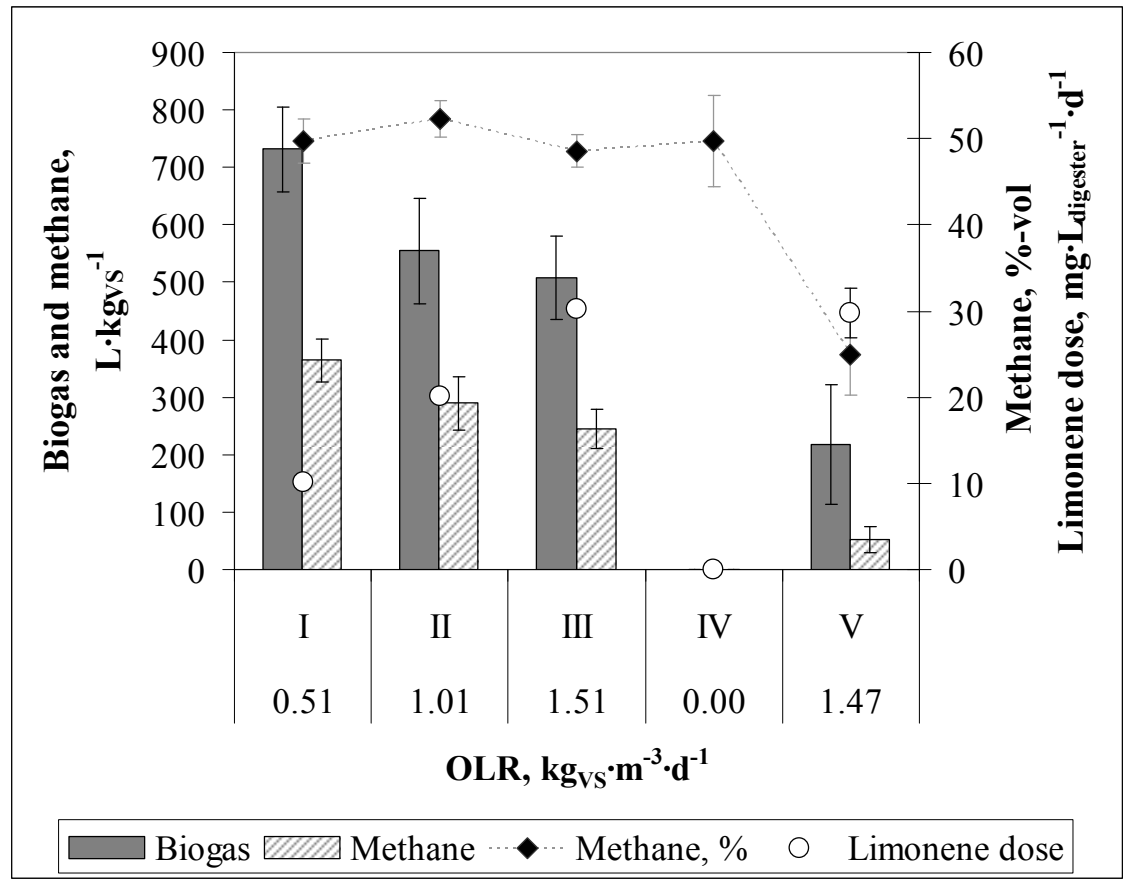

Figure 5.2. Specific biogas and methane production, and methane content in the biogas (\%-vol) of the mixture M1 for the five periods studied. Averages and standard deviations of the different periods are represented. 
Figure 5.3 (left) presents the volumetric methane production $\left(\mathrm{m}^{3}\right.$ of methane per $\mathrm{m}^{3}$ of digester and day) for each day of experiment. The methane production is in all cases lower than expected (calculated from estimated COD in the feed), and the difference increases with increasing OLR ( $26 \%$ in period I, $41 \%$ in period II, $50 \%$ in period III). In period V, with the same OLR as period III, the methane production is $89 \%$ lower than the estimated, due to the inhibition of the methanogenesis. All these differences are statistically significative (t-test, $\alpha=0.05$ ). However, the VS removal is similar in all periods, and around $75-80 \%$.

The methane content in the biogas and the limonene dose are presented in Figure 5.3 (right). The methane concentration in the biogas remained in values near 50\% except for the last period, where the methane concentration drops until values around $25 \%$ (methanogenesis inhibition).
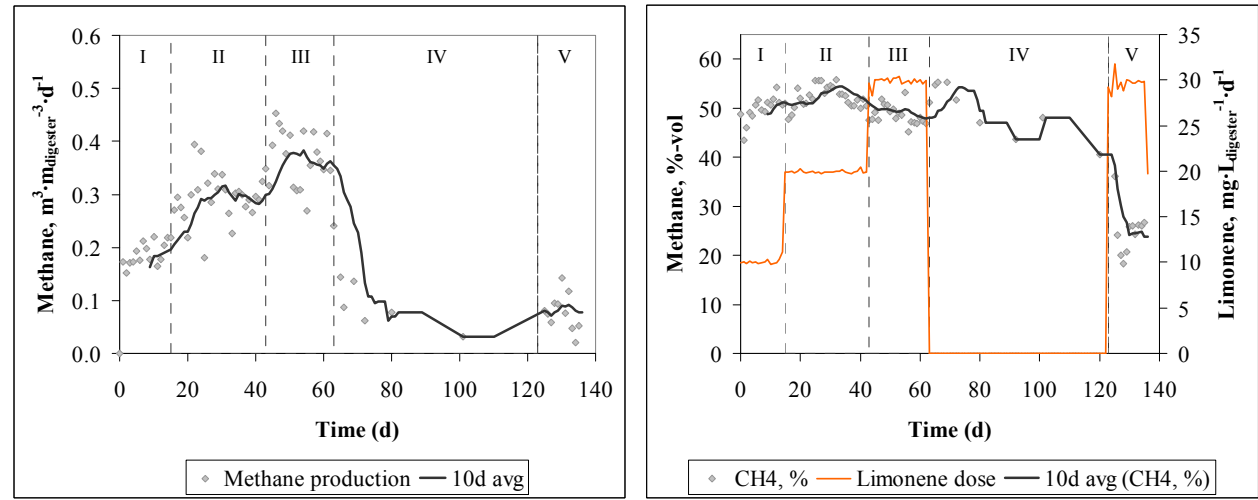

Figure 5.3. Methane production and concentration in the biogas from M1.
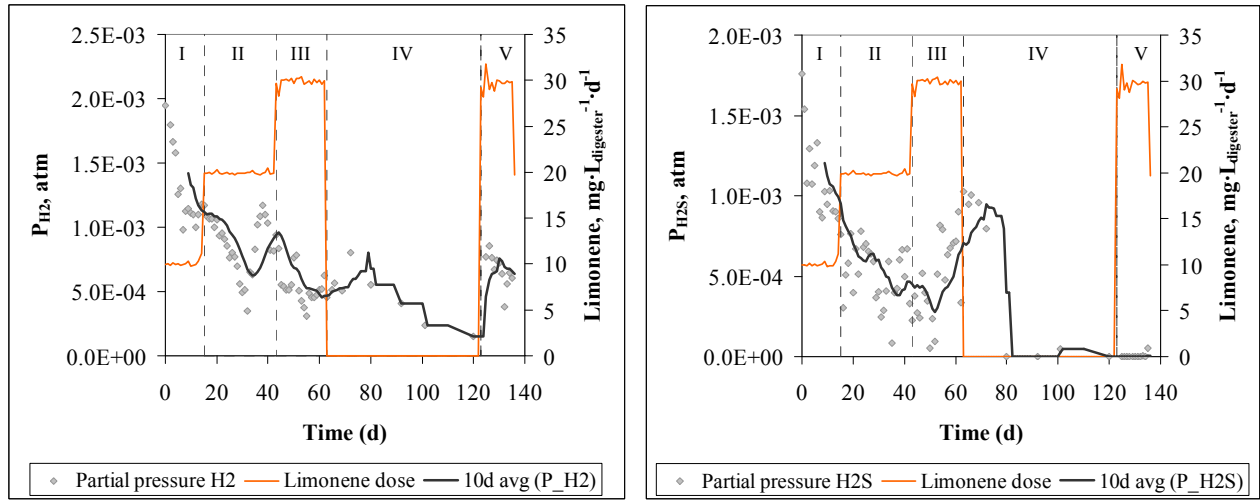

Figure 5.4. Hydrogen and hydrogen sulphide in the biogas from M1.

The partial pressure of hydrogen and hydrogen sulphide in the biogas is presented in Figure 5.4. Coinciding with methanogenesis inhibition, a decrease in the $\mathrm{H}_{2} \mathrm{~S}$ concentration in the biogas is observed. Since the feed composition is the same, this decrease is explained by an 
inhibition of the sulphate reducing bacteria. The average hydrogen partial pressure in the biogas in period $\mathrm{V}$ is $20 \%$ higher than in period III. This difference is statistically significative (t-test, $\alpha=0.05$ ), and indicates an inhibition of the hydrogenotrophic methanogenesis.

Volatile fatty acids (VFA) concentrations in the digester are presented in Figure 5.5.

Acetic acid remained in values under $500 \mathrm{mg} \cdot \mathrm{L}^{-1}$ in all the experimental periods except for the last one, when it increased suddenly to a value of $8416 \mathrm{mg} \cdot \mathrm{L}^{-1}$. This accumulation of acetic acid in period $\mathrm{V}$ is a sign of inhibition of the acetoclastic methanogenesis.

The concentration of propionic acid began to increase in period III (OLR $1.5 \mathrm{~kg}_{\mathrm{Vs}} \cdot \mathrm{m}^{-3} \cdot \mathrm{d}^{-1}$ ) until values around $2100-2400 \mathrm{mg} \cdot \mathrm{L}^{-1}$, and remained in these values even after stopping the feed for 60 days. The accumulation of propionic acid in concentrations higher than acetic acid was already observed by Kaparaju and Rintala (2006) in anaerobic digestion of citrus waste and by Forgács et al. (2011) in the co-digestion of citrus waste with OFMSW. The simultaneous accumulation of propionic acid and increase of hydrogen partial pressure in the biogas is a sign of inhibition of the hydrogenotrophic methanogenesis. The absence of simultaneous acetic acid accumulation in periods III and IV could mean either an inhibition of the acetogenic bacteria, or a good performance of the acetoclastic methanogenesis. The first hypothesis is more likely according to the rest of observations.

An increase in the n- forms of butyric and valeric acid was observed in the period III. Their concentration dropped immediately after stopping the feed in period IV until undetectable values. This fact suggests that this increase of period III might be due to either the OLR increase or the presence of the inhibitor and not by the influence of the propionic acid increase, since the propionic acid concentration remained at high values even after stopping the feed. After the day 85 of experiment, n-butyric and n-valeric acid concentration increased slightly. This increase coincided with a decrease in iso-butyric and iso-valeric acid, and the detection of iso-caproic acid. These phenomena seem to be correlated since they happen at the same time, but the reasons for this evolution are not clear and are probably a combination of the natural interactions and equilibria between VFAs and the inihibitory effects of limonene. N-butyric concentration increases sharply in period V indicating an inhibition of acetogenesis. Iso- forms of butyric and valeric acid were considerably more abundant than the n-forms, which is typical of perturbed anaerobic digestion systems (Pind et al., 2002).

The accumulation of butyric and valeric acid could be due not only to the inhibition of the corresponding bacteria by the limonene, but also to the product inhibition caused by propionic acid accumulation, according to the findings of Pind et al. (2002). However, according to these authors, propionic acid should have had an effect on iso-valeric acid as well, which is not observed in this work. In addition, accumulation of iso-valeric acid starts earlier than propionic acid, suggesting that its accumulation is due to an inhibition of the acetogenesis and not to the interactions between propionic acid and the rest of VFAs. Nevertheless, the effect of product inhibition by propionic acid may still be present at some extent in periods III and IV and/or on the other VFAs. 
Iso-caproic acid became detectable since day 90. This fact coincided in time with a decrease in iso-butyric and iso-valeric concentrations. Reverse $\beta$-oxidation has been proposed as responsible for the synthesis of VFA with 4-5 carbon atoms from ethanol (Bories et al., 2005), but not enough evideces have been found in this work to confirm the exact pathway.
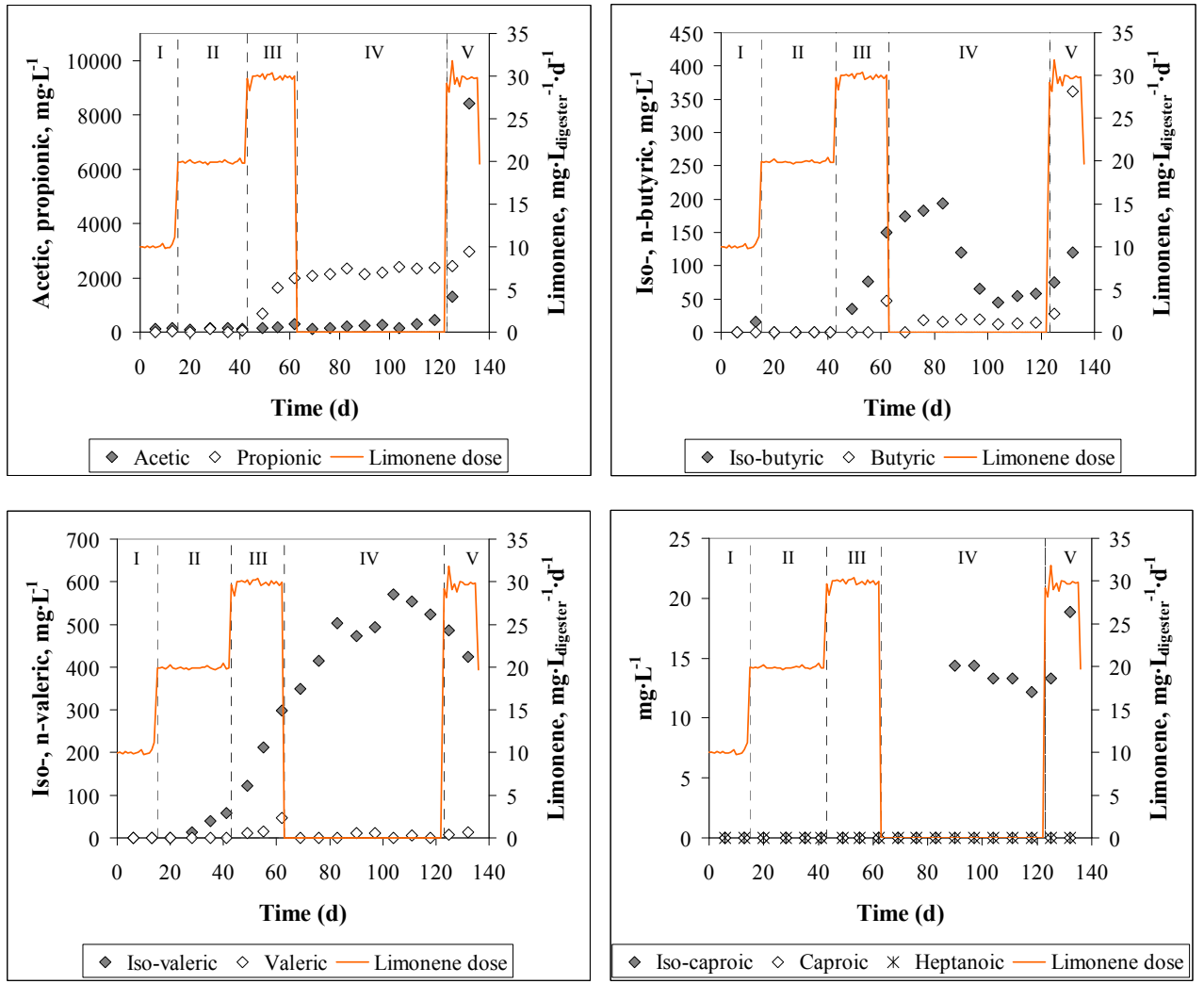

Figure 5.5. Volatile fatty acids concentration in the digestate from M1.

The $\mathrm{pH}$ and alkalinity ratio are affected by the VFA evolution (Figure 5.6). However, due to the high alkalinity provided by the manure, these parameters show instability late in relation to the increase in VFA concentrations, and therefore they are not valid for process control purposes at industrial scale. The $\mathrm{pH}$ value shows a decrease only in period $\mathrm{V}$ coinciding with an increase in the alkalinity ratio.

Ammonia nitrogen (Figure 5.7) is in all cases above the concentration of $4 \mathrm{~g} \cdot \mathrm{L}^{-1}$ considered the concentration when inhibition starts (Angelidaki y Ahring, 1993). However, concentrations up to $10 \mathrm{~g} \cdot \mathrm{L}^{-1}$ have been reported without inhibition (Chen et al., 2008). The concentration of ammonia nitrogen is high due to the presence in the mixture of chicken and pig manure that have higher nitrogen concentration than other manures such as cow manure. In this case, a $22 \%$ decrease in ammonia concentration (statistically significant 
with a level of confidence of $99.9 \%$ ) is observed in the last period possibly indicating an inhibition of the protein degradation pathway.
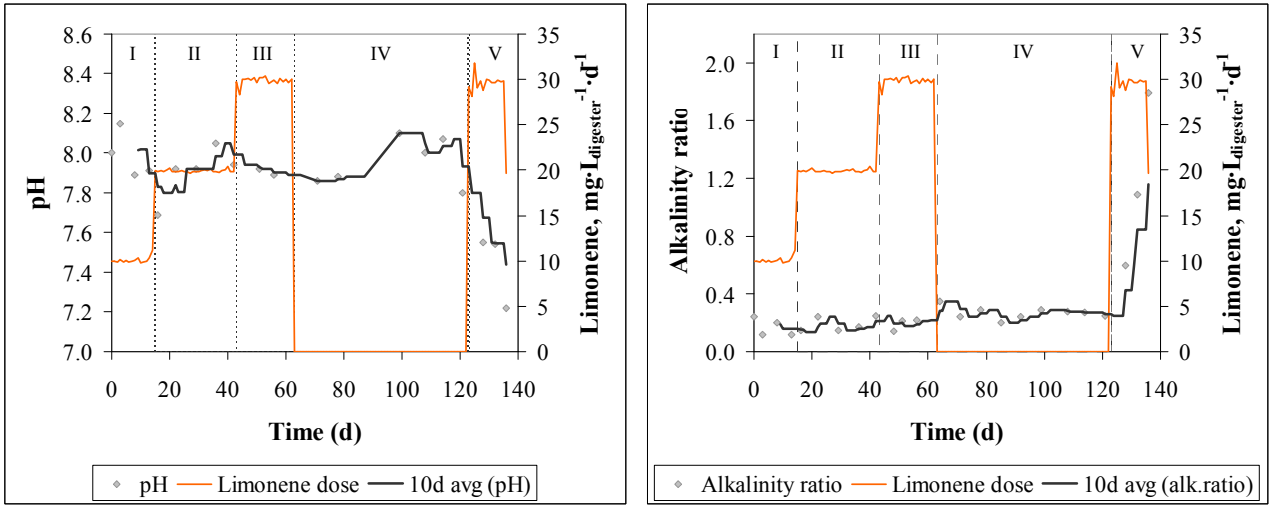

Figure 5.6. $\mathrm{pH}$ (left) and alkalinity ratio (right) in the digestate from M1.

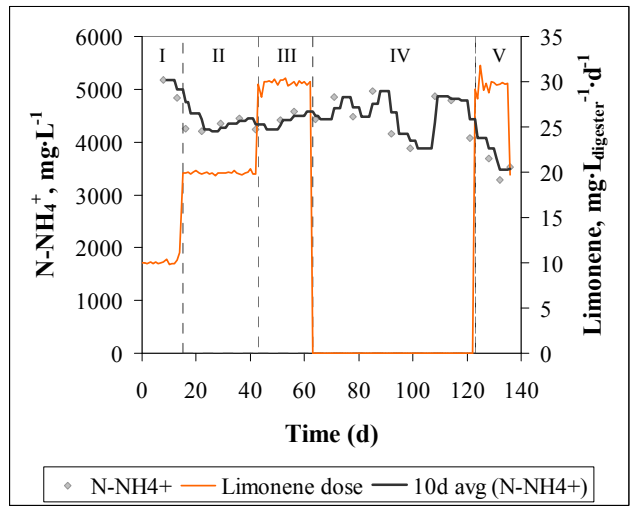

Figure 5.7. Ammonia nitrogen concentration in the digestate from M1.

Castillejos et al. (2006) observed that limonene at $500 \mathrm{mg} \cdot \mathrm{L}^{-1}$ in rumen reduced ammonia and branched-chain (iso) VFA concentrations, suggesting inhibition of the deamination of amino acids. In our work, a decrease was observed in ammonia but not in brached-chain VFA concentrations. However, this accumulation of VFA (not reduction) could be due to the inhibition of methanogenesis.

The most probable causes for the observations done in the semi-continuous anaerobic digestion of M1 are compiled in Table 5.4. Results for M1 suggest that limonene causes systemic inhibition, since an effect has been observed in the protein degradation pathway evidenced by ammonia nitrogen decrease, acetogenic bacteria (accumulation of propionic, butyric and valeric acid), acetoclastic methanogens (acetic acid accumulation in the last period) and hydrogenotrophic methanogens (further accumulation of propionic acid and hydrogen in the last period). 


\section{Table 5.4. Main observations in semi-continuous anaerobic digestion of M1.}

\begin{tabular}{|c|c|c|c|c|}
\hline Period & $\begin{array}{c}\text { OLR } \\
\left(\mathrm{kg}_{V S} \cdot \mathrm{m}^{-3} \cdot d^{-1}\right)\end{array}$ & $\begin{array}{c}\text { Limonene } \\
\text { dose } \\
\left(g \cdot m^{-3} \cdot d^{-1}\right)\end{array}$ & Observations & $\begin{array}{l}\text { Possible causes attributed to } \\
\text { limonene inhibition }\end{array}$ \\
\hline I & 0.51 & 10.1 & Stable operation & - \\
\hline II & 1.01 & 19.9 & Increase of iso-valeric acid. & Acetogenesis inhibition. \\
\hline III & 1.51 & 29.9 & $\begin{array}{l}\text { Increase of propionic acid. } \\
\text { Neither hydrogen, nor acetic acid } \\
\text { accumulates. }\end{array}$ & Acetogenesis inhibition. \\
\hline \multirow{3}{*}{ V } & \multirow{3}{*}{1.47} & \multirow{3}{*}{28.9} & $\begin{array}{l}\text { Methane concentration and } \\
\text { volumetric production decrease. } \\
\text { Increase of acetic acid, propionic } \\
\text { acid and hydrogen. }\end{array}$ & $\begin{array}{l}\text { Methanogenesis inhibition, both } \\
\text { acetoclastic and } \\
\text { hydrogenotrophic. }\end{array}$ \\
\hline & & & Hydrogen sulphide near zero. & $\begin{array}{l}\text { Inhibition of sulphate reducing } \\
\text { bacteria or inhibited } \\
\text { decomposition of S-containing } \\
\text { amino acids. }\end{array}$ \\
\hline & & & $\begin{array}{l}\text { Decrease in } \mathrm{N}-\mathrm{NH}_{4}{ }^{+} \\
\text {concentration. }\end{array}$ & $\begin{array}{l}\text { Inhibition of protein degradation } \\
\text { pathway. }\end{array}$ \\
\hline
\end{tabular}

The maximum OLR that was possible to achieve in a stable manner was $1.01 \mathrm{~kg}_{\mathrm{Vs}} \cdot \mathrm{m}^{-3} \cdot \mathrm{d}^{-1}$.

The highest limonene dose reached was $28.9 \mathrm{mg} \cdot \mathrm{L}_{\text {digester }}{ }^{-1} \cdot \mathrm{d}^{-1}$. This value is $60 \%$ lower than the reported by Lane (1984) and similar to the value observed by Mizuki et al. (1990), but $25 \%$ higher than the one reported by Srilatha et al. (1995).

The limonene concentration remaining in the digester was between 20 and $35 \mathrm{mg} \cdot \mathrm{L}^{-1}$. This value is much lower than the half maximum inhibitory concentration of $423 \mathrm{mg} \cdot \mathrm{kg}^{-1}$ observed by Ruiz and Flotats (2015). Below $200 \mathrm{mg} \cdot \mathrm{kg}^{-1}$ of limonene in the digester, complete degradation of limonene was observed in batch anaerobic digestions. This fact is also observed in the anaerobic digestion of M1, where the average limonene degradation was $99 \%$.

After the analysis of the GC peaks area obtained in the analysis of limonene, the bioproduction of other compounds was observed. The GC peak area of each of these compounds is presented in Figure 5.8. In period III, the predominant component was cymene, and limonene was not detected or its concentration was very low. At the end of this period, when the instability signs were more evident, a rise in the limonene concentration was observed, coinciding with a decrease of the cymene. This supports the hypothesis of the bioproduction of cymene from limonene by the anaerobic populations. According to Hylemon and Harder (1999), the degradation of monoterpenes to p-cymene can be achieved by methanogenic cultures. P-cymene favours the antimicrobial effect of other terpenes (Burt, 2004) and would therefore enhance their inhibitory effect on the anaerobic digestion process. 
In period IV the feeding was stopped, and a general decrease in the concentrations of all compounds was observed. This could be due either to the degradation of the limonene and its bioproducts by the anaerobic biomass, or to the accumulation of these compounds in the membrane of the microorganisms. Indeed, the chemical structure of the bioproducts is similar to the one of limonene and therefore their accumulation inside or onto the membrane (the second and third steps of the antimicrobial mechanism, see chapter 2) could occur as well with them.<smiles>C=C(C)C1CC=C(C)CC1</smiles>

Limonene<smiles>Cc1ccc(C(C)C)cc1</smiles>

Cymene<smiles>Cc1ccc(O)cc1</smiles>

p-cresol<smiles>CC1=CCC(C(C)(C)O)CC1</smiles>

$\alpha$-terpineol<smiles>C=C(C)C1C=CC=CC1</smiles>

Perillaldehyde

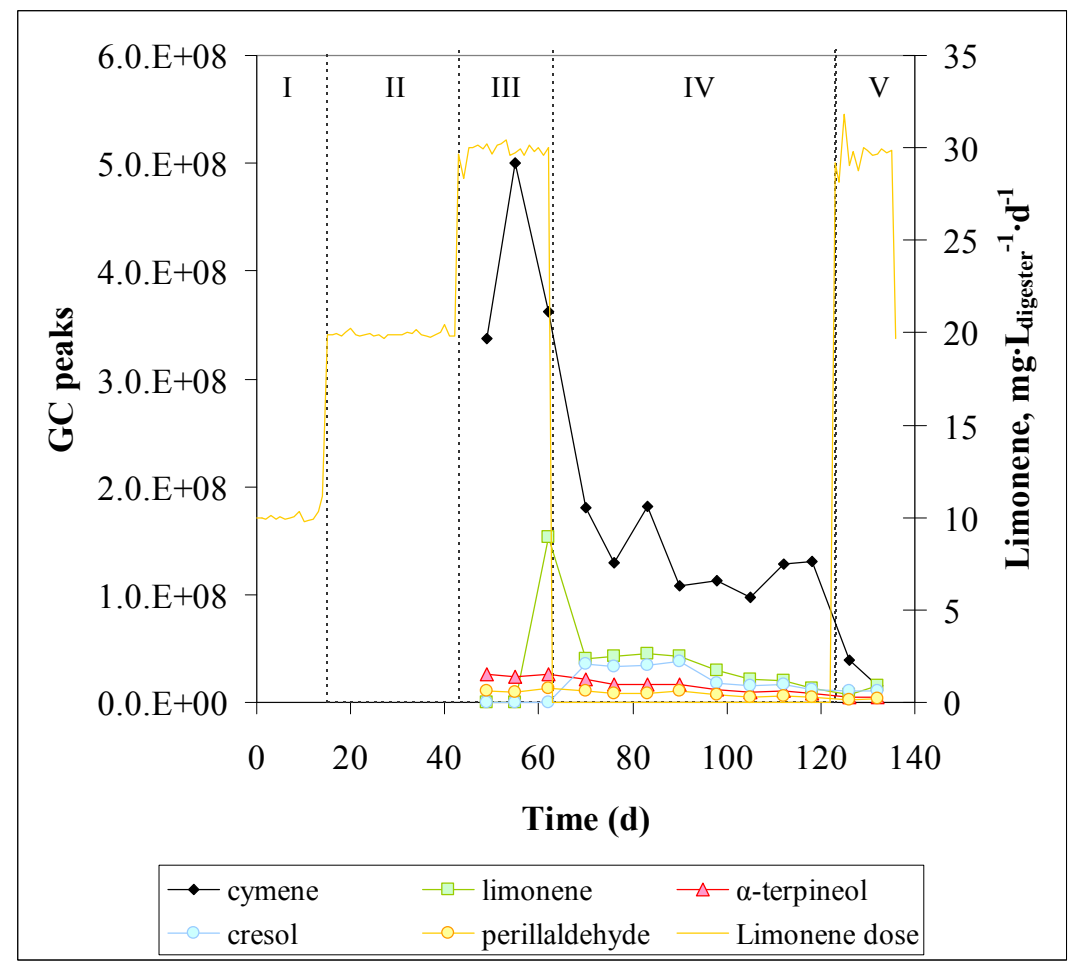

Figure 5.8. Evolution of the GC peaks during the semi-continuous anaerobic digestion of $M 1$.

When the feeding was resumed in period V with the same OLR used in period III, the methane production was much lower and the concentration of VFA rapidly increased. This could be related to the antimicrobial mechanism of CEO (cell lysis) described in the 
literature (Ruiz and Flotats, 2014). This could be pointing to the accumulation of terpenes in the membrane structure, rather than to their degradation.

However, the high HRT used in this experiment could have led to a low biomass activity, not ensuring a steady state regime with the low time used for each period (see Table 5.5). This hypothesis is supported by the fact that the total mesophilic anaerobes count at the end of the experiment was $9.1 \cdot 10^{5} \mathrm{UFC} \cdot \mathrm{g}^{-1}$ which is lower than the usual range of $10^{8}-10^{9}$ $\mathrm{UFC} \cdot \mathrm{mL}^{-1}$ (Deublein and Steinhauser, 2008). Therefore, it is not clear wether the phenomena observed in the last period are due to the cell lysis after accumulation of terpenes in the membrane, or to the low biomass activity despite a degradation of the terpenes in the period with no feeding.

Average values and standard deviations for each of the measured parameters are presented in Table 5.5. 
Table 5.5. Results of semi-continuous anaerobic co-digestion test M1: average values and standard deviation in each period.

\begin{tabular}{|c|c|c|c|c|c|}
\hline Period & I & II & III & IV & $\mathbf{V}$ \\
\hline \multicolumn{6}{|c|}{ OPERATIONAL PARAMETERS } \\
\hline OLR, $\mathrm{kg}_{\mathrm{vs}} \cdot \mathrm{m}^{-3} \cdot \mathrm{d}^{-1}$ & $0.51 \pm 0.01$ & $1.01 \pm 0.01$ & $1.51 \pm 0.02$ & $0.00 \pm 0.00$ & $1.47 \pm 0.09$ \\
\hline HRT, d & $309.5 \pm 6.5$ & $157.9 \pm 1.3$ & $105.3 \pm 1.7$ & - & $106.7 \pm 6.5$ \\
\hline Citrus waste, $\%$ VS & $78.4 \pm 1.1$ & $78.7 \pm 0.4$ & $78.7 \pm 0.4$ & - & $78.2 \pm 1.9$ \\
\hline Limonene dosis, $\mathrm{g} \cdot \mathrm{m}^{-3} \cdot \mathrm{d}^{-1}$ & $10.1 \pm 0.3$ & $19.9 \pm 0.1$ & $29.9 \pm 0.4$ & - & $28.9 \pm 2.8$ \\
\hline Duration, $\mathrm{d}$ & 15 & 28 & 20 & 60 & 14 \\
\hline \multicolumn{6}{|c|}{ BIOGAS PRODUCTION** } \\
\hline Biogas, $\mathrm{L}_{\mathrm{N}} \cdot \mathrm{kg}_{\mathrm{VS}}{ }^{-1}$ & $731.4 \pm 74.1$ & $554.7 \pm 92.3$ & $506.8 \pm 72.6$ & - & $217.0 \pm 104.5$ \\
\hline Methane, $\mathrm{L}_{\mathrm{N}} \cdot \mathrm{kg}_{\mathrm{Vs}}{ }^{-1}$ & $364.3 \pm 37.7$ & $289.2 \pm 46.3$ & $245.5 \pm 33.8$ & - & $51.9 \pm 22.6$ \\
\hline Biogas, $\mathrm{m}^{3} \cdot \mathrm{m}^{-3} \cdot \mathrm{d}^{-1}$ & $0.37 \pm 0.04$ & $0.56 \pm 0.09$ & $0.76 \pm 0.11$ & $0.05 \pm 0.13$ & $0.33 \pm 0.15$ \\
\hline Methane, $\mathrm{m}^{3} \cdot \mathrm{m}^{-3} \cdot \mathrm{d}^{-1}$ & $0.19 \pm 0.02$ & $0.29 \pm 0.05$ & $0.37 \pm 0.05$ & $0.08 \pm 0.09$ & $0.08 \pm 0.03$ \\
\hline \multicolumn{6}{|l|}{ BIOGAS COMPOSITION } \\
\hline $\mathrm{CH}_{4}, \%$ vol & $49.8 \pm 2.6$ & $52.3 \pm 2.1$ & $48.5 \pm 1.9$ & $49.7 \pm 5.3$ & $24.9 \pm 4.7$ \\
\hline $\mathrm{H}_{2}, \operatorname{atm}\left(\times 10^{5}\right)$ & $131 \pm 31$ & $86 \pm 22$ & $56 \pm 16$ & $47 \pm 19$ & $67 \pm 13$ \\
\hline $\mathrm{H}_{2} \mathrm{~S}, \operatorname{atm}\left(\times 10^{5}\right)$ & $111 \pm 27$ & $52 \pm 18$ & $47 \pm 25$ & $53 \pm 50$ & $1 \pm 2$ \\
\hline \multicolumn{6}{|c|}{ DIGESTATE CHARACTERISTICS } \\
\hline Acetic acid, $\mathrm{mg} \cdot \mathrm{L}^{-1}$ & $132 \pm 6$ & $128 \pm 19$ & $205 \pm 80$ & $229 \pm 102$ & $4857 \pm 5033$ \\
\hline Propionic acid, $\mathrm{mg} \cdot \mathrm{L}^{-1}$ & $10 \pm 14$ & $44 \pm 53$ & $1435 \pm 665$ & $2255 \pm 128$ & $2705 \pm 374$ \\
\hline Iso-butyric acid, $\mathrm{mg} \cdot \mathrm{L}^{-1}$ & $8 \pm 11$ & $0 \pm 0$ & $87 \pm 58$ & $111 \pm 64$ & $98 \pm 31$ \\
\hline Butyric acid, $\mathrm{mg} \cdot \mathrm{L}^{-1}$ & $0 \pm 0$ & $0 \pm 0$ & $16 \pm 27$ & $14 \pm 6$ & $195 \pm 236$ \\
\hline Iso-valeric acid, $\mathrm{mg} \cdot \mathrm{L}^{-1}$ & $0 \pm 0$ & $27 \pm 26$ & $210 \pm 88$ & $485 \pm 73$ & $455 \pm 43$ \\
\hline Valeric acid, $\mathrm{mg} \cdot \mathrm{L}^{-1}$ & $0 \pm 0$ & $0 \pm 0$ & $24 \pm 19$ & $4 \pm 5$ & $10 \pm 4$ \\
\hline Iso-caproic acid, $\mathrm{mg} \cdot \mathrm{L}^{-1}$ & $0 \pm 0$ & $0 \pm 0$ & $0 \pm 0$ & $8 \pm 7$ & $16 \pm 4$ \\
\hline Caproic acid, $\mathrm{mg} \cdot \mathrm{L}^{-1}$ & $0 \pm 0$ & $0 \pm 0$ & $0 \pm 0$ & $0 \pm 0$ & $0 \pm 0$ \\
\hline Heptanoic acid, $\mathrm{mg} \cdot \mathrm{L}^{-1}$ & $0 \pm 0$ & $0 \pm 0$ & $0 \pm 0$ & $0 \pm 0$ & $0 \pm 0$ \\
\hline $\mathrm{pH}$ & $8.0 \pm 0.1$ & $7.9 \pm 0.1$ & $7.9 \pm 0.0$ & $8.0 \pm 0.1$ & $7.4 \pm 0.2$ \\
\hline Alkalinity ratio & $0.17 \pm 0.06$ & $0.19 \pm 0.05$ & $0.19 \pm 0.04$ & $0.27 \pm 0.04$ & $1.16 \pm 0.60$ \\
\hline $\mathrm{N}-\mathrm{NH}_{4}{ }^{+}, \mathrm{mg} \cdot \mathrm{L}^{-1}$ & $5005 \pm 247$ & $4298 \pm 102$ & $4490 \pm 113$ & $4499 \pm 393$ & $3493 \pm 201$ \\
\hline VS removal $*, \%$ & $79.6 \pm 0.5$ & $81.3 \pm 1.4$ & $79.2 \pm 0.3$ & - & $74.0 \pm 9.8$ \\
\hline Limonene, $\mathrm{mg} \cdot \mathrm{L}^{-1}$ & n.a. & n.a. & $34.8 \pm 48.3$ & $19.5 \pm 5.8$ & $28.5 \pm 20.0$ \\
\hline Limonene removal, \% & n.a. & n.a. & $98.9 \pm 1.5$ & - & $99.1 \pm 0.6$ \\
\hline
\end{tabular}

*Values corrected with the VFA concentration (VFA are lost during the VS analysis). **Minimum flow rate of the gas measurement device is $0.5 \mathrm{~L} / \mathrm{h}$. The average flow rate of periods I, IV and V was below this value, what could have caused an error in the measurement. 


\subsubsection{Feeding mixture M2}

Mixture M2 had lower citrus waste proportion than M1 (see Table 5.1). The limonene concentration in the mixture $\mathrm{M} 2$ is lower than in $\mathrm{M} 1$, and therefore a better performance of the anaerobic digestion is expected. As a result of the lower limonene concentration, the limonene increase is done more slowly than in M1, thus giving more time to the microbiology for a possible adaptation to the inhibitor. The citrus fraction is still $50 \%$ orange and $50 \%$ mandarin $(\mathrm{w} / \mathrm{w})$, same as $\mathrm{M} 1$, and therefore the same minority compound concentration is expected in the CEO.

The specific biogas and methane production, the methane content of the biogas (\%-vol) and the average daily dosage of limonene in each period are shown in Figure 5.9. Biogas and methane production decreases as the OLR (and consequently, the limonene dose) increases, until period III (OLR $\left.1.5 \mathrm{~kg}_{\mathrm{vs}} \cdot \mathrm{m}^{-3} \cdot \mathrm{d}^{-1}\right)$. From period IV onwards, the differences between the biogas production in the different periods are not statistically significative (multiple range test, 95\%LSD). Specific methane production shows the same trend. In period VI (OLR $3 \mathrm{~kg}_{\mathrm{Vs}} \cdot \mathrm{m}^{-3} \cdot \mathrm{d}^{-1}$ ) instability was detected (increase of VFA). To avoid acidification, the OLR was decreased to $2.5 \mathrm{~kg} \mathrm{vs}_{\mathrm{vs}} \cdot \mathrm{m}^{-3} \cdot \mathrm{d}^{-1}$ (period VII). However, the process could not be recovered with this strategy and the feeding had to be stopped (period VIII). Since no recovery occurred, the test was discontinued. This last period was intended to be completely without feeding, but the digester was fed one day accidentally.

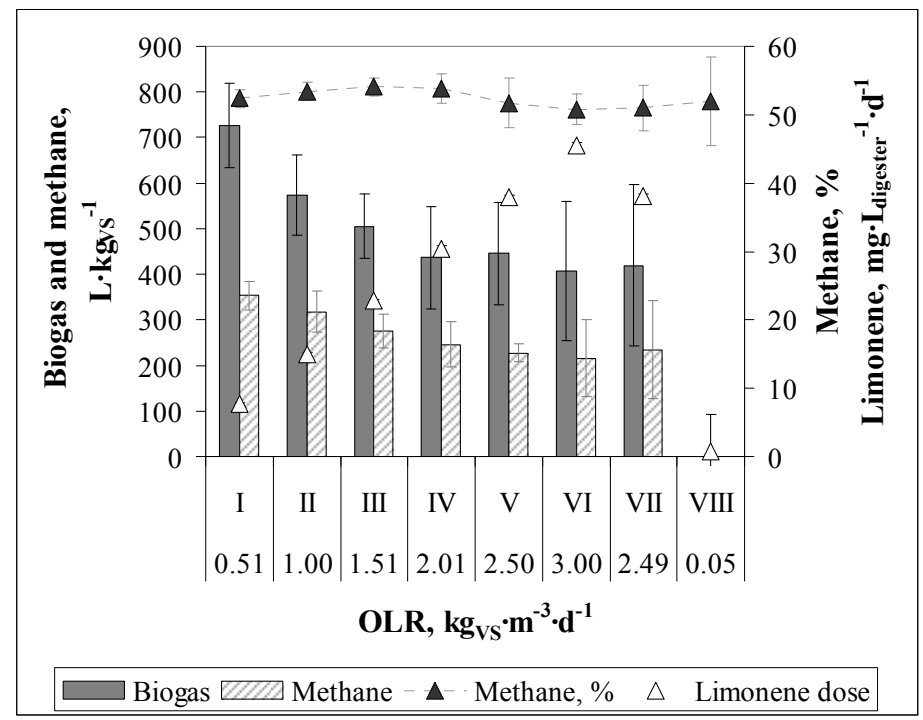

Figure 5.9. Specific biogas and methane production, and methane content in the biogas (\%-vol) of the mixture M2 for the eitght periods studied. Averages and standard deviations of the different periods are represented.

Figure 5.10 (left) presents the volumetric methane production $\left(\mathrm{m}^{3}\right.$ of methane per $\mathrm{m}^{3}$ of digester and day). The methane production is lower than expected (calculated from the 
estimated COD in the feed). The reductions in periods I, II, III, IV, V, VI and VII are of $28 \%, 35 \%, 44 \%, 50 \%, 54 \%, 56 \%$ and $52 \%$ respectively, statistically significant (t-test, $\alpha=0.05$ ).

The methane content in the biogas and the limonene dose are presented in Figure 5.10 (right). The methane concentration in the biogas shows similar values to the observed in experiment M1. Although no statistically significant difference is found in the averages of the different periods (ANOVA F-test, 95\% confidence), higher dispersion is observed in the last periods, which is a sign of instability.
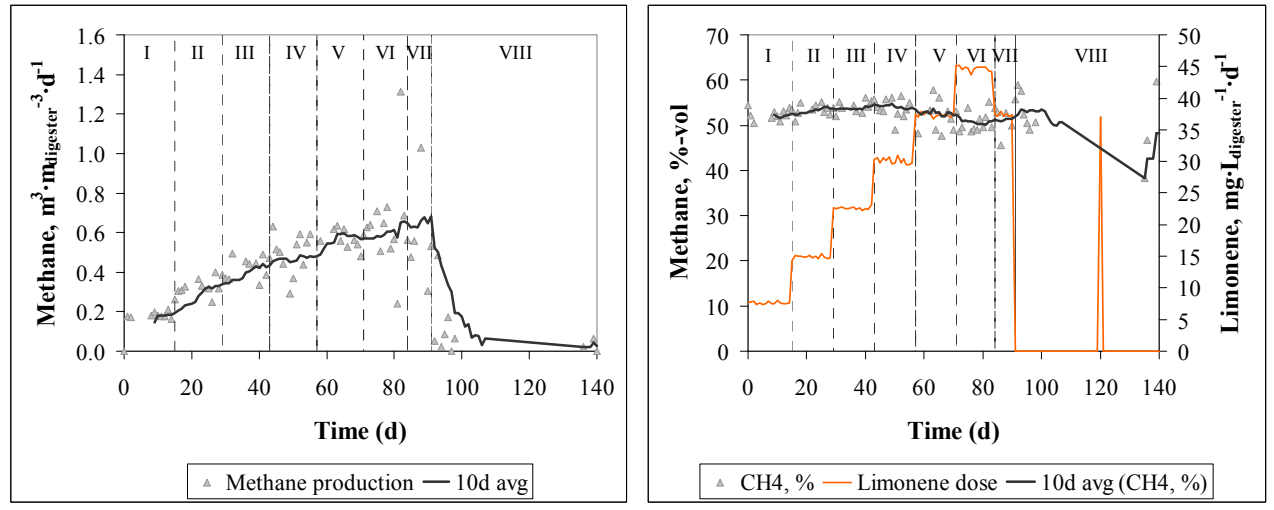

Figure 5.10.

Methane production and concentration in the biogas from M2.
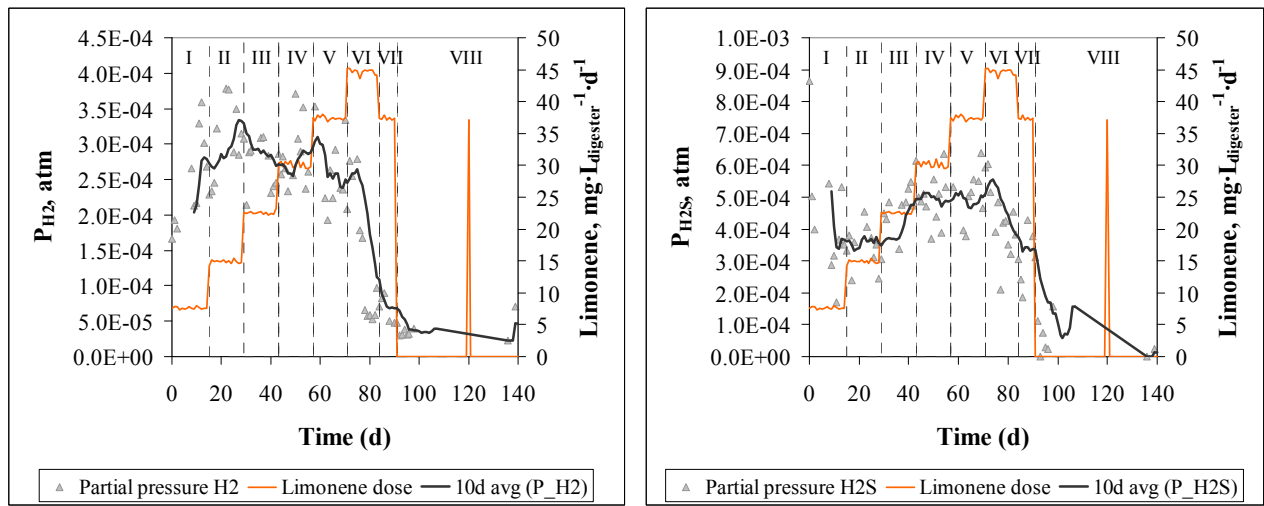

Figure 5.11.

Hydrogen and hydrogen sulphide in the biogas from M2.

Concentrations of hydrogen and hydrogen sulphide in the biogas are presented in Figure 5.11. Hydrogen concentration is lower than in experiment M1. In addition, the hydrogen concentration shows a decreasing trend and no accumulation is observed even in the periods with higher OLR, possibly indicating an inhibition of the hydrogen production through acetogenesis from propionic acid, rather than a good performance of the hydrogenotrophic methanogenesis. The values of the concentration of hydrogen sulphide in 
the biogas are most of the time in the range $2 \cdot 10^{-4}-6 \cdot 10^{-4} \mathrm{~atm}$. This is one order of magnitude less than M1. A reduction in the average $\mathrm{H}_{2} \mathrm{~S}$ concentration was observed from period VI onwards. Compared with period V, the average $\mathrm{H}_{2} \mathrm{~S}$ concentration in period VI and VII were $16 \%$ and $63 \%$ lower (statistically significant, t-test, $=0.05$ ). This is indicating an inhibition of the sulphate reducing bacteria.

VFA concentrations in the digester are presented in Figure 5.12.
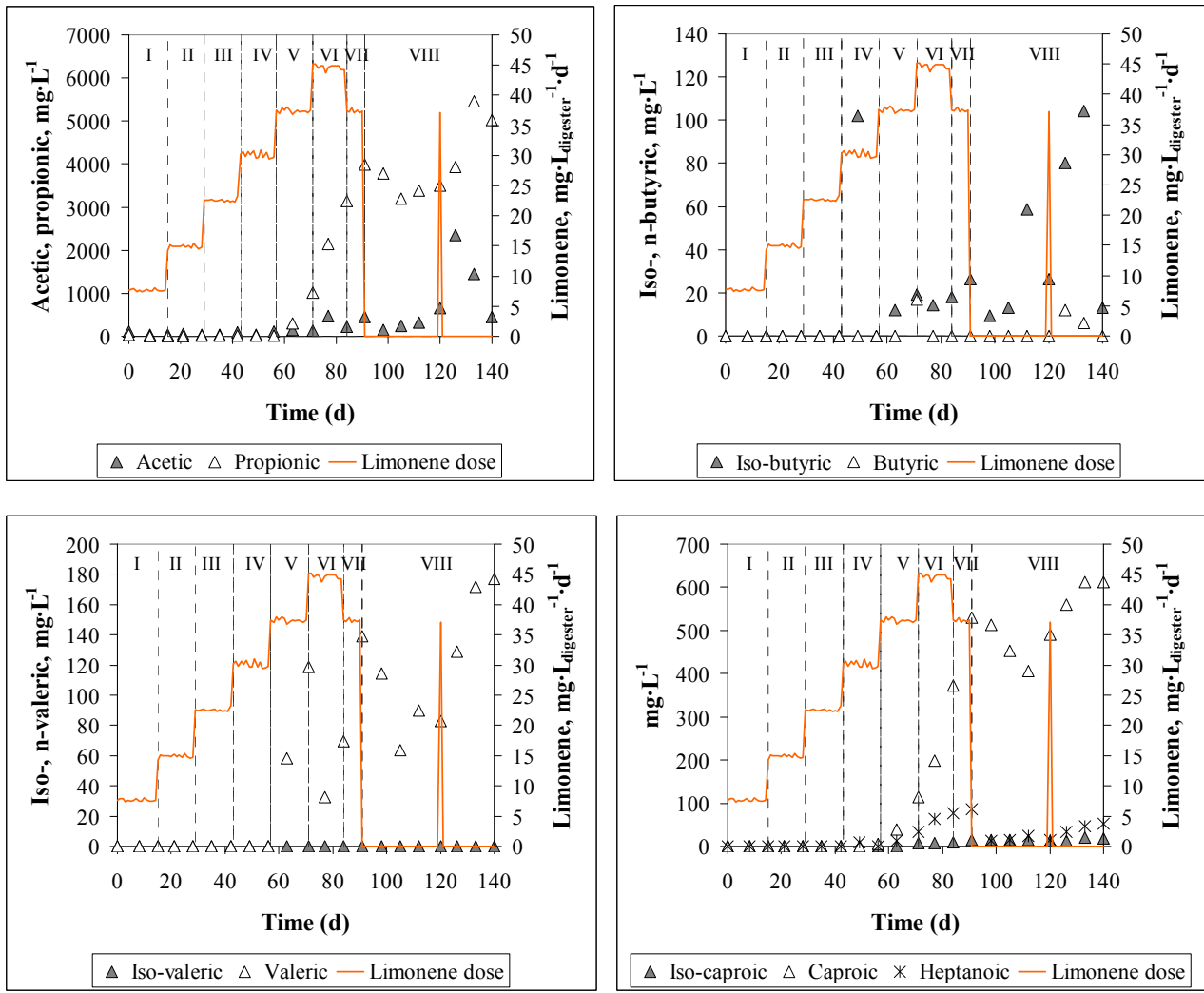

Figure 5.12.

Volatile fatty acids concentration in the digestate from M2.

Acetic acid remained in values under $100 \mathrm{mg} \cdot \mathrm{L}^{-1}$ until period $\mathrm{V}\left(\mathrm{OLR} 2.5 \mathrm{~kg} \mathrm{vs} \cdot \mathrm{m}^{-3} \cdot \mathrm{d}^{-1}\right)$. In period VI, acetic acid increased to $477 \mathrm{mg} \cdot \mathrm{L}^{-1}$ but was stabilized again after one week. During period VII (no feeding), acetic acid increased slowly from day 98 onwards. After the accidental feeding of the digester, acetic acid increased suddenly to $2360 \mathrm{mg} \cdot \mathrm{L}^{-1}$ but it decreased to 454 after two weeks.

The concentration of propionic acid began to steeply increase in period V (OLR 2.5 $\mathrm{kg}_{\mathrm{VS}} \cdot \mathrm{m}^{-3} \cdot \mathrm{d}^{-1}$ ) and kept increasing until the stop of the feed in period VII after reaching a maximum of $3980 \mathrm{mg} \cdot \mathrm{L}^{-1}$. It remained in similar values even after stopping the feed for 50 days, and increased again after the accidental feed of period VII. The maximum values reached are similar to experiment M1. Propionic acid accumulation, together with an 
absence of accumulation of hydrogen, would suggest an inhibition of the acetogenesis. The lack of accumulation of acetic acid during the periods where propionic acid concentration is high would support the hypothesis of the inhibition of acetogenesis, since a good performance of the acetoclastic methanogenesis is not likely.

Butyric acid was detected mostly in its iso- form. The concentration of iso-butyric acid started increasing from period $\mathrm{V}$ on, similarly to the propionic acid, but with a lower slope. The maximum values reached were lower than in experiment M1. The trend after stopping the feed (increase - decrease - increase) is similar than the observed in experiment M1. Nbutyric acid was above the detection limit only in three points (period V and VII). Similarly to acetic and propionic acid, there is an increase in the concentration of butyric acid after the accidental feed in period VIII.

$\mathrm{N}$ - forms of valeric and caproic acid are more abundant than iso- forms, that remain undetected except for iso-caproic acid in period without feeding. This represents a difference with respect to the observations done in M1, without a clear explanation of these different results. Again the trend increase - decrease - increase is observed for these VFAs. Heptanoic acid is detected from period V onwards.

The differences in the evolution observed for VFAs of longer chains $\left(\mathrm{C}_{4}-\mathrm{C}_{5}\right)$ between M1 and M2 could be attributed to the different composition of the mixtures. While the citrus waste/manure ratio in $\mathrm{M} 1$ is $80: 20$ (volatile solids), it is 60:40 in M2. The relative proportion pig manure - chicken manure is different as well. Therefore, the composition of the mixture (especially protein and amino acids, which influence greatly the production of VFAs $\mathrm{C}_{4}-\mathrm{C}_{5}$ ) is different.

The $\mathrm{pH}$ and alkalinity ratio are affected by the VFA evolution (Figure 5.13), but $\mathrm{pH}$ is not valid in this case as process control parameter, since its reaction is late in relation to the increase in VFA concentrations. On the contrary, alkalinity ratio starts increasing in period $\mathrm{V}$ coinciding with the first increase of propionic acid.
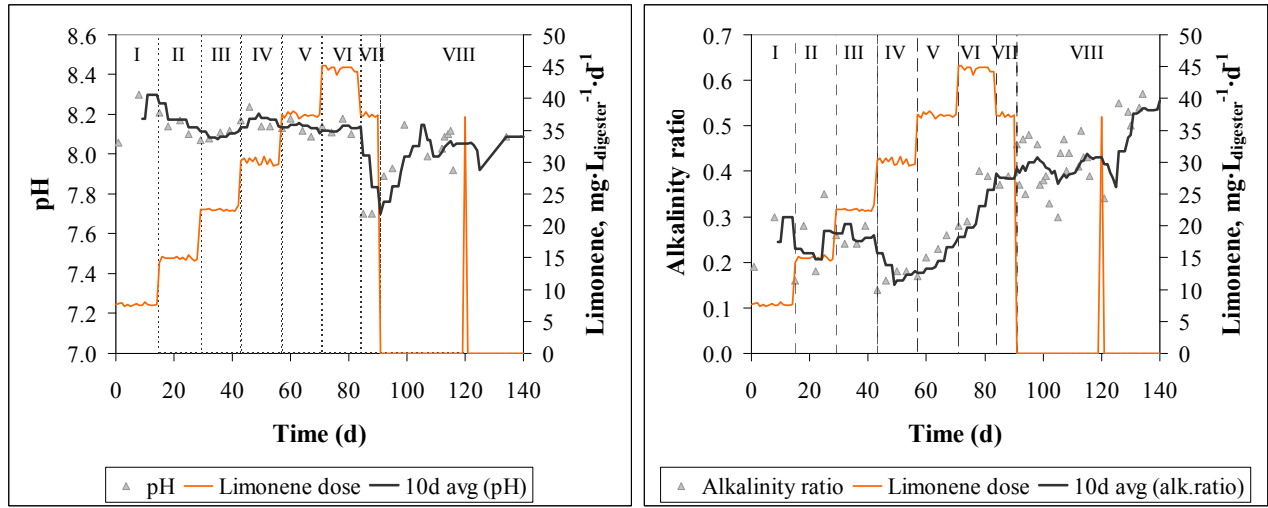

Figure 5.13. pH (left) and alkalinity ratio (right) in the digestate from $M 2$. 
Ammonia nitrogen (Figure 5.14) is around the concentration of $4 \mathrm{~g} \cdot \mathrm{L}^{-1}$ similarly to M1. No decrease in ammonia concentration is observed.

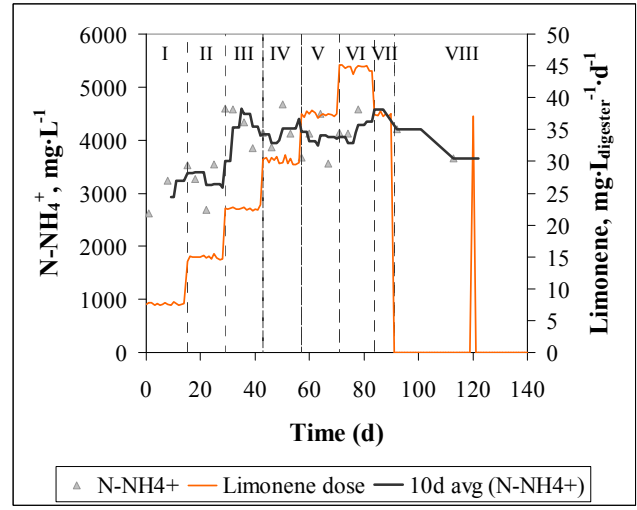

Figure 5.14.

Ammonia nitrogen concentration in the digestate from M2.

Limonene degradations observed are near $100 \%$ for all the periods. This happened even in the periods at limonene doses higher than the applied in M1.

Despite the high limonene degradation efficiencies, the inhibition persisted, since the degradation products of the limonene are inhibitory as well. This was already observed for the fungal limonene degradation products suggested by Ruiz and Flotats (2015) and also in the previous section 5.3.1. According to Hylemon and Harder (1999), the degradation of monoterpenes by methanogenic cultures yields p-cymene. Harder and Probian (1995) observed the formation of $\alpha$-terpinene and 2-carene from limonene in anaerobic media. P-cymene favours the antimicrobial effect of other terpenes, and $\alpha$-terpinene has antimicrobial effect on a number of species (Burt, 2004). In the experiment with the mixture M2, the presence of cymene was observed in the digestate (Figure 5.15). This is in agreement with the observations of Hylemon and Harder (1999) and would be the cause of the persistence of the inhibitory effect. Other inhibitory compounds formed were cresol and perillaldehyde. It is important to note that other GC peaks different to limonene were observed in the periods IV to VII, but it was not possible to identify the compounds formed. The concentration of both cymene and cresol decreased with the time in the period without feeding, similarly to mixture M1.

The maximum OLR that was possible to achieve in a stable manner was $2.01 \mathrm{~kg}_{\mathrm{VS}} \cdot \mathrm{m}^{-3} \cdot \mathrm{d}^{-1}$. The most probable causes for the observations done in experiment M2 are summarized in Table 5.6. Table 5.7 summarizes the results of experiment M2. 


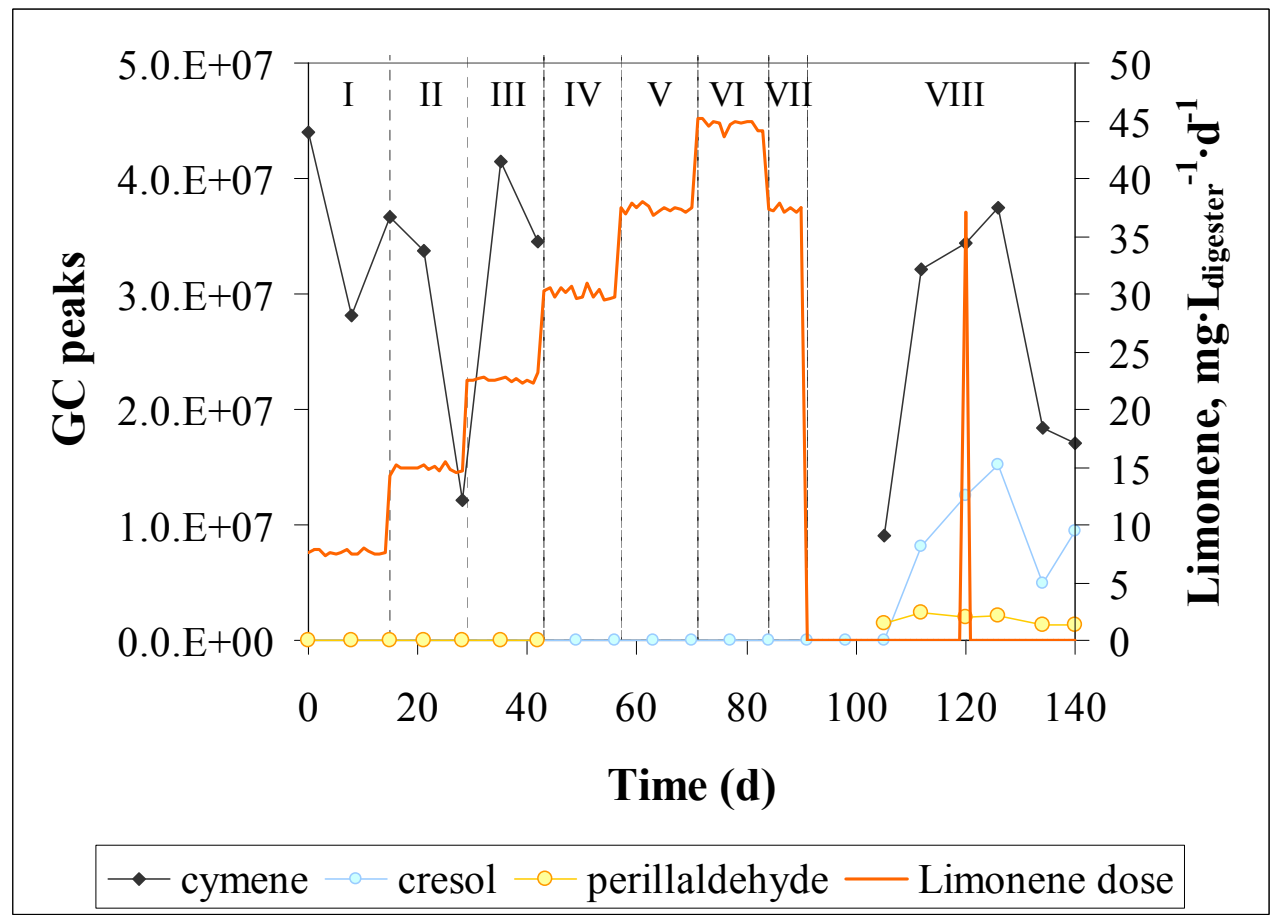

Figure 5.15. Evolution of the GC peaks during the semi-continuous anaerobic digestion of $M 2$.

Table 5.6. Main observations in semi-continuous anaerobic digestion of M2.

\begin{tabular}{|c|c|c|l|l|}
\hline Period & $\begin{array}{c}\text { OLR } \\
\left(\mathrm{kg}_{V S} \cdot \mathrm{m}^{-3} \cdot \mathrm{d}^{-1}\right)\end{array}$ & $\begin{array}{c}\text { Limonene } \\
\text { dose } \\
\left(g \cdot \mathrm{m}^{-3} \cdot \mathrm{d}^{-1}\right)\end{array}$ & Observations & $\begin{array}{l}\text { Possible causes attributed to } \\
\text { limonene inhibition }\end{array}$ \\
\hline I-IV & $0.51-2.01$ & $7.6-30.1$ & Decrease in $\mathrm{CH}_{4}$ starts & $\begin{array}{l}\text { None. It could be just due to the } \\
\text { OLR increase. }\end{array}$ \\
\hline V & 2.50 & 37.4 & $\begin{array}{l}\text { Propionic, butyric, iso-butyric, } \\
\text { valeric, caproic and heptanoic } \\
\text { increase. Neither hydrogen, nor } \\
\text { acetic acid accumulates. }\end{array}$ & Acetogenesis inhibition. \\
\hline VI & 3.00 & 44.7 & $\begin{array}{l}\text { Decrease in } \mathrm{H}_{2} \mathrm{~S} \text { concentration in } \\
\text { the biogas. } \\
\text { VFA accumulation continues. }\end{array}$ & $\begin{array}{l}\text { Inhibition of sulphate reducing } \\
\text { bacteria }\end{array}$ \\
\hline VII & 2.49 & 37.4 & $\begin{array}{l}\text { Further decrease in } \mathrm{H}_{2} \mathrm{~S} \\
\text { concentration in the biogas. } \\
\text { VFA accumulation continues. }\end{array}$ & $\begin{array}{l}\text { Inhibition of sulphate reducing } \\
\text { bacteria }\end{array}$ \\
\hline VIII & 0.05 & 0.7 & Acetic acid accumulation. & $\begin{array}{l}\text { Inhibition of acetoclastic } \\
\text { methanogenesis. }\end{array}$ \\
\hline
\end{tabular}


Table 5.7. Results of semi-continuous anaerobic co-digestion test M2: average values and standard deviations in each period.

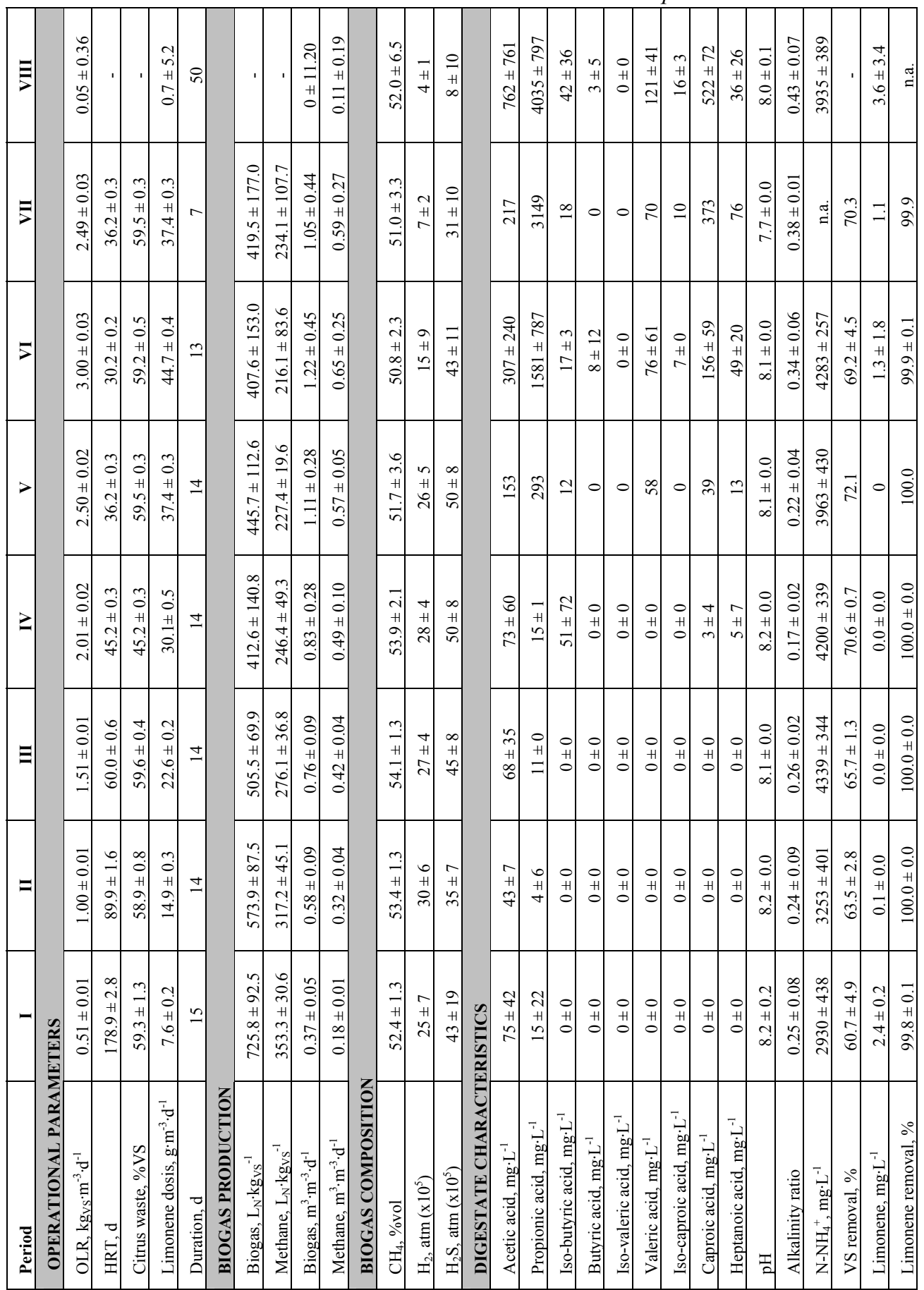




\subsubsection{Feeding mixture M3}

Mixture M3 has similar limonene concentration in the feed, but with lower citrus waste proportion in relation with manure ( $1: 1$, volatile solids). This was achieved by varying the relative proportions of mandarin and orange peel, which had different limonene concentrations. This could have also changed the minority compounds of the citrus essential oil.

The specific biogas and methane production, the methane content of the biogas (\%-vol) and the average daily dosage of limonene in each period are presented in Figure 5.16. Biogas and methane production is kept in similar values with increasing OLR and limonene dose. Only the biogas production of the period I was higher than the productions of all the other periods (ANOVA F-test, 95\% confidence). Biogas production of period IV was lower than the biogas production of periods I and II (multiple range test, 95\%LSD). Methane production from the periods IV to VI was lower from methane production from periods I to III (multiple range test, 95\%LSD). It is noteworthy that in period $\mathrm{V}$, the methane production was the same than in period IV, but the biogas production was higher, pointing to a higher $\mathrm{CO}_{2}$ production.

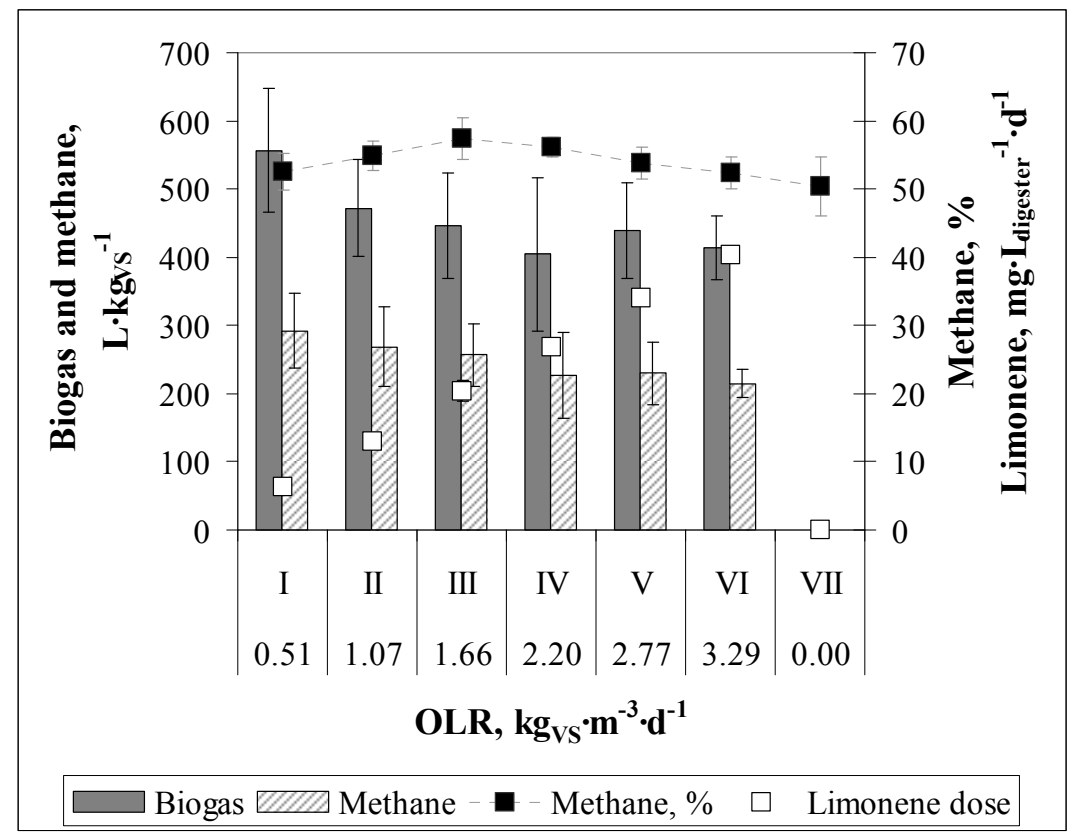

Figure 5.16.

Specific biogas and methane production, and methane content in the biogas (\%-vol) of mixture M3 for the seven periods studied. Averages and standard deviations of the different periods are presented.

Figure 5.17 (left) presents the volumetric methane production $\left(\mathrm{m}^{3}\right.$ of methane per $\mathrm{m}^{3}$ of digester and day). All methane productions were lower than the expected (calculated from 
the COD in the feed). The reductions in periods I to VI were of $21 \%, 28 \%, 31 \%, 39 \%, 38 \%$ and $43 \%$ respectively, statistically significant (t-test, $\alpha=0.05$ ).

The methane content in the biogas and the limonene dose are presented in Figure 5.17 (right). The methane concentration in the biogas is higher than the observed in previous experiments. An increase in the methane content in the biogas is observed from period I to period III, to decrease again from period III to period VII. However, there is not a statistically significant difference between period I and period VII (multiple range test, 95\%LSD).

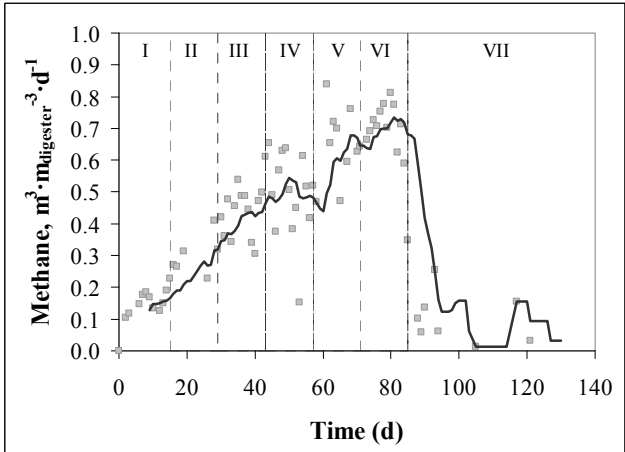

Methane production $-10 \mathrm{~d}$ avg

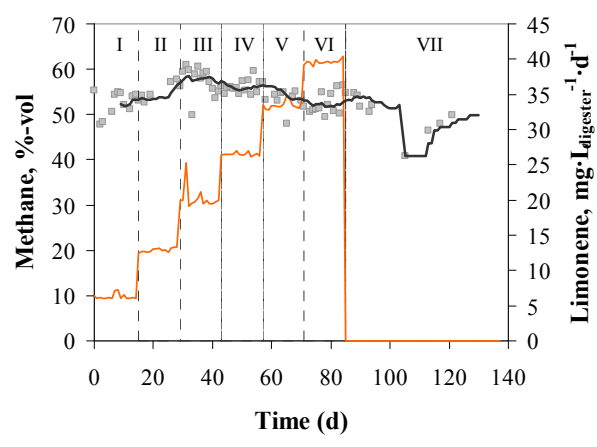

a $\mathrm{CH} 4, \%-$ Limonene dose $-10 \mathrm{~d}$ avg $(\mathrm{CH} 4, \%)$

Figure 5.17.

Methane production and concentration in the biogas from M3.
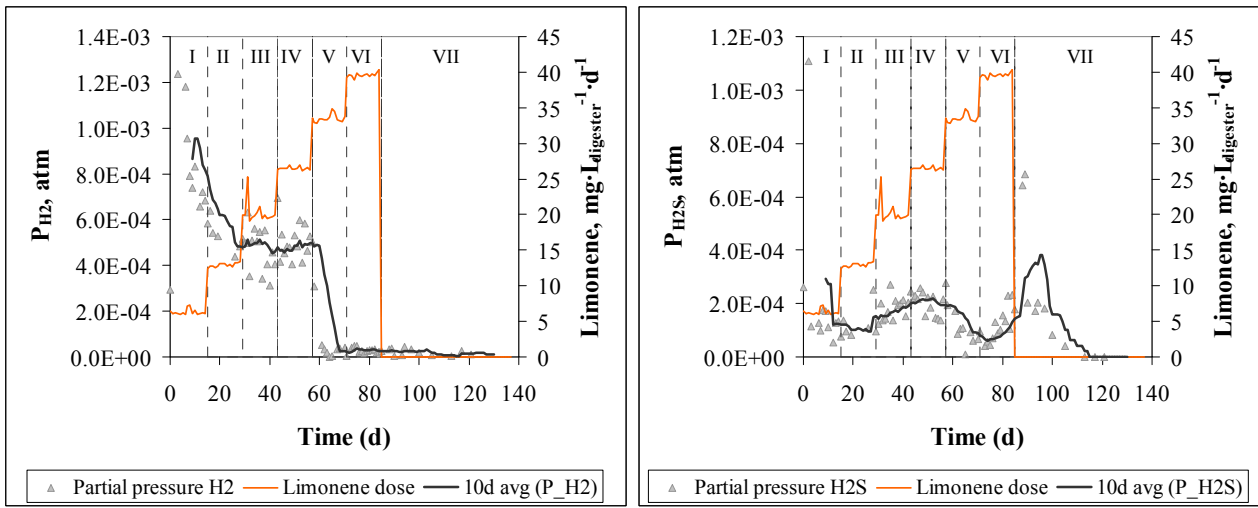

Figure 5.18.

Hydrogen and hydrogen sulphide in the biogas from M3.

The partial pressures of hydrogen and hydrogen sulphide are presented in Figure 5.18. The hydrogen partial pressure starts in similar values to previous experiments but is suddenly reduced in period $\mathrm{V}$ to values next to zero. This sudden decrease coincides with an increase in the propionic acid concentration, suggesting an inhibition of the acetogenesis that produces hydrogen from propionic acid. $\mathrm{H}_{2} \mathrm{~S}$ is relatively low in all periods considering the higher manure content of the feeding mixture. The lowest values are observed in periods $\mathrm{V}$ and VI, what could suggest an inhibition of the sulphate reducing bacteria. 
VFA concentrations in the digester are presented in Figure 5.19.
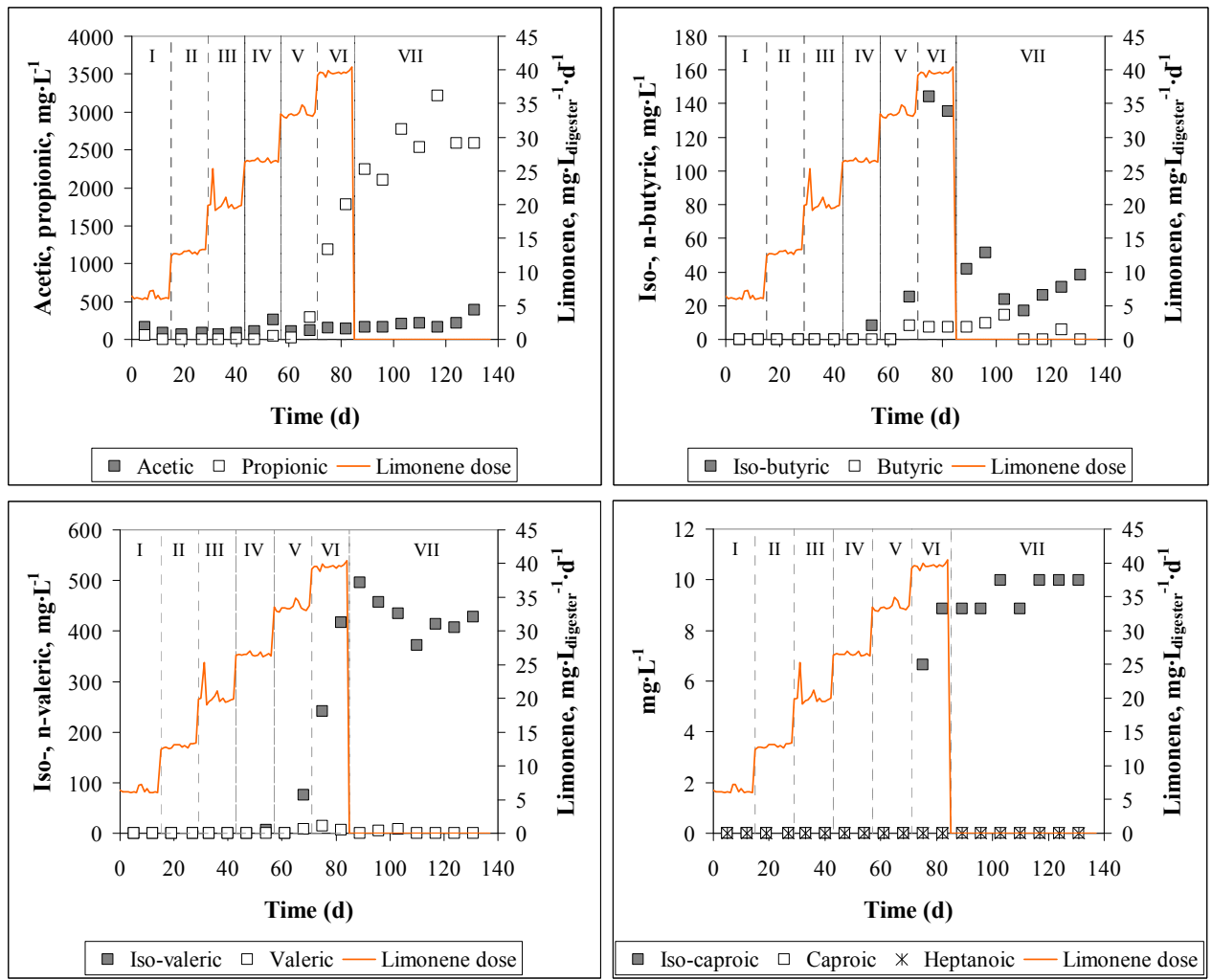

Figure 5.19.

Volatile fatty acids concentration in the digestate from M3.

Acetic acid remained most of the time below $100 \mathrm{mg} \cdot \mathrm{L}^{-1}$, except for the last period where acetic acid increased slightly at the end of the experiment (maximum $391 \mathrm{mg} \cdot \mathrm{L}^{-1}$ ). Propionic acid began to increase in period V (OLR $\left.2.8 \mathrm{~kg} \mathrm{Vs}^{-} \mathrm{m}^{-3} \cdot \mathrm{d}^{-1}\right)$, reached $1784 \mathrm{mg} \cdot \mathrm{L}^{-1}$ in period VI and continued increasing even after stopping the feed for 50 days (period VII).

The evolution of butyric and valeric acid, in terms of relative abundance of iso- forms vs. nforms and absolute values of the concentrations, is similar to M1. Increments in butyric and valeric acid coincide in time with the increase in propionic acid concentration.

The $\mathrm{pH}$ and alkalinity ratio are affected by the VFA evolution (Figure 5.20) and, similarly to $\mathrm{M} 1$, they are not valid as process control parameter, since their reaction is late in relation to the increase in VFA concentrations.

Ammonia nitrogen (Figure 5.21) is in all periods above the concentration of $4 \mathrm{~g} \cdot \mathrm{L}^{-1}$ considered inhibitory (Angelidaki and Ahring, 1993), although less than $10 \mathrm{~g} \cdot \mathrm{L}^{-1}$ reported by some authors without inhibition (Chen et al., 2008). This concentration is higher than M1 and M2 due to the higher proportion of animal manure in the mixture. No decrease in ammonia concentration is observed in any period. 
Average limonene degradation in the period of higher instability is higher than $95 \%$.
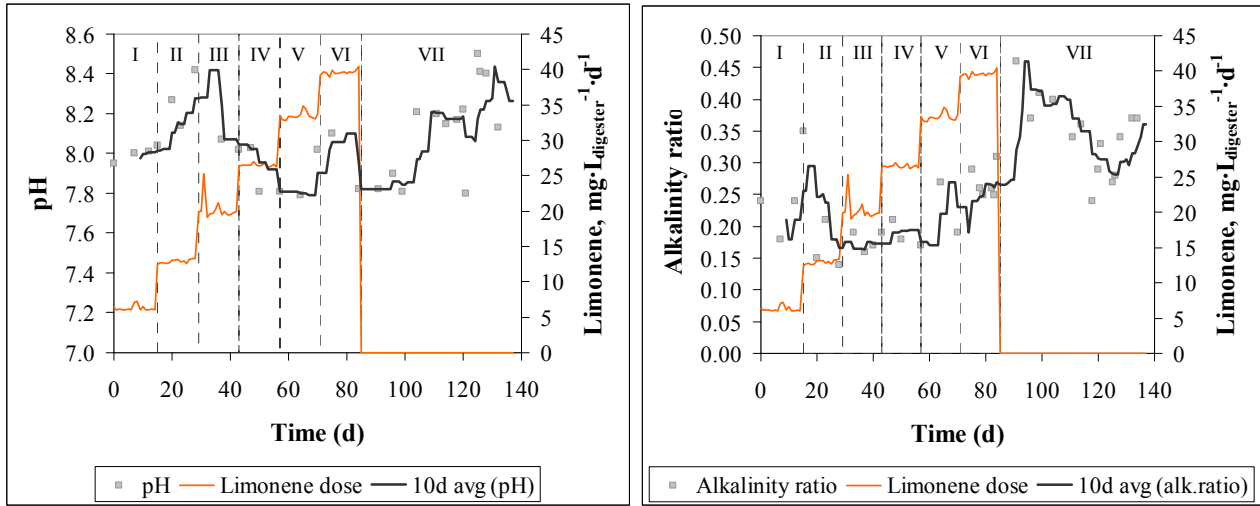

Figure 5.20.

pH (left) and alkalinity ratio (right) in the digestate from M3.

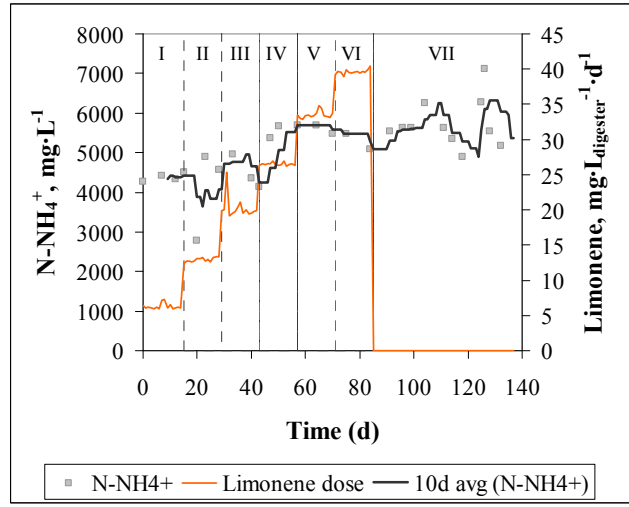

Figure 5.21.

Ammonia nitrogen concentration in the digestate from M3.

Similarly to what happened in experiments with mixtures M1 and M2, the concentration of limonene in the digester remained after the minimum inhibitory concentration and the limonene degradation was 99\%. The same products (cymene, cresol and perillaldehyde) were detected in the gas chromatography analysis (Figure 5.22). Again, the concentration of these products decreased with the time in the period without feeding (period VII).

The maximum OLR that was possible to achieve in a stable manner was $2.20 \mathrm{~kg}_{\mathrm{VS}} \cdot \mathrm{m}^{-3} \cdot \mathrm{d}^{-1}$.

To summarize the previous discussion the most probable causes for the observations done in the semi-continuous anaerobic digestion of M3 are compiled in Table 5.8. Table 5.9 summarizes the results of experiment M3. 


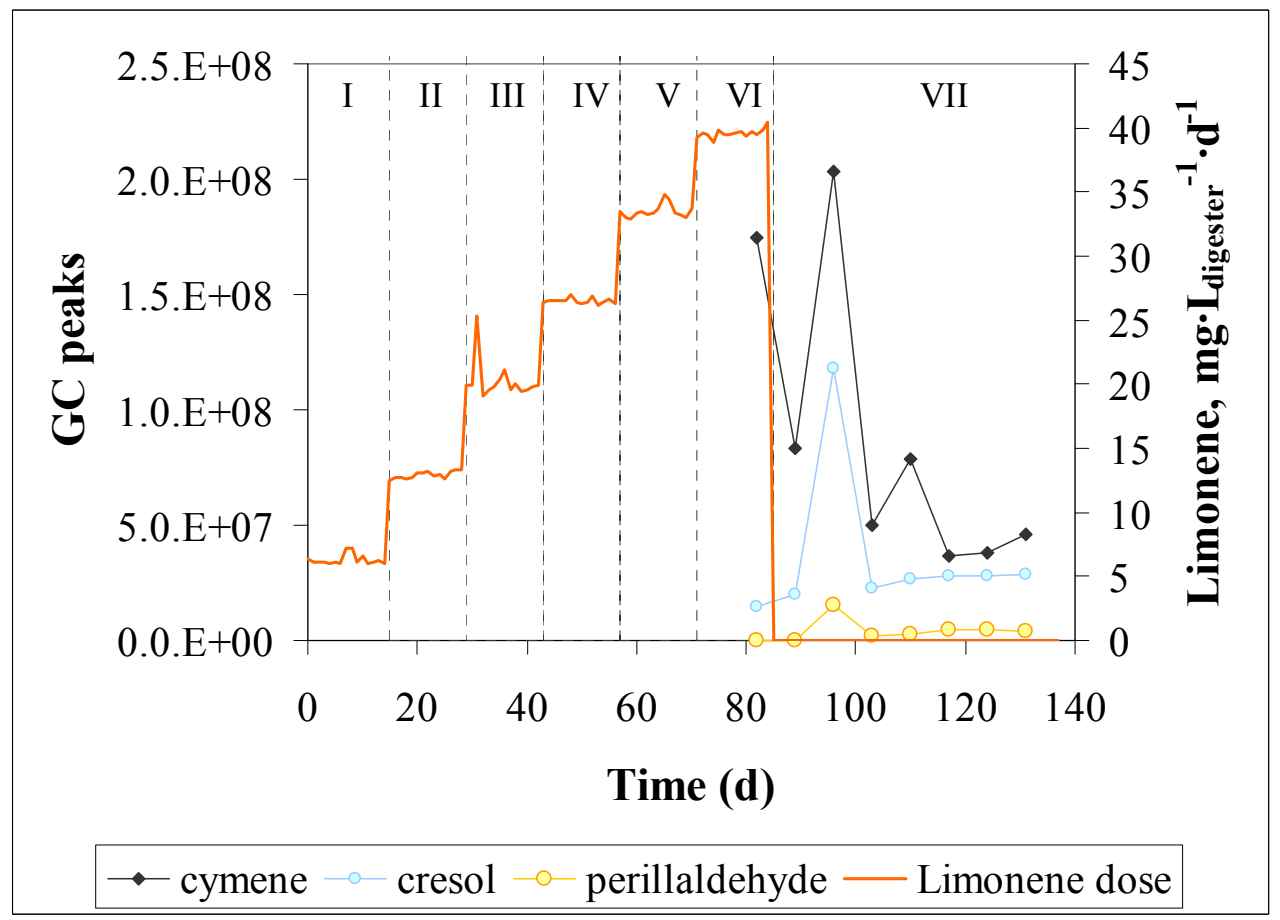

Figure 5.22. Evolution of the GC peaks during the semi-continuous anaerobic digestion of M3.

Table 5.8.

Main observations in semi-continuous anaerobic digestion of mixture M3.

\begin{tabular}{|c|c|c|l|l|}
\hline Period & $\begin{array}{c}\text { OLR } \\
\left(\mathrm{kg}_{V S} \cdot \mathrm{m}^{-3} \cdot \mathrm{d}^{-1}\right)\end{array}$ & $\begin{array}{c}\text { Limonene dose } \\
\left(\mathrm{g} \cdot \mathrm{m}^{-3} \cdot \mathrm{d}^{-1}\right)\end{array}$ & Observations & $\begin{array}{l}\text { Possible causes attributed } \\
\text { to limonene inhibition }\end{array}$ \\
\hline I-IV & $0.51-2.20$ & $6.3-26.5$ & Decrease in CH4 starts & $\begin{array}{l}\text { None. It could be just due } \\
\text { to the OLR increase. }\end{array}$ \\
\hline $\mathrm{V}$ & 2.77 & 33.5 & $\begin{array}{l}\text { Propionic, iso-butyric, } \\
\text { butyric, iso-valeric acid } \\
\text { increase. Neither hydrogen, } \\
\text { nor acetic acid accumulates. } \\
\mathrm{H}_{2} \mathrm{~S} \text { decrease. }\end{array}$ & $\begin{array}{l}\text { Acetogenesis inhibition. } \\
\text { Sulphate reducing bacteria } \\
\text { inhibition. }\end{array}$ \\
\hline
\end{tabular}


Table 5.9. Results of semi-continuous anaerobic co-digestion test M3. Each period corresponds to constant OLR and HRT. Average values and standard deviations are shown.

\begin{tabular}{|c|c|c|c|c|c|c|c|c|c|c|c|c|c|c|c|c|c|c|c|c|c|c|c|c|c|c|}
\hline $\bar{\Sigma}$ & 8 & & & $\mid \begin{array}{c}0 \\
0 \\
1 \\
0 \\
0\end{array}$ & $n$ & & & 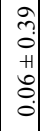 & $\begin{array}{c}0 \\
0 \\
0 \\
+1 \\
\dot{+} \\
0 \\
0\end{array}$ & ร & & 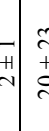 & & $\begin{array}{l}\vec{\infty} \\
+ \\
\overrightarrow{0} \\
\vec{N}\end{array}$ & $\begin{array}{l}0 \\
0 \\
+1 \\
\infty \\
\infty \\
n \\
\end{array}$ & $\begin{array}{l}7 \\
\text { ते } \\
\text { ले }\end{array}$ & & 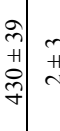 & $\begin{array}{lll}4 & \\
\Delta\end{array}$ & $\mid \begin{array}{l}0 \\
\text { 이 } \\
0\end{array}$ & $\begin{array}{l}\text { ㅇ } \\
\text { H }\end{array}$ & & 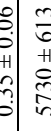 & & $\begin{array}{c}n \\
n \\
+1 \\
6 \\
\tilde{n} \\
0\end{array}$ & \\
\hline$\Sigma$ & & $\begin{array}{l}3 \\
0 \\
+1 \\
\infty \\
\dot{m}\end{array}$ & $\begin{array}{l}\tilde{0} \\
0 \\
+ \\
0 \\
\dot{q} \\
0\end{array}$ & $\mid \begin{array}{c}n \\
0 \\
+ \\
0 \\
0 \\
\dot{m}\end{array}$ & \pm & $\begin{array}{l}0 \\
5 \\
7 \\
+ \\
+ \\
9 \\
7\end{array}$ & 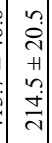 & 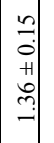 & 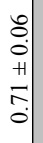 & 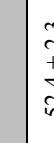 & & $\begin{array}{l}+ \\
m \\
m\end{array}$ & & $\begin{array}{l}\infty \\
+ \\
\tilde{f}\end{array}$ & 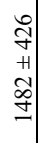 & $\begin{array}{l}0 \\
+ \\
9 \\
9\end{array}$ & & 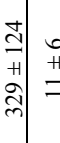 & $\begin{array}{l}+1 \\
+ \\
\infty \\
\infty\end{array}$ & $\begin{array}{l}0 \\
\text { 1 } \\
0\end{array}$ & & 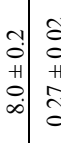 & 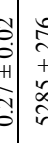 & 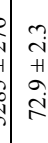 & $\begin{array}{l}\vec{n} \\
\vdots \\
+ \\
\\
=\end{array}$ & \\
\hline$>$ & & $\mid \begin{array}{l}\dot{d} \\
\dot{0} \\
\dot{0} \\
0 \\
\dot{d} \\
m\end{array}$ & $\begin{array}{l}m \\
\vdots \\
+1 \\
\infty \\
\vdots \\
\dot{\sigma}\end{array}$ & $\left|\begin{array}{c}0 \\
0 \\
+1 \\
n \\
m \\
m\end{array}\right|$ & \pm & $\begin{array}{l}0 \\
\dot{8} \\
+ \\
\infty \\
\infty \\
j\end{array}$ & 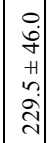 & $\mid \begin{array}{l}\stackrel{9}{9} \\
0 \\
+1 \\
\stackrel{+}{-}\end{array}$ & $\begin{array}{l}\text { I } \\
\\
+ \\
+1 \\
\dot{t} \\
\dot{0}\end{array}$ & $\frac{1}{2}$ & & $\begin{array}{ll}- & \infty \\
+ & + \\
0 & + \\
0 & +\end{array}$ & & $\begin{array}{l}\infty \\
+ \\
\pm \\
=\end{array}$ & 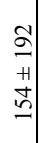 & $\begin{array}{l}\infty \\
\vec{m} \\
\rightarrow\end{array}$ & & & $\begin{array}{ll}0 & 0 \\
+\end{array}$ & \begin{tabular}{l|l}
0 \\
이 \\
\end{tabular} & & 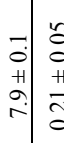 & 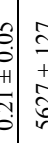 & 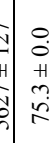 & $\stackrel{\stackrel{\oplus}{=}}{=}$ & 0 \\
\hline 2 & $\delta$ & 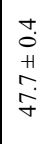 & $\begin{array}{c}n \\
0 \\
+1 \\
0 \\
\vdots \\
+\end{array}$ & $\left|\begin{array}{c}n \\
0 \\
+1 \\
n \\
0 \\
i\end{array}\right|$ & \pm & $\mid \begin{array}{l}7 \\
7 \\
7 \\
7 \\
7 \\
7\end{array}$ & 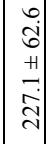 & 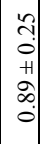 & $\begin{array}{l} \pm \\
\pm \\
0 \\
+1 \\
0 \\
n \\
0\end{array}$ & 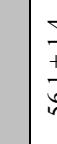 & & 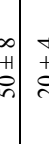 & & $\begin{array}{l}\vec{\Xi} \\
+ \\
\hat{0} \\
\hat{\sigma}\end{array}$ & \begin{tabular}{l|l}
$\stackrel{+}{2}$ \\
+ \\
$\stackrel{N}{+}$
\end{tabular} & $\begin{array}{l}0 \\
+ \\
\forall\end{array}$ & & \begin{tabular}{l|l}
$n$ & 0 \\
$H$ & + \\
$m$ & 0
\end{tabular} & $\begin{array}{l}0 \\
\text { ㅂ) } \\
0\end{array}$ & \begin{tabular}{|l|}
0 \\
1 \\
0
\end{tabular} & & \begin{tabular}{l|l}
- & 2 \\
0 & \\
+1 & + \\
0 & 0 \\
$\infty$ & 0
\end{tabular} & 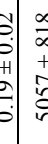 & 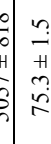 & تُ & \\
\hline$\Xi$ & 5 & 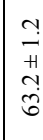 & $\begin{array}{c}\infty \\
- \\
+ \\
-1 \\
\dot{0} \\
n\end{array}$ & 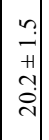 & \pm & $\begin{array}{l}0 \\
7 \\
7 \\
+ \\
\infty \\
0 \\
j\end{array}$ & 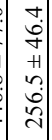 & 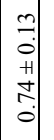 & $\begin{array}{l}\infty \\
\stackrel{0}{0} \\
+ \\
+ \\
\stackrel{+}{0} \\
\dot{0}\end{array}$ & 7 & & 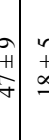 & & $\begin{array}{l}n \\
+1 \\
\infty \\
\infty\end{array}$ & $\begin{array}{l}n \\
\text { in } \\
n\end{array}$ & $\begin{array}{l}\text { 아 } \\
\text { 인 }\end{array}$ & & $\begin{array}{lll}0 & 0 \\
\text { H } & \text { म }\end{array}$ & $\begin{array}{ll}0 \\
1\end{array}$ & $\begin{array}{l}0 \\
\text { ㅂ } \\
0\end{array}$ & & $\vec{\infty}$ & 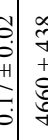 & 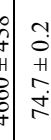 & & \\
\hline$=$ & 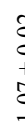 & $\begin{array}{l}0 \\
\dot{j} \\
+1 \\
\stackrel{\infty}{\infty} \\
\alpha\end{array}$ & $\begin{array}{l}\dot{0} \\
\dot{0} \\
+ \\
0 \\
\dot{0} \\
i\end{array}$ & 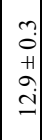 & \pm & $\begin{array}{l}7 \\
7 \\
+ \\
0 \\
7 \\
7\end{array}$ & 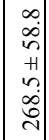 & $\left|\begin{array}{l}0 \\
0 \\
0 \\
+1 \\
0 \\
0 \\
0\end{array}\right|$ & 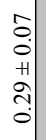 & 9 & & 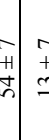 & & $\begin{array}{l}n \\
\sim \\
m \\
m\end{array}$ & $\begin{array}{l}0 \\
\text { ㅂ } \\
0\end{array}$ & 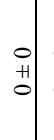 & & 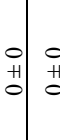 & $\begin{array}{ll}0 \\
4\end{array}$ & $\begin{array}{l}0 \\
\text { ㅂ } \\
0\end{array}$ & & 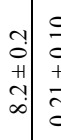 & 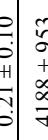 & 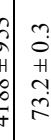 & $\stackrel{\oplus}{\sharp}$ & $=$ \\
\hline & 8 & 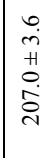 & $\begin{array}{l}+ \\
\dot{i} \\
+ \\
\dot{n} \\
\dot{n}\end{array}$ & $\mid \begin{array}{c}0 \\
0 \\
0 \\
+ \\
0 \\
0 \\
0\end{array}$ & 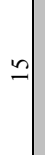 & $\begin{array}{l}2 \\
8 \\
+ \\
+ \\
5 \\
\text { in }\end{array}$ & 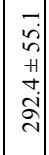 & $\left|\begin{array}{l}n \\
0 \\
0 \\
+1 \\
0 \\
0 \\
0\end{array}\right|$ & $\begin{array}{c}0 \\
0 \\
+1 \\
H \\
n \\
0\end{array}$ & 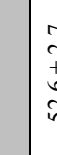 & 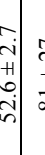 & 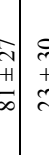 & 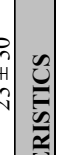 & $\begin{array}{c}\mathfrak{g} \\
+ \\
w \\
\mathfrak{g}\end{array}$ & $\begin{array}{l}\text { ले } \\
+ \\
\end{array}$ & 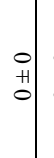 & & \begin{tabular}{l|l}
0 & 0 \\
H & H
\end{tabular} & $\begin{array}{ll}1 \\
0\end{array}$ & 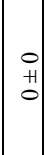 & & \begin{tabular}{l|l}
0 & \\
0 & \\
+ & + \\
0 & + \\
$\infty$ & $\vdots$
\end{tabular} & 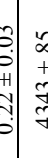 & 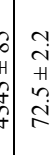 & $\stackrel{\oplus}{=}$ & $=$ \\
\hline & & $\frac{\pi}{\alpha}$ & $\begin{array}{l}n \\
0 \\
0 \\
0 \\
0 \\
0 \\
0 \\
\tilde{n} \\
0 \\
0 \\
0 \\
0 \\
0 \\
0\end{array}$ & 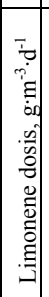 & : & 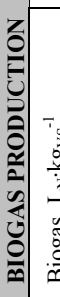 & 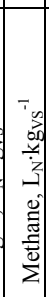 & 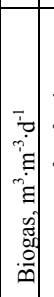 & 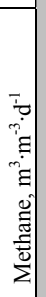 & 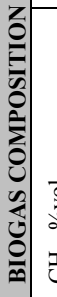 & 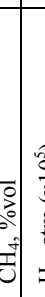 & 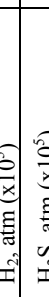 & 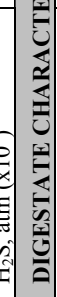 & 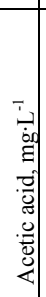 & 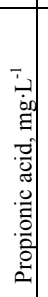 & 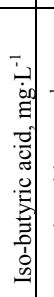 & 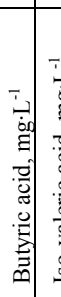 & 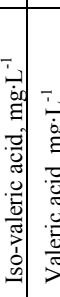 & 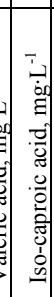 & 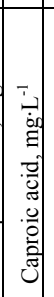 & 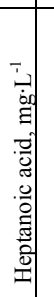 & $=$ & 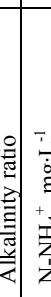 & 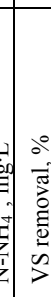 & 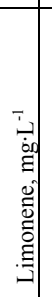 & \\
\hline
\end{tabular}




\subsubsection{Comparison of results of M1, M2 and M3.}

In none of the tests was possible to achieve a stable process for sufficient time to complete various HRT (steady state). However, different trends have been observed when feeding the digesters with the same operating conditions but different mixtures (different composition and limonene dose).

In Table 5.10, the main results of tests M1, M2 and M3 are summarized. The three mixtures are composed by citrus (orange and mandarin) waste and animal (pig and chicken) manure in different proportions. The variation in the relative proportions of the substrates gives different ratios of citrus waste / manure and, consequently, different limonene concentrations.

Table 5.10. $\quad$ Summary of main results of tests M1, M2 and M3.

\begin{tabular}{|c|c|c|c|}
\hline & M1 & M2 & M3 \\
\hline \multicolumn{4}{|l|}{ MIXTURE CHARACTERISTICS } \\
\hline Citrus waste/manure ratio (VS basis) & $80: 20$ & $60: 40$ & 50:50 \\
\hline Mandarin peel/orange peel ratio (VS basis) & 50:50 & $50: 50$ & $66: 33$ \\
\hline Chicken manure/pig manure ratio (VS basis) & $50: 50$ & $20: 80$ & $30: 70$ \\
\hline Limonene concentration in the feed $\left(\mathrm{g} \cdot \mathrm{kg}^{-1}\right)$ & 3.1 & 1.4 & 1.3 \\
\hline \multicolumn{4}{|l|}{ RESULTS } \\
\hline Maximum stable OLR reached $\left(\mathrm{kg}_{\mathrm{vs}} \cdot \mathrm{m}^{-3} \cdot \mathrm{d}^{-1}\right)$ & $1.01 \pm 0.01$ & $2.01 \pm 0.02$ & $2.20 \pm 0.02$ \\
\hline Corresponding HRT (days) & $157.9 \pm 1.3$ & $45.2 \pm 0.3$ & $47.7 \pm 0.4$ \\
\hline Corresponding limonene dose $\left(\mathrm{g} \cdot \mathrm{m}^{-3} \cdot \mathrm{d}^{-1}\right)$ & $19.9 \pm 0.1$ & $30.1 \pm 0.5$ & $26.5 \pm 0.2$ \\
\hline Corresponding volumetric methane production $\left(\mathrm{m}^{3} \cdot \mathrm{m}^{-3}\right.$ digester $\left.\cdot \mathrm{d}^{-1}\right)$ & $0.29 \pm 0.05$ & $0.49 \pm 0.10$ & $0.50 \pm 0.14$ \\
\hline Corresponding specific methane production $\left(\mathrm{L} \cdot \mathrm{kg}_{\mathrm{vs}}{ }^{-1}\right)$ & $289.2 \pm 46.3$ & $246.4 \pm 49.3$ & $227.1 \pm 62.6$ \\
\hline
\end{tabular}

The main difference observed is the different OLR that is possible to reach in a stable manner (without VFA accumulation). There is an inverse linear correlation $\left(\mathrm{R}^{2}=0.99\right)$ between the limonene concentration and the maximum stable OLR, in the range of concentrations tested. The methane production is lower than the predicted by the estimated COD content of the mixture, and reaches $0.5 \mathrm{~m}^{3} \cdot \mathrm{m}_{\text {digester }}{ }^{-3} \cdot \mathrm{d}^{-1}$ for M2 and M3. Specific methane production is higher for M1 and lower for M3, but this would be an effect of the different citrus waste/manure ratios (higher manure content in M3) and also to the higher corresponding OLR.

The main instability indicator is the propionic acid. This VFA shows a sudden increase when the limonene dose is $30 \mathrm{~g} \cdot \mathrm{m}_{\text {digester }}{ }^{-3} \cdot \mathrm{d}^{-1}$ of limonene in $\mathrm{M} 1$, and $38 \mathrm{~g} \cdot \mathrm{m}_{\text {digester }}{ }^{-3} \cdot \mathrm{d}^{-1}$ of limonene in M2 and M3. This would indicate a higher tolerance to the limonene in tests M2 and M3, what could be caused by the lower slope of the limonene dose in these two 
mixtures (Figure 5.23). At the same time, for a given OLR, less limonene is fed to the digester with mixture M3.

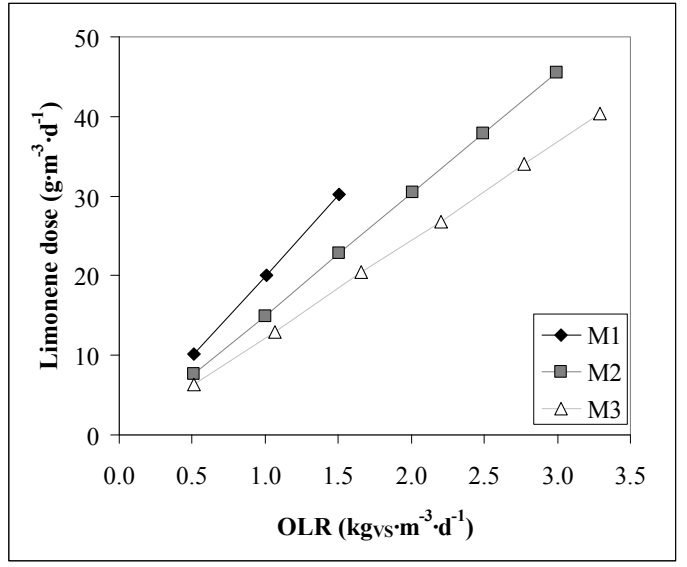

Figure 5.23. Limonene dose vs. OLR.

Iso- forms of valeric acid are more abundant than $\mathrm{n}$ - forms in M1 and M3, but the opposite situation is observed in M2. This could be due to the differences in the mixture composition, in particular the protein / amino acids composition, which strongly influences the concentration of valeric acid and its iso / $\mathrm{n}$ forms. The different relative proportion of pig/chicken manure in M2 could have been the responsible for this.

In all experiments, acetogenesis was the first process to show symptoms of instability. These symptoms were accumulation of iso-valeric acid at OLR of $1.01 \mathrm{~kg}_{\mathrm{vs}} \cdot \mathrm{m}^{-3} \cdot \mathrm{d}^{-1}$ and limonene dose $20.0 \mathrm{~g} \cdot \mathrm{m}_{\text {digester }}{ }^{-3} \cdot \mathrm{d}^{-1}$ in $\mathrm{M} 1$, and propionic acid increase without acetic acid or hydrogen accumulation in the three mixtures but at different OLR - limonene doses.

Acetoclastic methanogenesis was the next process to fail, being the signs the acetic acid accumulation and the drop in methane yield. In M2 and M3 this was observed only at the very end of the experiments, after stopping the feed for more than one month.

In Figure 5.24, the VS removal for each OLR in all three mixtures is presented. The maximum VS removal was reached for the maximum stable OLR except in M2, in which the best OLR $\left(2 \mathrm{~kg}_{\mathrm{VS}} \cdot \mathrm{m}^{-3} \cdot \mathrm{d}^{-1}\right)$ had a VS removal lower than for OLR $2.5 \mathrm{~kg}_{\mathrm{Vs}} \cdot \mathrm{m}^{-3} \cdot \mathrm{d}^{-1}$. This coincides with an increase of the $\mathrm{CO}_{2}$ production in this particular period.

Inhibition of hydrogenotrophic methanogenesis was observed only in M1 at a limonene dose of $29.8 \mathrm{~g} \cdot \mathrm{m}_{\text {digester }}{ }^{-3} \cdot \mathrm{d}^{-1}$. No accumulation of hydrogen was observed in anaerobic digestion of mixtures M2 or M3, even at higher limonene doses than the one that caused inhibition of this process in M1.

Sulphate reducing bacteria were inhibited in M1 and M3 but at different limonene doses. This did not happen in M2 despite the similar limonene concentration in the feed and the higher slope of the limonene increase with the time. This could be due to the higher 
mandarin concentration in the feed, since mandarin essential oil has shown stronger inhibitory effect than orange and lemon essential oil against several bacteria (Espina et al., 2011).

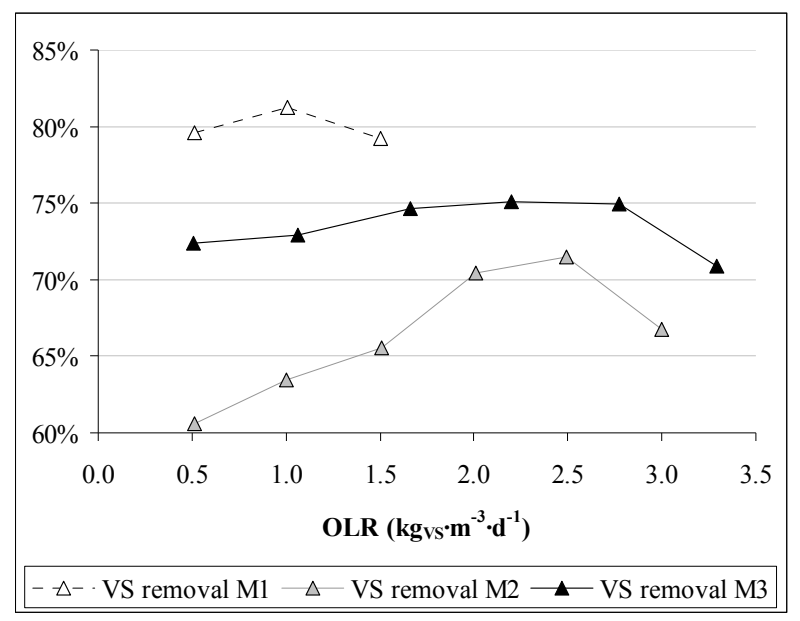

Figure 5.24.

VS removal in semi-continuous anaerobic digestion of the three mixtures.

Complete degradation of limonene was observed in all the measurements performed during the anaerobic digestion tests. This is in agreement with the observations made in chapter 3 . As a consequence, other toxic compounds appeared in the digesters, such as cymene, cresol, perillaldehyde and $\alpha$-terpineol. These compounds are inhibitory as well and therefore the inhibition persisted despite the complete degradation of limonene. A decrease in the concentration of these compounds is observed after some time without feeding the digester. This could be either to degradation by the anaerobic bacteria, or to an accumulation of the limonene or its bioproducts in the membrane of the microorganisms, which could prevent them to be detected in the analysis. The accumulation of this kind of hydrocarbons in the membrane structure has been described as a part of the toxicity mechanism by Bakkali et al. (2008).

To sum up, a systemic inhibition was observed in M1, with symptoms of inhibition on protein hydrolysis pathway, sulphate reduction, and acetogenesis. Acetogenesis was inhibited in all three mixtures but at different limonene doses $\left(20.0,37.9\right.$ and $34.0 \mathrm{~g} \cdot \mathrm{m}^{-3} \cdot \mathrm{d}^{-1}$ in M1, M2 and M3, respectively). Additionally, sulphate reduction process was observed to be inhibited at $34.0 \mathrm{~g}_{\text {limonene }} \cdot \mathrm{m}_{\text {digester }}{ }^{-3} \cdot \mathrm{d}^{-1}$ in $\mathrm{M} 3$.

\subsection{Conclusions}

The co-digestion of orange peel with pig and chicken manure diluted the concentration of limonene in the feed and therefore contributed to reduce the limonene dose at a given OLR. However, the degradation of the limonene led to the production of other toxic compounds 
such as cymene, p-cresol, perillaldehyde and $\alpha$-terpineol, which caused the inhibitory effect to persist even when the limonene degradation was almost complete. Therefore, strategies to remove or recover the limonene from the orange peel should be studied.

The main parameter to be regarded when studying inhibition by citrus essential oil is the dose (amount per digester volume unit and day). The rate of increase of the limonene dose has been inversely related to the maximum reachable organic loading rate.

The first affected microbial population was the acetogenic bacteria, shown by an accumulation of volatile fatty acids. Sulphate reducing bacteria and methanogenic archaea were also affected.

The concentration of the bioproducts of limonene decreases when the feeding is stopped. It was not clear wether this decrease is due to degradation by the anaerobic populations or due to accumulation in the membrane structure of the microorganisms. This would remain for future research.

\subsection{Acknowledgements}

The results of this investigation were obtained with funding from the regional government of Comunitat Valenciana (tender contract 4/2009).

\subsection{References}

Angelidaki, I., Ahring B.K. 1993. Thermophilic anaerobic digestion of livestock waste: the effect of ammonia. Applied Microbiology and Biotechnology 38, 560-564.

APHA-AWWA-WEF. 2006. Standard Methods for the examination of water and wastewater. American Public Health Association / American Water Works Association / Water Environment Federation. 19 ${ }^{\text {th }}$ ed., Washington DC, USA.

Bakkali, F., Averbeck, S., Averbeck, D., Idaomar, M. 2008. Biological effects of essential oils - a review. Food Chem. Toxicol. 46, 446-475.

Bories, A., Sire, Y., Colin, T. 2005. Odorous compounds treatment of winery and distillery effluents during natural evaporation in ponds. Water Science and Technology 51, 129-136.

Burt, S. 2004. Essential oils: their antimicrobial properties and potential applications in foods - a review. International Journal of Food Microbiology 94, 223-253.

CAPA. 2011. Informe del sector agrario valenciano 2011. Capítulo IV: estadísticas agrícolas. Cuadro 4.12: superficies, producciones y destino de la producción de cítricos. Comunitat Valenciana. Campaña 2010/2011. Conselleria de Agricultura, Pesca y Alimentación.

Castillejos, L., Calsamiglia, S., Ferret, A. 2006. Effect of essential oil active compounds on rumen microbiol fermentation and nutrient flow in in vitro systems. Journal of Dairy Science 89, 2649-2658.

Chen, Y., Cheng, J.J., Creamer, K.S. 2008. Inhibition of anaerobic digestion process: A review. Bioresource Technology 99, 4044-4064.

Deublein, D., Steinhauser, A. 2008. Biogas from waste and renewable resources - An introduction. Wiley-VCH. Verlag GmbH\&Co. KGaA, Weinheim. 
Effenberger, M., Lebuhn, M., Gronauer, A. 2007. Fermentermanagement - Stabiler Prozess bei NawaRo-Anlagen. 16. Jahrestagung des Fachvervandes Biogas e.V. Leipzig (Germany) $31^{\text {st }}$ january $-2^{\text {nd }}$ february.

Espina, L., Somolinos, M., Lorán, S., Conchello, P., García, D., Pagán, R. 2011. Chemical composition of commercial citrus fruit essential oils and evaluation of their antimicrobial activity acting alone or in combined processes. Food Control 22, 896-902.

Forgács, G., Pourbafrani, M., Niklasson, C., Taherzadeh, M.T., Hováth, I.S. 2011. Methane production from citrus wastes: process development and cost estimation. J. Chem. Technol. Biotechnol. 87, 250-255.

Hylemon, P.B., Harder, J. 1999. Biotransformation of monoterpenes, bile acids, and other isoprenoids in anaerobic ecosystems. FEMS Microbiology Reviews 22, 475-488.

Kaparaju, P.L.N., Rintala, J.A. 2006. Thermophilic anaerobic digestión of industrial orange waste. Environmental Technology 27, 623-633.

Lane, A.G. 1980. Production of aromatic acids during anaerobic digestion of citrus peel. Journal of Chemical Technology and Biotechnology 30, 345-350.

Lane, A.G. 1983. Pretreatment of citrus peel press liquor before anaerobic digestion. Environmental Technology Letters 4, 73-78.

Lane, A.G. 1984. Anaerobic digestion of orange peel. Food Technology in Australia 36, 125-127.

Martín, M.A., Siles, J.A., Chica, A.F., Martín, A. 2010. Biomethanization of orange peel waste. Bioresource Technology 101, 8993-8999.

Martín M.A., Fernández R., Serrano A., Siles J.A. 2013. Semi-continuous anaerobic digestion of orange peel waste and residual glycerol derived from biodiesel manufacturing. Waste Management 33, 1633-1639.

Mizuki, E., Akao, T., Saruwatari, T. 1990. Inhibitory effect of Citrus unshu peel on anaerobic digestion. Biological Wastes 33, 161-168.

Pascual Anderson R. 1982. Técnicas para el análisis microbiológico de alimentos y bebidas. Ed. Ministerio de Sanidad y Consumo, Instituto Nacional de Sanidad. Centro Nacional de Alimentación y Nutrición. Servicio de Microbiología. Majadahonda (Madrid).

Pind, P.F., Angelidaki, I., Ahring, B.K. 2002. Dynamics of the anaerobic process: effects of volatile fatty acids. Biotechnology and Bioengineering 82, 791-801.

Rittman B.E., McCarthy P.L. 2001. Environmental biotechnology: principles and applications. McGraw Hill.

Ruiz Fuertes, M.B., Silvestre Tormo, G., Rodrigo Ruiz, C., Diego Meliveo, L. 2013. Biogas production from sugar manufacturing solid by-product: co-digestion vs. mono-digestion. $13^{\text {th }}$ IWA World Congress on Anaerobic Digestion. 25-28 June 2013, Santiago de Compostela, Spain.

Ruiz B., Flotats X. 2014. Citrus essential oils and their influence on the anaerobic digestion process: An overview. Waste Management 34, 2063-2079.

Srilatha, H.R., Nand, K., Babu, K.S., Madhukara, K. 1995. Fungal pretreatment of orange processing waste by solid-state fermentation for improved production of methane. Process Biochemistry 30, 327-331.

VDI - Verein Deutscher Ingenieure 2006. Fermentation of organic materials. Characterisation of the substrate, sampling, collection of material data, fermentation tests. ICS 13.030.30; 27.190.

Westerholm, M., Moestedt, J., Schnürer, A. 2013. Improved biogas production at high ammonia by management of reactor operation for support of syntrophic acetate oxidisers. $13^{\text {th }}$ IWA World Congress on Anaerobic Digestion. 25-28 June 2013, Santiago de Compostela, Spain. 


\title{
Chapter 6
}

\section{Thermal and mechanical pretreatments of citrus fruit and co-digestion with cow manure as strategies to overcome inhibition of anaerobic digestion by citrus essential oil}

\begin{abstract}
Citrus fruit is a suitable substrate for anaerobic digestion due to its high carbohydrate content. However, the essential oils present in the peel inhibit the anaerobic digestion process. Moreover, the lack of nutrients and buffering capacity also hinders the anaerobic digestion process.

In this study, anaerobic co-digestion of citrus fruit, with and without thermal and mechanical pretreatment, was carried out with cow manure, which brought alkalinity and nutrients to the mixture. The pretreatment consisting in mechanical removal of the flavedo allowed reaching a higher organic loading rate and methane production in a stable manner (4.12 $\mathrm{kg}_{\mathrm{Vs}} \cdot \mathrm{m}^{-3} \cdot \mathrm{d}^{-1}, 120 \mathrm{~L}_{\mathrm{CH} 4} \cdot \mathrm{kg}_{\mathrm{Vs}}{ }^{-1}, 0.49 \mathrm{~m}_{\mathrm{CH} 4}{ }^{3} \cdot \mathrm{m}_{\text {digester }}{ }^{-3} \cdot \mathrm{d}^{-1}$ ) than the experiments without treatment $\left(2.72 \mathrm{~kg}_{\mathrm{vs}} \cdot \mathrm{m}^{-3} \cdot \mathrm{d}^{-1}, 111 \mathrm{~L}_{\mathrm{CH} 4} \cdot \mathrm{kg}_{\mathrm{Vs}}{ }^{-1}, 0.33 \mathrm{~m}_{\mathrm{CH} 4}{ }^{3} \cdot \mathrm{m}_{\text {digester }}{ }^{-3} \cdot \mathrm{d}^{-1}\right)$ or with thermal treatment $\left(2.96 \mathrm{~kg}_{\mathrm{VS}} \cdot \mathrm{m}^{-3} \cdot \mathrm{d}^{-1}, 123 \mathrm{~L}_{\mathrm{CH} 4} \cdot \mathrm{kg}_{\mathrm{VS}}{ }^{-1}, 0.36 \mathrm{~m}_{\mathrm{CH} 4}{ }^{3} \cdot \mathrm{m}_{\text {digester }}^{-3} \cdot \mathrm{d}^{-1}\right)$.
\end{abstract}

Scientific output of this chapter:

Ruiz B., Kaiser F., Andrade D., Povez A., Gronauer, A. Methane yield improvement in anaerobic codigestion of Valencia Late oranges and cattle manure. $11^{\text {th }}$ IWA World Congress on Anaerobic Digestion (AD11), 23-27 Septiembre 2007, Brisbane, Australia (poster).

Ruiz B., Kaiser F., Andrade D., Gronauer, A. Influence of pre-treatments and organic loading rate on process stability in co-digestion of oranges with cattle manure. $V^{\text {th }} I W A$ International Symposium on Anaerobic Digestion of Solid Wastes and Energy Crops (ADSWEC2008), 25-28 Mayo 2008, Hammammet, Túnez (oral presentation). 


\section{Table of contents}

6.1 Introduction .................................................................................................................... 133

6.2 Materials and methods ............................................................................................. 134

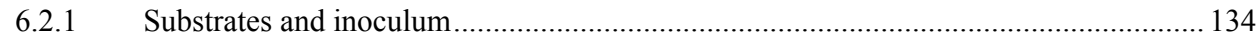

6.2.2 Semi-continuous anaerobic digestion tests......................................................... 134

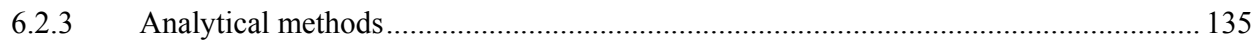

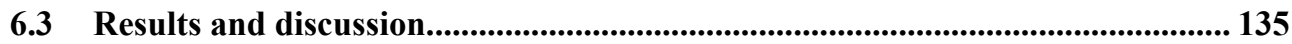

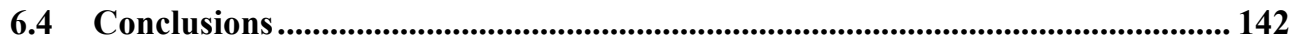

6.5 Acknowledgements..................................................................................................... 142

6.6 References ............................................................................................................... 147 


\subsection{Introduction}

The definition of citrus waste includes not only the peel and pressed pulp generated in the process of juice manufacturing, but also the fruits discarded for commercial reasons or due to production limiting regulations, which ranges $2-10 \%$ (CAPA, 2011). These fruits are not allowed to re-enter the food chain and have to be managed as waste.

Anaerobic digestion is a technically feasible, environmentally friendly and energy efficient process for the valorisation of citrus waste. However, the citrus essential oil (CEO), inhibitor of the anaerobic digestion, and the lack of nutrients and alkalinity (Ruiz and Flotats, 2014), can pose a risk on the process stability.

All experiments found in the literature with citrus waste as the only substrate needed supplementation with buffering solutions, macro and micronutrients, due to the low $\mathrm{pH}$ and the lack of nutrients of this substrate (Lane, 1980; Mizuki et al., 1990; Kaparaju and Rintala, 2006; Martín et al., 2010; Forgács et al., 2011; Martín et al., 2013). At industrial scale, this would reduce the economic feasibility of the plants. Lane (1984) suggested that the co-digestion of citrus waste with nitrogen-rich manure could be an economic alternative. However, this strategy is not enough to overcome the inhibition by the CEO present in the orange peel as already observed in chapter 5 since, although limonene (the main component of the CEO) is degraded during anaerobic digestion, it is transformed to other inhibitory compounds that are also toxic for the process. Therefore, it is necessary to remove or recover the limonene prior to the anaerobic digestion.

The limonene is located mainly in the oil vesicles in the flavedo of the orange peel (see chapter 2). Consequently, the mechanical removal of the flavedo and its oil vesicles removes the main part of the limonene from the orange peel.

On the other hand, according to the Regulation (EC) No 1069/2009 of the European Parliament and of the Council, of 21 October 2009, laying down health rules as regards animal by-products and derived products not intended for human consumption and repealing Regulation (EC) No 1774/2002 (Animal by-products Regulation), animal byproducts (ABP) not for human consumption have to be pasteurised $\left(70^{\circ} \mathrm{C}, 1 \mathrm{~h}\right)$ before entering an anaerobic digester for biogas production. In many plants, this pasteurisation is applied to the whole feeding mixture in order to reduce investment in additional tanks, machinery and automation. Since the orange peel waste should be co-digested in order to achieve an adequate nutrients balance and buffering capacity, the effect of this pasteurisation on the anaerobic digestion of orange peel should be analysed.

The objective of this study was to study the anaerobic co-digestion of citrus fruit with cow manure after applying a pretreatment (mechanical or thermal) to the orange peel. The mechanical treatment was applied in order to recover the limonene from the orange peel. The thermal treatment was applied in order to assess the effect of a potential pasteurisation treatment according to European regulations for animal by-products, with which the orange peel might be co-digested. The aim of the co-digestion was to supply the necessary buffering capacity and nutrients, thus avoiding the additive costs. 


\subsection{Materials and methods}

\subsubsection{Substrates and inoculum}

Cow manure (CM) was collected from Pellmeyer Farm (Freising, Germany). Citrus sinensis (orange) fruits variety "Valencia late" were bought in a local market and manually cut into pieces of 1-2 cm in the laboratory. Three different preparations were used in the anaerobic digestion experiments: cut orange (OC); cut and thermal treatment at $70^{\circ} \mathrm{C}$ for $1 \mathrm{~h}$ (OT); and manual removal of the flavedo with a kitchen grater and cut (OF). While the thermal treatment is not expected to remove the CEO from the orange peel, the removal of the flavedo (where the vesicles with the CEO are located) would almost completely remove the CEO from the orange.

To start the anaerobic digestion process, the digesters were filled with digested material from a pilot scale $\left(3.5 \mathrm{~m}^{3}\right)$ agricultural biogas plant fed with cow manure and maize silage at mesophilic temperature. The total solids (TS) and volatile solids (VS) of the inoculum were 103 and $85 \mathrm{~g} \cdot \mathrm{kg}^{-1}$, respectively.

\subsubsection{Semi-continuous anaerobic digestion tests.}

Semi-continuous anaerobic digestion tests were carried out according the VDI Standard 4630 Fermentation of organic materials (Verein Deutscher Ingenieure, 2006). Jacketed continuously stirred tank reactors (CSTR) of $36 \mathrm{~L}$ total volume (30 L working volume) were used as anaerobic digesters (Figure 6.1). The operating temperature was $38^{\circ} \mathrm{C}$ in all digesters. Feeding of substrates and removal of same amount of digestate was done once a day. Gas volume was measured by Ritter Milligascounters ${ }^{\circledR}$ MGC-10. Methane production data were expressed at standard pressure and temperature conditions $\left(0^{\circ} \mathrm{C}\right.$ and $\left.1 \mathrm{~atm}\right)$.

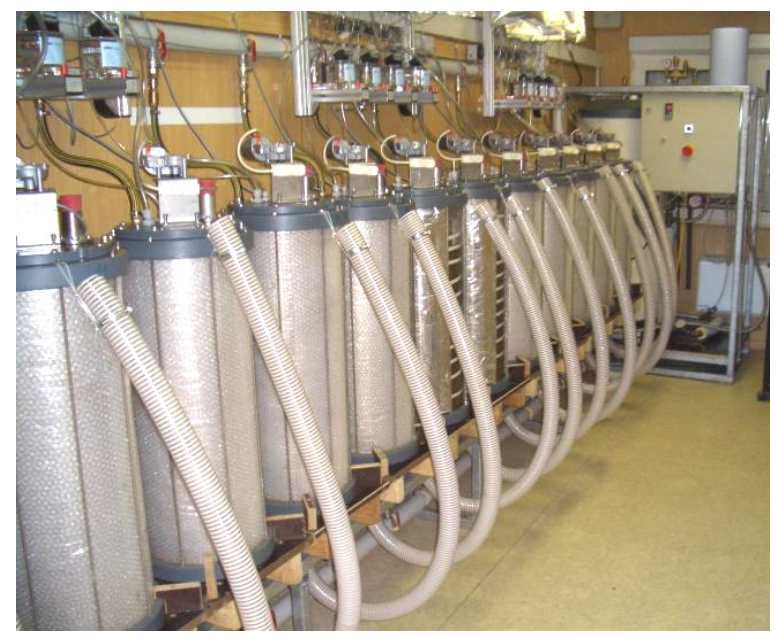

Figure 6.1. Laboratory set-up for the semi-continuous anaerobic digestion tests (LfLILT in Freising, Germany). 
Feeding started with an organic loading rate (OLR) of $0.5 \mathrm{~kg}_{\mathrm{Vs}} \cdot \mathrm{m}^{-3} \cdot \mathrm{d}^{-1}$, and was progressively increased every 14 days with the aim to find its maximum. OLR was considered to reach its maximum when the alkalinity ratio and volatile fatty acids (VFA) concentration exceeded the limits reported for stable operation (Effenberger et al., 2007): total VFA $>2000 \mathrm{mg} \cdot \mathrm{L}^{-1}$; acetic acid $>1000 \mathrm{mg} \cdot \mathrm{L}^{-1}$; propionic acid $>500 \mathrm{mg} \cdot \mathrm{L}^{-1}$; butyric acid $>500 \mathrm{mg} \cdot \mathrm{L}^{-1}$, alkalinity ratio $>0.3$; methane concentration $<48 \%$.

Each experiment was divided in periods for the data analysis. Each period corresponds to a time of constant OLR and hydraulic retention time (HRT). Mixture composition was kept constant for all periods except for the last one, in which the orange proportion was increased (see Table 6.1).

Analytical control of the digesters was done once a week.

Statistical analysis for comparison of the results of the different experiments was done with Statgraphics ANOVA test (p-value of F-test 0.05 ). In order to assess statistically significant differences between the averages of each period of the four experiments, the test of multiple range was used (test of the least significative differences LSD of Fisher).

Table 6.1. Summary of semi-continuous anaerobic digestion tests.

\begin{tabular}{|c|l|c|c|c|c|}
\hline Test & Substrate & $\%$ orange & $\begin{array}{c}\text { \% orange } \\
\text { (VS) }\end{array}$ & $\begin{array}{c}\text { \% orange } \\
\text { last period }\end{array}$ & $\begin{array}{c}\text { \% orange } \\
\text { last period } \\
\text { (VS) }\end{array}$ \\
\hline $\mathrm{A}$ & $\mathrm{CM}$ & $0 \pm 0$ & $0 \pm 0$ & $0 \pm 0$ & $0 \pm 0$ \\
\hline $\mathrm{B}$ & $\mathrm{CM}+\mathrm{OC}$ & $16.6 \pm 0.1$ & $40.7 \pm 0.1$ & $31.2 \pm 0.3$ & $56.2 \pm 0.3$ \\
\hline $\mathrm{C}$ & $\mathrm{CM}+\mathrm{OT}$ & $20.0 \pm 0.1$ & $40.8 \pm 0.1$ & $31.2 \pm 0.3$ & $56.8 \pm 0.4$ \\
\hline $\mathrm{D}$ & $\mathrm{CM}+\mathrm{OF}$ & $19.1 \pm 0.1$ & $40.6 \pm 0.1$ & $36.7 \pm 0.0$ & $57.4 \pm 0.0$ \\
\hline
\end{tabular}

\subsubsection{Analytical methods}

Analysis of total solids (TS), volatile solids (VS), alkalinity and $\mathrm{pH}$ were carried out according the Standard Methods of Analysis (APHA-AWWA-WEF, 2006). Individual volatile fatty acids (VFA) acetate, propionate, iso-butyrate, butyrate, iso-valerate, valerate, iso-caproate, caproate and heptanoate, were analysed by gas chromatography.

The biogas composition was analysed each 6 litres of biogas produced by means of a gas analyzer equipped with infrared sensors for methane, carbon dioxide and oxygen, and electrochemical sensors for hydrogen sulphide and hydrogen (Awite $\mathrm{GmbH}$, Germany).

\subsection{Results and discussion}

Chemical characteristics of cow manure and orange fruit samples are summarized in Table 6.2. The feeding mixture properties (TS and VS) for each test are compiled in Table 6.3. 
Table 6.2. $\quad$ Chemical characteristics of cow manure and orange fruit.

\begin{tabular}{|l|c|c|}
\hline Parameter, units & Cow manure & Orange fruit \\
\hline Total solids (TS), $\%$ & 5.93 & 16.40 \\
\hline Volatile solids (VS), \%TS & 72.21 & 96.86 \\
\hline $\mathrm{COD}, \mathrm{g} \cdot \mathrm{kg}^{-1}$ & 59.71 & 212.66 \\
\hline $\mathrm{pH}\left(20^{\circ} \mathrm{C}\right)$ & 8.30 & 4.10 \\
\hline Alkalinity, $\mathrm{mmol}_{\mathrm{CaC0}} \cdot \mathrm{L}^{-1}$ & 394.02 & n.a. \\
\hline Total VFA, $\mathrm{mg} \cdot \mathrm{L}^{-1}$ & 997.78 & n.a. \\
\hline Alkalinity ratio & 0.38 & n.a. \\
\hline
\end{tabular}

n.a.: not analyzed.

Table 6.3. $\quad$ Feeding mixture properties for each anaerobic digestion test performed.

\begin{tabular}{|c|l|c|c|}
\hline Test & Substrate & TS $\left(\mathbf{g} \cdot \mathbf{k g}^{-1}\right)$ & VS $\mathbf{( g \cdot \mathbf { k g } ^ { - 1 } )}$ \\
\hline A & CM & $71.7 \pm 0.0$ & $51.7 \pm 0.0$ \\
\hline B & CM+OC & $90.5 \pm 0.1$ & $73.3 \pm 0.1$ \\
\hline C & CM+OT & $87.6 \pm 0.1$ & $71.0 \pm 0.1$ \\
\hline D & CM+OF & $87.2 \pm 0.1$ & $70.6 \pm 0.1$ \\
\hline
\end{tabular}

Table 6.4, Table 6.5, Table 6.6 and Table 6.7 show the average values and standard deviation of each measured parameter in each period of experiments A, B, C and D, respectively.

The average specific methane production (SMP) and methane concentration in the biogas of each period is presented in Figure 6.2.

The SMP was higher in the co-digestion experiments than in the anaerobic digestion of cow manure alone. The difference was smaller in the last periods due to the decrease in the methane concentration in the biogas. This reduction was more marked in the last period, possibly indicating an inhibition of the process.

In period I, no statistically significant difference was observed in the average values of the SMP of the four experiments. From period II onwards, the SMP of the experiment A (cow manure only) was lower than the rest (statistically significant, level of confidence $95 \%$ ). No statistically significant difference was observed between the SMP of experiments B $(\mathrm{CM}+\mathrm{OC})$ and $\mathrm{C}(\mathrm{CM}+\mathrm{OT})$ in any of the periods. Experiment D yielded higher SMP from period IV onwards (in period III, D was higher than B but same as C). In the last period, where the relative amount of orange was increased in experiments $\mathrm{B}, \mathrm{C}$ and $\mathrm{D}$, the SMP of digester D was significantly higher than SMP of experiments A, B and C.

The methane concentration in the biogas is shown in Figure 6.3. While this value remained the same in all periods for experiment A (cow manure only), a sustained decrease was observed in experiments with orange and cow manure $(B, C, D)$. 


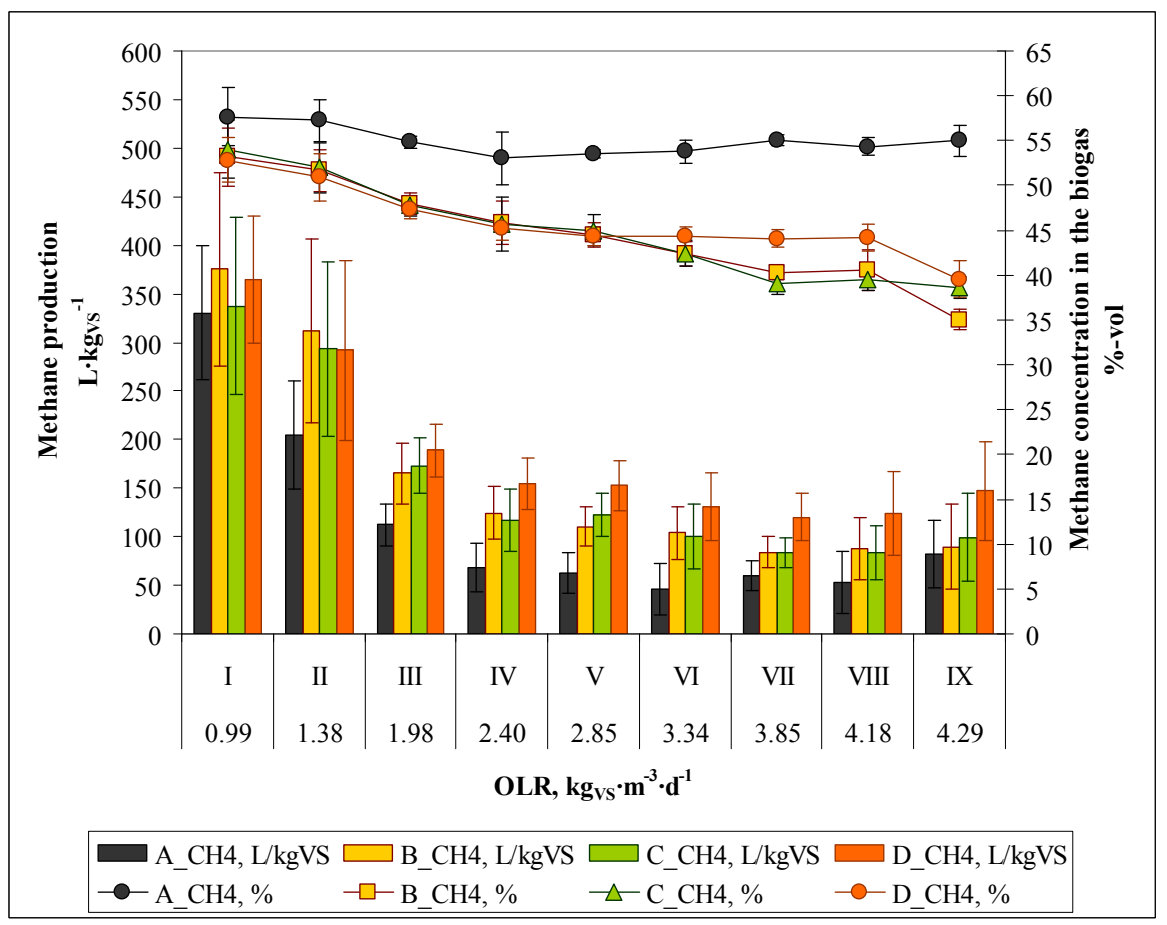

Figure 6.2. Specific methane production, and methane concentration in the biogas. Averages and standard deviations of the different periods are represented.

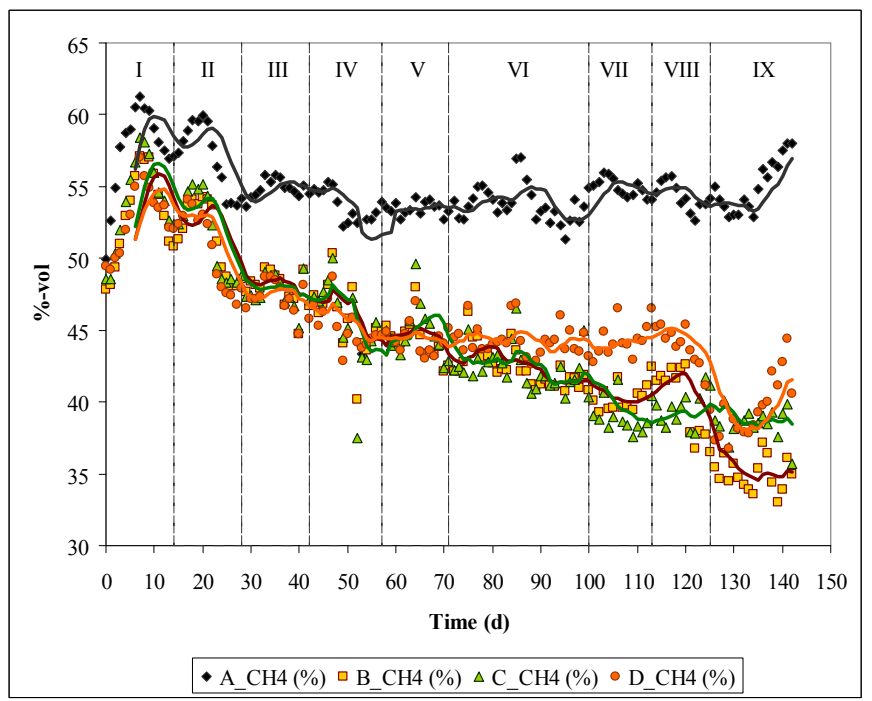

Figure 6.3. Methane concentration in the biogas. Averages of three runs are presented. 
The volumetric methane production $\left(\mathrm{m}^{3}\right.$ of methane per $\mathrm{m}^{3}$ of digester and day) is shown in Figure 6.4. All co-digestion experiments (B, C and D) yielded higher methane production than the blank (A, cow manure only). Experiment D yielded the highest methane production. This experiment was the one, in which the flavedo (and therefore most of the limonene) was removed before the anaerobic co-digestion with cow manure.

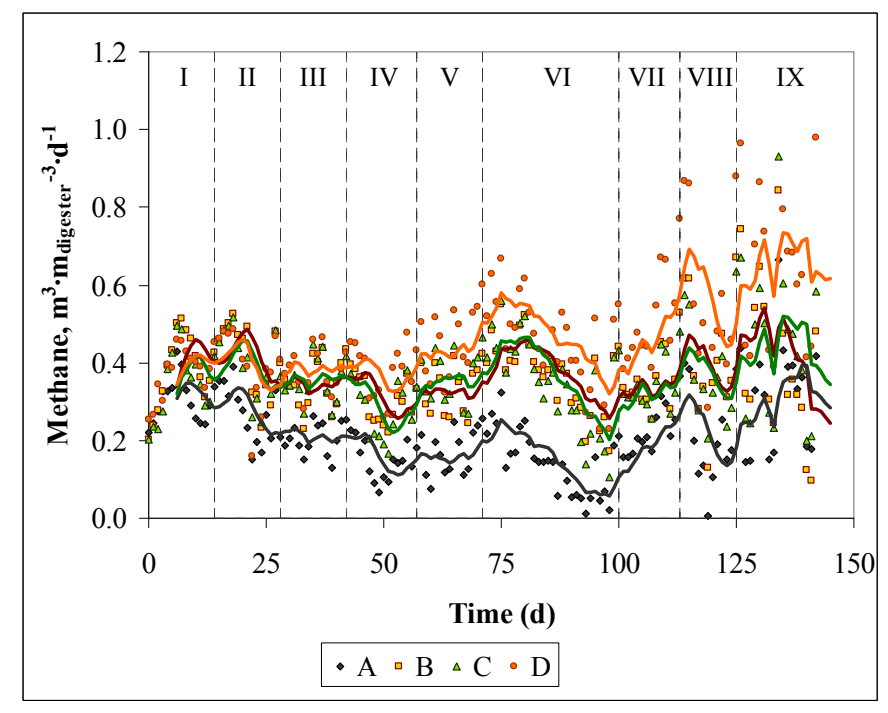

Figure 6.4. Volumetric methane production. Averages of three runs are presented.

Other parameters of the biogas, namely the partial pressure of hydrogen and hydrogen sulphide, were also monitored (Figure 6.5).
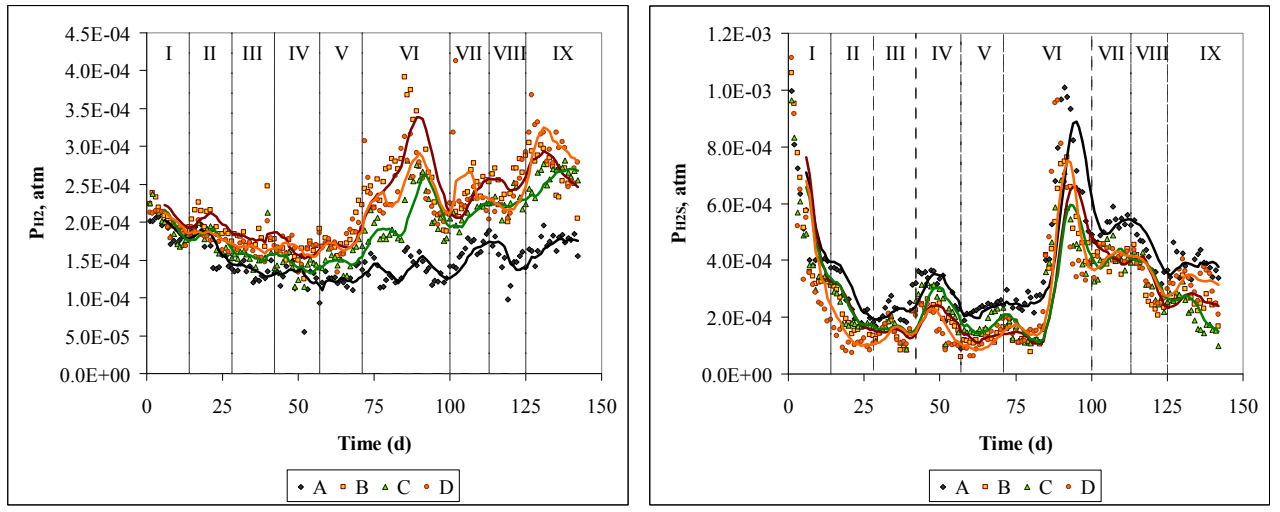

Figure 6.5. Partial pressure of hydrogen (left) and hydrogen sulphide (right) in the biogas. Averages of three runs are presented.

Hydrogen sulphide can cause damage to the biogas energy valorisation equipment. Moreover, the hydrogen sulphide producing bacteria compete with the methanogenic 
archaea for the organic matter. Therefore, an increase of the hydrogen sulphide concentration in the biogas could indicate a decrease in the activity of the methanogenic archaea, possibly due to an inhibition. After the high initial values, attributed to the still high presence of inoculum coming from an agricultural biogas plant, the hydrogen sulphide remained in relatively low concentrations in the biogas $(<400 \mathrm{ppm})$. A sudden increase was observed in period VI. Taking into account the sudden increase, the fact that it was produced several days before the last OLR increase, and that it was observed in all experiments, it was attributed to an increase of the sulphate concentration in the cow manure. Unfortunately, no experimental data was available to confirm this hypothesis.

Hydrogen concentration in the biogas in the tests with orange was higher than in the tests with cow manure only. Hydrogen accumulation (i.e., an increase of the hydrogen concentration in the biogas) can be interpreted as a sign of partial inhibition of hydrogenotrophic methanogenesis. The peak in period VI was coinciding with the hydrogen sulphide increase and also with an increment of the alkalinity ratio, and was considered to be related to this fact. Moreover, a transitory increase in the propionic acid was observed in tests $\mathrm{B}$ and $\mathrm{C}$ in this period as well.
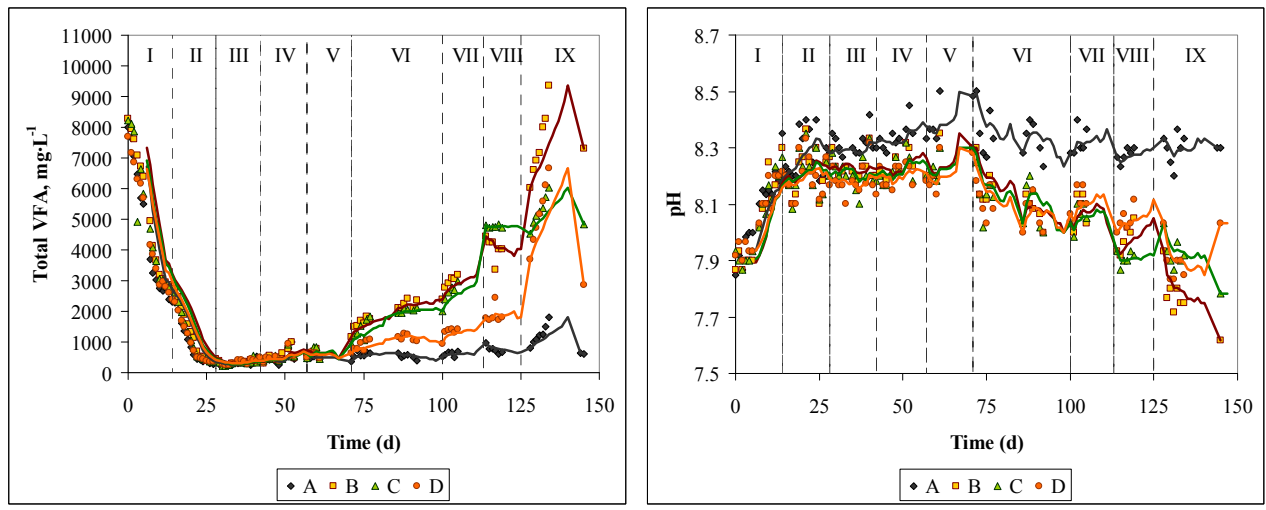

Figure 6.6. Total volatile fatty acids concentration (left) and pH (right). Averages of three runs are presented.

Total VFA concentration is presented in Figure 6.6 (left). The VFA concentration in the first periods was high due to the initial VFA concentration in the inoculum with which the digesters were filled $\left(6.2 \mathrm{~g} \cdot \mathrm{L}^{-1}\right)$ and in the cow manure (see Table 6.2). Then, it decreased until $300-500 \mathrm{mg} \cdot \mathrm{L}^{-1}$ indicating a stable process during periods II and III. The VFA concentration in the digesters operating with manure (A) remained in these values until period VIII, corresponding to an OLR of $3.94 \mathrm{~kg}_{\mathrm{VS}} \cdot \mathrm{m}^{-3} \cdot \mathrm{d}^{-1}$, where they increased after the increase of the OLR. Then, they stabilized again in the previous values. On the contrary, the VFA concentration in the digesters operating with cow manure and orange $(B, C, D)$ kept increasing from period $\mathrm{V}$ until the end of the test. In period VI, an accumulation followed by a partial consumption was noticed, coinciding with the partial inhibition caused by the increase in the hydrogen sulphide concentration that was overcomed. At the end of the experiment, VFA concentration reached values higher than $9000 \mathrm{mg} \cdot \mathrm{L}^{-1}$ in experiment $\mathrm{B}$. 
These values have been reported as inhibitors in the literature (Effenberger et al., 2007). While the VFA concentration in the digesters $\mathrm{B}$ and $\mathrm{C}$ were very similar, the VFA concentration of digester D (the one without limonene) was lower and below $2000 \mathrm{mg} \cdot \mathrm{L}^{-1}$ until period VIII.

The $\mathrm{pH}$ value varied accordingly to VFA evolution (Figure 6.6, right). While the $\mathrm{pH}$ value of digesters $\mathrm{A}$ is kept stable in all periods, except for a slight decrease in period VIII (OLR $\left.3.94 \mathrm{~kg}_{\mathrm{vs}} \cdot \mathrm{m}^{-3} \cdot \mathrm{d}^{-1}\right)$, the $\mathrm{pH}$ value of the digesters $\mathrm{B}, \mathrm{C}$ and $\mathrm{D}$ showed a sustained decrease from periods $\mathrm{V}$ to VIII. Although the last values measured were still adequate for anaerobic digestion, the lowering tendency, together with the increase in the concentration of VFA, demonstrated a high acidification risk.

The VFA were composed mainly of acetic and propionic acid (Figure 6.8). The concentration of acetic and propionic acid started increasing from period $\mathrm{V}$ until the end of the tests for digesters with orange. The concentration of acetic acid was higher than the concentration of propionic acid, what is typical in anaerobic digestion of carbohydrates (Batstone et al., 2000).

Alkalinity ratio also confirmed the observations made in total VFA concentration, $\mathrm{pH}$ and individual VFA (Figure 6.7, left). The alkalinity ratio of digesters B, C and D started increasing in period $\mathrm{V}\left(\mathrm{OLR} 3.11 \mathrm{~kg}_{\mathrm{VS}} \cdot \mathrm{m}^{-3} \cdot \mathrm{d}^{-1}\right)$. The alkalinity ratio of tests $\mathrm{B}$ and $\mathrm{C}$ increased more and with higher slope than the one of test $\mathrm{D}$. This parameter, together with the $\mathrm{pH}$, can be used as control parameters in industrial plants, since they are simple to measure and they were valuable indicators of the state of the process in this case.

Ammonia nitrogen (Figure 6.7, right) of A digesters (cow manure only) was slightly higher to the ammonia nitrogen of $\mathrm{B}, \mathrm{C}$ and $\mathrm{D}$ digesters, due to the different nitrogen content of cow manure and orange. The measured concentrations were in some cases slightly above of the $4 \mathrm{~g} \cdot \mathrm{L}^{-1}$ considered as limit (Angelidaki and Ahring, 1993). However, no signs of inhibition due to ammonia were detected, although HRTs lower than 45 days were used in the tests (Westerholm et al., 2013).
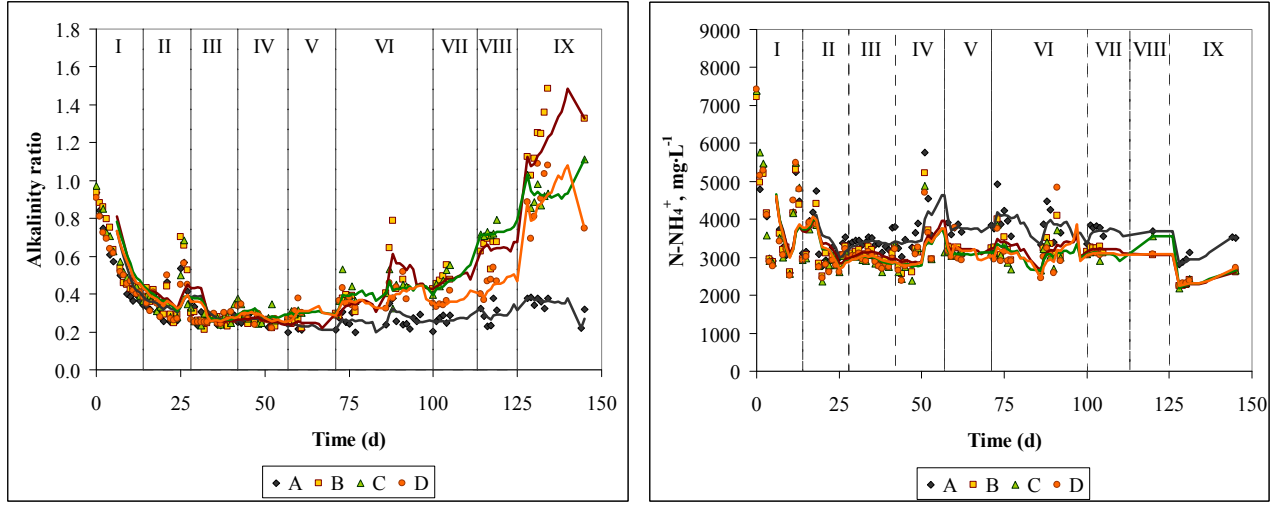

Figure 6.7. Alkalinity ratio (left) and concentration of ammonia nitrogen (right). Averages of three runs are presented. 

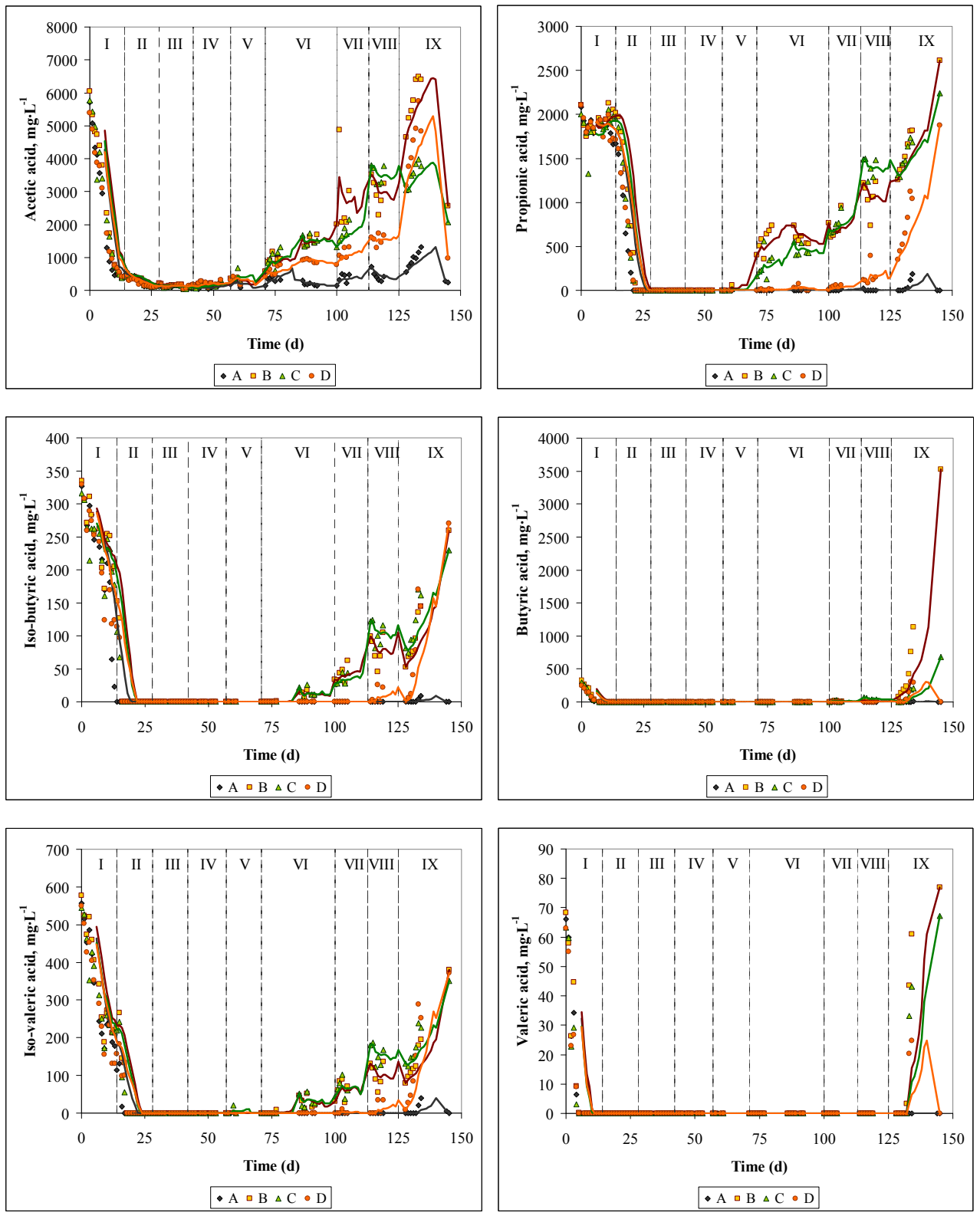

Figure 6.8. Volatile fatty acids concentration. Averages of three runs are presented. 


\subsection{Conclusions}

Anaerobic co-digestion of citrus fruit with different pretreatments and cow manure was tested. All co-digestion experiments yielded higher methane production than the cow manure alone.

The mechanical pretreatment applied to the citrus fruit allowed to reach an OLR of 4 $\mathrm{kg}_{\mathrm{VS}} \cdot \mathrm{m}^{-3} \cdot \mathrm{d}^{-1}$ without VFA accumulation and to produce more methane than in the codigestion of citrus fruit without pretreatment. The thermal pretratment did not influence the stability or the methane production.

At industrial scale, the mechanical process to remove the flavedo of the orange peel could be applied to citrus fruit by specific machinery in order to recover the essential oil as valuable product, thus allowing obtaining citrus peel without flavedo directly from the industrial facilities.

\subsection{Acknowledgements}

The authors want to thank the Instituto Valenciano de Competitividad Empresarial (IVACE, formerly named IMPIVA) for the funding allowing the stage of Begoña Ruiz in Bayerische Landesanstalt für Landwirtschaft - Institut für Landtechnik (LfL-ILT), where the work described in this chapter was carried out, and also the staff of LfL-ILT for the help with these experiments. 
Table 6.4. Average values and standard deviation in each period of experiment A.

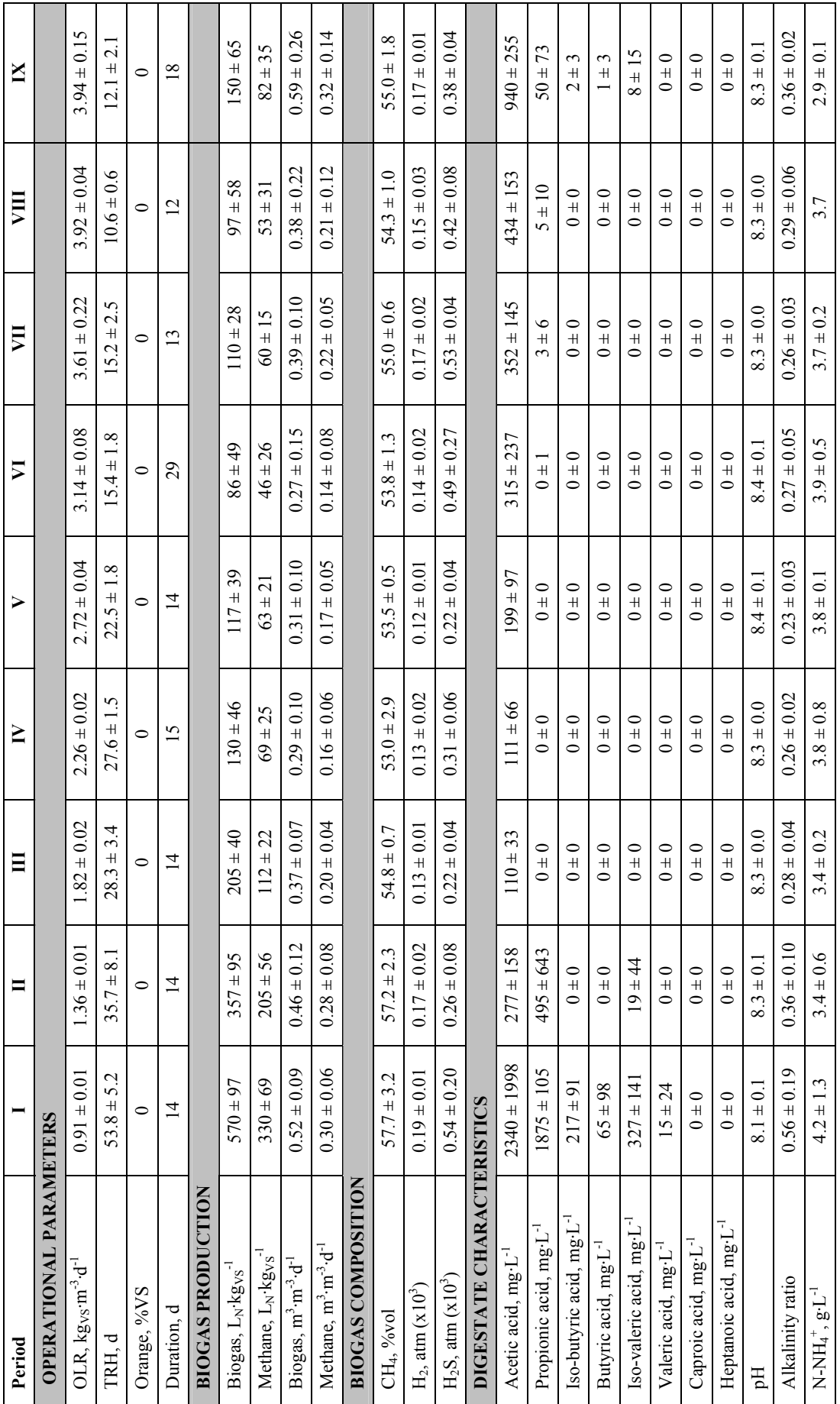


Table 6.5. Average values and standard deviation in each period of experiment $B$.

\begin{tabular}{|c|c|c|c|c|c|c|c|c|c|c|c|c|c|c|c|c|c|c|c|c|c|c|c|c|c|}
\hline$z$ & & $\begin{array}{l}\stackrel{n}{2} \\
\dot{0} \\
+ \\
+ \\
\vdots \\
\dot{n}\end{array}$ & $\begin{array}{l}\vec{i} \\
\vec{H} \\
\vec{n} \\
\vec{\longrightarrow}\end{array}$ & $\mid \begin{array}{l}\tilde{N} \\
\text { H } \\
\text { in } \\
\text { in }\end{array}$ & 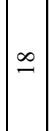 & & 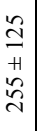 & $\begin{array}{l}7 \\
+ \\
\& \\
\&\end{array}$ & $\mid \begin{array}{c}0 \\
\dot{0} \\
+ \\
+ \\
\\
-\end{array}$ & 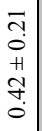 & & 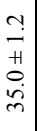 & $\begin{array}{l}\tilde{O} \\
0 \\
+ \\
\hat{n} \\
\tilde{o}\end{array}$ & 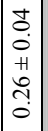 & & 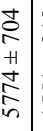 & 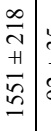 & & & & & $\begin{array}{l}0 \\
+1 \\
0\end{array}$ & & 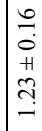 & $\begin{array}{c}- \\
\dot{\delta} \\
+ \\
\tilde{n} \\
\sim\end{array}$ \\
\hline $\bar{\Sigma}$ & & 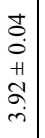 & $\mid$\begin{tabular}{l}
0 \\
0 \\
0 \\
+ \\
0 \\
0 \\
\hdashline
\end{tabular} & $\mid \begin{array}{l}0 \\
\dot{0} \\
+ \\
0 \\
\dot{\theta} \\
\dot{q}\end{array}$ & $\simeq$ & & 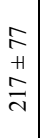 & $\begin{array}{l}\infty \\
m \\
+1 \\
\infty \\
\infty\end{array}$ & $\mid \begin{array}{l}\tilde{m} \\
\tilde{0} \\
+1 \\
\infty \\
o \\
0\end{array}$ & $\begin{array}{l} \pm \\
\pm \\
0 \\
+1 \\
0 \\
+ \\
\dot{0}\end{array}$ & & 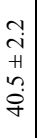 & 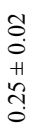 & $\mid \begin{array}{c}2 \\
0 \\
0 \\
+ \\
\tilde{H} \\
\tilde{0}\end{array}$ & & $\begin{array}{l}\vec{J} \\
+ \\
\vec{\sigma} \\
\vec{\sigma}\end{array}$ & 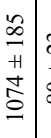 & $\begin{array}{l}2 \\
y \\
H \\
\infty \\
\infty\end{array}$ & & & $\begin{array}{ll}0 \\
\dot{H} \\
0\end{array}$ & $\begin{array}{l}0 \\
\text { H } \\
0\end{array}$ & $\begin{array}{l}\overrightarrow{0} \\
0 \\
+1 \\
0 \\
\infty \\
0\end{array}$ & $\begin{array}{l}8 \\
\stackrel{0}{0} \\
+ \\
\text { t } \\
\dot{0}\end{array}$ & $\vec{m}$ \\
\hline$\equiv$ & & 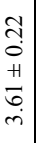 & 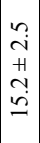 & 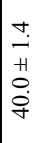 & $\cong$ & & $\begin{array}{l}\stackrel{f}{+} \\
+ \\
\stackrel{्}{े}\end{array}$ & $\begin{array}{l}0 \\
+1 \\
+1 \\
\infty\end{array}$ & $\mid$\begin{tabular}{c}
0 \\
\hdashline \\
0 \\
+ \\
$\dot{1}$ \\
$\infty$ \\
0 \\
0
\end{tabular} & $\begin{array}{l}0 \\
0 \\
0 \\
H \\
n \\
\tilde{0} \\
0\end{array}$ & & 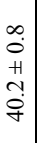 & 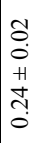 & $\mid \begin{array}{l}t \\
0 \\
0 \\
+ \\
\vec{J} \\
0\end{array}$ & & 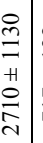 & 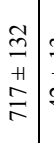 & $\begin{array}{l}m \\
\vec{H} \\
\stackrel{H}{F}\end{array}$ & \begin{tabular}{l|l}
$a$ & \\
+ & \\
0 &
\end{tabular} & 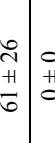 & $\begin{array}{ll}0 & 0 \\
H & H \\
0 & 0\end{array}$ & $\begin{array}{l}0 \\
+1 \\
0\end{array}$ & $\begin{array}{l}\overrightarrow{0} \\
+1 \\
\\
\infty\end{array}$ & $\begin{array}{l}\tilde{0} \\
\dot{0} \\
\dot{0} \\
+ \\
\infty \\
0 \\
0 \\
0\end{array}$ & $\begin{array}{l}- \\
0 \\
H \\
\sim \\
\tilde{m}\end{array}$ \\
\hline 5 & & $\begin{array}{l}\infty \\
\stackrel{0}{0} \\
+ \\
+ \\
\dot{\sim} \\
\dot{m}\end{array}$ & 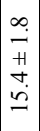 & $\begin{array}{l}\infty \\
0 \\
+1 \\
\tilde{+} \\
\tilde{q}\end{array}$ & ते & & $\begin{array}{l}8 \\
\text { D } \\
\text { J } \\
\text { I }\end{array}$ & $\begin{array}{l}\tilde{y} \\
+ \\
y \\
0 \\
-1\end{array}$ & $\left|\begin{array}{c}\vec{\sigma} \\
0 \\
+ \\
\tilde{\infty} \\
0 \\
0\end{array}\right|$ & $\begin{array}{l}g \\
\dot{0} \\
0 \\
H \\
\hat{n} \\
\tilde{0}\end{array}$ & & $\begin{array}{l}\stackrel{?}{Z} \\
\vec{H} \\
\vec{j} \\
\vec{q}\end{array}$ & 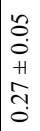 & $\begin{array}{c}\tilde{n} \\
\tilde{0} \\
+ \\
+ \\
\tilde{\omega} \\
\tilde{0}\end{array}$ & & $\begin{array}{l}\stackrel{8}{0} \\
\text { ñ } \\
+ \\
\text { ô } \\
=\end{array}$ & 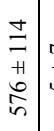 & & \begin{tabular}{l|l}
0 & $=$ \\
+ & 7
\end{tabular} & 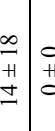 & $\begin{array}{ll}0 \\
\text { H } \\
0\end{array}$ & $\begin{array}{l}0 \\
+1 \\
0\end{array}$ & $\begin{array}{l}\overrightarrow{0} \\
+ \\
+ \\
\\
\end{array}$ & 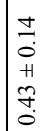 & $\begin{array}{l}\dot{+} \\
\dot{0} \\
+ \\
\tilde{m} \\
\tilde{m}\end{array}$ \\
\hline $1>$ & & 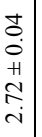 & 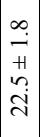 & $\begin{array}{l}\infty \\
0 \\
+1 \\
0 \\
0 \\
\dot{\sigma}\end{array}$ & \pm & & $\begin{array}{l}f \\
f \\
+ \\
0 \\
\\
\end{array}$ & $\begin{array}{l}\text { I } \\
\text { H } \\
\Xi \\
\Xi\end{array}$ & $\mid \begin{array}{l}J \\
0 \\
H \\
H \\
\Delta \\
0 \\
0\end{array}$ & $\begin{array}{l}\stackrel{0}{0} \\
\dot{0} \\
H \\
m \\
\tilde{0}\end{array}$ & & 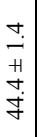 & $\mid \begin{array}{l}\tilde{O} \\
0 \\
+ \\
+1 \\
\infty \\
0 \\
0\end{array}$ & 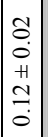 & & 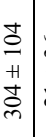 & $\begin{array}{l}0 \\
\tilde{N} \\
+ \\
\vec{N}\end{array}$ & $\begin{array}{l}0 \\
\text { 1 } \\
0\end{array}$ & & \begin{tabular}{l|l}
0 & 0 \\
H & 1
\end{tabular} & $\begin{array}{ll}0 \\
\\
0\end{array}$ & $\begin{array}{l}0 \\
\text { H1 }\end{array}$ & $\begin{array}{l}\overrightarrow{0} \\
\dot{0} \\
+1 \\
0 \\
\infty\end{array}$ & 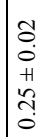 & $\begin{array}{l}- \\
0 \\
H \\
H \\
\tilde{y} \\
m\end{array}$ \\
\hline$\geq$ & & 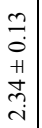 & $\mid \begin{array}{c}\tilde{n} \\
\tilde{H} \\
\tilde{N} \\
\tilde{N} \\
\tilde{N}\end{array}$ & $\mid$\begin{tabular}{l}
0 \\
$\dot{0}$ \\
+1 \\
+1 \\
\multirow{\sigma}{\sigma}{} \\
$\dot{q}$
\end{tabular} & $\because$ & & 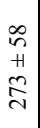 & $\begin{array}{l}\tilde{y} \\
+ \\
+ \\
I \\
I\end{array}$ & \begin{tabular}{l} 
\pm \\
\hdashline 0 \\
+ \\
+ \\
$\infty$ \\
0 \\
0 \\
0
\end{tabular} & $\begin{array}{c}\hat{0} \\
\dot{0} \\
H \\
\tilde{0} \\
\tilde{0}\end{array}$ & & $\begin{array}{c}\stackrel{\dot{ }}{i} \\
\vec{H} \\
\infty \\
\dot{q}\end{array}$ & $\mid \begin{array}{c}\overrightarrow{0} \\
\dot{0} \\
+ \\
\dot{0} \\
\ddot{0}\end{array}$ & $\left|\begin{array}{c}2 \\
0 \\
0 \\
+ \\
\\
0 \\
0\end{array}\right|$ & & $\begin{array}{l}\infty \\
i \\
H \\
\tilde{N} \\
\infty \\
-1\end{array}$ & $\begin{array}{l}0 \\
\text { +1 } \\
0\end{array}$ & $\begin{array}{l}0 \\
\text { H } \\
0\end{array}$ & $\begin{array}{l}0 \\
\text { H } \\
0\end{array}$ & \begin{tabular}{l|l}
0 & 0 \\
H & + \\
0
\end{tabular} & $\begin{array}{ll}0 \\
\text { H } \\
0\end{array}$ & $\begin{array}{l}0 \\
+ \\
0\end{array}$ & $\begin{array}{l}0 \\
0 \\
+1 \\
\tilde{1} \\
\infty \\
\end{array}$ & 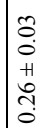 & $\begin{array}{l}\infty \\
0 \\
\dot{0} \\
H \\
\tilde{j} \\
\tilde{m}\end{array}$ \\
\hline$\Xi$ & & $\begin{array}{l}\infty \\
0 \\
0 \\
+ \\
+ \\
\stackrel{0}{i} \\
i\end{array}$ & $\begin{array}{c}\sim \\
\tilde{n} \\
+1 \\
\dot{n} \\
\dot{m} \\
n\end{array}$ & 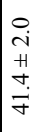 & \pm & & $\begin{array}{l}0 \\
+ \\
+ \\
\text { H }\end{array}$ & $\begin{array}{l}\bar{m} \\
+ \\
\hat{6} \\
-\end{array}$ & $\left|\begin{array}{c}m \\
+ \\
\vec{H} \\
\dot{0}\end{array}\right|$ & 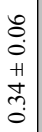 & & 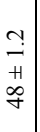 & $\mid \begin{array}{c}\tilde{O} \\
\dot{0} \\
+ \\
\infty \\
\infty \\
\dot{0}\end{array}$ & $\mid \begin{array}{c} \pm \\
0 \\
0 \\
+1 \\
\pm \\
0 \\
\end{array}$ & & $\begin{array}{l}\text { in } \\
\text { H } \\
\text { 品 }\end{array}$ & \begin{tabular}{l|l}
0 & \\
H & \\
0 &
\end{tabular} & $\begin{array}{l}0 \\
\text { H1 } \\
0\end{array}$ & $\begin{array}{l}0 \\
\text { H } \\
0\end{array}$ & \begin{tabular}{c|c}
0 & 0 \\
$H$ & + \\
0 & 0
\end{tabular} & $\begin{array}{l}\text { H } \\
\text { H } \\
0\end{array}$ & $\begin{array}{l}0 \\
+ \\
0 \\
0\end{array}$ & $\begin{array}{l}0 . \\
0 \\
+1 \\
\tilde{n} \\
\infty\end{array}$ & 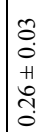 & $\begin{array}{l}\tilde{1} \\
0 \\
+1 \\
0 \\
\dot{m}\end{array}$ \\
\hline$=$ & & 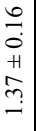 & 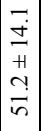 & $\begin{array}{l}\stackrel{\partial}{\dot{\gamma}} \\
+ \\
\tilde{m} \\
\stackrel{f}{f}\end{array}$ & \pm & & $\begin{array}{l}\mathbb{I} \\
I \\
+ \\
8 \\
0\end{array}$ & $\begin{array}{l}n \\
o \\
y \\
\text { m }\end{array}$ & $\begin{array}{l}-1 \\
0 \\
0 \\
+1 \\
0 \\
\infty \\
0\end{array}$ & $\begin{array}{l}\stackrel{g}{0} \\
\dot{0} \\
+ \\
\text { I } \\
\stackrel{0}{0}\end{array}$ & & 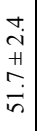 & $\begin{array}{c}\overrightarrow{0} \\
\dot{0} \\
+ \\
+ \\
\tilde{i} \\
0\end{array}$ & 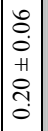 & & $\begin{array}{l}\stackrel{\sim}{\sim} \\
\stackrel{H}{\infty} \\
\infty \\
\infty \\
\sim\end{array}$ & $\begin{array}{l}\text { Dे } \\
\infty \\
+ \\
\tilde{~} \\
\infty \\
\infty\end{array}$ & $\begin{array}{l}\vec{n} \\
+ \\
\tilde{N}\end{array}$ & $\begin{array}{l}0 \\
\text { H1 } \\
0\end{array}$ & $\begin{array}{ll}n & \\
+ & + \\
n & + \\
n & \end{array}$ & $\begin{array}{ll}\text { H } \\
\text { H }\end{array}$ & $\begin{array}{l}0 \\
+ \\
0 \\
0\end{array}$ & $\begin{array}{l}-1 \\
0 \\
+1 \\
0 \\
\infty \\
\infty\end{array}$ & 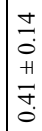 & $\begin{array}{l}n \\
o \\
+1 \\
\tilde{y} \\
m\end{array}$ \\
\hline- & 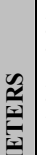 & $\begin{array}{l}\overrightarrow{0} \\
\dot{0} \\
+ \\
\overrightarrow{0} \\
\dot{-}\end{array}$ & 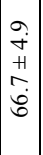 & $\begin{array}{l}\partial \\
\dot{0} \\
+ \\
\dot{m} \\
\dot{m}\end{array}$ & \pm & & $\begin{array}{l}\vec{n} \\
+1 \\
\infty \\
0 \\
0\end{array}$ & $\mid \begin{array}{l}2 \\
+1 \\
y \\
0 \\
m\end{array}$ & $\mid \begin{array}{l}n \\
0 \\
0 \\
+1 \\
0 \\
0 \\
0\end{array}$ & $\begin{array}{l}0 \\
0 \\
0 \\
+ \\
\infty \\
0 \\
0 \\
0\end{array}$ & & 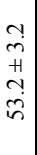 & $\mid \begin{array}{c}\tilde{O} \\
\dot{0} \\
+ \\
+ \\
\tilde{N} \\
0\end{array}$ & $\mid \begin{array}{c}\stackrel{2}{0} \\
\tilde{0} \\
+1 \\
\tilde{n} \\
0\end{array}$ & 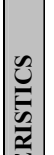 & 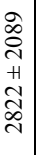 & 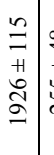 & $\begin{array}{l}\infty \\
+ \\
+ \\
n \\
n \\
n \\
n\end{array}$ & $\begin{array}{l}\stackrel{\text { I }}{1} \\
\text { H } \\
\text { \& }\end{array}$ & 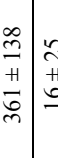 & 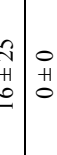 & $\begin{array}{l}0 \\
+1 \\
0\end{array}$ & $\begin{array}{l}-\overrightarrow{0} \\
+1 \\
0 \\
0 \\
\infty\end{array}$ & 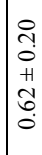 & 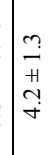 \\
\hline$\tilde{\Xi}$ & 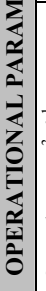 & 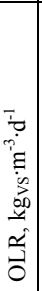 & 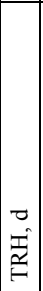 & 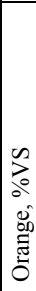 & 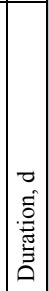 & 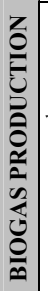 & 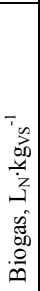 & 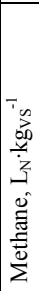 & 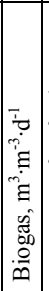 & 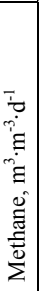 & 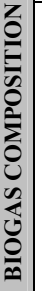 & 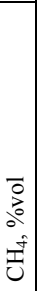 & 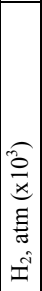 & 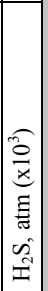 & 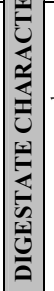 & 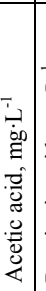 & 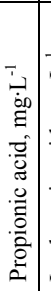 & 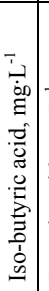 & 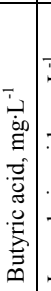 & 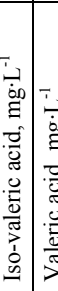 & 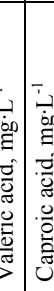 & 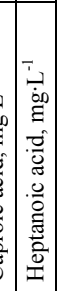 & 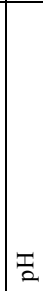 & 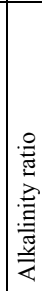 & 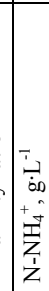 \\
\hline
\end{tabular}


Table 6.6. Average values and standard deviation in each period of experiment $C$.

\begin{tabular}{|c|c|c|c|c|c|c|c|c|c|c|c|c|c|c|c|c|c|c|c|c|c|c|c|c|}
\hline & & 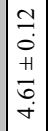 & 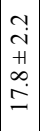 & $\begin{array}{l}n \\
-1 \\
+1 \\
\infty \\
\dot{8} \\
n\end{array}$ & 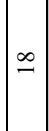 & & $\begin{array}{l}\overrightarrow{2} \\
\vec{z} \\
+ \\
\infty \\
\\
\end{array}$ & $\begin{array}{l}f \\
y \\
+1 \\
\alpha\end{array}$ & $\begin{array}{l}\tilde{N} \\
\tilde{0} \\
+1 \\
\infty \\
\approx \\
ت \\
ت\end{array}$ & $\begin{array}{l}\stackrel{1}{0} \\
0 \\
+ \\
0 \\
0 \\
0 \\
0\end{array}$ & & 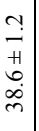 & 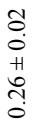 & 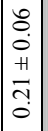 & & 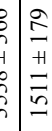 & 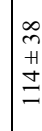 & $\begin{array}{l}\infty \\
\infty \\
+ \\
i \\
n\end{array}$ & 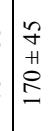 & $\begin{array}{l}2 \\
\vec{H} \\
=\end{array}$ & & & 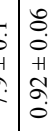 & $\begin{array}{l}\overrightarrow{0} \\
+ \\
\tilde{O} \\
\sim\end{array}$ \\
\hline & & $\begin{array}{l}\infty \\
0 \\
0 \\
+ \\
+ \\
\dot{+} \\
\dot{+} \\
\end{array}$ & $\mid \begin{array}{l}n \\
0 \\
+ \\
\tilde{y} \\
\tilde{z} \\
-\end{array}$ & $\begin{array}{l}\stackrel{0}{0} \\
\dot{0} \\
+ \\
\sim \\
\stackrel{\sigma}{q}\end{array}$ & $\simeq$ & & $\begin{array}{l}\vec{\lambda} \\
+ \\
\overrightarrow{\vec{N}}\end{array}$ & $\begin{array}{l}\hat{N} \\
+ \\
\tilde{\infty}\end{array}$ & $\begin{array}{l}\overrightarrow{\tilde{m}} \\
\hat{\sigma} \\
+ \\
\tilde{\sigma} \\
\tilde{o}\end{array}$ & 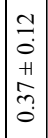 & & 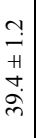 & $\begin{array}{l}\overline{0} \\
\dot{0} \\
+ \\
\tilde{n} \\
0\end{array}$ & $\begin{array}{l}\hat{0} \\
\dot{0} \\
+ \\
\tilde{m} \\
\tilde{0} \\
0\end{array}$ & 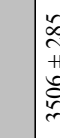 & 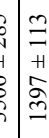 & 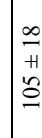 & $\begin{array}{l}\text { I } \\
\text { 年 } \\
\text { r }\end{array}$ & $\begin{array}{l}\text { N } \\
+ \\
0 \\
n \\
-\end{array}$ & $\begin{array}{l}0 \\
0 \\
\text { 1 } \\
0\end{array}$ & $\begin{array}{l}0 \\
\text { H } \\
0\end{array}$ & \begin{tabular}{l|l}
0 & 0 \\
+ & 0 \\
0 & + \\
0
\end{tabular} & 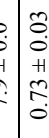 & $\underset{\sim}{\infty}$ \\
\hline & & $\begin{array}{l}\stackrel{o}{0} \\
\dot{0} \\
+ \\
0 \\
\dot{\sigma} \\
\dot{+}\end{array}$ & $\left|\begin{array}{c}n \\
i \\
+ \\
+ \\
m \\
\infty \\
-1 \\
-1\end{array}\right|$ & $\begin{array}{l}n \\
0 \\
+1 \\
+ \\
\dot{0} \\
\dot{f}\end{array}$ & $\cong$ & & $\begin{array}{l}f \\
+ \\
+ \\
\text { V }\end{array}$ & $\begin{array}{l}0 \\
+1 \\
+1 \\
\infty\end{array}$ & $\mid \begin{array}{l}- \\
0 \\
0 \\
+1 \\
\infty \\
\infty \\
0\end{array}$ & $\begin{array}{l}0 \\
\stackrel{0}{0} \\
0 \\
+1 \\
+ \\
\tilde{0} \\
0\end{array}$ & & 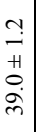 & 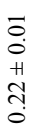 & $\begin{array}{l}n \\
0 \\
0 \\
+ \\
H \\
\vec{f} \\
0\end{array}$ & \begin{tabular}{l}
$\infty$ \\
\multirow{1}{*}{} \\
+ \\
0 \\
0 \\
0
\end{tabular} & 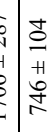 & $\begin{array}{l}\infty \\
+1 \\
m \\
m\end{array}$ & $\begin{array}{l}\text { Z } \\
\stackrel{+}{\simeq}\end{array}$ & $\begin{array}{l}2 \\
+1 \\
1 \\
6\end{array}$ & $\mid \begin{array}{l}0 \\
+1 \\
0\end{array}$ & $\begin{array}{l}0 \\
\text { म1 } \\
0\end{array}$ & \begin{tabular}{l|l}
0 & 0 \\
+ & 0 \\
0 & + \\
\end{tabular} & 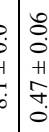 & $\begin{array}{l}\bar{D} \\
\dot{H} \\
\bar{m}\end{array}$ \\
\hline & & 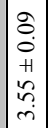 & 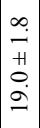 & $\begin{array}{l}n \\
0 \\
+1 \\
\infty \\
\infty \\
\dot{q}\end{array}$ & సे & & 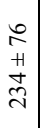 & $\begin{array}{l}m \\
m \\
+1 \\
8 \\
0\end{array}$ & $\begin{array}{l}\hat{y} \\
\hat{0} \\
+1 \\
\infty \\
\infty \\
0\end{array}$ & \begin{tabular}{l}
$\simeq$ \\
\hdashline \\
0 \\
+1 \\
$\sim$ \\
$\tilde{0}$ \\
0
\end{tabular} & & $\begin{array}{l}\vec{J} \\
\dot{\vec{H}} \\
\vec{J} \\
\vec{j}\end{array}$ & $\begin{array}{l}\tilde{O} \\
\dot{0} \\
+ \\
\tilde{T} \\
0\end{array}$ & 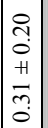 & $\begin{array}{l}\text { î } \\
\text { के } \\
\text { है } \\
\text { İ }\end{array}$ & 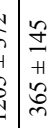 & $\begin{array}{l}a \\
+ \\
\text { b }\end{array}$ & $\begin{array}{l}0 \\
\text { 1 }\end{array}$ & 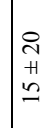 & $\mid \begin{array}{l}0 \\
+1 \\
0\end{array}$ & \begin{tabular}{l|l} 
& 0 \\
H & .
\end{tabular} & \begin{tabular}{l|l}
0 & 0 \\
+ & 0 \\
0 & + \\
\end{tabular} & 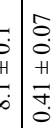 & 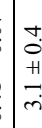 \\
\hline & & 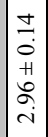 & 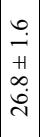 & $\begin{array}{l}\stackrel{0}{ } \\
\text { in } \\
+ \\
\vec{\sigma} \\
\dot{m}\end{array}$ & \pm & & $\begin{array}{l}\vec{n} \\
+ \\
\stackrel{n}{\sim} \\
\end{array}$ & $\mid \begin{array}{l}\tilde{A} \\
+ \\
\tilde{I} \\
\tilde{y}\end{array}$ & $\begin{array}{l} \pm \\
\\
0 \\
+1 \\
0 \\
0 \\
0\end{array}$ & $\mid \begin{array}{l}0 \\
0 \\
0 \\
+1 \\
0 \\
0 \\
0 \\
0\end{array}$ & & $\begin{array}{c}\infty \\
\dot{\sim} \\
\overrightarrow{+} \\
\dot{b} \\
\dot{b}\end{array}$ & $\begin{array}{l}\vec{a} \\
0 \\
+ \\
n \\
0 \\
0 \\
0\end{array}$ & $\mid \begin{array}{l}t \\
0 \\
0 \\
H \\
I \\
-1 \\
0\end{array}$ & $\begin{array}{l}\infty \\
0 \\
+ \\
0 \\
0\end{array}$ & 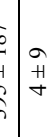 & $\begin{array}{l}\text { ㅇ } \\
\text { + }\end{array}$ & $\begin{array}{l}0 \\
\text { H }\end{array}$ & $\begin{array}{l}O \\
\text { H } \\
\text { in }\end{array}$ & $\begin{array}{l}0 \\
+ \\
0\end{array}$ & $\begin{array}{l}0 \\
\text { 1 } \\
0\end{array}$ & \begin{tabular}{l|l}
0 & 0 \\
+ & + \\
0 & + \\
0 & $\alpha$
\end{tabular} & 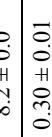 & $\left\{\begin{array}{l}\overrightarrow{0} \\
\frac{1}{m}\end{array}\right.$ \\
\hline & & 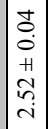 & 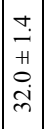 & $\begin{array}{l}\infty \\
0 \\
\dot{0} \\
+1 \\
\sim \\
\tilde{\sigma} \\
\dot{\sigma}\end{array}$ & $\because$ & & 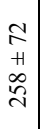 & $\begin{array}{l}2 \\
m \\
+1 \\
= \\
\Xi\end{array}$ & \begin{tabular}{l}
$\infty$ \\
\hdashline \\
0 \\
+1 \\
0 \\
0 \\
0
\end{tabular} & 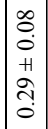 & & $\begin{array}{c}0 \\
\dot{r} \\
H \\
0 \\
\dot{g} \\
\dot{q}\end{array}$ & \begin{tabular}{|l|}
$\overrightarrow{0}$ \\
0 \\
+ \\
+ \\
\pm \\
\\
\end{tabular} & 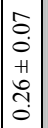 & $\begin{array}{l}8 \\
+ \\
i \\
i n\end{array}$ & 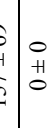 & $\begin{array}{l}0 \\
\text { H } \\
\text { O }\end{array}$ & $\begin{array}{l}0 \\
\text { 1 } \\
0\end{array}$ & $\begin{array}{l}0 \\
+1 \\
0\end{array}$ & $\begin{array}{l}0 \\
+ \\
0\end{array}$ & $\begin{array}{l}0 \\
\text { H } \\
0\end{array}$ & \begin{tabular}{l|l}
0 & 0 \\
+ & 0 \\
+ & + \\
0 & 0
\end{tabular} & 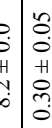 & $\begin{array}{l}2 \\
\dot{0} \\
\frac{1}{m}\end{array}$ \\
\hline & & $\begin{array}{l}\tilde{O} \\
\dot{0} \\
+ \\
\tilde{O} \\
\dot{i} \\
\end{array}$ & $\mid \begin{array}{l}\vec{m} \\
+ \\
m \\
\tilde{m} \\
\tilde{m}\end{array}$ & $\begin{array}{l}3 \\
0 \\
+1 \\
\text { के } \\
\hat{q}\end{array}$ & \pm & & $\begin{array}{l}n \\
n \\
H \\
\tilde{d} \\
n\end{array}$ & 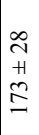 & $\begin{array}{l}= \\
0 \\
+ \\
H \\
\tilde{0} \\
0\end{array}$ & $\mid \begin{array}{c}8 \\
0 \\
0 \\
+1 \\
0 \\
\tilde{c} \\
0\end{array}$ & & 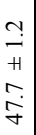 & $\mid \begin{array}{c}\tilde{O} \\
0 \\
0 \\
+ \\
0 \\
0 \\
0 \\
0\end{array}$ & $\mid \begin{array}{c}0 \\
0 \\
0 \\
+ \\
+ \\
0 \\
0 \\
0\end{array}$ & $\begin{array}{l}0 \\
+ \\
+ \\
9 \\
=\end{array}$ & 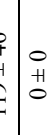 & $\begin{array}{l}\circ \\
\text { H } \\
\text { O }\end{array}$ & $\begin{array}{l}0 \\
\text { 1 } \\
0\end{array}$ & $\begin{array}{l}0 \\
\text { 1 }\end{array}$ & $\begin{array}{l}0 \\
+ \\
0\end{array}$ & $\begin{array}{l}0 \\
\text { H } \\
0\end{array}$ & & 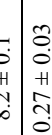 & $\begin{array}{l}0 \\
0 \\
+ \\
2 \\
2\end{array}$ \\
\hline & & $\begin{array}{l}n \\
\stackrel{n}{0} \\
+1 \\
+ \\
- \\
-\end{array}$ & 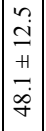 & 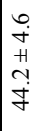 & \pm & & 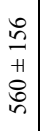 & $\begin{array}{l}\infty \\
+ \\
+ \\
\tilde{i} \\
\text { în }\end{array}$ & $\begin{array}{l}n \\
\stackrel{n}{0} \\
+ \\
\text { n } \\
\hat{0}\end{array}$ & $\begin{array}{l}0 \\
\stackrel{0}{0} \\
0 \\
+ \\
0 \\
\dot{0} \\
0\end{array}$ & & $\begin{array}{l}\infty \\
i \\
+ \\
0 \\
i \\
i\end{array}$ & $\begin{array}{l}\overrightarrow{0} \\
\dot{0} \\
+1 \\
\infty \\
0 \\
0 \\
0\end{array}$ & 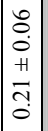 & 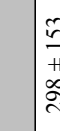 & 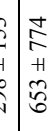 & $\begin{array}{l}\text { तै } \\
\text { I } \\
\text { I }\end{array}$ & $\begin{array}{l}0 \\
\text { 1 }\end{array}$ & 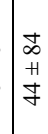 & $\begin{array}{l}0 \\
+ \\
0\end{array}$ & $\begin{array}{l}0 \\
\text { +1 } \\
0\end{array}$ & \begin{tabular}{l|l}
0 & 0 \\
+ & + \\
0 & + \\
0 &
\end{tabular} & 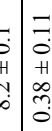 & $\begin{array}{l}n \\
0 \\
+ \\
m\end{array}$ \\
\hline & 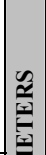 & $\begin{array}{l}0 \\
0 \\
0 \\
+1 \\
\tilde{c} \\
- \\
- \\
\end{array}$ & \begin{tabular}{|l|}
$\infty$ \\
$\dot{0}$ \\
+ \\
+ \\
$\infty$ \\
$\dot{0}$ \\
\end{tabular} & $\begin{array}{l}0 \\
\text { i } \\
+1 \\
\stackrel{\partial}{o} \\
\dot{q}\end{array}$ & \pm & & $\begin{array}{l}\stackrel{m}{m} \\
+1 \\
\frac{\infty}{b}\end{array}$ & $\mid \begin{array}{l}\sigma \\
\hat{H} \\
+ \\
\tilde{m} \\
m\end{array}$ & $\begin{array}{l} \pm \\
\\
0 \\
+ \\
0 \\
0 \\
0\end{array}$ & 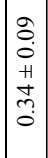 & & $\begin{array}{l}m \\
\dot{m} \\
+ \\
0 \\
\dot{n} \\
n\end{array}$ & 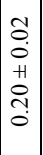 & $\begin{array}{l}\vec{T} \\
0 \\
+ \\
+ \\
\stackrel{t}{0} \\
0\end{array}$ & 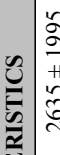 & 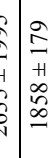 & $\begin{array}{l}+ \\
+ \\
\text { मे } \\
\text { } \\
\text { N }\end{array}$ & 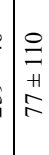 & $\begin{array}{l}\mathfrak{n} \\
\text { I } \\
+ \\
b \\
\infty \\
m\end{array}$ & $\begin{array}{l}\tilde{N} \\
+ \\
\pm \\
-\end{array}$ & $\begin{array}{l}0 \\
\text { H } \\
0\end{array}$ & & 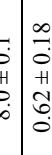 & $\begin{array}{l}\frac{1}{7} \\
7 \\
7\end{array}$ \\
\hline & 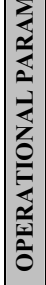 & 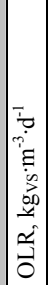 & $\begin{array}{l}\vec{\Xi} \\
\overrightarrow{\widetilde{Z}} \\
\widetilde{\widetilde{F}}\end{array}$ & 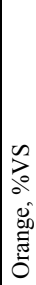 & 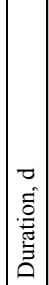 & 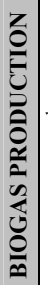 & 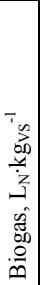 & 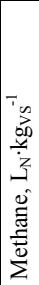 & 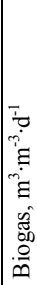 & 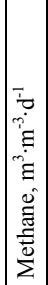 & 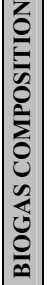 & $\begin{array}{l}\overrightarrow{0} \\
\vdots \\
0 \\
0 \\
\vec{y} \\
\vec{y}\end{array}$ & 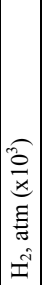 & 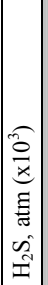 & 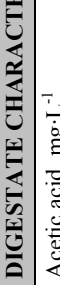 & 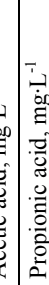 & 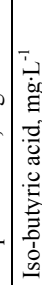 & 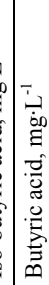 & 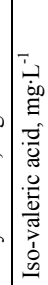 & 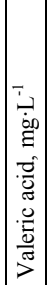 & 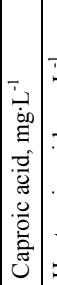 & 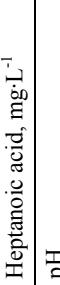 & 卧| & $\begin{array}{l}7 \\
\vdots \\
\vdots \\
z \\
z \\
z\end{array}$ \\
\hline
\end{tabular}


Table 6.7. Average values and standard deviation in each period of experiment D.

\begin{tabular}{|c|c|c|c|c|c|c|c|c|c|c|c|c|c|c|c|c|c|c|c|c|c|c|c|c|c|}
\hline & & $\begin{array}{c}0 \\
0 \\
0 \\
+ \\
1 \\
0 \\
+ \\
+\end{array}$ & 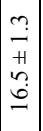 & $\begin{array}{l}= \\
\text { I } \\
+ \\
\text { त. } \\
\text { in }\end{array}$ & 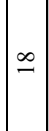 & & $\begin{array}{l}\hat{m} \\
\vec{n} \\
+ \\
+ \\
m \\
m\end{array}$ & $\begin{array}{l}\vec{n} \\
+ \\
\sigma \\
\text { a }\end{array}$ & $\begin{array}{l}3 \\
0 \\
0 \\
H \\
\text { H } \\
\text { I. } \\
-\end{array}$ & 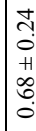 & & $\begin{array}{l}\vec{i} \\
+ \\
+ \\
0 \\
\dot{m} \\
\dot{m}\end{array}$ & $\begin{array}{l}\tilde{O} \\
0 \\
+ \\
\ddot{0} \\
\tilde{e} \\
0\end{array}$ & $\begin{array}{l}n \\
0 \\
0 \\
H \\
\tilde{J} \\
\tilde{o}\end{array}$ & & $\begin{array}{l}\mathscr{n} \\
\infty \\
+1 \\
n \\
\tilde{f} \\
\tilde{y}\end{array}$ & $\begin{array}{l}\hat{2} \\
+ \\
\hat{2} \\
\hat{2}\end{array}$ & $\begin{array}{l}8 \\
+1 \\
0 \\
6\end{array}$ & $\mid \begin{array}{c}\stackrel{2}{m} \\
+ \\
\cong \\
ٍ\end{array}$ & & & & 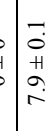 & $\begin{array}{l}n \\
\tilde{o} \\
+ \\
\tilde{\sigma} \\
\tilde{o}\end{array}$ & 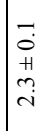 \\
\hline & & $\begin{array}{c} \pm \\
\dot{0} \\
+ \\
\dot{1} \\
\dot{v} \\
\dot{v}\end{array}$ & $\begin{array}{c}0 \\
0 \\
+1 \\
m \\
\tilde{n} \\
-\end{array}$ & $\mid \begin{array}{l}\mathcal{I} \\
\text { H } \\
\tilde{y} \\
\text { o }\end{array}$ & $\simeq$ & & 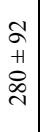 & $\begin{array}{l}f \\
y \\
H \\
I \\
I \\
g\end{array}$ & $\begin{array}{l}\text { fo } \\
0 \\
\text { H } \\
\text { İ } \\
\text { In }\end{array}$ & $\begin{array}{l}2 \\
0 \\
+ \\
1 \\
n \\
0 \\
0\end{array}$ & & $\begin{array}{l}n \\
\stackrel{n}{H} \\
\text { r } \\
\text { f } \\
\dot{f}\end{array}$ & $\begin{array}{l}\delta \\
\delta \\
0 \\
\ddot{1} \\
\tilde{O} \\
0\end{array}$ & $\begin{array}{l}\hat{0} \\
0 \\
+ \\
\tilde{n} \\
\tilde{o} \\
0\end{array}$ & & $\begin{array}{l}\hat{\sigma} \\
+1 \\
\tilde{n} \\
\tilde{n}\end{array}$ & $\begin{array}{l}\Omega \\
\Xi \\
+ \\
\underline{O} \\
\underline{-}\end{array}$ & $\begin{array}{l}\simeq \\
+ \\
\infty\end{array}$ & $\begin{array}{l}m \\
+ \\
-1\end{array}$ & $\begin{array}{l}\text { 开 } \\
\text { H } \\
=\end{array}$ & & \begin{tabular}{c|c}
0 \\
+ & + \\
0 & + \\
0
\end{tabular} & $\begin{array}{l}0 \\
\dot{0} \\
+ \\
\dot{0} \\
\infty \\
\infty\end{array}$ & $\begin{array}{l}8 \\
\stackrel{0}{0} \\
+ \\
\text { if } \\
\text { f. }\end{array}$ & $\vec{m}$ \\
\hline & & $\begin{array}{c}= \\
\overrightarrow{0} \\
+ \\
+1 \\
\underset{+}{+}\end{array}$ & $\mid \begin{array}{c}n \\
n \\
+ \\
m \\
\infty \\
-\end{array}$ & $\begin{array}{l}n \\
0 \\
+1 \\
m \\
o \\
q\end{array}$ & $\cong$ & & $\begin{array}{l}0 \\
n \\
n \\
n \\
\tilde{N}\end{array}$ & 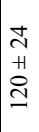 & $\begin{array}{l}\tilde{N} \\
\text { O } \\
+ \\
\cong \\
\cong \\
-\end{array}$ & \begin{tabular}{l}
0 \\
\hdashline \\
0 \\
+1 \\
$\stackrel{+}{0}$ \\
0
\end{tabular} & & 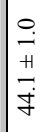 & 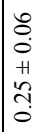 & 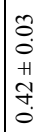 & & 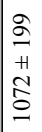 & 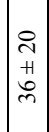 & $\begin{array}{l}0 \\
+ \\
0\end{array}$ & $\begin{array}{l}0 \\
\text { H } \\
0\end{array}$ & $\begin{array}{l}+ \\
+ \\
H \\
\sim\end{array}$ & & \begin{tabular}{c|c}
0 & 0 \\
0 & +1 \\
0 & 0
\end{tabular} & $\mid \begin{array}{l}\overrightarrow{0} \\
+1 \\
\vec{\infty}\end{array}$ & $\begin{array}{l}\tilde{o} \\
\dot{0} \\
+1 \\
\tilde{D} \\
\tilde{o} \\
0\end{array}$ & $\begin{array}{l}\stackrel{0}{0} \\
\text { H } \\
\dot{m}\end{array}$ \\
\hline & & $\begin{array}{c} \pm \\
\pm \\
0 \\
+1 \\
\tilde{n} \\
\tilde{n} \\
\tilde{n}\end{array}$ & $\mid \begin{array}{l}a \\
\dot{a} \\
\hat{\sigma} \\
\infty \\
-\end{array}$ & $\begin{array}{l}\hat{O} \\
\dot{0} \\
\dot{0} \\
\dot{\sigma} \\
\dot{q}\end{array}$ & ते & & 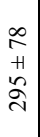 & $\mid \begin{array}{l}n \\
+1 \\
\ddot{m} \\
m\end{array}$ & 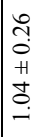 & $\begin{array}{l}7 \\
0 \\
0 \\
+ \\
0 \\
0 \\
0\end{array}$ & & $\begin{array}{l}f \\
\text { H } \\
H \\
\text { J. } \\
\dot{f}\end{array}$ & $\begin{array}{l}\text { I } \\
0 \\
0 \\
\text { H } \\
\text { Ju } \\
0\end{array}$ & 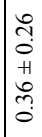 & & 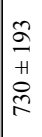 & $\begin{array}{l}\stackrel{N}{N} \\
+ \\
\pm \\
\pm\end{array}$ & $\begin{array}{l}0 \\
+1 \\
0\end{array}$ & $\begin{array}{l}0 \\
+ \\
0\end{array}$ & $\begin{array}{l}0 \\
\text { H1 } \\
0\end{array}$ & & \begin{tabular}{c|c}
0 & 0 \\
+1 & +1 \\
0 & 0
\end{tabular} & 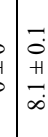 & $\mid \begin{array}{l}\mathscr{0} \\
\dot{0} \\
+ \\
\text { + } \\
\tilde{0} \\
\tilde{0}\end{array}$ & $\begin{array}{c}0 \\
\dot{0} \\
+1 \\
\dot{H} \\
\dot{m}\end{array}$ \\
\hline & & $\mid \begin{array}{l}n \\
0 \\
0 \\
1 \\
0 \\
8 \\
\dot{m}\end{array}$ & $\begin{array}{c}\tilde{I} \\
\dot{H} \\
\dot{0} \\
\dot{\dot{d}} \\
\sim\end{array}$ & $\mid \begin{array}{l}0 \\
0 \\
+1 \\
0 \\
\dot{+}\end{array}$ & \pm & & $\begin{array}{l}\text { in } \\
+ \\
n \\
\text { yn } \\
\text { m }\end{array}$ & 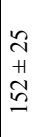 & $\begin{array}{l}\infty \\
\stackrel{\infty}{0} \\
+1 \\
\stackrel{0}{-} \\
-\end{array}$ & $\begin{array}{l}\infty \\
0 \\
0 \\
+ \\
+ \\
\text { if } \\
0\end{array}$ & & $\begin{array}{l}0 \\
\dot{T} \\
H \\
+ \\
\dot{+} \\
\dot{+}\end{array}$ & $\mid \begin{array}{l}0 \\
0 \\
0 \\
+1 \\
0 \\
0 \\
0\end{array}$ & $\begin{array}{l}n \\
0 \\
0 \\
+1 \\
= \\
0 \\
0\end{array}$ & & $\begin{array}{l}\Xi \\
\Xi \\
+ \\
\\
\tilde{n}\end{array}$ & $\begin{array}{l}0 \\
+1 \\
0\end{array}$ & $\begin{array}{l}0 \\
\text { H } \\
0\end{array}$ & $\begin{array}{l}0 \\
\text { H } \\
0\end{array}$ & F & & \begin{tabular}{l|l}
0 & 0 \\
& 0 \\
0 & + \\
\end{tabular} & $\begin{array}{l}\overrightarrow{0} \\
\dot{y} \\
\sim \\
\infty \\
\dot{H}\end{array}$ & 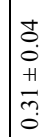 & 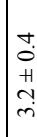 \\
\hline & & 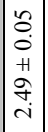 & 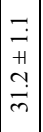 & $\mid \begin{array}{l}\hat{O} \\
+ \\
\text { + } \\
\dot{\sigma}\end{array}$ & $\because$ & & \begin{tabular}{|l|}
$\vec{\sigma}$ \\
+ \\
$\tilde{y}$ \\
$\tilde{m}$
\end{tabular} & 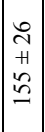 & $\begin{array}{l}\stackrel{2}{2} \\
0 \\
0 \\
+1 \\
\infty \\
0 \\
0\end{array}$ & 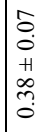 & & $\begin{array}{l}n \\
n \\
+ \\
m \\
n \\
\text { f }\end{array}$ & $\begin{array}{l}\tilde{O} \\
0 \\
0 \\
+1 \\
\stackrel{H}{0} \\
\stackrel{0}{0}\end{array}$ & $\begin{array}{l}0 \\
0 \\
0 \\
H \\
1 \\
I \\
0 \\
0\end{array}$ & & $\mid \begin{array}{l}2 \\
+1 \\
2 \\
2\end{array}$ & $\begin{array}{l}0 \\
+ \\
0\end{array}$ & $\begin{array}{l}0 \\
+1 \\
0\end{array}$ & $\mid \begin{array}{l}0 \\
+1 \\
0\end{array}$ & $\begin{array}{l}0 \\
\text { 11 } \\
0\end{array}$ & & \begin{tabular}{l|l}
0 & 0 \\
$H$ & $H$ \\
0 & H
\end{tabular} & $\begin{array}{l}0 \\
0 \\
0 \\
+1 \\
\sim \\
\infty \\
\infty\end{array}$ & $\begin{array}{l}\text { t } \\
0 \\
0 \\
+1 \\
0 \\
0 \\
0\end{array}$ & $\begin{array}{l}\hat{0} \\
\dot{0} \\
\sim \\
\tilde{n}\end{array}$ \\
\hline & & $\begin{array}{c}\tilde{0} \\
\dot{0} \\
+ \\
\dot{0} \\
\dot{i}\end{array}$ & $\mid \begin{array}{c}n \\
m \\
+ \\
r \\
\dot{m} \\
m\end{array}$ & $\begin{array}{l}\stackrel{0}{0} \\
\dot{0} \\
+ \\
\dot{\sigma}\end{array}$ & \pm & & $\mid \begin{array}{l}0 \\
\stackrel{n}{n} \\
+1 \\
2 \\
\text { mे }\end{array}$ & $\begin{array}{l}\hat{\sim} \\
+ \\
\infty \\
\infty \\
-\end{array}$ & $\begin{array}{l}= \\
0 \\
0 \\
+1 \\
0 \\
0 \\
0\end{array}$ & 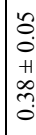 & & 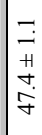 & 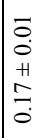 & 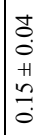 & & $\mid \begin{array}{l}\vec{g} \\
+ \\
\tilde{m} \\
\end{array}$ & $\begin{array}{l}0 \\
+ \\
0\end{array}$ & $\begin{array}{l}0 \\
+ \\
0\end{array}$ & $\begin{array}{l}0 \\
+1 \\
0\end{array}$ & $\begin{array}{l}0 \\
\ddot{1} \\
0\end{array}$ & & \begin{tabular}{l|l}
0 & 0 \\
$H$ & \\
0 & 0
\end{tabular} & $\begin{array}{l}\overrightarrow{0} \\
\dot{0} \\
+ \\
\sim \\
\infty \\
\infty\end{array}$ & 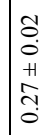 & $\begin{array}{l}\overrightarrow{0} \\
+ \\
+ \\
\hat{i}\end{array}$ \\
\hline & & \begin{tabular}{l}
$n$ \\
\hdashline \\
0 \\
+1 \\
0 \\
+ \\
-
\end{tabular} & $\begin{array}{l}0 \\
\tilde{m} \\
+1 \\
+ \\
\dot{n} \\
\dot{n}\end{array}$ & $\begin{array}{l}\infty \\
\dot{+} \\
+ \\
\infty \\
\dot{f}\end{array}$ & \pm & & $\begin{array}{l}\stackrel{0}{\sim} \\
\vec{\sim} \\
+ \\
\infty \\
\vec{n}\end{array}$ & $\begin{array}{l}\tilde{2} \\
\hat{H} \\
\tilde{i} \\
\hat{i}\end{array}$ & $\begin{array}{l}\text { I } \\
\text { o } \\
\text { H } \\
\stackrel{2}{0} \\
\text { o }\end{array}$ & 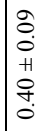 & & $\begin{array}{l}0 \\
i \\
+ \\
+ \\
\hat{\delta} \\
\hat{s}\end{array}$ & $\mid \begin{array}{l}\overrightarrow{0} \\
0 \\
+1 \\
\infty \\
\stackrel{0}{0}\end{array}$ & \begin{tabular}{l}
$n$ \\
0 \\
0 \\
$H$ \\
I \\
\hdashline \\
0
\end{tabular} & & 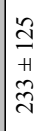 & $\begin{array}{c}\vec{b} \\
\dot{0} \\
+ \\
n \\
i n \\
i n\end{array}$ & $\begin{array}{l}\hat{e} \\
+ \\
\simeq \\
-\end{array}$ & $\begin{array}{l}0 \\
+1 \\
0\end{array}$ & $\begin{array}{l}8 \\
\dot{0} \\
\ddot{m} \\
m\end{array}$ & $\begin{array}{l}0 \\
\text { H } \\
0\end{array}$ & \begin{tabular}{l|l}
0 & 0 \\
H & H \\
0 & 0
\end{tabular} & $\begin{array}{l}\vec{z} \\
+ \\
\sim \\
\sim \\
\infty \\
\infty\end{array}$ & $\begin{array}{c}a \\
o \\
0 \\
+1 \\
\hat{o} \\
\tilde{o} \\
0\end{array}$ & $\begin{array}{l}n \\
0 \\
\ddot{H} \\
\tilde{m}\end{array}$ \\
\hline & $\frac{\pi}{x}$ & $\begin{array}{c}\tilde{O} \\
\dot{d} \\
+ \\
\tilde{\delta} \\
\dot{-} \\
-\end{array}$ & $\mid \begin{array}{c}\infty \\
n \\
n \\
+1 \\
n \\
n \\
0\end{array}$ & $\begin{array}{l}\infty \\
\dot{0} \\
+1 \\
\stackrel{2}{2} \\
\dot{m}\end{array}$ & \pm & & $\begin{array}{l}\bar{T} \\
+ \\
\stackrel{\partial}{0}\end{array}$ & $\mid \begin{array}{l}6 \\
0 \\
+1 \\
6 \\
0 \\
n\end{array}$ & $\begin{array}{l}\mathcal{I} \\
0 \\
+1 \\
\infty \\
0 \\
0 \\
0\end{array}$ & 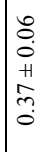 & & $\begin{array}{l}\vec{v} \\
i \\
+ \\
\hat{~} \\
\text { ì }\end{array}$ & 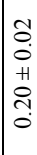 & 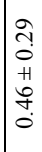 & 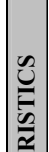 & 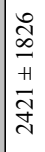 & $\begin{array}{l}\Xi \\
\Xi \\
+ \\
2 \\
\infty \\
\infty\end{array}$ & \begin{tabular}{l}
$\mathbb{N}$ \\
+ \\
$\mathbb{Z}$ \\
\multirow{2}{*}{}
\end{tabular} & $\begin{array}{l}8 \\
2 \\
+1 \\
0\end{array}$ & $\begin{array}{l}\vec{J} \\
+ \\
\infty \\
m \\
m\end{array}$ & $\begin{array}{l}\text { A } \\
\text { H } \\
\text { I }\end{array}$ & \begin{tabular}{l|l}
0 & 0 \\
+ & + \\
0 & 0 \\
0
\end{tabular} & $\begin{array}{l}- \\
0 \\
0 \\
+1 \\
0 \\
\infty\end{array}$ & $\begin{array}{l}0 \\
0 \\
0 \\
+1 \\
\infty \\
0 \\
0 \\
0\end{array}$ & $\begin{array}{l}\stackrel{+}{+} \\
\stackrel{+}{+} \\
\stackrel{f}{*}\end{array}$ \\
\hline & 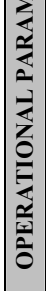 & 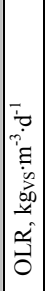 & 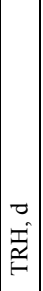 & 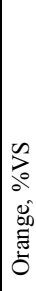 & 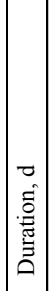 & 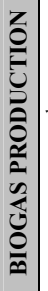 & 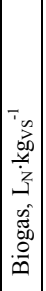 & 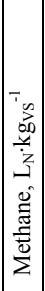 & 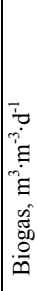 & 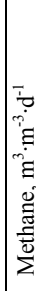 & 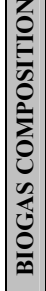 & 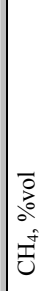 & 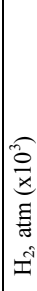 & 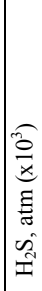 & 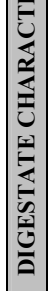 & 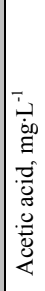 & 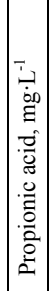 & 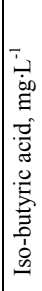 & 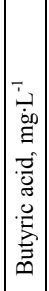 & 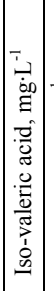 & 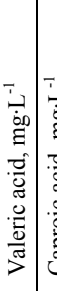 & 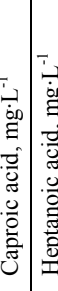 & 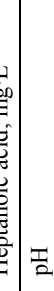 & 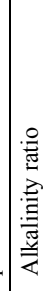 & 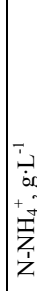 \\
\hline
\end{tabular}




\subsection{References}

Angelidaki, I., Ahring B.K. 1993. Thermophilic anaerobic digestion of livestock waste: the effect of ammonia. Applied Microbiology and Biotechnology 38, 560-564.

APHA-AWWA-WEF. 2006. Standard Methods for the examination of water and wastewater. American Public Health Association / American Water Works Association / Water Environment Federation. 19 ${ }^{\text {th }}$ ed., Washington DC, USA.

Batstone, D.J., Keller J., Angelidaki I., Kalyuzhny S.V., Pavlostathis S.G., Rozzi A., Sanders W.T.M., Siegrist H., Vavilin V.A. 2000. Anaerobic Digestion Model No. 1. ISBN 1-900222-24-8.

CAPA. 2011. Informe del sector agrario valenciano 2011. Capítulo IV: estadísticas agrícolas. Cuadro 4.12: superficies, producciones y destino de la producción de cítricos. Comunitat Valenciana. Campaña 2010/2011. Conselleria de Agricultura, Pesca y Alimentación.

Effenberger, M., Lebuhn, M., Gronauer, A. 2007. Fermentermanagement - Stabiler Prozess bei NawaRo-Anlagen. 16. Jahrestagung des Fachvervandes Biogas e.V. Leipzig (Germany) $31^{\text {st }}$ january $-2^{\text {nd }}$ february.

Forgács, G., Pourbafrani, M., Niklasson, C., Taherzadeh, M.T., Hováth, I.S. (2011). Methane production from citrus wastes: process development and cost estimation. J. Chem. Technol. Biotechnol. 87, 250-255.

Kaparaju, P.L.N., Rintala, J.A. 2006. Thermophilic anaerobic digestión of industrial orange waste. Environmental Technology 27, 623-633.

Lane, A.G. 1980. Production of aromatic acids during anaerobic digestion of citrus peel. Journal of Chemical Technology and Biotechnology 30, 345-350.

Lane, A.G. 1984. Anaerobic digestion of orange peel. Food Technology in Australia 36, 125-127.

Martín, M.A., Siles, J.A., Chica, A.F., Martín, A. 2010. Biomethanization of orange peel waste. Bioresource Technology 101, 8993-8999.

Martín M.A., Fernández R., Serrano A., Siles J.A. 2013. Semi-continuous anaerobic digestion of orange peel waste and residual glycerol derived from biodiesel manufacturing. Waste Management 33, 1633-1639.

Mizuki, E., Akao, T., Saruwatari, T. 1990. Inhibitory effect of Citrus unshu peel on anaerobic digestion. Biological Wastes 33, 161-168.

Ruiz B., Flotats X. 2014. Citrus essential oils and their influence on the anaerobic digestion process: An overview. Waste Management 34, 2063-2079.

VDI - Verein Deutscher Ingenieure. 2006. Fermentation of organic materials. Characterisation of the substrate, sampling, collection of material data, fermentation tests. ICS 13.030.30;27.190.

Westerholm, M., Moestedt, J., Schnürer, A. 2013. Improved biogas production at high ammonia by management of reactor operation for support of syntrophic acetate oxidisers. $13^{\text {th }}$ IWA World Congress on Anaerobic Digestion. 25-28 June 2013, Santiago de Compostela, Spain. 


\title{
Chapter 7
}

\section{Biological and extractive pretreatments of orange peel and codigestion with cow manure as strategies to overcome inhibition of anaerobic digestion by citrus essential oil}

\begin{abstract}
Anaerobic co-digestion of orange peel was carried out with cow manure, in order to provide enough nutrients and buffer capacity to the digester. Three different strategies were tested to avoid the expected inhibition by citrus essential oil: long adaptation times, biological treatment by fungi of the orange peel and ethanol extraction of the limonene from the orange peel.

Neither the long adaptation times, nor the biological treatment, allowed for a stable process with a mixture composition of $80 \%$ orange peel and $20 \%$ cow manure (volatile solids basis). On the contrary, the ethanol extraction of the limonene previously to the anaerobic co-digestion of $95 \%$ orange peel and $5 \%$ cow manure (volatile solids basis) allowed to reach a stable process until an organic loading rate of $3.5 \mathrm{kgvs} \cdot \mathrm{m}^{-3} \cdot \mathrm{d}^{-1}$, with a methane yield of $286 \mathrm{~L} \cdot \mathrm{kg}_{\mathrm{VS}}{ }^{-1}$ and $0.99 \mathrm{~m}^{3} \cdot \mathrm{m}_{\text {digester }}^{-3} \cdot \mathrm{d}^{-1}$. At higher organic loading rates, accumulation of volatile fatty acids was observed due to organic overloading, but not inhibition by citrus essential oil.
\end{abstract}




\section{Table of contents}

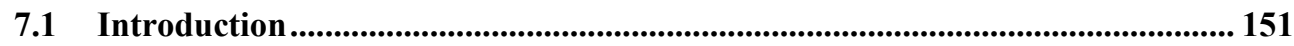

7.2 Materials and methods ........................................................................................ 152

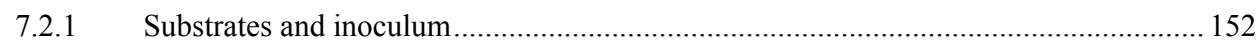

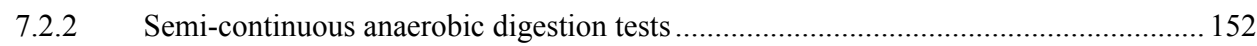

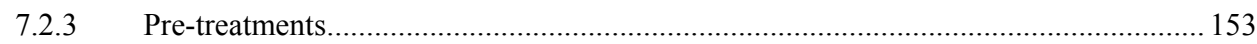

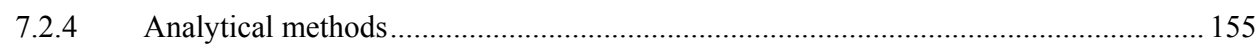

7.3 Results and discussion.............................................................................................. 155

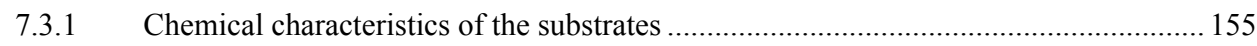

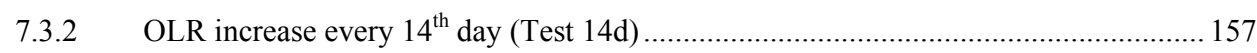

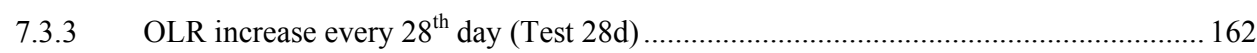

7.3.4 Biological treatment and OLR increase every $14^{\text {th }}$ day (Test $\left.14 \mathrm{dBT}\right) \ldots \ldots \ldots \ldots \ldots \ldots \ldots \ldots \ldots . . . . . . . . . . . .168$

7.3.5 Biological treatment and OLR increase every $28^{\text {th }}$ day (Test 28dBT) ........................ 176

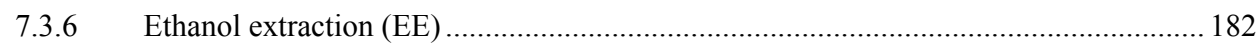

7.4 Conclusions ................................................................................................................... 186

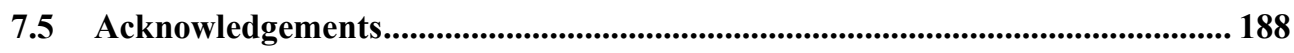

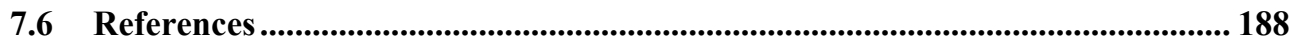




\subsection{Introduction}

As argumented in previous chapters, anaerobic digestion is a technically feasible, environmentally friendly and energy efficient process for the valorisation of citrus waste. However, the citrus essential oil (CEO), inhibitor of the anaerobic digestion, and the lack of nutrients, hampers the valorisation of citrus waste through this technology.

Lane (1984), Mizuki et al. (1990), Kaparaju and Rintala (2006) and Martín et al. (2010) studied the anaerobic digestion of citrus peel. In all cases dilution, $\mathrm{pH}$ adjustment and/or supplementation with micro and macro nutrients was applied in order to overcome the lack of nutrients and the acidity of the citrus peel. The maximum organic loading rate (OLR) values reached in mesophilic conditions were between 2.0 and $3.5 \mathrm{~kg}_{\mathrm{vs}} \cdot \mathrm{m}^{-3} \cdot \mathrm{d}^{-1}$ corresponding to limonene dosages between 24 and $75 \mathrm{mg} \cdot \mathrm{L}_{\text {digester }}{ }^{-1} \cdot \mathrm{d}^{-1}$. The methane production ranged between 0.25 and $0.29 \mathrm{~m}^{3} \cdot \mathrm{kg}_{\mathrm{vs}}{ }^{-1}$.

At industrial scale, the addition of nutrients and buffering solutions would reduce the economic feasibility of the plants. Lane (1984) suggested that the co-digestion of citrus waste with nitrogen-rich manure could be an economic alternative. Co-digestion experiments of citrus waste with different substrates have been carried out by Forgács et al. (2011) and Martín et al. (2013). While the methane production of the mixture was higher than the values reported in the literature for the citrus waste alone, the maximum limonene dose was in the same range than in the experiments with citrus waste only. In chapter 5 , the anaerobic co-digestion of citrus waste (orange and mandarin peel) with pig and chicken manure was assessed. Similar results to the literature were obtained, in terms of maximum OLR reached $\left(2.2 \mathrm{~kg}_{\mathrm{VS}} \cdot \mathrm{m}^{-3} \cdot \mathrm{d}^{-1}\right)$, maximum limonene dose $\left(26.5 \mathrm{mg} \cdot \mathrm{L}_{\text {digester }}{ }^{-1} \cdot \mathrm{d}^{-1}\right)$ and methane yield $\left(0.23 \mathrm{~m}^{3} \cdot \mathrm{kg}_{\mathrm{vs}}{ }^{-1}\right)$. Thus, co-digestion alone is not capable to overcome the inhibition of the anaerobic digestion by the CEO, and pretreatments are necessary to remove or recover the CEO from the citrus peel.

In chapter 6, citrus waste consisting in citrus fruit with and without pre-treatment was codigested with cow manure. Compared with the process with no pretreatment of the orange peel, a significant improvement in the methane yield (48\%) was observed in the experiment that included mechanical removal of limonene as a pretreatment, while the thermal treatment did not have any influence on the process. In the batch anaerobic digestion experiments performed in chapter 4 , different pre-treatments were applied to the orange peel to remove or recover limonene, being the most energy efficient the biological treatment and the ethanol extraction. While no significant improvement of the specific methane yield is expected with biological treatment due to the bioproduction of other inhibitory compounds, such as $\alpha$-terpineol, a possible increase in the maximum OLR reached, as observed by Srilatha et al. (1995), could lead to an increase of the volumetric methane yield.

The objective of this work was to study the anaerobic co-digestion of pretreated orange peel with cow manure. The studied pretreatments have been the biological treatment by fungi (limonene removal) and the ethanol extraction of limonene (limonene recovery). The aim of 
the co-digestion was to reduce the remaining limonene dose by the dilution effect and to supply the necessary buffering capacity and nutrients, thus avoiding the additive costs. Moreover, the co-digestion with and without previous biological treatment was done with two different durations of constant OLR, in order to see if this could have an influence on the adaptation of the biomass to the inhibitor.

\subsection{Materials and methods}

\subsubsection{Substrates and inoculum}

Substrates for experimental tests included cow manure and citrus waste. Cow manure (CM) was collected from a dairy farm in Requena (Valencia). Citrus waste consisting in orange (Citrus sinensis var. Navelina) peel (OP) was taken from a juice manufacturing facility located near Valencia (Spain) when no limonene extraction was done.

To start the anaerobic digestion process, the digesters were filled with digested material from a full scale agricultural biogas plant fed with cow manure and vegetable substrates at mesophilic temperature and an OLR of $3 \mathrm{~kg}_{\mathrm{vs}} \cdot \mathrm{m}^{-3} \cdot \mathrm{d}^{-1}$.

\subsubsection{Semi-continuous anaerobic digestion tests}

Semi-continuous anaerobic digestion tests were carried out according the Verein Deutscher Ingenieure (VDI) Standard 4630 Fermentation of organic materials (VDI, 2006). This standard recommends to increase OLR in steps of $0.5 \mathrm{~kg} \mathrm{Vs}^{-3} \cdot \mathrm{m}^{-3} \cdot \mathrm{d}^{-1}$ each 14 days until reaching the maximum stable conditions, and keep then the OLR for enough time to reach steady state. Since the objective was to find the maximum OLR possible, the steady state was not reached.

Table 7.1 summarizes the conditions and the properties of the feeding mixtures of the five semi-continuous tests carried out. Neither buffering solution nor nutrients were added to the digesters. Each experiment was divided in periods characterized by constant OLR and hydraulic retention time (HRT). Analytical control of the digesters was done once a week.

\begin{tabular}{|c|l|c|c|}
\hline \multicolumn{1}{|c|}{ Table 7.1.} & Time of constant OLR and HRT & Target \%OP (VS basis) \\
\hline Code & OP treatment & 14 days & 80 \\
\hline $14 \mathrm{~d}$ & None & 28 days & 80 \\
\hline $28 \mathrm{~d}$ & None & 14 days & 80 \\
\hline $14 \mathrm{dBT}$ & Biological & 28 days & 80 \\
\hline $28 \mathrm{dBT}$ & Biological & 14 days & 95 \\
\hline EE & Extraction & Tiontion tests. \\
\hline
\end{tabular}

OP: orange peel; OLR: organic loading rate; HRT: hydraulic retention time; VS: volatile solids 
Jacketed continuously stirred tank reactors (CSTR) of $36 \mathrm{~L}$ total volume (30 L working volume) were used as anaerobic digesters (Figure 7.1). The operating temperature was $38^{\circ} \mathrm{C}$ in all digesters. Feeding of substrates and removal of same amount of digestate was done once a day. Gas volume was measured by Ritter Milligascounters ${ }^{\circledR}$ MGC-10. Methane production data were expressed at standard pressure and temperature conditions $\left(0^{\circ} \mathrm{C}\right.$ and 1 atm).

The inoculum described in section 7.2.1 was used for the start-up of the digesters. Feeding started with an organic loading rate (OLR) of $0.5 \mathrm{~kg} \mathrm{vs}^{-3} \cdot \mathrm{m}^{-3} \cdot \mathrm{d}^{-1}$, and was progressively increased until its maximum. OLR was considered to reach its maximum when the alkalinity ratio and volatile fatty acids (VFA) concentration exceeded the limits reported for stable operation (Effenberger et al., 2007): total VFA $>2000 \mathrm{mg} \cdot \mathrm{L}^{-1}$; acetic acid $>1000$ $\mathrm{mg} \cdot \mathrm{L}^{-1}$; propionic acid $>500 \mathrm{mg} \cdot \mathrm{L}^{-1}$; butyric acid $>500 \mathrm{mg} \cdot \mathrm{L}^{-1}$, alkalinity ratio $>0.3$; methane concentration $<48 \%$.

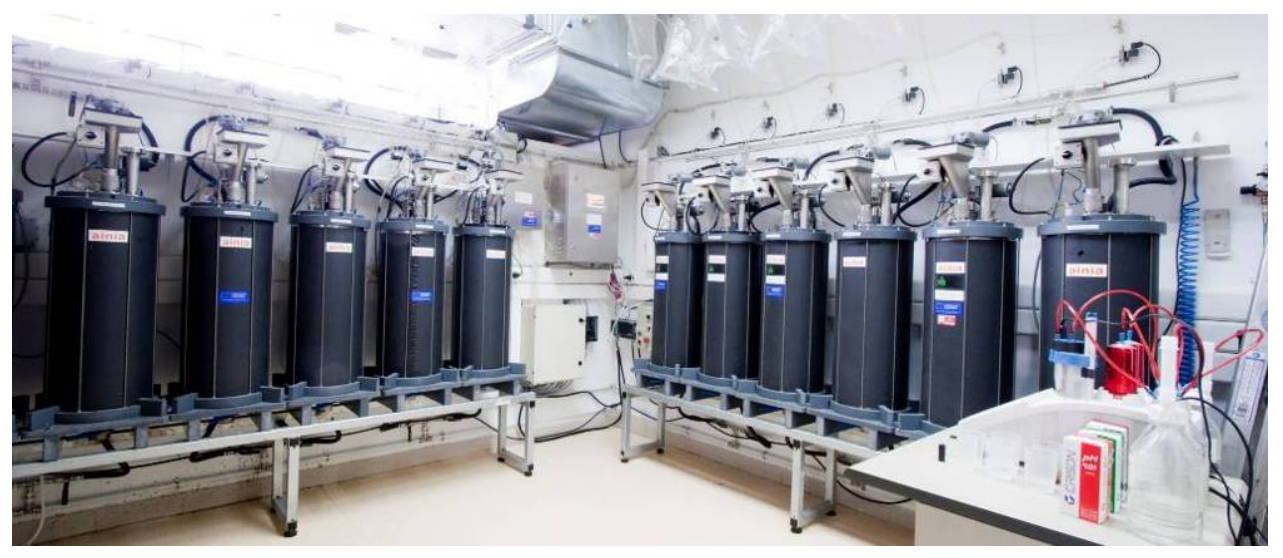

Figure 7.1. Laboratory set-up for the semi-continuous anaerobic digestion tests.

\subsubsection{Pre-treatments}

Pre-treatments applied to the orange peel before some of the anaerobic digestion tests consisted in biological treatment and ethanol extraction.

Biological treatment consisted on a controlled inoculation of the sample with a mix of Penicillium digitatum and Penicillium italicum. The preparation of this inoculum was done through growth in PDA (potato dextrose agar) at $25^{\circ} \mathrm{C}$ for $5-7$ dys. Once the degree of sporulation of the microorganism was adequate, the spores were purified according ASTM Standard G-21:1996. An air atomizer Aztek Contempo Airbrush (Testors, USA) was used for the inoculation of the product, in order to guarantee a homogeneous inoculation in the whole sample. PDA is composed by potato infusion $\left(4 \mathrm{~g} \cdot \mathrm{L}^{-1}\right)$, dextrose $\left(20 \mathrm{~g} \cdot \mathrm{L}^{-1}\right)$ and bacteriological agar $\left(15 \mathrm{~g} \cdot \mathrm{L}^{-1}\right)$ and has a $\mathrm{pH}$ of $5.6 \pm 0.2$. The sample was then incubated for one week at $25^{\circ} \mathrm{C}$ in partially closed recipients that allowed contact with air but prevented massive loss of humidity. 
Ethanol extraction was carried out in a closed stainless steel vessel, $200 \mathrm{~L}$ capacity, $0.5 \mathrm{CV}$ stirrer and jacketed for temperature control (Figure 7.2). Ethanol extraction was carried out with a mixture of $70 \%$ ethanol and $30 \%$ water (volume basis), with a peel/solvent ratio of 1:10 for 60 minutes at ambient temperature. Continuous mixing was applied during the extraction.
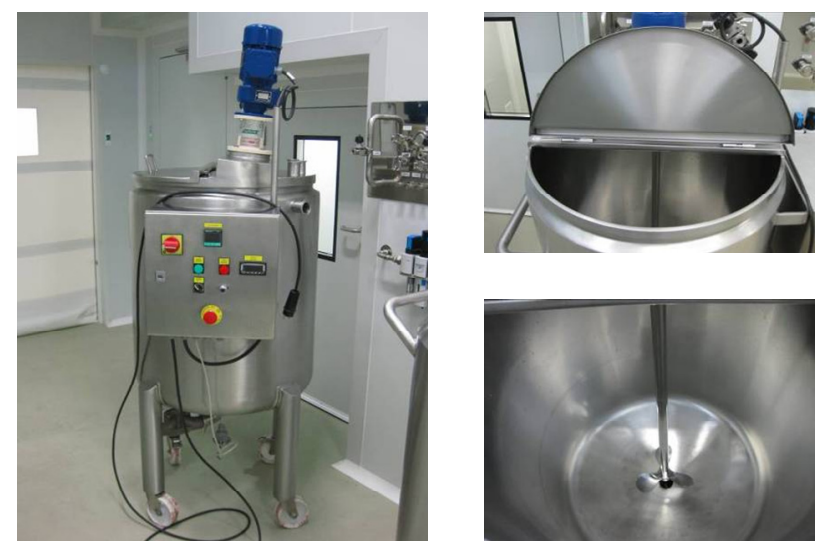

Figure 7.2. Equipment used for the ethanol extraction of the citrus essential oil from the orange peel.

The drying step to remove the solvent was carried out in an experimental horizontal dryer (Figure 7.3) designed for the drying of solids with hot air by forced convection. The dryer was operated with air at $25^{\circ} \mathrm{C}$ and $1 \mathrm{~m} \cdot \mathrm{s}^{-1}$ for over 14 hours to simulate natural drying. These conditions were selected to ensure complete removal of residual ethanol and avoid losses of organic matter, although the continuous measurement of the sample weigh revealed that 5 hours would be enough to achieve almost complete drying.

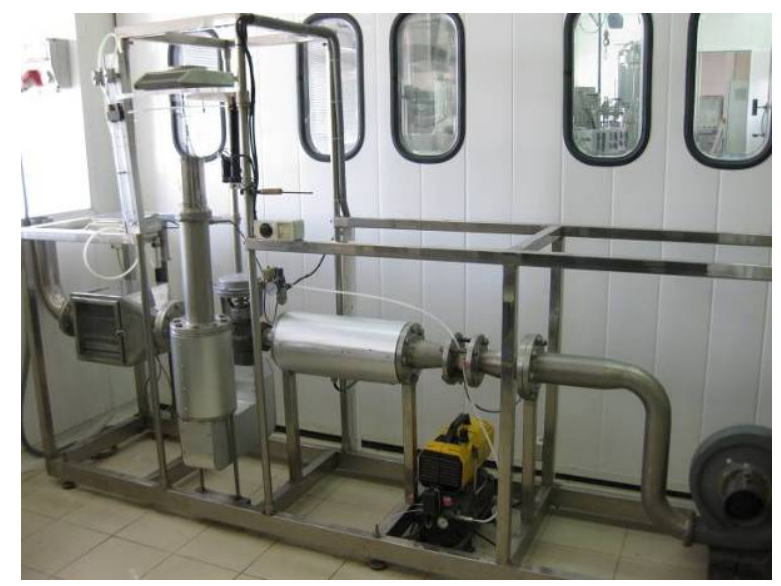

Figure 7.3. Experimental horizontal dryer used for the drying step after ethanol extraction of the orange peel. 


\subsubsection{Analytical methods}

Analysis of total solids (TS), volatile solids (VS), phosphorus, potassium, total Kjeldahl nitrogen (TKN), ammonia nitrogen $\left(\mathrm{NH}_{4}{ }^{+}-\mathrm{N}\right)$, total and soluble chemical oxygen demand (COD, sCOD) and total carbon were carried out according the Standard Methods of Analysis (APHA-AWWA-WEF, 2006).

Individual volatile fatty acids (VFA) acetic, propionic, iso-butyric, butyric, iso-valeric, valeric, iso-caproic, caproic and heptanoic, as well as limonene and other CEO components, were analysed by gas chromatography (GC) as described by Ruiz and Flotats (2015).

The biogas composition was analysed each 6 litres of biogas produced by means of an Awite Serie-6 gas analyzer (Awite GmbH, Germany). This device is equipped with infrared sensors for methane, carbon dioxide and oxygen, and electrochemical sensors for hydrogen sulphide and hydrogen.

\subsection{Results and discussion}

\subsubsection{Chemical characteristics of the substrates}

Chemical characteristics of cow manure and orange peel samples used in the experiments are summarized in Table 7.2 and Table 7.3. The properties of the feeding mixtures used in all the experiments are shown in Table 7.4.

The orange peel underwent biological treatment and ethanol extraction as described in section 2 for some of the anaerobic digestion experiments (see Table 7.1).

TS, VS and limonene were analysed in the pretreated samples. While the VS concentration in terms of $\mathrm{g} \cdot \mathrm{kg}_{\mathrm{TS}}{ }^{-1}$ remained at similar values, the orange peel samples became drier after the treatment. This effect was more pronounced in the ethanol extraction treatment $(297 \%$ increment of the TS), which included a drying step after extraction, than in the biological treatment ( $50 \%$ increment of the TS).

The limonene removal efficiency was in average $24 \%$ for the biological treatment and $94 \%$ for the ethanol extraction. These values are similar to the obtained in chapter 4 . Unfortunately, in the biological treatment, very uneven results were obtained in the different pre-treatment batches regarding limonene removal efficiency in experiment $28 \mathrm{dBT}$ (data not shown). Moreover, other products were detected in the GC analysis or the pre-treated samples, such as $\alpha$-terpineol and perillaldehyde. Those compounds can be inhibitory of the anaerobic digestion as well. 
Table 7.2. Chemical characteristics of animal manures and citrus waste used for the experiments $14 d, 14 d B T, 28 d$ and $28 d B T$.

\begin{tabular}{|l|c|c|}
\hline Parameter, units & Cow manure & Orange peel \\
\hline Total solids (TS), $\mathrm{g} \cdot \mathrm{kg}^{-1}$ & $90 \pm 18$ & $154 \pm 8$ \\
\hline Volatile solids $(\mathrm{VS}), \mathrm{g} \cdot \mathrm{kg}^{-1}$ & $75 \pm 14$ & $148 \pm 0$ \\
\hline Total organic carbon, $\mathrm{g} \cdot \mathrm{kg}^{-1}$ & 6.6 & $47.2 \pm 1.9$ \\
\hline Total Kjeldahl Nitrogen $(\mathrm{TKN}), \mathrm{g} \cdot \mathrm{kg}^{-1}$ & $3.9 \pm 0.5$ & $1.2 \pm 0.5$ \\
\hline Ammonia nitrogen, $\mathrm{g} \cdot \mathrm{kg}^{-1}$ & $1.9 \pm 0.2$ & $0.22 \pm 0.07$ \\
\hline Phosphorus, $\mathrm{mg} \cdot \mathrm{kg}^{-1}$ & $617 \pm 43$ & $206 \pm 11$ \\
\hline Potassium, $\mathrm{mg} \cdot \mathrm{kg}^{-1}$ & $2044 \pm 306$ & $1242 \pm 53$ \\
\hline $\mathrm{C}_{\text {org }} / \mathrm{N}_{\text {org }}$ ratio & 3.3 & 48.2 \\
\hline $\mathrm{pH}\left(20^{\circ} \mathrm{C}\right)$ & $7.2 \pm 0.5$ & $4.0 \pm 0.0$ \\
\hline Conductivity $\left(\mu \mathrm{S} \cdot \mathrm{cm}^{-1}, 20^{\circ} \mathrm{C}\right)$ & $15750 \pm 1071$ & $589 \pm 10$ \\
\hline Limonene, $\mathrm{g} \cdot \mathrm{kg}^{-1}$ & n.a. & $2.5 \pm 0.5$ \\
\hline Acetic acid, $\mathrm{mg} \cdot \mathrm{kg}^{-1}$ & $5917 \pm 592$ & $0 \pm 0$ \\
\hline Propionic acid, $\mathrm{mg} \cdot \mathrm{kg}^{-1}$ & $1050 \pm 87$ & $0 \pm 0$ \\
\hline Iso-butyric acid, $\mathrm{mg}^{-1} \mathrm{~kg}^{-1}$ & $87 \pm 6$ & $0 \pm 0$ \\
\hline Butyric acid, $\mathrm{mg} \cdot \mathrm{kg}^{-1}$ & $378 \pm 36$ & $0 \pm 0$ \\
\hline Iso-valeric acid, ${\mathrm{mg} \cdot \mathrm{kg}^{-1}}^{-1}$ & $115 \pm 12$ & $0 \pm 0$ \\
\hline Valeric acid, $\mathrm{mg} \cdot \mathrm{kg}^{-1} *$ & $68 \pm 7$ & $0 \pm 0$ \\
\hline
\end{tabular}

n.a.: not analyzed. *Iso-caproic, caproic and heptanoic acid were also analyzed but not detected in the samples.

Table 7.3. Chemical characteristics of cow manure and orange peel after ethanol extraction, used for experiment EE.

\begin{tabular}{|l|c|c|}
\hline Parameter, units & Cow manure & $\begin{array}{c}\text { Orange peel after } \\
\text { ethanol extraction }\end{array}$ \\
\hline Total solids (TS), $\mathrm{g} \cdot \mathrm{kg}^{-1}$ & $91 \pm 7$ & $599 \pm 197$ \\
\hline Volatile solids (VS), $\mathrm{g} \cdot \mathrm{kg}^{-1}$ & $76 \pm 6$ & $569 \pm 187$ \\
\hline Limonene, $\mathrm{g} \cdot \mathrm{kg}^{-1}$ & n.a. & $0.604 \pm 0.515$ \\
\hline
\end{tabular}

n.a.: not analyzed. 
Table 7.4. Feeding mixture properties in the anaerobic digestion tests.

\begin{tabular}{|c|c|c|c|c|c|}
\hline \multirow{2}{*}{ Code } & \multirow{2}{*}{$\%$ OP } & \multirow{2}{*}{$\%$ OP (VS) } & \multicolumn{3}{|c|}{ Feeding mixture properties } \\
\cline { 4 - 6 } & & & $T S\left(g \cdot \mathrm{kg}^{-1}\right)$ & $V S\left(g \cdot \mathrm{kg}^{-1}\right)$ & Limonene $\left(\mathrm{g} \cdot \mathrm{kg}^{-1}\right)$ \\
\hline $14 \mathrm{~d}$ & $66.3 \pm 3.1$ & $77.3 \pm 2.5$ & $137 \pm 2$ & $127 \pm 2$ & $1.7 \pm 0.5$ \\
\hline $28 \mathrm{~d}$ & $67.1 \pm 2.7$ & $82.1 \pm 1.6$ & $129 \pm 2$ & $121 \pm 2$ & $1.7 \pm 0.5$ \\
\hline $14 \mathrm{dBT}$ & $74.7 \pm 2.7$ & $82.2 \pm 2.1$ & $131 \pm 1$ & $121 \pm 1$ & $0.9 \pm 0.3$ \\
\hline $28 \mathrm{dBT}$ & $54.7 \pm 9.2$ & $79.1 \pm 1.5$ & $155 \pm 31$ & $142 \pm 29$ & $1.9 \pm 1.3$ \\
\hline EE & $70.0 \pm 5.7$ & $94.7 \pm 1.4$ & $446 \pm 57$ & $420 \pm 53$ & $0.3 \pm 0.4$ \\
\hline
\end{tabular}

OP: orange peel; OLR: organic loading rate; HRT: hydraulic retention time; TS: total solids; VS: volatile solids

\subsubsection{OLR increase every $14^{\text {th }}$ day (Test 14d)}

The specific biogas and methane production, the methane concentration in the biogas and the average daily dosage of limonene in each period are presented in Figure 7.4. After an initial increase, biogas and methane production decrease as the OLR (and consequently, the limonene dose) increases. At OLR $1.81 \mathrm{~kg}_{\mathrm{VS}} \cdot \mathrm{m}^{-3} \cdot \mathrm{d}^{-1}$ (period IV) a rise in the VFA concentration was detected, that continued in period V (OLR $\left.2.26 \mathrm{~kg}_{\mathrm{vS}} \cdot \mathrm{m}^{-3} \cdot \mathrm{d}^{-1}\right)$ and it was necessary to stop the process to avoid complete acidification (period VI). However, after four weeks without feeding, the acetic acid concentration was still $4.7 \mathrm{~g} \cdot \mathrm{kg}^{-1}$ and the experiment was stopped.

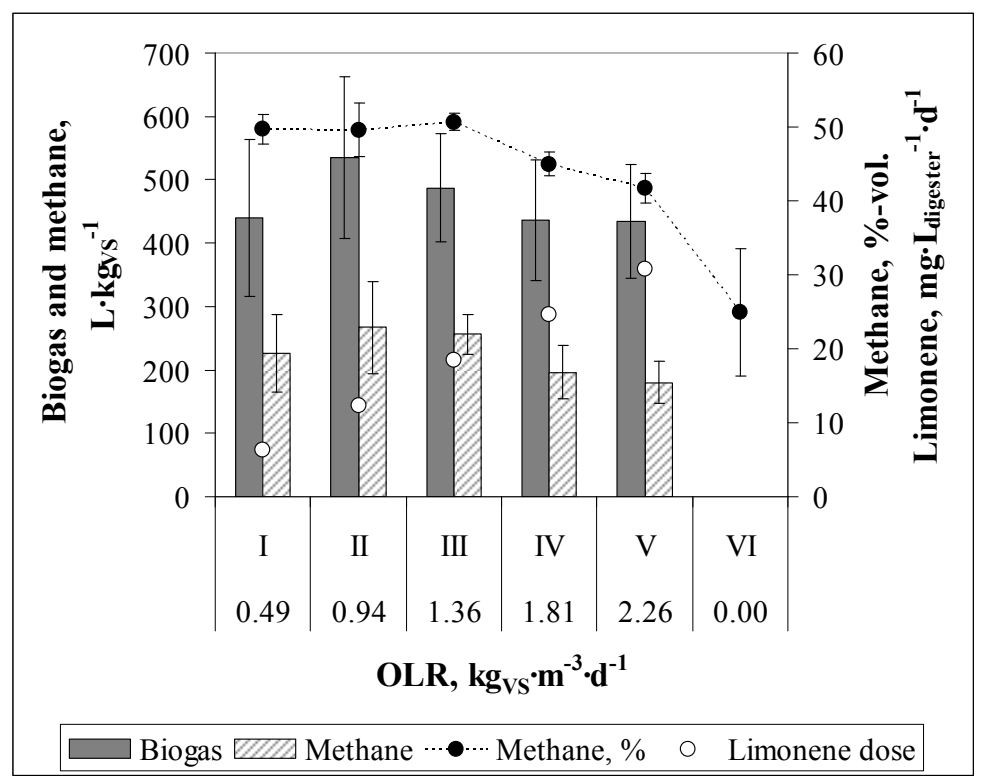

Figure 7.4. Specific biogas and methane production and methane content in the biogas (\%-vol) of the test $14 \mathrm{~d}$ for the six periods studied. Averages and standard deviations of the different periods are presented. 
Figure 7.5 (left) presents the volumetric methane production $\left(\mathrm{m}^{3}\right.$ of methane per $\mathrm{m}^{3}$ of digester and day) for each day of experiment. The methane production increased with OLR up to a maximum of $0.41 \mathrm{~m}^{3} \cdot \mathrm{m}_{\text {digester }}^{-3} \cdot \mathrm{d}^{-1}$ in period $\mathrm{V}$. In period VI, a decrease is observed since no feeding was done. The methane content in the biogas is presented in Figure 7.5 (right). It remained in values near $50 \%$ for the first three periods, and started decreasing from period IV onwards, indicating an inhibition of the methanogenesis. In the last period, the methane concentration dropped until values below $10 \%$.
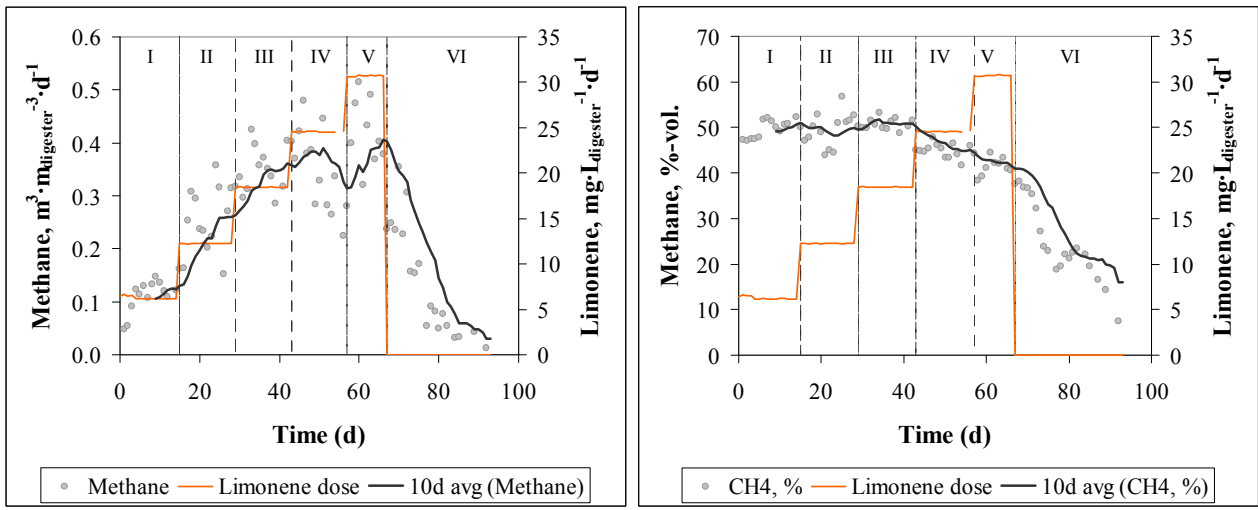

Figure 7.5. Methane production and concentration in the biogas in test 14d.

The partial pressure of hydrogen and hydrogen sulphide in the biogas is shown in Figure 7.6. Coinciding with the decrease of the methane concentration in the biogas (period IV), an increase of the hydrogen partial pressure is observed, indicating an inhibition of the hydrogenotrophic methanogenesis.

In the last period, a steep increase of the hydrogen sulphide is observed, possibly due to an increase of the activity of the sulphate reducing bacteria after the inhibition of the competing methanogenic bacteria. At the end, the partial pressure of the hydrogen sulphide decreases again, what could indicate an inhibition of these bacteria as well.
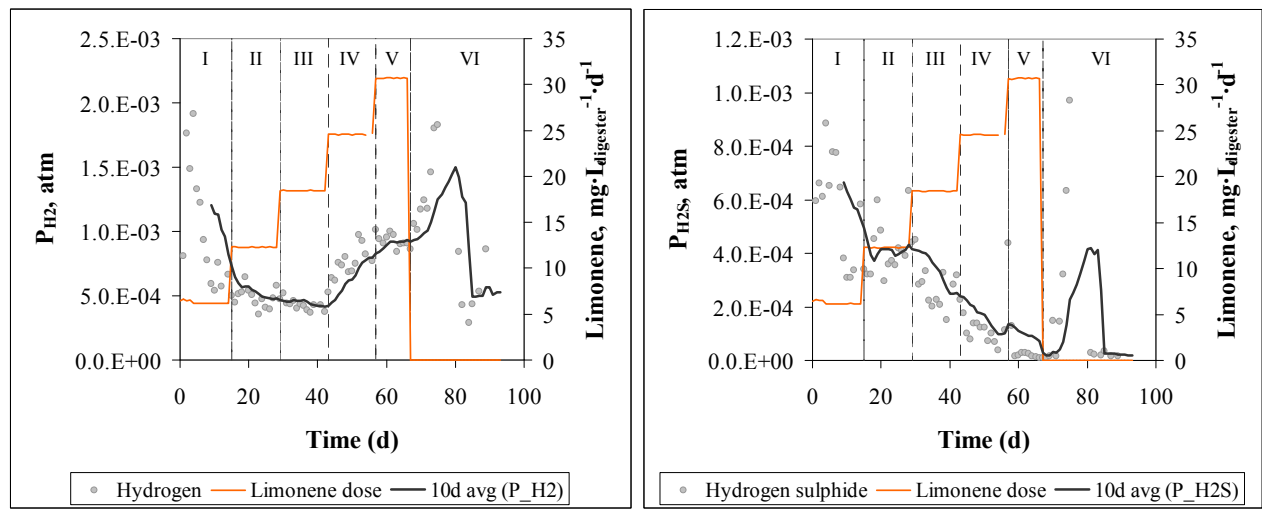

Figure 7.6. Hydrogen and hydrogen sulphide in the biogas from test 14d. 
Volatile fatty acids (VFA) concentrations in the digester are presented in Figure 7.7.
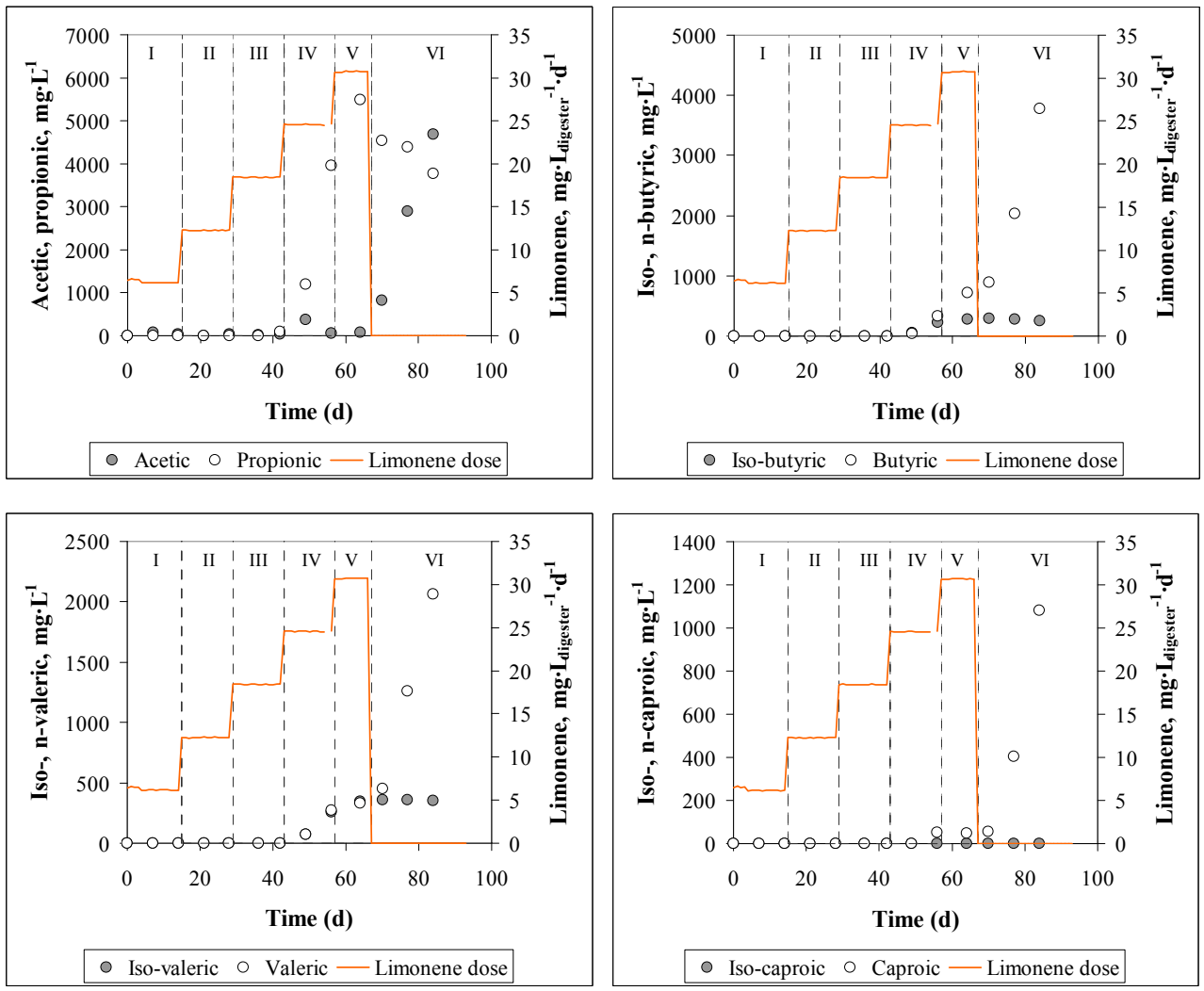

Figure 7.7. Volatile fatty acids concentration in the digestate from test $14 \mathrm{~d}$.

Acetic acid remained in values under $400 \mathrm{mg} \cdot \mathrm{L}^{-1}$ in all the experimental periods except for the last one, when it started to steeply increase until reaching a value of $4688 \mathrm{mg} \cdot \mathrm{L}^{-1}$. This accumulation of acetic acid in period VI is interpreted as a symptom of inhibition of the acetoclastic methanogenesis.

The concentration of propionic acid began to increase already in period IV (OLR 1.8 $\mathrm{kg}_{\mathrm{vS}} \cdot \mathrm{m}^{-3} \cdot \mathrm{d}^{-1}$ ) until values higher than $5000 \mathrm{mg} \cdot \mathrm{L}^{-1}$. Immediatley after stopping the feed, the propionic acid started decreasing while the acetic acid increased, which could be due to the transformation of propionic into acetic (acetogenesis from propionate). Simultaneous decrease of the partial pressure of hydrogen in the biogas was observed, which is interpreted as a sign of recovery of the process. This was not observed in other tests.

The accumulation of propionate in concentrations higher than acetate was already observed by Kaparaju and Rintala (2006) in anaerobic digestion of citrus waste and by Forgács et al. (2011) in the co-digestion of citrus waste with OFMSW. In the experiments of co-digestion of citrus waste (orange and mandarin peels) and pig and chicken manure described in chapter 5 , the same effect was observed. The simultaneous accumulation of propionic acid 
and increase of hydrogen partial pressure in the biogas is a sign of inhibition of the hydrogenotrophic methanogenesis. The absence of simultaneous acetic acid accumulation in periods IV and $\mathrm{V}$, taking into account all the observations together, points to an inhibition of the acetogenic bacteria, which is reversible since propionic acid degradation was observed when the feeding is stopped.

An increase in the $n$ - forms of butyric, valeric and caproic acid was observed in the period IV (coinciding with the propionic increase). Their concentration continued increasing until the end of the experiment. The iso forms of butyric and valeric acid started increasing at the same time but stabilized in values of around 300 and $350 \mathrm{mg} \cdot \mathrm{kg}^{-1}$ respectively. The accumulation of butyric and valeric acid could be due not only to the inhibition of the corresponding bacteria by the limonene, but also to the product inhibition caused by propionic acid accumulation, according to the findings of Pind et al. (2002).

The $\mathrm{pH}$ and alkalinity ratio are affected by the VFA evolution (Figure 7.8). However, due to the high alkalinity provided by the manure, these parameters evidence the instability later than the VFA.
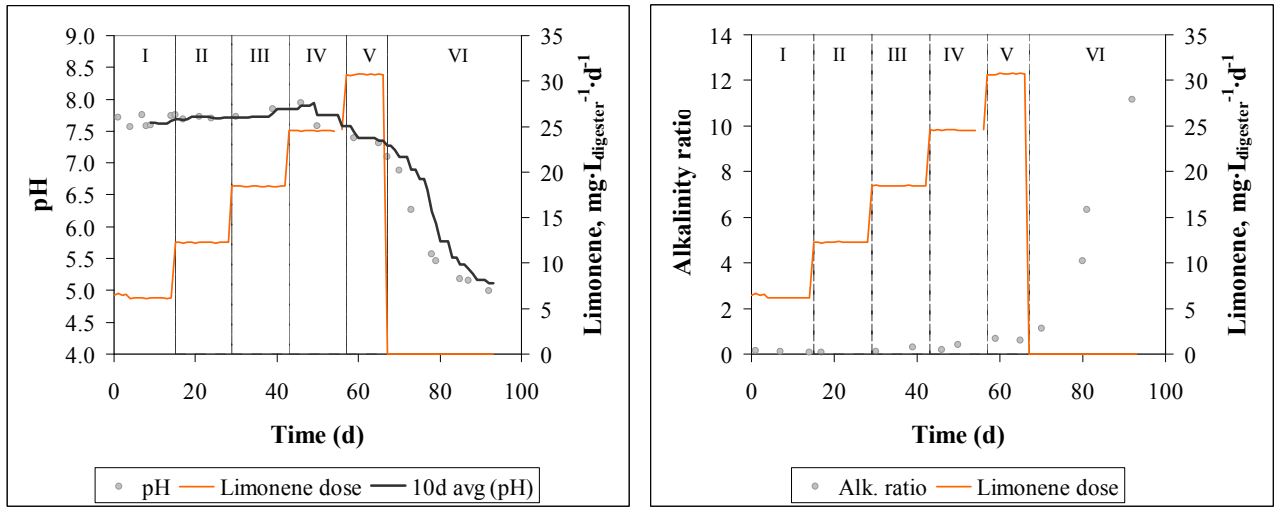

Figure 7.8. pH (left) and alkalinity ratio (right) in the digestate from experiment $14 \mathrm{~d}$.

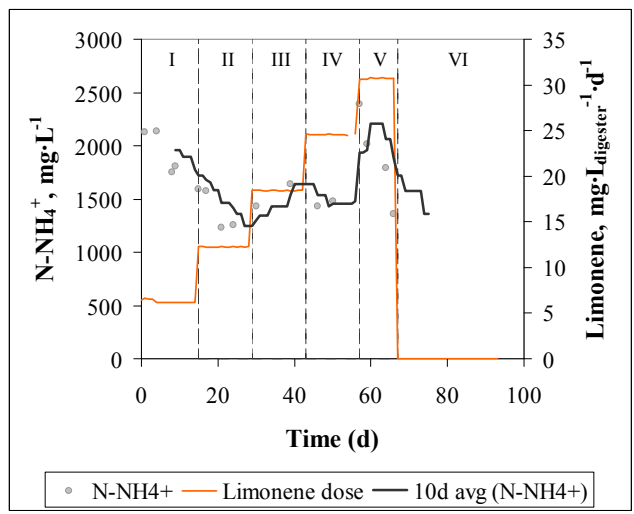

Figure 7.9. Ammonia nitrogen concentration in the digestate from experiment $14 d$. 
Ammonia nitrogen (Figure 7.9) is in all cases below the concentration of $4 \mathrm{~g} \cdot \mathrm{L}^{-1}$ considered as the concentration when inhibition starts (Angelidaki y Ahring, 1993).

The highest limonene dose reached in a stable manner was $18.4 \mathrm{mg} \cdot \mathrm{L}_{\text {digester }}{ }^{-1} \cdot \mathrm{d}^{-1}$. This is lower than the reported in the literature and also to the values reached in chapter 5.

The limonene concentration remaining in the digester at the end of the experiment was 97.4 $\mathrm{mg} \cdot \mathrm{L}^{-1}$. This value is much lower than the half maximum inhibitory concentration $\left(\mathrm{IC}_{50}\right)$ of $423 \mathrm{mg} \cdot \mathrm{kg}^{-1}$ and also under the minimum inhibitory concentration (MIC) of around 200 $\mathrm{mg} \cdot \mathrm{kg}^{-1}$ of limonene in the batch anaerobic digester observed by Ruiz and Flotats (2015). Therefore complete degradation was expected and it was confirmed by the experimental data. The inhibition signs observed despite the almost complete degradation of the limonene would be due to the bioproduction of other inhibitory compounds from limonene, as observed in previous experiments in chapter 5. These compounds were, in order of abundance: cymene, perillaldehyde, $\alpha$-terpineol and 4-terpineol.

The most probable causes for the observations done in the semi-continuous anaerobic digestion of experiment $14 \mathrm{~d}$ are compiled in Table 7.5. Results suggest that limonene causes systemic inhibition, since an effect has been observed in the acetogenic bacteria (accumulation of propionic, butyric and valeric acid), acetoclastic methanogens (acetic acid accumulation in the last period) and hydrogenotrophic methanogens (further accumulation of hydrogen in the last period).

Table 7.6 shows the average values and standard deviation of each measured parameter in each period.

Table 7.5. Main observations in semi-continuous anaerobic digestion of experiment $14 d$.

\begin{tabular}{|c|c|c|l|l|}
\hline Period & $\begin{array}{c}\text { OLR } \\
\left(\mathrm{kg}_{V S} \cdot \mathrm{m}^{-3} \cdot \mathrm{d}^{-1}\right)\end{array}$ & $\begin{array}{c}\text { Limonene } \\
\text { dose } \\
\left(\mathrm{g} \cdot \mathrm{m}^{-3} \cdot \mathrm{d}^{-1}\right)\end{array}$ & Observations & $\begin{array}{l}\text { Possible causes attributed } \\
\text { to limonene inhibition }\end{array}$ \\
\hline I-III & $0.49-1.36$ & $6.3-18.4$ & Stable operation & - \\
\hline IV-V & $1.81-2.26$ & $24.6-30.7$ & $\begin{array}{l}\text { Increase of propionic, butyric, valeric } \\
\text { and hydrogen. } \\
\text { No acetic acid accumulation. } \\
\text { Methane concentration decrease. }\end{array}$ & $\begin{array}{l}\text { Acetogenesis inhibition. } \\
\text { Hydrogenotrophic } \\
\text { methanogenesis inhibition. }\end{array}$ \\
\hline VI & No feeding & $\begin{array}{l}\text { No } \\
\text { feeding }\end{array}$ & $\begin{array}{l}\text { Further decrease of methane } \\
\text { concentration. Methane production } \\
\text { decrease. } \\
\text { Increase of acetic, hydrogen and n- } \\
\text { forms of butyric and valeric. } \\
\text { Decrease of propionic. Iso- forms of } \\
\text { butyric and valeric remain constant. } \\
\text { Steep increase of hydrogen sulphide } \\
\text { followed by a sudden decrease. }\end{array}$ & $\begin{array}{l}\text { Methanogenesis inhibition, } \\
\text { both acetoclastic and } \\
\text { hydrogenotrophic. } \\
\text { Inhibition of sulphate } \\
\text { reducing bacteria after an } \\
\text { initial increase of activity } \\
\text { due to the lack of } \\
\text { competition of } \\
\text { methanogenic archaea. }\end{array}$ \\
\hline
\end{tabular}


Table 7.6. Results of semi-continuous anaerobic co-digestion experiment $14 d$ : average values and standard deviation in each period.

\begin{tabular}{|c|c|c|c|c|c|c|c|c|c|c|c|c|c|c|c|c|c|c|c|c|c|c|c|c|c|c|c|}
\hline 5 & & & & & $\hat{\sim}$ & & & $\begin{array}{l}\text { ஸे } \\
0 \\
+1 \\
\text { ஸे }\end{array}$ & $\begin{array}{l}0 \\
0 \\
+ \\
\pm \\
\pm \\
0\end{array}$ & & $\begin{array}{l}\text { f } \\
\text { ○ } \\
\text { H } \\
8 \\
8\end{array}$ & $\begin{array}{c}0 \\
0 \\
0 \\
+ \\
0 \\
0 \\
0\end{array}$ & & 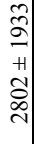 & 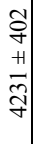 & 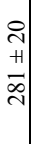 & 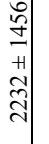 & $\begin{array}{l}n \\
+1 \\
0 \\
b \\
n\end{array}$ & 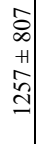 & & 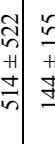 & 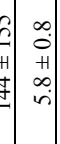 & 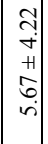 & $\stackrel{\widetilde{\pi}}{=}$ & & & \\
\hline$>$ & 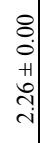 & & $\begin{array}{l}\overrightarrow{0} \\
+ \\
0 \\
\infty \\
\infty\end{array}$ & $\begin{array}{l}\overrightarrow{0} \\
+ \\
\hat{0} \\
\dot{n}\end{array}$ & ㅇ & $\begin{array}{l}8 \\
+1 \\
\omega \\
\gamma\end{array}$ & $\begin{array}{l}\text { ले } \\
+1 \\
0 \\
-\end{array}$ & $\begin{array}{l}\text { ̂․ } \\
0 \\
+1 \\
\infty \\
0 \\
0\end{array}$ & $\begin{array}{l}0 \\
0 \\
0 \\
+ \\
7 \\
0 \\
0\end{array}$ & ¿ & $\begin{array}{l}\varkappa \\
0 \\
H \\
\tilde{\sigma} \\
\hat{0}\end{array}$ & $\begin{array}{l}m \\
0 \\
0 \\
H \\
0 \\
0 \\
0\end{array}$ & & $\begin{array}{l}\infty \\
+1 \\
\infty\end{array}$ & 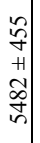 & 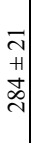 & $\begin{array}{l}5 \\
+ \\
+ \\
\pm \\
\therefore\end{array}$ & $\begin{array}{l}n \\
m \\
+1 \\
\text { fै } \\
m\end{array}$ & $\begin{array}{l}0 \\
0 \\
+ \\
心 \\
m\end{array}$ & & & 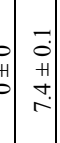 & $\mid \begin{array}{l}0 \\
0 \\
0 \\
+1 \\
0 \\
0 \\
0\end{array}$ & \begin{tabular}{l|}
$\bar{\gamma}$ \\
+ \\
0 \\
0 \\
0
\end{tabular} & $\stackrel{9}{=}$ & 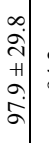 & \\
\hline$\geq$ & $\begin{array}{c}0 \\
0 \\
0 \\
+1 \\
+\infty \\
-\infty\end{array}$ & & $\begin{array}{l}\overrightarrow{0} \\
+1 \\
0 \\
\dot{2}\end{array}$ & $\begin{array}{l}0 \\
0 \\
+1 \\
0 \\
\dot{1} \\
\text { In }\end{array}$ & \pm & $\begin{array}{l}\varkappa \\
+ \\
\hat{\sigma} \\
\hat{q}\end{array}$ & $\begin{array}{l}f \\
7 \\
+ \\
\circ \\
=\end{array}$ & $\begin{array}{l}\text { - } \\
0 \\
+1 \\
\infty \\
0 \\
0\end{array}$ & $\begin{array}{l}\infty \\
0 \\
0 \\
+ \\
0 \\
0\end{array}$ & $\begin{array}{l}0 \\
+ \\
0 \\
y\end{array}$ & 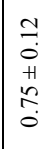 & 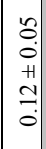 & & $\begin{array}{l}\text { त̂ } \\
+ \\
\vec{N}\end{array}$ & 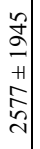 & 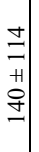 & 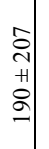 & $\begin{array}{l}\vec{m} \\
+ \\
+ \\
0 \\
0\end{array}$ & $\begin{array}{l}\vec{y} \\
+ \\
\mathbb{N} \\
\Xi\end{array}$ & & & \begin{tabular}{c|c}
0 \\
+ \\
$H$
\end{tabular} & $\mid \begin{array}{c}0 \\
0 \\
\dot{1} \\
0 \\
0 \\
0 \\
0\end{array}$ & $\begin{array}{l}m \\
0 \\
n \\
\hat{y} \\
0\end{array}$ & $\begin{array}{l}0 \\
0 \\
+ \\
0 \\
\dot{t} \\
\end{array}$ & & \\
\hline$\Xi$ & $\left|\begin{array}{c}0 \\
0 \\
0 \\
+1 \\
0 \\
-1\end{array}\right|$ & $\begin{array}{l}0 \\
+ \\
+ \\
\Delta\end{array}$ & $\begin{array}{l}-0 \\
0 \\
0 \\
0 \\
\dot{2}\end{array}$ & $\begin{array}{l}0 \\
\dot{0} \\
+1 \\
+ \\
\dot{0} \\
0\end{array}$ & \pm & $\begin{array}{c}\infty \\
\infty \\
+1 \\
\hat{\infty} \\
\dot{\alpha}\end{array}$ & 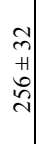 & $\begin{array}{l}\stackrel{0}{0} \\
0 \\
+1 \\
: \\
0 \\
0\end{array}$ & $\begin{array}{l} \pm \\
0 \\
0 \\
+ \\
0 \\
0\end{array}$ & $\begin{array}{l}7 \\
+ \\
2\end{array}$ & \begin{tabular}{l}
\multirow{J}{0}{} \\
0 \\
+ \\
$\stackrel{1}{0}$ \\
$\stackrel{0}{0}$
\end{tabular} & 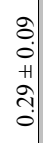 & & $\begin{array}{l}m \\
m \\
m \\
m\end{array}$ & $\begin{array}{l}3 \\
0 \\
1 \\
0\end{array}$ & 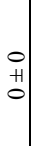 & $\begin{array}{l}\text { 아 } \\
\text { 마 }\end{array}$ & $\begin{array}{l}0 \\
\text { H } \\
0\end{array}$ & 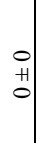 & & $\begin{array}{ll}\text { 이 } \\
\text { +1 }\end{array}$ & 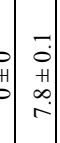 & $\left|\begin{array}{l}0 \\
0 \\
+1 \\
0 \\
0 \\
0\end{array}\right|$ & $\begin{array}{l}\stackrel{\infty}{ \pm} \\
+ \\
\hat{n} \\
\hat{\Omega}\end{array}$ & 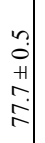 & & \\
\hline 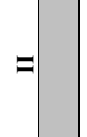 & $\mid \begin{array}{l}0 \\
0 \\
+ \\
+ \\
0 \\
0\end{array}$ & $\begin{array}{l}- \\
+ \\
+ \\
-\end{array}$ & 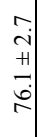 & 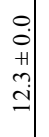 & \pm & $\begin{array}{l}\hat{y} \\
+ \\
\tilde{n} \\
\hat{n}\end{array}$ & $\begin{array}{l}\mathbb{N} \\
+1 \\
\hat{6}\end{array}$ & $\begin{array}{l}= \\
0 \\
+1 \\
0 \\
0 \\
0\end{array}$ & $\begin{array}{l}0 \\
0 \\
0 \\
+ \\
4 \\
0 \\
0\end{array}$ & to & $\begin{array}{l}\infty \\
0 \\
0 \\
+ \\
o \\
o \\
0\end{array}$ & $\begin{array}{c}0 \\
\vdots \\
0 \\
+ \\
\vec{t} \\
0\end{array}$ & & $\begin{array}{l}\Delta \\
\text { I } \\
\text { I }\end{array}$ & $\begin{array}{l}0 \\
\text { H1 } \\
0\end{array}$ & $\begin{array}{l}\text { 일 } \\
\text { - }\end{array}$ & $\begin{array}{l}\text { 아 } \\
\text { 이 }\end{array}$ & $\begin{array}{l}0 \\
\text { ㅍ }\end{array}$ & $\begin{array}{l}0 \\
\text { ㅂ }\end{array}$ & & \begin{tabular}{l|l}
0 & 0 \\
H & + \\
0 & 0
\end{tabular} & 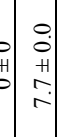 & o & $\begin{array}{l}\hat{0} \\
+ \\
\\
\vec{y}\end{array}$ & $\begin{array}{l}n \\
1 \\
0 \\
\text { i }\end{array}$ & & \\
\hline 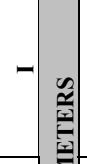 & $\mid \begin{array}{l}8 \\
0 \\
1 \\
0 \\
9 \\
0 \\
0\end{array}$ & 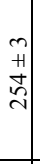 & 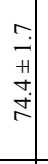 & 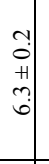 & $\therefore$ & 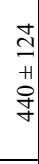 & 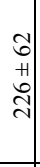 & 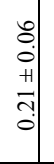 & $\begin{array}{l}0 \\
0 \\
+1 \\
= \\
0 \\
0\end{array}$ & $\begin{array}{l}0 \\
\text { ta } \\
+ \\
0\end{array}$ & 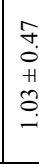 & $\begin{array}{c}0 \\
0 \\
0 \\
H \\
\infty \\
0 \\
0\end{array}$ & 0 & $\begin{array}{l}q \\
+ \\
+ \\
q\end{array}$ & $\begin{array}{l}0 \\
\text { H1 } \\
0\end{array}$ & $\begin{array}{l}0 \\
\text { H1 } \\
0\end{array}$ & $\begin{array}{l}0 \\
\text { ㅁ }\end{array}$ & $\begin{array}{l}0 \\
\text { H }\end{array}$ & $\begin{array}{l}0 \\
\text { ㅁ } \\
0\end{array}$ & $\begin{array}{l}0 \\
\text { ㅂ } \\
0\end{array}$ & \begin{tabular}{l|l}
0 & 0 \\
11 & + \\
0 & 0
\end{tabular} & 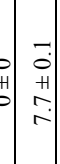 & 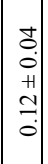 & 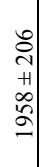 & $\begin{array}{l}\stackrel{0}{+} \\
+ \\
\stackrel{+}{m} \\
\infty \\
\infty\end{array}$ & $\stackrel{\overbrace{}]}{g}$ & \\
\hline 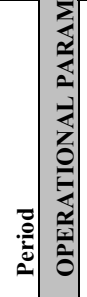 & 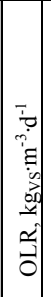 & 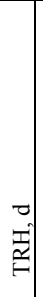 & 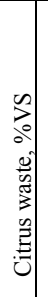 & 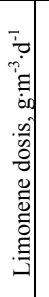 & 栉 & 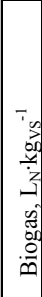 & 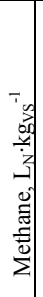 & 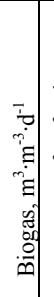 & 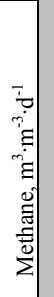 & 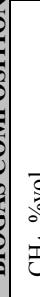 & 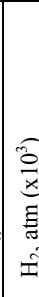 & 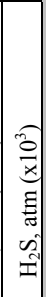 & 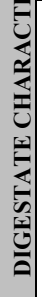 & 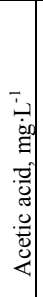 & 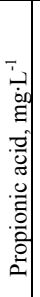 & 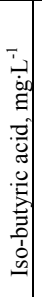 & 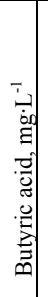 & $\begin{array}{l}0.0 \\
\vdots \\
0 \\
0 \\
0 \\
0 \\
0 \\
0 \\
0 \\
0 \\
0 \\
0 \\
0 \\
0\end{array}$ & 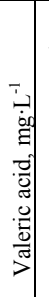 & 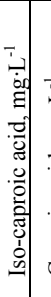 & 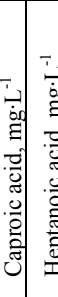 & 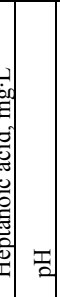 & 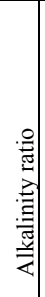 & 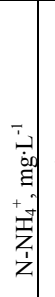 & 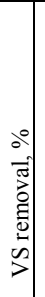 & 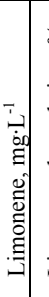 & \\
\hline
\end{tabular}

\subsubsection{OLR increase every $28^{\text {th }}$ day (Test 28d)}

A mixture with the same composition as in experiment $14 \mathrm{~d}$ was tested but this time OLR was kept constant during 28 instead 14 days with the aim to observe wether any adaptation could take place, according to the results described in section 7.3.2 and chapter 5 .

The specific biogas and methane production, the methane content of the biogas (\%-vol) and the average daily dosage of limonene in each period are shown in Figure 7.10. Biogas and methane production decreases as the OLR (and consequently, the limonene dose) increases. In period III (OLR $\left.1.46 \mathrm{~kg}_{\mathrm{VS}} \cdot \mathrm{m}^{-3} \cdot \mathrm{d}^{-1}\right)$, several symptoms of instability were detected and the 
feeding was stopped (period IV) until recovery was observed in the form of VFA degradation. The feeding was restarted at OLR $1.46 \mathrm{~kg} \mathrm{vs} \cdot \mathrm{m}^{-3} \cdot \mathrm{d}^{-1}$ (period V) but instability was observed again and the experiment was stopped.

It is noteworthy that, despite the longer periods of constant OLR and corresponding limonene dosage, the instability was observed at a lower OLR and limonene dosage than in experiment $14 \mathrm{~d}$. In both cases, it took place approximately on day 50 from the beginning of the experiments.

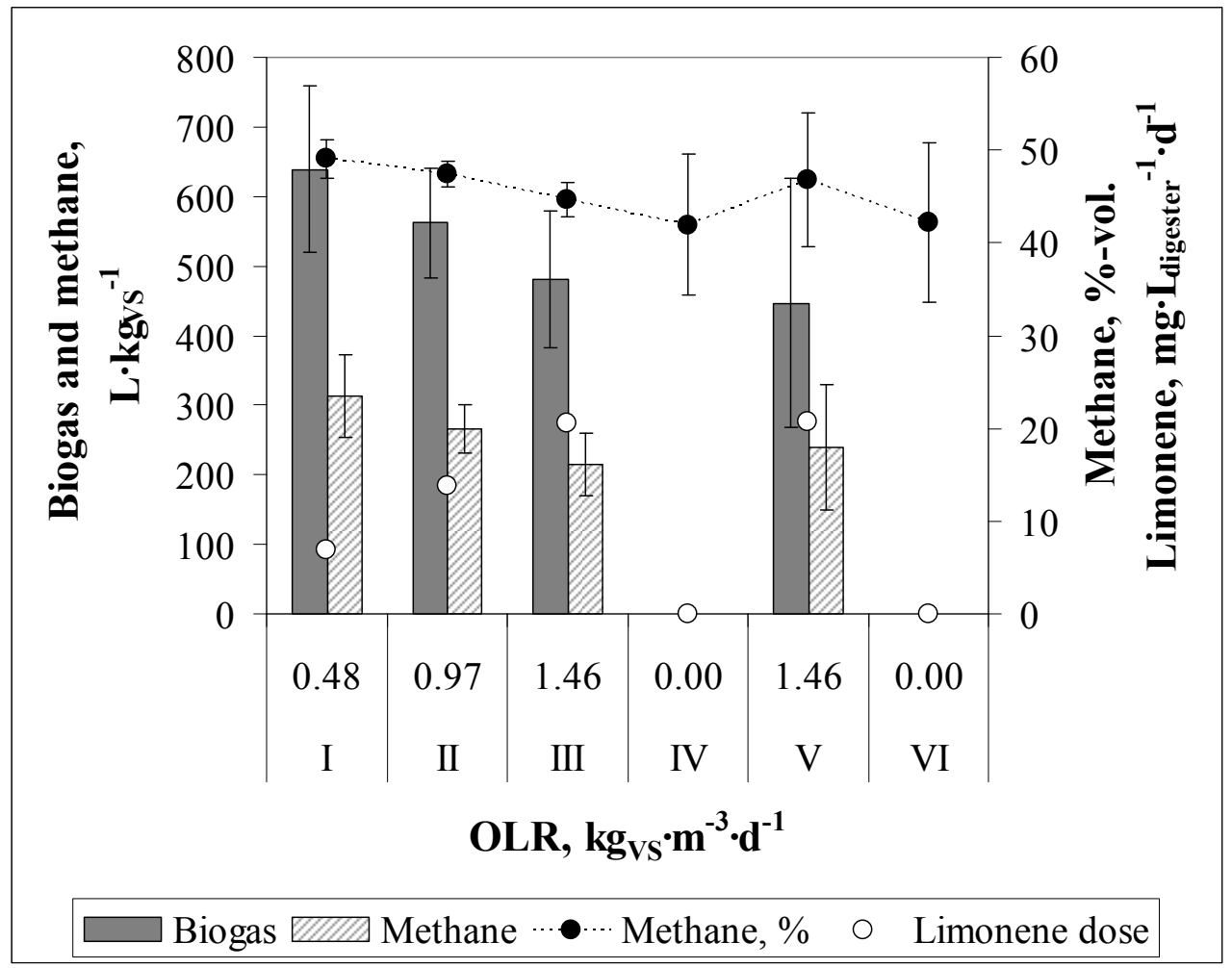

Figure 7.10.

Specific biogas and methane production and methane content in the biogas (\%-vol) of the experiment $28 d$ for the six periods studied. Averages and standard deviations of the different periods are presented.

Figure 7.11 (left) shows the volumetric methane production $\left(\mathrm{m}^{3}\right.$ of methane per $\mathrm{m}^{3}$ of digester and day). The observed values at OLR $1.46 \mathrm{~kg} \mathrm{Vs}_{\mathrm{VS}} \cdot \mathrm{m}^{-3} \cdot \mathrm{d}^{-1}$ were similar to the ones obtained in experiment $14 \mathrm{~d}$ at similar OLR.

The methane content in the biogas and the limonene dose are presented in Figure 7.11 (right). Methane content was between 45 and 50\%-vol, which is also similar to the results obtained in experiment $14 \mathrm{~d}$. 

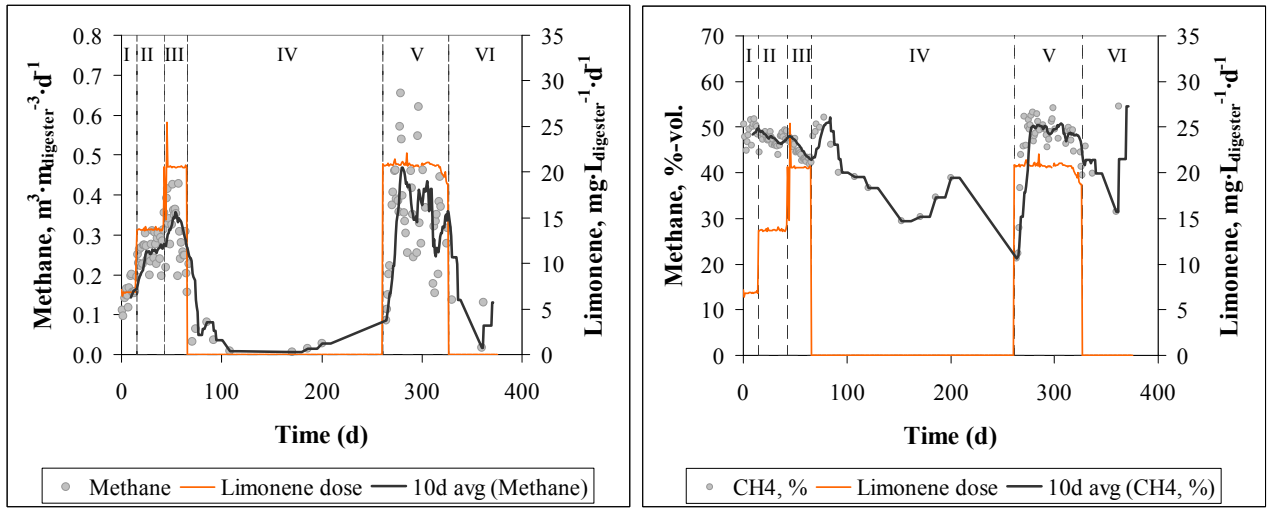

Figure 7.11 .

Methane production and concentration in the biogas in test $28 d$.

Concentrations of hydrogen and hydrogen sulphide in the biogas are presented in Figure 7.12. The hydrogen accumulation in the period of highest OLR (period III) is higher than the corresponding period of experiment $14 \mathrm{~d}$. At the same OLR but after the time without feeding, the hydrogen concentration was significantly lower, which is attributed to an inhibition of the acetogenesis of propionic acid and, therefore, a lower hydrogen production is observed.

The values of the concentration of hydrogen sulphide in the biogas are lower than in experiment 14d. A sudden increase of the hydrogen sulphide was observed at the beginning of period IV coinciding with a decrease of the methane production. This is attributed to an increase of the activity of the sulphate reducing bacteria due to lack of competition.
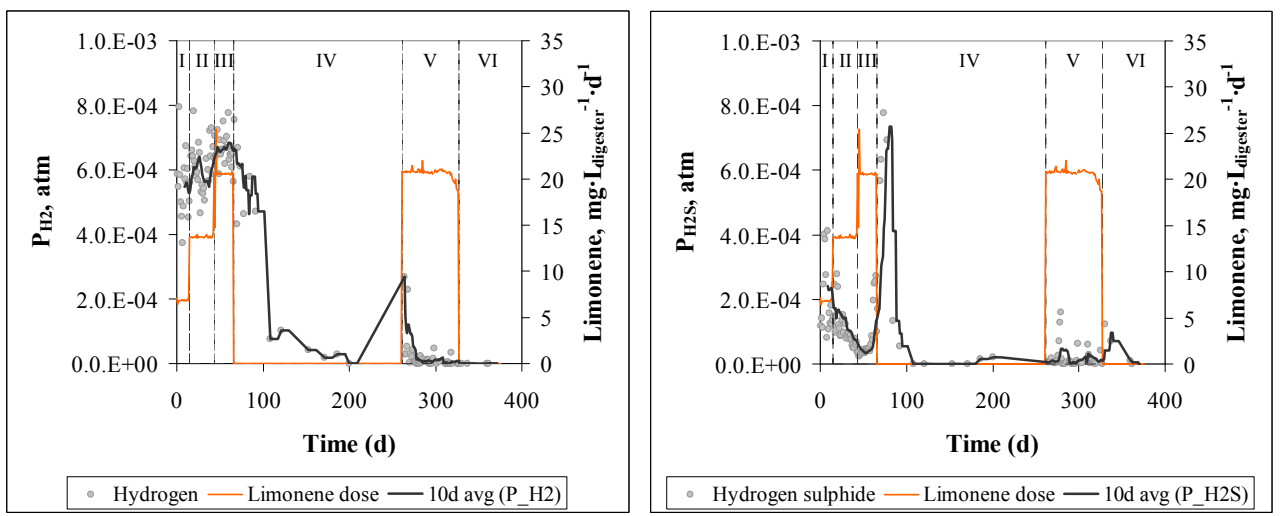

Figure 7.12.

Hydrogen and hydrogen sulphide in the biogas from experiment $28 d$.

VFA concentrations in the digester are presented in Figure 7.13.

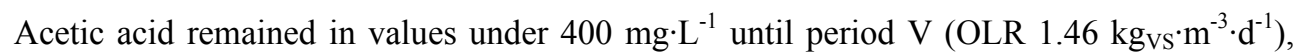
when it increased to near $2000 \mathrm{mg} \cdot \mathrm{L}^{-1}$ after restart of the feeding. After this initial increase, 
it decreased back to the previous values. In period VI, when the feeding was stopped again after observing an increase of the propionic acid, the acetic acid concentration increased as well, which is attributed to an inhibition of the acetoclastic methanogenesis.

Propionic acid started increasing in period III, from undetectable concentrations to 4600 $\mathrm{mg} \cdot \mathrm{L}^{-1}$ in 21 days. After stopping the feed, the propionic acid concentration increased further until near $8000 \mathrm{mg} \cdot \mathrm{L}^{-1}$ and then decreased again and remained at values of around $4200 \mathrm{mg} \cdot \mathrm{L}^{-1}$ for more than 100 days. At this point, it decreased from these values to less than $200 \mathrm{mg} \cdot \mathrm{L}^{-1}$ in 35 days. In this 35 days period, an increase in the methane production and in the acetic acid concentration was observed.

Propionic acid accumulation, together with an absence of accumulation of hydrogen, would suggest an inhibition of the acetogenesis. The lack of accumulation of acetic acid during the periods when propionate concentration is high supports the hypothesis of acetogenesis inhibition.

Butyric and valeric acid were detected mostly in their iso- forms from period III onwards, similarly to the propionic acid. The maximum values reached were lower than in experiment $14 \mathrm{~d}$.
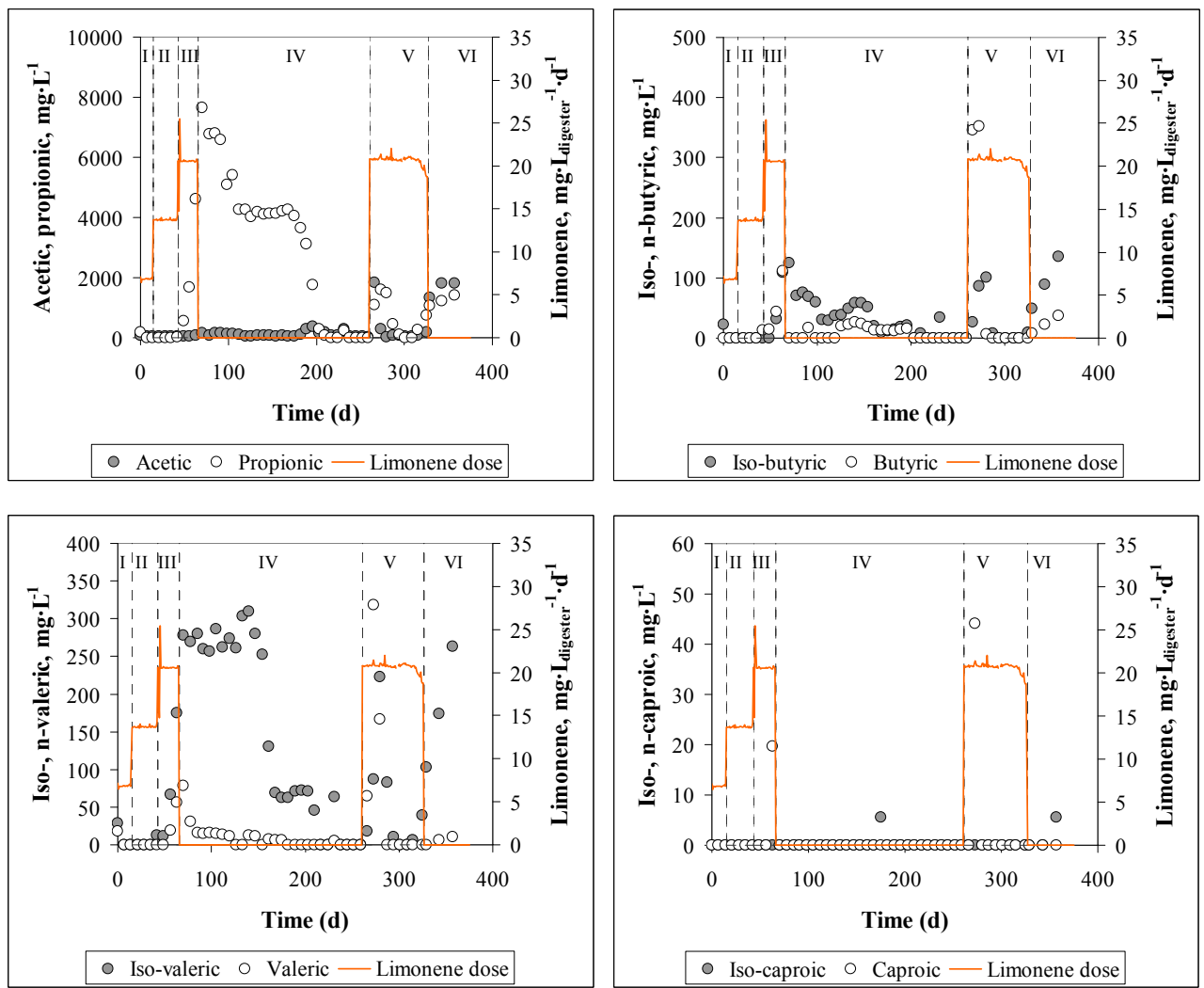

Figure 7.13.

Volatile fatty acids concentration in the digestate from experiment $28 d$. 
The $\mathrm{pH}$ remained at values above 7 during all the experiment. Alkalinity ratio was affected by the VFA evolution (Figure 7.14), following a trend very similar to the one of propionate.
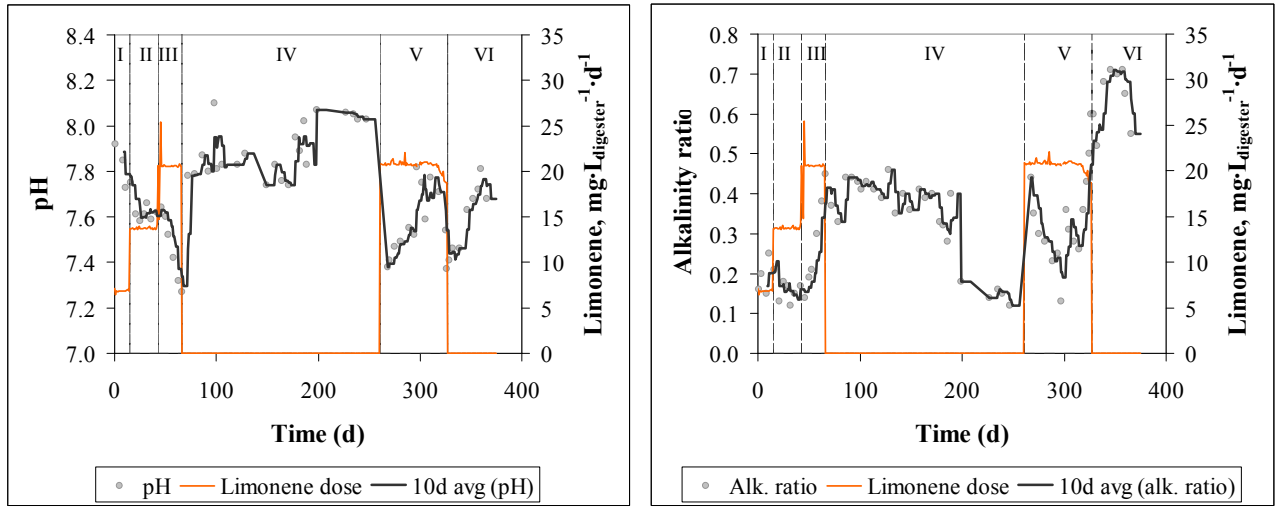

Figure 7.14.

pH (left) and alkalinity ratio (right) in the digestate from experiment $28 d$.

Ammonia nitrogen (Figure 7.15) was below the concentration of $4 \mathrm{~g} \cdot \mathrm{L}^{-1}$ similarly to experiment $14 \mathrm{~d}$.

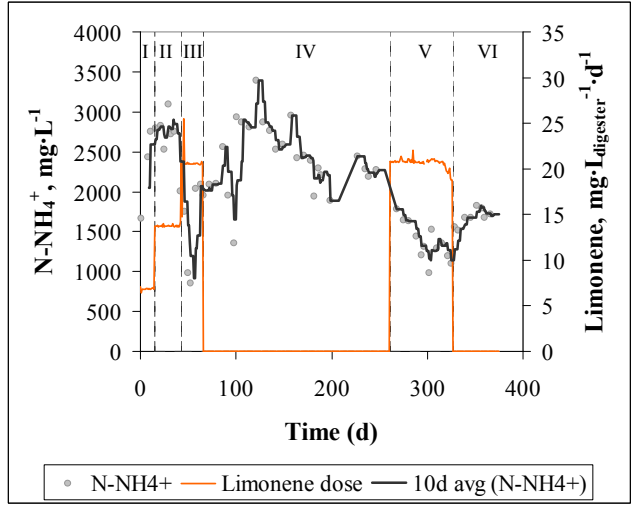

Figure 7.15.

Ammonia nitrogen concentration in the digestate from experiment $28 d$.

Limonene degradations observed were higher than $80 \%$ in all measurements. Similarly to the conclusions drawn from chapter 5, the minority compounds of the CEO might be playing an important role in the inhibition. In experiment $28 \mathrm{~d}$, the production of other inhibitory compounds such as cymene, cresol, $\alpha$-terpineol and $\alpha$-terpinolene was detected in the GC analysis of limonene (see Figure 7.16). The three latter compounds appeared only after 200 days of experiment. Cresol was not detected in the analysis performed on day 64 of test $14 \mathrm{~d}$. The trend observed for the cymene in period IV is similar to the ones of 
propionic and iso-valeric acid, indicating that the acetogenic bacteria could be responsible or are related with the consumption pathway of these compounds.

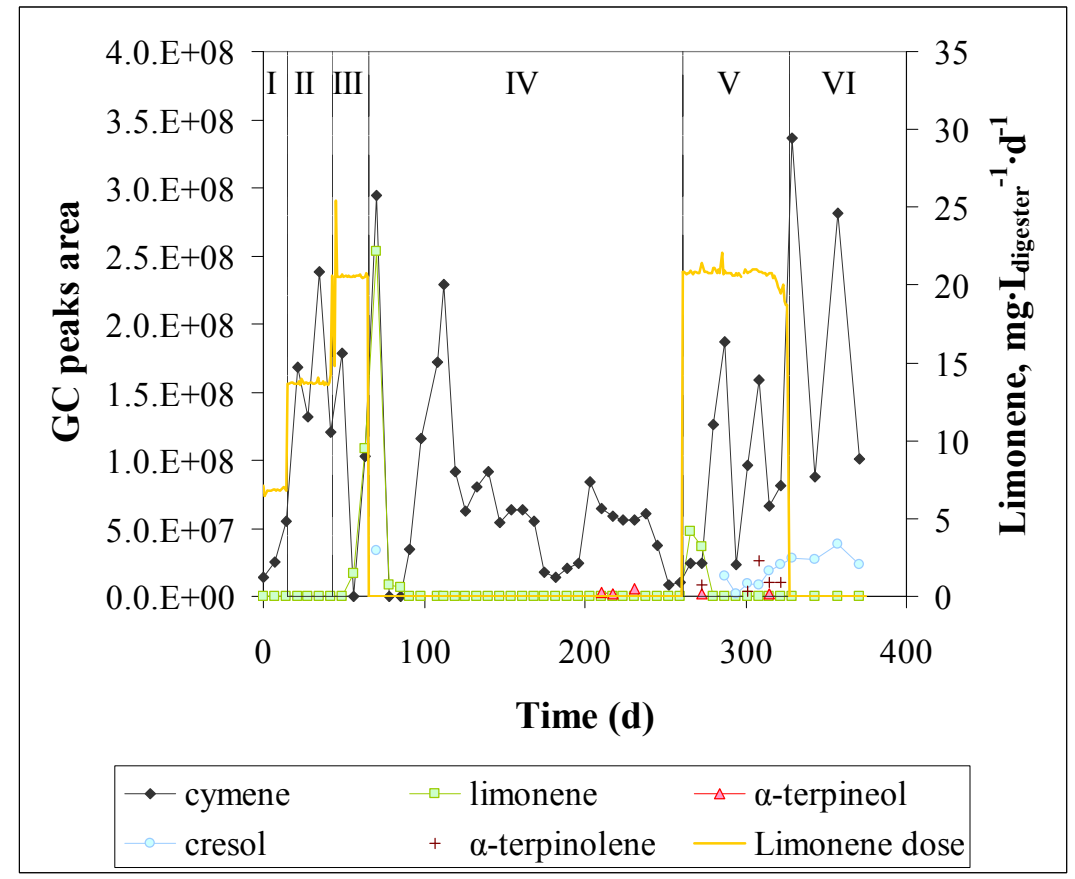

Figure 7.16. Main GC peaks area in the CEO analysis of $28 d$ digestate.

The most probable causes for the observations done are summarised in Table 7.7. Table 7.8 summarises the results of experiment $28 \mathrm{~d}$.

Table 7.7. Main observations in semi-continuous anaerobic digestion of experiment $28 d$.

\begin{tabular}{|c|c|c|l|l|}
\hline Period & $\begin{array}{c}\text { OLR } \\
\left(\mathrm{kg}_{V S} \cdot \mathrm{m}^{-3} \cdot \mathrm{d}^{-1}\right)\end{array}$ & $\begin{array}{c}\text { Limonene } \\
\mathbf{d o s e} \\
\left(\mathrm{g} \cdot \mathrm{m}^{-3} \cdot \mathrm{d}^{-1}\right)\end{array}$ & Observations & $\begin{array}{l}\text { Possible causes attributed } \\
\text { to limonene inhibition }\end{array}$ \\
\hline I-II & $0.48-0.97$ & $6.8-13.7$ & No signs of inhibition & - \\
\hline III & 1.46 & 20.5 & $\begin{array}{l}\text { Propionic, butyric, valeric acid, } \\
\text { increase. Neither hydrogen, nor acetic } \\
\text { acid accumulates. }\end{array}$ & Acetogenesis inhibition. \\
\hline IV & No feeding & $\begin{array}{c}\text { No } \\
\text { feeding }\end{array}$ & $\begin{array}{l}\text { VFA accumulation remains for a period } \\
\text { of } 100 \text { days and then decreases. Similar } \\
\text { trend is observed in the alkalinity ratio. }\end{array}$ & Recovery observed. \\
\hline V & 1.46 & $\begin{array}{c}20.7 \\
\text { VI }\end{array}$ & $\begin{array}{l}\text { VFA accumulation is observed again. } \\
\text { Hydrogen partial pressure remains low. }\end{array}$ & Acetogenesis inhibition. \\
\hline
\end{tabular}


Table 7.8. Results of semi-continuous anaerobic co-digestion experiment 28d: average values and standard deviations in each period.

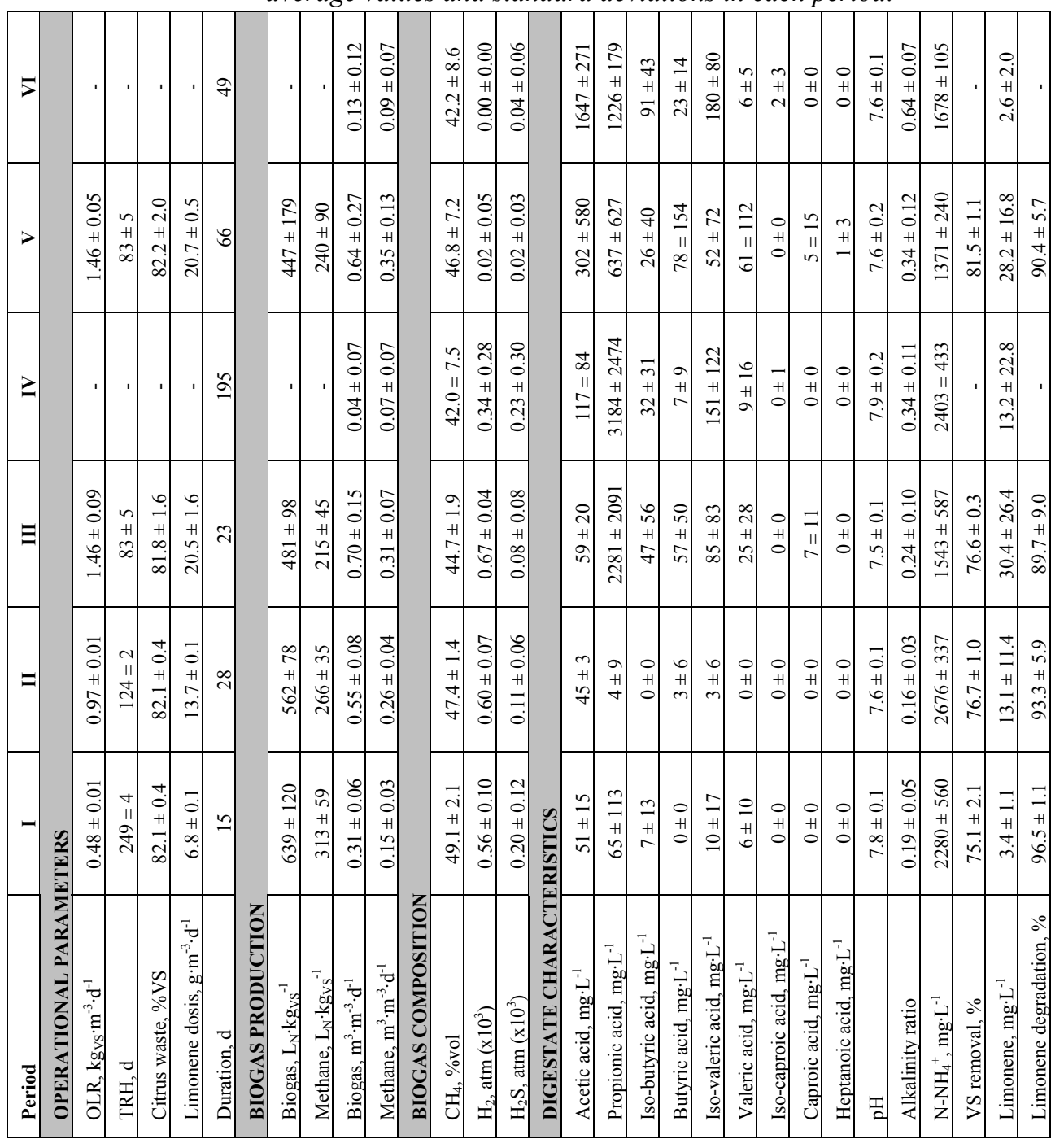

\subsubsection{Biological treatment and OLR increase every $14^{\text {th }}$ day (Test 14dBT)}

The specific biogas and methane production, the methane concentration in the biogas and the average daily dosage of limonene in each period are presented in Figure 7.17. After three periods of similar values, biogas and methane production decrease as the OLR (and consequently, the limonene dose) increases. At OLR $1.95 \mathrm{~kg}_{\mathrm{vs}} \cdot \mathrm{m}^{-3} \cdot \mathrm{d}^{-1}$ (period IV) the VFA concentration started to increase, and continued increasing in period V (OLR 2.56 $\mathrm{kg}_{\mathrm{VS}} \cdot \mathrm{m}^{-3} \cdot \mathrm{d}^{-1}$ ) when the experiment was discontinued. 


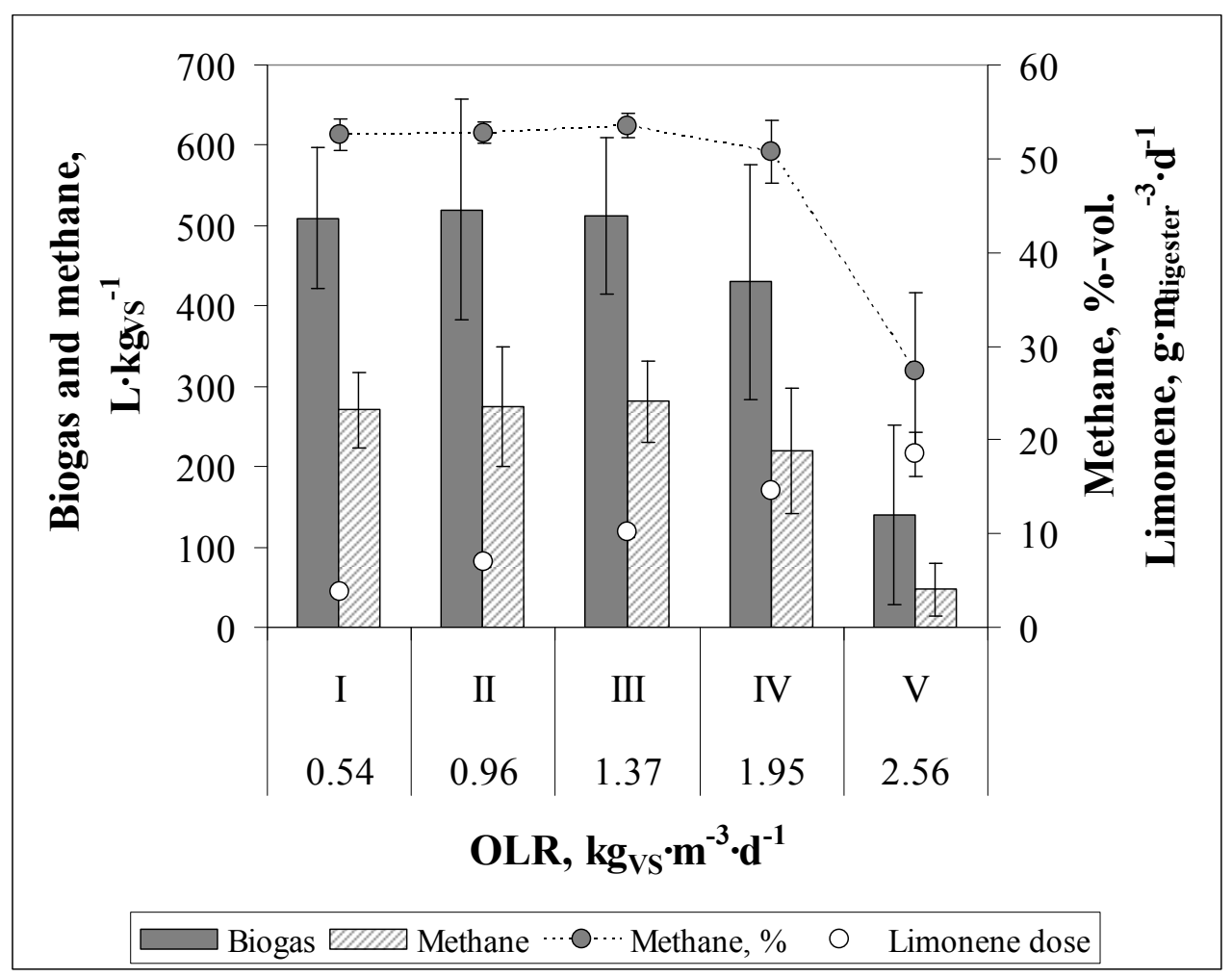

Figure 7.17.

Specific biogas and methane production and methane content in the biogas (\%-vol) of the experiment $14 d B T$ for the five periods studied. Averages and standard deviations of the different periods are presented.

Figure 7.18 (left) presents the volumetric methane production $\left(\mathrm{m}^{3}\right.$ of methane per $\mathrm{m}^{3}$ of digester and day) for each day of experiment. The methane production increased with OLR up to a maximum of $0.42 \mathrm{~m}^{3} \cdot \mathrm{m}_{\text {digester }}{ }^{-3} \cdot \mathrm{d}^{-1}$ in period IV, higher than in experiment $14 \mathrm{~d}$ (no biological pretreatment). In period $\mathrm{V}$, a decrease is observed due to inhibition of methanogenesis.

The methane content in the biogas is presented in Figure 7.18 (right). The methane concentration in the biogas remained in values near 50\%-vol. for the first three periods, and started decreasing from period IV onwards, indicating an inhibition of the methanogenesis. In the last period, the behaviour of the methane concentration in the biogas follows a decrease-increase-decrease trend. The second decrease coincides with a decrease in the concentration of butyric acid and a high hydrogen concentration in the biogas. This trend in the methane concentration is also present in experiment $14 \mathrm{~d}$ (without biological treatment), although not so marked. 

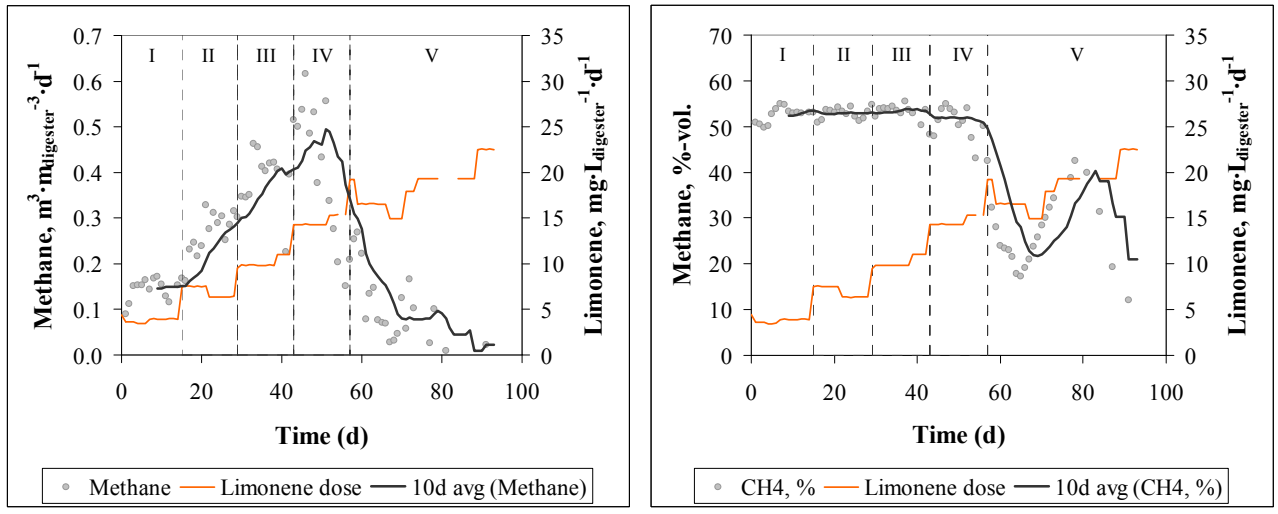

Figure 7.18.

Methane production and concentration in the biogas, test $14 d B T$.

The partial pressure of hydrogen and hydrogen sulphide in the biogas is presented in Figure 7.19. The partial pressure of hydrogen starts increasing already in period III coinciding with the first values of low methane concentration. This increase would indicate an inhibition of the hydrogenothrophic methanogenesis.

During period $\mathrm{V}$, the partial pressure of hydrogen is above the measurement range of the sensor, which would affect the acetogenesis. The concentrations of propionic and butyric acid decrease in this period, while acetic acid concentration increases. The $\mathrm{pH}$ decrease could have affected the methanogenesis. The increasing concentration of hydrogen sulphide in period $\mathrm{V}$ is also indicating the methanogenesis inhibition.
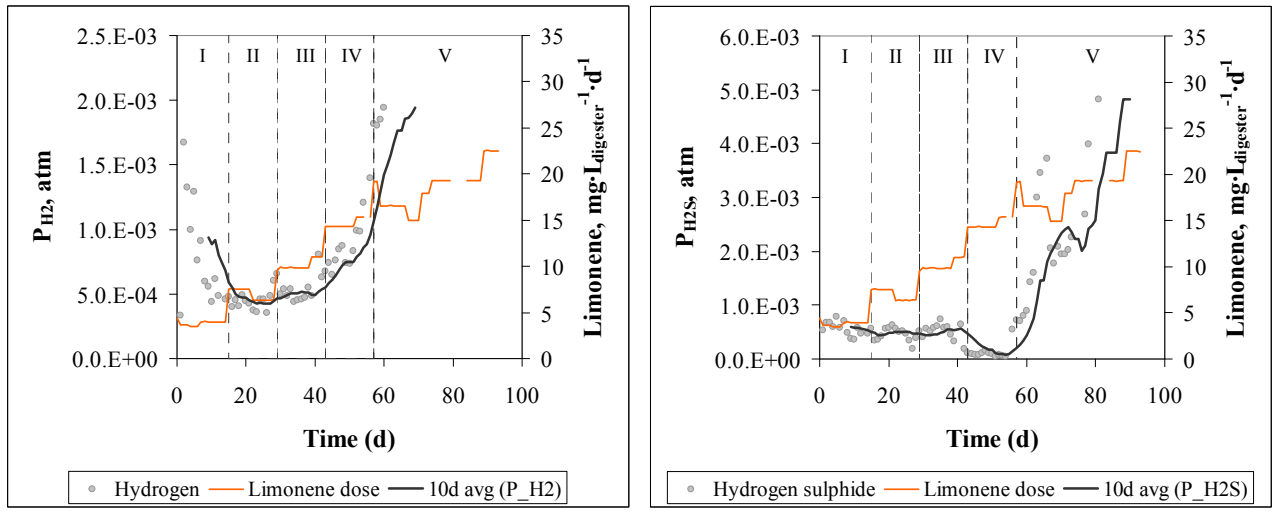

Figure 7.19.

Hydrogen and hydrogen sulphide in the biogas from $14 d B T$.

Volatile fatty acids (VFA) concentrations in the digester are presented in Figure 7.20.

Acetic acid remained in values under $60 \mathrm{mg} \cdot \mathrm{L}^{-1}$ in all the experimental periods except for the last one, when it started to steeply increase until reaching a value of $6927 \mathrm{mg} \cdot \mathrm{L}^{-1}$. This accumulation of acetic acid in period VI is a sign of inhibition of the acetoclastic methanogenesis. 

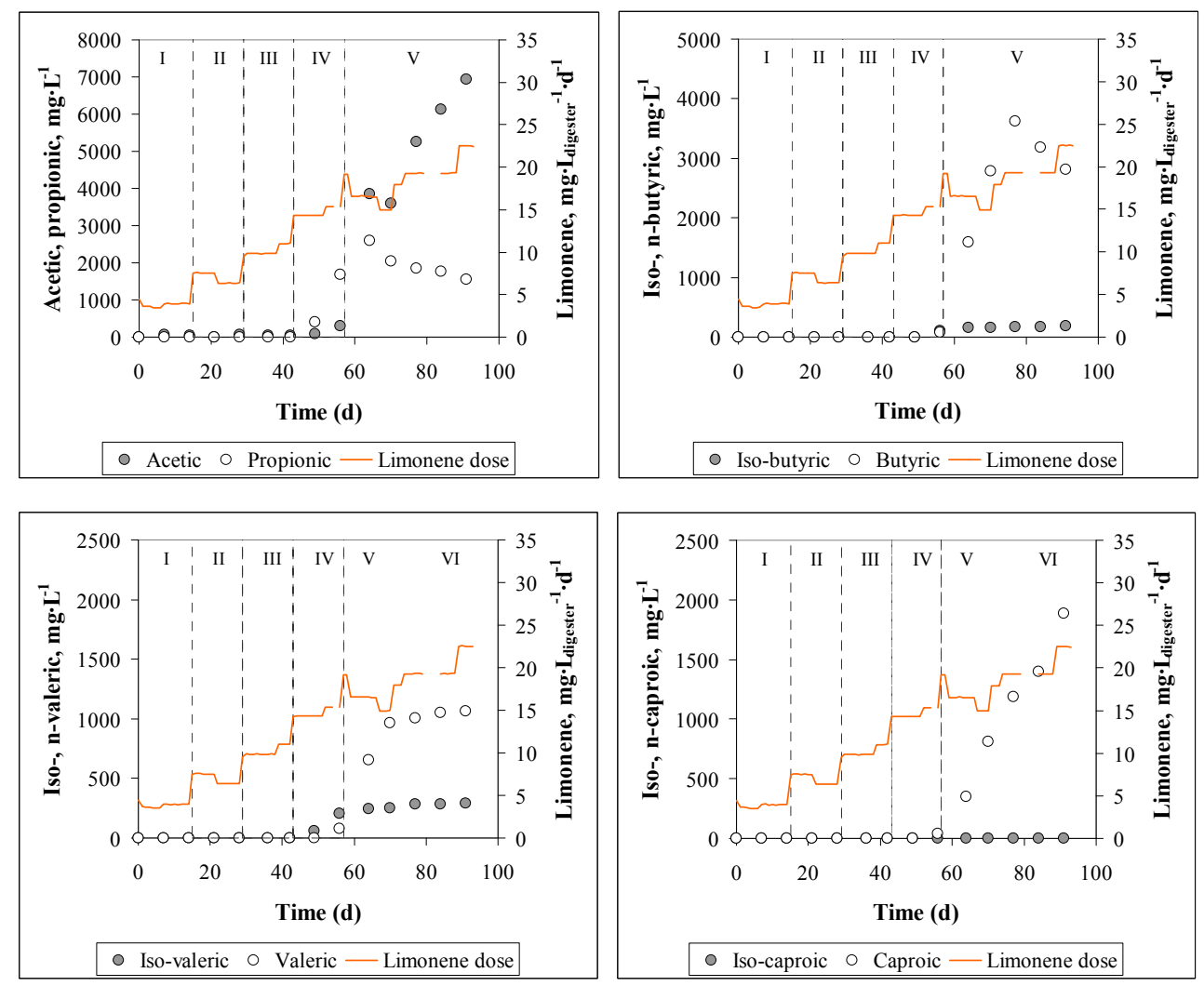

Figure 7.20.

Volatile fatty acids concentration in the digestate from $14 \mathrm{dBT}$.

The concentration of propionic acid began to increase already in period IV (OLR 1.95 $\mathrm{kg}_{\mathrm{VS}} \cdot \mathrm{m}^{-3} \cdot \mathrm{d}^{-1}$ ) until values higher than $2600 \mathrm{mg} \cdot \mathrm{L}^{-1}$. In the last period the propionic acid concentration decreased while the acetic acid increased, which could be partly due to the transformation of propionic into acetic. This effect was already observed in the previous experiments. The simultaneous accumulation of propionic acid and increase of hydrogen partial pressure in the biogas is a sign of inhibition of the acetogenesis by high hydrogen partial pressure. However, the high concentrations of hydrogen measured are not compatible with a consumption of propionic acid (Solera et al., 2014). This fact remains without a clear explanation. The butyric acid can be degraded at hydrogen partial pressures lower than $10^{-2} \mathrm{~atm}$. This could be the point where the consumption of butyric starts (day 77); unfortunately, the hydrogen partial pressure was still too high to be detected by the sensor and this hypothesis could not be confirmed. The absence of simultaneous acetic acid accumulation in period IV, taking into account all the observations together, points to an inhibition of the acetogenic bacteria.

An increase in the $\mathrm{n}$ - forms of butyric, valeric and caproic acid was observed in the period $\mathrm{V}$. The iso- forms of butyric and valeric acid started increasing earlier but stabilized in values of around 90 and $80 \mathrm{mg} \cdot \mathrm{kg}^{-1}$ respectively. The accumulation of butyric and valeric 
acid could be due not only to the inhibition of the corresponding bacteria by the limonene, but also to the product inhibition caused by propionic acid accumulation, according to the findings of Pind et al. (2002).

The $\mathrm{pH}$ and alkalinity ratio are affected by the VFA evolution (Figure 7.21). The $\mathrm{pH}$ started decreasing in period IV coinciding with the increase in VFA concentrations. The alkalinity ratio increased in period $\mathrm{V}$, later than the VFA increase, due to the alkalinity present in the system (co-digestion with cow manure).
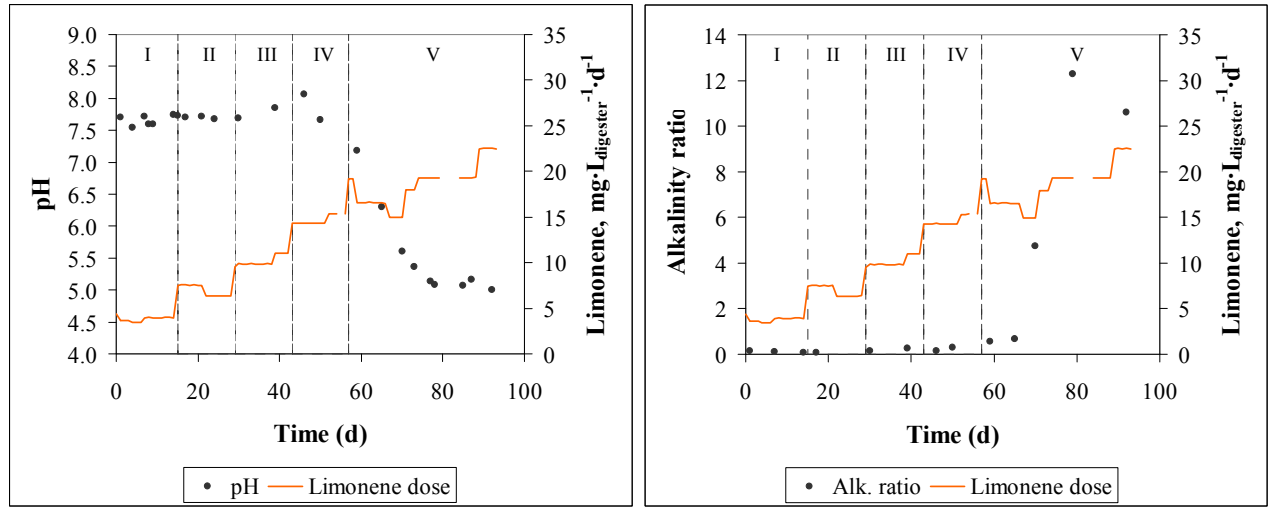

Figure 7.21.

pH (left) and alkalinity ratio (right) in the digestate from $14 \mathrm{dBT}$.

Ammonia nitrogen (Figure 7.22) is in all cases below the concentration of $4 \mathrm{~g} \cdot \mathrm{L}^{-1}$ which is considered the concentration when inhibition starts (Angelidaki y Ahring, 1993).

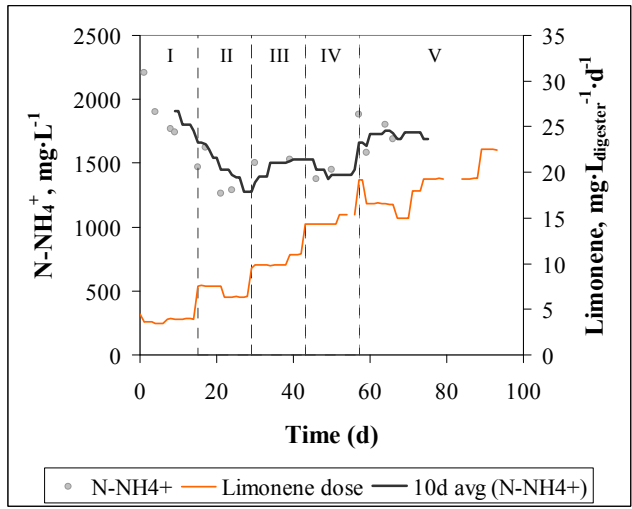

Figure 7.22.

Ammonia nitrogen concentration in the digestate from $14 \mathrm{dBT}$.

The highest limonene dose reached in a stable manner was $10.2 \mathrm{mg} \cdot \mathrm{L}_{\text {digester }}{ }^{-1} \cdot \mathrm{d}^{-1}$. This is lower than the value reached in the experiment without biological treatment, and also than the reported in the literature and the ones reached in chapter 5. The formation of $\alpha$-terpineol during the biological treatment, as observed in chapter 4 , might have been the cause for this 
fact. Indeed, the analysis of the CEO in the digestate indicated the presence, in order of abundance, of $\alpha$-terpineol, limonene, cymene, perillaldehyde, cresol and 4-terpineol. The concentration of $\alpha$-terpineol was much higher in test $14 \mathrm{dBT}$ than in test $14 \mathrm{~d}$ (see Figure 7.23). This molecule is much more inhibitory than the limonene, what would explain the apparently lower tolerance of the process to the limonene dosage in the feed.

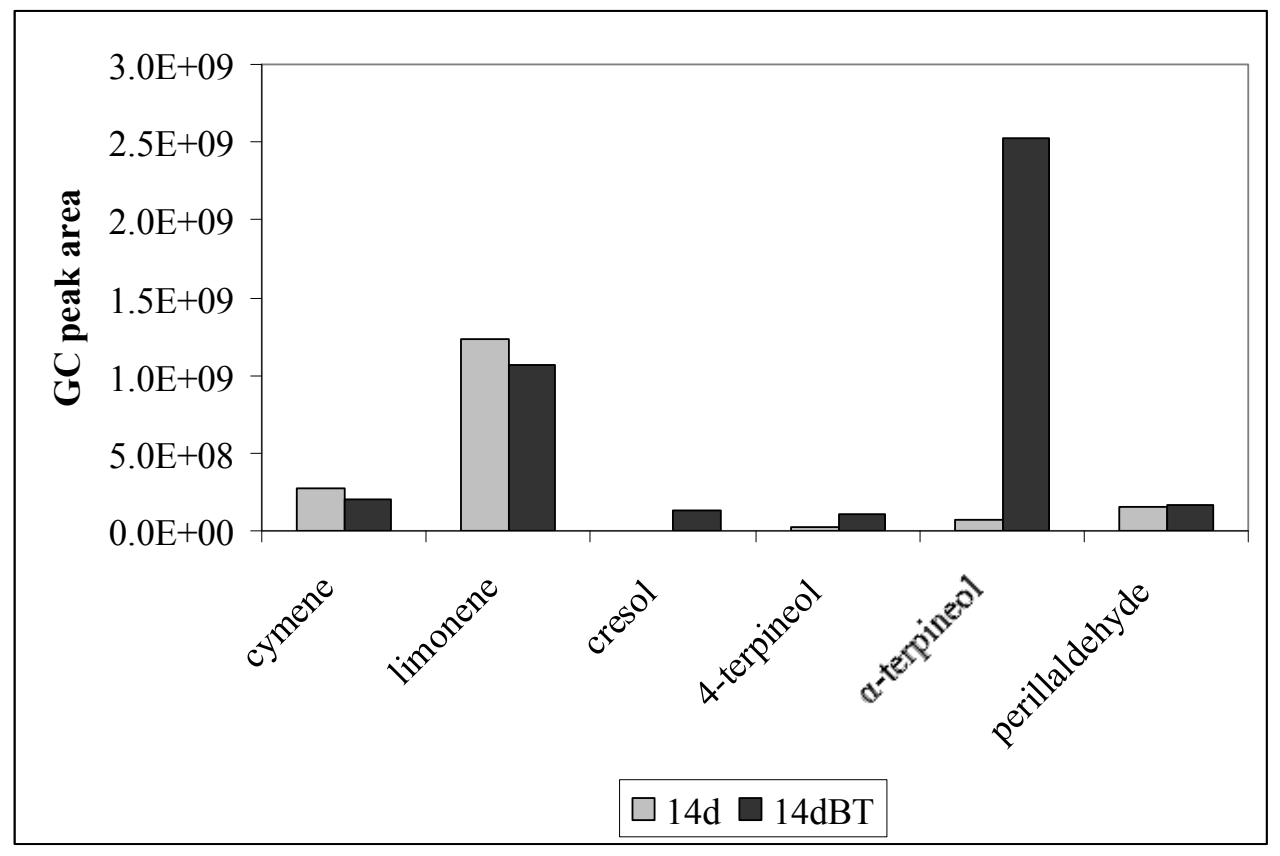

Figure 7.23.

GC peak area of the CEO analysis in tests $14 d$ and $14 d B T$ (data from the digestate collected on day 64 of experiment).

The limonene concentration remaining in the digester at the end of the experiment was 81.5 $\mathrm{mg} \cdot \mathrm{L}^{-1}$ which is much lower than the $\mathrm{IC}_{50}$ of $423 \mathrm{mg} \cdot \mathrm{kg}^{-1}$ and than the $\mathrm{MIC}$ of $200 \mathrm{mg} \cdot \mathrm{kg}^{-1}$, at which complete degradation of limonene was observed in batch anaerobic digestions by Ruiz and Flotats (2015). High limonene degradation was observed in test 14dBT (91.5\%).

The most probable causes for the observations done in the semi-continuous anaerobic digestion of experiment $14 \mathrm{dBT}$ are compiled in Table 7.9. An effect attributed to the limonene has been observed in the acetogenic bacteria (accumulation of propionic, butyric, valeric and hydrogen), acetoclastic methanogens (acetate accumulation in the last period) and hydrogenotrophic methanogens (further accumulation of hydrogen in the last period).

Table 7.10 shows the average values and standard deviation of each measured parameter in each period. 
Table 7.9.

Main observations in semi-continuous anaerobic digestion of $14 d B T$.

\begin{tabular}{|c|c|c|l|l|}
\hline Period & $\begin{array}{c}\text { OLR } \\
\left(\mathrm{kg} V S_{V} \mathrm{~m}^{-3} \cdot \mathrm{d}^{-1}\right)\end{array}$ & $\begin{array}{c}\text { Limonene } \\
\text { dose } \\
\left(g \cdot \mathrm{m}^{-3} \cdot \mathrm{d}^{-1}\right)\end{array}$ & Observations & $\begin{array}{l}\text { Possible causes attributed to } \\
\text { limonene inhibition }\end{array}$ \\
\hline I-III & $0.54-0.96$ & $3.8-7.0$ & Stable operation & - \\
\hline III & 1.37 & 10.2 & Start of hydrogen accumulation & $\begin{array}{l}\text { Hydrogenotrophic } \\
\text { methanogenesis inhibition }\end{array}$ \\
\hline IV & 1.95 & 14.6 & $\begin{array}{l}\text { Increase of propionic, butyric, } \\
\text { valeric and hydrogen. } \\
\text { No acetic accumulation. } \\
\text { Methane concentration and } \\
\text { production decrease. }\end{array}$ & $\begin{array}{l}\text { Acetogenesis inhibition. } \\
\text { Hydrogenotrophic } \\
\text { methanogenesis inhibition }\end{array}$ \\
\hline V & 18.5 & $\begin{array}{l}\text { Further decrease of methane } \\
\text { concentration. Methane } \\
\text { production decrease. } \\
\text { Steep increase of acetate, } \\
\text { hydrogen and iso-forms of } \\
\text { butyrate and valerate. Slight } \\
\text { decrease of propionate. Iso- forms } \\
\text { of butyric and valeric remain } \\
\text { constant. } \\
\text { pH drop and alkalinity ratio } \\
\text { increase. } \\
\text { Steep increase of hydrogen } \\
\text { sulphide. }\end{array}$ & $\begin{array}{l}\text { Methanogenesis inhibition, both } \\
\text { acetoclastic and } \\
\text { hydrogenotrophic. }\end{array}$ \\
\hline
\end{tabular}


Table 7.10. Results of semi-continuous anaerobic co-digestion 14dBT: average values and standard deviation in each period.

\begin{tabular}{|c|c|c|c|c|c|}
\hline Period & I & II & III & IV & $\mathbf{V}$ \\
\hline \multicolumn{6}{|c|}{ OPERATIONAL PARAMETERS } \\
\hline OLR, $\mathrm{kg}_{\mathrm{vS}} \cdot \mathrm{m}^{-3} \cdot \mathrm{d}^{-1}$ & $0.54 \pm 0.03$ & $0.96 \pm 0.10$ & $1.37 \pm 0.06$ & $1.95 \pm 0.06$ & $2.56 \pm 0.32$ \\
\hline TRH, d & $224 \pm 13$ & $127 \pm 14$ & $90 \pm 4$ & $63 \pm 2$ & $48 \pm 6$ \\
\hline Citrus waste, $\% \mathrm{VS}$ & $80.6 \pm 0.9$ & $81.6 \pm 1.3$ & $83.9 \pm 0.8$ & $84.9 \pm 0.4$ & $81.4 \pm 2.1$ \\
\hline Limonene dosis, $\mathrm{g} \cdot \mathrm{m}^{-3} \cdot \mathrm{d}^{-1}$ & $3.8 \pm 0.3$ & $7.0 \pm 0.6$ & $10.2 \pm 0.6$ & $14.6 \pm 0.5$ & $18.5 \pm 2.3$ \\
\hline Duration, $\mathrm{d}$ & 15 & 14 & 14 & 14 & 37 \\
\hline \multicolumn{6}{|c|}{ BIOGAS PRODUCTION** } \\
\hline Biogas, $\mathrm{L}_{\mathrm{N}} \cdot \mathrm{kg}_{\mathrm{Vs}}{ }^{-1}$ & $509 \pm 88$ & $520 \pm 138$ & $512 \pm 98$ & $430 \pm 146$ & $140 \pm 112$ \\
\hline Methane, $\mathrm{L}_{\mathrm{N}} \cdot \mathrm{kg}_{\mathrm{vs}}{ }^{-1}$ & $270 \pm 47$ & $275 \pm 74$ & $281 \pm 51$ & $220 \pm 78$ & $47 \pm 33$ \\
\hline Biogas, $\mathrm{m}^{3} \cdot \mathrm{m}^{-3} \cdot \mathrm{d}^{-1}$ & $0.27 \pm 0.04$ & $0.49 \pm 0.10$ & $0.70 \pm 0.12$ & $0.79 \pm 0.31$ & $0.33 \pm 0.26$ \\
\hline Methane, $\mathrm{m}^{3} \cdot \mathrm{m}^{-3} \cdot \mathrm{d}^{-1}$ & $0.14 \pm 0.02$ & $0.26 \pm 0.05$ & $0.38 \pm 0.07$ & $0.42 \pm 0.14$ & $0.11 \pm 0.08$ \\
\hline \multicolumn{6}{|l|}{ BIOGAS COMPOSITION } \\
\hline $\mathrm{CH}_{4}, \%$ vol & $52.5 \pm 1.7$ & $52.8 \pm 1.1$ & $53.5 \pm 1.3$ & $50.8 \pm 3.4$ & $27.3 \pm 8.4$ \\
\hline $\mathrm{H}_{2}, \operatorname{atm}\left(\times 10^{3}\right)$ & $0.80 \pm 0.41$ & $0.44 \pm 0.07$ & $0.54 \pm 0.10$ & $0.88 \pm 0.22$ & $1.85 \pm 0.06^{*}$ \\
\hline $\mathrm{H}_{2} \mathrm{~S}, \operatorname{atm}\left(\times 10^{3}\right)$ & $0.56 \pm 0.13$ & $0.46 \pm 0.12$ & $0.52 \pm 0.14$ & $0.12 \pm 0.13$ & $2.21 \pm 1.16$ \\
\hline \multicolumn{6}{|c|}{ DIGESTATE CHARACTERISTICS } \\
\hline Acetic acid, $\mathrm{mg} \cdot \mathrm{L}^{-1}$ & $31 \pm 30$ & $27 \pm 38$ & $44 \pm 10$ & $193 \pm 147$ & $5151 \pm 1436$ \\
\hline Propionic acid, $\mathrm{mg} \cdot \mathrm{L}^{-1}$ & $0 \pm 0$ & $0 \pm 0$ & $0 \pm 0$ & $1041 \pm 909$ & $1961 \pm 402$ \\
\hline Iso-butyric acid, $\mathrm{mg} \cdot \mathrm{L}^{-1}$ & $0 \pm 0$ & $0 \pm 0$ & $0 \pm 0$ & $55 \pm 78$ & $169 \pm 12$ \\
\hline Butyric acid, $\mathrm{mg} \cdot \mathrm{L}^{-1}$ & $0 \pm 0$ & $0 \pm 0$ & $0 \pm 0$ & $42 \pm 59$ & $2802 \pm 756$ \\
\hline Iso-valeric acid, $\mathrm{mg} \cdot \mathrm{L}^{-1}$ & $0 \pm 0$ & $0 \pm 0$ & $0 \pm 0$ & $132 \pm 105$ & $272 \pm 21$ \\
\hline Valeric acid, $\mathrm{mg} \cdot \mathrm{L}^{-1}$ & $0 \pm 0$ & $0 \pm 0$ & $0 \pm 0$ & $39 \pm 56$ & $949 \pm 168$ \\
\hline Iso-caproic acid, $\mathrm{mg} \cdot \mathrm{L}^{-1}$ & $0 \pm 0$ & $0 \pm 0$ & $0 \pm 0$ & $0 \pm 0$ & $0 \pm 0$ \\
\hline Caproic acid, $\mathrm{mg} \cdot \mathrm{L}^{-1}$ & $0 \pm 0$ & $0 \pm 0$ & $0 \pm 0$ & $19 \pm 27$ & $1126 \pm 582$ \\
\hline Heptanoic acid, $\mathrm{mg} \cdot \mathrm{L}^{-1}$ & $0 \pm 0$ & $0 \pm 0$ & $0 \pm 0$ & $0 \pm 0$ & $250 \pm 138$ \\
\hline $\mathrm{pH}$ & $7.6 \pm 0.1$ & $7.7 \pm 0.0$ & $7.8 \pm 0.1$ & $7.9 \pm 0.3$ & $5.5 \pm 0.7$ \\
\hline Alkalinity ratio & $0.12 \pm 0.04$ & 0.07 & $0.22 \pm 0.09$ & $0.23 \pm 0.10$ & $5.78 \pm 5.47$ \\
\hline $\mathrm{N}-\mathrm{NH}_{4}{ }^{+}, \mathrm{mg} \cdot \mathrm{L}^{-1}$ & $1905 \pm 215$ & $1410 \pm 168$ & $1515 \pm 21$ & $1413 \pm 53$ & $1738 \pm 131$ \\
\hline VS removal, $\%$ & $81.6 \pm 5.6$ & $76.1 \pm 0.6$ & $76.0 \pm 0.1$ & $72.3 \pm 0.2$ & $62.4 \pm 5.9$ \\
\hline Limonene, $\mathrm{mg} \cdot \mathrm{L}^{-1}$ & n.a. & n.a. & n.a. & n.a. & 81.5 \\
\hline Limonene degradation, $\%$ & n.a. & n.a. & n.a. & n.a. & 91.5 \\
\hline
\end{tabular}

n.a. not analyzed. * Many measurements in this period were above the upper detection limit of the sensor; only the available measurements are included in this average value. 


\subsubsection{Biological treatment and OLR increase every $28^{\text {th }}$ day (Test 28dBT)}

The specific biogas and methane production, the methane concentration in the biogas and the average daily dosage of limonene in each period are presented in Figure 7.24. The average biogas and methane production in the first three periods was not statistically different. In the fourth period (OLR $2.20 \mathrm{~kg} \mathrm{Vs} \cdot \mathrm{m}^{-3} \cdot \mathrm{d}^{-1}$, limonene dose $38.1 \mathrm{mg} \cdot \mathrm{L}_{\text {digester }}{ }^{-1} \cdot \mathrm{d}^{-1}$ ), a significant decrease was observed. An increase of the VFA concentrations was also detected in period IV and the feed was stopped (period V). The recovery of the active biomass was not possible despite of the long period left without feeding (more than 6 months).

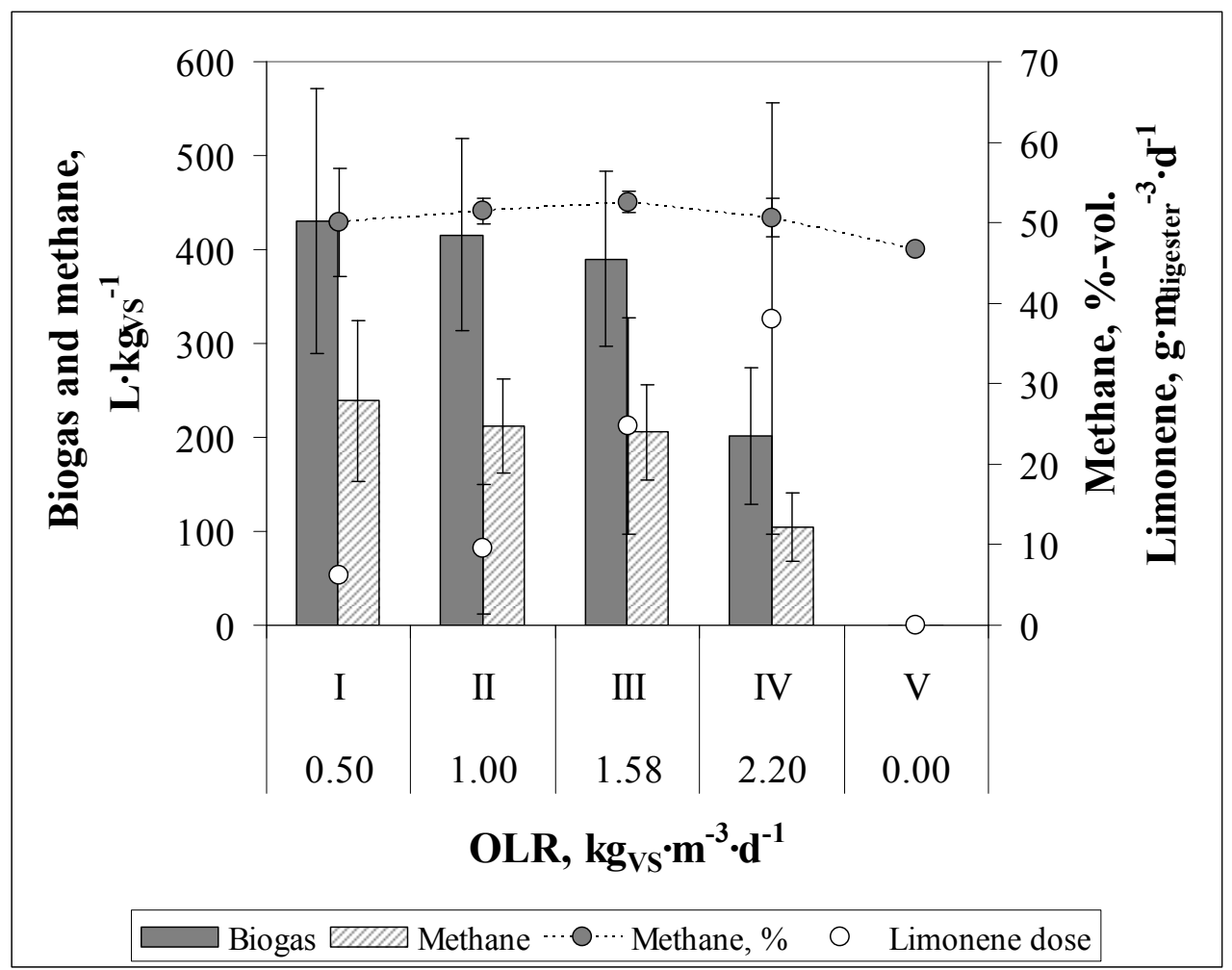

Figure 7.24.

Specific biogas and methane production and methane content in the biogas (\%-vol) of the experiment $28 d B T$ for the five periods studied. Averages and standard deviations of the different periods are presented.

Figure 7.25 (left) presents the volumetric methane production $\left(\mathrm{m}^{3}\right.$ of methane per $\mathrm{m}^{3}$ of digester and day) for each day of experiment. The volumetric methane production increased with OLR up to a maximum of $0.32 \mathrm{~m}^{3} \cdot \mathrm{m}_{\text {digester }}{ }^{-3}$ in period III. In period IV, a decrease is observed, possibly due to an inhibition of the methanogenesis, and in period V (no feeding) no methane production was detected. 
The methane content in the biogas is presented in Figure 7.25 (right). The methane concentration in the biogas remained in values near $50 \%$ for the first four periods, while a decreasing trend was observed in period IV. Since no biogas production was detected in period $\mathrm{V}$, no methane concentration analysis is available for this period.
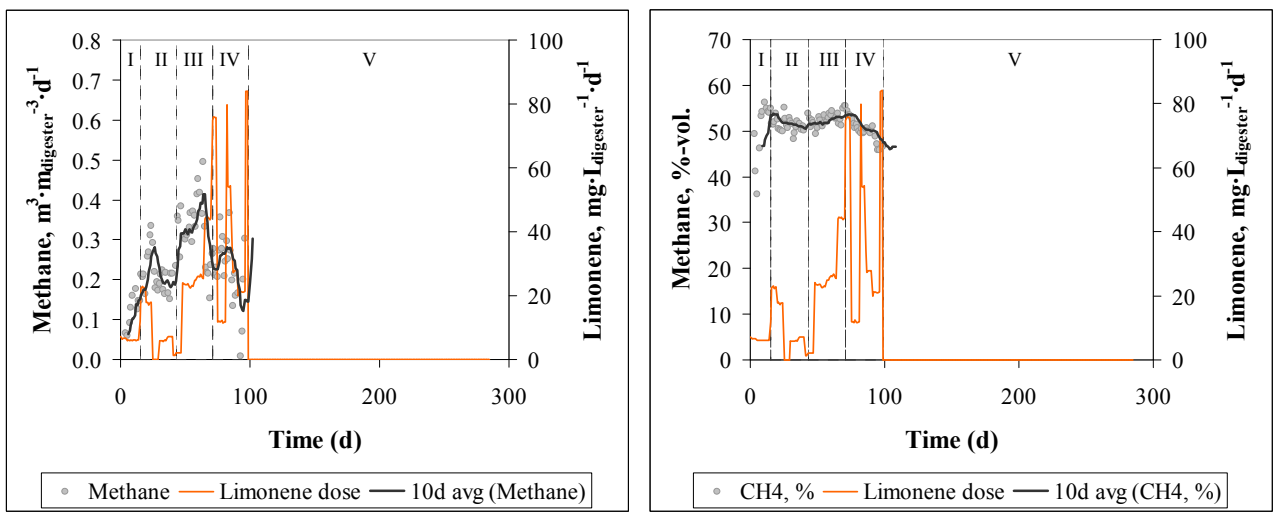

Figure 7.25.

Methane production and concentration in the biogas, test $28 \mathrm{dBT}$.

The partial pressure of hydrogen and hydrogen sulphide in the biogas is presented in Figure 7.26. Contrarily to the previous experiments described in this chapter, no significant hydrogen accumulation is observed in the biogas. The partial pressure of hydrogen sulphide shows a similar trend but with different absolute values.
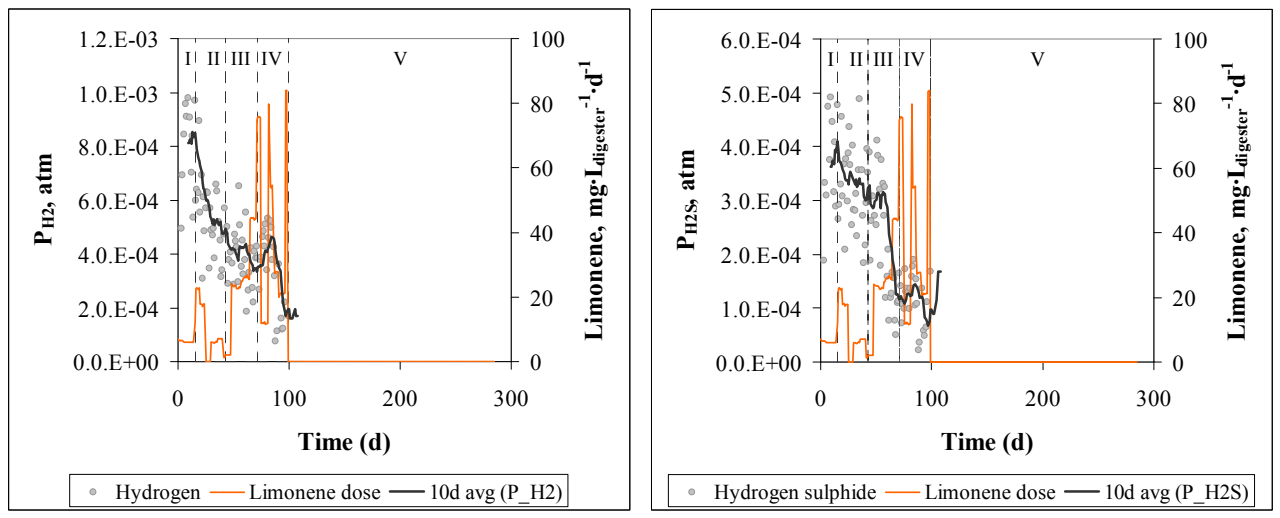

Figure 7.26.

Hydrogen and hydrogen sulphide in the biogas from $28 \mathrm{dBT}$.

Volatile fatty acids (VFA) concentrations in the digester are presented in Figure 7.27.

Acetic acid remained in values under $400 \mathrm{mg} \cdot \mathrm{L}^{-1}$ in all the experimental periods except for the last one, when it started to steeply increase until reaching a value of $2886 \mathrm{mg} \cdot \mathrm{L}^{-1}$. This accumulation of acetic acid in period $\mathrm{V}$ is a symptom of inhibition of the acetoclastic methanogenesis. Acetic acid concentration decreased afterwards, indicating acetoclastic activity. Methane production was not detected, without a clear explanation for this fact. 
The concentration of propionic acid began to increase already in period IV (OLR 2.2 $\mathrm{kg}_{\mathrm{Vs}} \cdot \mathrm{m}^{-3} \cdot \mathrm{d}^{-1}$ ) until values around $3000 \mathrm{mg} \cdot \mathrm{L}^{-1}$. After stopping the feed, the propionic acid kept in these values for 120 days, and then it dropped to values around $2000 \mathrm{mg} \cdot \mathrm{L}^{-1}$ and kept in this level for another 50 days. Finally, the concentration of propionate suddenly decreased to $370 \mathrm{mg} \cdot \mathrm{L}^{-1}$ while the acetic acid started to increase, which could be partly due to the transformation of propionic into acetic. This effect has been also observed in the previous experiments. These facts point to an inhibition of the acetogenic bacteria.
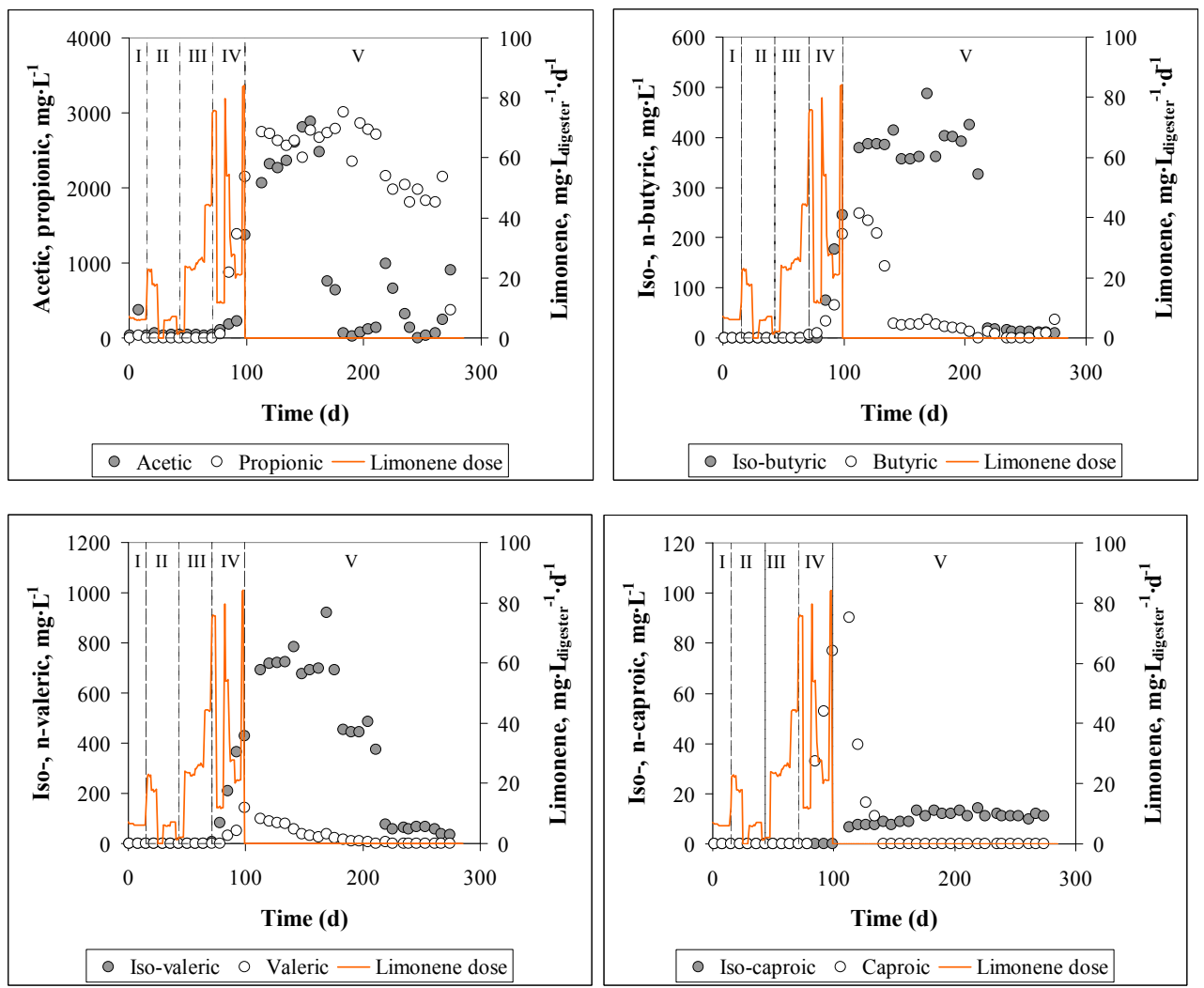

Figure 7.27.

Volatile fatty acids concentration in the digestate from $28 d B T$.

An increase in the concentrations of butyric, valeric and caproic acid was observed in the period IV (coinciding with the propionic increase). The concentration of iso-butyric and iso-caproic acid kept high and above the concentrations measured of n-forms until the point when the propionic acid decreased from 3000 to $2000 \mathrm{mg} \cdot \mathrm{L}^{-1}$. This could be related to the product inhibition caused by propionate accumulation as suggested by Pind et al. (2002).

The $\mathrm{pH}$ was not affected by the VFA evolution, but the alkalinity ratio did show significant changes depending on the VFA concentration (Figure 7.28). Alkalinity ratio started increasing at period IV and kept above 0.3 in period $\mathrm{V}$. 

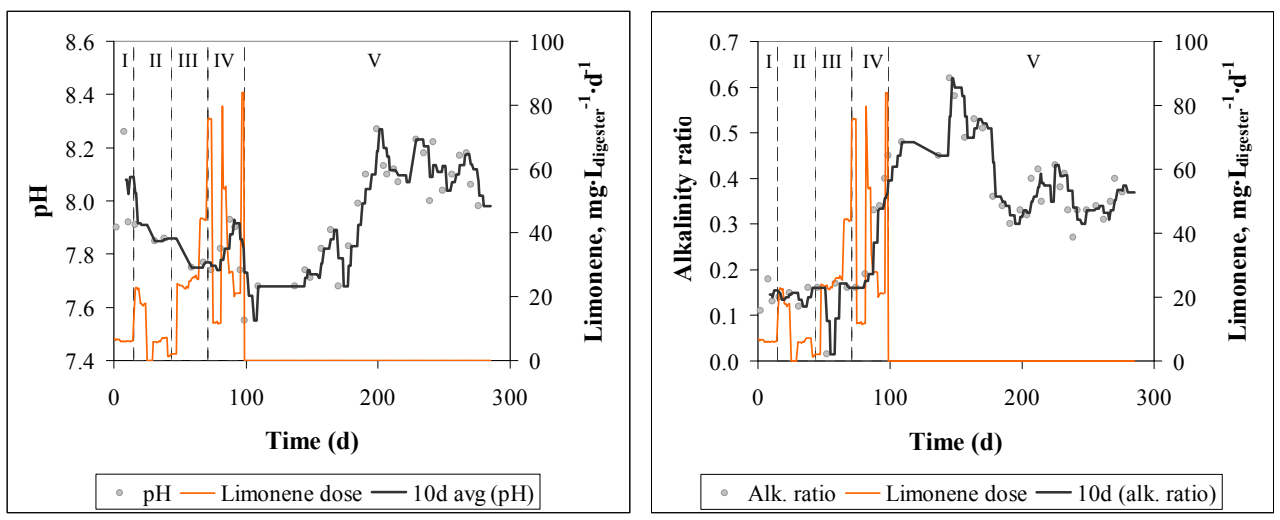

Figure 7.28. pH (left) and alkalinity ratio (right) in the digestate from $28 \mathrm{dBT}$.

Ammonia nitrogen (Figure 7.29) is in all cases below the concentration of $4 \mathrm{~g} \cdot \mathrm{L}^{-1}$ considered the concentration when inhibition starts (Angelidaki y Ahring, 1993).

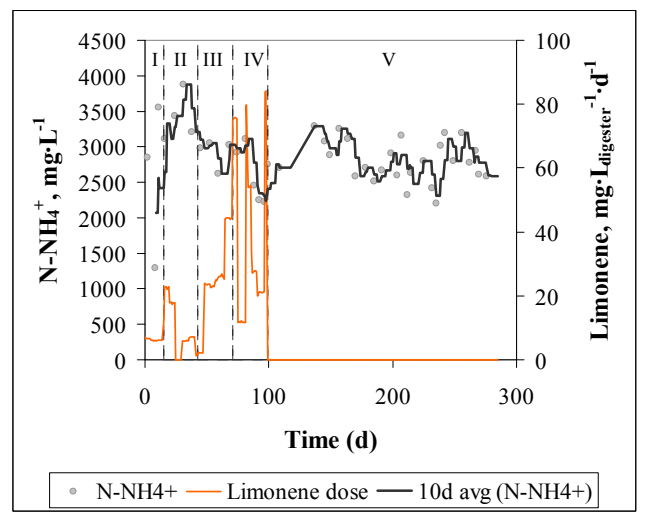

Figure 7.29 .

Ammonia nitrogen concentration in the digestate from $28 \mathrm{dBT}$.

The highest limonene dose reached in a stable manner was $24.7 \mathrm{mg} \cdot \mathrm{L}_{\mathrm{digester}}{ }^{-1} \cdot \mathrm{d}^{-1}$. This is lower than the reported in the literature and also to the values reached in chapter 5.

The limonene concentration remaining in the digester was low in all periods, with limonene degradations close to $100 \%$. At the end of the experiment, the limonene concentration was $25 \mathrm{mg} \cdot \mathrm{L}^{-1}$. This value is much lower than the $\mathrm{IC}_{50}$ of $423 \mathrm{mg} \cdot \mathrm{kg}^{-1}$ and the MIC of 200 $\mathrm{mg} \cdot \mathrm{kg}^{-1}$ observed by Ruiz and Flotats (2015). Both the Penicillium and the anaerobic microbiota are able to transform the limonene into $\alpha$-terpineol by, a compound which is more inhibitory than the limonene itself. This biotransformation has been reported in the literature (Badee et al., 2011) and experimentally observed in the batch experiments in chapter 3 and 4 . Indeed, peaks of this compound were detected as well in the pre-treated orange peel before anaerobic digestion (data not shown), but at lower intensities than the peaks detected in the analysis of the digestate. Other compounds such as cresol and cymene 
were also detected (see Figure 7.30). This would have been the real cause of the inhibition, rather than the limonene, that was degraded almost completely in the experiment.

Again, a similarity was found between the trend of cymene and the one of iso-valeric acid, suggesting that the acetogenic bacteria could be related to the degradation of this compound.

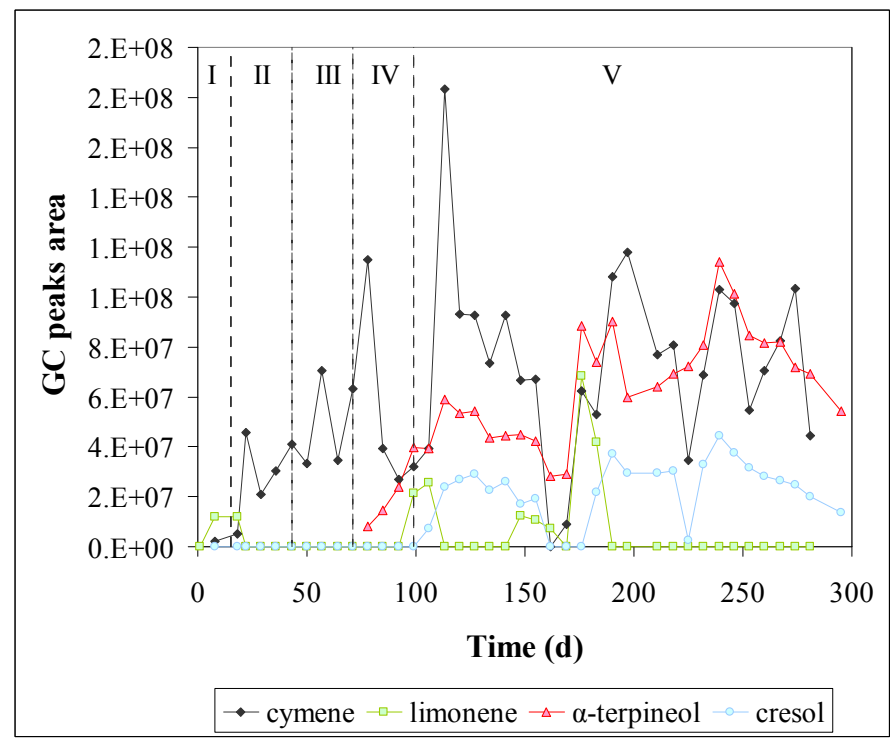

Figure 7.30. Main GC peaks area in the CEO analysis of 28dBT digestate.

The most probable causes for the observations done in the semi-continuous anaerobic digestion of experiment $28 \mathrm{dBT}$ are compiled in Table 7.11. Results suggest that limonene caused systemic inhibition in period $\mathrm{V}$, since all biological processes seemed to either stop or slow down.

Table 7.11. Main observations in semi-continuous anaerobic digestion of 28dBT.

\begin{tabular}{|c|c|c|l|l|}
\hline Period & $\begin{array}{c}\text { OLR } \\
\left(\mathrm{kg}_{V \mathrm{~S}^{*}} \mathrm{~m}^{-3} \cdot \mathrm{d}^{-1}\right)\end{array}$ & $\begin{array}{c}\text { Limonene } \\
\text { dose } \\
\left(\mathrm{g} \cdot \mathrm{m}^{-3} \cdot \mathrm{d}^{-1}\right)\end{array}$ & Observations & $\begin{array}{l}\text { Possible causes } \\
\text { attributed to limonene } \\
\text { inhibition }\end{array}$ \\
\hline I-III & $0.50-1.58$ & $6.2-24.7$ & Stable operation & - \\
\hline IV & 2.20 & 38.1 & $\begin{array}{l}\text { Increase of propionate, butyrate, valerate. } \\
\text { No acetate or hydrogen accumulation. } \\
\text { Methane concentration starts decreasing. }\end{array}$ & Acetogenesis inhibition. \\
\hline V & No feeding & $\begin{array}{c}\text { No } \\
\text { feeding }\end{array}$ & $\begin{array}{l}\text { Methane production stops (therefore, no } \\
\text { data available about biogas composition). } \\
\text { Propionic, butyric and valeric remain at } \\
\text { high concentrations but constant until a } \\
\text { certain point where they decrease and } \\
\text { acetate increases. }\end{array}$ & Systemic inhibition. \\
\hline
\end{tabular}


Table 7.12 shows the average values and standard deviation of each measured parameter in each period.

Table 7.12. Results of semi-continuous anaerobic co-digestion 28dBT: average values and standard deviation in each period.

\begin{tabular}{|c|c|c|c|c|c|}
\hline Period & I & II & III & IV & $\mathbf{V}$ \\
\hline \multicolumn{6}{|c|}{ OPERATIONAL PARAMETERS } \\
\hline $\mathrm{OLR}, \mathrm{kg}_{\mathrm{vs}} \cdot \mathrm{m}^{-3} \cdot \mathrm{d}^{-1}$ & $0.50 \pm 0.00$ & $1.00 \pm 0.01$ & $1.58 \pm 0.08$ & $2.20 \pm 0.23$ & - \\
\hline TRH, d & $230 \pm 31$ & $169 \pm 29$ & $93 \pm 6$ & $57 \pm 9$ & - \\
\hline Citrus waste, $\% \mathrm{VS}$ & $79.7 \pm 2.1$ & $79.2 \pm 0.4$ & $79.1 \pm 0.6$ & $78.8 \pm 2.2$ & - \\
\hline Limonene dosis, $\mathrm{g} \cdot \mathrm{m}^{-3} \cdot \mathrm{d}^{-1}$ & $6.2 \pm 0.4$ & $9.5 \pm 8.0$ & $24.7 \pm 13.4$ & $38.1 \pm 26.8$ & - \\
\hline Duration, $\mathrm{d}$ & 15 & 28 & 28 & 28 & 187 \\
\hline \multicolumn{6}{|c|}{ BIOGAS PRODUCTION** } \\
\hline Biogas, $\mathrm{L}_{\mathrm{N}} \cdot \mathrm{kg}_{\mathrm{Vs}}{ }^{-1}$ & $430 \pm 140$ & $415 \pm 103$ & $390 \pm 93$ & $201 \pm 73$ & - \\
\hline Methane, $\mathrm{L}_{\mathrm{N}} \cdot \mathrm{kg}_{\mathrm{Vs}}{ }^{-1}$ & $239 \pm 86$ & $212 \pm 50$ & $206 \pm 50$ & $105 \pm 37$ & - \\
\hline Biogas, $\mathrm{m}^{3} \cdot \mathrm{m}^{-3} \cdot \mathrm{d}^{-1}$ & $0.22 \pm 0.07$ & $0.42 \pm 0.10$ & $0.61 \pm 0.15$ & $0.44 \pm 0.16$ & - \\
\hline Methane, $\mathrm{m}^{3} \cdot \mathrm{m}^{-3} \cdot \mathrm{d}^{-1}$ & $0.12 \pm 0.04$ & $0.21 \pm 0.05$ & $0.32 \pm 0.08$ & $0.23 \pm 0.08$ & - \\
\hline \multicolumn{6}{|l|}{ BIOGAS COMPOSITION } \\
\hline $\mathrm{CH}_{4}, \%$ vol & $50.0 \pm 6.7$ & $51.5 \pm 1.6$ & $52.6 \pm 1.4$ & $50.6 \pm 2.4$ & - \\
\hline $\mathrm{H}_{2}, \operatorname{atm}\left(\mathrm{x} 10^{3}\right)$ & $0.79 \pm 0.17$ & $0.55 \pm 0.16$ & $0.39 \pm 0.10$ & $0.35 \pm 0.14$ & - \\
\hline $\mathrm{H}_{2} \mathrm{~S}, \operatorname{atm}\left(\mathrm{x} 10^{3}\right)$ & $0.36 \pm 0.09$ & $0.33 \pm 0.08$ & $0.23 \pm 0.11$ & $0.12 \pm 0.05$ & - \\
\hline \multicolumn{6}{|c|}{ DIGESTATE CHARACTERISTICS } \\
\hline Acetic acid, $\mathrm{mg} \cdot \mathrm{L}^{-1}$ & $202 \pm 235$ & $43 \pm 14$ & $41 \pm 3$ & $139 \pm 81$ & $1053 \pm 1064$ \\
\hline Propionic acid, $\mathrm{mg} \cdot \mathrm{L}^{-1}$ & $17 \pm 24$ & $0 \pm 0$ & $0 \pm 0$ & $576 \pm 670$ & $2346 \pm 555$ \\
\hline Iso-butyric acid, $\mathrm{mg} \cdot \mathrm{L}^{-1}$ & $0 \pm 0$ & $0 \pm 0$ & $0 \pm 0$ & $63 \pm 83$ & $247 \pm 183$ \\
\hline Butyric acid, $\mathrm{mg} \cdot \mathrm{L}^{-1}$ & $0 \pm 0$ & $0 \pm 0$ & $0 \pm 0$ & $29 \pm 27$ & $54 \pm 81$ \\
\hline Iso-valeric acid, $\mathrm{mg} \cdot \mathrm{L}^{-1}$ & $0 \pm 0$ & $0 \pm 0$ & $0 \pm 0$ & $166 \pm 157$ & $419 \pm 303$ \\
\hline Valeric acid, $\mathrm{mg} \cdot \mathrm{L}^{-1}$ & $0 \pm 0$ & $0 \pm 0$ & $0 \pm 0$ & $20 \pm 25$ & $30 \pm 39$ \\
\hline Iso-caproic acid, $\mathrm{mg} \cdot \mathrm{L}^{-1}$ & $0 \pm 0$ & $0 \pm 0$ & $0 \pm 0$ & $0 \pm 0$ & $10 \pm 3$ \\
\hline Caproic acid, $\mathrm{mg} \cdot \mathrm{L}^{-1}$ & $0 \pm 0$ & $0 \pm 0$ & $0 \pm 0$ & $21 \pm 26$ & $9 \pm 24$ \\
\hline Heptanoic acid, $\mathrm{mg} \cdot \mathrm{L}^{-1}$ & $0 \pm 0$ & $0 \pm 0$ & $0 \pm 0$ & $0 \pm 0$ & $0 \pm 0$ \\
\hline $\mathrm{pH}$ & $8.0 \pm 0.2$ & $7.9 \pm 0.0$ & $7.8 \pm 0.0$ & $7.8 \pm 0.1$ & $8.0 \pm 0.2$ \\
\hline Alkalinity ratio & $0.14 \pm 0.04$ & $0.14 \pm 0.02$ & $0.13 \pm 0.07$ & $0.28 \pm 0.10$ & $0.40 \pm 0.09$ \\
\hline $\mathrm{N}-\mathrm{NH}_{4}{ }^{+}, \mathrm{mg} \cdot \mathrm{L}^{-1}$ & $2563 \pm 1158$ & $3410 \pm 342$ & $2920 \pm 202$ & $2592 \pm 401$ & $2804 \pm 291$ \\
\hline VS removal, $\%$ & $75.2 \pm 1.4$ & $78.4 \pm 3.1$ & $76.7 \pm 1.8$ & $75.0 \pm 2.5$ & - \\
\hline Limonene, $\mathrm{mg} \cdot \mathrm{L}^{-1}$ & $6.1 \pm 7.1$ & $4.6 \pm 4.3$ & $1.2 \pm 0.5$ & $3.3 \pm 1.5$ & $25.0 \pm 27.5$ \\
\hline Limonene degradation, $\%$ & $99.7 \pm 0.4$ & $99.7 \pm 0.2$ & $99.8 \pm 0.2$ & $99.8 \pm 0.1$ & - \\
\hline
\end{tabular}




\subsubsection{Ethanol extraction (EE)}

The specific biogas and methane production, the methane concentration in the biogas and the average daily dosage of limonene in each period are presented in Figure 7.31. No significant difference was observed in any of the experimental periods.

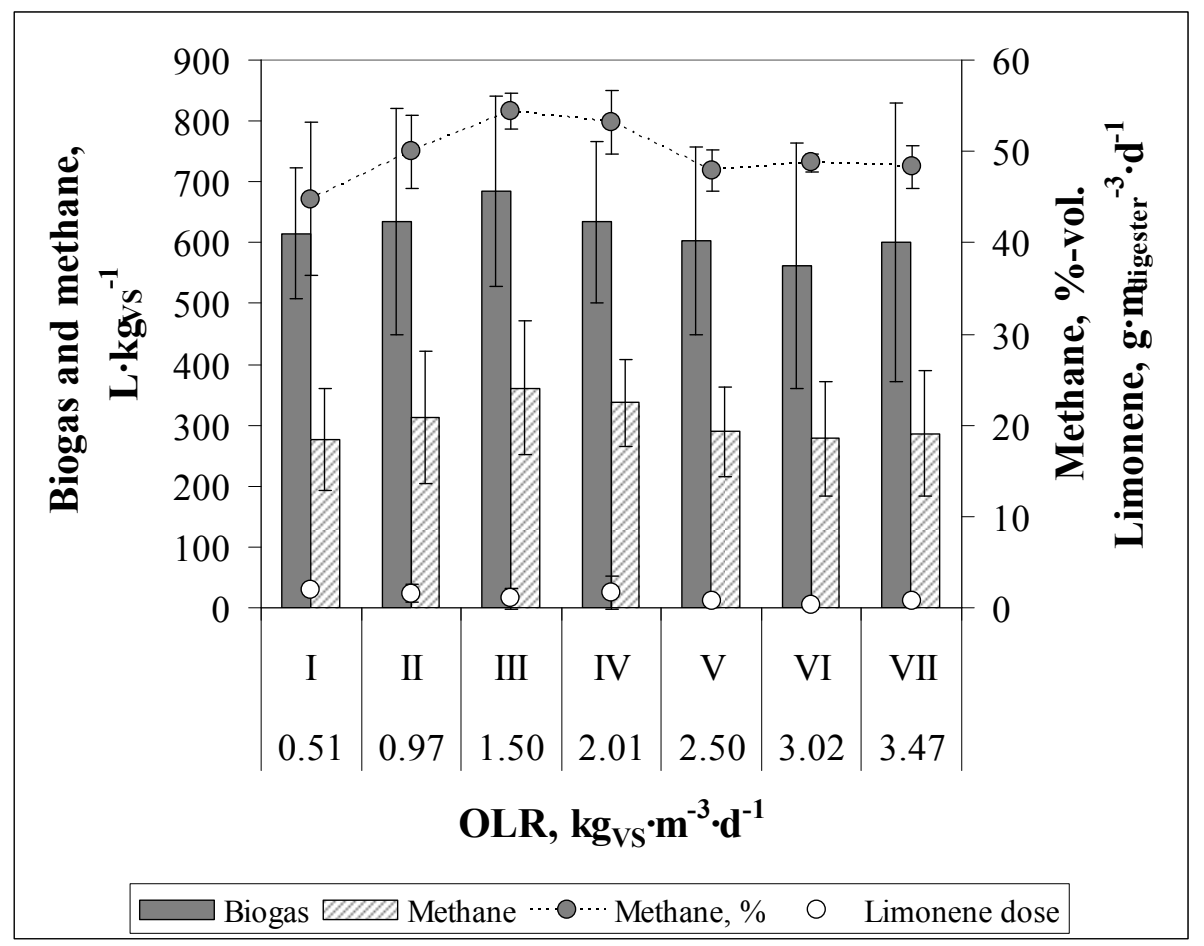

Figure 7.31. Specific biogas and methane production and methane content in the biogas (\%-vol) of the experiment EE for the seven periods studied. Averages and standard deviations of the different periods are presented.

Figure 7.32 (left) presents the volumetric methane production $\left(\mathrm{m}^{3}\right.$ of methane per $\mathrm{m}^{3}$ of digester and day) for each day of experiment. The methane production increased with OLR up to $0.99 \mathrm{~m}^{3} \cdot \mathrm{m}_{\text {digester }}{ }^{-3}$ in period VII, corresponding to an OLR of $3.47 \mathrm{~kg}_{\mathrm{vs}} \cdot \mathrm{m}^{-3} \cdot \mathrm{d}^{-1}$.

The methane content in the biogas is presented in Figure 7.32 (right). The methane concentration in the biogas remained in values near $50 \%$.

The partial pressure of hydrogen and hydrogen sulphide in the biogas is presented in Figure 7.33. After an initial stabilization stage, both hydrogen and hydrogen sulphide remain at low concentration. Hydrogen sulphide was expected to be lower in this experiment than in the previous ones, due to the lower cow manure percentage used in the feeding mixture. Therefore, inhibition by hydrogen sulphide was not expected. An increase was observed in the last period, although the maximum concentrations reached are not considered inhibitory or symptom of inhibition. 

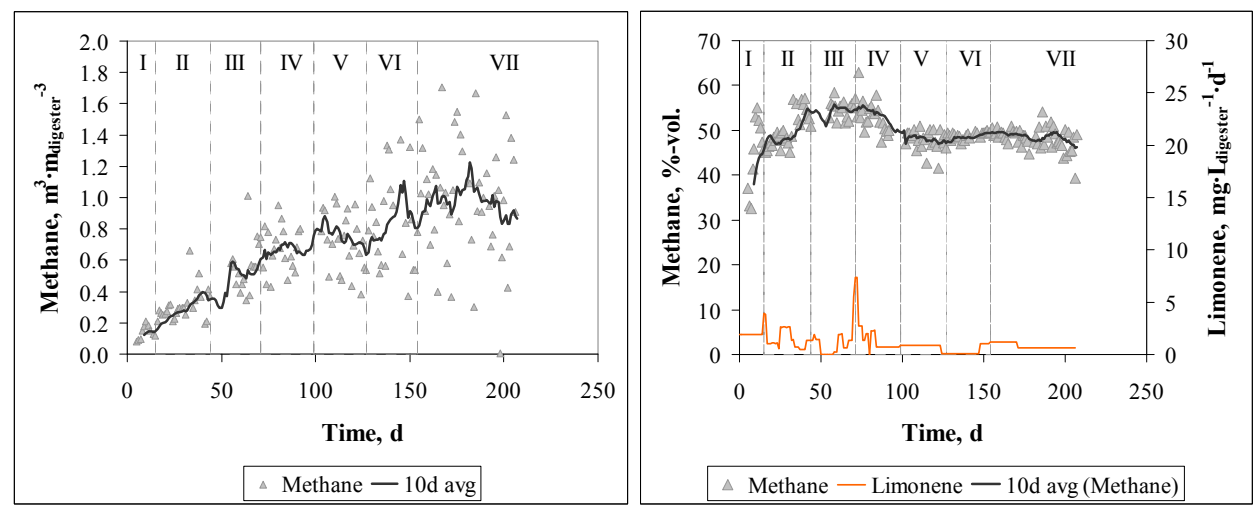

Figure 7.32 .

Methane production and concentration in the biogas in test EE.
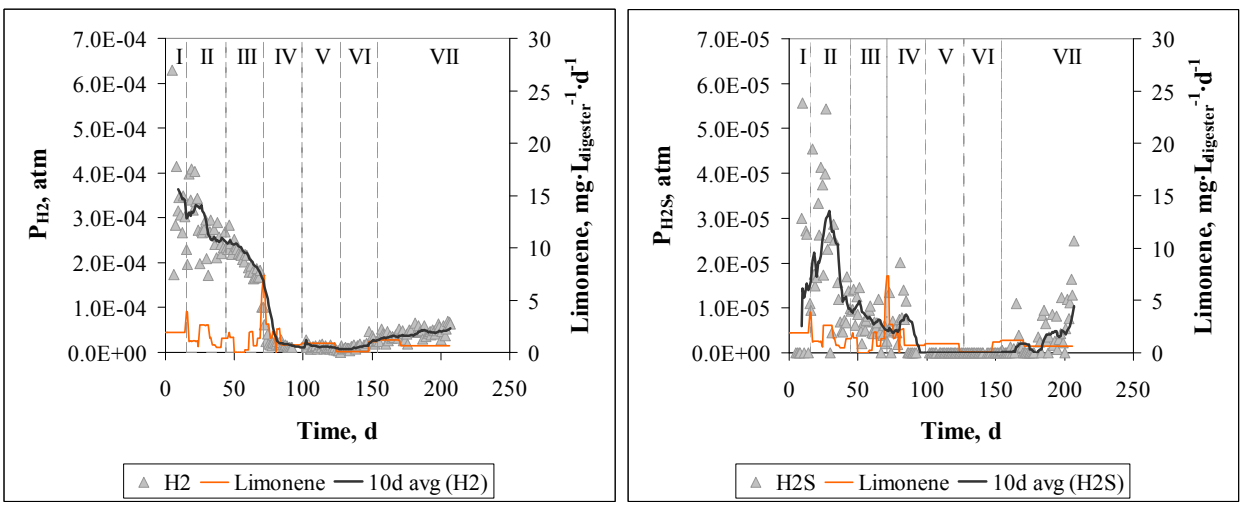

Figure 7.33.

Hydrogen and hydrogen sulphide in the biogas from EE.

Volatile fatty acids (VFA) concentrations in the digester are presented in Figure 7.34.

Acetic acid remained in values under $400 \mathrm{mg} \cdot \mathrm{L}^{-1}$ in all the experimental periods except for the last two measurements, when it increased until $1984 \mathrm{mg} \cdot \mathrm{L}^{-1}$. This accumulation of acetic acid in period VII is attributed to an organic overload, rather than to an inhibition by CEO. On the one hand, propionate, which is the first VFA to increase due to inhibition by CEO according to the previous experiments, remained at low concentrations in all the experiment (less than $140 \mathrm{mg} \cdot \mathrm{L}^{-1}$ ). Moreover, the limonene dose was in all periods below 2 $\mathrm{mg} \cdot \mathrm{L}_{\text {digester }}{ }^{-1} \cdot \mathrm{d}^{-1}$, which is much less than the inhibitory doses reported in the literature and observed in the previous experiments.

The concentration of iso- and n-butyric, iso-valeric and iso-caproic acid increased at the same time that the acetic acid did. Again, this is attributed to organic overload rather than to inhibition by CEO.

$\mathrm{pH}$ remained in the range 7.8-8.2 which is the normal range for an anaerobic digestion process. Alkalinity ratio increased in the last period coinciding with the increase of VFA (Figure 7.35). 

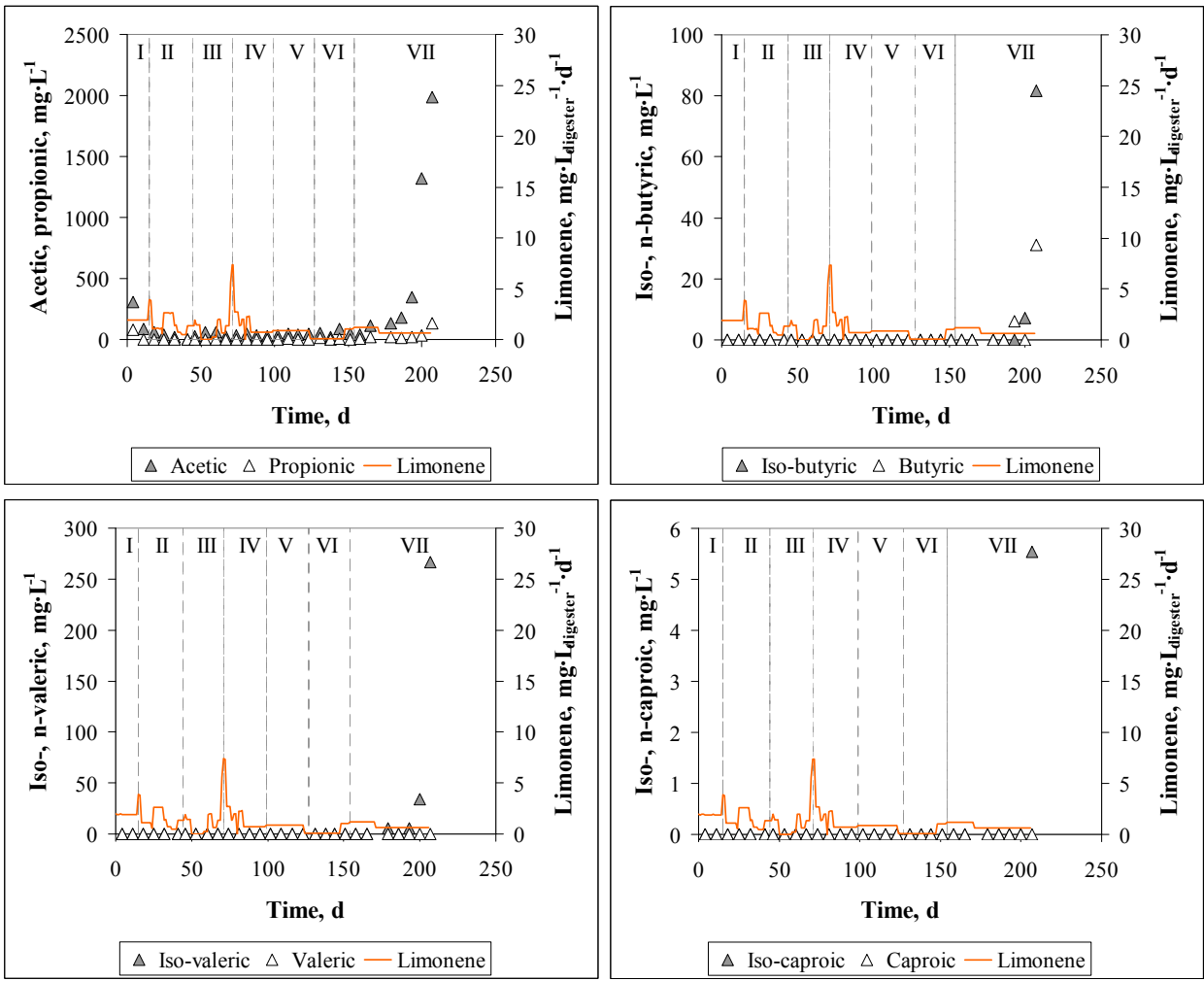

Figure 7.34.

Volatile fatty acids concentration in the digestate from EE.
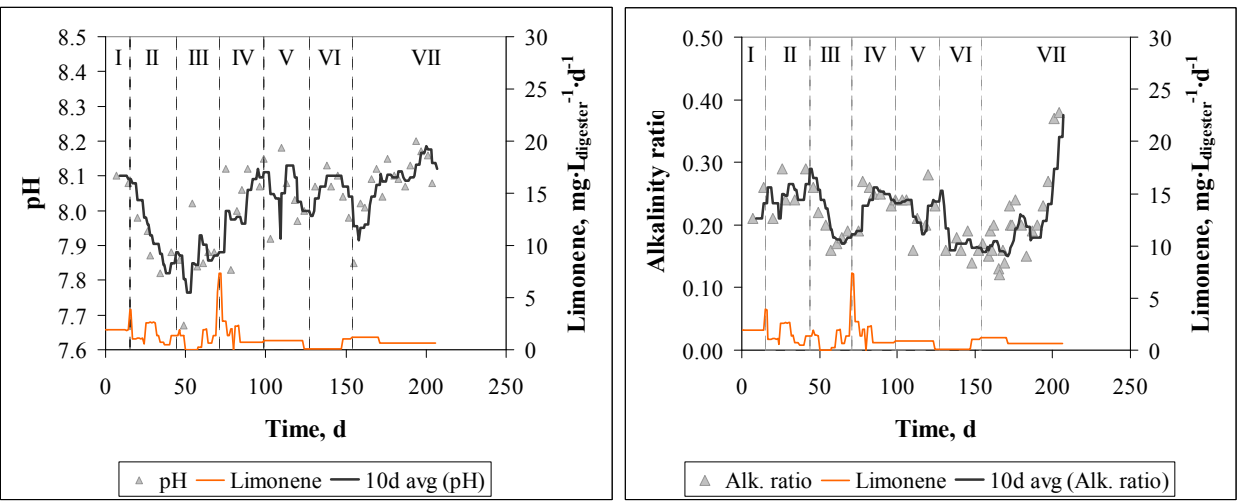

Figure 7.35.

$\mathrm{pH}$ (left) and alkalinity ratio (right) in the digestate from EE.

Ammonia nitrogen (Figure 7.36) is in all cases below the concentration of $4 \mathrm{~g} \cdot \mathrm{L}^{-1}$ considered the concentration when inhibition starts (Angelidaki y Ahring, 1993). 


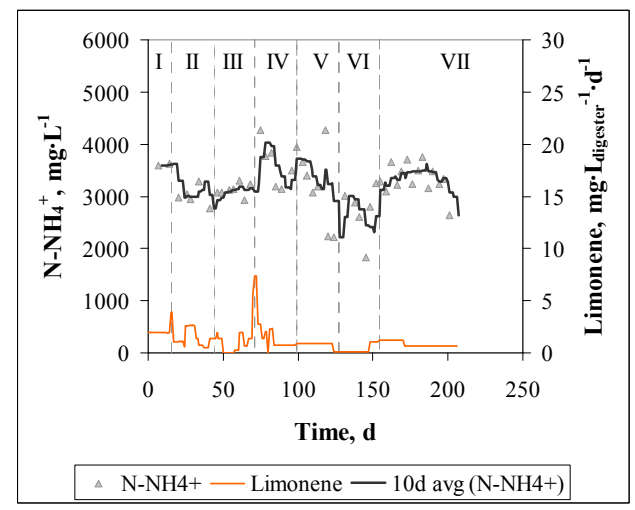

Figure 7.36.

Ammonia nitrogen concentration in the digestate from EE.

Despite the high limonene removal efficiencies, some limonene remained in the orange peel after the ethanol extraction and before the co-digestion with the cow manure. The analysis of the GC peaks obtained in the limonene analysis revealed the production of cymene (see Figure 7.37). Perillaldehyde was also detected in the digestate but it was already present in the orange peel after the ethanol extraction (data not shown).

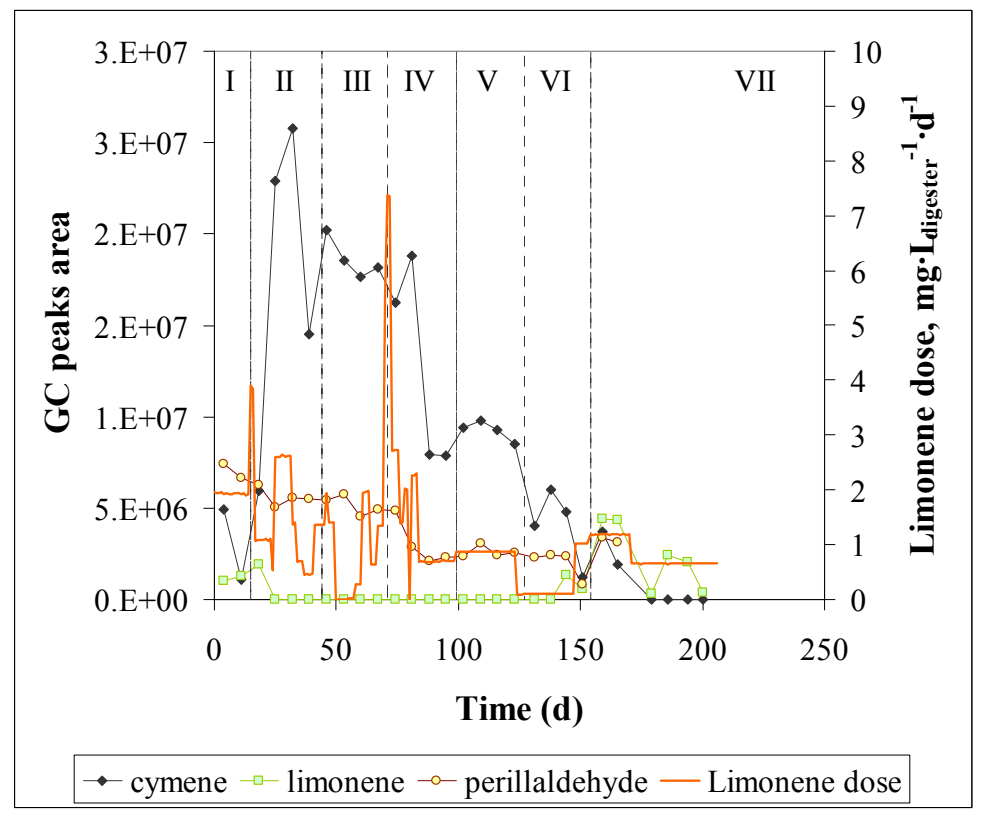

Figure 7.37. Main GC peaks area in the CEO analysis of EE digestate.

The cymene decreases gradually with the time. In periods I to $\mathrm{V}$, the cymene production seemed to correlate with the limonene dose; after an increase of the limonene dose, the concentration of cymene in the digestate increased, and the opposite as well. At the end of 
period VI and in period VII, the limonene degradation decreased slightly, and limonene peaks were detected at the same time as cymene peaks decreased or even disappeared.

The other two possibilities to explain the decrease in the cymene and limonene concentrations in period I to $\mathrm{V}$ are the accumulation of the hydrocarbons in or onto the membrane structure and the phase separation due to the lipophilic nature of the terpenes. The first hypothesis seems to be less likely than the limonene transformation into cymene, according to the observed trends of limonene feed, limonene in the digester and cymene in the digester. Moreover, the bioproduction of cymene from limonene was previously observed by Hylemon and Harder (1999). The second hypothesis was checked by analyzing the upper part of the digester to see if the concentration of limonene was higher in this part, but no difference was found between the limonene concentration between the lower and the upper part of the digester.

The main observations done in the semi-continuous anaerobic digestion of EE are compiled in Table 7.13. Table 7.14 shows the average values and standard deviation of each measured parameter in each period.

Table 7.13. Main observations in semi-continuous anaerobic digestion of EE.

\begin{tabular}{|c|c|c|l|l|}
\hline Period & $\begin{array}{c}\text { OLR } \\
\left(\mathrm{kg}_{V S} \cdot \mathrm{m}^{-3} \cdot \mathrm{d}^{-1}\right)\end{array}$ & $\begin{array}{c}\text { Limonene } \\
\text { dose } \\
\left(\mathrm{g} \cdot \mathrm{m}^{-3} \cdot \mathrm{d}^{-1}\right)\end{array}$ & Observations & $\begin{array}{l}\text { Possible causes attributed to } \\
\text { limonene inhibition }\end{array}$ \\
\hline I-VI & $0.51-3.02$ & $0.3-1.9$ & Stable operation & - \\
\hline VII & 3.47 & 0.8 & $\begin{array}{l}\text { Increase of acetate, propionate, } \\
\text { butyrate, valerate, hydrogen and } \\
\text { hydrogen sulphide. }\end{array}$ & $\begin{array}{l}\text { Partial methanogenesis } \\
\text { inhibition, attributed to organic } \\
\text { overload. }\end{array}$ \\
\hline
\end{tabular}

\subsection{Conclusions}

Three possible strategies to overcome inhibition of anaerobic digestion of orange peel were tested in this chapter: long adaptation times, biological treatment to remove limonene from the orange peel, and ethanol extraction to recover the limonene from the orange peel.

Neither the long adaptation times, nor the biological treatment, allowed for a stable anaerobic co-digestion of a mixture of $80 \%$ orange peel and $20 \%$ cow manure (VS basis).

The ethanol extraction of the limonene from the orange peel, with an efficiency of $94 \%$, before the anaerobic digestion, allowed for a stable anaerobic co-digestion of a mixture of 95\% orange peel and 5\% cow manure (VS basis). The low percentage of cow manure produced low concentration of hydrogen sulphide in the biogas, thus lowering the risk of inhibition due to this fact, compared with the other tests carried out in this chapter.

The remaining limonene was almost completely degraded during the anaerobic digestion. The main product was cymene, which is known to enhance the inhibitory effect of other terpenes. Acetogenic bacteria seemed to be related with the cymene degradation. Other 
compounds detected were perillaldehyde, cresol and $\alpha$-terpineol. The concentration of the latter was highest in the anaerobic digestion after biological treatment. In the other tests, it appeared at low concentration and after more than 200 days of experiment.

Table 7.14. Results of semi-continuous anaerobic co-digestion EE: average values and standard deviation in each period.

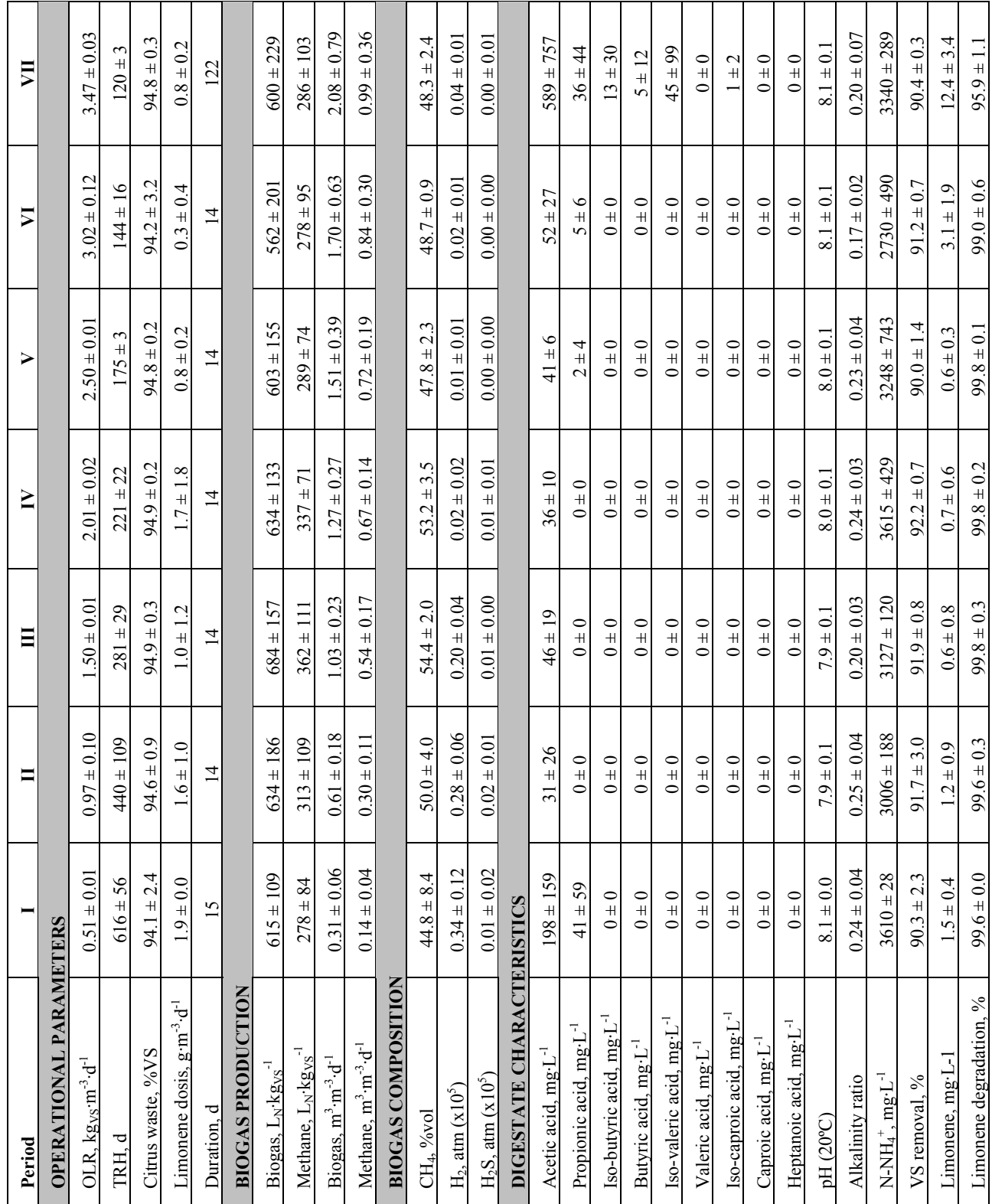




\subsection{Acknowledgements}

The results of this investigation were obtained in the projects PS-120000-2007-6 and IAP560630-2008-14, co-financed by the Spanish Ministry of Economy and Competitivity.

Amparo de Benito and Daniel Rivera, both from AINIA technology centre, collaborated in the biological and extraction pretreatments, respectively.

\subsection{References}

Angelidaki, I., Ahring B.K. 1993. Thermophilic anaerobic digestion of livestock waste: the effect of ammonia. Applied Microbiology and Biotechnology 38, 560-564.

APHA-AWWA-WEF. 2006. Standard Methods for the examination of water and wastewater. American Public Health Association / American Water Works Association / Water Environment Federation. 19 ${ }^{\text {th }}$ ed., Washington DC, USA.

Badee A.Z.M., Helmy S.A., Morsy N.F.S. 2011. Utilisation of orange peel in the production of $\alpha$-terpineol by Penicillium digitatum (NRRL 1202). Food Chemistry 126, 849-854.

CAPA. 2011. Informe del sector agrario valenciano 2011. Capítulo IV: estadísticas agrícolas. Cuadro 4.12: superficies, producciones y destino de la producción de cítricos. Comunitat Valenciana. Campaña 2010/2011. Conselleria de Agricultura, Pesca y Alimentación.

Effenberger, M., Lebuhn, M., Gronauer, A. 2007. Fermentermanagement - Stabiler Prozess bei NawaRo-Anlagen. 16. Jahrestagung des Fachvervandes Biogas e.V. Leipzig (Germany) $31^{\text {st }}$ january $-2^{\text {nd }}$ february.

Forgács, G., Pourbafrani, M., Niklasson, C., Taherzadeh, M.T., Hováth, I.S. 2011. Methane production from citrus wastes: process development and cost estimation. J. Chem. Technol. Biotechnol. 87, 250-255.

Hylemon, P.B., Harder, J. 1999. Biotransformation of monoterpenes, bile acids, and other isoprenoids in anaerobic ecosystems. FEMS Microbiology Reviews 22, 475-488.

Kaparaju, P.L.N., Rintala, J.A. 2006. Thermophilic anaerobic digestión of industrial orange waste. Environmental Technology 27, 623-633.

Lane, A.G. 1983. Pretreatment of citrus peel press liquor before anaerobic digestion. Environmental Technology Letters 4, 73-78.

Lane, A.G. 1984. Anaerobic digestion of orange peel. Food Technology in Australia 36, 125-127.

Lohrasbi M., Pourbafrani M., Niklasson C., Taherzadeh M.J. 2010. Process design and economic analysis of a citrus waste biorefinery with biofuels and limonene as products. Bioresource Technology 101, 7382-7388.

Martín, M.A., Siles, J.A., Chica, A.F., Martín, A. 2010. Biomethanization of orange peel waste. Bioresource Technology 101, 8993-8999.

Martín M.A., Fernández R., Serrano A., Siles J.A. 2013. Semi-continuous anaerobic digestion of orange peel waste and residual glycerol derived from biodiesel manufacturing. Waste Management 33, 1633-1639.

Mizuki, E., Akao, T., Saruwatari, T. 1990. Inhibitory effect of Citrus unshu peel on anaerobic digestion. Biological Wastes 33, 161-168.

Pind, P.F., Angelidaki, I., Ahring, B.K. 2002. Dynamics of the anaerobic process: effects of volatile fatty acids. Biotechnology and Bioengineering 82, 791-801.

Ruiz B., Flotats X. 2015. Effect of limonene on batch anaerobic digestion of citrus peel waste (submitted).

Solera R., Álvarez C.J., Aymerich E., Bedmar E.J., Carballa M., Castrillón L., Flotats X., Font X., López M.J., Marañón E., Prenafeta F.X., Tortosa G., Vicent T. 2014. De residuo a recurso, el camino hacia la 
sostenibilidad, volumen II.2: Procesos de biotransformación de la materia orgánica. Aspectos biológicos de la digestión anaerobia. Red Española de Compostaje, Ediciones Mundi-Prensa, Madrid. ISBN 9788484767008. 319 Ps.

Srilatha, H.R., Nand, K., Sudhakar Babu, K., Madhukara, K. 1995. Fungal pretreatment of orange processing waste by solid-state fermentation for improved production of methane. Process Biochemistry 30, 327331.

VDI - Verein Deutscher Ingenieure. 2006. Fermentation of organic materials. Characterisation of the substrate, sampling, collection of material data, fermentation tests. ICS 13.030.30; 27.190. 


\section{Chapter 8}

\section{Conclusions and suggestions for future research}

\section{Table of contents}

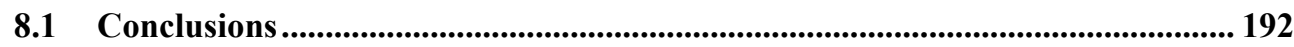

8.1.1 Review on anaerobic digestion of citrus peel and inhibition by citrus essential oil...... 192

8.1.2 Inhibitory concentration of limonene in batch anaerobic digestion .............................. 192

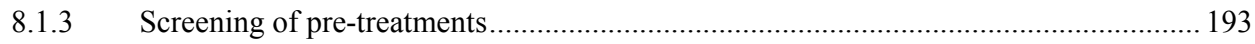

8.1.4 Anaerobic co-digestion of citrus waste and manure ................................................ 193

8.1.5 Combination of co-digestion and pre-treatments to overcome inhibition...................... 194

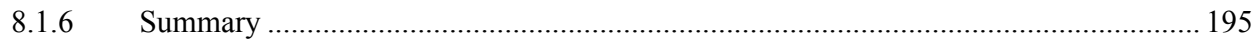

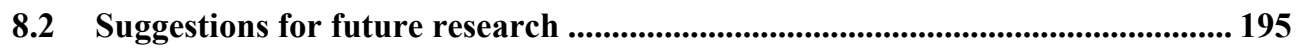




\subsection{Conclusions}

\subsubsection{Review on anaerobic digestion of citrus peel and inhibition by citrus essential oil}

The main technical difficulty for the anaerobic digestion of citrus waste is related to the presence of essential oils in the peel that can inhibit the process since they cause cell toxicity. Although adaptation is proven possible in in vitro tests, pilot scale trials of anaerobic digestion of citrus waste have failed when a particular organic loading rate (OLR) is reached or a daily inhibitor dosage is surpassed.

The main component of the citrus essential oil (CEO) is limonene, and therefore this component has been taken as reference. The composition of the CEO varies with several factors (fruit variety, climate conditions, etc.) and modulates the inhibitory effect.

Several strategies have been adopted to overcome inhibition of anaerobic digestion by CEO: keeping the OLR in low values to avoid excess dosage of the inhibitor, supplementing the citrus waste with nutrient and buffering solutions or pre-treating the citrus waste in order to reduce the CEO concentration, either by recovery or by degradation of the CEO. Nevertheless, although some of them have been proven successful in recovering/degrading the CEO, none of them has been applied at full scale operation.

After review of the existing literature, several issues remained for research:

- To determine the biodegradation pathway of CEOs, and specifically limonene. The mechanism by which the CEOs inhibit the anaerobic digestion is still not elucidated.

- To determine the inhibitory concentration values of CEO, specifically limonene, for the anaerobic digestion process.

- To identify and to study strategies allowing economically feasible anaerobic digestion of citrus waste. This includes avoid supplementation, low-cost pretreatments, or the application of biorefinery concepts.

\subsubsection{Inhibitory concentration of limonene in batch anaerobic digestion}

The limonene in citrus peel has an inhibitory effect on anaerobic digestion for concentrations higher than $200 \mathrm{mg} \cdot \mathrm{kg}^{-1}$ of limonene in the digester.

Grinding the citrus peel releases the limonene into the medium and increases its inhibitory effect. Toxicity is observed after biodegradation of the limonene, which was attributed to its biotransformation into other inhibitory compounds.

The $\mathrm{IC}_{50}$ of limonene $\left(423 \mathrm{mg} \cdot \mathrm{kg}^{-1}\right.$ in an initial run and $669 \mathrm{mg} \cdot \mathrm{kg}^{-1}$ in a second run of batch experiments) was lower than its usual concentration in citrus waste, which suggests that inhibition of the anaerobic digestion of citrus waste is always to be expected. 
Recovery and adaptation of the anaerobic biomass was observed despite the non-reversible inhibition mechanism reported in the literature.

\subsubsection{Screening of pre-treatments}

The three pretreatments applied to orange peel (biological treatment, steam distillation and ethanol extraction) were able to reduce the limonene concentration. The most efficient was the ethanol extraction, followed by steam distillation and biological treatment with fungi of the Penicillium genus. All treatments yielded limonene concentrations below the minimum inhibitory concentration. Therefore, the experiments aimed to assess the effect of these pretreatments on the methane yield for causes different to the limonene removal.

Biological treatment with Penicillium did not improve the methane yield. These fungi are able to degrade limonene but during the treatment $\alpha$-terpineol is produced, which presents a stronger inhibition effect.

Extraction treatments (steam distillation and solid-liquid extraction) resulted in improved methane potential and production rate, depending on the treatment conditions. These improvements are attributed to the extraction of minority compounds that are known to strongly influence the toxic effect of the citrus essential oils.

For an industrial application focused on the energy recovery from the orange peel, the most interesting treatments would be the biological treatment and the ethanol extraction, due to their favourable energy balances. The limonene recovery achieved with the ethanol extraction could improve the profitability of the whole process.

\subsubsection{Anaerobic co-digestion of citrus waste and manure}

Three different continuous anaerobic co-digestion tests were performed:

a) Citrus (orange and mandarin) peel with pig and chicken manure; citrus peel proportion between $50 \%$ and $80 \%(\mathrm{w} / \mathrm{w}, \mathrm{VS}$ basis)

b) Citrus (orange) peel with cow manure; citrus peel proportion $80 \%$ (w/w, VS basis)

c) Citrus (orange) fruit with cow manure; citrus proportion $40 \%$ (w/w, VS basis)

The co-digestion of orange peel with pig and chicken manure diluted the concentration of limonene in the feed and therefore contributed to reduce the limonene dose at a given OLR. However, the degradation of the limonene led to the production of other toxic compounds such as cymene, cresol, perillaldehyde and $\alpha$-terpineol, which caused the inhibitory effect to persist even when the limonene degradation was almost complete. Therefore, strategies to remove or recover the limonene from the orange peel should be studied.

The main parameter to be regarded when studying inhibition by citrus essential oil is the dose (amount per digester volume unit and day). The rate of increase of the limonene dose has been inversely related to the maximum reachable organic loading rate. 
The first affected microbial population was the acetogenic bacteria, shown by an accumulation of volatile fatty acids. Sulphate reducing bacteria and methanogenic archaea were also affected.

The concentration of the bioproducts of limonene decreases when the feeding is stopped. It was not clear wether this decrease is due to degradation by the anaerobic populations or to accumulation in the membrane structure of the microorganisms.

The co-digestion with cow manure led to similar results, even when using longer adaptation times of constant OLR.

\subsubsection{Combination of co-digestion and pre-treatments to overcome inhibition}

The following pre-treatments were tested before continuous anaerobic co-digestion:

a) Thermal treatment (applied to citrus fruit)

b) Mechanical treatment (applied to citrus fruit)

c) Biological treatment (applied to citrus peel)

d) Ethanol extraction (applied to citrus peel)

The thermal pretratment did not influence the stability or the methane production.

The mechanical pretreatment applied to the citrus fruit allowed to reach an OLR of 4 $\mathrm{kg}_{\mathrm{Vs}} \cdot \mathrm{m}^{-3} \cdot \mathrm{d}^{-1}$ without VFA accumulation and to produce more methane than during the codigestion of citrus fruit without pretreatment.

The biological treatment by fungi of the Penicillium genus was not able to allow a stable anaerobic co-digestion of a mixture of $80 \%$ orange peel and $20 \%$ cow manure (volatile solids basis).

The ethanol extraction of the limonene from the orange peel, with an efficiency of $94 \%$, before the anaerobic digestion, allowed a stable anaerobic co-digestion of a mixture of $95 \%$ orange peel and 5\% cow manure (volatile solids basis). This low percentage of cow manure produced low concentration of hydrogen sulphide in the biogas, thus lowering the risk of inhibition due to this fact, compared with the other tests carried out with higher cow manure proportion in the feeding mixture.

The limonene was almost completely degraded during the anaerobic digestions. The main product was cymene, which is known to enhance the inhibitory effect of other terpenes. Acetogenic bacteria seemed to be responsible for or related to the cymene degradation pathway. Other compounds detected were perillaldehyde, cresol and $\alpha$-terpineol. The concentration of the latter was highest in the anaerobic digestion after biological treatment, while it appeared at low concentration and only after more than 200 days of experiment in the other tests. 


\subsubsection{Summary}

The inhibitory effect of the limonene on the anaerobic digestion of citrus waste has been characterised and a successful strategy to overcome it has been found.

The minimum inhibitory concentration and the half maximum inhibitory concentration of limonene in the digester were $200 \mathrm{mg} \cdot \mathrm{kg}^{-1}$ and $423 \mathrm{mg} \cdot \mathrm{kg}^{-1}$, respectively. Adaptation of the anaerobic biomass was observed in batch anaerobic digestion.

The limonene was almost completely degraded during anaerobic digestion, but its degradation products were inhibitory as well. Treatments able to recover the limonene make possible the anaerobic digestion of citrus waste. Extraction pretreatment with ethanol is suggested as the most promising technique, since it allows the recovery of citrus essential oils and enhances the anaerobic digestion process.

\subsection{Suggestions for future research}

The results described in this thesis represent a contribution to the knowledge of the anaerobic digestion of citrus waste and the inhibition by citrus essential oil. However, some aspects are to be taken into account when addressing studies on this field in the future.

Biological treatments are a relatively cheap way to remove the citrus essential oil from the citrus waste. However, other strongly inhibitory compounds such as $\alpha$-terpineol appear when the biological treatment is performed by fungi of the Penicillium genus. The possibility to use other microorganisms or treatment conditions leading to non-inhibitory compounds production would be a future research opportunity.

The ethanol extraction of the limonene makes possible the anaerobic digestion of citrus peel with small amounts of cow manure. The application of biorefinery concept to increase the economic viability of the whole process was not explored in this thesis but could have industrial interest. In this sense, the quality of the ethanolic extract and the purification processes necessary to obtain the limonene, as well as the extraction conditions, should be analysed.

In the continuous anaerobic digestion experiments, the concentration of iso- and n- forms of the volatile fatty acids was analysed. In some experiments, the iso- forms were predominant, while in other experiments, the $\mathrm{n}$ - forms were more abundant. This fact remains without a clear explanation.

The concentration of limonene by-products decreases when the feeding stops. This fact has been explained by the degradation of these compounds by the acetogenic bacteria. However, an accumulation of these compounds in the membrane structure of the microorganisms could happen as well. The degree in which this happens has not been analysed in this thesis and some specific experiments designed to measure the dynamics of adsorbtion onto the cell membrane should be done. 
